\title{
CARACTERIZACIÓN Y USO DE COMPOST DE ALPERUJO COMO ENMIENDA ORGÁNICA. EVALUACIÓN AGRONÓMICA Y MEDIOAMBIENTAL
}

Rosana García de la Fuente 


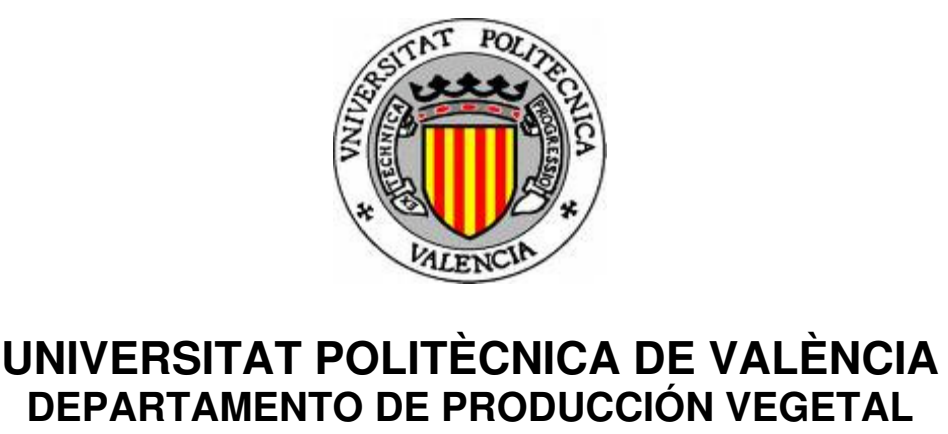

\section{"CARACTERIZACIÓN Y USO DE COMPOST DE ALPERUJO COMO ENMIENDA ORGÁNICA. EVALUACIÓN AGRONÓMICA Y MEDIOAMBIENTAL"}

Memoria de la Tesis Doctoral presentada por Rosana García de la Fuente para optar al Grado de Doctor

Dirigida por el Dr. Fernando Fornes Sebastiá y el Dr. Manuel Abad Berjón

Valencia, junio de 2011 


\section{Esta editorial es miembro de la UNE, lo que garantiza la difusión y comercialización de sus publicaciones a nivel Uximensrrakis Esprasous nacional e internacional.}

(c) Rosana García de la Fuente, 2011

Primera edición, 2011

(c) de la presente edición:

Editorial Universitat Politècnica de València

www.editorial. upv.es

ISBN: 978-84-694-8675-7

Ref. editorial: 5507

Queda prohibida la reproducción, distribución, comercialización, transformación, y en general, cualquier otra forma de explotación, por cualquier procedimiento, de todo o parte de los contenidos de esta obra sin autorización expresa y por escrito de sus autores. 


\section{AGRADECIMIENTOS}

Durante estos cinco años de desarrollo profesional y personal, son muchos los organismos y las personas a las que deseo mostrar mi gratitud.

En primer lugar, quiero agradecer a la Conselleria de Educación de la Generalitat Valenciana la financiación de una Ayuda Predoctoral de Formación de Personal Investigador (FPI) para elaborar la presente Tesis Doctoral, así como una beca para la realización de una estancia de investigación en la Università degli Studi di Firenze y ayudas para la asistencia a jornadas, congresos y otras actividades relacionadas con mi formación. Asimismo, esta Tesis se ha realizado en el marco del Proyecto PETRI titulado "Evaluación agronómica de composts y de extractos orgánicos solubles obtenidos mediante compostaje de alperujo e hidrolizado enzimático graso de proteínas animales (PTR1995-0894-OP-02-02)", financiado por el Ministerio de Educación y Ciencia, y del Proyecto de Investigación Interdisciplinar "Acondicionamiento de composts de residuos agrícolas y agroalimentarios de importancia en la Comunidad Valenciana, y aprovechamiento de sus propiedades supresoras de enfermedades en el cultivo de especies ornamentales. Estudios agronómicos y microbiológicos (PPI-05-05-5542)", financiado por la Universidat Politècnica de Valencia.

A mis Directores, a los que estoy infinitamente agradecida, por su enorme paciencia y esfuerzo, y por preocuparse tanto por mí en lo profesional y personal; me siento muy afortunada de haber trabajado estos años junto a ellos.

A mi Director el Dr. Manuel Abad, por su constancia y su gran implicación en esta Tesis (en cada una de las palabras que la componen), y por enseñarme el valor del esfuerzo y la lucha. Gracias a él he podido comprobar que todavía hay personas que se apasionan por su trabajo y además mantienen sus ideales y sus principios intactos. Por su simpatía, generosidad y ánimo en todo momento y, sobre todo, por su amistad.

A mi Director el Dr. Fernando Fornes, por depositar su confianza en mí, por su ilusión y dedicación para abordar los distintos temas de la Tesis, y por estar siempre pendiente ante cualquier problema o duda. Por su amistad y sus palabras de apoyo en los momentos difíciles.

A la Dra. Rosa María Belda, por su ayuda y atenciones en momentos clave de esta Tesis y por sus consejos, y al Dr. Vicente Noguera, por alegrar con sus bromas y recomendaciones el trabajo de laboratorio y mostrar a la juventud el lado hedonista de la vida.

Gracias al personal de los Departamentos de Producción Vegetal, de Biotecnología, y de Química por facilitar el asesoramiento y los medios técnicos necesarios para la realización de trabajos experimentales incluidos en esta Memoria.

Al Dr. Juan Cegarra y al Dr. José Antonio Alburquerque, del Centro de Edafología y Biología Aplicada del Segura (CEBAS-CSIC, Murcia), por elaborar y proporcionar los composts de alperujo y la materia orgánica soluble objeto de la Tesis, y también por su ayuda en el análisis del extracto de las sustancias húmicas. A BIOIBÉRICA S.A. (Barcelona), por haber suministrado el hidrolizado enzimático graso de proteínas animales utilizado para el cocompostaje con alperujo. 
Al Dr. Antonio de Haro (IAS-CSIC, Córdoba) y al Dr. Pascual Fernández de Córdova (COMAV-UPV, Valencia) por proporcionar semillas de Brassica, y al Dr. Francisco Cabrera y a la Dra. Engracia Madejón (IRNAS-CSIC, Sevilla) por facilitar el suelo ácido contaminado utilizado en el experimento de fitorremediación.

Muchas gracias a la Unidad Docente de Edafología, especialmente al Dr. Antonio Lidón, la Dra. Inmaculada Bautista y la Dra. Cristina Lull, por su inestimable colaboración e indicaciones a la hora de realizar parte de los análisis de suelos. A Dña. Joana Oliver y a D. Luis Lado, por compartir consejos, trabajo de laboratorio y conversaciones trascendentales que me han servido de gran apoyo.

Al Dr. Gonzalo Cuesta, por su enorme dedicación y esfuerzo en la caracterización e identificación de microorganismos de esta Tesis, y por su amabilidad y sus atenciones.

Especialmente al Prof. Paolo Nannipieri, la Prof. Loretta Landi y el Dr. Giancarlo Renella, por aceptarme para realizar una estancia de investigación en el Dipartimento di Scienze delle Produzioni Vegetali, del Suolo e dell'Ambiente Agroforestale de la Università degli Studi di Firenze, recibirme y atenderme con gran amabilidad durante los meses de investigación en Italia, así como por sus acertadas sugerencias a la hora de interpretar los resultados obtenidos. A mis amigos, la Dra. Laura Giagnoni, la Dra. Andressa Silveira y D. Andrea Migliaccio, por introducirme en la cultura y lengua italianas y por los buenos momentos vividos.

Agradecer también al Dr. Joaquín Moreno, la Dra. Francisca Suárez, la Dra. María José López y la Dra. Ma Carmen Vargas, de la Universidad de Almería, por enseñarme el protocolo de evaluación de supresividad in vivo en una estancia breve en su laboratorio.

A la Dra. Carolina Carrión, que me enseñó gran parte de las metodologías utilizadas durante la Tesis y que ha sido para mí un referente de suma importancia a la hora de abordar los trabajos de campo y laboratorio.

A Pepe Oliver, por ceder desinteresadamente el suelo calizo utilizado en los experimentos de esta Tesis y por sus ingeniosos inventos a la hora de solventar ciertos problemas.

Con cariño, a Elenita, Helen, Laura, María, Pepe, Alicia, Pilar, Paco, Mary Rus, Fran, Juan, Julio, Nella, Sofía y María Mercedes, que tanto me ayudaron en el trabajo y me brindaron además su valiosa amistad.

A la Dra. Daicy Mendoza, desde el corazón, una persona muy especial para mí, compañera durante todo este tiempo de arduo, tedioso y gratificante trabajo. Gran parte del trabajo de esta Tesis no habría podido realizarse sin su colaboración, su espíritu de lucha y su bondad. Con Daicy he compartido innumerables momentos de complicidad y alegría (a carcajadas) y gracias a ella los años de realización de esta Tesis serán inolvidables para mí. Hermana, me haces mucha falta.

A todos mis amigos, que han sabido comprender mi encierro durante la redacción de la Tesis, y siempre me han dado fuerzas y ánimo para continuar.

A mis padres, mis hermanos, tíos y primos, por quererme, comprenderme y por estar siempre ahí, incondicionalmente. 
"Convertid un árbol en leña y podrá arder para vosotros, pero ya no producirá flores ni frutos"

R. Tagore

“...parecía que habíamos llegado al final del camino y resulta que era sólo una curva abierta a otro paisaje y a nuevas curiosidades"

J. Saramago 


\section{RESUMEN}

El objetivo global de esta Tesis Doctoral es caracterizar y evaluar el uso como enmiendas orgánicas de 2 composts de alperujo -uno regado con agua de pozo durante el proceso de compostaje (compost A) y el otro con un hidrolizado enzimático graso de proteínas animales procedente de la industria farmacéutica (compost $\mathrm{A}+\mathrm{H}$ )-, desarrollando diferentes estudios agronómicos y medioambientales con el fin de alcanzar dicho objetivo. Se encontraron diferencias marcadas en las características físicas, físico-químicas y biológicas, en la composición, y en el grado de madurez y estabilidad entre los 2 composts estudiados, siendo A más estable y maduro que $\mathrm{A}+\mathrm{H}$. Los 2 composts mejoraron las propiedades físicas y aumentaron la fertilidad del suelo en un experimento de 1 año de duración, siendo generalmente el efecto de la dosis aplicada (12 a 96 t materia orgánica total/ha) más marcado que el del origen del compost (A vs. A+H). Los bioensayos realizados pusieron de manifiesto que $\mathrm{A}+\mathrm{H}$ inmovilizó $\mathrm{N}$ mineral tras su aplicación, y que tanto la respiración microbiana como las actividades enzimáticas, así como el contenido en $\mathrm{N}$ mineral del suelo fueron superiores en un suelo franco-arenoso italiano en comparación con uno francoarcilloso español. Los composts estudiados difirieron marcadamente en sus efectos sobre el primer cultivo establecido tras su aplicación al suelo (rábano, año 1), con valores significativamente superiores para el compost $A$; estas diferencias desaparecieron en los siguientes 2 cultivos de la rotación, lechuga y judía (en el año 1). La dosis de aplicación de compost de $24 \mathrm{t} /$ ha y el programa de fertilización mineral estándar (F1) proporcionaron resultados superiores en comparación con la dosis de 12 t/ha y la fertilización reducida en nitrógeno y potasio (F2), respectivamente. Los efectos descritos disminuyeron con el tiempo, siendo de mayor magnitud en el año 1 (efecto directo) que en el año 2 (efecto residual). En adición, tanto $\mathrm{A}$ como $\mathrm{A}+\mathrm{H}$ incrementaron la fertilidad del suelo -especialmente la potásicaen comparación con los controles sin enmendar el año 1 del estudio, manteniéndose este efecto durante el año 2 aunque en una cuantía comparativamente inferior. Las investigaciones sobre la materia orgánica soluble (MOS) extraída de los composts en medio alcalino revelaron que, de los 3 factores estudiados -Origen (compost A vs. $A+H$ ) de la MOS, Dosis de aplicación de ésta, y Programa de fertilización mineral-, la dosis de aplicación de la MOS fue el que tuvo efectos más consistentes y significativos sobre los parámetros medidos en el cultivo (alfalfa) y en el suelo (calizo) utilizados, registrándose los mejores resultados con las dosis bajas de MOS (entre 200 y 3200 mg carbono orgánico total/kg suelo). Los estudios realizados sobre la supresividad de los composts frente a agentes fitopatógenos permitieron aislar 49 cepas de actinomicetos de $\mathrm{A}, \mathrm{A}+\mathrm{H}$ y el suelo enmendado con estos 2 composts, que se estudiaron frente a 1 bacteria y 5 hongos fitopatógenos en un ensayo in vitro, mostrando 12 cepas una actividad antagonista muy marcada; 11 aislados pertenecieron al género Streptomyces, y 1 con actividad quitinolítica al género Lechevalieria. El ensayo de supresividad in vivo realizado con el patosistema melón (cv. "Rochet")-Fusarium oxysporum f. sp. melonis, utilizando como sustratos de cultivo mezclas de los composts con turba, reveló que el efecto antagonista en los sustratos con A fue superior a los preparados con $\mathrm{A}+\mathrm{H}$. El estudio de los efectos del compost A sobre la biodisponibilidad de metales pesados y arsénico, y sobre el crecimiento de plantas de Brassica, en 2 suelos contaminados (S1, $\mathrm{pH}=7,9$ y $\mathrm{S} 2, \mathrm{pH}=3,8)$ puso de manifiesto que el compost perjudicó el crecimiento y la acumulación de elementos traza en las plantas que crecieron en $\mathrm{S} 1$, siendo las especies más indicadas como fitoextractoras $B$. carinata y $B$. juncea, mientras que la aplicación de A a S2 aumentó el pH de éste, permitiendo así el crecimiento de todas las especies, siendo las más adecuadas en estas condiciones $B$. carinata y $B$. oleracea. Finalmente, se aislaron 8 cepas de bacterias oxidadoras del azufre del compost $A$ enmendado con azufre elemental ( $S^{0}$ ) micronizado, con objeto de reducir y adecuar así su pH, habiéndose identificado 7 de éstas como Paracoccus thiocyanatus, y 1 como Halothiobacillus neapolitanus. Las cepas nativas del compost mostraron una elevada eficiencia de acidificación ( $\geq 68 \%$ ) cuando A se enmendó con $\mathrm{S}^{0}$, no encontrándose efecto adicional alguno con la ayuda de cepas tipo, de referencia. 


\section{SUMMARY}

\section{CHARACTERIZATION AND USE OF COMPOSTED TWO-PHASE OLIVE MILL WASTE ('ALPERUJO') AS ORGANIC SOIL IMPROVER. AGRONOMIC AND ENVIRONMENTAL ASSESSMENT}

The overall objective of this PhD Thesis is to characterize and assess the use as organic soil improvers of 2 composts prepared from two-phase olive mill waste ('alperujo') -one irrigated with well water during the composting process (compost A) and the other one with a liquid, animal fatty-proteinaceous waste from the pharmaceutical industry (compost A+H)-, developing several agronomic and environmental studies with the aim of accomplishing this objective. Outstanding differences in physical, physico-chemical and biological characteristics, in composition, and in maturity and stability parameters were found between the 2 composts, A being more stable and mature than $\mathrm{A}+\mathrm{H}$. These two composts improved soil physical properties and increased soil fertility in a 1-year experiment, the effect of compost rate (12 to $96 \mathrm{Mg}$ total organic matter/ha) being in general more pronounced than compost source (A vs. $\mathrm{A}+\mathrm{H}$ ). Bioassays performed with two different textured soils (one sandy loam from Pisa-Italy and one clay loam from Valencia-Spain) disclosed that $\mathrm{A}+\mathrm{H}$ application immobilized mineral $\mathrm{N}$, and that both microbial respiration and enzyme activities as well as mineral $\mathrm{N}$ content in soil were higher in the Italian soil in comparison with the Spanish one. Both composts differed remarkably in their effects on the first crop grown immediately after they were applied to the soil (radish, 1 ${ }^{\text {st }}$ year), with values significantly higher for $A$; these differences disappeared in the following 2 crops of the rotation, lettuce and green bean (in the $1^{\text {st }}$ year). Compost application rate of $24 \mathrm{Mg} / \mathrm{ha}$ and the standard mineral fertilization programme (F1) gave better results than compost application rate of $12 \mathrm{Mg} /$ ha and the reduced fertilization (for both nitrogen and potassium, F2), respectively. These effects decreased with time, being in the $1^{\text {st }}$ year (direct effect) higher than in the $2^{\text {nd }}$ one (residual effect). In addition, $\mathrm{A}$ and $\mathrm{A}+\mathrm{H}$ enhanced soil fertility -especially in potassium - in comparison with unamended controls after the $1^{\text {st }}$ year of the experiment, this effect being maintained during the $2^{\text {nd }}$ year but to a lesser extent. Investigations carried out on the soluble organic matter (MOS) extracted with alkali from the composts revealed that, from the 3 factors studied -MOS Source (compost A vs. $\mathrm{A}+\mathrm{H})$, MOS application Rate, and mineral Fertilization programme-, MOS application rate was the one which most consistently and significantly affected the parameters measured in the crop (lucerne) and in the soil (calcareous), the best results being recorded with the lowest MOS application rates (from 200 to $3200 \mathrm{mg}$ total organic carbon/kg soil). Experiments developed about compost suppressiveness towards phytopathogens allowed to isolate 49 actinomycete strains from $\mathrm{A}, \mathrm{A}+\mathrm{H}$ and the soil amended with these 2 composts, which were co-cultured with 5 phytopathogenic fungi and 1 bacteria in in vitro assays, 12 isolates showing a remarkable antagonistic activity; 11 strains belonged to Streptomyces genus, and 1 -with chitinolytic activity- to Lechevalieria genus. In vivo suppressive assays carried out with the phytopathosystem melon 'Rochet'-Fusarium oxysporum f. sp. melonis by using compost and peat mixes as container growing media revealed that substrates containing compost A showed greater antagonistic effects than those prepared with $\mathrm{A}+\mathrm{H}$. The study of the effects of compost A on heavy metal and arsenic bioavailability, and on growth of Brassica plants in 2 polluted soils ( $\mathrm{S} 1, \mathrm{pH}=7.9$ and $\mathrm{S} 2, \mathrm{pH}=3.8)$ demonstrated that compost impaired both growth and shoot accumulation of trace elements in plants growing in $\mathrm{S} 1, B$. carinata and $B$. juncea being the most suitable species for phytoextraction purposes, whereas compost application to S2 increased soil $\mathrm{pH}$, thus allowing plant growth, $B$. carinata and $B$. oleracea being the most appropriate species in these conditions. Finally, 8 sulphur-oxidizing bacteria strains were isolated from compost $A$ amended with elemental sulphur ( $\left.\mathrm{S}^{0}\right)$ aiming to lower compost $\mathrm{pH}$, thus providing a suitable material for containerised plant growth. Seven of these isolates were identified as Paracoccus thiocyanatus, and 1 as Halothiobacillus neapolitanus. Indigenous compost strains showed high acidification efficiency ( $\geq 68 \%$ ) when A was amended with $S^{0}$, and no additional effect was found with the inoculation of reference strains. 


\section{RESUM}

\section{CARACTERITZACIÓ I ÚS DE COMPOST DE ALPERUJO COM ESMENA ORGÀNICA. AVALUACIÓ AGRONÒMICA I MEDIAMBIENTAL}

L'objectiu global d'aquesta Tesi Doctoral és caracteritzar i avaluar l'ús com a esmenes orgàniques de 2 composts d'alperujo - un regat amb aigua de pou durant el procés de compostatge (compost A) i l'altre amb un hidrolitzat enzimàtic gras de proteïnes animals procedent de la indústria farmacèutica (compost $\mathrm{A}+\mathrm{H}$ )-, desenvolupant diferents estudis agronòmics i mediambientals a fi d'aconseguir aquest objectiu. Es van trobar diferències marcades en les característiques físiques, fisicoquímiques i biològiques, en la composició, i en el grau de maduresa i estabilitat entre els 2 composts estudiats, sent A més estable i madur que $\mathrm{A}+\mathrm{H}$. Els 2 composts van millorar les propietats físiques i van augmentar la fertilitat del sòl en un experiment d'un any de duració, amb un efecte de la dosi aplicada (12 a $96 \mathrm{t}$ matèria orgànica total/ha) generalment més marcat que el de l'origen del compost ( $A$ vs. $A+H)$. Els bioassajos realitzats van posar de manifest que $\mathrm{A}+\mathrm{H}$ va immobilitzar $\mathrm{N}$ mineral després de la seua aplicació, i que tant la respiració microbiana com les activitats enzimàtiques, així com el contingut en $\mathrm{N}$ mineral del sòl van ser superiors en un sòl franc-arenós italià en comparació amb un franc-argilós espanyol. Els composts estudiats van diferir marcadament en els seus efectes sobre el primer cultiu establit després de la seua aplicació al sòl (rave, any 1), amb valors significativament superiors per al compost $A$; Aquestes diferències van desaparéixer en els següents 2 cultius de la rotació, encisam i fesol (any 1). La dosi d'aplicació de compost de 24 t/ha i el programa de fertilització mineral estàndard (F1) van proporcionar resultats superiors en comparació amb la dosi de 12 t/hi ha i la fertilització reduïda en nitrogen i potassi (F2), respectivament. Els efectes descrits van disminuir amb el temps, i van ser de major magnitud l'any 1 (efecte directe) que l'any 2 (efecte residual). A més, tant A com A+H van incrementar la fertilitat del sòl -especialment la potàssica- en comparació amb els controls sense esmenar l'any 1 de l'estudi, mantenint-se aquest efecte durant l'any 2 encara que en una quantia comparativament inferior. Les investigacions sobre la matèria orgànica soluble (MOS) extreta dels composts al mig alcalí van revelar que, dels 3 factors estudiats Origen (compost A vs. A+H) de la MOS, Dosi d'aplicació d'aquesta, i Programa de fertilització mineral-, la dosi d'aplicació de la MOS va ser el que va tindre efectes més consistents i significatius sobre els paràmetres mesurats en el cultiu (alfals) i en el sòl (calcari) utilitzats, registrant-se els millors resultats amb les dosis baixes de MOS (entre 200 i 3200 mg carboni orgànic total/kg sòl). Els estudis realitzats sobre la supressivitat dels composts enfront d'agents fitopatògens van permetre aïllar 49 ceps d'actinomicets de $\mathrm{A}, \mathrm{A}+\mathrm{H}$ i el sòl esmenat amb aquests 2 composts, que es van estudiar enfront d' 1 bacteri i 5 fongs fitopatògens en un assaig in vitro, mostrant 12 ceps una activitat antagonista molt marcada; 11 aillats van pertànyer al gènere Streptomyces, i 1 amb activitat quitinolítica al gènere Lechevalieria. L'assaig de supressivitat in vivo realitzat amb el patosistema meló (cv. "Rochet")-Fusarium oxysporum f. sp. melonis, utilitzant com a substrats de cultiu mescles dels composts amb torba, va revelar que l'efecte antagonista en els substrats amb A va ser superior als preparats amb $A+H$. L'estudi dels efectes del compost A sobre la biodisponibilitat de metalls pesants $i$ arsènic, i sobre el creixement de plantes de Brassica, en 2 sòls contaminats (S1, pH=7,9 i S2, $\mathrm{pH}=3,8$ ) va posar de manifest que el compost va perjudicar el creixement i l'acumulació d'elements traça en les plantes que van créixer en $\mathrm{S} 1$, sent les espècies més indicades com fitoextractores $B$. carinata i $B$. juncea, mentre que l'aplicació de A a S2 va augmentar el pH d'aquest, permetent així el creixement de totes les espècies, sent les més adequades en aquestes condicions $B$. carinata i $B$. oleracea. Finalment, es van aïllar 8 ceps de bacteris oxidants del sofre del compost A esmenat amb sofre elemental $\left(\mathrm{S}^{0}\right)$ micronitzat, a fi de reduir $\mathrm{i}$ adequar així el seu pH, havent-se identificat 7 com Paracoccus thiocyanatus, i 1 com Halothiobacillus neapolitanus. Els ceps natius del compost van mostrar una elevada eficiència d'acidificació ( $\geq 68 \%$ ) quan A es va esmenar amb So, no trobant-se cap efecte addicional amb l'ajuda de ceps de referència. 
ÍNDICE 
1.1.1. Preámbulo 3

1.1.2. Residuos generados. Sus características y composición. Problemática ........ 5

1.1.2.1. Residuos de origen animal ................................................................... 8

1.1.2.2. Residuos de origen vegetal................................................................. 9

1.1.3. Gestión: alternativas para su tratamiento....................................................12

\subsection{RESIDUOS Y SUBPRODUCTOS ORGÁNICOS GENERADOS POR LA INDUSTRIA} OLEÍCOLA. TIPOS, SUS CARACTERÍSTICASY APROVECHAMIENTO

1.2.1. Procesos utilizados en la industria extractiva del aceite de oliva: evolución histórica

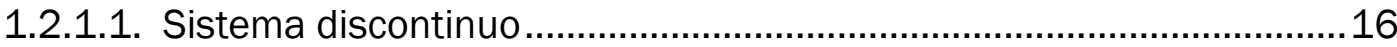

1.2.1.2. Sistema de centrifugación en continuo ............................................17

1.2.2. Residuos generados. Características y composición. Problemática ..............19

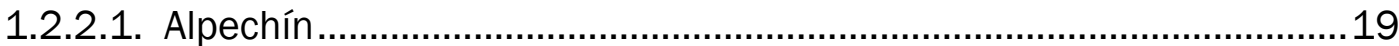

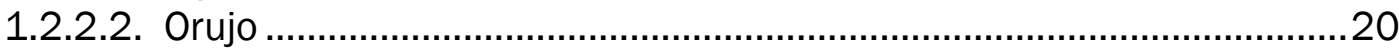

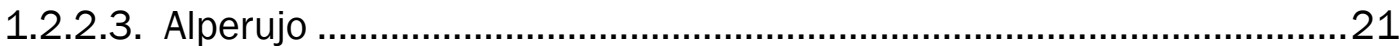

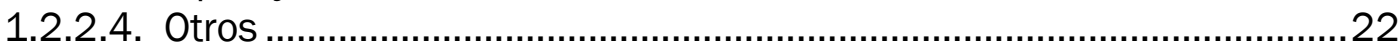

1.2.3. Tratamiento y aprovechamiento: Métodos de valorización ............................23

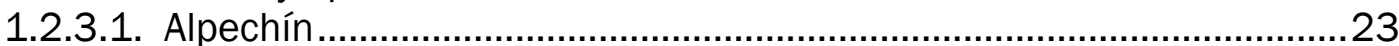

1.2.3.2. Alperujo y otros subproductos sólidos .............................................2 25

1.3. EL COMPOSTAJE, UN SISTEMA DE TRATAMIENTO Y ESTABILIZACIÓN DE LOS RESIDUOS ORGÁNICOS CON FINES AGRÍCOLAS 28

1.3.1. Concepto y funciones del compostaje .........................................................28

1.3.2. Factores que afectan al proceso .....................................................................30

1.3.2.1. Parámetros relativos a la naturaleza del sustrato (mezcla de residuos)

1.3.2.2. Parámetros de seguimiento del proceso ...............................................32

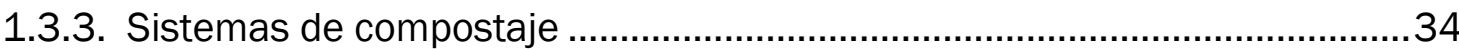

1.3.4. Calidad del compost. Parámetros a considerar y regulación.........................35

1.3.5. El caso particular del compostaje de alperujo...............................................40

1.3.5.1. Materiales utilizados en el co-compostaje del alperujo........................41 4

1.3.5.2. Características diferenciales del proceso ............................................43

1.3.5.3. Características y calidad de los composts de alperujo........................45 


\subsection{APROVECHAMIENTO Y APLICACIONES DEL COMPOST: USOS AGRONÓMICOS} Y MEDIOAMBIENTALES

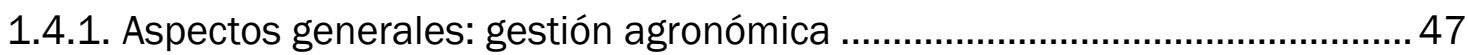

1.4.2. Aprovechamiento como enmiendas orgánicas ............................................ 48

1.4.3. Aprovechamiento como abonos orgánicos y órgano-minerales..................... 48

1.4.4. Aprovechamiento como sustratos de cultivo .............................................50

1.4.5. Uso para control biológico de agentes fitopatógenos ...................................51

1.4.6. Aplicación en la recuperación de suelos contaminados...............................53

1.4.7. Utilización como fuente de materia orgánica soluble ....................................56

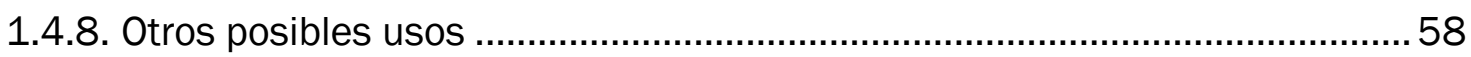

1.5. USO DE COMPOSTS COMO ENMIENDAS O MEJORADORES DEL SUELO.

EFECTOS SOBRE EL SISTEMA SUELO-PLANTA .....................................................5

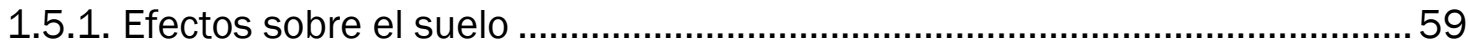

1.5.1.1. Sobre las propiedades físicas .......................................................60

1.5.1.2. Sobre las propiedades físico-químicas y químicas .............................61 61

1.5.1.3. Sobre las propiedades bioquímicas y microbiológicas..........................63 63

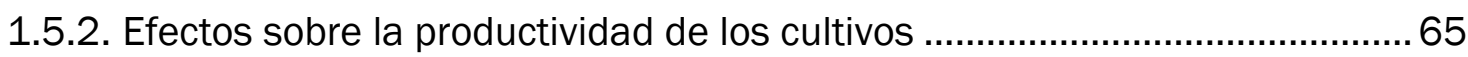

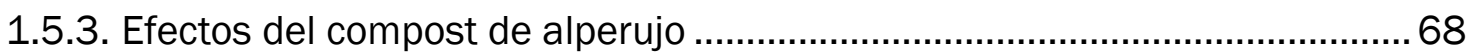

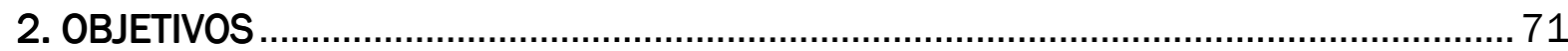

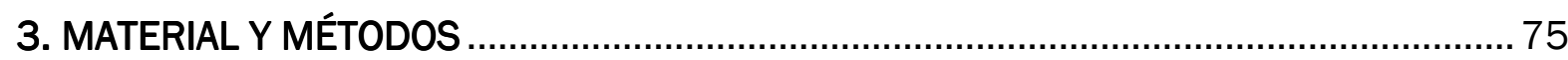

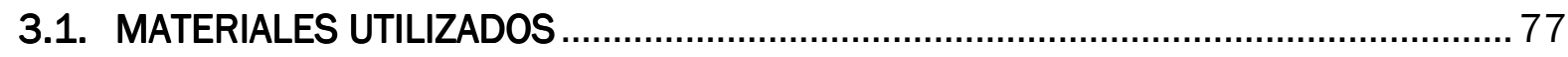

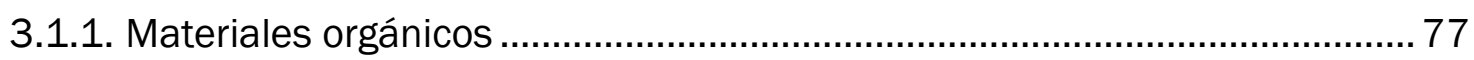

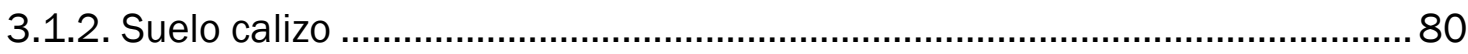

3.2. CARACTERIZACIÓN FÍSICA, FÍSICO-QUÍMICA, QUÍMICA Y BIOLÓGICA DE LOS COMPOSTS DE ALPERUJO $A$ Y $A+H$

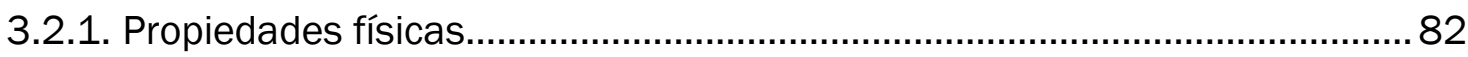

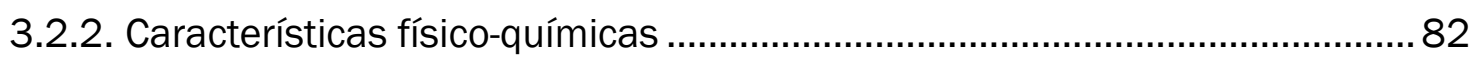

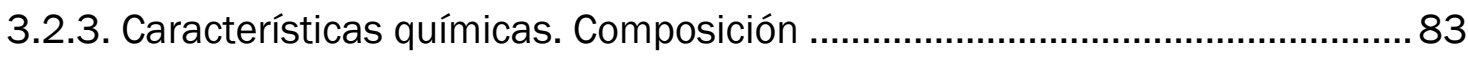

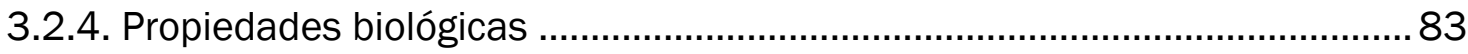




\subsection{INFLUENCIA DE LOS COMPOSTS $A$ Y $A+H$ EN LAS PROPIEDADES DEL} SUELO. ESTUDIO DE LA DINÁMICA DEL NITRÓGENO

3.3.1. Experimento 1. Estudio de las propiedades físicas y las características químicas del suelo calizo enmendado con los composts

3.3.1.1. Descripción del experimento ................................................................84

3.3.1.2. Parámetros físicos, físico-químicos y químicos estudiados ..................86

3.3.2. Estudio de la dinámica del nitrógeno en el suelo calizo enmendado con los composts (Experimento 2.1)

3.3.3. Efectos de la aplicación de los composts sobre parámetros biológicos y bioquímicos en dos suelos con texturas diferentes (Experimento 2.2) ........87

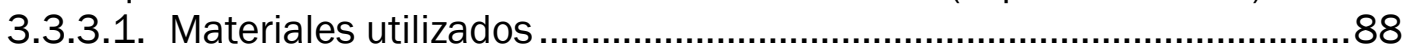

3.3.3.2. Diseño experimental .................................................................... 88

3.3.3.3. Parámetros químicos, biológicos y bioquímicos determinados ...........88

\subsection{EVALUACIÓN DE LOS COMPOSTS $A$ Y A+H COMO ENMIENDAS DEL SUELO.} EFECTO DIRECTO Y RESIDUAL SOBRE LOS CULTIVOS Y EL SUELO

3.4.1. Diseño del experimento de evaluación agronómica .....................................89

3.4.2. Parámetros de crecimiento y productividad controlados ..............................93

3.4.3. Análisis elemental del material vegetal........................................................95

3.4.4. Determinación de las características físico-químicas y químicas del suelo cultivado

3.5. EFECTOS DE LA MATERIA ORGÁNICA SOLUBLE EXTRAÍDA DE LOS COMPOSTS A Y A+H SOBRE EL CULTIVO DE ALFALFA Y EL SUELO CALIZO

3.5.1. Planteamiento y diseño del experimento .......................................................96

3.5.2. Parámetros controlados en las plantas de Medicago sativa..........................98

3.5.3. Parámetros determinados en el suelo cultivado y no cultivado.....................98

\subsection{ESTUDIO IN VITRO E IN VIVO DE LA SUPRESIVIDAD DE LOS COMPOSTS A Y} $A+H$.

3.6.1. Aislamiento de actinomicetos y evaluación de sus efectos antagonistas frente a agentes fitopatógenos, e identificación de las cepas supresoras .. 99

3.6.1.1. Aislamiento de cepas de actinomicetos 99

3.6.1.2. Evaluación de la inhibición de agentes fitopatógenos por los aislados en ensayos in vitro

3.6.1.3. Identificación de las cepas mediante técnicas moleculares 101

3.6.1.4. Caracterización de las cepas de actinomicetos mediante técnicas fenotípicas 
3.6.2. Bioensayo de supresividad in vivo frente a Fusarium oxysporum f. sp. melonis....

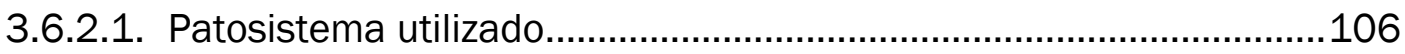

3.6.2.2. Preparación del inóculo de Fusarium oxysporum f. sp.

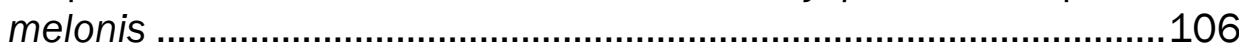

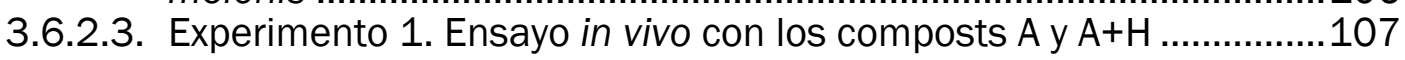

3.6.2.4. Experimento 2. Efecto del volumen de compost $A$ en la mezcla sobre la supresividad.

3.7. APLICACIÓN DE COMPOST DE ALPERUJO A DOS SUELOS CONTAMINADOS. INFLUENCIA EN LA BIODISPONIBILIDAD DE METALES PESADOS $Y$ ARSÉNICO, Y EN EL CRECIMIENTO DE PLANTAS DE BRASSICA ............................109

3.7.1. Suelos, compost y especies vegetales utilizadas ....................................109

3.7.2. Caracterización física, química y biológica de los suelos ............................110

3.7.3. Fitotoxicidad potencial. Germinación de semillas de cebada ......................110

3.7.4. Descripción del experimento ................................................................. 111

3.7.5. Análisis del suelo al final del experimento...............................................112

3.7.6. Parámetros controlados en el material vegetal .......................................112

3.8. DISMINUCIÓN DEL pH DEL COMPOST DE ALPERUJO MEDIANTE LA ADICIÓN DE AZUFRE ELEMENTAL.

3.8.1. Experimento de acidificación con el compost ...........................................113

3.8.1.1 Curva de valoración del compost....................................................113

3.8.1.2 Ensayo de incubación ................................................................ 114

3.8.2. Aislamiento e identificación de cepas oxidadoras del azufre.......................116

3.8.3. Evaluación de la eficiencia acifidificadora de las bacterias oxidadoras del azufre.

\subsection{CARACTERÍSTICAS, PROPIEDADES Y COMPOSICIÓN DE LOS COMPOSTS A Y} $A+H$

4.1.1. Propiedades físicas.............................................................................. 122

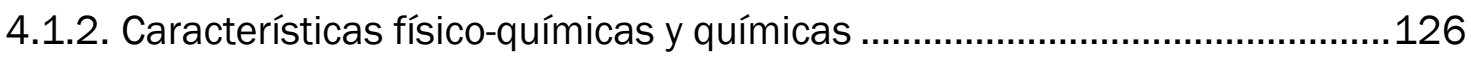

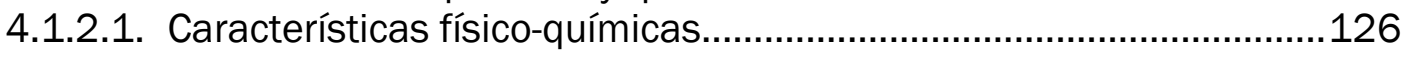

4.1.2.2. Características químicas. Composición ............................................127 


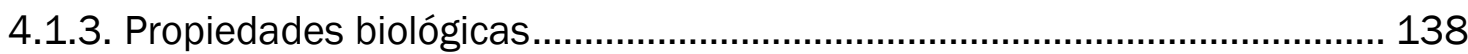

4.1.3.1. Biomasa y actividad microbiana .................................................. 138

4.1.3.2. Bioensayos de germinación y crecimiento ..................................... 139

4.1.4. Análisis de Componentes Principales..................................................... 144

4.1.5. Evaluación de la madurez y estabilidad de los composts $A$ y $A+H \ldots \ldots . . . . . . .147$

\subsection{EFECTOS DE LOS COMPOSTS $A$ Y $A+H$ SOBRE LAS PROPIEDADES FÍSICAS, LAS CARACTERÍSTICAS QUÍMICAS Y LA DINÁMICA DEL NITRÓGENO DE LOS SUELOS ENMENDADOS.}

4.2.1. Experimento 1. Efectos sobre las propiedades físicas y las características químicas del suelo ........................................................... 156

4.2.2. Experimento 2. Dinámica del nitrógeno en los suelos tratados con los composts $\mathrm{A}$ y $\mathrm{A}+\mathrm{H}$. Caracterización química, bioquímica y microbiológica

4.2.2.1. Experimento 2.1. Ensayo de incubación con el suelo calizo

4.2.2.2. Experiment 2.2. Short-term incubation assay with a Spanish clay loam soil and an Italian sandy loam soil

\subsection{EVALUACIÓN AGRONÓMICA DE LOS COMPOSTS A Y $A+H$ COMO ENMIENDAS ORGÁNICAS. INFLUENCIA EN LOS CULTIVOS Y EN EL SUELO: EFECTO DIRECTO Y RESIDUAL}

4.3.1. Influencia de los composts y su interacción con la fertilización mineral en el crecimiento, desarrollo y productividad de las tres especies hortícolas. Efecto directo (a corto plazo) y residual.

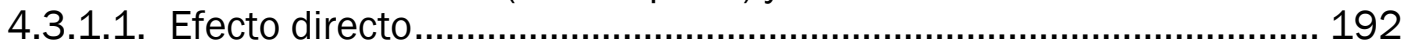

4.3.1.2. Efecto residual ............................................................................... 215

4.3.1.3. Estudio comparativo del efecto directo y residual de la aplicación de compost sobre la rotación rábano-lechuga-judía

4.3.2. Influencia de los composts y su interacción con la fertilización mineral en el estado nutricional de las tres especies hortícolas estudiadas. Efecto directo y residual

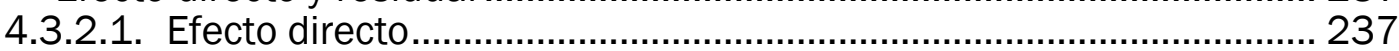

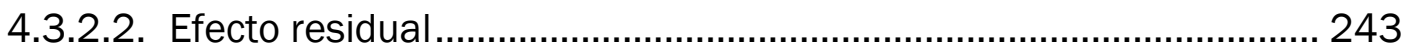

4.3.3. Influencia de los composts en combinación con la fertilización mineral y los cultivos en la fertilidad del suelo. Efecto directo y residual

4.3.3.1. Efecto directo sobre las características físico-químicas y químicas

4.3.3.2. Efecto residual sobre las características y la composición del suelo. 


\subsection{EFECTOS DE LA MATERIA ORGÁNICA SOLUBLE (MOS) EXTRAIIDA DE LOS COMPOSTS A Y A+H SOBRE MEDICAGO SATIVA Y EL SUELO CALIZO}

4.4.1. Efectos de la materia orgánica soluble (MOS) sobre el cultivo de Medicago sativa y su interacción con la fertilización mineral

4.4.2. Efecto conjunto de la materia orgánica soluble (MOS) y el cultivo de Medicago sativa sobre las características físico-químicas y químicas del suelo

4.4.3. Efecto de la materia orgánica soluble (MOS) sobre las características físico-químicas y químicas del suelo no cultivado.

4.4.4. Comparación de las características físico-químicas y químicas entre el suelo cultivado y el no cultivado....

\subsection{EVALUACIÓN DE LAS PROPIEDADES SUPRESIVAS DE LOS COMPOSTS $A$ Y} $A+H$ MEDIANTE ESTUDIOS IN VITRO E IN VIVO

4.5.1. Experimento de supresividad in vitro

4.5.1.1. Aislamiento de cepas de actinomicetos

4.5.1.2. Ensayo de antagonismo de las cepas de actinomicetos aisladas frente a cinco hongos fitopatógenos

4.5.1.3. Estudio de antagonismo de las cepas de actinomicetos aisladas frente a Agrobacterium tumefaciens

4.5.1.4. Identificación de las cepas de actinomicetos con mayor supresividad potencial mediante técnicas moleculares y fenotípicas

4.5.2. Experimentos de supresividad in vivo frente Fusarium oxysporum f. sp. melonis

4.5.2.1. Experimento 1. Ensayo in vivo con los composts $A$ y $A+H$ como componentes de los sustratos de cultivo estudiados

4.5.2.2. Experimento 2. Efecto del volumen de compost $A$ en la mezcla sobre las propiedades supresivas de los sustratos estudiados

\subsection{EFECTOS DEL COMPOST DE ALPERUJO SOBRE LA BIODISPONIBILIDAD DE METALES PESADOS Y ARSÉNICO, Y SOBRE EL CRECIMIENTO DE PLANTAS DE BRASSICA EN DOS SUELOS CONTAMINADOS}

4.6.1. Caracterización de los suelos contaminados y los respectivos controles no contaminados

4.6.1.1. Parámetros físicos, físico-químicos y composición ...........................324

4.6.1.2. Contenido y biodisponibilidad de los elementos traza .......................326

4.6.1.3. Poblaciones y actividad microbiana ..............................................326

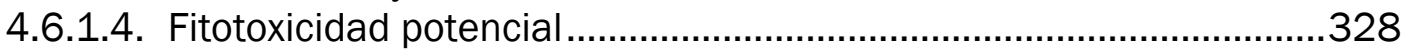

4.6.2. Efecto de la aplicación de compost de alperujo sobre las características físico-químicas y la biodisponibilidad de los principales contaminantes en los suelos estudiados. 
4.6.3. Efectos de la aplicación de compost de alperujo sobre las poblaciones y actividades microbianas en los suelos estudiados.

4.6.4. Efectos de la aplicación de compost de alperujo a los suelos sobre cinco especies del género Brassica

4.6.4.1. Influencia del compost en la supervivencia y el crecimiento de las plantas cultivadas en los suelos estudiados

4.6.4.2. Efecto del compost sobre la acumulación de Al, As, $\mathrm{Pb}$ y $\mathrm{Zn}$ en el vástago de las plantas cultivadas en los suelos contaminados

\subsection{EL USO DE COMPOST DE ALPERUJO EN LA PREPARACIÓN DE SUSTRATOS DE CULTIVO COMO NUEVA LÍNEA DE INVESTIGACIÓN. CORRECCIÓN DEL pH CON VISTAS A SU ADECUACIÓN}

4.7.1. Estudio del proceso de acidificación del compost tratado con azufre elemental micronizado

4.7.1.1. Curva de valoración del compost ..................................................... 346

4.7.1.2. Experimento de acidificación: ensayo de incubación ........................ 348

4.7.2. Estudio de la eficiencia de acidificación de los microorganismos aislados del compost

4.7.2.1. Aislamiento y caracterización de cepas oxidadoras del azufre autóctonas del compost

4.7.2.2. Identificación fenotípica y molecular de los aislados seleccionados

4.7.3. Eficiencia acidificadora in situ (en el compost) de las bacterias oxidadoras del azufre seleccionadas

5. CONCLUSIONES

6. BIBLIOGRAFÍA

ANEJO I: MÉTODOS ANALÍTICOS

ANEJO II: MATRIZ DE CORRELACIÓN 
ÍNDICE DE TABLAS 
Tabla 1.1. Clasificación de las industrias agroalimentarias en función de los residuos que éstas producen

Tabla 1.2. Clasificación de las principales industrias agroalimentarias según la procedencia de las materias primas que éstas utilizan.

Tabla 1.3. Tratamientos químicos y biológicos utilizados para el tratamiento de los residuos de las industrias agroalimentarias, y objetivos de los mismos.

Tabla 1.4. Características y composición de diferentes alperujos según diversos estudios (número total de muestras analizadas, $n=86$ ).

Tabla 1.5. Clasificación de las metodologías utilizadas para el pretratamiento o tratamiento del alpechín

Tabla 1.6. Parámetros a considerar en la evaluación de la calidad de un compost

Tabla 1.7. Parámetros a considerar, y su importancia relativa, en la evaluación de la calidad de un compost en función del uso final del mismo.

Tabla 1.8. Normativa española y propuesta europea referentes a los requerimientos mínimos de calidad de los composts.

Tabla 1.9. Relación de composts de alperujo y parámetros químicos seleccionados en los mismos con vistas a su uso agrícola y medioambiental

Tabla 1.10. Efectos principales de los composts sobre las propiedades y funcionalidad de los suelos cultivados

Tabla 1.11. Estudios sobre aplicación de composts de diferentes orígenes y características al suelo en el cultivo de varias especies hortícolas, con indicación de sus efectos sobre la producción.

Tabla 3.1. Características y composición (sobre peso de extracto fresco) de los extractos alcalinos de la materia orgánica soluble (MOS) procedente de los composts $A$ y $A+H$.....

Tabla 3.2. Características físicas y físico-químicas, y composición (sobre materia seca) del suelo utilizado en la evaluación agronómica de los composts

Tabla 3.3. Parámetros físicos determinados en los composts, y sus métodos (referencias) correspondientes

Tabla 3.4. Parámetros determinados en la caracterización química de los composts, con indicación de sus respectivos métodos (referencias)

Tabla 3.5. Características y composición del agua de riego utilizada en el experimento.....

Tabla 3.6. Programas de fertilización mineral estándar (F1) y reducida (F2) aplicados a los cultivos

Tabla 3.7. Clave de los tratamientos estudiados en la evaluación agronómica e los composts A y $\mathrm{A}+\mathrm{H}$

Tabla 3.8. Labores culturales realizadas y momento de su aplicación en los dos años del experimento

Tabla 3.9. Parámetros controlados en rábano, lechuga y judía el Año 1 (efecto directo) y el Año 2 (efecto residual) en el experimento de evaluación agronómica

Tabla 3.10. Ecuaciones de ajuste del área de la hoja (S, expresada en $\mathrm{cm}^{2}$ ) de mayor tamaño en los cultivos estudiados y los dos años de experimento

Tabla 3.11. Disoluciones de $\mathrm{FeSO}_{4} \cdot 7 \mathrm{H}_{2} \mathrm{O}$ y agua para la obtención de la curva de valoración del compost

Tabla 4.1.1. Requisitos que deben cumplir los composts de alperujo, especificados en el Anexo I de la Orden PRE/630/2011, de 23 de marzo, por la que se modifican los anexos I a VI del Real Decreto 824/2005 sobre productos fertilizantes.

Tabla 4.1.2. Propiedades físicas seleccionadas de los dos composts estudiados $(A$ y $A+H)$ 123 
Tabla 4.1.3. Características físico-químicas y composición (sobre materia seca) de los dos composts estudiados $(\mathrm{A}$ y $\mathrm{A}+\mathrm{H})$, y rangos de variación encontrados según diversos autores.

Tabla 4.1.4. Concentración de metales pesados ( $\mathrm{mg} / \mathrm{kg} \mathrm{ms}$ ) en los dos composts estudiados (A y A+H), y límites máximos de concentración permitidos según el RD 824/2005 sobre productos fertilizantes.

Tabla 4.1.5. Comparación de los niveles de elementos minerales solubles (expresados en $\mathrm{mg} / \mathrm{L}$ de compost) de los dos composts estudiados ( $\mathrm{A}$ y $\mathrm{A}+\mathrm{H}$ ) utilizando agua destilada y $\mathrm{CaCl}_{2} / \mathrm{DTPA}$ como extractantes.

Tabla 4.1.6. Comparación de los niveles de elementos minerales solubles (expresados como porcentajes [\%] de los niveles determinados con agua regia) de los dos composts estudiados (A y $\mathrm{A}+\mathrm{H}$ ) utilizando agua destilada y $\mathrm{CaCl}_{2} /$ DTPA como extractantes.

Tabla 4.1.7. Componentes seleccionados de la materia orgánica de los dos composts estudiados $(\mathrm{A}$ y $\mathrm{A}+\mathrm{H})$, y rangos de variación encontrados según diversos autores.

Tabla 4.1.8. Poblaciones microbianas y actividad microbiana en los dos composts estudiados (A y $\mathrm{A}+\mathrm{H})$.

Tabla 4.1.9. Efectos principales de los tratamientos estudiados -compost y dilución de los extractos obtenidos- sobre el índice de germinación (IG) de berro y de lechuga en los bioensayos realizados.

Tabla 4.1.10. Parámetros determinados en el bioensayo de siembra directa de semillas de berro en los sustratos preparados con los dos composts estudiados (A y A+H). Comparación con el sustrato control de turba.

Tabla 4.1.11. Componentes principales de las propiedades físicas, las características físicoquímicas y químicas, y las propiedades biológicas de los dos composts estudiados $(A$ y $A+H) \ldots \ldots . .145$

Tabla 4.1.12. Parámetros e índices utilizados como indicadores de madurez y estabilidad de residuos orgánicos compostados, y niveles de éstos en los dos composts estudiados ( $\mathrm{A}$ y $\mathrm{A}+\mathrm{H}) \ldots 149$

Tabla 4.2.1. Efectos principales de los tratamientos estudiados -Compost (A vs. A+H) y Dosis de aplicación de éste (D1, D2, D3 y D4, equivalente a 12, 24, 48 y 96 t de materia orgánica total/ha, respectivamente)- sobre propiedades físicas seleccionadas del suelo al final del experimento...

Tabla 4.2.2. Influencia del compost $(A$ y $A+H)$ y de la dosis de aplicación de éste (D1, D2, D3 y D4, equivalente a 12, 24, 48 y 96 t de materia orgánica total/ha, respectivamente) en propiedades físicas seleccionadas del suelo al final del experimento. Comparación con el control (CO, que no recibió compost).

Tabla 4.2.3. Influencia del compost $(A$ y $A+H)$ y de la dosis de aplicación de éste (D1, D2, D3 y D4, equivalente a 12, 24, 48 y 96 t de materia orgánica total/ha, respectivamente) en el pH y la conductividad eléctrica (CE) del suelo al inicio y al final del experimento, y valores de estos parámetros en el control sin enmendar (CO) .

Tabla 4.2.4. Influencia del compost $(\mathrm{A}$ y $\mathrm{A}+\mathrm{H})$ y de la dosis de aplicación de éste (D1, D2, D3 y D4, equivalente a 12, 24, 48 y 96 t de materia orgánica total/ha, respectivamente) en la composición del suelo al inicio y al final del experimento, y valores de los parámetros determinados en el control sin enmendar (CO).

Tabla 4.2.5. Efectos principales de los tratamientos estudiados -Compost (A vs. A+H) y Dosis de aplicación de éste (D1, D2, D3 y D4, equivalente a 12, 24, 48 y 96 t de materia orgánica total/ha, respectivamente)- sobre las características físico-químicas y la composición del suelo al final del experimento

Tabla 4.2.6. Influencia del compost (A y A+H) y de la dosis de aplicación de éste (D1, D2, D3 y D4, equivalente a 12, 24, 48 y 96 t de materia orgánica total/ha, respectivamente) en las características físico-químicas y la composición del suelo al final del experimento. Comparación con el control (CO, que no recibió compost). 
Tabla 4.2.7. Cinética de la concentración neta de nitrógeno mineral (nítrico + amoniacal) en el suelo tratado con los composts $\mathrm{A}$ y $\mathrm{A}+\mathrm{H}$ a las dosis de 12, 24 y 48 t/ha en el ensayo de incubación

Table 4.2.8. Main effects of the experimental treatments tested -Compost ( $\mathrm{As}$. $A+H)$ and Soil (S1 vs. S2)- on chemical characteristics and on biological properties studied in compostamended soils at selected intervals from the beginning of the incubation assay

Table 4.2.9. Parameters for the first-order kinetic model $\left(\mathrm{C}_{\min }=\mathrm{C}_{0}\left[1-\mathrm{e}^{-\mathrm{kt}}\right]\right)$ adjusted to the net cumulative values (control values substracted) of $\mathrm{CO}_{2}-\mathrm{C}$ released from soils $\mathrm{S} 1$ and $\mathrm{S} 2$ amended with composts $\mathrm{A}$ and $\mathrm{A}+\mathrm{H}$ at $24 \mathrm{Mg}$ total organic matter ha-1

Table 4.2.10. Main effects of the experimental treatments tested -Compost (A vs. A+H) and Soil (S1 vs. S2)- on enzyme activities studied in compost-amended soils at selected intervals from the beginning of the incubation assay.

Tabla 4.3.1. Análisis factorial de la varianza $(P)$ para los efectos de los tratamientos estudiados -Compost (alperujo vs. alperujo más hidrolizado), Dosis de aplicación de éste (12 vs. 24 t de materia orgánica total/ha) y Programa de fertilización mineral (estándar vs. reducida) - sobre el crecimiento vegetativo (hojas y raíz) de rábano. Primer año del experimento (Año 1)

Tabla 4.3.2. Análisis factorial de la varianza $(P)$ para los efectos de los tratamientos estudiados -Compost (alperujo vs. alperujo más hidrolizado), Dosis de aplicación de éste (12 vs. 24 t de materia orgánica total/ha) y Programa de fertilización mineral (estándar, F1 vs. reducida, F2)sobre la acumulación y distribución de biomasa, y sobre la producción total de raíces en rábano. Año 1.

Tabla 4.3.3. Análisis factorial de la varianza $(P)$ para los efectos de los tratamientos estudiados -Compost (alperujo vs. alperujo más hidrolizado), Dosis de aplicación de éste (12 vs. 24 t de materia orgánica total/ha) y Programa de fertilización mineral (estándar vs. reducida)- sobre el desarrollo de la hoja en lechuga. Año 1

Tabla 4.3.4. Análisis factorial de la varianza $(P)$ para los efectos de los tratamientos estudiados - Compost (alperujo vs. alperujo más hidrolizado), Dosis de aplicación de éste (12 vs. 24 t de materia orgánica total/ha) y Programa de fertilización mineral (estándar vs. reducida)- sobre la acumulación y distribución de biomasa, y sobre la producción total de cogollos en lechuga. Año 1 .

Tabla 4.3.5. Análisis factorial de la varianza $(P)$ para los efectos de los tratamientos estudiados - Compost (alperujo vs. alperujo más hidrolizado), Dosis de aplicación de éste (12 vs. 24 t de materia orgánica total/ha) y Programa de fertilización mineral (estándar vs. reducida)- sobre el crecimiento vegetativo y el desarrollo reproductivo de judía. Año 1

Tabla 4.3.6. Análisis factorial de la varianza $(P)$ para los efectos de los tratamientos estudiados - Compost (alperujo vs. alperujo más hidrolizado), Dosis de aplicación de éste (12 vs. 24 t de materia orgánica total/ha) y Programa de fertilización mineral (estándar vs. reducida)- sobre la acumulación y distribución de biomasa en judía. Año 1

Tabla 4.3.7. Efectos de los tratamientos experimentales estudiados -Compost (A y A+H), Dosis de aplicación de éste (D1 y D2, equivalentes a 12 y 24 t de materia orgánica total/ha, respectivamente) y Programa de fertilización mineral (estándar, F1 y reducida, F2) - sobre la producción de vainas de judía en las cuatro recolecciones efectuadas (1 a 4) a lo largo del experimento. Comparación con los controles (CO, que no recibieron compost). Año 1

Tabla 4.3.8. Efectos de los tratamientos experimentales estudiados -Compost (A y A+H), Dosis de aplicación de éste (D1 y D2, equivalentes a 12 y 24 t de materia orgánica total/ha, respectivamente) y Programa de fertilización mineral (estándar, F1 y reducida, F2)- sobre la producción precoz y total de vainas de judía, y sobre los días transcurridos hasta alcanzar el $50 \%$ de la producción total obtenida. Comparación con los controles (CO, que no recibieron compost). Año 1 
Tabla 4.3.9. Análisis factorial de la varianza $(P)$ para los efectos de los tratamientos estudiados -Compost (alperujo vs. alperujo más hidrolizado), Dosis de aplicación de éste (12 vs. 24 t de materia orgánica total/ha) y Programa de fertilización mineral (estándar vs. reducida)- sobre el crecimiento vegetativo (hojas y raíz) de rábano. Segundo año del experimento (Año 2) .....

Tabla 4.3.10. Análisis factorial de la varianza $(P)$ para los efectos de los tratamientos estudiados -Compost (alperujo vs. alperujo más hidrolizado), Dosis de aplicación de éste (12 vs. $24 \mathrm{t}$ de materia orgánica total/ha) y Programa de fertilización mineral (estándar vs. reducida) - sobre la acumulación y distribución de biomasa, y sobre la producción total de raíces de rábano. Año 2 .

Tabla 4.3.11. Análisis factorial de la varianza $(P)$ para los efectos de los tratamientos estudiados -Compost (alperujo vs. alperujo más hidrolizado), Dosis de aplicación de éste (12 vs. $24 \mathrm{t}$ de materia orgánica total/ha) y Programa de fertilización mineral (estándar vs. reducida)- sobre el desarrollo de la hoja en lechuga. Año 2.

Tabla 4.3.12. Análisis factorial de la varianza $(P)$ para los efectos de los tratamientos estudiados -Compost (alperujo vs. alperujo más hidrolizado), Dosis de aplicación de éste (12 vs. 24 t de materia orgánica total/ha) y Programa de fertilización mineral (estándar vs. reducida) - sobre la acumulación y distribución de biomasa, y sobre la producción total de cogollos en lechuga. Año 2

Tabla 4.3.13. Análisis factorial de la varianza $(P)$ para los efectos de los tratamientos estudiados -Compost (alperujo vs. alperujo más hidrolizado), Dosis de aplicación de éste (12 vs. $24 \mathrm{t}$ de materia orgánica total/ha) y Programa de fertilización mineral (estándar vs. reducida) - sobre el crecimiento vegetativo (tallo, hojas y raíz) y el desarrollo reproductivo (vainas) de judía. Año 2

Tabla 4.3.14. Análisis factorial de la varianza $(P)$ para los efectos de los tratamientos estudiados -Compost (alperujo vs. alperujo más hidrolizado), Dosis de aplicación de éste (12 vs. $24 \mathrm{t}$ de materia orgánica total/ha) y Programa de fertilización mineral (estándar vs. reducida)- sobre la acumulación y distribución de biomasa en judía. Año 2.

Tabla 4.3.15. Efectos de los tratamientos experimentales estudiados -Compost ( $\mathrm{A}$ y $\mathrm{A}+\mathrm{H})$, Dosis de aplicación de éste (D1 y D2, equivalentes a 12 y 24 t de materia orgánica total/ha, respectivamente) y Programa de fertilización mineral (estándar, F1 y reducida, F2)- sobre la producción de vainas de judía en las cuatro recolecciones efectuadas (1 a 4) a lo largo del experimento. Comparación con los controles (CO, que no recibieron compost). Año 2.

Tabla 4.3.16. Efectos de los tratamientos experimentales estudiados -Compost ( $\mathrm{A}$ y $\mathrm{A}+\mathrm{H})$, Dosis de aplicación de éste (D1 y D2, equivalentes a 12 y 24 t de materia orgánica total/ha, respectivamente) y Programa de fertilización mineral (estándar, F1 y reducida, F2)- sobre la producción precoz y total de vainas de judía, y sobre los días transcurridos hasta alcanzar el $50 \%$ de la producción total obtenida. Comparación con los controles (CO, que no recibieron compost). Año 2

Tabla 4.3.17. Efecto directo (Año 1) y residual (Año 2) de la aplicación de los composts A y A+H a las dosis D1 y D2 (equivalentes a 12 y 24 t materia orgánica total/ha, respectivamente) junto con los programas de fertilización mineral F1 y F2 (estándar y reducida, respectivamente)- sobre el crecimiento, la acumulación y distribución de biomasa, y la productividad en rábano. En cada parámetro, las cifras indican el ratio calculado como cociente entre el valor medido en el tratamiento con compost y el control sin enmendar que recibió idéntico programa de fertilización mineral.

Tabla 4.3.18. Efecto directo (Año 1 ) y residual (Año 2) de la aplicación de los composts A y A+H a las dosis D1 y D2 (equivalentes a 12 y 24 t materia orgánica total/ha, respectivamente) junto con los programas de fertilización mineral F1 y F2 (estándar y reducida, respectivamente)- sobre el crecimiento, la acumulación y distribución de biomasa, y la productividad en lechuga. En cada parámetro, las cifras indican el ratio calculado como cociente entre el valor medido en el tratamiento con compost y el control sin enmendar que recibió idéntico programa de fertilización mineral. 
Tabla 4.3.19. Efecto directo (Año 1) y residual (Año 2) de la aplicación de los composts $A$ y $A+H$ a las dosis D1 y D2 (equivalentes a 12 y 24 t materia orgánica total/ha, respectivamente) junto con los programas de fertilización mineral F1 y F2 (estándar y reducida, respectivamente)- sobre el crecimiento, la acumulación y distribución de biomasa, y la productividad en judía. En cada parámetro, las cifras indican el ratio calculado como cociente entre el valor medido en el tratamiento con compost y el control sin enmendar que recibió idéntico programa de fertilización mineral.

Tabla 4.3.20. Análisis factorial de la varianza $(P)$ para los efectos de los tratamientos estudiados -Compost (alperujo vs. alperujo más hidrolizado), Dosis de aplicación de éste (12 vs. 24 t de materia orgánica total/ha) y Programa de fertilización mineral (estándar vs. reducida)- sobre el contenido foliar de nutrientes en rábano. Primer año del experimento (Año 1).

Tabla 4.3.21. Análisis factorial de la varianza $(P)$ para los efectos de los tratamientos estudiados -Compost (alperujo vs. alperujo más hidrolizado), Dosis de aplicación de éste (12 vs. 24 t de materia orgánica total/ha) y Programa de fertilización mineral (F1 vs. reducida)sobre el contenido foliar de nutrientes en lechuga. Año 1

Tabla 4.3.22. Análisis factorial de la varianza $(P)$ para los efectos de los tratamientos estudiados -Compost (alperujo vs. alperujo más hidrolizado), Dosis de aplicación de éste (12 vs. 24 t de materia orgánica total/ha) y Programa de fertilización mineral (estándar vs. reducida)- sobre el contenido foliar de nutrientes en judía. Año 1

Tabla 4.3.23. Análisis factorial de la varianza $(P)$ para los efectos de los tratamientos estudiados -Compost (alperujo vs. alperujo más hidrolizado), Dosis de aplicación de éste (12 vs. 24 t de materia orgánica total/ha) y Programa de fertilización mineral (estándar vs. reducida)- sobre el contenido foliar de nutrientes en rábano. Segundo año del experimento (Año 2)

Tabla 4.3.24. Análisis factorial de la varianza $(P)$ para los efectos de los tratamientos estudiados -Compost (alperujo vs. alperujo más hidrolizado), Dosis de aplicación de éste (12 vs. 24 t de materia orgánica total/ha) y Programa de fertilización mineral (estándar vs. reducida)- sobre el contenido foliar de nutrientes en lechuga. Año 2 .

Tabla 4.3.25. Análisis factorial de la varianza $(P)$ para los efectos de los tratamientos estudiados -Compost (alperujo vs. alperujo+hidrolizado), Dosis de aplicación de éste (12 vs. 24 t de materia orgánica total/ha, respectivamente) y Programa de fertilización mineral (estándar vs. reducida)- sobre el contenido foliar de nutrientes en judía. Año 2.

Tabla 4.3.26. Análisis factorial de la varianza $(P)$ para los efectos de los tratamientos estudiados -Compost (alperujo vs. alperujo más hidrolizado), Dosis de aplicación de éste (12 vs. $24 \mathrm{t}$ de materia orgánica total/ha) y Programa de fertilización mineral (estándar vs. reducida)- sobre el $\mathrm{pH}$ y la conductividad eléctrica (CE) del suelo al final del primer año del experimento (Año 1)

Tabla 4.3.27. Análisis factorial de la varianza $(P)$ para los efectos de los tratamientos estudiados -Compost (alperujo vs. alperujo más hidrolizado), Dosis de aplicación de éste (12 vs. 24 t de materia orgánica total/ha) y Programa de fertilización mineral (estándar vs. reducida)- sobre la composición química del suelo al final del primer año del experimento (Año 1).......

Tabla 4.3.28. Análisis factorial de la varianza $(P)$ para los efectos de los tratamientos estudiados -Compost (alperujo vs. alperujo más hidrolizado), Dosis de aplicación de éste (12 vs. $24 \mathrm{t}$ de materia orgánica total/ha) y Programa de fertilización mineral (estándar vs. reducida)- sobre el $\mathrm{pH}$ y la conductividad eléctrica (CE) del suelo al final del segundo año del experimento (Año 2)

Tabla 4.3.29. Análisis factorial de la varianza $(P)$ para los efectos de los tratamientos estudiados -Compost (alperujo vs. alperujo más hidrolizado), Dosis de aplicación de éste (12 vs. $24 \mathrm{t}$ de materia orgánica total/ha) y Programa de fertilización mineral (estándar vs. reducida)- sobre la composición química del suelo al final del segundo año del experimento (Año 2) 
Tabla 4.4.1. Efectos principales de los tratamientos estudiados -Materia orgánica soluble (MOS) extraída del compost (A vs. A+H), Dosis de aplicación de la MOS (en mg de carbono orgánico total/kg de suelo) y Programa de fertilización mineral (estándar, F1 vs. reducida, F2)sobre el crecimiento y la producción de Medicago sativa en el primer corte (siega) realizado ....

Tabla 4.4.2. Influencia de la materia orgánica soluble (MOS) extraída de los composts A y A+H, la dosis de aplicación de ésta (en mg de carbono orgánico total/kg de suelo) y el programa de fertilización mineral (estándar, F1 y reducida, F2) en el crecimiento y la producción de Medicago sativa en el primer corte (siega) realizado. Comparación con los controles (CO, que no recibieron MOS)

Tabla 4.4.3. Efectos principales de los tratamientos estudiados -Materia orgánica soluble (MOS) extraída del compost (A vs. A+H), Dosis de aplicación de la MOS (en mg de carbono orgánico total/kg de suelo) y Programa de fertilización mineral (estándar, F1 vs. reducida, F2)sobre el crecimiento y la producción de Medicago sativa en el segundo corte realizado......

Tabla 4.4.4. Influencia de la materia orgánica soluble (MOS) extraída de los composts A y A+H, la dosis de aplicación de ésta (en mg de carbono orgánico total/kg de suelo) y el programa de fertilización mineral (estándar, F1 y reducida, F2) en el crecimiento y la producción de Medicago sativa en el segundo corte realizado. Comparación con los controles (CO, que no recibieron MOS)

Tabla 4.4.5. Efectos principales de los tratamientos estudiados -Materia orgánica soluble (MOS) extraída del compost (A vs. A+H), Dosis de aplicación de la MOS (en mg de carbono orgánico total/kg de suelo) y Programa de fertilización mineral (estándar, F1 vs. reducida, F2)sobre el crecimiento y la producción de Medicago sativa en el tercer corte realizado.

Tabla 4.4.6. Influencia de la materia orgánica soluble (MOS) extraída de los composts A y A+H, la dosis de aplicación de ésta (en mg de carbono orgánico total/kg de suelo) y el programa de fertilización mineral (estándar, F1 y reducida, F2) en el crecimiento y la producción de Medicago sativa en el tercer corte realizado. Comparación con los controles (CO, que no recibieron MOS).... 271

Tabla 4.4.7. Efectos principales de los tratamientos estudiados -Materia orgánica soluble (MOS) extraída del compost (A vs. A+H), Dosis de aplicación de la MOS (en mg de carbono orgánico tota/kg de suelo) y Programa de fertilización mineral (estándar, F1 vs. reducida, F2)sobre el crecimiento y producción de Medicago sativa en el cuarto corte realizado

Tabla 4.4.8. Influencia de la materia orgánica soluble (MOS) extraída de los composts A y A+H, la dosis de aplicación de ésta (en $\mathrm{mg}$ de carbono orgánico total/kg de suelo) y el programa de fertilización mineral (estándar, F1 y reducida, F2) en el crecimiento y la producción de Medicago sativa en el cuarto corte realizado. Comparación con los controles (CO, que no recibieron MOS)... 273

Tabla 4.4.9. Efectos principales de los tratamientos estudiados -Materia orgánica soluble (MOS) extraída del compost (A vs. A+H), Dosis de aplicación de la MOS (en mg de carbono orgánico total/kg de suelo) y Programa de fertilización mineral (estándar, F1 vs. reducida, F2)sobre el crecimiento de la raíz de Medicago sativa al finalizar el experimento......

Tabla 4.4.10. Influencia de la materia orgánica soluble (MOS) extraída de los composts A y A+H, la dosis de aplicación de ésta (en mg de carbono orgánico total /kg de suelo) y el programa de fertilización mineral (estándar, F1 y reducida, F2) en el crecimiento de la raíz de Medicago sativa al finalizar el experimento. Comparación con los controles (CO, que no recibieron MOS) ..... 276

Tabla 4.4.11. Efectos principales de los tratamientos estudiados -Materia orgánica soluble (MOS) extraída del compost (A vs. A+H), Dosis de aplicación de la MOS (en mg de carbono orgánico total/kg de suelo) y Programa de fertilización mineral (estándar, F1 vs. reducida, F2)sobre la acumulación y distribución de la biomasa producida (expresada en g de materia seca/contenedor) por Medicago sativa a lo largo del experimento

Tabla 4.4.12. Influencia de la materia orgánica soluble (MOS) extraída de los composts A y A+H, la dosis de aplicación de ésta (en $\mathrm{mg}$ de carbono orgánico total/kg de suelo) y el programa de fertilización mineral (estándar, F1 y reducida, F2) en la acumulación de biomasa en la parte aérea de Medicago sativa (expresada en g de materia seca/contenedor) en los cuatros cortes efectuados $\left(1^{\circ}\right.$ a $\left.4^{\circ}\right)$ a lo largo del experimento. Comparación con los controles (CO, que no recibieron MOS)... 
Tabla 4.4.13. Influencia de la materia orgánica soluble (MOS) extraída de los composts A y A+H, la dosis de aplicación de ésta (en mg de carbono orgánico total/kg de suelo) y el programa de fertilización mineral (estándar, F1 y reducida, F2) en la acumulación y distribución de la biomasa producida (expresada en g de materia seca/contenedor) por Medicago sativa en el experimento. Comparación con los controles (CO, que no recibieron MOS) .....

Tabla 4.4.14. Efectos principales de los tratamientos estudiados -Materia orgánica soluble (MOS) extraída del compost (A vs. A+H) y Dosis de aplicación de ésta (en mg de carbono orgánico total/kg de suelo) - sobre las características físico-químicas y la composición (sobre materia seca) del suelo (abonado con el programa de fertilización mineral reducida [F2] y cultivado con Medicago sativa) al final del experimento

Tabla 4.4.15. Influencia de la materia orgánica soluble (MOS) extraída de los composts A y A+H y la dosis de aplicación de ésta (en mg de carbono orgánico total/kg de suelo) en las características físico-químicas y la composición (sobre materia seca) del suelo (abonado con el programa de fertilización reducida [F2] y cultivado con Medicago sativa) al final del experimento. Comparación con el control (CO F2, que no recibió MOS)

Tabla 4.4.16. Efectos principales de los tratamientos estudiados -Materia orgánica soluble (MOS) extraída del compost (A vs. A+H) y Dosis de aplicación de ésta (en mg de carbono orgánico total/kg de suelo) - sobre las características físico-químicas y la composición (sobre materia seca) del suelo (abonado con el programa de fertilización mineral reducida [F2] y no cultivado, desnudo) al final del experimento.....

Tabla 4.4.17. Influencia de la materia orgánica soluble (MOS) extraída de los composts $A$ y $A+H$ y de la dosis de aplicación de ésta (en mg de carbono orgánico total/kg de suelo) en las características físico-químicas y la composición (sobre materia seca) del suelo (abonado con el programa de fertilización mineral reducida [F2] y no cultivado, desnudo) al final del experimento. Comparación con el control (CO F2, que no recibió MOS)

Tabla 4.4.18. Efectos principales de los tratamientos estudiados -Materia orgánica soluble (MOS) extraída del compost (A vs. A+H), Dosis de aplicación de ésta (en mg de carbono orgánico total/kg de suelo) y Cultivo de Medicago sativa (presente, + vs. ausente, -)- sobre las características físico-químicas y la composición (sobre materia seca) del suelo al final de los experimentos.

Tabla 4.5.1. Descripción macroscópica de las cepas de actinomicetos aisladas (en el medio ISP-2) de los composts $\mathrm{A}$ y $\mathrm{A}+\mathrm{H}$ y del suelo calizo enmendado con dichos composts

Tabla 4.5.2. Efecto antagonista de las cepas de actinomicetos aisladas frente a cinco hongos fitopatógenos seleccionados utilizando el medio de cultivo YMA

Tabla 4.5.3. Efecto antagonista de las cepas de actinomicetos aisladas frente a cinco hongos fitopatógenos seleccionados utilizando el medio de cultivo PDA.

Tabla 4.5.4. Radio (en $\mathrm{mm}$ ) de los halos de inhibición entre el crecimiento de Agrobacterium tumefaciens (en tres concentraciones, equivalentes a 1,5·107, 1,5.106 y 1,5·10 $\mathrm{UFC} / \mathrm{mL}$ ) y las cepas de actinomicetos cultivadas previamente en los medios YMA y PDA tras 48 horas de incubación en medio PCA.

Tabla 4.5.5. Identificación de los aislados de actinomicetos mediante análisis 16S rDNA y características fenotípicas de los mismos.

Tabla 4.5.6. Efectos principales de los tratamientos estudiados -Compost (A vs. A+H) y Dosis de inóculo (D1 vs. D2) - sobre parámetros seleccionados, indicadores de la severidad de la enfermedad ocasionada por Fusarium oxysporum f. sp. melonis (FOM) en plantas de melón .

Tabla 4.5.7. Parámetros indicadores de la severidad de la enfermedad ocasionada por Fusarium oxysporum f. sp. melonis en plantas de melón cultivadas en sustratos preparados con los composts $\mathrm{A}$ y $\mathrm{A}+\mathrm{H}$

Tabla 4.5.8. Efectos principales de los tratamientos estudiados -Mezcla (con A, 8\% vs. 16\%) y Dosis de inóculo (D1 vs. D2)- sobre parámetros seleccionados, indicadores de la severidad de la enfermedad ocasionada por Fusarium oxysporum f. sp. melonis (FOM) en plantas de melón 
Tabla 4.5.9. Parámetros indicadores de la severidad de la enfermedad ocasionada por Fusarium oxysporum f. sp. melonis en plantas de melón cultivadas en sustratos preparados con el compost A.

Tabla 4.6.1. Características físicas y físico-químicas seleccionadas, y composición (sobre materia seca) de los suelos contaminados (S1 y S2) y sus respectivos suelos control no contaminados (SC1 y SC2). Valores expresados como la media \pm la desviación estándar.

Tabla 4.6.2. Concentración total, concentración biodisponible y fracción biodisponible de los elementos traza determinados en los suelos contaminados (S1 y S2) y en sus respectivos suelos control no contaminados (SC1 y SC2). Valores expresados como la media \pm la desviación estándar

Tabla 4.6.3. Principales poblaciones microbianas (bacterias heterótrofas, actinomicetos, y mohos y levaduras) y su actividad respiratoria e hidrolítica en los suelos contaminados (S1 y S2) y en sus respectivos suelos control no contaminados (SC1 y SC2).....

Tabla 4.6.4. Resultados del bioensayo de crecimiento de raíces de cebada (Hordeum vulgare) en los suelos contaminados (S1 y S2) en comparación con sus respectivos suelos control no contaminados (SC1 y SC2) y un control adicional de arena

Tabla 4.6.5. Efecto de la aplicación del compost A sobre la concentración total y biodisponible $(\mathrm{mg} / \mathrm{kg})$ y sobre la fracción biodisponible (\% del total) de los elementos traza determinados en los suelos contaminados (S1 y S2) y en sus respectivos suelos control no contaminados (SC1 y $\mathrm{SC} 2)$.

Tabla 4.6.6. Supervivencia y producción de biomasa del vástago (g de materia seca) en las cinco especies de Brassica tras 16 semanas de cultivo en los suelos contaminados (S1 y S2) y en sus respectivos suelos control no contaminados (SC1 y SC2) tanto enmendados con el compost A (+) como no enmendados (-)

Tabla 4.6.7. Concentración ( $\mu \mathrm{g} / \mathrm{g} \mathrm{ms}$ ) y acumulación total ( $\mu \mathrm{g})$ de Pb y Zn en los vástagos de las cinco especies de Brassica tras 16 semanas de cultivo en el suelo básico contaminado S1 y en su respectivo suelo control no contaminado SC1 tanto enmendados con el compost A (+) como no enmendados $(-)$.

Tabla 4.6.8. Concentración y acumulación total de Al, As, $\mathrm{Pb}$ y $\mathrm{Zn}$ en los vástagos de tres especies de Brassica tras 16 semanas de cultivo en el suelo ácido contaminado S2 y en su respectivo suelo control no contaminado $\mathrm{SC} 2$, ambos enmendados con el compost $\mathrm{A}$.

Tabla 4.6.9. Factores de bioconcentración (FBC y FBC') para Al, As, Pb y Zn en los vástagos de las cinco especies de Brassica cultivadas durante 16 semanas en los suelos contaminados S1 y S2 tanto enmendados con el compost A (+) como no enmendados (-) .

Tabla 4.7.1. Valores de la eficiencia de acidificación (e.a., \%) y de los parámetros relacionados con su cálculo para las dos dosis de azufre elemental $\left(\mathrm{S}^{0}\right)$ micronizado estudiadas.

Tabla 4.7.2. Parámetros de ajuste al modelo exponencial $\mathrm{pH}_{\mathrm{t}}=\mathrm{pH}_{\text {final }}+\mathrm{a} \cdot \mathrm{e}^{(-\mathrm{b} \cdot \mathrm{t})}$ para la variación del $\mathrm{pH}$ del compost enmendado con azufre elemental $\left(\mathrm{S}^{0}\right)$ micronizado a las dosis 1xD y 1,5xD durante el ensayo de acidificación

Tabla 4.7.3. Características macroscópicas y resultados de la tinción Gram y de las pruebas bioquímicas de la catalasa y la oxidasa realizadas en las cepas aisladas del compost A enmendado con $\mathrm{S}^{0}$

Tabla 4.7.4. Características macroscópicas y resultados de la tinción Gram y de las pruebas bioquímicas de la catalasa y la oxidasa realizadas en las cepas de referencia de la Colección del Instituto Pasteur (CIP) 
Tabla 4.7.5. Variaciones $(\Delta)$ respecto al compost original no enmendado $(\mathrm{pH}=9,17$ y conductividad eléctrica $[C E]=3,65 \mathrm{dS} / \mathrm{m}$ ) del $\mathrm{pH}$ y la conductividad eléctrica (CE), y eficiencia de acidificación (e.a.), del compost no autoclavado y no inoculado, y de los composts esterilizados e inoculados con las cepas aisladas del compost enmendado e identificadas como Halothiobacillus neapolitanus (Alp 15) y Paracoccus thiocyanatus (Alp 1, Alp 8-1, Alp 8-2, Alp 83, Alp 17, Alp 18, y Alp 30), o con las tres cepas de referencia procedentes del Instituto Pasteur (Halothiobacillus neapolitanus CIP 104769, Thiobacillus denitrificans CIP 104767 y Thiomonas intermedia CIP 104401) tras 18 días desde la enmienda con So

Tabla 4.7.6. Variaciones $(\Delta)$ respecto al compost original no enmendado $(\mathrm{pH}=9,17$, conductividad eléctrica $[\mathrm{CE}]=3,65 \mathrm{dS} / \mathrm{m}$, y población de bacterias oxidadoras del azufre $=3,2 \cdot 10^{7} \mathrm{UFC} / \mathrm{g}$ ) del $\mathrm{pH}$, la conductividad eléctrica (CE) y la población de bacterias oxidadoras del azufre, y eficiencia de acidificación (e.a.), del compost no inoculado (control) y del compost inoculado con las tres cepas de referencia procedentes del Instituto Pasteur (Halothiobacillus neapolitanus CIP 104769, Thiobacillus denitrificans CIP 104767 y Thiomonas intermedia CIP 104401) tras 25 días desde la enmienda con So 
ÍNDICE DE FIGURAS 
Figura 1.1. Países productores de aceite de oliva en el mundo en 2009/2010.

Figura 1.2. Esquema de las operaciones del proceso de elaboración del aceite de oliva con los sistemas de prensado y centrifugación de tres y dos fases.

Figura 4.1.1. Histograma de frecuencias del tamaño de partícula de los dos composts estudiados $(\mathrm{A}$ y $\mathrm{A}+\mathrm{H})$.

Figura 4.1.2. Parámetros determinados (G, Lm e IG) en los bioensayos de germinación de semillas de berro (izquierda) y de lechuga (derecha) realizados, utilizando los extractos acuosos puros y diluidos (al 25\%) de los dos composts estudiados ( $\mathrm{A}$ y $\mathrm{A}+\mathrm{H}$ )

Figura 4.1.3. Distribución ortogonal del análisis de componentes principales (CP1 y CP2) para los composts A y $\mathrm{A}+\mathrm{H}$ (arriba), y para los parámetros físicos, físico-químicos, químicos y biológicos determinados en éstos (abajo).

Figura 4.2.1. Variación de la concentración de nitrógeno mineral $\left(\mathrm{N}_{-} \mathrm{NH}_{4}{ }^{+}\right.$y $\mathrm{N}-\mathrm{NO}_{3}{ }^{-}$) en el suelo tratado con los composts $\mathrm{A}$ y $\mathrm{A}+\mathrm{H}$ a las dosis de 12, 24 y 48 t/ha a lo largo del ensayo de incubación. Comparación con el control ( $\mathrm{CO}$, que no recibió compost).

\left. Figura 4.2.2. Mineralización/inmovilización neta ( ${\mathrm{N}-\mathrm{NH}_{4}+}^{+}+\mathrm{N}-\mathrm{NO}_{3}{ }^{-}\right)$del nitrógeno orgánico en el suelo -tratado con los composts $\mathrm{A}$ y $\mathrm{A}+\mathrm{H}$ a las dosis de 12, 24 y $48 \mathrm{t} / \mathrm{ha}-$ a lo largo del ensayo de incubación (resultados obtenidos restando los valores en el control)......

Figure 4.2.3. Influence of compost application ( $\mathrm{A}$ and $\mathrm{A}+\mathrm{H}$ at $24 \mathrm{Mg}$ total organic matter ha-1) to two different textured soils (S1 and S2) on soil mineral nitrogen concentration $\left(\mathrm{NO}_{3}^{-}-\mathrm{N}+\mathrm{NH}_{4}^{+}-\mathrm{N}\right)$ throughout the incubation experiment.

Figure 4.2.4. Influence of compost application ( $\mathrm{A}$ and $\mathrm{A}+\mathrm{H}$ at $24 \mathrm{Mg}$ total organic matter ha-1) to two different textured soils (S1 and S2) on soil microbial biomass carbon $\left(\mathrm{B}_{\mathrm{c}}\right)$ and on soil microbial biomass nitrogen $\left(B_{N}\right)$ throughout the incubation experiment. Results are expressed as changes with regard to the initial values for each treatment.

Figure 4.2.5. Influence of compost application ( $\mathrm{A}$ and $\mathrm{A}+\mathrm{H}$ at $24 \mathrm{Mg}$ total organic matter ha-1) to two different textured soils (S1 and $S 2)$ on soil basal respiration throughout the incubation experiment.

Figure 4.2.6. Influence of compost application ( $\mathrm{A}$ and $\mathrm{A}+\mathrm{H}$ at $24 \mathrm{Mg}$ total organic matter ha-1) to two different textured soils (S1 and S2) on net cumulative values of soil respiration (control values substracted) throughout the incubation experiment

Figure 4.2.7. Influence of compost application ( $\mathrm{A}$ and $\mathrm{A}+\mathrm{H}$ at $24 \mathrm{Mg}$ total organic matter ha-1) to two different textured soils (S1 and S2) on arginine ammonification throughout the incubation experiment

Figure 4.2.8. Influence of compost application ( $\mathrm{A}$ and $\mathrm{A}+\mathrm{H}$ at $24 \mathrm{Mg}$ total organic matter ha-1) to two different textured soils (S1, left and S2, right) on alkaline and acid phosphomonoesterase activities and on phosphodiesterase activity throughout the incubation experiment.

Figure 4.2.9. Influence of compost application ( $\mathrm{A}$ and $\mathrm{A}+\mathrm{H}$ at $24 \mathrm{Mg}$ total organic matter ha-1) to two different textured soils (S1, left and S2, right) on $\beta$-glucosidase and on protease activities throughout the incubation experiment.

Figura 4.3.1. Influencia del compost $(A$ y $A+H)$, la dosis de aplicación de éste (D1 y D2, equivalentes a 12 y 24 t de materia orgánica total/ha, respectivamente) y el programa de fertilización mineral (estándar, F1 y reducida, F2) en el crecimiento vegetativo (hojas y raíz) de rábano. Comparación con los controles ( $\mathrm{CO}$, que no recibieron compost). Primer año del experimento (Año 1)

Figura 4.3.2. Influencia del compost $(A$ y $A+H)$, la dosis de aplicación de éste (D1 y D2, equivalentes a 12 y 24 t de materia orgánica total/ha, respectivamente) y el programa de fertilización mineral (estándar, F1 y reducida, F2) en la acumulación y distribución de biomasa en rábano. Comparación con los controles (CO, que no recibieron compost). Año 1 
Figura 4.3.3. Influencia del compost (A y A+H), la dosis de aplicación de éste (D1 y D2, equivalentes a 12 y 24 t de materia orgánica total/ha, respectivamente) y el programa de fertilización mineral (estándar, F1 y reducida, F2) en la producción total de raíces en rábano. Comparación con los controles (CO, que no recibieron compost). Año 1 ......

Figura 4.3.4. Influencia del compost $(\mathrm{A}$ y $\mathrm{A}+\mathrm{H})$, la dosis de aplicación de éste (D1 y D2, equivalentes a 12 y 24 t de materia orgánica total/ha, respectivamente) y el programa de fertilización mineral (estándar, F1 y reducida, F2) en el desarrollo de la hoja de lechuga. Comparación con los controles (CO, que no recibieron compost). Año 1

Figura 4.3.5. Influencia del compost $(\mathrm{A}$ y $\mathrm{A}+\mathrm{H}$ ), la dosis de aplicación de éste (D1 y D2, equivalentes a 12 y 24 t de materia orgánica total/ha, respectivamente) y el programa de fertilización mineral (estándar, F1 y reducida, F2) en la acumulación y distribución de biomasa en lechuga. Comparación con los controles (CO, que no recibieron compost). Año 1.

Figura 4.3.6. Influencia del compost $(\mathrm{A}$ y $\mathrm{A}+\mathrm{H}$ ), la dosis de aplicación de éste (D1 y D2, equivalentes a 12 y 24 t de materia orgánica total/ha, respectivamente) y el programa de fertilización mineral (estándar, F1 y reducida, F2) en la producción total de cogollos de lechuga. Comparación con los controles (CO, que no recibieron compost). Año 1

Figura 4.3.7. Influencia del compost $(\mathrm{A}$ y $\mathrm{A}+\mathrm{H}$ ), la dosis de aplicación de éste (D1 y D2, equivalentes a 12 y 24 t de materia orgánica total/ha, respectivamente) y el programa de fertilización mineral (estándar, F1 y reducida, F2) en el crecimiento vegetativo (tallo, hojas y raíz) y el desarrollo reproductivo (vainas) de judía. Comparación con los controles (CO, que no recibieron compost). Año 1.

Figura 4.3.8. Influencia del compost $(\mathrm{A}$ y $\mathrm{A}+\mathrm{H}$ ), la dosis de aplicación de éste (D1 y D2, equivalentes a 12 y 24 t de materia orgánica total/ha, respectivamente) y el programa de fertilización mineral (estándar, F1 y reducida, F2) en la acumulación y distribución de biomasa en judía. Comparación con los controles (CO, que no recibieron compost). Año 1.

Figura 4.3.9. Evolución temporal de la producción acumulada de vainas de judía (expresada como porcentaje [\%] de la producción total obtenida en las cuatro recolecciones realizadas) en los tratamientos con los composts $\mathrm{A}$ y $\mathrm{A}+\mathrm{H}$ a las dosis D1 y D2 (equivalentes a 12 y $24 \mathrm{t}$ de materia orgánica total/ha, respectivamente) en combinación con la fertilización mineral (programa F1, estándar, arriba y F2, reducida, abajo). Comparación con los controles (CO, que no recibieron compost). Año 1

Figura 4.3.10. Influencia del compost $(A$ y $A+H)$, la dosis de aplicación de éste (D1 y D2, equivalentes a 12 y 24 t de materia orgánica total/ha, respectivamente) y el programa de fertilización mineral (estándar, F1 y reducida, F2) en el crecimiento vegetativo (hojas y raíz) de rábano. Comparación con los controles (CO, que no recibieron compost). Segundo año del experimento (Año 2)

Figura 4.3.11. Influencia del compost $(A$ y $A+H)$, la dosis de aplicación de éste (D1 y D2, equivalentes a 12 y 24 t de materia orgánica total/ha, respectivamente) y el programa de fertilización mineral (estándar, F1 y reducida, F2) en la acumulación y distribución de biomasa en rábano. Comparación con los controles (CO, que no recibieron compost). Año 2

Figura 4.3.12. Influencia del compost $(A$ y $A+H)$, la dosis de aplicación de éste (D1 y D2, equivalentes a 12 y 24 t de materia orgánica total/ha, respectivamente) y el programa de fertilización mineral (estándar, F1 y reducida, F2) en la producción total de raíces en rábano. Comparación con los controles (CO, que no recibieron compost). Año 2

Figura 4.3.13. Influencia del compost $(A$ y $A+H)$, la dosis de aplicación de éste (D1 y D2, equivalentes a 12 y 24 t de materia orgánica total/ha, respectivamente) y el programa de fertilización mineral (estándar, F1 y reducida, F2) en el desarrollo de la hoja en lechuga. Comparación con los controles ( $\mathrm{CO}$, que no recibieron compost). Año 2 .....

Figura 4.3.14. Influencia del compost $(A$ y $A+H)$, la dosis de aplicación de éste (D1 y D2, equivalentes a 12 y 24 t de materia orgánica total/ha, respectivamente) y el programa de fertilización mineral (estándar, F1 y reducida, F2) en la acumulación y distribución de biomasa en lechuga. Comparación con los controles (CO, que no recibieron compost). Año 2 ...... 
Figura 4.3.15. Influencia del compost $(\mathrm{A}$ y $\mathrm{A}+\mathrm{H}$ ), la dosis de aplicación de éste (D1 y D2, equivalentes a 12 y $24 \mathrm{t}$ de materia orgánica total/ha, respectivamente) y el programa de fertilización mineral (estándar, F1 y reducida, F2) en la producción total de cogollos de lechuga. Comparación con los controles (CO, que no recibieron compost). Año 2.

Figura 4.3.16. Influencia del compost $(\mathrm{A}$ y $\mathrm{A}+\mathrm{H}$ ), la dosis de aplicación de éste (D1 y D2, equivalentes a 12 y 24 t de materia orgánica total/ha, respectivamente) y el programa de fertilización mineral (estándar, F1 y reducida, F2) en el crecimiento vegetativo (tallo, hojas y raíz) y el desarrollo reproductivo (vainas) de judía. Comparación con los controles (CO, que no recibieron compost). Año 2

Figura 4.3.17. Influencia del compost $(\mathrm{A}$ y $\mathrm{A}+\mathrm{H})$, la dosis de aplicación de éste (D1 y D2, equivalentes a 12 y 24 t de materia orgánica total/ha, respectivamente) y el programa de fertilización mineral (estándar, F1 y reducida, F2) en la acumulación y distribución de biomasa en judía. Comparación con los controles (CO, que no recibieron compost). Año 2.

Figura 4.3.18. Evolución temporal de la producción acumulada de vainas de judía (expresada como porcentaje [\%] de la producción total obtenida en las cuatro recolecciones realizadas) en los tratamientos con los composts $\mathrm{A}$ y $\mathrm{A}+\mathrm{H}$ a las dosis D1 y D2 (equivalentes a 12 y $24 \mathrm{t}$ de materia orgánica total/ha, respectivamente) en combinación con la fertilización mineral (programa F1, estándar, arriba y F2, reducida, abajo). Comparación con los controles (CO, que no recibieron compost). Año 2

Figura 4.3.19. Influencia del compost $(\mathrm{A}$ y $\mathrm{A}+\mathrm{H}$ ), la dosis de aplicación de éste (D1 y D2, equivalentes a 12 y 24 t de materia orgánica total/ha, respectivamente) y el programa de fertilización mineral (estándar, F1 y reducida, F2) en el contenido foliar de nutrientes (expresado en \% de materia seca) en rábano. Comparación con los controles ( $\mathrm{CO}$, que no recibieron compost). Primer año del experimento (Año 1)

Figura 4.3.20. Influencia del compost $(\mathrm{A}$ y $\mathrm{A}+\mathrm{H}$ ), la dosis de aplicación de éste (D1 y D2, equivalentes a 12 y 24 t de materia orgánica total/ha, respectivamente) y el programa de fertilización mineral (estándar, F1 y reducida, F2) en el contenido foliar de nutrientes (expresado en \% de materia seca) en lechuga. Comparación con los controles (CO, que no recibieron compost). Año 1

Figura 4.3.21. Influencia del compost $(\mathrm{A}$ y $\mathrm{A}+\mathrm{H}$ ), la dosis de aplicación de éste (D1 y D2, equivalentes a 12 y 24 t de materia orgánica total/ha, respectivamente) y el programa de fertilización mineral (estándar, F1 y reducida, F2) en el contenido foliar de nutrientes (expresado en \% de materia seca) en judía. Comparación con los controles (CO, que no recibieron compost). Año 1

Figura 4.3.22. Influencia del compost $(\mathrm{A}$ y $\mathrm{A}+\mathrm{H}$ ), la dosis de aplicación de éste (D1 y D2, equivalentes a 12 y 24 t de materia orgánica total/ha, respectivamente) y el programa de fertilización mineral (estándar, F1 y reducida, F2) en el contenido foliar de nutrientes (expresado en \% de materia seca) en rábano. Comparación con los controles (CO, que no recibieron compost). Segundo año del experimento (Año 2).

Figura 4.3.23. Influencia del compost $(A$ y $A+H)$, la dosis de aplicación de éste (D1 y D2, equivalentes a 12 y 24 t de materia orgánica total/ha, respectivamente) y el programa de fertilización mineral (estándar, F1 y reducida, F2) en el contenido foliar de nutrientes (expresado en \% de materia seca) en lechuga. Comparación con los controles (CO, que no recibieron compost). Año 2

Figura 4.3.24. Influencia del compost $(\mathrm{A}$ y $\mathrm{A}+\mathrm{H}$ ), la dosis de aplicación de éste (D1 y D2, equivalentes a 12 y 24 t de materia orgánica total/ha, respectivamente) y el programa de fertilización mineral (estándar, F1 y reducida, F2) en el contenido foliar de nutrientes (expresado en \% de materia seca) en judía. Comparación con los controles (CO, que no recibieron compost). Año 2 
Figura 4.3.25. Influencia del compost $(\mathrm{A}$ y $\mathrm{A}+\mathrm{H}$ ), la dosis de aplicación de éste (D1 y D2, equivalentes a 12 y 24 t de materia orgánica total/ha, respectivamente) y el programa de fertilización mineral (estándar, F1 y reducida, F2) en el pH y la conductividad eléctrica (CE) del suelo al final del primer año del experimento (Año 1). Comparación con los controles (CO, que no recibieron compost).

Figura 4.3.26. Influencia del compost $(\mathrm{A}$ y $\mathrm{A}+\mathrm{H}$ ), la dosis de aplicación de éste (D1 y D2, equivalentes a 12 y 24 t de materia orgánica total/ha, respectivamente) y el programa de fertilización mineral (estándar, F1 y reducida, F2) en la composición química del suelo al final del primer año del experimento (Año 1). Comparación con los controles (CO, que no recibieron compost)

Figura 4.3.27. Influencia del compost $(A$ y $A+H)$, la dosis de aplicación de éste (D1 y D2, equivalentes a 12 y 24 t de materia orgánica total/ha, respectivamente) y el programa de fertilización mineral (estándar, F1 y reducida, F2) en el pH y la conductividad eléctrica (CE) del suelo al final del segundo año del experimento (Año 2). Comparación con los controles (CO, que no recibieron compost).

Figura 4.3.28. Influencia del compost $(A$ y $A+H)$, la dosis de aplicación de éste (D1 y D2, equivalentes a 12 y 24 t de materia orgánica total/ha, respectivamente) y el programa de fertilización mineral (estándar, F1 y reducida, F2) en la composición química del suelo al final del segundo año del experimento (Año 2). Comparación con los controles (CO, que no recibieron compost)

Figura 4.5.1. Imágenes de los efectos supresivos de cepas de actinomicetos aisladas frente a los agentes fitopatógenos seleccionados.

Figura 4.5.2. Árboles filogenéticos basados en las secuencias del gen $16 \mathrm{~S}$ rDNA, mostrando la relación entre los once Streptomyces aislados y las cepas de referencia de dicho género. Las cifras en los nodos indican el valor obtenido en 1000 remuestreos (bootstrapping). Sólo se muestran los valores superiores al 50\%. La escala indica 0,02 sustituciones por nucleótido...

Figura 4.5.3. Árbol filogenético basado en las secuencias del gen 16S rDNA, mostrando la relación entre la cepa de Lechevalieria sp. aislada (T2-19) y las cepas de referencia de dicho género. Las cifras en los nodos indican el valor obtenido en 1000 remuestreos (bootstrapping). Sólo se muestran los valores superiores al 50\%. La escala indica 0,02 sustituciones por nucleótido......

Figura 4.5.4. Porcentaje de plantas infectadas, peso fresco y longitud del tallo en plantas de melón cultivadas en sustratos preparados con los composts $\mathrm{A}$ y $\mathrm{A}+\mathrm{H}$ infectados con diferentes dosis de inóculo de Fusarium oxysporum f. sp. melonis.

Figura 4.5.5. Curva de progresión de la enfermedad en plantas de melón cultivadas en sustratos preparados con los composts $\mathrm{A}$ y $\mathrm{A}+\mathrm{H}$ infectados con diferentes dosis de inóculo de Fusarium oxysporum f. sp. melonis .

Figura 4.5.6. Porcentaje de plantas infectadas, peso fresco y longitud del tallo en plantas de melón cultivadas en sustratos preparados con el compost A infectados con diferentes dosis de inóculo de Fusarium oxysporum f. sp. melonis.

Figura 4.5.7. Curva de progresión de la enfermedad en plantas de melón cultivadas en sustratos preparados con el compost A infectados con diferentes dosis de inóculo de Fusarium oxysporum f. sp. melonis

Figura 4.6.1. Población de bacterias heterótrofas, actinomicetos, y mohos y levaduras en los suelos contaminados (S1 y S2) y en sus respectivos suelos control no contaminados (SC1 y SC2) tanto enmendados con el compost $A(+)$ como no enmendados (-), después de 16 semanas

Figura 4.6.2. Respiración microbiana e hidrólisis del diacetato de fluoresceína (FDA) en los suelos contaminados (S1 y S2) y en sus respectivos suelos control no contaminados (SC1 y SC2) tanto enmendados con el compost A (+) como no enmendados (-), después de 16 semanas 


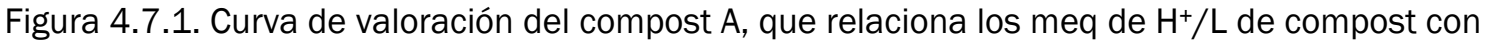
los valores de $\mathrm{pH}$

Figura 4.7.2. Variación del $\mathrm{pH}$ y de la conductividad eléctrica (CE) del compost A a lo largo del ensayo de acidificación con azufre elemental $\left(\mathrm{S}^{0}\right)$ micronizado

Figura 4.7.3. Relación entre el incremento de la conductividad eléctrica $(\triangle C E)$ y la disminución incremento del $\mathrm{pH}(\Delta \mathrm{pH})$ del compost A durante la acidificación de éste con azufre elemental $\left(\mathrm{S}^{\circ}\right)$ micronizado

Figura 4.7.4. Variación del pH y del contenido en carbonatos y en sulfatos del compost A a lo largo del ensayo de acidificación con azufre elemental $\left(\mathrm{S}^{0}\right)$ micronizado.

Figura 4.7.5. Variación de las poblaciones microbianas estudiadas en el compost A a lo largo del ensayo de acidificación con azufre elemental $\left(\mathrm{S}^{0}\right)$ micronizado

Figura 4.7.6. Viraje del medio 152 de la colección ATCC (American Type Culture Collection) a las 24 y 48 horas tras la siembra de una cepa aislada del compost A enmendado con $\mathrm{S}^{0}$

Figura 4.7.7. Productos de la amplificación del 16S rADN de algunas cepas seleccionadas del compost $A$ enmendado con azufre elemental $\left(\mathrm{S}^{0}\right)$ micronizado

Figura 4.7.8. Árbol que muestra las relaciones filogenéticas entre los aislados Alp 1, Alp 8-1, Alp 8-2, Alp 8-3, Alp 17, Alp 18 y Alp 30 y las especies tipo del género Paracoccus más cercanas. Las cifras en los nodos indican el valor obtenido en 1000 remuestreos (bootstrapping). Sólo se muestran los valores superiores al 50\%. La escala indica 0,02 sustituciones por nucleótido.

Figura 4.7.9. Árbol que muestra las relaciones filogenéticas entre el aislado Alp 15 y las especies tipo del género Halothiobacillus más cercanas. Las cifras en los nodos indican el valor obtenido en 1000 remuestreos (bootstrapping). Sólo se muestran los valores superiores al $50 \%$. La escala indica 0,02 sustituciones por nucleótido 
ÍNDICE DE FOTOGRAFÍAS 
Fotografía 3.1. Composts de alperujo $(\mathrm{A}$ y $\mathrm{A}+\mathrm{H})$ estudiados en esta Tesis Doctoral. 78

Fotografía 3.2. Vista aérea de la parcela de donde se muestreó el suelo calizo utilizado en esta Tesis Doctoral.

Fotografía 3.3. Vista de la disposición de las macetas sin cultivar utilizadas en el estudio de las propiedades físicas, físico-químicas y químicas del suelo enmendado con los composts $\mathrm{A}$ y $\mathrm{A}+\mathrm{H}$ un año después de la aplicación de éstos.

Fotografía 3.4. Vista general de la parcela y los tres cultivos en contenedor estudiados en la evaluación agronómica de los composts A y A+H durante el primer año (Año 1) del experimento. Rábano (arriba), lechuga (centro) y judía (abajo).

Fotografía 3.5. Vista general de las plantas de alfalfa cultivadas en maceta tras la aplicación de materia orgánica soluble (MOS) al suelo calizo utilizado.

Fotografía 3.6. Vista general de las plantas de melón utilizadas en el bioensayo de supresividad in vivo con los composts $\mathrm{A}$ y $\mathrm{A}+\mathrm{H}$ (Experimento 1 ).

Fotografía 4.3.1. Imagen que compara las plantas de rábano producidas en los tratamientos (mezclas de suelo) con los composts A y A+H, aplicados a las dosis D1 y D2 (equivalentes a 12 y 24 t materia orgánica total/ha, respectivamente), junto con el programa de fertilización mineral estándar (F1), y en el control (CO, que no recibió aporte de materia orgánica) con idéntica fertilización mineral. Año 1 del experimento.

Fotografía 4.3.2. Imagen que compara las piezas de lechuga producidas en los tratamientos (mezclas de suelo) con los composts A y A+H, aplicados a las dosis D1 y D2 (equivalentes a 12 y 24 t materia orgánica total/ha, respectivamente), junto con el programa de fertilización mineral estándar (F1), y en el control (CO, que no recibió aporte de materia orgánica) con idéntica fertilización mineral. Año 1 del experimento.

Fotografía 4.3.3. Imagen que compara las plantas de judía producidas en los tratamientos (mezclas de suelo) con los composts A y A+H, aplicados a las dosis D1 y D2 (equivalentes a 12 y 24 t materia orgánica total/ha, respectivamente), junto con el programa de fertilización mineral estándar (F1), y en el control (CO, que no recibió aporte de materia orgánica) con idéntica fertilización mineral. Año 1 del experimento.

Fotografía 4.4.1. Crecimiento de plantas de alfalfa en maceta inmediatamente antes de realizar el cuarto corte (o siega) en el experimento de evaluación agronómica de la materia orgánica soluble (MOS) extraída de los composts A y A+H. 
1. INTRODUCCIÓN 


\subsection{SUBPRODUCTOS Y RESIDUOS DE LA INDUSTRIA AGROALIMENTARIA. UNA VISIÓN GLOBAL}

\subsubsection{Preámbulo}

Se define como residuo el material que no es el producto primario de un proceso (es decir, que no se ha producido con vistas a su comercialización en el mercado) y que no puede ser utilizado por quien lo generó para los fines propios de la producción, transformación o consumo, y que, por ello, debe ser desechado/eliminado. Los residuos pueden generarse durante la extracción de materias primas, en su procesado para elaborar otros productos (intermedios o finales), durante el consumo de productos finales, o por otras actividades realizadas por el ser humano (OECD, 2003; UN - United Nations, 1997).

Por consiguiente, los residuos carecen de valor económico tanto por la inexistencia de tecnologías adecuadas para su reciclado y aprovechamiento como por la dificultad en la comercialización de los productos recuperados, bien sea por su elevado coste, la ausencia de mercados para tales materiales, o el rechazo del mercado a dichos productos.

Con el fin de proteger la salud humana y el medio ambiente de los efectos deletéreos derivados de la generación de residuos, éstos están sujetos a legislación específica, distinguiéndose: legislación comunitaria (Directiva 2008/98/CE del Parlamento Europeo y del Consejo, de 19 de noviembre, sobre los residuos y por la que se derogan determinadas Directivas), estatal (Ley 10/1998, de 21 de abril, de residuos, modificada y derogada parcialmente por la Ley 16/2002, de 1 de julio, y la Ley 34/2007, de 15 de noviembre), y autonómica (Ley 10/2000, de 12 de diciembre, de residuos de la Comunidad Valenciana). Éstas aplican el término residuo a "cualquier sustancia u objeto del cual su poseedor se desprenda o del que tenga la intención o la obligación de desprenderse", teniendo en consideración los que figuran en la Lista Europea de Residuos (Decisión 2000/532/CE de la Comisión, de 3 de mayo, modificada posteriormente por otras Decisiones, y transpuesta por la Orden MAM/304/2002, de 8 de febrero).

La definición de residuo ha sido un aspecto clave en la protección del medio ambiente contra los efectos de la generación y la gestión inadecuada de los residuos en los últimos años. Sin embargo, han surgido algunos problemas -en el ámbito 
jurídico- en relación con la interpretación de este término. Por ello, y a efectos de aplicación de la legislación ambiental, es primordial distinguir entre materiales residuales y materiales que no son el objeto principal del proceso de producción, pero que se consideran subproductos (y no residuos). Dicha necesidad ya se expresó en la Comunicación de la Comisión, de 21 de febrero de 2007, titulada "Comunicación interpretativa sobre residuos y subproductos"; posteriormente, la Directiva 2008/98/CE, en su artículo 5, recoge la definición del término subproducto como "sustancia u objeto resultante de un proceso de producción, producida como parte integrante de éste, cuya finalidad primaria no es la producción de esa sustancia u objeto, que va a ser utilizado ulteriormente para un uso legal, y que puede además utilizarse directamente sin tener que someterse a una transformación posterior distinta de la práctica industrial normal". Por otro lado, la Directiva mencionada también especifica los criterios que debe reunir un material para que deje de ser considerado residuo, bajo la denominación de “fin de condición de residuo" (del inglés "end-of-waste"): debe haber sido sometido a una operación de valorización, incluyendo el reciclado; tiene que poder ser utilizado para finalidades específicas; debe cumplir los requerimientos técnicos y la legislación y normas aplicables al producto; ha de existir un mercado o una demanda para dicha sustancia u objeto; y, no debe generar impactos adversos sobre el medio ambiente o la salud humana.

Asimismo, la Estrategia Temática para la Prevención y el Reciclado -recogida en la Comunicación de la Comisión $\operatorname{COM}(2005)$ 666, de 21 de diciembre- establece, como objetivo a largo plazo, que la Unión Europea se convierta en una sociedad del reciclado, que trate de evitar la generación de residuos, y que, en su lugar, éstos puedan ser utilizados como recursos. Tal fin se encuentra incluido, a su vez, en las prioridades de la Estrategia Europa 2020, con la que se pretende promover un uso más eficiente de los recursos para garantizar la sostenibilidad de los sectores de producción (Comunicación de la Comisión COM(2011) 21, de 26 de enero).

Los residuos pueden clasificarse, según su naturaleza, en orgánicos e inorgánicos, destacando los primeros en virtud del alto volumen generado y su fuerte impacto sobre el medio ambiente. 
Desde el punto de vista de los distintos sectores de actividad (producción y consumo) que generan residuos orgánicos, se distinguen tres grandes grupos (Abad y Puchades, 2002; Bernal y Gondar, 2008; Climent et al., 1996):

- Sector primario: residuos agrícolas, ganaderos y forestales

- Sector secundario: residuos industriales (agroalimentarios, papeleros, textiles, etc.)

- Sector terciario: residuos urbanos (residuos sólidos urbanos, lodos de depuración de aguas residuales, etc.)

Se estima que en la Unión Europea (UE) se producen más de 1600 millones de toneladas anuales de materia orgánica exógena (es decir, materia orgánica aplicable al suelo para mejorar su productividad de acuerdo con la definición dada por la propia UE), de las que el $86 \%$ corresponde al sector primario, el $7 \%$ al sector secundario, y el 7\% restante al sector terciario (Van-Camp et al., 2004).

La industria agroalimentaria es uno de los sectores de mayor importancia en la UE y, como consecuencia de sus actividades, produce gran cantidad de residuos de naturaleza fundamentalmente orgánica. Según los datos recogidos en el año 2008 por la Oficina Europea de Estadística ‘Eurostat' para la UE-27, el sector de la industria de la alimentación, bebidas y tabaco produjo más de 53 millones de toneladas de residuos, de los cuales 35 millones correspondieron a residuos biodegradables de origen vegetal y animal. En dicho año, las industrias agroalimentarias españolas generaron 3,2 millones de toneladas de residuos, estimándose que 2 millones correspondieron a residuos de origen animal y vegetal. Como se verá más adelante, estas cifras de la industria agroalimentaria española son inferiores a las presentadas en otras estadísticas, poniéndose así de manifiesto las dificultades para inventariar los residuos agroindustriales orgánicos y, por tanto, la necesidad urgente de crear bases de datos unificadas y contrastadas (Flotats y Solé, 2008; Ukita et al., 2008).

\subsubsection{Residuos generados. Sus características y composición. Problemática}

Una elevada proporción de las materias (primas) obtenidas en el sector primario se transforman en las industrias agroalimentarias mediante una serie de procesos tecnológicos industrializados, cuya finalidad es elaborar un producto alimenticio preparado para su salida inmediata al mercado y su posterior consumo. Los 
procedimientos empleados varían en función del tipo de industria y de las características de la materia prima y el producto final que se desea obtener, pudiendo ser de naturaleza química, física (o mecánica) y biológica (Seoánez, 2002). Además, las materias primas que se utilizan en las industrias agroalimentarias tienen en común: la complejidad de su composición química; la escasa homogeneidad de las partidas en textura, tamaño y estado; su gran sensibilidad a determinados agentes físicos, siendo materiales perecederos; el desarrollo de microorganismos patógenos o inocuos sobre ellas; $y$, la estacionalidad de su disponibilidad, entre otras características (Aleixandre y García, 1999).

De forma genérica, las industrias agroalimentarias pueden clasificarse en dos grandes grupos: las industrias de primera transformación, que tratan las materias primas y suelen establecerse en las zonas de producción agrícola y ganadera (por ejemplo, industrias extractivas del aceite, productoras de harina a partir de trigo, o mataderos de carne, entre otras); y, las de segunda transformación, que elaboran productos alimentarios a partir de productos agrícolas y ganaderos transformados, y se localizan generalmente en las proximidades de las áreas urbanas, de consumo (industrias panificadoras, de producción de alimentos precocinados, etc.) (Cegarra y Paredes, 2008).

Asimismo, la agrupación de las actividades agroindustriales puede realizarse también según el tipo de residuos que éstas generan, contemplándose entonces dicha clasificación en el marco del Capítulo 02 "Residuos de la agricultura, horticultura, acuicultura, silvicultura, caza y pesca; residuos de la preparación y elaboración de alimentos" de la Lista Europea de Residuos ya citada (Tabla 1.1). De acuerdo con este último criterio, se contemplan un total de 6 subcapítulos -en los que se enmarcan los residuos producidos por las diferentes actividades agroindustriales-, ninguno de ellos catalogado como "residuo peligroso".

Por otro lado, los principales subsectores de la industria agroalimentaria pueden agruparse, en función de la naturaleza de la materia prima utilizada, como de origen vegetal o animal (Tabla 1.2). 
Tabla 1.1. Clasificación de las industrias agroalimentarias en función de los residuos que éstas producen

\begin{tabular}{|c|c|}
\hline Código & Residuo (Origen/Procedencia) \\
\hline 0202 & $\begin{array}{l}\text { Residuos de la preparación y elaboración de carne, pescado y otros alimentos de } \\
\text { origen animal }\end{array}$ \\
\hline 020201 & Lodos de lavado y limpieza \\
\hline 020202 & Residuos de tejidos de animales \\
\hline 020203 & Materiales inadecuados para el consumo o la elaboración \\
\hline 020204 & Lodos del tratamiento in situ de efluentes \\
\hline 020299 & Residuos no especificados en otra categoría \\
\hline 0203 & $\begin{array}{l}\text { Residuos de la preparación y elaboración de frutas, hortalizas, cereales, aceites } \\
\text { comestibles, cacao, café, té y tabaco; producción de conservas; producción de } \\
\text { levadura y extracto de levadura, preparación y fermentación de melazas }\end{array}$ \\
\hline 020301 & Lodos de lavado, limpieza, pelado, centrifugado y separación \\
\hline 020302 & Residuos de conservantes \\
\hline 020303 & Residuos de la extracción con disolventes \\
\hline 020304 & Materiales inadecuados para el consumo o la elaboración \\
\hline 020305 & Lodos del tratamiento in situ de efluentes \\
\hline 020399 & Residuos no especificados en otra categoría \\
\hline 0204 & Residuos de la elaboración de azúcar \\
\hline 020401 & Tierra procedente de la limpieza y lavado de la remolacha \\
\hline 020402 & Carbonato cálcico fuera de especificación \\
\hline 020403 & Lodos del tratamiento in situ de efluentes \\
\hline 020499 & Residuos no especificados en otra categoría \\
\hline 0205 & Residuos de la industria de productos lácteos \\
\hline 020501 & Materiales inadecuados para el consumo o la elaboración \\
\hline 020502 & Lodos del tratamiento in situ de efluentes \\
\hline 020599 & Residuos no especificados en otra categoría \\
\hline 0206 & Residuos de la industria de panadería y pastelería \\
\hline 020602 & Residuos de conservantes \\
\hline 020603 & Lodos del tratamiento in situ de efluentes \\
\hline 020699 & Residuos no especificados en otra categoría \\
\hline 0207 & $\begin{array}{l}\text { Residuos de la producción de bebidas alcohólicas y no alcohólicas (excepto café, té y } \\
\text { cacao) }\end{array}$ \\
\hline 020701 & Residuos de lavado, limpieza y reducción mecánica de materias primas \\
\hline 020702 & Residuos de la destilación de alcoholes \\
\hline 020703 & Residuos del tratamiento químico \\
\hline 020704 & Materiales inadecuados para el consumo o la elaboración \\
\hline 020705 & Lodos del tratamiento in situ de efluentes \\
\hline 020799 & Residuos no especificados en otra categoría \\
\hline
\end{tabular}

Fuente: Lista Europea de Residuos (Decisión 2000/532/CE de la Comisión, de 3 de mayo, modificada posteriormente por otras Decisiones, transpuestas por la Orden MAM/304/2002, de 8 de febrero) 
Tabla 1.2. Clasificación de las principales industrias agroalimentarias según la procedencia de las materias primas que éstas utilizan

\begin{tabular}{|c|c|}
\hline Origen animal & Origen vegetal \\
\hline Industrias cárnicas y mataderos & Industrias de frutas y hortalizas \\
\hline Industrias lácteas y derivados & Industrias de cereales y derivados \\
\hline Industrias del pescado y otros productos marinos & Industria azucarera y productos azucarados \\
\hline \multirow[t]{4}{*}{ Industrias de los huevos y derivados } & Industrias de aceites y grasas \\
\hline & Industrias de bebidas alcohólicas \\
\hline & Industrias de bebidas analcohólicas \\
\hline & Otras industrias (de especias, café y té) \\
\hline
\end{tabular}

Fuente: Aleixandre y García (1999); Seoánez (2002)

\subsubsection{Residuos de origen animal}

De entre los residuos procedentes de las industrias cárnicas y mataderos, se consideran fundamentalmente los provenientes de la anatomía (tejidos y órganos) del animal -sangre, huesos, plumas, pelos, pezuñas, tejidos grasos, conjuntivos y musculares, etc.-, debiendo también incluirse estiércoles, aguas residuales y lodos de flotación, así como materiales de naturaleza vegetal, como el contenido intestinal de los animales consistente en alimentos parcialmente digeridos (Bernal y Gondar, 2008; Cegarra y Paredes, 2008). Se estima que alrededor del $21 \%$ del peso total del animal puede considerarse material residual, o subproducto, de nulo o escaso valor económico (Van-Camp et al., 2004); se trata básicamente de materiales con altos contenidos en proteínas y grasas, y por ello, se caracterizan por su alta concentración en nitrógeno, fósforo, potasio y calcio (Johns, 1995; Mittal, 2006). Generalmente, suele distinguirse entre los subproductos que se generan durante el sacrificio y la “carnización" de los animales, con cierto valor económico, y los residuos derivados de estas actividades, cuya gestión y tratamiento resultan indispensables por motivos higiénicos y ambientales a pesar de no obtenerse beneficio económico de ellos. El valor de estos subproductos ha experimentado un descenso notable en los últimos años debido a que su uso ha ido sustituyéndose progresivamente por el empleo de materiales más novedosos, como las fibras sintéticas y los detergentes en lugar de la lana (o el cuero) y el jabón procedente de la saponificación de las grasas animales, respectivamente (Cegarra y Paredes, 2008).

Por otra parte, las industrias lácteas y sus derivados generan principalmente efluentes como material de desecho, que están sujetos a una alta variabilidad estacional. Además, se elaboran diferentes tipos de productos en estas actividades 
industriales (leche, mantequilla, queso, yogures, postres, etc.), por lo que las características de sus vertidos también varían en función de los distintos sistemas y operaciones de transformación utilizados. Los vertidos de las industrias lácteas y sus derivados proceden de actividades de limpieza (locales, equipos y recipientes), lavado de la mantequilla, refrigeración, condensación de los evaporadores, y restos de leche, suero y otros subproductos (Seoánez, 2002). Estas aguas residuales poseen una alta carga orgánica, constituida principalmente por proteínas, lípidos y lactosa, pH variable (4,4-11), y elevados niveles de $N$ y $P, y$ pueden contener además microorganismos patógenos (Cegarra y Paredes, 2008; Seoánez, 2002).

Los subproductos sólidos que generan las industrias alimentarias del pescado están compuestos por espinas, pieles, cabezas y vísceras de peces; las aguas residuales de estas industrias -tanto con materiales disueltos como con sólidos en suspensión- contienen proteínas, grasas, sangre y pequeñas porciones de pescado, por lo que se caracterizan por sus altas concentraciones de materia orgánica (Kroyer, 1995; Islam et al., 2004).

\subsubsection{Residuos de origen vegetal}

Una gran variedad de industrias producen residuos de origen vegetal, destacando algunos sectores por su importancia en el ámbito agroindustrial: industrias azucareras, industrias conserveras de frutas y hortalizas, industrias de la cerveza, industrias vitivinícolas, industrias del arroz, e industrias de extracción del aceite de oliva, principalmente.

La industria azucarera más común en Europa y España corresponde a la elaboración de azúcar de remolacha, de la que se procesan anualmente alrededor de 100 Mt y 6 Mt, respectivamente. Por cada tonelada de remolacha azucarera se generan $70 \mathrm{~kg}$ de pulpa seca, $230 \mathrm{~kg}$ de lodos de lavado, $60 \mathrm{~kg}$ de lodos calizos y 150 kg de vinazas procedentes de la melaza tras la cristalización del azúcar (Bernal y Gondar, 2008), lo que representa un alto volumen de materiales residuales que precisan una gestión adecuada.

El sector de transformación de frutas y hortalizas engloba diferentes tipos de procesos para su conservación: esterilización por calor, congelación, deshidratación, etc. Las actividades de mayor importancia de estas industrias corresponden a la fabricación de conservas, congelados, zumos y concentrados vegetales. Los rasgos que caracterizan a este tipo de industrias son su carácter estacional, la diversidad de 
materiales procesados, el alto consumo de agua -que supone una elevada producción de efluentes-, y su proximidad a las áreas productoras de las materias primas (Cegarra y Paredes, 2008; Seoánez, 2002; Van-Camp et al., 2004). Los residuos sólidos y líquidos que éstas generan se producen en cantidades más elevadas durante las etapas de acondicionamiento de la materia prima, y su carga contaminante varía en función del tipo de materia prima procesada, la calidad de la misma (frutos dañados, excesiva o insuficientemente maduros, etc.), y la tecnología de fabricación empleada, entre otros factores (Viniegra, 2001). Además, parte de los residuos sólidos se incorporan a los efluentes durante las diferentes operaciones de los procesos de transformación (Cegarra y Paredes, 2008). En general, las aguas residuales son ricas en glúcidos, nitrógeno y sodio, y generan lodos y gases (Seoánez, 2002).

En cuanto a los materiales residuales de la industria de la cerveza, la elaboración del producto se realiza a partir de diferentes cereales en estado crudo o malteado, siendo la cebada el más común y el único que precisa necesariamente ser malteado. Para su producción se usan tres materiales básicos: malta de cebada, lúpulo y agua; y, adicionalmente, levadura y otros aditivos. En el proceso de fabricación se generan una serie de subproductos y residuos tales como efluentes, gas carbónico, levaduras, tierra filtrante, brotes y puré de malta, estimándose una producción de $10 \mathrm{~kg}$ de residuos sólidos por hectolitro de cerveza producida (Bernal y Gondar, 2008).

En el caso de la industria vitivinícola, cuya actividad se ubica mayoritariamente en la Cuenca Mediterránea, la producción de vino genera altas cantidades de residuos y subproductos sólidos y líquidos tales como raspón, orujo, lías, aguas residuales y vinazas (Bustamante et al., 2009). Los orujos y las lías se consideran subproductos, ya que son utilizados por las industrias alcoholeras para su destilación, produciéndose entonces en éstas el orujo desalcoholizado como residuo sólido y la vinaza como efluente residual. Las aguas residuales de bodega se originan del agua utilizada en las operaciones relacionadas con el acondicionamiento del fruto y la limpieza de los equipos empleados en la recepción de la vendimia y la vinificación, los trasiegos, y los filtrados. Los efluentes de bodega y de alcoholera se caracterizan por su alto contenido en materia orgánica, con grandes cantidades de sólidos en suspensión, un $\mathrm{pH}$ generalmente ácido, y la presencia -en concentraciones variables- de polifenoles de difícil descomposición. La vinaza posee niveles de nitrógeno, calcio y potasio 
superiores a las aguas residuales de bodega, presentando estas últimas mayor variabilidad respecto a la concentración de macro- y micro-nutrientes. Por otro lado, la composición de los residuos sólidos de bodega es muy heterogénea, destacando su pH ácido, valores bajos de conductividad eléctrica, altos niveles de materia orgánica y polifenoles, y bajos contenidos en calcio, magnesio, micronutrientes y metales pesados (Cegarra y Paredes, 2008).

El proceso de elaboración del arroz, actividad industrial de gran importancia a nivel mundial, consiste fundamentalmente en las operaciones de limpieza, descascarillado, separación y blanqueado (o eliminación del salvado) del arroz para obtener como producto final el grano de arroz blanco (Aleixandre y García, 1999). Se estima que el producto final industrializado representa el 65\% (en peso) del grano de arroz no procesado (Sanjuán et al., 2001), obteniéndose distintos subproductos: la cascarilla, el salvado, el germen y los medianos (o granos rotos). La cascarilla, o cubierta que cubre el grano de arroz, es el subproducto más abundante y presenta altos niveles de sílice, celulosa, hemicelulosa y lignina, baja conductividad eléctrica, y pH cercano a la neutralidad (Cegarra y Paredes, 2008).

Por último, merecen destacarse los residuos y subproductos procedentes del sector de extracción del aceite de oliva, cuyas características, problemática y tratamiento se abordarán en la sección 1.2.

La subproductos y residuos de la industria agroalimentaria plantean problemas importantes desde los puntos de vista medioambiental y de gestión adecuada de los mismos, y representan, además, una pérdida de biomasa y nutrientes del procesado de los alimentos, que podrían ser aprovechados para otros usos o aplicaciones (Laufenberg et al., 2003). Por otra parte, la gran diversidad de productos y procesos agroalimentarios existentes implica la producción de residuos y subproductos de características muy diferentes. No obstante, éstos tienen algunos rasgos comunes tales como: altos niveles de materia orgánica; elevadas concentraciones de proteínas, carbohidratos y lípidos; presencia de grandes cantidades de sólidos y/o grasas en suspensión; altas demanda bioquímica de oxígeno (DBO) y demanda química de oxígeno (DQO); elevada concentración de nitrógeno; y, variaciones marcadas de $\mathrm{pH}$, entre otros (Kroyer, 1995; Ukita et al., 2008).

En general, los residuos procedentes de las industrias agroalimentarias poseen un alto potencial contaminante, debiendo prestarse especial atención a los vertidos líquidos que éstas generan, que se caracterizan por su gran especificidad, por lo que 
cada tipo de efluente requerirá técnicas de tratamiento distintas. La contaminación de las aguas ocasionada por los efluentes residuales de origen agroindustrial puede producirse tanto a nivel de la capa freática (aguas subterráneas) como a nivel de las aguas superficiales (cursos y masas de agua continentales, y aguas marinas), pudiendo llegar a provocar incluso desequilibrios en los ecosistemas (Seoánez, 2002).

Debido a la prevención de la contaminación ambiental y a motivos económicos, existe en la actualidad gran interés por la búsqueda de nuevas técnicas de tratamiento de los residuos del procesado de los alimentos para obtener materiales potencialmente útiles como, por ejemplo, productos de alto valor añadido y materias primas para otros procesos industriales, o para alimentación animal, entre otras aplicaciones (Laufenberg et al., 2003).

\subsubsection{Gestión: alternativas para su tratamiento}

Con el fin de minimizar los efectos perjudiciales de la producción de residuos, favorecer el uso eficiente de los mismos, y concienciar y sensibilizar a los consumidores respecto al impacto de sus decisiones en la generación de dichos residuos, la estrategia comunitaria europea establece -como principio básico- una distinción jerárquica del manejo de los residuos, especificando el orden prioritario a seguir a la hora de adoptar una alternativa de gestión de los mismos: en primer lugar se da preferencia a la prevención, seguida de la preparación para la reutilización, el reciclado (o valorización material), otras operaciones de valorización (incluyendo la valorización energética), y, finalmente, la eliminación (que incluye la incineración sin recuperación de energía y el vertido) (Sexto Programa de Acción de la Comunidad Europea en materia de medio ambiente -COM(2001) 31- y Directiva 2008/98/CE del Parlamento Europeo y del Consejo).

La prevención y minimización de la generación de residuos puede alcanzarse a través de (Sanjuán et al., 2001): a) el desarrollo de tecnologías más limpias, en base a las “Mejores Técnicas Disponibles (MTD)” descritas en la legislación; b) la mejora del diseño de los productos, en el marco del diseño ecológico; c) el desarrollo de técnicas adecuadas para eliminar las sustancias peligrosas de los residuos antes de su recuperación o tratamiento; $y$, d) el fomento de nuevos modelos de consumo, proponiendo y apoyando hábitos más racionales mediante el suministro al consumidor de información basada en metodologías de análisis y evaluación de efectos 
ambientales (por ejemplo, mediante el Análisis de Ciclo de Vida - ACV), entre otras actuaciones.

Algunos subproductos procedentes de las industrias agroalimentarias pueden utilizarse (aprovecharse) tal y como se generan (aplicación directa), o bien someterse a un tratamiento más o menos complejo para su uso posterior.

Como ejemplos de recuperación directa de residuos y subproductos de origen alimentario merecen destacarse sus usos en alimentación animal (salvado y medianos de cereales, cáscara de cítricos, etc.), como cama para el ganado (cascarilla del arroz), como combustibles, y como fertilizantes (Cegarra y Paredes, 2008; Sanjuán et al., 2001; Ukita et al., 2008). Adicionalmente, en las industrias cárnicas se comercializan los subproductos comestibles; en las industrias lácteas, el lactosuero se emplea como ingrediente de bebidas nutritivas; y, en el sector de los cítricos, se industrializan los excedentes no aptos para consumo en fresco, por razones de calidad o de exigencias del mercado.

Otros subproductos de las actividades agroindustriales precisan operaciones muy simples para la recuperación de productos con valor económico. Por ejemplo, las harinas y aceites de pescado, mediante deshidratación y centrifugación; la carne adherida a los huesos, utilizando separación mecánica o inyección de agua a presión; y, la separación del plasma y la fracción sólida de la sangre, por centrifugación (Sanjuán et al., 2001).

Asimismo, en los últimos años han ido adquiriendo gran importancia las tecnologías de extracción química de productos que pueden utilizarse para otros fines. Así, las proteínas del suero láctico y del salvado resultan interesantes desde el punto de vista nutricional; de los subproductos cítricos se obtienen aceites esenciales, carotenoides, flavonoides y pectinas; y, de los subproductos vitivinícolas sólidos se extraen antioxidantes, colorantes, proteínas y azúcares, entre otros (Sanjuán et al., 2001).

Para el tratamiento de las aguas residuales generadas en las industrias agroalimentarias se han propuesto diferentes procedimientos de gestión, que pueden ser primarios o de eliminación del material sólido en suspensión (sedimentación, floculación, filtración, separación de grasas y aceites, etc.); secundarios o de reducción de la DBO (filtros biológicos, lodos activos, lagunas de estabilización, etc.); y, terciarios o de mejora de la calidad de los vertidos mediante sistemas de refinado (filtración, adsorción, ósmosis inversa, cloración, etc.) (Seoánez, 2002). Tras estos 
tratamientos se obtienen lodos residuales que, a su vez, deben gestionarse adecuadamente y someterse a nuevos procesos de tratamiento.

En la Tabla 1.3 se presentan los tratamientos químicos y biológicos más utilizados para el tratamiento de residuos de origen agroindustrial (Arvanitoyannis et al., 2006, 2008; Flotats y Solé, 2008).

Tabla 1.3. Tratamientos químicos y biológicos utilizados para el tratamiento de los residuos de las industrias agroalimentarias, y objetivos de los mismos

\begin{tabular}{|c|c|}
\hline Tratamiento & Objetivo \\
\hline Compostaje & Descomposición biológica aeróbica en condiciones controladas \\
\hline \multicolumn{2}{|l|}{ Digestión } \\
\hline Anaerobia & $\begin{array}{l}\text { Tratamiento biológico en ausencia de oxígeno que permite la estabilización de } \\
\text { la materia orgánica y la recuperación de energía, generando gases con alto } \\
\text { contenido en metano }\end{array}$ \\
\hline Anaerobia termófila & $\begin{array}{l}\text { Tratamiento biológico en ausencia de oxígeno y condiciones termófilas que } \\
\text { permite la estabilización de la materia orgánica y la recuperación de energía, } \\
\text { generando gases con alto contenido en metano }\end{array}$ \\
\hline Aerobia & $\begin{array}{l}\text { Tratamiento biológico con consumo de oxígeno que permite la estabilización } \\
\text { de la materia orgánica }\end{array}$ \\
\hline $\begin{array}{l}\text { Sistema de reactores } \\
\text { secuenciales de flujo } \\
\text { discontinuo }\end{array}$ & $\begin{array}{l}\text { Tratamiento biológico que utiliza un lodo activo aireado en un único reactor } \\
\text { para el proceso de aireación, sedimentación y decantación }\end{array}$ \\
\hline Electrodiálisis & $\begin{array}{l}\text { Técnica para extraer iones disueltos en agua mediante el uso de membranas } \\
\text { ion-selectivas y energía eléctrica }\end{array}$ \\
\hline Oxidación húmeda & $\begin{array}{l}\text { Proceso de oxidación de la materia orgánica en medio acuoso mediante una } \\
\text { corriente de aire (enriquecido o no en oxígeno) a temperaturas elevadas y } \\
\text { altas presiones }\end{array}$ \\
\hline Fermentación en estado sólido & $\begin{array}{l}\text { Proceso de fermentación realizado por microorganismos sobre un soporte } \\
\text { sólido húmedo en ausencia de agua libre }\end{array}$ \\
\hline Ozonización & $\begin{array}{l}\text { Técnica de oxidación de compuestos orgánicos recalcitrantes utilizando ozono } \\
\text { como oxidante }\end{array}$ \\
\hline Pirólisis & $\begin{array}{l}\text { Técnica de conversión, termoquímica anaerobia, del residuo en gas para } \\
\text { producción de vapor o agua caliente }\end{array}$ \\
\hline Gasificación & $\begin{array}{l}\text { Técnica de conversión termoquímica del residuo en gas mediante reacción } \\
\text { con un agente gasificante a elevada temperatura para combustión posterior }\end{array}$ \\
\hline Incineración & $\begin{array}{l}\text { Tratamiento de combustión para recuperación de energía térmica a } \\
\text { temperaturas elevadas }\end{array}$ \\
\hline
\end{tabular}

Fuente: Arvanitoyannis et al., 2006, 2008; Flotats y Solé, 2008

En distintos estudios sobre compostaje de residuos de la industria agroalimentaria se han mezclado éstos con otros materiales que actuaban como agentes estructurantes y absorbentes de humedad, habiéndose utilizado para tal fin cascarilla de arroz, serrín y otros materiales vegetales (Cegarra y Paredes, 2008; Jolanun et al., 2005). Los subproductos con alto contenido en aceites y grasas, y por tanto, con elevado potencial energético, son susceptibles de valorización energética directa o producción de biocombustibles, mientras que su compostaje o digestión anaerobia se realiza mediante co-tratamiento con otros subproductos complementarios, para evitar problemas de toxicidad para los microorganismos (Elías, 2005; Flotats y Solé, 2008). 
Respecto a la valorización de los residuos de la industria cárnica, con alta concentración de proteínas y grasas, su tratamiento biológico para eliminar microorganismos patógenos implica la liberación del amoníaco desprendido al descomponerse las proteínas; ello sugiere la realización del compostaje en sistemas cerrados, para controlar los gases emitidos, o el uso de tratamientos anaeróbicos para evitar la emisión de malos olores y producir energía aprovechable por la propia instalación, pudiéndose combinar así la biometanización seguida del compostaje de los digestados generados como solución viable (Cegarra y Paredes, 2008).

La mayoría de los residuos orgánicos de origen agroindustrial pueden tratarse juntamente con otros tipos de residuos con el fin de aplicar estrategias de recuperación más adecuadas desde el punto de vista económico. Así, el cotratamiento (por ejemplo, co-digestión o co-compostaje) permite aprovechar la complementariedad de la composición y características de los diferentes residuos utilizados, compartir instalaciones y metodologías de gestión, y reducir costes de inversión y explotación, entre otros beneficios (Flotats y Solé, 2008).

Por último, deberían considerarse también las operaciones de eliminación de los residuos de las industrias agroalimentarias, tales como la incineración sin recuperación de energía y su traslado a vertederos o almacenes permanentes, que deberían utilizarse únicamente como última alternativa, ya que representan una pérdida de recursos y contribuyen, además, a la contaminación ambiental.

\subsection{RESIDUOS Y SUBPRODUCTOS ORGÁNICOS GENERADOS POR LA INDUSTRIA OLEÍCOLA. TIPOS, SUS CARACTERÍSTICAS Y APROVECHAMIENTO}

La extracción y utilización del aceite de oliva se ha vinculado a la cultura e historia del área mediterránea desde el 4000 a.C., siendo el aceite de oliva un producto muy apreciado por sus propiedades nutritivas y efectos beneficiosos sobre la salud (Awad et al., 2008). En la actualidad, la industria oleícola es una actividad de gran importancia socioeconómica en la Cuenca Mediterránea, destacando España como principal país productor a nivel mundial $-46 \%$ de la producción de aceite de oliva en el mundo en 2009/2010, según datos del International Olive Council (2011), y una producción anual media de unos 1,2 Mt de aceite durante las campañas 2006 a 2010 (Agencia para el Aceite de Oliva, 2011)- seguido (por orden decreciente) por Italia y Grecia con el $15 \%$ y el $11 \%$ de la producción mundial, respectivamente (Figura 1.1). Actualmente, el procesado de aceitunas (tanto para extracción de aceite como 
para aceituna de mesa) es uno de los sectores agroindustriales con mayor crecimiento en la Unión Europea, existiendo además nuevos países emergentes, tales como Australia, Chile, Argentina o Albania (International Olive Council, 2011; Niaounakis y Halvadakis, 2006).

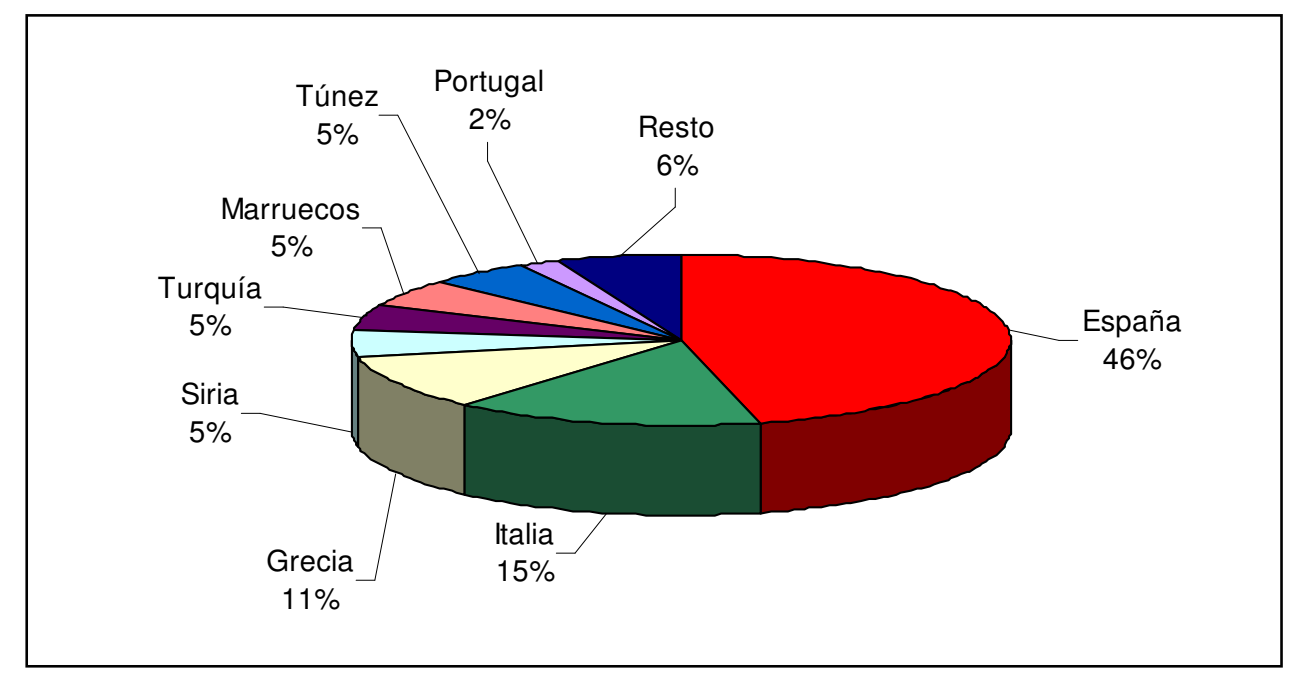

Figura 1.1. Países productores de aceite de oliva en el mundo en 2009/2010 Fuente: International Olive Council, 2011

\subsubsection{Procesos utilizados en la industria extractiva del aceite de oliva: evolución histórica}

Tras la recolección de la aceituna, ésta se deposita en la almazara donde se clasifica y limpia para eliminar restos de hojas, ramas y otras impurezas del fruto, generándose entonces un volumen inicial de residuos sólidos. A continuación, se prepara la pasta (o masa) mediante molienda, que libera el aceite de la pulpa, y posterior batido, que rompe la emulsión aceite-agua y reúne las gotas de aceite así obtenidas. A partir de la masa batida tiene que separarse la fase líquida de la fase sólida, utilizándose para ello dos procedimientos: presión o centrifugación; en estas dos metodologías se basan los sistemas tradicionales y los más novedosos de extracción de aceite en las almazaras (Cegarra y Paredes, 2008).

\subsubsection{Sistema discontinuo}

El sistema tradicional de extracción del aceite de oliva utilizado durante siglos, y que ha sufrido sólo algunas modificaciones, consta de prensas hidráulicas en discontinuo, en las que la masa se coloca en discos filtrantes o "capachos" que se 
someten a presión, reteniendo los sólidos (orujo) y liberando la fracción líquida constituida por el mosto oleoso (Figura 1.2.). Posteriormente, éste se decanta o centrifuga para separar la fase oleosa como producto final, generándose como residuo el efluente denominado alpechín. Este sistema tiene rendimientos muy bajos y resulta poco racional y operativo, además de requerir abundante mano de obra y presentar problemas de limpieza e higiene, así como fermentaciones susceptibles de alterar la calidad del aceite de oliva elaborado (Cegarra y Paredes, 2008).

\subsubsection{Sistemas de centrifugación en continuo}

La separación por centrifugación en sistema continuo consiste en inyectar la masa batida directamente a una centrífuga o decantador ("decanter") horizontal, donde se separan sus distintas fracciones por diferencias de densidad (Cegarra y Paredes, 2008). Sin embargo, la fuerza centrífuga que se origina no facilita la salida de las gotas del aceite ocluido en el interior de los microgeles formados durante el proceso, por lo que hay que añadir agua durante el batido de forma que puedan modificarse las características de estos microgeles y transformarse así en aceite (Aleixandre y García, 1999). En función de las salidas que posea la centrífuga, se distinguen: el sistema de tres fases, que separa el orujo (fracción sólida), el agua residual (alpechín), y el aceite; y, el de dos fases, con el que se obtiene el aceite y la mezcla del orujo con las fracciones acuosas (alperujo). Una vez que se ha extraído el aceite, éste arrastra todavía partículas en suspensión y cierta proporción de agua, que se eliminan mediante tamizado, decantación o centrifugación.

\section{De tres fases}

Durante la década de los 70 , el sistema de extracción mediante prensas en discontinuo se sustituyó por la técnica de centrifugación de tres fases (Figura 1.2.), que presentaba una serie de ventajas: mejora considerable del control del proceso (automatización y trabajo en continuo) y de la calidad del aceite, reducción del área necesaria para el proceso, y disminución de las necesidades de mano de obra (Cegarra y Paredes, 2008; Roig et al., 2006). No obstante, y como ya se ha indicado, el proceso de extracción con centrífuga requiere la aplicación de agua para el funcionamiento óptimo de dicha centrífuga y la fluidificación de la pasta de aceituna, lo que representó un incremento en el consumo de agua y energía, y del volumen de efluente residual (alpechín). Este vertido, capaz de generar problemas 

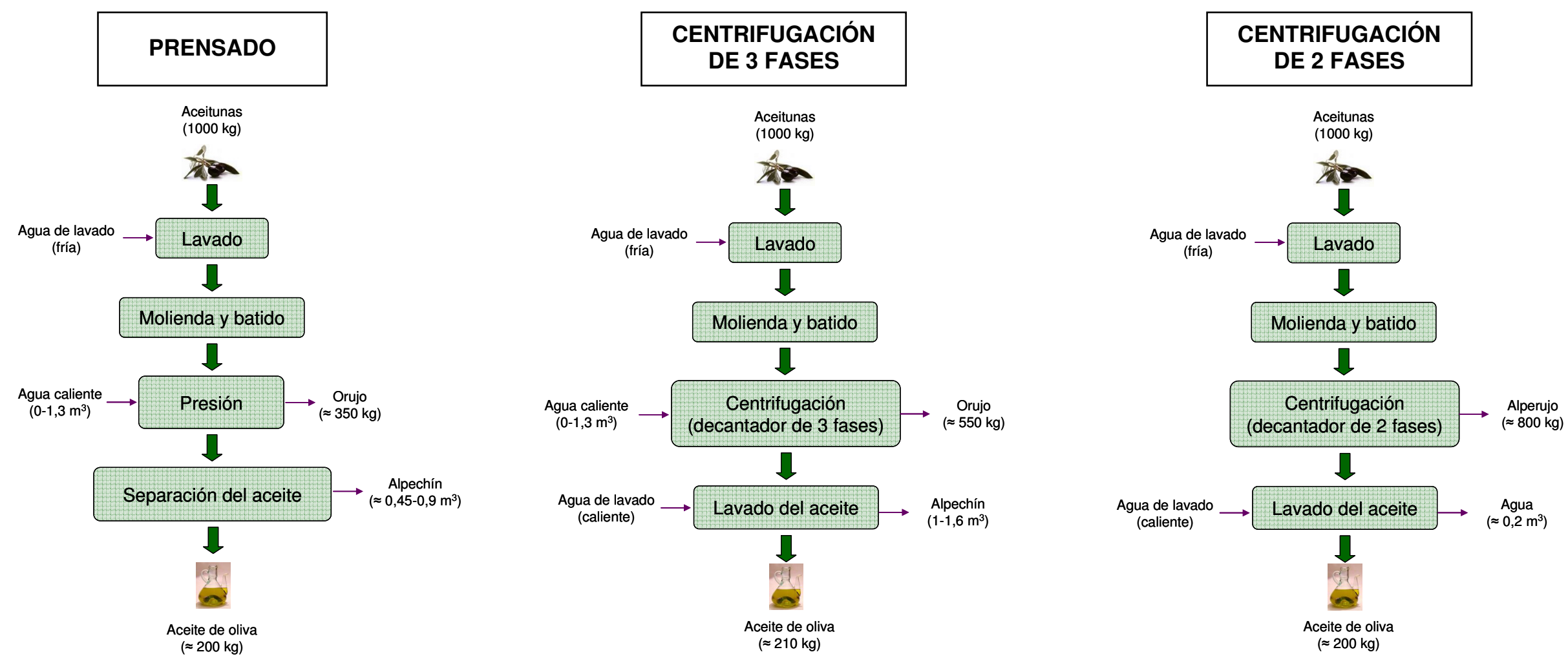

Figura 1.2. Esquema de las operaciones del proceso de elaboración del aceite de oliva con los sistemas de prensado y centrifugación de tres y dos fases

Fuente: Alburquerque et al., 2004; Cegarra y Paredes, 2008 
medioambientales graves, se produce además durante un breve período de tiempo (noviembre a febrero) en grandes volúmenes, lo que unido a la ineficacia y los elevados costes de su aprovechamiento y depuración, propiciaron la búsqueda de un nuevo diseño para minimizar el consumo de agua y la producción de efluentes (Cegarra y Paredes, 2008).

De dos fases o "ecológico"

Con el fin de mitigar el alto potencial contaminante del vertido de alpechín procedente de la centrifugación en tres fases, a principios de los años 90 se desarrolló el sistema de centrifugación en continuo en dos fases para la extracción de aceite de oliva (Figura 1.2.). La centrifugación en dos fases, también denominada "ecológica", permite separar el aceite reduciendo el consumo de agua (65\%-70\%) y energía de calefacción respecto a la centrifugación en tres fases, y disminuye, por tanto, el volumen de efluente y su impacto medioambiental, generando un residuo orgánico semisólido o pastoso denominado "alperujo" (Alburquerque et al., 2004; Cayuela et al., 2007), cuya producción en España se estima que asciende a más de 4 Mt/año (López-Piñeiro et al., 2008). Actualmente, el 90\% de las almazaras españolas produce aceite de oliva mediante el sistema de centrifugación de dos fases (Borja et al., 2005). Otras ventajas del sistema ecológico respecto al de tres fases es que permite obtener un aceite de mayor estabilidad y calidad (Borja et al., 2006), y un caudal de trabajo similar o superior a este último (Cegarra y Paredes, 2008). Sin embargo, el elevado volumen de alperujo generado, de difícil manejo por su consistencia pastosa, debe ser gestionado adecuadamente para evitar la contaminación del entorno natural.

\subsubsection{Residuos generados. Características y composición. Problemática}

\subsubsection{Alpechín}

El alpechín es el efluente originado en la extracción del aceite de oliva por prensado o mediante el sistema de centrifugación de tres fases, que se compone de las aguas de vegetación del fruto y el agua utilizada en las distintas etapas de elaboración del aceite, tales como la que se consume al acondicionar el fruto o durante la molienda, batido y centrifugación, y en la limpieza de las instalaciones y equipos (Cegarra y Paredes, 2008; Roig et al., 2006). Es una emulsión relativamente 
estable con pulpa de aceituna, mucílago y pectina en suspensión (Paredes et al., 1999), cuya composición varía principalmente en función de la variedad, madurez y contenido en agua de la drupa, propiedades del suelo en el que se cultivó, además de las condiciones climáticas, el momento de la recolección, la tecnología de extracción, y las condiciones de almacenamiento (Niaounakis y Halvadakis, 2006). A pesar de la alta variabilidad observada en sus características y composición, el alpechín se caracteriza por su color oscuro, olor penetrante, $\mathrm{pH}$ ligeramente ácido, conductividad eléctrica alta, y elevada concentración de compuestos orgánicos, especialmente ácidos grasos, glúcidos, grasas y polifenoles (taninos, entre otros), que están estrechamente relacionados con el carácter fitotóxico de este vertido y ponen de manifiesto, además, la necesidad de una gestión apropiada del mismo para evitar problemas medioambientales (Aviani et al., 2010; Morillo et al., 2009; Niaounakis y Halvadakis, 2006; Paredes et al., 1999). Por otro lado, el alpechín presenta también niveles elevados de potasio, además de contenidos notables en nitrógeno, fósforo, calcio, hierro y magnesio (Paredes et al., 1999). Además, diferentes autores han descrito el efecto antimicrobiano del alpechín, que radica principalmente en su alto contenido en fenoles (Morillo et al., 2009; Niaounakis y Halvadakis, 2006; RamosCormenzana et al., 1996). Debido al carácter anfifílico (o anfipático, es decir con propiedades tanto hidrofílicas como hidrofóbicas) de los fenoles de la aceituna, sólo una pequeña fracción de éstos pasa al aceite, mientras que una alta proporción se incorpora a la fase acuosa del alpechín (Niaounakis y Halvadakis, 2006; Rodis et al., 2002).

Comparando la producción de alpechín mediante el método de prensa tradicional con el sistema de centrifugación de tres fases, este último genera el doble de aguas residuales por tonelada de aceituna procesada (Figura 1.2).

\subsubsection{Orujo}

Al igual que en el caso del alpechín, la composición del orujo -fracción sólida generada durante la elaboración del aceite por prensado o centrifugación de tres fases- varía dependiendo de la variedad y características del fruto cosechado así como de las condiciones del proceso de extracción. En el orujo se encuentran huesos molturados, piel, pulpa, agua y restos de aceite, destacando su alto contenido en lignina y su baja concentración en proteínas (Niaounakis y Halvadakis, 2006). Generalmente, el orujo se utiliza para la extracción del aceite residual con disolventes 
orgánicos, dando lugar al orujo agotado u orujillo (Hachicha et al., 2008). Como puede apreciarse en la Figura 1.2, la adopción del sistema de centrifugación de tres fases representó un incremento en la producción de orujo sólido del 57\% respecto al sistema de prensas tradicional.

\subsubsection{Alperujo}

El alperujo obtenido en la extracción del aceite por centrifugación de dos fases es un material de consistencia semisólida o viscosa, con escasa porosidad total y elevada humedad, que posee un alto contenido en materia orgánica (superior al 90\% como valor medio) y abundantes cantidades de lignina, celulosa, y hemicelulosa, además de niveles importantes de lípidos, glúcidos y fenoles. Su pH es de fuerte a ligeramente ácido y la conductividad eléctrica varía desde valores cercanos a $1 \mathrm{dS} / \mathrm{m}$ hasta más de $5 \mathrm{dS} / \mathrm{m}$. Respecto a su contenido en nutrientes, destaca la elevada riqueza en potasio, lo que es característico de los residuos y subproductos de almazara, y, por el contrario, sus contenidos generalmente bajos en nitrógeno, fósforo, calcio y magnesio en comparación con otros residuos orgánicos (Alburquerque et al., 2004; Cegarra et al., 1993; Niaounakis y Halvadakis, 2006; Pascual et al., 1997). En cuanto a los microelementos y elementos metálicos, merece destacarse su elevada concentración en hierro (Alburquerque et al., 2004) y su bajo contenido en metales pesados (Madejón et al., 1998; Roig et al., 2006). De manera similar al alpechín, se atribuyen al alperujo propiedades fitotóxicas y antimicrobianas por los elevados niveles de lípidos y fenoles que éste contiene, lo que está además estrechamente vinculado con los riesgos medioambientales de su aplicación directa al suelo (Alburquerque et al., 2004; Linares et al., 2003; Niaounakis y Halvadakis, 2006). Una recopilación de las características y composición de alperujos con diferentes orígenes -realizada tras revisar diferentes estudios independientes- se ha presentado en Roig et al. (2006) (Tabla 1.4).

Los diagramas de flujo recogidos en la Figura 1.2 indican que la utilización del sistema de extracción de dos fases disminuye notablemente la producción de vertido líquido (sólo 0,2 $\mathrm{m}^{3}$ por tonelada de aceituna), pero aumenta significativamente la de residuo sólido en forma de alperujo respecto a los otros dos métodos (800 kg en el sistema de dos fases frente a $350 \mathrm{~kg}$ y $550 \mathrm{~kg}$ en la extracción por prensado y por centrifugación de tres fases, respectivamente). 
Tabla 1.4. Características y composición de diferentes alperujos según diversos estudios (número total de muestras analizadas, $\mathrm{n}=86$ )

\begin{tabular}{lccc}
\hline \multicolumn{1}{c}{ Parámetro } & Valor medio & Valor mediano & Rango de variación \\
\hline Humedad & 62,2 & 64,0 & $49,6-71,4$ \\
$\mathrm{pH}$ & 5,48 & 5,32 & $4,9-6,8$ \\
Conductividad eléctrica (dS m-1) & 2,99 & 3,14 & $1,2-5,2$ \\
Materia orgánica total (\%) & 90,7 & 94,4 & $60,3-98,5$ \\
Relación C/N & 45,0 & 47,2 & $29,3-59,7$ \\
Elementos totales: & & & \\
$\mathrm{N}$ (g/kg) & 12,0 & 11,2 & $9,7-18,5$ \\
$\mathrm{P}(\mathrm{g} / \mathrm{kg})$ & 0,97 & 1,05 & $0,3-1,5$ \\
$\mathrm{~K}$ (g/kg) & 18,7 & 18,5 & $6,3-29,0$ \\
Ca (g/kg) & 5,08 & 4,03 & $2,3-12,0$ \\
Mg (g/kg) & 1,03 & 0,95 & $0,5-1,7$ \\
Na (g/kg) & 0,67 & 0,81 & $0,2-1$ \\
Fe (mg/kg) & 1107 & 769 & $526-2600$ \\
Cu (mg/kg) & 41,2 & 17,2 & $13-138$ \\
Mn (mg/kg) & 25,8 & 16,4 & $13-67$ \\
Zn (mg/kg) & 19,6 & 21,3 & $10,0-27,0$ \\
Lignina (\%) & 38,8 & 41,9 & $19,8-47,5$ \\
Hemicelulosa (\%) & 29,7 & 35,1 & $15,3-38,7$ \\
Celulosa (\%) & 23,5 & 19,4 & $17,3-33,7$ \\
Lípidos (\%) & 11,0 & 11,4 & $3,76-18,0$ \\
Proteínas (\%) & 6,95 & 6,95 & $6,7-7,2$ \\
Carbohidratos (\%) & 12,3 & 10,4 & $9,60-19,3$ \\
Fenoles (\%) & 1,36 & 1,30 & $0,5-2,4$ \\
\hline & & &
\end{tabular}

Fuente: Elaboración propia a partir de Roig et al. (2006)

\subsubsection{Otros}

Además de los residuos y subproductos hasta aquí mencionados, el proceso genera otros materiales sólidos, como hojas y pequeñas ramas, y el orujo agotado u orujillo, procedente del orujo del sistema de centrifugación de tres fases o del alperujo de la centrifugación de dos fases. Éste es un material seco ( $8 \%$ a 10\% de humedad) que contiene restos de pulpa y hueso de aceituna, cuya composición presenta altos niveles de lignina, celulosa y hemicelulosa (Niaounakis y Halvadakis, 2006). 


\subsubsection{Tratamiento y aprovechamiento: Métodos de valorización}

\subsubsection{Alpechín}

La aplicación directa de alpechín al suelo ha producido efectos positivos en algunas investigaciones, debido a su contenido en nutrientes (especialmente potasio) y a la movilización de iones en el medio edáfico, mientras que otros estudios han encontrado resultados negativos, debido a su alta salinidad, bajo $\mathrm{pH}$ y presencia de compuestos fitotóxicos (Paredes et al., 1999). Otras investigaciones han señalado su posible aplicación para disminuir la lixiviación de sustancias contaminantes, por ejemplo herbicidas, o el aprovechamiento de sus propiedades antimicrobianas como inhibidoras del desarrollo de agentes fitopatógenos (Roig et al., 2006).

Las alternativas de tratamiento del alpechín se han estudiado ampliamente durante varias décadas, presentándose en la Tabla 1.5 una clasificación de las mismas en función del tipo de pretratamiento o tratamiento aplicado.

En la práctica, el alpechín se ha gestionado generalmente utilizando la evaporación en tanques al aire libre, debido al bajo coste que este método representa y a las condiciones climáticas mediterráneas, que favorecen su evaporación. No obstante, dicha técnica requiere una superficie extensa en la almazara y provoca, además, problemas de diversa índole, como malos olores, proliferación de insectos, y riesgo de filtraciones. La evaporación del alpechín genera un lodo, que suele eliminarse en vertedero, aunque -por sus características y composición- puede utilizarse con fines agrícolas, para compostaje, o como combustible por su alto poder calorífico (Roig et al., 2006).

Para evitar los efectos deletéreos de la aplicación directa del alpechín al suelo, se han realizado diversos estudios de co-compostaje de alpechín con otros materiales orgánicos sólidos, que proporcionaban estructura a la mezcla a compostar, obteniéndose así composts con materia orgánica estabilizada, exentos de fitotoxicidad (Abid y Sayadi, 2006; Aviani et al., 2010; Hachicha et al., 2008; Mari et al., 2003; Paredes et al., 2000; Tomati et al., 1995). 
Tabla 1.5. Clasificación de las metodologías utilizadas para el pretratamiento o tratamiento del alpechín

\begin{tabular}{|c|c|}
\hline Pretratamiento/tratamiento & Proceso \\
\hline Físico & $\begin{array}{l}\text { Dilución } \\
\text { Sedimentación } \\
\text { Filtración } \\
\text { Flotación } \\
\text { Centrifugación } \\
\text { Filtración por membrana } \\
\quad \text { Microfiltración } \\
\quad \text { Ultrafiltración } \\
\quad \text { Nanofiltración } \\
\text { Ósmosis inversa }\end{array}$ \\
\hline Térmico & $\begin{array}{l}\text { Evaporación/Destilación } \\
\text { Combustión } \\
\text { Pirólisis } \\
\text { Gasificación }\end{array}$ \\
\hline Físico-químico & $\begin{array}{l}\text { Neutralización } \\
\text { Precipitación/Floculación } \\
\text { Adsorción } \\
\text { Oxidación química } \\
\quad \text { Oxidación avanzada } \\
\quad \text { Oxidación húmeda } \\
\quad \text { Oxidación electro-química } \\
\text { Intercambio ión ico }\end{array}$ \\
\hline Biológico & $\begin{array}{l}\text { Digestión anaerobia y aerobia } \\
\text { Biofilms } \\
\text { Sistema de fangos activados } \\
\text { Sistema de reactores secuenciales de flujo discontinuo } \\
\text { Sistemas aerobios-anaerobios } \\
\text { Compostaje } \\
\text { Sistemas de fitorremediación }\end{array}$ \\
\hline
\end{tabular}

Otra de las metodologías comúnmente utilizadas para el tratamiento de residuos orgánicos es la digestión anaerobia -con producción de energía en forma de biogás y de un efluente (digestado) que puede a su vez reutilizarse-, que, en el caso del alpechín, se ve dificultada porque los compuestos fenólicos y los ácidos orgánicos presentes en el mismo inhiben el crecimiento de las bacterias metanogénicas, lo que obliga a realizar un pretratamiento para eliminar dichos componentes (Roig et al., 2006).

Aunque se han propuesto gran variedad de procedimientos para el tratamiento y aprovechamiento del alpechín (Tabla 1.5) -muchos de ellos orientados a la degradación de los fenoles que éste contiene-, la mayoría de éstos no suelen 
utilizarse por los altos costes de sus instalaciones (y equipos) y mantenimiento. Dichos costes se ven además incrementados porque algunos de estos métodos sirven únicamente como tratamiento primario o pretratamiento, del que se obtienen lodos que deben también gestionarse posteriormente (Cegarra y Paredes, 2008).

\subsubsection{Alperujo y otros subproductos sólidos}

La aplicación directa del alperujo al suelo ha sido objeto de distintos estudios, debido a su alta concentración en potasio, su bajo coste y la posibilidad de aplicación en áreas cercanas a las almazaras, reduciéndose así los costes de su transporte. Sin embargo, los estudios sobre el uso del material fresco han generado resultados contradictorios. Así, Thompson y Nogales (1999) observaron desequilibrios nutricionales en el suelo derivados de la adición de alperujo fresco, que modificó el ciclo del nitrógeno debido a su elevada relación C/N. Ordóñez et al. (1999) señalaron la necesidad de incorporar fertilizantes nitrogenados adicionales para compensar la modificación de la dinámica del nitrógeno tras su aplicación (inmovilización de $\mathrm{N}^{-\mathrm{NO}_{3}}$ y efectos negativos sobre la actividad de las bacterias del ciclo del nitrógeno). LópezPiñeiro et al. (2007) encontraron una mejora en las propiedades físicas y químicas de dos suelos mediterráneos, y en la cosecha de trigo cultivado sobre los mismos tras aplicar este residuo. Y, finalmente, López-Piñeiro et al. (2008) obtuvieron un incremento en la productividad de un olivar (en Portugal) más marcado cuando el alperujo se aplicó a la dosis más baja de las estudiadas (30 t/ha vs. 60 t/ha). En general, y debido a las propiedades químicas más arriba indicadas, no es recomendable su aplicación directa al suelo (Canet et al., 2008).

El alperujo se emplea también para extraer su aceite residual mediante una segunda centrifugación, obteniéndose así un residuo que es secado y sometido a una extracción con disolventes orgánicos para producir aceite de orujo (Alburquerque et al., 2004). No obstante, las marcadas diferencias en aspecto y características entre el orujo de tres fases y el alperujo del sistema de dos fases (este último con elevada humedad, abundancia de sólidos de granulometría fina, y presencia de azúcares, ácidos orgánicos y polialcoholes) hacen que la excesiva fluidez del alperujo ocasione problemas de manejo -almacenamiento, transporte y secado, principalmente-, teniendo que adaptarse entonces las instalaciones y equipos mediante modificaciones costosas a dichas características: sustitución de las superficies abiertas de almacenamiento por balsas para el vertido, cambio de las cintas 
transportadoras por tornillos sinfín o cintas de cangilones, adquisición de camiones de tipo cuba, etc. (Cegarra y Paredes, 2008; Roig et al., 2006). Por otra parte, las características diferenciales del alperujo ya señaladas dificultan la extracción del aceite residual que contiene, ya que al secarse éste, y debido a su alta concentración de azúcares, tiende a caramelizarse, formando masas apelmazadas que se secan únicamente en superficie; por lo que han tenido que desarrollarse sistemas especiales de secado. Los compuestos de naturaleza orgánica del alperujo impiden además la correcta infiltración de los disolventes orgánicos y originan problemas de percolación (Balis et al., 2001; Cegarra y Paredes, 2008). En adición, la presencia de hidrocarburos policíclicos aromáticos en el aceite elaborado mediante extracción con disolventes orgánicos ha obligado a desarrollar procesos de purificación adicionales, incrementándose los costes de su producción (Alburquerque et al., 2004; Cegarra y Paredes, 2008).

La alternativa del aprovechamiento energético de los subproductos incluye: la combustión directa del orujillo y el hueso de aceituna para generar energía eléctrica o térmica (Caputo et al., 2003), que puede utilizarse para el secado del alperujo; la generación de energía eléctrica en ciclos de vapor a partir de alperujo u orujillo (Cegarra y Paredes, 2008); la co-generación de energía térmica y eléctrica a partir del orujillo (Alburquerque et al., 2004); la gasificación del orujillo, alperujo seco o hueso de aceituna, en la que el subproducto se transforma en gas sintético (o "syngas"), mezcla de monóxido de carbono e hidrógeno. Asimismo, se ha propuesto la utilización de alperujo para la obtención de biocombustibles: biogás a partir de digestión anaerobia, y bioalcohol por hidrólisis enzimática de los polisacáridos y posterior fermentación alcohólica con levaduras (Morillo et al., 2009).

Los tratamientos biológicos son sin duda las alternativas más interesantes por ser más respetuosos con el medio ambiente y por su viabilidad económica (Mantzavinos y Kalogerakis, 2005). En este contexto, merece destacarse -como alternativa de gran interés- el compostaje del alperujo por sus beneficios ambientales y económicos, ya que el compost final resultante puede utilizarse para la preparación de enmiendas y abonos orgánicos, así como sustratos de cultivo, aprovechables a escala local, contribuyendo así a la optimización del uso de los recursos naturales mediante su reciclado y valorización material. En adición, se ha propuesto el vermicompostaje de alperujos como técnica adecuada para su gestión (Plaza et al., 2008). 
Otra aplicación de interés es la alimentación animal, aunque el bajo contenido en fibras digeribles del alperujo requiere la suplementación con productos ricos en proteínas. En este ámbito, sus propiedades nutritivas pueden incrementarse utilizando el método de fermentación en estado sólido, desarrollado por microorganismos sobre un soporte sólido, que se ha utilizado con éxito en la producción de enzimas y componentes de alimentos para animales (Molina Alcaide et al., 2003).

Como posibles opciones de valorización adicionales, se encuentran: la obtención de productos de alto valor añadido, pectinas y antioxidantes, principalmente (Niaounakis y Halvadakis, 2006; Roig et al., 2006); la aplicación a suelos agrícolas para incrementar la fijación de herbicidas y disminuir su lixiviación, evitándose así la contaminación de acuíferos (Cabrera et al., 2010); y, el aporte al suelo para el control biológico de plagas y enfermedades (Cayuela et al., 2008a), entre otras.

Por último, los restos vegetales (hojas y partes leñosas) eliminados durante el proceso pueden utilizarse para alimentación animal, como fuente de calor, o para la extracción de compuestos con propiedades diuréticas y antioxidantes. Algunas almazaras utilizan sistemas que separan el hueso de la pulpa de la aceituna para aumentar así la eficiencia de la extracción de aceite, pudiendo utilizarse entonces el hueso para valorización energética, cultivos sin suelo (como sustrato), producción de carbono activo, o extracción de productos de alto valor añadido (Roig et al., 2006).

Con objeto de seleccionar la alternativa de valorización más adecuada en cada caso, deberían considerarse distintos factores, tales como el volumen de residuos y subproductos producidos, el coste de la inversión a realizar, la situación del mercado en la zona respecto a los aprovechamientos y usos objeto de explotación, aspectos legislativos, etc. Sin embargo, su uso en Agricultura contribuirá a paliar la baja fertilidad de los suelos y el progresivo incremento de la erosión en el área mediterránea. En adición, el tratamiento y aprovechamiento óptimo del alperujo de almazara deberá considerarse en el marco de la gestión integrada y multidisciplinar, que intenta combinar diferentes metodologías que permitan aumentar la eficiencia de éstas y, a su vez, minimizan el impacto ambiental y favorecen el uso de recursos en el contexto del Desarrollo Sostenible (Awad et al., 2008; Niaounakis y Halvadakis, 2006). 


\subsection{EL COMPOSTAJE, UN SISTEMA DE TRATAMIENTO Y ESTABILIZACIÓN DE LOS RESIDUOS ORGÁNICOS CON FINES AGRÍCOLAS}

La aplicación directa al suelo de los residuos orgánicos frescos, es decir sin tratar, plantea una serie de inconvenientes, tales como inmovilización de nitrógeno, deficiencia de oxígeno, incremento excesivo de la temperatura a nivel de la rizosfera, y fitotoxicidad, principalmente (Abad et al., 1997, 2001; Khalil et al., 2008; Ortega et al., 1996). Entre los distintos métodos de adecuación de los residuos orgánicos para fines agrícolas cabe destacar el compostaje, tanto desde el punto de vista ambiental como económico (Bernal et al., 2009; Raviv, 1998, 2005), ya que mediante esta técnica se logra estabilizar e higienizar la materia orgánica procedente de los residuos orgánicos, facilitando y permitiendo así su reintroducción en los ciclos productivos (Soliva, 2001). El resultado es un producto inocuo, estable y maduro denominado compost, que favorece el crecimiento y desarrollo de las plantas tras su aplicación al suelo (Soliva, 2001; Soliva et al., 2008).

De origen tradicional, el compostaje constituye actualmente un proceso tecnológico industrializado, económicamente viable, e integrado en el contexto de sostenibilidad de la sociedad.

Respecto a la preparación de compost, las organizaciones Organic Recovery \& Biological Treatment y European Compost Network (ORBIT/ECN, 2008) estimaron que se produjeron más de 13 millones de toneladas de compost en la Unión Europea en 2005, procedentes de la fracción biodegradable de los residuos sólidos urbanos y de lodos de depuración de aguas residuales urbanas. La proporción de residuos compostados varía notablemente entre los distintos países que forman la UE, destacando Alemania como productor principal (4,4 millones de toneladas anuales), seguido por Francia, Reino Unido, Holanda e Italia.

\subsubsection{Concepto y funciones del compostaje}

La definición técnica del compostaje más ampliamente aceptada es "la descomposición biológica aeróbica de residuos orgánicos bajo condiciones controladas" (Abad y Puchades, 2002; Climent et al., 1996; Saña y Soliva, 1987; Soliva et al., 2008).

Según Haug (1993), el compost se puede describir como “la materia orgánica que ha sido estabilizada hasta transformarse en un producto parecido a las 
sustancias húmicas del suelo, que está libre de patógenos y de semillas de malas hierbas, que no atrae insectos ni vectores, que puede ser manejada y almacenada sin ocasionar molestias, y que es beneficiosa para el suelo y el crecimiento de las plantas".

Una definición reciente, incluida en el Informe Técnico de la Comisión Europea "Working document for end-of-waste criteria on biodegradable waste subject to biological treatment", describe el compost como "el material sólido higienizado y estabilizado que se obtiene mediante compostaje, entendiéndose éste como el proceso de descomposición controlada de materiales biodegradables bajo condiciones dirigidas, predominantemente aerobias, que permiten el incremento de la temperatura hasta niveles adecuados para las bacterias termófilas como resultado del calor generado biológicamente" (Institute for Prospective Technological Studies IPTS, 2011).

Estas definiciones del compostaje revelan que los factores que afectan al proceso están estrechamente relacionados con la naturaleza del sustrato a compostar, las condiciones ambientales en las que se desarrolla, y el modo en que transcurre dicho proceso (Abad y Puchades, 2002; Saña y Soliva, 1987).

Se trata de un proceso dinámico, biológico, aerobio y parcialmente termófilo, que requiere materia orgánica, una población microbiana inicial, y las condiciones óptimas para el desarrollo de ésta, considerando múltiples funciones y actividades sinérgicas. El control adecuado del proceso permite alcanzar una alta eficiencia, minimizar las emisiones y pérdidas de nutrientes, y, por último, obtener un producto final de características conocidas y apropiadas para el uso al que está destinado (Soliva, 2001; Soliva et al., 2008).

En el proceso industrial del compostaje se diferencian dos etapas sucesivas: por un lado, la fase bio-oxidativa, caracterizada por la gran actividad de los microorganismos en virtud de la elevada disponibilidad de compuestos fácilmente biodegradables; y por otro, la fase de maduración o estabilización, en la que la actividad microbiana decae debido al agotamiento progresivo de los materiales biodegradables (Abad y Puchades, 2002; Climent et al., 1996; Costa et al., 1991; Moreno y Mormeneo, 2008; Saña y Soliva, 1987). En la primera fase prevalece la mineralización de la fracción orgánica, mientras que en la segunda predomina la polimerización y condensación de compuestos, produciéndose un material final (compost) con características similares al humus (Insam y de Bertoldi, 2007). 
A su vez, la fase bio-oxidativa puede dividirse en tres etapas consecutivas: mesófila $\left(10-42^{\circ} \mathrm{C}\right)$; termófila $\left(45-70^{\circ} \mathrm{C}\right)$; y, finalmente, segunda etapa mesófila o fase de enfriamiento, previa a la fase de maduración (Moreno y Mormeneo, 2008).

El compostaje se caracteriza por la interacción y sucesión de varios grupos de microorganismos, que presentan demandas nutricionales y ambientales distintas. Las poblaciones microbianas nativas del material orgánico original, en combinación con las que colonizan la pila de compostaje desde el exterior (exógenas), forman el conjunto de agentes biológicos responsables del proceso de biotransformación. Las bacterias alcanzan sus mayores niveles de población en las fases mesófila y termófila iniciales, mientras que los hongos y los actinomicetos (estos últimos de características diferenciales al resto de las bacterias) suceden a aquéllas en las fases de enfriamiento y maduración, en las que los polímeros de lignina y celulosa son los únicos compuestos remanentes (Moreno y Mormeneo, 2008).

Asimismo, debe indicarse que las condiciones termófilas y la presencia de microorganismos con actividad antagonista frente a patógenos y capacidad para degradar/transformar compuestos contaminantes -compuestos orgánicos y metales pesados- contribuyen eficazmente al efecto higienizante del proceso de compostaje.

\subsubsection{Factores que afectan al proceso}

La acción de los microorganismos sobre el material orgánico se desarrolla bajo la influencia de distintos factores - principalmente temperatura, humedad y aireación-, produciéndose durante el compostaje altas temperaturas y disminuciones del volumen y el peso de los residuos hasta alcanzar prácticamente su humificación. Dichos factores deben controlarse para garantizar así que el proceso transcurra de forma aeróbica y los microorganismos actúen el tiempo necesario según sus ciclos biológicos (Bueno et al., 2008).

Los parámetros de mayor importancia en el proceso de compostaje son de dos tipos: parámetros relativos a la naturaleza del sustrato a compostar, y parámetros de seguimiento del proceso.

\subsubsection{Parámetros relativos a la naturaleza del sustrato (mezcla de residuos)}

Las características del material orgánico sujeto a compostaje deben permitir tanto el buen desarrollo del proceso como la obtención de un producto final que 
cumpla una serie de requisitos mínimos de calidad (Soliva y Paulet, 2001). Para ello, al inicio del proceso deben determinarse ciertos parámetros relativos a la mezcla de residuos, con el fin de ajustarlos a sus valores óptimos. Entre las variables más importantes a controlar se encuentran: tamaño de partícula, relación $\mathrm{C} / \mathrm{N}$, composición elemental, contenido en materia orgánica, y conductividad eléctrica (Bueno et al., 2008).

Cuanto mayor es la superficie específica de las partículas tanto más elevada y completa es la acción microbiana durante el proceso. Por tanto, un porcentaje elevado de partículas finas en la mezcla a compostar resulta en un importante ataque microbiano, aunque una trituración excesiva puede reducir el espacio poroso entre las partículas y aumentar la compactación, lo que limita la difusión gaseosa (oxígeno hacia el interior y dióxido de carbono hacia el exterior) en detrimento del crecimiento microbiano (Bueno et al., 2008; Haug, 1993).

Otro factor relevante para la optimización del proceso es la relación $C / N$, parámetro que influye en la velocidad y pérdida de nitrógeno amoniacal durante el proceso. De manera general, se considera que los microorganismos utilizan 30 partes de carbono por cada parte de nitrógeno consumido, por lo que se ha establecido un rango óptimo de este parámetro para los materiales (mezclas) de 25 a 35 (Jhorar et al., 1991). Si la relación C/N supera este intervalo, la actividad biológica disminuye y el proceso se ralentiza, ya que los microorganismos deben oxidar el exceso de carbono y la síntesis proteica se ve, entonces, dificultada por la escasez de nitrógeno. Por el contrario, valores bajos de la relación $\mathrm{C} / \mathrm{N}$ de la mezcla aceleran el proceso de compostaje (Zhu, 2006), pero el exceso de nitrógeno se libera en forma amoniacal, produciéndose así una pérdida de este nutriente y afectando negativamente, además, al entorno natural.

Desde el punto de vista químico, el contenido en elementos nutritivos de los materiales destinados al compostaje constituye un factor clave para el proceso, ya que los microorganismos sólo pueden metabolizar compuestos sencillos y, por tanto, las moléculas complejas son transformadas mediante hidrólisis enzimática para obtener otras más sencillas (Castaldi et al., 2005). Para el crecimiento microbiano son necesarios macronutrientes, principalmente carbono, nitrógeno y fósforo, que desempeñan un papel importante en la síntesis celular y la multiplicación microbiana, y micronutrientes, cuya presencia es esencial para el metabolismo y el transporte celular (Miyatake e Iwabuchi, 2006). 
El contenido en materia orgánica de la mezcla de residuos es otro de los factores a considerar, ya que su concentración en el producto final es determinante a la hora de evaluar su valor agronómico. El nivel de materia orgánica disminuye a lo largo del proceso como consecuencia de su mineralización, con liberación de carbono en forma de anhídrido carbónico, transformándose los glúcidos de cadenas largas en compuestos más sencillos, y reagrupándose algunos de ellos en compuestos húmicos (Castaldi et al., 2005). La velocidad de transformación de la materia orgánica está estrechamente relacionada con sus características físicas y químicas, los microorganismos involucrados en el proceso, y las condiciones imperantes a lo largo del mismo (Michel et al., 2004).

Por último, la conductividad eléctrica, reflejo de la concentración de sales y la presencia de iones amonio o nitrato (Sánchez-Monedero et al., 2001), tiende a aumentar durante el proceso de compostaje debido a la mineralización de la materia orgánica y el aumento en la concentración de aquellas sales e iones.

\subsubsection{Parámetros de seguimiento del proceso}

Con relación al desarrollo óptimo del proceso de compostaje, los parámetros de seguimiento (temperatura, humedad, $\mathrm{pH}$, aireación y porosidad) deben controlarse y, en caso de ser necesario, corregirse para que los valores de los mismos se encuentren dentro del rango adecuado.

Las poblaciones microbianas beneficiadas en cada intervalo de temperaturas descomponen gradualmente la materia orgánica, generando energía en forma de calor, con el consiguiente incremento de la temperatura de la pila. A partir de la evolución de este parámetro puede estimarse la eficiencia y el grado de estabilización alcanzados en el proceso, ya que existe una alta correlación entre la temperatura y el nivel de degradación de la materia orgánica. Asimismo, se ha demostrado que pequeñas variaciones de temperatura influyen en mayor medida en la actividad de los microorganismos que pequeños cambios de humedad, $\mathrm{pH}$ o relación $\mathrm{C} / \mathrm{N}$, de lo que se deduce la importancia de los valores de la temperatura durante el proceso (Miyatake e Iwabuchi, 2006).

En cuanto a la humedad de la masa en compostaje, la presencia de agua resulta imprescindible para suplir las necesidades fisiológicas de los microorganismos, ya que este medio es el utilizado para el transporte celular de sustancias nutritivas y desechos (Madejón et al., 2002). Es necesario ajustar la humedad a un rango óptimo, 
que se sitúa entre el $50 \%$ y el $70 \%$, ya que un contenido en agua muy elevado desplaza el aire del espacio poroso del material, desarrollándose entonces condiciones anaerobias; y, por el contrario, una humedad muy baja disminuye la actividad microbiana y ralentiza el proceso (Bueno et al., 2008; Saña y Soliva, 1987).

En general, un valor de $\mathrm{pH}$ extremo no impide que se desarrolle el proceso, pero afecta negativamente a su cinética, además de dificultar su puesta en marcha y el tipo de reacciones que tienen lugar (Soliva, 2001). En general, el intervalo comprendido entre 5,5 y 8 unidades se considera óptimo, ya que el desarrollo de las bacterias es idóneo con valores de pH próximos a la neutralidad, mientras que el crecimiento de los hongos se ve favorecido por un ambiente moderadamente ácido (Díaz y Savage, 2007). La fase mesófila inicial se desarrolla con una disminución del pH debido a la acción microbiana sobre los compuestos orgánicos lábiles, produciéndose ácidos orgánicos. A continuación, la descomposición de éstos y la formación de amoníaco, procedente de la degradación de las proteínas, provocan una alcalinización progresiva del medio (Sánchez-Monedero et al., 2001) hasta alcanzar valores finales de pH superiores a 7,5, si las condiciones de aireación son apropiadas.

Uno de los parámetros más importantes es la aireación, que cumple fundamentalmente tres objetivos: suministrar el oxígeno requerido por la población microbiana para desarrollar las reacciones de biodegradación en condiciones aerobias, facilitar la regulación del exceso de humedad por evaporación, y, por último, contribuir a mantener la temperatura adecuada (Soliva, 2001). Un aporte de oxígeno insuficiente favorece la proliferación de microorganismos anaerobios, la formación de sulfuro de hidrógeno, y la producción de malos olores (Bidlingmaier, 1996). Por el contrario, una aireación excesiva provoca el enfriamiento de la masa en compostaje y, al disminuir la humedad del material, la reducción de la actividad metabólica de los microorganismos (Zhu, 2006).

La porosidad total del material sujeto a compostaje debe incluir un volumen de agua (humedad) tal que permita además la circulación de oxígeno y otros gases producidos en el proceso. El espacio de aire libre, o volumen de poros ocupado por aire, relaciona la humedad, la densidad aparente y la densidad de partícula (o densidad real), por lo que el contenido óptimo de humedad de la matriz en compostaje puede calcularse a partir de los valores de densidad. Debido a que la densidad de partícula es un valor prácticamente constante para cada material y a que la densidad aparente varía en función del grado de humedad, sería conveniente 
determinar la densidad aparente a distintos niveles de humedad para poder calcular así la humedad óptima de las pilas en compostaje (Bueno et al., 2008).

\subsubsection{Sistemas de compostaje}

Las tecnologías industriales del compostaje presentan variantes según la forma de efectuar el proceso y el modo en que controlan las características del material en tratamiento. Éstas pueden clasificarse en función de la presencia o ausencia de movimientos del material (sistemas dinámicos o estáticos, respectivamente), o bien según la disposición física de la mezcla (sistemas en pilas, trincheras, zanjas, mesetas, etc.), aunque la clasificación comúnmente adoptada es la que se realiza en función del aislamiento o contacto de la mezcla a compostar con el exterior, distinguiéndose entonces los sistemas abiertos, semicerrados y cerrados. En los sistemas abiertos, los residuos orgánicos se apilan al aire libre. En los sistemas semicerrados, el conjunto de operaciones de realiza dentro de una nave cubierta y cerrada, que dispone de un sistema de extracción de gases a través de tuberías. En los sistemas cerrados se usan reactores (Chica y García, 2008; Costa et al., 1991; Rynk y Richard, 2005; Saña y Soliva, 1987).

En adición, los sistemas de compostaje se diferencian en el modo en que se suministra el oxígeno: difusión pasiva, o aireación natural, debido a la difusión y el movimiento natural del aire; y, aireación forzada, donde el aporte de oxígeno se realiza mecánicamente (Chica y García, 2008).

Los sistemas abiertos en pilas, mesetas, zanjas y trincheras se utilizan más frecuentemente por su bajo coste y su tecnología sencilla. La técnica consiste en homogeneizar la mezcla tras su preparación, y extenderla en eras, montones o pilas de dimensiones variables. La aireación puede realizarse de forma dinámica, con volteos periódicos del material, o bien in situ mediante métodos estáticos que utilizan tuberías perforadas, repartidas por el terreno donde se ha extendido la masa a compostar, que aspiran los gases emitidos (sistema Beltsville) o inyectan aire (sistema Rutgers). Otro tipo de sistema abierto, denominado sistema mixto, combina el volteo y la aireación forzada (Chica y García, 2008; Rynk y Richard, 2005).

Con los sistemas semicerrados se logra un control de las operaciones de trabajo superior a los sistemas abiertos; suelen estar ideados para atender a núcleos de población medianos y grandes, debido a que pueden controlar factores ambientales adversos, tales como los malos olores. El modelo más común es el de trincheras o 
calles, entre muretes longitudinales, que suelen estar provistos de sistemas de tratamiento de las emisiones gaseosas (por ejemplo, biofiltros).

Los sistemas cerrados se componen de reactores verticales $u$ horizontales, que mantienen continuamente las condiciones aerobias. Dichos reactores estancos ocupan menor espacio y aceleran el proceso, permitiendo controlar además los parámetros que intervienen en el mismo (temperatura, humedad, aireación, etc.). Éstos, a su vez, pueden ser sistemas continuos, con reactores cilíndricos, de tambor rotatorio, que giran lentamente a lo largo de su eje principal, oscilando el tiempo de permanencia en el tambor entre 5 y 7 días en función del material a tratar; o sistemas discontinuos, con una serie de contenedores de hormigón u otros materiales, donde el material original se distribuye por capas, variando entonces el tiempo de residencia de los residuos de 2 (lo más habitual) a 6 semanas. El material que sale de los sistemas cerrados pasa un periodo posterior de maduración controlada, utilizando diversos sistemas (pilas con volteo, túneles de maduración, etc.) (Chica y García, 2008; Rynk y Richard, 2005).

Aunque los sistemas cerrados necesitan sistemas de aireación, riego, estanqueidad y control más complejos, y requieren, por tanto, mayor inversión inicial y costes de mantenimiento que los sistemas abiertos, presentan una serie de ventajas: reducen los posibles impactos ambientales; controlan mejor el proceso, los lixiviados y los malos olores; necesitan menos espacio; producen compost de forma más homogénea; y, presentan menor riesgo sanitario para los trabajadores (Soliva, 2001).

\subsubsection{Calidad del compost. Parámetros a considerar y regulación}

El concepto de calidad del compost es difícil de definir, ya que han de considerarse múltiples aspectos, y está sujeto, además, a cierta subjetividad (Masaguer y Benito, 2008). Ante la heterogeneidad de materiales orgánicos de partida y la extensa gama de aplicaciones o usos del producto final obtenido tras el proceso de compostaje, la dificultad radica principalmente en establecer los parámetros a controlar/determinar y los intervalos aceptables/óptimos de los mismos para evaluar la calidad de los composts (Soliva y Molina, 1996).

La calidad del compost debería considerarse a partir de las consecuencias derivadas de la aplicación de un tratamiento (compostaje) que tenga en cuenta la protección del medio ambiente y la salud, compatibles con una gestión racional de los residuos, y que posea como finalidad la elaboración de un producto para uso agrícola 
(Masaguer y Benito, 2008). Asimismo, el desarrollo del mercado del compost debe avanzar paralelamente a la evolución de la conciencia de calidad, por lo que debe fomentarse la comunicación y sensibilización de los productores y los consumidores del producto final, adaptando además el producto a cada situación particular (Abad y Puchades, 2002; Raviv, 2005).

Los requerimientos generales de calidad están relacionados principalmente con: aspecto y olor aceptables, higienización adecuada, concentración muy baja de impurezas y sustancias contaminantes, contenido conocido de elementos minerales útiles para suelos y cultivos, y características homogéneas a lo largo del tiempo (Abad y Puchades, 2002; Soliva, 2001; Soliva y Paulet, 2001). Existen otros parámetros, particularmente los que están estrechamente relacionados con la madurez y estabilidad del compost, que pueden resultar de gran interés para determinar su calidad. Así, la calidad agronómica del compost debe considerarse teniendo en cuenta otros parámetros relevantes para su uso, tales como: granulometría, pH, conductividad eléctrica, capacidad de intercambio catiónico, relación $\mathrm{C} / \mathrm{N}$, nivel de nutrientes, contenido y estabilidad de la materia orgánica, índice de germinación de semillas, y actividad microbiana, entre otros (Abad y Puchades, 2002; Goyal et al., 2005; Masaguer y Benito, 2008).

Además de las bases antes señaladas para definir la calidad del compost, una evaluación más detallada debería incluir una serie de parámetros específicos que deberían determinarse en las materias primas, a lo largo del proceso de compostaje, y, necesariamente, en el producto final, con el fin de establecer la aplicación más adecuada para el compost (Goyal et al., 2005). En la Tabla 1.6 se recogen una serie de parámetros a considerar a la hora de valorar la calidad del compost (Soliva, 2001).

Por otro lado, el destino final del compost determina también su calidad, ya que cada tipo de aprovechamiento, aplicación o uso necesita unos requerimientos específicos; por ello, la selección de los parámetros que mejor definan las características del compost en función del uso al que éste va a destinarse es de capital importancia (Masaguer y Benito, 2008). En la Tabla 1.7 se presenta la importancia relativa de diferentes parámetros físicos, físico-químicos, químicos y biológicos, según el uso final del compost producido (Sullivan y Miller, 2005), observándose que los requerimientos para su aprovechamiento como sustrato de cultivo son comparativamente superiores a su aplicación como enmienda, abono orgánico, o para acolchado. 
Tabla 1.6. Parámetros a considerar en la evaluación de la calidad de un compost

\begin{tabular}{cll}
\hline Propiedad & \multicolumn{1}{c}{ Parámetro } & \multicolumn{1}{c}{ Informa sobre } \\
\hline Física & Densidad aparente & Transporte, manejo, aplicación \\
& Color & Aceptación \\
& Olor & Aceptación, higiene, impacto ambiental \\
& Humedad & Transporte, manejo \\
& Granulometría & Manejo, aceptación, efectos sobre el suelo \\
& Capacidad de retención de agua & Efectos sobre el suelo, ahorro de agua \\
& Presencia de inertes & Aceptación, impacto ambiental, seguridad \\
\hline Química & Contenido y estabilidad de la materia & $\begin{array}{l}\text { Efectos sobre el suelo, efectos sobre las } \\
\text { plantas, aceptación }\end{array}$ \\
& orgánica & Efectos sobre el suelo, efectos sobre las \\
& Nutrientes minerales & plantas \\
& Contaminantes & Salud, efectos sobre el suelo, efectos sobre \\
& las plantas, impacto ambiental \\
& pH & Disponibilidad de nutrientes \\
& Sales solubles & Efectos sobre el suelo, efectos sobre las \\
& plantas, impacto ambiental \\
\hline Biológica & Patógenos & Salud, impacto ambiental \\
& Semillas de malas hierbas & Efectos sobre el suelo, efectos sobre la \\
producción vegetal
\end{tabular}

Tabla 1.7. Parámetros a considerar, y su importancia relativa, en la evaluación de la calidad de un compost en función del uso final del mismo

\begin{tabular}{lcccc}
\hline \multicolumn{1}{c}{ Parámetro } & \multicolumn{3}{c}{ Uso } \\
\cline { 2 - 5 } & $\begin{array}{c}\text { Enmienda } 0 \\
\text { abono orgánico }\end{array}$ & $\begin{array}{c}\text { Sustrato de } \\
\text { cultivo }\end{array}$ & $\begin{array}{c}\text { Sustrato para } \\
\text { semillero }\end{array}$ & Acolchado \\
\hline Respuesta del crecimiento & $++z$ & ++ & ++ & - \\
Contenido en nutrientes & + & + & - & - \\
pH/Sales solubles & + & ++ & ++ & + \\
Color/Olor & + & ++ & ++ & + \\
Presencia de inertes & + & ++ & ++ & + \\
Madurez/Estabilidad & + & ++ & ++ & + \\
Tamaño de partícula & + & + & &
\end{tabular}


Esta gama de criterios ha dado también lugar a que numerosas organizaciones, tanto públicas como privadas, hayan elaborado especificaciones, normas y recomendaciones sobre evaluación de la calidad del compost. En relación con los criterios anteriormente citados, es obligatorio el cumplimiento de las disposiciones legislativas vigentes -Real Decreto $824 / 2005$, de 8 de julio, sobre Productos Fertilizantes, modificado por el Real Decreto 1769/2007, de 28 de diciembre, la Orden APA/863/2008, de 25 de marzo, el Real Decreto 108/2010, de 5 de febrero, y la Orden PRE/630/2011, de 23 de marzo; y, Real Decreto 865/2010, de 2 de julio, sobre Sustratos de Cultivo- en materia de contenido mínimo exigido en materia orgánica y otros parámetros, y umbrales máximos de contenido de humedad, contenido en polifenoles, metales pesados, organismos patógenos y nocivos, etc., con el fin de garantizar unos niveles mínimos de calidad, principalmente para evitar perjuicios para la salud y la contaminación del entorno natural.

Dentro de la Unión Europea no existe uniformidad en cuanto a normativa se refiere, contemplándose la calidad del compost desde una perspectiva medioambiental. El proyecto de propuesta "Working Document: Biological Treatment of Biowaste, $2^{\text {nd }}$ draft" (Comisión Europea, 2001) ha servido en los últimos años como punto de partida para establecer un marco legislativo relativo a la calidad del compost a nivel europeo. Recientemente, el Instituto de Prospectiva Tecnológica -instituto de investigación del Centro Común de Investigación de la Comisión Europea- ha publicado el primer informe técnico denominado "First Working Document on End-ofWaste Criteria on Biodegradable Waste Subject to Biological Treatment" (IPTS, 2011), en el que se considera el uso agronómico del compost como mejorador del suelo y como sustrato de cultivo, y se indica, además, la importancia de determinar diferentes parámetros de calidad, como $\mathrm{pH}$, conductividad eléctrica, densidad aparente, tamaño de partícula, actividad microbiana, etc.

En la Tabla 1.8 se presentan los requisitos que deben cumplir los composts distribuidos como enmiendas o abonos orgánicos en España, así como los recogidos en la última propuesta europea (IPTS, 2011). En el ámbito español existen tres niveles de exigencia respecto al contenido en metales pesados (A, B y C), siendo la clase A la más restrictiva y, por tanto, la de mayor calidad. 
Tabla 1.8. Normativa española y propuesta europea referentes a los requerimientos mínimos de calidad de los composts

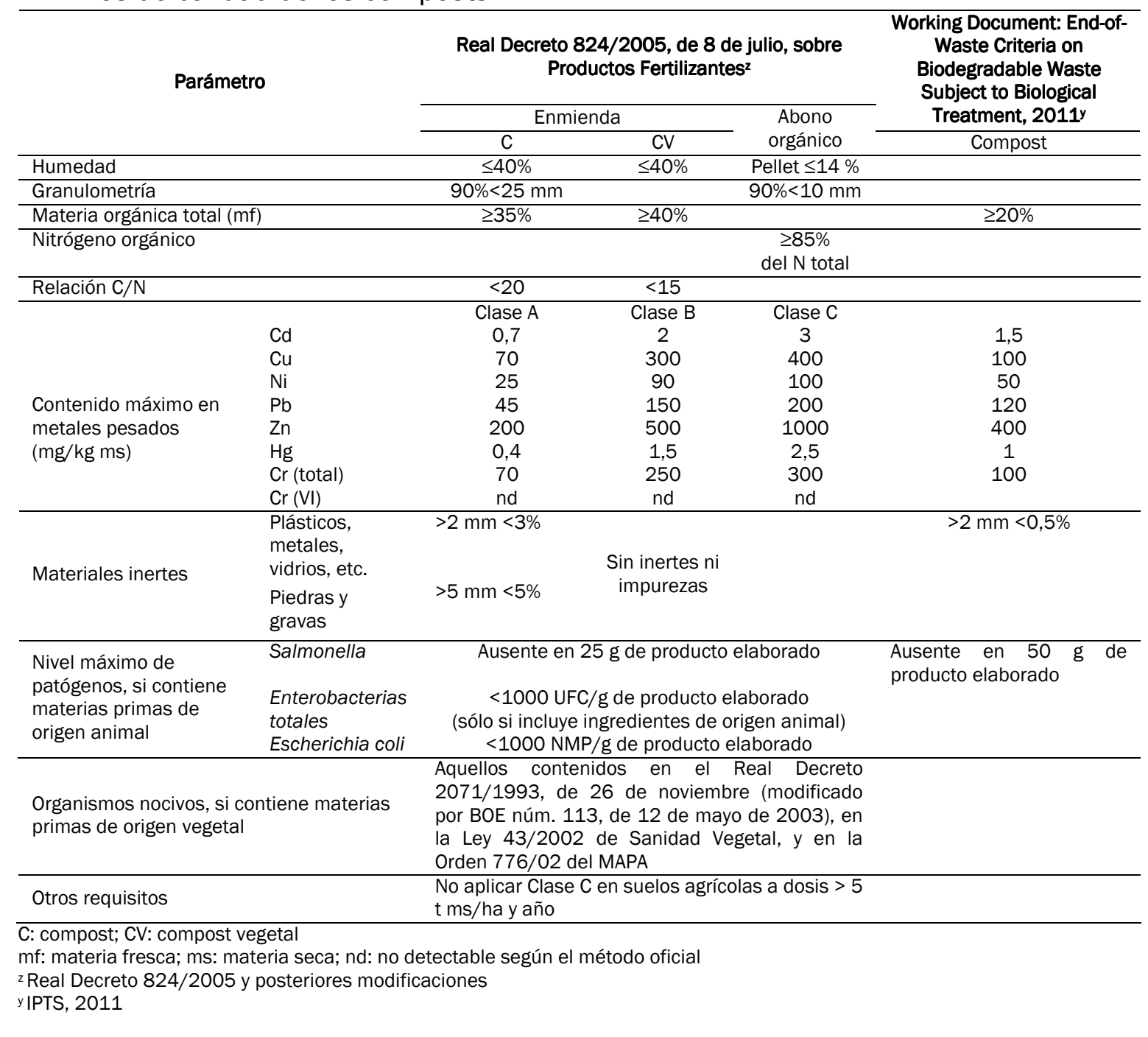

Según el Real Decreto sobre Sustratos de Cultivo, los composts deben tener un contenido mínimo en materia orgánica del 20\% (sobre materia seca) para su uso como sustratos y únicamente pueden utilizarse composts de clase A y B para dicho aprovechamiento (con concentraciones similares a las clases A y B de la Orden PRE/630/2011), prohibiéndose además la aplicación de composts clase B en cultivos hortícolas comestibles. Respecto a los niveles de patógenos, dicho Real Decreto incluye niveles máximos en recuentos de Listeria monocytogenes, Enterococcaceae y Clostridium perfringens.

Con relación a otras normativas que regulan la calidad del compost, merecen destacarse las Decisiones de la Comisión Europea relativas a la concesión de la etiqueta ecológica comunitaria a enmiendas del suelo y sustratos de cultivo -Decisión 2006/799/CE, de 3 de noviembre y Decisión 2007/64/CE, de 15 de diciembre, 
respectivamente-, que establecen criterios ecológicos para fomentar la confianza en la producción y el consumo de productos y servicios más respetuosos con el entorno, y garantizar así a los usuarios la calidad que éstos demandan.

En la actualidad, la industria del compostaje posee conocimientos y tecnologías suficientes para asumir la producción de composts de calidad, que cumplan las exigencias de las normativas aplicables y las necesidades del consumidor. No obstante, todavía no se ha consolidado la realización de unos controles de calidad mínimos en el compost, lo que sigue generando desconfianza en los usuarios, ya que éstos carecen de información del producto relativa a sus propiedades, efectos beneficiosos, modo de empleo, y estándares de calidad, principalmente (Masaguer y Benito, 2008; Raviv, 2005).

\subsubsection{El caso particular del compostaje de alperujo}

Como ya se ha mencionado (ver la sección 1.2.3.2) anteriormente, el tratamiento del alperujo mediante compostaje es una alternativa de gran interés a la hora de gestionar este residuo (Alburquerque et al., 2004; Canet et al., 2008; Montemurro et al., 2009). Sin embargo, el proceso de compostaje presenta algunas dificultades (Cegarra y Paredes, 2008; García-Gómez et al., 2003) relacionadas principalmente con: su elevado contenido en lignina, alto valor de la relación $\mathrm{C} / \mathrm{N}$-debido a su bajo contenido en nitrógeno-, efecto antimicrobiano de algunos de sus componentes (polifenoles y lípidos, entre otros), y aspecto/presentación del material (semisólido, pastoso), que limita la difusión de oxígeno en el mismo para que el proceso aeróbico de la biodegradación de la materia orgánica pueda desarrollarse satisfactoriamente. En este contexto, debe considerarse también que la fracción orgánica del alperujo presenta un nivel de proteínas elevado (alrededor del 7\%), pero con baja disponibilidad para el crecimiento inicial de los microorganismos debido a su asociación con la fracción lignocelulósica (Alburquerque et al., 2004). Por estos motivos, la viabilidad del proceso depende en gran medida de la adición (y mezcla) de otros materiales (co-sustratos para el co-compostaje), denominados comúnmente agentes estructurantes, que sirven como fuente adicional de nitrógeno y equilibran, además, la relación $\mathrm{C} / \mathrm{N}$ hasta alcanzar valores en el rango óptimo (Alburquerque et al., 2004; Cegarra y Paredes, 2008; Morillo et al., 2009). 


\subsubsection{Materiales utilizados en el co-compostaje del alperujo}

El co-compostaje del alperujo debe realizarse con materiales orgánicos con bajo contenido en humedad y mayor tamaño de partícula que éste, con objeto de absorber el exceso de humedad del alperujo y facilitar la aireación de la mezcla. Como agentes estructurantes se han utilizado diferentes materiales: raspón de uva (Alburquerque et al., 2006a, 2006c, 2009; Baeta-Hall et al., 2005), hojas de olivo u hojín (Alburquerque et al., 2006a, 2006c, 2009; Alfano et al., 2008), corteza y serrín de chopo (Filippi et al., 2002), gallinaza (de la Fuente et al., 2011; Walker y Bernal, 2008), residuos del desmotado del algodón (Alburquerque et al., 2006b, 2006c, 2007, 2009; Walker y Bernal, 2008), paja de trigo (Altieri y Esposito, 2010; Montemurro et al., 2009), residuos del lavado de la lana (Altieri y Esposito, 2010), estiércol ovino fresco (Cayuela et al., 2006, 2010), y restos de poda y otros estiércoles de diferentes orígenes y características (Alburquerque et al., 2009; Cegarra et al., 2006; Montemurro et al., 2009), principalmente.

En algunos experimentos de co-compostaje se aportó urea a la mezcla (Alburquerque et al., 2006a, 2006c, 2009), aunque esto no es deseable desde el punto de vista medioambiental (Morillo et al., 2009). No se tiene conocimiento de ningún trabajo que haya investigado el aprovechamiento de un residuo orgánico líquido como fuente adicional de nitrógeno y compuestos fácilmente biodegradables para el compostaje del alperujo, tema que ha sido objeto de estudio de la presente Tesis, en la que se ha aplicado (mediante riegos) un hidrolizado enzimático de proteínas animales mezclado con una fracción lipídica procedentes de la industria farmacéutica (material que se ha denominado " $\mathrm{H}$ " en el texto) durante el compostaje de una mezcla de alperujo y estiércol de caballo fresco. Una descripción más detallada de la naturaleza, características, composición e importancia de la producción de este residuo (hidrolizado, H) se presenta más adelante.

Además de lo anterior, deben tenerse en cuenta otros aspectos como la disponibilidad del material, su coste, y su proximidad a la planta de compostaje (Baeta-Hall et al., 2005; Cegarra y Paredes, 2008). Por ello, y para el compostaje del alperujo a escala industrial, se han sugerido materiales del entorno de las zonas del cultivo del olivo y de la extracción del aceite, como hojín o estiércol (Cayuela et al., 2004), con el fin de incrementar la viabilidad económica del proceso, solucionar paralelamente los problemas de gestión de otros tipos de residuos locales, y fomentar 
su posterior uso en Agricultura. De este modo, el aprovechamiento y la valorización de los recursos propios de una zona podrían contribuir a potenciar la confianza en el compostaje del alperujo -como una opción de tratamiento más atractiva- en el marco de un sistema de gestión integral que atendiera a las necesidades y características específicas de cada zona.

\section{El caso particular del hidrolizado $(H)$ de la industria farmacéutica}

La fabricación de biomoléculas para la industria farmacéutica (heparina, condroitín sulfato y ácido hialurónico, entre otras) por parte de la empresa BIOIBÉRICA S.A. (Barcelona) conlleva la generación y acumulación de grandes volúmenes de hidrolizados (enzimáticos) proteicos (alrededor de 27 millones de litros/año) y de lípidos (en torno a 1,5 millones de litros/año), lo que representa graves problemas de tratamiento y gestión medioambiental. El hidrolizado proteico es una fracción líquida (acuosa) de aminoácidos y péptidos resultantes de la hidrólisis enzimática de tejidos animales. La fracción lipídica, con humedad máxima del 50\%, se compone principalmente de grasas neutras, gomas y esteroles, que dificultan su purificación y manipulación. Estos volúmenes se almacenan por separado en depósitos de gran capacidad para su gestión medioambiental.

El co-compostaje de estos dos residuos junto con el alperujo se plantea como una buena alternativa de valorización de los residuos de la industria farmacéutica, además de facilitar globalmente la gestión medioambiental de los mismos.

El hidrolizado proteico y los lípidos son de gran interés para su co-compostaje con el alperujo por dos razones principales (Jaume Girbent, comunicación personal). Por un lado, es bien conocida la gran demanda de agua para riego a lo largo del proceso de compostaje de las mezclas de residuos orgánicos, que podría ser aportada en parte por la fracción peptídica que se genera en forma acuosa. Y por otro, el alto contenido en formas de nitrógeno y carbono fácilmente biodegradables de estos dos residuos sería de gran utilidad en el proceso de co-compostaje y contribuiría a incrementar el valor fertilizante mineral y orgánico del compost producido. La adición (mezcla) de la fracción grasa al hidrolizado proteico, aprovechando su capacidad de emulsión y ajustando su estabilidad, es un proceso sencillo que podría ponerse en práctica para suministrar ambas fracciones, peptídica y lipídica, mezcladas a las plantas de compostaje de alperujo. La biodegradabilidad del hidrolizado proteico junto con la fracción lipídica no debería representar problema alguno, ya que la microbiota 
responsable del compostaje del alperujo posee gran actividad lipolítica (Alburquerque et al., 2006b; 2009) y es capaz, por tanto, de consumir materias grasas durante el proceso.

\subsubsection{Características diferenciales del proceso}

A lo largo del co-compostaje del alperujo se observa generalmente un incremento en el pH (pudiendo llegar a alcanzar valores de más de 9 unidades), la conductividad eléctrica, la capacidad de intercambio catiónico, y el contenido en nitrógeno total (como consecuencia de la reducción del peso de la mezcla y del efecto de concentración durante el proceso); y, pérdidas de materia orgánica, una disminución de la relación $\mathrm{C} / \mathrm{N}$, y una humificación gradual del material orgánico de partida (Alburquerque et al., 2006c; Alfano et al., 2008; Baeta-Hall et al., 2005; Cayuela et al., 2010; Cegarra et al., 2005a, 2006; Montemurro et al., 2009).

El incremento de $\mathrm{pH}$ se debe a la biodegradación de compuestos con grupos carboxílicos y fenólicos, y a la mineralización de otros compuestos orgánicos, tales como proteínas, aminoácidos y péptidos que dan lugar a la formación de amonio (Paredes et al., 2000). Alburquerque et al. (2006a, 2006b) registraron un incremento en el contenido en amonio al iniciarse la fase termófila seguido de una disminución de la concentración de éste según avanzaba el proceso. Por el contrario, durante el compostaje no se detectó la formación de nitrógeno en forma nítrica, ya que la baja concentración de amonio juntamente con la alcalinidad del medio limitan el proceso de nitrificación al inhibir el crecimiento de las bacterias nitrificantes (Alburquerque et al., 2006a, 2006b; Cayuela et al., 2008b; Cegarra et al., 2006).

Merece destacarse la biodegradación progresiva del contenido en carbono orgánico hidrosoluble, glúcidos, fenoles solubles y lípidos observada generalmente durante el proceso (Alburquerque et al., 2006b, 2006c; Baeta-Hall et al., 2005; Cegarra et al., 2006; Filippi et al., 2002), coincidiendo con el incremento paulatino en el índice de germinación de semillas, confirmándose así la detoxificación progresiva del material (Alburquerque et al., 2006c; Cegarra et al., 2006). La oxidación enzimática de los compuestos fenólicos de bajo peso molecular en residuos de almazara produce radicales libres muy reactivos, que se polimerizan para formar compuestos menos tóxicos y más solubles. Asimismo, los compuestos fenólicos pueden ser degradados por microorganismos especializados y, de este modo, la caída en el contenido de fenoles solubles es notable cuando los procesos de polimerización 
y biodegradación prevalecen sobre la producción de compuestos fenólicos mediante la degradación de compuestos como la lignina (Alburquerque et al., 2006a). De acuerdo con lo anterior, algunos autores han observado que una degradación muy intensa de la lignina durante el compostaje del alperujo puede traducirse en una menor disminución (e incluso nula) del contenido en fenoles (Cayuela et al., 2006).

En algunos casos, se ha apreciado un incremento en la duración del período de compostaje, especialmente de la fase termófila, que podría deberse a la escasa disponibilidad de nitrógeno, la alta concentración de compuestos resistentes a la degradación (por ejemplo, lignina) (Alburquerque et al., 2006b, 2006c), y la presencia de sustancias oleosas que liberan gran cantidad de energía e incrementan el período de degradación de las moléculas estables (Alburquerque et al., 2009; Manios et al., 2006).

Con relación a los parámetros biológicos y bioquímicos relativos al compostaje del alperujo, Cayuela et al. (2008b) observaron un incremento de la actividad microbiana, así como de las actividades fosfatasa alcalina y arilsulfatasa, mientras que las actividades ureasa y fosfatasa ácida no presentaron variaciones significativas debido al bajo nivel de nitrógeno y los altos valores de $\mathrm{pH}$ de la mezcla en compostaje.

Por otra parte, la selección del sistema de aireación a utilizar depende de la naturaleza de la mezcla de residuos orgánicos a compostar, considerándose, de manera genérica, que la aireación forzada de pilas estáticas proporciona un suministro continuo de oxígeno, reduce las pérdidas de nitrógeno por volatilización, y facilita un mejor control de la temperatura, aunque puede favorecer la formación de canales preferentes de flujo de aire, y por tanto zonas de anaerobiosis, e impedir además la homogeneización de dicha mezcla (redistribución de microorganismos, nutrientes y agua); en contraste con lo anterior, el sistema de pilas con volteos periódicos es más económico y permite homogeneizar la mezcla, pero impide mantener un nivel continuo de oxígeno y limita además el control de la temperatura y de las pérdidas de nitrógeno (Cayuela et al., 2006; Cegarra et al., 2006). La combinación de estos dos sistemas representa costes más elevados, pero consigue eliminar los inconvenientes de ambos métodos (Stentiford, 1996). Debido a las propiedades físicas características del alperujo (alto contenido de humedad, baja porosidad y necesidad de adición de agentes estructurantes), algunos autores han evaluado la eficiencia del uso de diferentes sistemas de aireación para su cocompostaje. La aplicación del sistema de volteos periódicos resultó más eficiente que 
el sistema estático de aireación forzada (Rutgers; Baeta-Hall et al., 2005; Cayuela et al. 2006), dificultándose además con este último la adecuada aireación en las fases iniciales del proceso, con la consiguiente ralentización de éste (Cayuela et al., 2006). García-Gómez y Bernal (2005) atribuyeron la menor eficiencia del sistema de ventilación forzada a la fracción lipídica del alperujo, que confiere una matriz particular a la masa en compostaje, dificultando tanto su humectación -debido a su carácter hidrofóbico- como su aireación. Los beneficios del volteo mecánico en el cocompostaje del alperujo están estrechamente vinculados con la reducción de la compactación del material así como con la reinoculación y la redistribución de oxígeno en la matriz en co-compostaje, evitándose así el desarrollo de condiciones anaerobias derivadas de la obstrucción de los poros (Alburquerque et al., 2006a, 2006c; Cegarra et al., 2005a). Por otro lado, Alburquerque et al. (2006c, 2009) y Cegarra et al. (2006) compararon el uso de volteos mecánicos con el sistema mixto de volteos periódicos más ventilación forzada, demostrando que el proceso era algo más rápido con este último, si bien la madurez y la calidad de los productos obtenidos (composts) con ambos procedimientos fueron similares, por lo que prescindir de la aireación forzada representó un ahorro económico considerable sin disminuir la calidad del compost final.

\subsubsection{Características y calidad de los composts de alperujo}

El co-compostaje del alperujo con otros materiales (estructurantes) produce generalmente composts con un buen grado de humificación, no fitotóxicos, libres de patógenos, y con niveles aceptables de nutrientes (Tabla 1.9.) (Alburquerque et al. 2006c, 2009; Alfano et al., 2008; Cayuela et al., 2004, 2010; Roig et al., 2006).

Los composts de alperujo suelen presentar $\mathrm{pH}$ fuertemente alcalino, conductividad eléctrica moderada a alta, y contenido elevado en materia orgánica. Gran parte de la fracción orgánica está formada por lignina, compuesto precursor de las sustancias húmicas y relacionado en gran medida con los altos valores de la relación $\mathrm{C} / \mathrm{N}$ observados generalmente en estos composts. También poseen contenidos importantes en celulosa y hemicelulosa, y en menor cuantía de lípidos, glúcidos y fenoles. Al estudiar comparativamente el compost de alperujo con estiércoles y otros composts de distintos orígenes, puede apreciarse que los composts de alperujo presentan un contenido más elevado de materia orgánica -aunque menos biodegradable debido a su naturaleza lignocelulósica- potasio y nitrógeno orgánico, 
mientras que las concentraciones de fósforo, calcio, magnesio, sodio y micronutrientes son menores en éste (Alburquerque et al., 2009; Cegarra y Paredes, 2008; Cegarra et al., 2005a). No obstante, al realizar el co-compostaje del alperujo con una amplia gama de materiales estructurantes, algunas de sus características, como su contenido en nutrientes, están sujetas a una variabilidad importante.

Tabla 1.9. Relación de composts de alperujo y parámetros químicos seleccionados en los mismos con vistas a su uso agrícola y medioambiental

\begin{tabular}{|c|c|c|c|c|c|c|}
\hline $\begin{array}{c}\text { Mezcla } \\
\text { (en peso seco) }\end{array}$ & $\begin{array}{c}\text { Materia } \\
\text { orgánica total } \\
(\mathrm{g} / \mathrm{kg})\end{array}$ & $\begin{array}{l}\text { Relación } \\
\mathrm{C} / \mathrm{N}\end{array}$ & $\mathrm{N}$ & $\begin{array}{c}\mathbf{P} \\
(\mathrm{g} / \mathrm{kg})\end{array}$ & + & Referencia \\
\hline $\begin{array}{l}\text { alperujo+estiércol+raspón de } \\
\text { uva }(60 / 25 / 15)\end{array}$ & 408 & 14,6 & 17,4 & 1,4 & 13,7 & Cayuela (2004) \\
\hline $\begin{array}{l}\text { alperujo+raspón de uva+urea } \\
(87 / 12 / 1)\end{array}$ & 896 & 20,7 & 22,7 & 1,6 & 37,0 & $\begin{array}{l}\text { Alburquerque et al. (2006a, } \\
2006 c, 2009) \text {; Cegarra et al. } \\
(2005 b)\end{array}$ \\
\hline $\begin{array}{l}\text { alperujo+hojas de olivo+urea } \\
(87 / 12 / 1)\end{array}$ & 912 & 21,0 & 23,1 & 1,5 & 36,2 & $\begin{array}{l}\text { Alburquerque et al. (2006a, } \\
2006 c, 2009)\end{array}$ \\
\hline $\begin{array}{l}\text { alperujo+residuo del } \\
\text { desmotado del algodón } \\
(80 / 20) \text { (aireación forzada, } \\
\text { temperatura umbral } 50^{\circ} \mathrm{C} \text { ) }\end{array}$ & 900 & 22,7 & 21,7 & 1,5 & 24,9 & $\begin{array}{l}\text { Alburquerque et al. (2006b, } \\
2006 c)\end{array}$ \\
\hline $\begin{array}{l}\text { alperujo+residuo del } \\
\text { desmotado del algodón } \\
(80 / 20) \text { (aireación forzada, } \\
\text { temperatura umbral } 60^{\circ} \mathrm{C} \text { ) }\end{array}$ & 890 & 22,3 & 21,9 & 1,4 & 27,5 & $\begin{array}{l}\text { Alburquerque et al. (2006c, } \\
\text { 2007) }\end{array}$ \\
\hline $\begin{array}{l}\text { alperujo+ estiércol de vaca+ } \\
\text { compost maduro }(87 / 11 / 2) \\
\text { (aireación mecánica) }\end{array}$ & 816 & 16,8 & 26,3 & 1,9 & 42,7 & $\begin{array}{l}\text { Alburquerque et al. (2006c, } \\
\text { 2009); Cegarra et al. (2006) }\end{array}$ \\
\hline $\begin{array}{l}\text { alperujo+ estiércol de vaca+ } \\
\text { compost maduro }(87 / 11 / 2) \\
\text { (aireación por sistema mixto) }\end{array}$ & 793 & 16,6 & 26,2 & 1,9 & 42,5 & $\begin{array}{l}\text { Alburquerque et al. (2006c, } \\
\text { 2009); Cegarra et al. (2006) }\end{array}$ \\
\hline $\begin{array}{l}\text { alperujo+ residuo del } \\
\text { desmotado del algodón } \\
(67 / 33)\end{array}$ & 825 & 19,1 & 24,5 & 2,4 & 26,7 & Walker y Bernal (2008) \\
\hline $\begin{array}{l}\text { alperujo+residuos del lavado } \\
\text { de la lana+paja de trigo } \\
(72 / 14 / 14)\end{array}$ & 692 & 10,8 & 35,0 & 1,7 & 23,0 & Altieri y Esposito (2010) \\
\hline
\end{tabular}

Por otra parte, los residuos de almazara, con bajos contenidos en sustancias tóxicas recalcitrantes, aseguran la calidad de los composts tras la biotransformación de aquellos mediante compostaje, obteniéndose así productos (composts) cuyo uso es seguro desde el punto de vista medioambiental (Alfano et al., 2008; Roig et al., 2006). 


\subsection{APROVECHAMIENTO Y APLICACIONES DEL COMPOST: USOS AGRONÓMICOS Y MEDIOAMBIENTALES}

\subsubsection{Aspectos generales: gestión agronómica}

Los beneficios del aprovechamiento de los composts son, por una parte, de carácter ambiental, al eliminarse los residuos sin alteración relevante del equilibrio de los ecosistemas, y por otra, de tipo agronómico, al recuperarse y aprovecharse la materia orgánica y los elementos fertilizantes contenidos en dichos residuos.

El aspecto positivo más importante del uso agrícola de compost está relacionado con la sostenibilidad de esta práctica cultural, ya que una actividad o un sistema no pueden contemplarse aisladamente $y$, a través del aprovechamiento agrícola, se cierra el ciclo de los nutrientes (Tittarelli et al., 2007), considerándose además la aplicación de compost con fines agrícolas una estrategia de alto potencial de secuestro de carbono en el contexto del cambio climático (Moral et al., 2009).

A nivel práctico, y al proponer el uso de materiales orgánicos en Agricultura, es necesario diferenciar entre el compost y el resto de materiales, ya que el compost es un producto elaborado mediante un tratamiento biológico controlado y específico, con un contenido de humedad inferior al del resto de materiales orgánicos frescos (inferior al $40 \%$ ), lo que implica diferencias importantes en su manejo y aplicación al suelo. Por tanto, y debido al proceso industrial de su elaboración, el coste del compost es superior al de otros materiales residuales orgánicos, ha de dosificarse en menores cantidades debido a su escasa humedad y alto contenido en nutrientes, y debe aportarse con otros tipos de sistemas de aplicación (Moral y Muro, 2008). No obstante, la producción de composts de buena calidad a partir de residuos orgánicos debe estar orientada a actividades agrícolas específicas, para poder justificar los costes de producción y venta del mismo (Moral et al., 2009).

La valorización agrícola de los residuos orgánicos se realiza principalmente al aprovechar los composts preparados con éstos como enmiendas húmicas de los suelos de cultivo, como abonos orgánicos u órgano-minerales para el material vegetal cultivado, y/o como sustratos o componentes de sustratos para el cultivo sin suelo (Carmona y Abad, 2008; Abad y Puchades, 2002; Moral y Muro, 2008; Soliva y Paulet, 2001). Por otra parte, las aplicaciones medioambientales de estos materiales orgánicos incluyen su uso para el control biológico de agentes fitopatógenos y en la 
recuperación de suelos contaminados, entre otros usos potenciales (Boulter et al., 2000; de la Fuente et al., 2011).

\subsubsection{Aprovechamiento como enmiendas orgánicas}

Una de las aplicaciones del compost es su adición al suelo con objeto de mantener o elevar el contenido en humus del mismo. Al cultivar un suelo, se produce una disminución progresiva del nivel de humus del mismo a lo largo del tiempo (Acosta-Martínez et al., 2003; Senesi et al., 2007). Dicha reducción acarrea una pérdida global de fertilidad, que se manifiesta en la aceleración de los procesos erosivos y en el deterioro de las propiedades físicas, químicas y biológicas del suelo (Bauer y Black, 1994). La aplicación continuada de diferentes tipos de materia orgánica, especialmente de compost, puede revertir estos procesos perjudiciales (Grandy et al., 2002; Moral y Muro, 2008; Raviv, 2005).

En este aprovechamiento, la aplicación de compost puede realizarse como enmienda de mantenimiento, para restituir anualmente la pérdida de humus, o como enmienda de corrección, con el fin de incrementar el contenido en humus del suelo cuando éste es inferior al nivel aceptable u óptimo (Abad y Puchades, 2002).

Para seleccionar un compost como enmienda orgánica deben tenerse en cuenta diversos factores, tales como la dosis de aplicación, el nivel de elementos o sustancias potencialmente contaminantes, el grado de higienización, madurez y estabilidad, la época de incorporación al suelo, las características edáficas y climáticas, y la especie vegetal a cultivar (Danés y Boixadera, 2001).

Debido a la relevancia de la aplicación de compost como mejorador del suelo en la presente Tesis, los efectos de las enmiendas orgánicas sobre las propiedades de los suelos y las especies cultivadas se han desarrollado más extensamente en la sección 1.5 .

\subsubsection{Aprovechamiento como abonos orgánicos y órgano-minerales}

Con el fin de mitigar el impacto negativo de la producción agrícola sobre el entorno natural, una estrategia esencial de actuación se basa en reemplazar el uso excesivo de insumos externos, tales como productos fitosanitarios de síntesis y fertilizantes químicos, por un uso racional de los mismos -basado en el estudio científico y reforzado, además, por la utilización de insumos naturales-, como la 
aplicación de composts como abonos orgánicos. Éstos poseen gran valor en Agricultura Ecológica, donde las fuentes de materia orgánica y macroelementos constituyen el factor limitante de la producción (Canet y Albiach, 2008; Hargreaves et al., 2008)

La utilización de composts como abonos depende de una serie de factores que condicionan su eficacia a corto y largo plazo: concentración de nutrientes, equilibrio nutritivo, velocidad de mineralización de los componentes orgánicos, etc.

En general, los composts poseen un contenido desequilibrado en nitrógeno y fósforo, lo que añadido a los menores requerimientos de fósforo de los cultivos, induce a pensar que el método idóneo para determinar la dosis de compost a aplicar se base en las necesidades de fósforo de los cultivos. De este modo, se logra evitar acumulaciones progresivas de este nutriente en el suelo, haciendo inevitable la aplicación de nitrógeno en cobertera en función de las exigencias del cultivo a lo largo del tiempo.

Por otra parte, el valor de los residuos orgánicos compostados como abonos no se limita únicamente a los tres macronutrientes primarios, ya que los elementos secundarios y los micronutrientes presentes en ellos constituyen otra fuente nutritiva de alto valor agronómico. Además, la fracción orgánica de los composts destaca por sus propiedades quelantes, que favorecen la disponibilidad de los micronutrientes para las plantas (Abad y Puchades, 2002).

En la elaboración de abonos órgano-minerales a partir de composts, debe considerarse: el bajo contenido en nutrientes del compost en comparación con los abonos minerales; la oportunidad de preparar "abonos a la carta", ajustando la concentración de algunos elementos mediante la adición de abonos minerales; y, la mayor biodisponibilidad de los nutrientes aportados en virtud de la aplicación de éstos junto con materia orgánica estabilizada, incrementando así la eficiencia del abono aplicado (Moral y Muro, 2008).

Por último, y con el fin de prevenir el riesgo de toxicidad y contaminación inherente a un aporte excesivo de nutrientes y otros elementos metálicos, debe controlarse la calidad y la dosis de compost aplicada (Felipó, 1995). 


\subsubsection{Aprovechamiento como sustratos de cultivo}

El volumen creciente de residuos orgánicos producidos por la sociedad actual, unido a la complejidad y el coste de su reciclaje, son los condicionantes que han fomentado la ampliación de los campos de aplicación de dichos residuos. Uno de ellos, de gran importancia por sus beneficios y su potencial de comercialización, corresponde a su inclusión como ingredientes en la formulación de sustratos de cultivo (Abad et al., 2008; Bustamante et al., 2008). De este modo, muchos residuos y subproductos de naturaleza orgánica generados por actividades agrarias, industriales, urbanas, etc., convenientemente compostados, están siendo utilizados con éxito, puros o mezclados con turba, fibra de coco, etc., como medios para el cultivo sin suelo (Carmona y Abad, 2008). No obstante, el uso de residuos orgánicos como componentes de sustratos de cultivo no debería hacerse extensivo a la obtención de productos comestibles, sino que debería restringirse al ámbito de la producción de planta ornamental, flor cortada, plantas cultivadas con fines paisajísticos y de jardinería, y viveros forestales, entre otros.

La turba, material utilizado ampliamente como componente de sustratos de cultivo por sus excelentes propiedades físicas y químicas, no sólo posee un alto coste, sino que representa además un recurso natural difícilmente renovable, que desempeña un papel fundamental en la fijación del dióxido de carbono atmosférico y en la calidad de las aguas subterráneas (Cunha-Queda et al., 2007). Además, es un material "conductivo" de enfermedades transmitidas por hongos del suelo. Por ello, la sustitución de la turba, total o parcial, como componente de sustratos por materiales orgánicos renovables y con propiedades "supresivas" frente a patógenos vegetales se presenta como una alternativa eficaz (Pane et al., 2011; Raviv, 2005; Raviv et al., 2002;).

Aunque las propiedades físicas de los materiales residuales biodegradables pueden modificarse -especialmente su baja capacidad de retención de agua, mediante afinado por fragmentación y tamizado-, los composts se caracterizan por una serie de factores que limitan su uso como sustratos de cultivo puros: $\mathrm{pH}$ alcalino, elevada salinidad, alta densidad aparente, y posible presencia de materiales inertes, entre otros (Cunha-Queda et al., 2007). Por ello, se requiere su adecuación mediante técnicas rápidas y económicas, por ejemplo la mezcla con otros materiales. Para la mezcla suele utilizarse una proporción de compost que oscila entre el $25 \%$ y más del 
$50 \%$ del volumen final de la misma. Otra alternativa consiste en el compostaje de mezclas de residuos orgánicos previamente seleccionados, obteniéndose así un producto final que puede utilizarse puro como sustrato de cultivo (Abad y Puchades, 2002).

Muchos composts poseen valores de $\mathrm{pH}$ entre moderado y fuertemente alcalinos (Fitzpatrick, 2005; Nappi y Barberis, 1993), lo que dificulta la disponibilidad de los nutrientes, ya que el rango óptimo se sitúa entre 5,5 y 6,5 unidades en los sustratos preparados con materiales orgánicos (Peterson, 1981). Por encima de pH 6, aumentan las dificultades para asimilar hierro, fósforo, manganeso, boro y zinc. Es necesario, por tanto, corregir el pH del sustrato, si éste se encuentra fuera de los límites del intervalo óptimo, con el fin de que los nutrientes estén en formas solubles para satisfacer las necesidades de la planta (Fisher y Argo, 2005). Existen diferentes estrategias para reducir el pH del compost: la mezcla con otros materiales de $\mathrm{pH}$ ácido o neutro; la adición de ácido nítrico o fosfórico antes del establecimiento del cultivo o durante éste (Mazuela et al., 2005; Raviv, 2005); y, la adición de enmiendas de azufre y sus derivados (sulfato ferroso, principalmente) (Carrión et al., 2008; García de la Fuente et al., 2007; Mahimairaja et al., 1994, 1995; Roig et al., 2004).

\subsubsection{Uso para control biológico de agentes fitopatógenos}

Un compost supresor se define como aquel que, por su actividad microbiana o su naturaleza química, previene el desarrollo de enfermedades en plantas sensibles a determinados patógenos aún en condiciones favorables para el desarrollo de la enfermedad (Cook y Baker, 1983; Trillas, 2002). Su aplicación puede realizarse en distintas formas: como enmienda, como sustrato o componente del mismo, o en estado líquido, empleando el extracto acuoso del compost o éste fermentado aeróbica o anaeróbicamente (Koné et al., 2010; Litterick et al., 2004).

Las nocivas consecuencias medioambientales vinculadas al uso masivo de fungicidas, tales como la destrucción de la biota del agroecosistema, la toxicidad residual, la biomagnificación a través de la cadena trófica, y la resistencia creciente desarrollada por los organismos fitopatógenos, han motivado el interés por el estudio de las propiedades supresivas de los materiales orgánicos compostados y su aplicación en el ámbito del control biológico (Hoitink et al., 1997, 2005).

El aprovechamiento de los composts suele fundamentarse sólo en sus características y propiedades físicas y químicas. Sin embargo, se ha demostrado que 
los composts poseen también propiedades supresivas, que pueden ser de gran interés en los distintos sistemas agrícolas. Ello representa un uso alternativo para estos materiales orgánicos y una ventaja frente al uso, comúnmente extendido, de la turba como sustrato de cultivo (Aviani et al., 2010; Hoitink y Boehm, 1999), ya que ésta se caracteriza por sus propiedades conductivas de enfermedades y su rápida infección por una amplia variedad de patógenos vegetales (Borrero et al., 2005; Maher et al., 2008; Yogev et al., 2006). Los estudios sobre supresividad de los composts han abordado principalmente la inhibición de enfermedades de tipo fúngico, pero se han encontrado también efectos inhibitorios de éstos frente a nematodos (Raviv et al., 2005) y bacterias (Schönfeld et al., 2003). Dichos efectos antagonistas frente a fitopatógenos están sujetos a una alta variabilidad y son difícilmente predecibles (Pane et al., 2011); se deben fundamentalmente a factores de tipo biológico (Yogev et al., 2009, 2010), y están estrechamente relacionados con la recolonización del compost por microorganismos mesófilos durante la fase de maduración de éste (Hoitink et al., 1997, 2005).

En las técnicas de control biológico se diferencian dos aspectos: la supresividad específica (directa) y la supresividad general (natural). La supresividad específica es la introducción o inoculación de una especie, o un grupo restringido de microorganismos, que pueden inhibir la actividad de un patógeno, haciendo alusión al efecto antagonista directo de un microorganismo frente a otro (Boulter et al., 2000; Hoitink et al., 1997, 2005). Los mecanismos de supresividad general se refieren a la manipulación del balance de poblaciones microbianas mediante prácticas de cultivo y aplicaciones de productos al suelo, por ejemplo composts (Boulter et al., 2000; Lucas, 1998).

Diferentes autores (Coventry et al., 2001; Hoitink y Boehm, 1999; Maher et al., 2008) han sugerido varios mecanismos de supresividad: competición por nutrientes y espacio con otros microorganismos; hiperparasitismo; antibiosis; inducción de la germinación de los propágulos del patógeno en ausencia de hospedante; adsorción de señales químicas de patógenos; incremento de la nutrición y vigor de la planta; síntesis de compuestos volátiles tóxicos; e, inducción de resistencia sistémica.

La inducción de resistencia sistémica en plantas consiste en la activación de los sistemas de defensa del hospedador frente a patógenos, en virtud de su interacción previa con otro microorganismo no patógeno, al que se denomina agente de control biológico. Cuando se induce este tipo de resistencia, se produce la expresión de una 
serie de genes de la planta que codifican para factores de resistencia, tales como callosa y glicoproteínas ricas en hidroxiprolina, relacionadas con la deposición de lignina (Rubio y Fereres, 2005; Vargas y Suárez-Estrella, 2008).

Además, las propiedades físicas, físico-químicas y químicas del compost pueden influir en sus efectos supresivos, ya que éste proporciona el soporte y la fuente de nutrientes para los microorganismos (Termorshuizen et al., 2006). Así, la humedad, porosidad total, aireación, $\mathrm{pH}$, nivel de nutrientes, y el contenido y componentes de la materia orgánica son algunos de los parámetros que pueden afectar al desarrollo de patógenos y microorganismos antagonistas (Boulter et al., 2000).

Las investigaciones relacionadas con los efectos supresores de los composts han prestado especial atención a los mecanismos de supresividad, habiéndose llegado a adquirir mayor conocimiento sobre los mecanismos de antagonismo en los sustratos de cultivo a base de compost que en su uso como enmiendas orgánicas (o mejoradores del suelo), debido a que en esta última aplicación las condiciones son más variables y el control inferior (Litterick et al., 2004; Noble, 2011; Noble y Coventry, 2005). Algunos microorganismos aislados de composts con actividad antagonista de enfermedades son: Bacillus spp., Enterobacter spp., Flavobacterium balustinum, Pseudomonas spp., Streptomyces spp., Penicillium spp., Trichoderma spp. y Gliocladium virens, entre otros (Hoitink et al., 2005).

En este contexto, se ha mostrado especial interés por el estudio de los actinomicetos como agentes de control biológico, particularmente los pertenecientes al género Streptomyces. El interés por las bacterias de este género radica en su capacidad para producir antibióticos, habiéndose aislado alrededor del $60 \%$ de los antibióticos utilizados en agricultura a partir de estreptomicetos (Hwang et al., 2001). El aislamiento e identificación de microorganismos que puedan inhibir el desarrollo de agentes fitopatógenos mediante estudios in vitro ha sido objeto de diversos estudios (Loffredo y Senesi, 2009; Suárez-Estrella et al., 2007), con vistas a la inoculación de éstos en experimentos in vivo y a la preparación de productos de biocontrol a nivel comercial.

\subsubsection{Aplicación en la recuperación de suelos contaminados}

Se entiende por suelo contaminado todo aquel cuyas características físicas, químicas o biológicas han sido alteradas negativamente por la presencia de componentes de carácter peligroso de origen humano, en concentración tal que 
comporte un riesgo para la salud humana o el medio ambiente, de acuerdo con los criterios y estándares que se determinen por el Gobierno (Ley 10/1998, de 21 de abril, de Residuos, y modificaciones posteriores).

La contaminación de un suelo se produce cuando se aportan materiales exógenos en calidad o en cantidad tal que no pueden ser acogidos/asimilados mediante los complejos procesos edáficos de cada tipo de suelo (Gómez-Orea, 2004). En general, los suelos poseen una elevada capacidad de amortiguación frente a una determinada agresión externa, disminuyendo los efectos de los agentes contaminantes por medio de las propiedades y compuestos propios del suelo, mediante reacciones de oxidación-reducción, procesos de intercambio iónico, fenómenos de adsorción, desorción y complejación, y reacciones de precipitación y disolución, principalmente. No obstante, cuando se supera el umbral de dicha capacidad de recuperación, se produce un problema de contaminación del suelo (García y Lobo, 2008).

En este contexto, la Comisión Europea elaboró un documento -“Estrategia Temática para la Protección del Suelo", Comunicación de la Comisión Europea $\operatorname{COM(2006)~231-~que~establece~como~objetivo~el~desarrollo~de~una~Directiva~Marco~}$ con la finalidad de establecer unas bases para prevenir la degradación del suelo y la conservación de sus funciones, y poder restaurar así los suelos para devolverles un nivel de funcionalidad acorde con su uso.

De manera general, los contaminantes que se encuentran en el suelo son metales pesados, compuestos orgánicos y sales en exceso. Por otro lado, las actividades que originan la contaminación pueden ser focos puntuales (gestión inadecuada, accidentes, etc.) o focos difusos (actividades agrícolas y ganaderas, medios de transporte, etc.). Además, debe considerarse que la propia dinámica del suelo facilita la dispersión de los contaminantes a otros sistemas, pudiendo ser éste fuente de contaminación para animales y plantas de consumo humano (García y Lobo, 2008; Gómez-Orea, 2004).

A la hora de seleccionar las técnicas más adecuadas para eliminar o reducir -hasta niveles no perjudiciales- un determinado contaminante, debe tenerse en cuenta la protección de la salud y el medio ambiente, la legislación sobre la materia, los costes, y la durabilidad de la solución propuesta. Previamente, debe diagnosticarse el tipo de contaminante, la dimensión física de la contaminación, y el futuro uso del lugar contaminado una vez recuperado, lo que permite elegir la alternativa de 
remediación más apropiada en función de su adecuación a la situación específica y de otros condicionantes de carácter técnico (García y Lobo, 2008).

Los métodos de descontaminación incluyen tratamientos físico-químicos (técnicas térmicas, neutralización, intercambio iónico, lavado, etc.) y tratamientos biológicos (biorremediación, fitoextracción, rizofiltración, etc.), aunque frecuentemente se utilizan técnicas que combinan ambos procedimientos. Algunos tratamientos se basan en la disminución de la concentración del contaminante, mientras que otros intentan disminuir la concentración de las formas biodisponibles de éstos (Clemente et al., 2004; García y Lobo, 2008; Iskandar y Adriano, 1997).

Las técnicas físico-químicas provocan una gran agresión sobre el medio edáfico, alterando en gran medida sus características, mientras que las técnicas biológicas no causan generalmente alteraciones en el entorno, si bien la magnitud de la contaminación y el tiempo de descontaminación requerido no las hacen adecuadas para todos los casos.

Entre los métodos de carácter biológico, se distinguen dos tipos de técnicas: de biorremediación, que utilizan microorganismos capaces de degradar los compuestos orgánicos e inorgánicos contaminantes del medio; y, de fitorremediación, que utilizan plantas, enmiendas del suelo y otras técnicas agronómicas para desarrollar acciones de eliminación o transformación de los agentes contaminantes (Chaney et al., 1997; Lombi et al., 2000; McCutcheon y Schnoor, 2003). Estas últimas resultan de gran interés debido a su bajo coste, la posible actuación in situ, su contribución a la estabilización del suelo y la mejora del paisaje, sus bajos requerimientos técnicos - por basarse en técnicas agrícolas convencionales-, y la reducción de la lixiviación y el transporte de los contaminantes en el medio, aunque el período de recuperación del suelo es más prolongado que con otras técnicas (Carpena y Bernal, 2007; García y Lobo, 2008). Asimismo, pueden destacarse dos tipos de fitorremediación: la fitoestabilización, que utiliza plantas y enmiendas para reducir la biodisponibilidad de los contaminantes en el medio, y la fitoextracción, que usa plantas acumuladoras para la extracción de los contaminantes. Por tanto, las plantas y enmiendas utilizadas extraen y cambian la forma química de los contaminantes en el medio, respectivamente, para disminuir así su disponibilidad biológica o química (Clemente et al., 2004; García y Lobo, 2008).

La utilización de compost de calidad en fitorremediación no sólo influye en las propiedades físicas, físico-químicas, químicas y biológicas de los suelos, sino que 
puede también contribuir a optimizar las tecnologías de remediación de dichos suelos (Alburquerque et al., 2011; García y Lobo, 2008). Así, la aplicación de compost mejora las propiedades físicas y químicas del suelo, lo que se traduce en un aumento en la actividad de los microorganismos de dicho suelo y en la productividad (biomasa) de las especies vegetales acumuladoras, facilitando la implantación de éstas y el incremento en la producción de biomasa, lo que repercute favorablemente en la absorción de los contaminantes (de la Fuente et al., 2011; McGrath, 1998). Por otro lado, la aplicación de enmiendas orgánicas incrementa las actividades enzimáticas de los suelos (Madejón et al., 2001a, 2001b), su contenido en carbono orgánico y su pH (Geebelen et al., 2002), y disminuye la biodisponibilidad de los elementos metálicos (Alburquerque et al., 2011; Chen et al., 2000; Walker et al., 2003). En este sentido, la materia orgánica desempeña un papel muy importante en la disponibilidad de los metales pesados, debido a la mejora de las propiedades químicas del suelo que aquella provoca y a su capacidad para formar quelatos. Dichos procesos dependen de distintos parámetros, como el $\mathrm{pH}$, pero también de la composición de la materia orgánica, ya que cuando ésta es estable y humificada disminuye la disponibilidad de los metales pesados, redistribuyéndolos de las fracciones solubles a las formas menos disponibles mediante la formación de complejos estables con las sustancias húmicas (Clemente y Bernal, 2006; Clemente et al., 2006).

\subsubsection{Utilización como fuente de materia orgánica soluble}

El estudio de las sustancias húmicas se remonta al año 1786, cuando F.K. Achard utilizó una disolución alcalina para extraer de una turba un material que en la actualidad denominamos sustancias húmicas. A Saussure (1804) se le atribuye la introducción del término "humus" para referirse a la materia orgánica de color oscuro del suelo.

Las sustancias húmicas son el material orgánico que predomina en la Naturaleza (Nardi et al., 2002; Trevisan et al., 2010), y se han definido como sustancias orgánicas naturales, biogénicas y heterogéneas, constituidas por un conjunto de moléculas altamente polimerizadas, de peso molecular relativamente alto, y con un color de amarillo a negro (Aiken et al., 1985). Dicho concepto corresponde más a una descripción de las características y propiedades de las mismas que a una definición en sentido estricto, lo que alude a la baja especificidad que prevalece en el estudio de las sustancias húmicas (Chen y Aviad, 1990). Se considera además que son 
sustancias amorfas y con propiedades coloidales muy marcadas, que están constituidas principalmente por carbono, hidrógeno, oxígeno y nitrógeno. Contienen además estructuras moleculares alifáticas y aromáticas, y muestran una elevada capacidad de intercambio catiónico así como gran cantidad de grupos carboxílicos y fenólicos (Kulikova et al., 2005; Trevisan et al., 2010).

La mezcla de compuestos orgánicos extraíbles del suelo, y de los materiales orgánicos más o menos humificados, se denomina sustancias húmicas solubles, que pueden clasificarse en ácidos húmicos, ácidos fúlvicos y huminas, en función de su solubilidad. Los ácidos húmicos y fúlvicos son solubles en medio alcalino; los primeros precipitan en medio ácido, mientras que la fracción fúlvica permanece en disolución después de acidificar el extracto alcalino. Las huminas no son extraíbles con disoluciones alcalinas, aunque se considera que poseen una estructura similar a los ácidos húmicos, diferenciándose de éstos en su menor aromaticidad (Hatcher et al., 1985).

La importancia de las sustancias húmicas de los residuos orgánicos radica en que, para obtener efectos beneficiosos en su aplicación agrícola, éstos deben transformarse en un material estable y maduro mediante tratamientos (como el compostaje) en los que están involucrados los procesos de humificación (Senesi et al., 1996). Así, la cantidad y calidad de las sustancias húmicas contenidas en el compost son indicadores del éxito de su aplicación agrícola y garantizan un uso medioambientalmente seguro (Senesi et al., 2007).

Actualmente, el uso de productos líquidos concentrados a base de sustancias húmicas en Agricultura es una aplicación de gran interés, ya que los efectos beneficiosos del humus del suelo suelen estar relacionados con la presencia de ácidos húmicos y fúlvicos (Verlinden et al., 2010), relacionándose la influencia de las sustancias húmicas en los cultivos con efectos fisiológicos, bioquímicos y morfológicos. La adición de sustancias húmicas al medio de cultivo incrementa la absorción de nutrientes y la permeabilidad de las paredes celulares, y regula los mecanismos relacionados con el estímulo del crecimiento vegetal. Asimismo, los efectos derivados de ellas generan una mejora en la fertilidad del suelo, que se manifiesta en un incremento en la disponibilidad de los nutrientes para las plantas (Trevisan et al., 2010; Verlinden et al., 2010).

En este contexto, distintos autores han extraído las sustancias húmicas de composts y vermicomposts de diferentes orígenes y características para evaluar el 
efecto de los extractos húmicos líquidos obtenidos sobre el crecimiento y desarrollo de especies de interés agrícola, obteniendo resultados que diferían en función de la especie cultivada, el origen (compost y vermicompost) y la dosis de aplicación de los materiales húmicos, y la metodología de extracción utilizada (Arancon et al., 2003, 2006; Atiyeh et al., 2002; Caravaca et al., 2006; Cardoso et al., 2006; Eyheraguibel et al., 2008; Kohler et al., 2008; Lulakis y Petsas, 1995; Valdrighi et al., 1996).

\subsubsection{Otros posibles usos}

Además de los aprovechamientos hasta aquí indicados, el estudio del compostaje como sistema de gestión y tratamiento de los residuos orgánicos ha suscitado el interés por el uso de los composts producidos en otros campos de aplicación.

En primer lugar, debe señalarse su importancia en el marco de la Agricultura Ecológica, siendo su uso fundamentalmente como enmienda o abono orgánico, como extracto acuoso, o como sustrato de cultivo (en horticultura). Este uso particular se caracteriza por los estrictos criterios de calidad que deben cumplir los residuos de partida, así como por los pequeños volúmenes que suelen compostarse, la adición de sustancias minerales y extractos biológicamente activos a la mezcla a compostar, y el uso de metodologías tradicionales para el desarrollo del proceso (Canet y Albiach, 2008).

Diferentes grupos de investigación han desarrollado líneas de trabajo orientadas a la obtención de productos de alto valor añadido a partir de compost. Éstas han dirigido su atención hacia la recuperación de enzimas mediante extracción, separación y purificación en el contexto de la proteómica ambiental (Nannipieri, 2006), y hacia la desmetalización o extracción de los elementos tóxicos, de alto interés en la descontaminación de suelos, entre otros usos (González et al., 2008).

La necesidad de incorporar de forma permanente elementos naturales en el entorno urbano, ha motivado la incorporación de cubiertas vegetales en los núcleos urbanos (movimiento de "naturación urbana"), empleando composts como sustratos de cultivo para las especies vegetales en fachadas, cubiertas y edificios, principalmente (Briz, 2004).

Otras aplicaciones de interés contemplan el tratamiento de aguas residuales mediante humedales artificiales, su uso como acolchado para mantener la humedad del suelo, su aplicación en la producción de tepes y manejo de céspedes de campos 
deportivos y jardines, así como en la recuperación de áreas degradadas (carreteras, canteras y vertederos) y en paisajismo, como soporte para la implantación de cubiertas vegetales (Barker, 2005; Faucette et al., 2006; Rynk y Richard, 2005; Sastre-Conde et al., 2006; Sullivan y Miller, 2005).

\subsection{USO DE COMPOSTS COMO ENMIENDAS O MEJORADORES DEL SUELO. EFECTOS SOBRE EL SISTEMA SUELO-PLANTA}

\subsubsection{Efectos sobre el suelo}

Uno de los problemas ambientales más importantes es la degradación del suelo, ya que éste constituye un componente crítico de la biosfera no sólo porque es el soporte de la producción de alimentos, sino también porque sustenta la calidad ambiental (Marcote et al., 2001). Además, el suelo constituye un recurso no renovable, con procesos de formación y regeneración de muy larga duración (VanCamp et al., 2004). Las técnicas de producción aplicadas en los sistemas agrícolas intensivos han provocado un deterioro en la calidad del suelo, que se manifiesta en pérdidas de su contenido en materia orgánica y en el deterioro de su estructura, afectando a los flujos de agua, aire y nutrientes, y, por consiguiente, al crecimiento de las plantas (Golchin et al., 1995; Melero et al., 2008). Además, se ha observado que la degradación edáfica y la desertificación están estrechamente relacionadas con el efecto invernadero y el cambio climático (Komatsuzaki y Ohta, 2007).

La fertilidad del suelo se define como la capacidad que éste posee para satisfacer los requerimientos físicos, químicos y biológicos de las plantas en cuanto a crecimiento, productividad, reproducción y calidad de éstas se refiere, en función de la especie, tipo de suelo, uso del suelo y condiciones climáticas (Abbott y Murphy, 2007).

La aplicación de enmiendas orgánicas es una estrategia que sirve para restituir la pérdida de fertilidad y calidad derivada de la agricultura intensiva en los agroecosistemas, y ha sido objeto de numerosos estudios (Ferreras et al., 2006; Goyal et al., 1999; Madejón et al., 2001c; Raviv, 2005; Wander et al., 2002). En la Tabla 1.10 se presentan los efectos principales de la aplicación de composts sobre las propiedades físicas, químicas y biológicas de los suelos. 
Tabla 1.10. Efectos principales de los composts sobre las propiedades y funcionalidad de los suelos cultivados

\begin{tabular}{|c|c|}
\hline Propiedad & Efecto \\
\hline Física & $\begin{array}{l}\text { - Mejora de la estructura (agregación de las partículas elementales) } \\
\text { - Mantenimiento de la estabilidad de los agregados } \\
\text { - Reducción de la densidad aparente } \\
\text { - Incremento de la porosidad total } \\
\text { - Aumento de la permeabilidad al aire y al agua } \\
\text { - Incremento de la infiltración } \\
\text { - Incremento de la capacidad de retención de agua útil } \\
\text { - Mejora del balance hídrico } \\
\text { - Disminución de los efectos erosivos }\end{array}$ \\
\hline Química & $\begin{array}{l}\text { - Mantenimiento o aumento del pH } \\
\text { - Incremento de la capacidad de intercambio catiónico } \\
\text { - Incremento de la capacidad tampón } \\
\text { - Aumento de la salinidad, que puede disminuir posteriormente por lluvias y riego } \\
\text { - Aumento del contenido en materia orgánica } \\
\text { - Incremento de los niveles de macro- y micro-nutrientes esenciales para las plantas } \\
\text { - Mejora de la retención de los nutrientes } \\
\text { - Mayor asimilabilidad de los micronutrientes (por quelación) }\end{array}$ \\
\hline Biológica & $\begin{array}{l}\text { - Potenciación de la coexistencia de diferentes especies de microorganismos } \\
\text { - Incremento de la microbiota edáfica beneficiosa (población y actividad) } \\
\text { - Estimulación de diferentes actividades enzimáticas } \\
\text { - Efectos supresivos contra nematodos y otros agentes fitopatógenos } \\
\text { - Estimulación del desarrollo vegetal y aumento de la producción y calidad de las cosechas }\end{array}$ \\
\hline
\end{tabular}

\subsubsection{Sobre las propiedades físicas}

La compactación del suelo es un proceso de degradación estrechamente vinculado a las técnicas de manejo y laboreo utilizadas, y a la erosividad de las precipitaciones. La materia orgánica regula la elasticidad de los suelos a través de la amortiguación de cargas y la acción estabilizante de la estructura de éstos (en función de su textura y composición), observándose que la aplicación de enmiendas orgánicas al suelo disminuye la compactación y la densidad aparente, incrementa la porosidad total, y modifica la distribución del tamaño de los poros (con poros de mayor diámetro y longitud) (Erhart y Hartl, 2010; Evanylo et al., 2008; Ingelmo y Rubio, 2008).

Por otro lado, varios autores registraron un aumento en la estabilidad de los agregados (estructura) tras la aplicación de compost (Ferreras et al., 2006; Insam y de Bertoldi, 2007). La magnitud del efecto varió en función del tipo de enmienda, la dosis 
aplicada y el período de muestreo -al estar aquel relacionado con la biodegradación de la materia orgánica, polisacáridos y lípidos-, habiéndose señalado que la dosis debe ser suficientemente elevada para mostrar dichos efectos (Abiven et al., 2008; Albiach et al., 2001; Ingelmo y Rubio, 2008). Este incremento en la estabilidad estructural ha mostrado, además, una alta variabilidad entre los distintos estudios realizados (Aggelides y Londra, 2000; García-Orenes et al., 2005).

Adicionalmente, el aporte de compost provoca un aumento en la capacidad de retención de agua útil para las plantas (Insam y de Bertoldi, 2007; Zeytin y Baran, 2003), relacionándose dicho efecto con la mezcla de las partículas del compost con las del suelo, generándose una estructura con un reparto equilibrado de poros de distinto tamaño, que permanece además estable (Ingelmo et al., 2007; Kay y Angers, 2002). En base a la mayor porosidad total y tamaño de los poros anteriormente señalada, la capacidad de retención de agua a potenciales hídricos bajos aumenta, siendo este fenómeno de mayor magnitud en suelos de textura gruesa o media (Ingelmo y Rubio, 2008).

Por último, la aplicación de compost sobre la superficie del suelo ejerce un efecto de acolchado, que disminuye los efectos de sellado del mismo por el impacto de las gotas de lluvia así como las pérdidas de agua por evaporación directa, incrementándose la velocidad de infiltración y la capacidad de retención y almacenamiento de agua. De igual modo, el efecto de la enmienda orgánica se manifiesta en una disminución del efecto erosivo de las gotas de lluvia, regulando la energía de éstas y evitando la dispersión de partículas (Ingelmo y Rubio, 2008).

\subsubsection{Sobre las propiedades físico-químicas y químicas}

El incremento de la capacidad de intercambio catiónico al aplicar enmiendas orgánicas al suelo se basa en la interacción humus-arcilla, que da lugar al desarrollo del complejo de intercambio iónico del suelo, controlando éste numerosos procesos edáficos (incluida la regulación de los nutrientes). A partir de la materia orgánica se forman distintos tipos de complejos, entre los que destacan los complejos metálicos y los complejos de adsorción de compuestos húmicos en la superficie y los espacios interlaminares de las arcillas. Estos últimos son estables y su asociación es la base de la retención y la disponibilidad de los nutrientes en el suelo (Ingelmo y Rubio, 2008).

Respecto a la influencia de la aplicación de enmiendas orgánicas en el $\mathrm{pH}$, el efecto de éstas depende del valor original de este parámetro en el suelo (Diacono y 
Montemurro, 2011). El suelo es un medio cuyo pH varía lentamente, debido a su poder tampón, lo que aporta estabilidad para la actividad microbiana y la disponibilidad de los nutrientes, fuertemente condicionadas por el pH de la solución del suelo. De manera general, los composts maduros tienen valores de $\mathrm{pH}$ de ligera a fuertemente alcalinos, por lo que en suelos ácidos los composts elevan el pH, mejorando las condiciones para los microorganismos y la disponibilidad de los nutrientes, y, por el contrario, en suelos neutros o básicos no se producen grandes cambios en este parámetro (Erhart y Hartl, 2010; Ingelmo y Rubio, 2008).

El valor agronómico de las enmiendas suele relacionarse con el aporte de materia orgánica para el suelo y de nutrientes para las plantas. Distintos autores han señalado un incremento en el contenido en carbono orgánico del suelo tras la adición de enmiendas orgánicas (Cherif et al., 2009; Montemurro et al., 2006). Debido a que los composts son materiales estables, el valor fertilizante de éstos a corto plazo no es muy elevado (Diacono y Montemurro, 2011), por lo que suele ser necesario complementarlos con la aplicación de abonos minerales (Moral y Muro, 2008). Así, la dinámica de mineralización de los nutrientes del compost suele ser muy variable, atribuyéndose la resistencia al ataque microbiano a elevadas concentraciones de lignina y carbono recalcitrante (Vigil y Kissel, 1995). Los principales factores que afectan a la mineralización del compost en el suelo son: la humedad, la temperatura, la salinidad, el pH, la textura, y las propiedades del compost (relación $\mathrm{C} / \mathrm{N}$, grado de humificación y granulometría) (Moral y Muro, 2008).

En el caso del nitrógeno, elemento que se encuentra mayoritariamente en forma orgánica y es de gran importancia desde el punto de vista agrícola y medioambiental (Insam y de Bertoldi, 2007; Ramos y Úbeda, 2009), su lenta liberación presenta ventajas en cuanto a suministro regular y progresivo, evitándose así problemas de contaminación. El nitrógeno orgánico que no es mineralizado tras su aplicación queda almacenado en el suelo y es liberado posteriormente de forma progresiva (Erhart y Hartl, 2010; Ingelmo y Rubio, 2008), siendo muy variable la velocidad de mineralización del mismo (Castro et al., 2006).

La aplicación de enmiendas orgánicas incrementa generalmente el contenido en fósforo y potasio asimilables (Erhart y Hartl, 2010; Herencia et al., 2007). Con relación al fósforo, la aplicación de compost al suelo provoca un incremento en el contenido en formas asimilables, tanto por efecto directo (aumento de los niveles de este elemento) como por el incremento en la disponibilidad del mismo (mediante la formación de 
fosfo-humatos). El potasio del compost es un elemento disponible para las plantas, por lo que su aporte al suelo puede ser una alternativa muy adecuada en situaciones en las que se hayan producido pérdidas por lixiviación. Por su parte, los niveles de calcio y magnesio no suelen presentar problemas para cubrir las necesidades de los cultivos en suelos neutros o alcalinos, mientras que en los suelos ácidos su incorporación con el compost puede mejorar notablemente la nutrición cálcica y magnésica de las plantas (Ingelmo y Rubio, 2008).

La disponibilidad de hierro, cobre y zinc es generalmente baja en suelos calizos, por lo que un aporte externo de éstos, como es el caso de las enmiendas orgánicas, incrementa los niveles disponibles de estos micronutrientes. No obstante, la adición de materia orgánica puede aumentar o disminuir su disponibilidad, solubilidad y absorción por las plantas. Los compuestos de baja solubilidad de la materia orgánica forman complejos órgano-metálicos insolubles, que dificultan su absorción por la planta, mientras que las formas de carbono solubles aumentan la solubilidad de los metales mediante la formación de complejos de alta solubilidad (Erhart y Hartl, 2010).

\subsubsection{Sobre las propiedades bioquímicas y microbiológicas}

Las propiedades biológicas del suelo también se alteran como consecuencia de la adición de compost (Pérez Piqueres et al., 2006), bien sea por variaciones de los parámetros físico-químicos o químicos del suelo, o debido a la incorporación de los microorganismos nativos del compost (García-Gil et al., 2000). La actividad microbiológica del suelo desempeña un papel clave en la estabilidad y la fertilidad de éste, observándose interrelaciones entre los ámbitos físico-químicos y biológicos (Vargas y Suárez-Estrella, 2008). Diversos autores consideran de gran interés el estudio de las propiedades biológicas y bioquímicas del suelo como indicadores de los efectos de la adición de materia orgánica, ya que estos parámetros poseen mayor sensibilidad -a corto plazo- a los cambios producidos por el manejo de dicho suelo, que los parámetros físicos y químicos (Diacono y Montemurro, 2011; Madejón et al., 2007; Melero et al., 2007a, 2007b).

Los estudios realizados señalan generalmente un incremento de biomasa microbiana tras la aplicación de compost (Pérez de Mora et al., 2006; SánchezMonedero et al., 2004; Tejada et al., 2006, 2009), aunque algunos autores registraron disminuciones, o variaciones no significativas, en los valores de este parámetro (Ros et al., 2006a). Esto último suele relacionarse con la composición del 
compost empleado, concretamente la presencia de sustancias que afectan negativamente al desarrollo microbiano, tales como metales pesados (Schloter et al., 2003).

La influencia del compost en los microorganismos no es sólo de tipo global (o general), ya que los cambios en los parámetros físico-químicos y químicos del suelo que conlleva la adición de aquel modifican la distribución de los distintos grupos microbianos (poblaciones) que colonizan el medio edáfico (Pérez de Mora et al., 2006), lo que depende del tipo de compost aplicado (Ros et al., 2006b). Aunque no siempre puede relacionarse la dosis de compost aportada con la respuesta de las comunidades microbianas, la incorporación frecuente de compost se considera una estrategia adecuada con vistas al desarrollo óptimo de las funciones edáficas (Carpenter-Boggs et al., 2000). Además, no es necesario un alto grado de diversidad microbiana para que se desarrollen los procesos de transformación propios del suelo, debido a que la diversidad funcional permite que una misma actividad metabólica pueda llevarse a cabo por un número relativamente amplio de especies (Vargas y Suárez-Estrella, 2008).

Las acciones de biotransformación de los microorganismos se realizan a través de un amplio grupo de enzimas que catalizan sus actividades metabólicas y están estrechamente vinculadas con la disponibilidad de nutrientes y la funcionalidad del suelo. Existe un elevado número de enzimas que se relacionan de forma específica con los procesos de transformación de los elementos nutritivos (destacando el carbono, el nitrógeno y el fósforo), por lo que la determinación de éstas debe limitarse a una selección adecuada que proporcione la información necesaria para interpretar las condiciones del suelo. De esta forma, la determinación de las actividades deshidrogenasa y hidrólisis del diacetato de fluoresceína (FDA) proporcionan información genérica sobre la actividad microbiana presente; la acción de las $\beta$ glucosidasas permite conocer el estado de transformación de la materia orgánica y la disponibilidad de los sustratos de carbono; ureasas y proteasas muestran la capacidad para hidrolizar compuestos nitrogenados; y, fosfatasas y arilsulfatasas son relevantes en los procesos de mineralización del fósforo orgánico y de producción de sulfato asimilable, respectivamente (Vargas y Suárez-Estrella, 2008).

La adición de compost al suelo ejerce un efecto estimulante sobre la actividad enzimática (Ferreras et al., 2006; Tejada et al., 2009), por lo que incrementa generalmente el valor de las actividades deshidrogenasa y de hidrólisis del diacetato 
de fluoresceína (FDA) (Debosz et al., 2002; Marcote et al., 2001). Del mismo modo, la actividad $\beta$-glucosidasa suele estimularse con la aplicación de enmiendas orgánicas, especialmente cuando los niveles de carbono fácilmente biodegradable son elevados (Marcote et al., 2001). Y, por su parte, la actividad arilsulfatasa también aumenta tras la aplicación de compost (Albiach et al., 2000). Por el contrario, las actividades ureasa, proteasa y fosfatasa no muestran una tendencia clara de variación en relación con los aportes de compost (Vargas y Suárez-Estrella, 2008).

\subsubsection{Efectos sobre la productividad de los cultivos}

Según Lal (2006), existen tres tipos de respuesta de los cultivos al contenido en carbono orgánico del suelo: incremento de la cosecha como consecuencia del incremento de la reserva de carbono del suelo, incremento de la cosecha paralelo a la disminución del nivel de carbono orgánico, y efecto nulo o ligera disminución de la cosecha en combinación con la reducción en el contenido de carbono orgánico. La influencia de la aplicación de compost en la productividad de los cultivos depende de distintos factores, relacionados principalmente tanto con la mineralización de los nutrientes en el suelo como con los propios cultivos (exigencias en nutrientes y dinámica de absorción de éstos, entre otros factores) (Erhart y Hartl, 2010).

En líneas generales, la aplicación de compost eleva la productividad vegetal (Ingelmo y Rubio, 2008), particularmente cuando se combina con fertilizantes minerales (Diacono y Montemurro, 2011). Además de las características del material orgánico, en el efecto de éste influye también el tipo de suelo, lo que hace necesario estudiar las propiedades del mismo con vistas a seleccionar la enmienda más adecuada (Vargas y Suárez-Estrella, 2008). Según Diacono y Montemurro (2011), se obtienen resultados tanto mejores cuanto mayores son la frecuencia y la dosis de material orgánico aplicado. Para mejorar el efecto de las enmiendas orgánicas, se recomienda, además, la elaboración de mezclas de distintos tipos de residuos orgánicos para su compostaje (Manios, 2004).

Desde el punto de vista de la calidad de la cosecha, distintos estudios señalan que la aplicación de enmiendas orgánicas mantiene o mejora la calidad de ésta (Diacono y Montemurro, 2011; Erhart et al., 2005; Mantovi et al., 2005).

En la Tabla 1.11 se resumen los efectos de la aplicación de compost sobre el desarrollo y la productividad de distintos cultivos hortícolas, encontrados en la revisión bibliográfica realizada. 
Tabla 1.11. Estudios sobre aplicación de composts de diferentes orígenes y características al suelo en el cultivo de varias especies hortícolas, con indicación de sus efectos sobre la producción

\begin{tabular}{|c|c|c|c|}
\hline Cultivo & $\begin{array}{c}\text { Compost } \\
\text { (composición) }\end{array}$ & $\begin{array}{c}\text { Efecto } \\
\text { sobre la } \\
\text { producción }\end{array}$ & Referencia \\
\hline
\end{tabular}

Liliaceae

Cebolla

Puerro

Asteraceae

Lechuga

Cruciferae

Bróculi

Col

Col china

Coliflor

Colirrábano

Rábano

Chenopodiaceae

Espinaca

Cucurbitaceae

Calabaza (de invierno)

Calabaza (de verano)

Melón

Pepino

Fabaceae

Judía verde

$\begin{array}{ccl}\text { LD/RA } & +,= & \text { Smith et al., } 1992 \\ \text { LD/VM } & + & \text { Bevacqua y Mellano, } 1993 \\ \text { RP } & + & \text { Maynard y Hill, 2000 } \\ \text { RP } & = & \text { Elfstrand et al., } 2007\end{array}$

$\begin{array}{ccl}\text { LD/VM } & + & \text { Bevacqua y Mellano, } 1993 \\ \mathrm{RIA} & +,= & \text { Lee et al., 2004 } \\ \mathrm{RSU} & + & \text { Castro et al., } 2009 \\ \mathrm{RIA} & + & \text { Altieri y Esposito, } 2010 \\ \mathrm{RSU} & + & \text { Fagnano et al., } 2011\end{array}$

RSU Roe et al., 1990

RG, RA $\quad+\quad$ Buchanan y Gliessman, 1991

RG $\quad+,=\quad$ Maynard, 1994

RG + Roe y Cornforth, 1997

LD/RA + $\quad$ Smith et al., 1992

RG/RA $\quad+,-\quad$ Kao, 1993

$\begin{array}{lll}\text { RG } & +,= & \text { Maynard, } 1994 \\ \text { RIA } & + & \text { Vogtmann y Fricke, } 1989 \\ \text { LD } & + & \text { Cai et al., } 2008\end{array}$

LD $\quad+,=\quad$ Bevacqua y Mellano, 1993

$\begin{array}{ccl}\text { RSU } & = & \text { Roe et al., 1993 } \\ \text { RSU } & +,= & \text { Bryan et al., 1994 } \\ \text { RG } & + & \text { Roe y Cornforth, 1997 } \\ \text { RA } & + & \text { Kostov et al., 1995 } \\ \text { RIA } & = & \text { Ehaliotis et al., } 2005\end{array}$

$\begin{array}{ccl}\text { RSU } & +,= & \text { Ozores-Hampton y Bryan, 1993a } \\ \text { RG } & +,= & \text { Allen y Preer, 1995 } \\ \text { RP } & +,= & \text { Gray y Tahwid, 1995 } \\ \text { RG/Papel } & + & \text { Baziramakenga y Simard, 2001 } \\ \text { RA } & +,= & \text { Karungi et al., 2006 }\end{array}$

\footnotetext{
$\mathrm{z}+,-,=$ : efecto positivo, negativo o nulo, respectivamente, con relación al control (suelo sin enmendar, sin aporte de materia orgánica)

LD: lodos de depuración de aguas residuales urbanas; RA: residuos agrícolas; VM: virutas de madera; RSU: residuos sólidos urbanos; RG: residuos ganaderos, RP: restos de poda; RIA: residuos de la industria agroalimentaria
} 
Tabla 1.11. (Ctón.) Estudios sobre aplicación de composts de diferentes orígenes y características al suelo en el cultivo de varias especies hortícolas, con indicación de sus efectos sobre la producción

\begin{tabular}{|c|c|c|c|}
\hline Cultivo & $\begin{array}{c}\text { Compost } \\
\text { (composición) }\end{array}$ & $\begin{array}{c}\text { Efecto } \\
\text { sobre la } \\
\text { producciónz }\end{array}$ & Referencia \\
\hline
\end{tabular}

Graminae

Maíz

Solanaceae

\begin{tabular}{|c|c|c|c|}
\hline \multirow[t]{2}{*}{ Berenjena } & RSU & $=$ & Roe et al., 1992 \\
\hline & RSU & + & Ozores-Hampton y Bryan, 1993b \\
\hline \multirow[t]{3}{*}{ Patata } & RIA & + & Vogtmann et al., 1993 \\
\hline & $\mathrm{RP}$ & $=$ & Klasink y Steffens, 1996 \\
\hline & RSU & $=$ & Volterrani et al., 1996 \\
\hline \multirow[t]{7}{*}{ Pimiento } & RSU & - & Ozores-Hampton y Bryan, 1993b \\
\hline & RSU & - & Clark et al., 1994 \\
\hline & RSU & - & Roe et al., 1994 \\
\hline & LD/RP & $=$ & Roe y Stoffella, 1994a \\
\hline & $\mathrm{RP}$ & $=$ & Maynard, 1996 \\
\hline & LD/RP & + & Roe et al., 1997 \\
\hline & RIA & $=$ & Alburquerque et al., 2006b \\
\hline \multirow[t]{14}{*}{ Tomate } & RSU & + & Bryan y Lance, 1991 \\
\hline & RSU & + & Manios y Kapetanios, 1992 \\
\hline & RSU & $=,-$ & Bryan et al., 1994 \\
\hline & RSU & + & Clark et al., 1994 \\
\hline & RA &,$+=,-$ & Maynard, 1994 \\
\hline & RSU &,+- & Obreza y Reeder, 1994 \\
\hline & RSU &,+- & Ozores-Hampton et al., 1994 \\
\hline & LD/RP & $=$ & Roe y Stoffella, 1994b \\
\hline & LD & + & Allen y Preer, 1995 \\
\hline & $R G+R P / R G$ &,+- & Álvarez et al., 1995 \\
\hline & RSU & + & Bryan et al., 1995 \\
\hline & RSU & + & Maynard, 1995 \\
\hline & RA & + & Stoffella y Graetz, 1997 \\
\hline & RIA & + & Altieri y Esposito, 2010 \\
\hline \multicolumn{4}{|l|}{ Umbeliferae } \\
\hline Zanahoria & $\mathrm{RG}$ &,$+=$ & Warman y Havard, 1997 \\
\hline
\end{tabular}

$\begin{array}{ccl}\text { LD/RP } & - & \text { Hornick, } 1988 \\ \text { RG } & + & \text { De Toledo et al., 1996 } \\ \text { RP } & + & \text { Parkinson et al., 1999 } \\ \text { RG/RP } & =,- & \text { Reider et al., 2000 } \\ \text { RA/RIA } & = & \text { Madejón et al., 2001c } \\ \text { RIA/leonardita } & = & \text { Madejón et al., 2001c } \\ \text { RA/RIA/leonardita } & + & \text { Madejón et al., 2001c }\end{array}$




\subsubsection{Efectos del compost de alperujo}

Debido a que la extracción del aceite de oliva mediante el sistema de centrifugación de dos fases se ha limitado principalmente a las almazaras españolas (Roig et al., 2006) y a que la producción de alperujo es relativamente reciente (Alburquerque et al., 2004), no se han llevado a cabo muchas investigaciones sobre el uso de compost de alperujo en el campo de la producción vegetal.

Cayuela et al. (2004) indicaron que la adición de composts elaborados con alperujo y estiércol de oveja en olivar incrementó el nivel de materia orgánica y el valor de la capacidad de intercambio catiónico del suelo. Alburquerque et al. (2006b) evaluaron los efectos a corto plazo de varios materiales orgánicos -un compost de alperujo más residuo del desmotado de algodón, un estiércol de vaca, y un compost de lodos de depuración de aguas residuales urbanas- sobre la producción de pimiento, encontrando que los tres materiales proporcionaron una cosecha similar al control (todos los tratamientos recibieron el mismo programa de fertilización mineral) y que el contenido en materia orgánica del suelo tras el cultivo disminuyó cuando se aplicó el estiércol o el compost de lodos de depuradora, mientras que se mantuvo con el compost de alperujo, demostrándose así la resistencia de éste a la biodegradación. Asimismo, Alburquerque et al. (2007) observaron, en un experimento con raigrás, que la aplicación de compost de alperujo incrementó la producción de biomasa aérea, aunque el rendimiento fue significativamente superior cuando éste se complementó con fertilizantes minerales. Otro estudio con compost de alperujo (Altieri y Esposito, 2010) en suelos cultivados con tomate y lechuga, registró un incremento (a corto plazo) en el contenido de carbono orgánico y carbono extraíble (en medio alcalino) al final del experimento, y un rendimiento de los cultivos de cuantía similar al control (sin enmendar) que recibió la dosis estándar de fertilizantes minerales.

Otras investigaciones han utilizado compost de alperujo para incrementar la disponibilidad de los nutrientes (formas solubles e intercambiables) y su posterior absorción por las especies Beta maritima y Beta vulgaris en un suelo salino (Walker y Bernal, 2008), y en la biorremediación de suelos contaminados por metales pesados (Alburquerque et al., 2011; de la Fuente et al., 2011).

De acuerdo con lo indicado en la sección 1.3.5, durante los últimos 7 años se han publicado varios estudios de co-compostaje de alperujo con otros residuos orgánicos, habiéndose procedido a caracterizar las propiedades de los composts 
resultantes. No obstante, continúan siendo escasos e incompletos los trabajos que investigan los efectos del compost de alperujo sobre los suelos agrícolas y las plantas cultivadas, especialmente de consistencia herbácea. Todo ello justifica adecuadamente los objetivos de la presente Tesis Doctoral, que examina y estudia la caracterización y el uso de dos composts de alperujo -con diferente composición y características- como mejoradores del suelo, abordando aspectos agronómicos y medioambientales de interés. 
2. OBJECTIVES 
The overall objective of this PhD Thesis is to characterize and assess the use as organic soil improvers of two composts prepared from two-phase olive mill waste ('alperujo') -one irrigated with well water during the composting process (compost A) and the other one with a liquid, animal fatty-proteinaceous waste from the pharmaceutical industry (compost $\mathrm{A}+\mathrm{H}$ )- by developing various agronomic and environmental studies.

With this aim in view, eight specific objectives were approached:

1. To characterize the aforesaid composts by determining their main physical, physico-chemical and biological properties, their mineral and organic composition, and outstanding maturity and stability parameters.

2. To determine the effects of the composts studied on selected physical and chemical characteristics of a calcareous soil in one experiment lasting for one year.

3. To ascertain the short-term effects of these composts on soil nitrogen dynamics in two different textured soils (from Spain and Italy) by studying chemical, biochemical and microbiological issues.

4. To evaluate the direct and residual effects of the composted materials when applied to a calcareous soil, in combination with two mineral fertilization programs, on growth, yield and nutritional status of a vegetable crops rotation, and on selected soil chemical characteristics, during two consecutive years.

5. To assess the effects of the soluble organic matter extracted from the composts on growth and yield of a forage crop, and on the chemical characteristics of a calcareous soil either cultivated or uncultivated.

6. To test the suppressive capability of the composted materials towards phytopathogens by isolating and identifying actinomycetes from the materials studied, and by developing in vitro and in vivo assays with phytopathogenic agents.

7. To investigate the effects of amending two heavy metal- and arsenic-polluted soils -one alkaline and the other one acidic- with an 'alperujo' compost on trace element bioavailability, on microbial population and activity, and on growth and phytoextraction capability for pollutants of various Brassica species.

8. To study the main chemical and microbial changes throughout the acidification process of an 'alperujo' compost amended with elemental sulphur, for its use as soilless container medium, and to isolate and identify microorganisms involved in this process. 
3. MATERIALES Y MÉTODOS 
Los experimentos y determinaciones realizadas en la presente Tesis Doctoral se desarrollaron en las Unidades Docentes de Fitotecnia General, Edafología, y Microbiología, adscritas a los Departamentos de Producción Vegetal, Química, y Biotecnología, respectivamente, de la Escuela Técnica Superior de Ingeniería Agronómica y del Medio Natural de la Universitat Politécnica de València durante un período de cuatro años (2007-2011), así como en el Dipartimento di Scienze delle Produzioni Vegetali, del Suolo e dell'Ambiente Agroforestale de la Università degli Studi di Firenze (Italia) en una estancia de investigación de cuatro meses de duración realizada en el último semestre de 2010. Se ha contado, además, con la colaboración del Departamento de Conservación de Suelos y Agua y Manejo de Residuos Orgánicos del Centro de Edafología y Biología Aplicada del Segura (CEBAS-CSIC, Murcia), donde se prepararon los dos composts estudiados, mediante compostaje de la mezcla de materiales residuales frescos (de partida), que se indican a continuación, y se extrajo además la materia orgánica soluble de dichos composts, con objeto de llevar a cabo los estudios desarrollados en esta Tesis Doctoral.

\subsection{MATERIALES UTILIZADOS}

\subsubsection{Materiales orgánicos}

Los dos composts de alperujo -el subproducto orgánico generado por las almazaras durante la extracción de aceite de oliva mediante el sistema de centrifugación de 2 fases- se prepararon en la Planta Piloto de Compostaje del CEBAS-CSIC (Murcia). Para cada uno de los composts, se construyeron 2 pilas de $10000 \mathrm{~kg}$ cada una.

El compost $\boldsymbol{A}$ (Fotografía 3.1) se preparó mezclando 85\% (composición expresada en peso seco) de alperujo de dos fases - producido por la almazara Aceites Guadalentín S.L. (Pozo Alcón, Jaén)- y 15\% de estiércol de caballo fresco (deyecciones + cama) procedente de la Yegüada JJ Montes (Finca Santa Ana, Totana, Murcia). Este compost se obtuvo utilizando un sistema abierto (al aire libre) dinámico, con volteos periódicos, cuya duración fue de 195 días para la fase bio-oxidativa activa más otros 66 días para la fase de maduración. El riego de las pilas durante la fase activa se realizó con agua de pozo $(\mathrm{pH}=7,50$; conductividad eléctrica $=4,88 \mathrm{dS} / \mathrm{m})$, contabilizándose un consumo total de 7050 L/pila. 
El compost $\boldsymbol{A}+\boldsymbol{H}$ (Fotografía 3.1) se elaboró a partir de una mezcla compuesta por $74 \%$ de alperujo más $13 \%$ de estiércol de caballo fresco y $13 \%$ (en peso seco) de hidrolizado enzimático graso de proteínas animales -en emulsión alcalinaprocedente de la industria farmacéutica BIOIBERICA S.A. (Barcelona). El alperujo y el estiércol utilizados procedían de los mismos lotes empleados para el compost A. Para el desarrollo del proceso, se utilizó un sistema de compostaje abierto con volteos periódicos; entre los días 9 y 38 de dicho proceso, la mezcla de residuos sólidos (alperujo y estiércol) repartida entre dos pilas se regó con el hidrolizado (4450 L/pila) y, posteriormente, con agua de pozo (4400 L/pila). La duración del proceso fue de 195 días para la fase activa, seguida de otros 66 días de maduración.

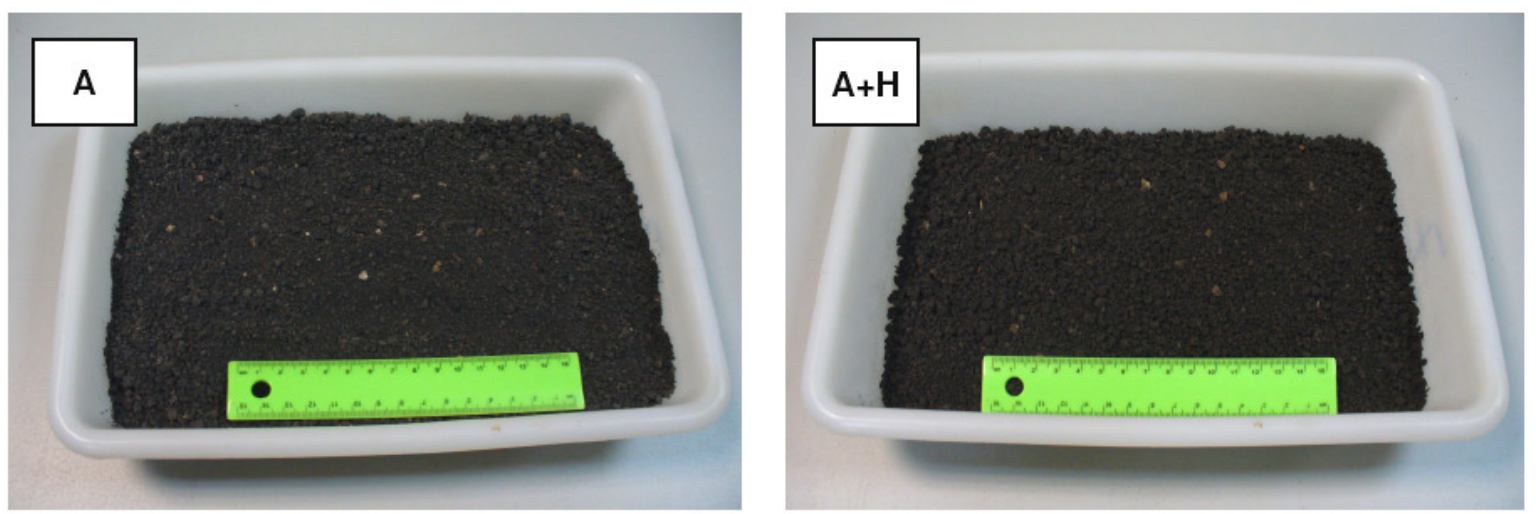

Fotografía 3.1. Composts de alperujo $(\mathrm{A}$ y $\mathrm{A}+\mathrm{H})$ estudiados en esta Tesis Doctoral

El alperujo (A) utilizado para elaborar los composts presentó un pH fuertemente ácido (5,03 unidades), un contenido en materia orgánica total de $896 \mathrm{~g} / \mathrm{kg}$, y una concentración de nitrógeno total de 15,9 g/kg. Además, su relación $\mathrm{C} / \mathrm{N}$ fue de 32,2, siendo los niveles de fósforo y potasio (totales) de 1,2 g/kg y 16,0 g/kg, respectivamente.

Por su parte, el estiércol de caballo fresco poseía un pH cercano a la neutralidad $(7,24)$ y concentraciones de materia orgánica total y nitrógeno total de $578 \mathrm{~g} / \mathrm{kg}$ y $15,3 \mathrm{~g} / \mathrm{kg}$, respectivamente. Su relación C/N fue de 20,4 y su contenido en fósforo y potasio totales de $2,3 \mathrm{~g} / \mathrm{kg}$ y $21,2 \mathrm{~g} / \mathrm{kg}$, respectivamente.

El hidrolizado enzimático graso de proteínas animales $(H)$, procedente de la industria farmacéutica, utilizado en la preparación del compost $\mathrm{A}+\mathrm{H}$ perteneció al grupo de subproductos clasificados como SANDACH (Subproductos Animales No Destinados A Consumo Humano). Con relación a sus características y composición, merece destacarse su valor de $\mathrm{pH}$ muy fuertemente alcalino $(9,99)$ y su elevada conductividad eléctrica $(35,4 \mathrm{dS} / \mathrm{m})$, además de un contenido en materia orgánica 
total de $678 \mathrm{~g} / \mathrm{kg}$. Su concentración en nitrógeno total fue alta $(80,6 \mathrm{~g} / \mathrm{kg})$ y su relación $\mathrm{C} / \mathrm{N}$ baja $(5,2)$. Respecto a la composición en otros elementos fertilizantes, el hidrolizado presentó niveles de fósforo y potasio totales de 7 g/kg y $59 \mathrm{~g} / \mathrm{kg}$, respectivamente.

La composición del alperujo $(A)$, el estiércol y el hidrolizado $(H)$ indicada más arriba se ha expresado sobre materia seca.

La materia orgánica soluble (MOS) de los dos composts señalados más arriba (A y $\mathrm{A}+\mathrm{H}$ ) se obtuvo -tras secado al aire y trituración de éstos- mediante extracción con $\mathrm{KOH} 1 \mathrm{M}$ en la proporción compost/extractante 1/3 (p/v) durante 24 horas, con agitación y temperatura de $70^{\circ} \mathrm{C}$. Los extractos así producidos se centrifugaron posteriormente a $10000 \mathrm{rpm}$ durante 30 minutos, filtrándose los sobrenadantes obtenidos a través de nylon para conseguir las dos MOS (de $\mathrm{A}$ y $\mathrm{A}+\mathrm{H}$, respectivamente) objeto de estudio en el experimento de evaluación agronómica realizado (sección 3.5). El volumen de MOS requerido para realizar los estudios indicados se extrajo a partir de diferentes lotes ("batches"), que, una vez reunidos en un volumen de aproximadamente $13 \mathrm{~L}$ para cada una de las dos MOS a estudiar, presentaron un contenido en carbono orgánico total de $63,8 \mathrm{~g} / \mathrm{kg}$ de extracto y 56,2 g/ kg de extracto para la MOS del compost $\mathrm{A}$ y el $\mathrm{A}+\mathrm{H}$, respectivamente. Las características y composición de los extractos alcalinos de ambas MOS se presentan en la Tabla 3.1.

Tabla 3.1. Características y composición (sobre peso de extracto fresco) de los extractos alcalinos de la materia orgánica soluble (MOS) procedente de los composts $\mathrm{A}$ y $\mathrm{A}+\mathrm{H}$

\begin{tabular}{lcc}
\hline \multirow{2}{*}{ Parámetroz $^{2}$} & MOS de compost \\
\hline Humedad (\%) & $\mathbf{A}$ & $\mathbf{A + H}$ \\
$\mathrm{ny}$ & 86,1 & 86,4 \\
Conductividad eléctrica (CE, dS/m) & 13,2 & 13,1 \\
Materia orgánica total (g/kg) & 51,8 & 51,5 \\
Carbono orgánico total (g/kg) & 76,2 & 66,6 \\
Nitrógeno total (g/kg) & 63,8 & 56,2 \\
Relación C/N & 4,5 & 4,7 \\
Fósforo total (mg/kg) & 14,2 & 12,0 \\
Potasio total (g/kg) & 283 & 246 \\
Azufre total (mg/kg) & 44 & 36 \\
Calcio total (mg/kg) & 1443 & 2908 \\
Magnesio total (mg/kg) & 1052 & 839 \\
Sodio (mg/kg) & 338 & 104 \\
\hline
\end{tabular}




\subsubsection{Suelo calizo}

Para la evaluación de los composts como enmiendas o mejoradores del suelo (y también de la MOS extraída de éstos) se utilizó un suelo calizo procedente de Lliria, Valencia, tomado de una parcela sin cultivar durante varios años, correspondiendo el centro de dicha parcela a las coordenadas UTM x: 705782,98 e y: 4399153,53, (Fotografía 3.2). El suelo era de textura franco-arcillosa, con pH alcalino $(8,39)$ y conductividad eléctrica de 0,155 dS/m. En relación con las características químicas, el suelo poseía un bajo contenido en materia orgánica ( $C$ orgánico=7,4 g/kg) y una reducida capacidad de fertilización mineral, ya que sus niveles de nitrógeno total, fósforo asimilable y potasio asimilable fueron de 0,76 g/kg, 8,1 mg/kg y $120 \mathrm{mg} / \mathrm{kg}$, respectivamente (Tabla 3.2).

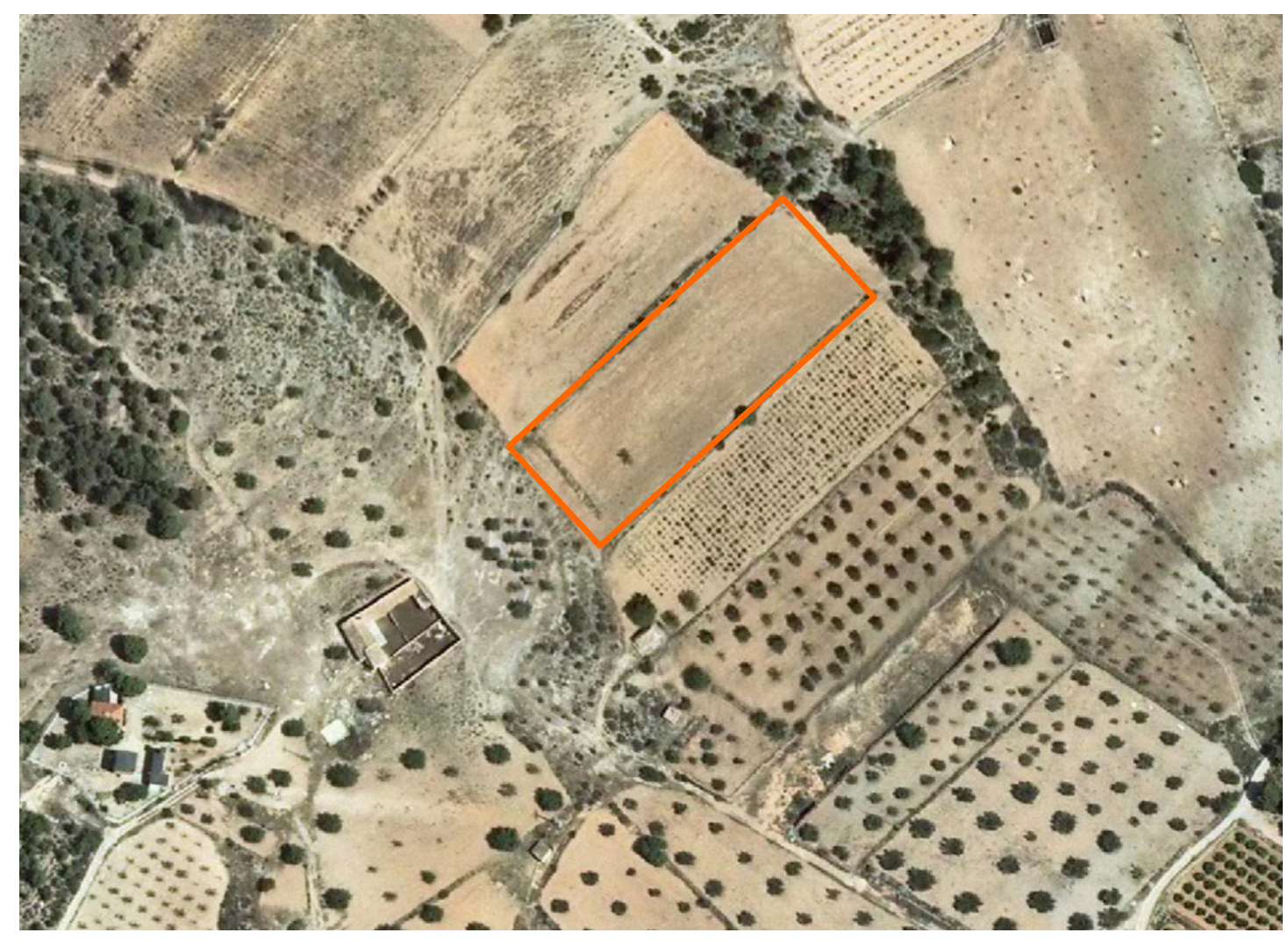

Fotografía 3.2. Vista aérea de la parcela de donde se muestreó el suelo calizo utilizado en esta Tesis Doctoral 
Tabla 3.2. Características físicas y físico-químicas, y composición química (sobre materia seca) del suelo calizo utilizado en esta Tesis Doctoral

\begin{tabular}{|c|c|c|}
\hline Análisis / Parámetro & Valor & $\sigma$ \\
\hline \multicolumn{3}{|l|}{ Análisis granulométrico } \\
\hline Arcilla (\%) & 28 & 2 \\
\hline Limo (\%) & 40 & 1 \\
\hline Arena (\%) & 32 & 2 \\
\hline Textura & Franco-arcillosa & - \\
\hline Color & 2,5 YR $5 / 6$ & - \\
\hline $\mathrm{pH}(1 / 2,5, \mathrm{p} / \mathrm{v})$ & 8,39 & 0,03 \\
\hline Conductividad eléctrica $(1 / 5, \mathrm{p} / \mathrm{v}, \mathrm{dS} / \mathrm{m})$ & 0,155 & 0,014 \\
\hline Carbono orgánico (g/kg) & 7,4 & 0,01 \\
\hline $\mathrm{N}$ total $(\mathrm{g} / \mathrm{kg})$ & 0,76 & 0,01 \\
\hline Relación C/N & 9,74 & 0,2 \\
\hline $\mathrm{P}$ asimilable (mg/kg) & 8,1 & 0,3 \\
\hline $\mathrm{K}$ asimilable (mg/kg) & 120 & 7 \\
\hline \multicolumn{3}{|l|}{ Cationes de cambio (meq/100 g) } \\
\hline $\mathrm{Ca}^{2+}$ & 23,9 & 1,2 \\
\hline $\mathrm{Mg}^{2+}$ & 1,1 & 0,1 \\
\hline $\mathrm{K}^{+}$ & 0,52 & 0,03 \\
\hline $\mathrm{Na}^{+}$ & 0,007 & 0,005 \\
\hline Carbonatos $\left(\mathrm{CaCO}_{3}, \%\right)$ & 37,7 & 0,4 \\
\hline Caliza activa $\left(\mathrm{CaCO}_{3}, \%\right)$ & 5,4 & 0,3 \\
\hline
\end{tabular}

\subsection{CARACTERIZACIÓN FÍSICA, FÍSICO-QUÍMICA, QUÍMICA Y BIOLÓGICA DE LOS COMPOSTS DE ALPERUJO A Y A+H}

Una vez se recepcionaron las muestras de compost $\mathrm{A}$ y $\mathrm{A}+\mathrm{H}$ en el laboratorio, se procedió a realizar la caracterización de dichos materiales, siguiéndose para ello los protocolos recogidos en las Normas UNE-EN correspondientes a "Mejoradores del Suelo y Sustratos de Cultivo" de la Asociación Española de Normalización y Certificación (AENOR, Madrid), y, en ausencia de éstos, según las metodologías indicadas en la bibliografía. Los protocolos utilizados en la toma de muestras y la caracterización física, físico-química, química y biológica de los composts se recogen en la sección I.1 del Anejo I de Métodos Analíticos.

A continuación se indican las determinaciones realizadas y las metodologías utilizadas en la presente Tesis Doctoral para la caracterización de los composts, así 
como la referencia del método empleado. Todas las determinaciones físicas, físicoquímicas y químicas se realizaron por triplicado.

\subsubsection{Propiedades físicas}

Los parámetros físicos determinados en las muestras de compost $\mathrm{A}$ y $\mathrm{A}+\mathrm{H}$ -tamizados por la malla de luz de $6 \mathrm{~mm}$ - se presentan en la Tabla 3.3, recogiéndose la descripción detallada de los métodos utilizados en la sección I.1.2 del Anejo I de Métodos Analíticos.

Tabla 3.3. Parámetros físicos determinados en los composts $\mathrm{A}$ y $\mathrm{A}+\mathrm{H}$, y sus métodos (referencias) correspondientes

\begin{tabular}{ll}
\hline \multicolumn{1}{c}{ Parámetro } & \multicolumn{1}{c}{ Método/Referencia } \\
\hline Granulometría & Norma UNE-EN 15428 (2008) \\
Índice de grosor & Richards et al. (1986) \\
Diámetro medio geométrico & Shirazi y Boersma (1984) \\
\hline Densidad aparente & Norma UNE-EN 13041:2001/A1 (2007) \\
\hline Densidad de partícula & Norma UNE-EN 13041:2001/A1 (2007) \\
\hline Porosidad total & Norma UNE-EN 13041:2001/A1 (2007) \\
\hline Volumen de agua & Norma UNE-EN 13041:2001/A1 (2007) \\
\hline Volumen de aire & Norma UNE-EN 13041:2001/A1 (2007) \\
\hline Mojabilidad & Norma australiana AS 3743 - Australian Standards (2003) \\
\hline Contracción de volumen & Norma UNE-EN 13041:2001/A1 (2007) \\
\hline
\end{tabular}

\subsubsection{Características físico-químicas}

Para la determinación del pH y la conductividad eléctrica (CE) se preparó una suspensión acuosa de los composts 1/5 (v/v) (Norma UNE-EN 13040, 2008), realizándose las medidas según se indica en las Normas UNE-EN 13037 (2001) y 13038 (2001) para el pH (en la suspensión) y la conductividad eléctrica (CE, en el extracto obtenido tras filtración a vacío), respectivamente.

La capacidad de intercambio catiónico se determinó de acuerdo con Harada e Inoko (1980), siguiendo además las modificaciones propuestas por Kakezawa et al. (1992) y Jokova et al. (1997).

Una descripción de estos métodos se encuentra en la sección I.1.3 del Anejo de Métodos Analíticos. 


\subsubsection{Características químicas. Composición}

La caracterización química de los composts se realizó determinando los parámetros que se presentan en la Tabla 3.4, según los métodos (referencias) que se indican.

Tabla 3.4. Parámetros determinados en la caracterización química de los composts A y $\mathrm{A}+\mathrm{H}$, con indicación de sus respectivos métodos (referencias)

\begin{tabular}{|c|c|}
\hline Parámetro & Método/Referencia \\
\hline Materia orgánica total y cenizas & Norma UNE-EN 13039 (2001) \\
\hline Carbono orgánico total, nitrógeno total y relación $\mathrm{C} / \mathrm{N}$ & Navarro et al. (1991) \\
\hline Carbono orgánico oxidable & Walkley y Black (1934), Roca-Pérez et al. (2009) \\
\hline Carbono orgánico extraíble en medio alcalino & Sánchez-Monedero et al. (1996) \\
\hline Carbono de ácidos húmicos y fúlvicos & Cegarra et al. (1974) \\
\hline Carbono orgánico hidrosoluble y nitrógeno hidrosoluble & Sánchez-Monedero et al. (1996) \\
\hline Elementos solubles en agua regia & Norma UNE-EN 13650 (2002) \\
\hline Nitrógeno mineral (amoniacal y nítrico) & Sommers et al. (1992), Bernal et al. (1998) \\
\hline $\begin{array}{l}\text { Elementos minerales solubles en agua }\left({\mathrm{N}-\mathrm{NO}_{3}}^{-}, \mathrm{N}^{-\mathrm{NH}_{4}}{ }^{+} \text {, }\right. \\
\mathrm{P}, \mathrm{K}, \mathrm{S}, \mathrm{Ca}, \mathrm{Mg}, \mathrm{Na}, \mathrm{Fe}, \mathrm{Zn}, \mathrm{Cu}, \mathrm{Mn}, \mathrm{Mo} \mathrm{y} \mathrm{B})\end{array}$ & UNE-EN 13652 (2002) \\
\hline $\begin{array}{l}\text { Elementos minerales solubles en } \mathrm{CaCl}_{2} / \mathrm{DTPA}\left(\mathrm{N}_{-} \mathrm{NO}_{3}{ }^{-}\right. \\
\left.\mathrm{N}-\mathrm{NH}_{4}{ }^{+}, \mathrm{P}, \mathrm{K}, \mathrm{S}, \mathrm{Mg}, \mathrm{Na}, \mathrm{Fe}, \mathrm{Zn}, \mathrm{Cu}, \mathrm{Mn}, \mathrm{Mo} \text { y } \mathrm{B}\right)\end{array}$ & UNE-EN 13651 (2002) \\
\hline Carbonatos & MAPA (1994), García de la Fuente et al. (2007) \\
\hline Sulfatos & Eaton et al. (2005), García de la Fuente et al. (2007) \\
\hline Lignina, celulosa y hemicelulosa & Van Soest et al. (1991), Giger (1995) \\
\hline Grasas & Soxhlet (Alburquerque et al., 2004) \\
\hline Polifenoles solubles & Kuwatsuka y Shindo (1973) \\
\hline Carbohidratos solubles & Brink et al. (1960) \\
\hline Metales pesados & $\begin{array}{l}\text { Norma UNE-EN } 13650 \text { (2001), Norma UNE-EN } 13806 \\
(2003)\end{array}$ \\
\hline
\end{tabular}

Varios de estos parámetros se utilizaron para evaluar y calcular diferentes índices relacionados con la madurez y estabilidad de los composts (ver la sección 4.1.5 de Resultados y Discusión).

\subsubsection{Propiedades biológicas}

Se realizaron, por un lado, recuentos de poblaciones microbianas (bacterias autótrofas, bacterias heterótrofas, actinomicetos, y mohos y levaduras) mediante diluciones seriadas y siembra (y posterior cultivo) en placa en medios selectivos (ver 
sección I.1.5.1, Anejo I); y por otro, se evaluó la actividad microbiana determinando la hidrólisis del diacetato de fluoresceína (FDA) y la respiración basal $\left(\mathrm{O}_{2}\right.$ consumido), según se recoge en la sección I.1.5.2 (Anejo I). Teniendo en cuenta la estequiometría de la reacción de oxidación de la materia orgánica por los microorganismos (respiración microbiana), y a partir de la cantidad de oxígeno consumido registrada en la determinación de la respiración basal ( $\mathrm{mg} \mathrm{O}_{2}$ consumido $\mathrm{kg}^{-1}$ día-1), se calculó la cantidad de $\mathrm{CO}_{2}$ desprendido ( $\mathrm{mg} \mathrm{CO}_{2}$ emitido $\mathrm{kg}^{-1} \mathrm{~h}^{-1}$ ) que se presenta en la sección 4.1.5 (Evaluación de la madurez y estabilidad de los composts). Las determinaciones de biomasa y actividad microbiana se realizaron por duplicado.

Asimismo, se evaluó la fitotoxidad potencial de los composts $\mathrm{A}$ y $\mathrm{A}+\mathrm{H}$ mediante bioensayos de germinación de semillas de berro y de lechuga, utilizando extractos acuosos de los composts (Zucconi et al., 1981a, 1981b), así como de emergencia y crecimiento de plántulas berro en sustratos preparados mezclando el compost con un sustrato comercial de turba Sphagnum (Norma AFNOR XP U44-165, 2004) (ver la sección I.1.5.3, Anejo I).

Los bioensayos de germinación de semillas de berro y lechuga se realizaron por quintuplicado, y en el de emergencia y crecimiento de plántulas de berro se incluyeron cuatro repeticiones por tratamiento.

\subsection{INFLUENCIA DE LOS COMPOSTS DE $A$ Y A+H EN LAS PROPIEDADES DEL SUELO. ESTUDIO DE LA DINÁMICA DEL NITRÓGENO}

\subsubsection{Experimento 1. Estudio de las propiedades físicas y las características químicas del suelo calizo enmendado con los composts}

\subsubsection{Descripción del experimento}

Se evaluaron los efectos de los dos composts de alperujo (A y $A+H$, sección 3.1.1) sobre las características físicas, físico-químicas y químicas del suelo calizo (sección 3.1.2). Para ello, se estudiaron un total de 8 tratamientos, resultantes de la combinación factorial de los 2 composts (A vs. A+H) x 4 dosis de aplicación de los mismos (equivalentes a 12, 24, 48 y 96 t de materia orgánica total/ha, denominándose D1, D2, D3 y D4, respectivamente). Además, se incluyó un control (CO) que no recibió aporte de materia orgánica, para permitir comparaciones. 
Para facilitar la homogeneidad de las mezclas de suelo y compost, éstos se tamizaron por las mallas de luz de $10 \mathrm{~mm}$ y $6 \mathrm{~mm}$, respectivamente. Dichas mezclas se colocaron en macetas de plástico de $3 \mathrm{~L}$ de capacidad de base cuadrada y perforaciones (drenaje) en el fondo, a razón de $3 \mathrm{~kg}$ de mezcla por maceta. Las macetas se colocaron, a su vez, en bandejas de plástico -para humedecer periódicamente las mezclas de suelo por subirrigación- según un diseño experimental de bloques al azar, con 3 repeticiones de 4 macetas cada una por tratamiento. Éstas se mantuvieron durante 1 año (desde julio de 2009 hasta julio de 2010) en un invernadero de cristal sin calefacción en el Campus de Vera de la Universitat Politècnica de València, bajo condiciones de humedad del suelo controladas, entre el $50 \%$ y el $100 \%$ de la capacidad de campo, comprobando el contenido en humedad mediante peso periódico de las macetas (Fotografía 3.3).

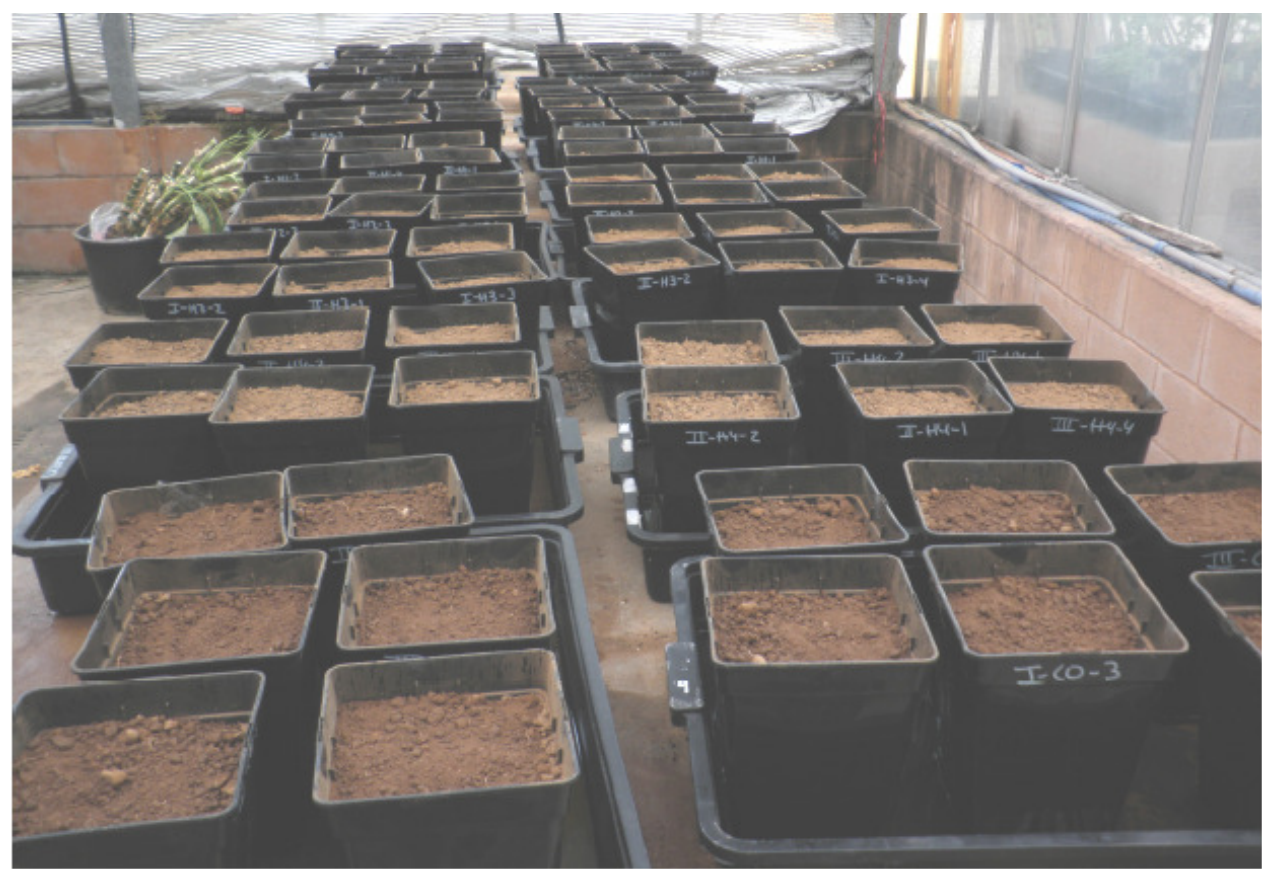

Fotografía 3.3. Vista de la disposición de las macetas sin cultivar utilizadas en el estudio de las propiedades físicas, físico-químicas y químicas del suelo enmendado con los composts $\mathrm{A}$ y $\mathrm{A}+\mathrm{H}$ un año después de la aplicación de éstos

Las características y composición del agua de riego utilizada se recogen en la Tabla 3.5. 
Tabla 3.5. Características y composición del agua de riego utilizada en el experimento

\begin{tabular}{|c|c|}
\hline Parámetro & Valor \\
\hline $\mathrm{pH}$ & 7,93 \\
\hline Conductividad eléctrica (dS/m) & 1,16 \\
\hline Nitrógeno amoniacal (N-NH4 $\left.4^{+}, \mathrm{mg} / \mathrm{L}\right)$ & 0,12 \\
\hline 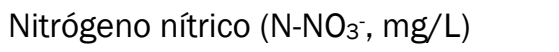 & 4,7 \\
\hline Fósforo (P, mg/L) & 0,11 \\
\hline Potasio (K, mg/L) & 2,5 \\
\hline Calcio (Ca, mg/L) & 127 \\
\hline Magnesio (Mg, mg/L) & 31,1 \\
\hline Sulfatos $\left(\mathrm{SO}_{4}{ }^{2-}, \mathrm{mg} / \mathrm{L}\right)$ & 292 \\
\hline Sodio (Na, mg/L) & 65,7 \\
\hline Cloruros $(\mathrm{Cl}, \mathrm{mg} / \mathrm{L})$ & 109 \\
\hline Bicarbonatos $\left(\mathrm{HCO}_{3}, \mathrm{mg} / \mathrm{L}\right)$ & 162 \\
\hline
\end{tabular}

\subsubsection{Parámetros físicos, físico-químicos y químicos estudiados}

Se muestrearon las mezclas iniciales inmediatamente después de elaborarlas, preparándose entonces la muestra tal y como se señala en la sección I.2.1 del Anejo de Métodos Analíticos, para determinar diferentes parámetros físico-químicos y químicos del suelo: pH (MAPA, 1994), conductividad eléctrica (CE) (MAPA, 1994), carbono orgánico (Corg) (Walkley y Black, 1934), nitrógeno total ( $\mathrm{N}$ total) (Kjeldahl; Bremner, 1965), nitrógeno mineral -como suma de nitrógeno nítrico y nitrógeno amoniacal- (Nmin) (Keeney y Nelson, 1982), y P (Burriel-Hernando, modificado por Díez, 1982), K, Ca, Mg y Na asimilables (MAPA, 1994). Una descripción detallada de los métodos utilizados en estas determinaciones se encuentra en las secciones I.2.3.1 a I.2.4.6 del Anejo I de Métodos Analíticos.

Al finalizar el experimento, al cabo de 1 año, se determinaron, además de los parámetros físico-químicos y químicos arriba indicados, el carbono orgánico hidrosoluble, según Yakovchenko y Sikora (1998) (sección I.2.4.2 del Anejo de Métodos), y diferentes parámetros físicos: densidad aparente -como la relación o cociente entre la masa del suelo seco y el volumen aparente ocupado por el suelo húmedo ( capacidad de campo) colocado en la maceta utilizada en este experimento (volumen $=3 \mathrm{~L})$-, porosidad -estimando indirectamente la densidad de partícula del suelo, en función de su contenido en materia orgánica (determinada mediante oxidación) y aplicando la fórmula presentada en Porta et al. (2003)-, conductividad hidráulica saturada en laboratorio y a la succión de 0,5 cm en campo con ayuda de un infiltrómetro de minidisco (MAPA, 1994; Zhang, 1997) (secciones I.2.2.4 a I.2.2.6 del 
Anejo de Métodos Analíticos), y humedad volumétrica a capacidad de campo (Richards, 1954) (sección 1.2.2.2, Anejo I).

\subsubsection{Estudio de la dinámica del nitrógeno en el suelo calizo enmendado con los composts (Experimento 2.1)}

Se estudió, en un ensayo de incubación en laboratorio, la tasa de mineralización del nitrógeno orgánico del suelo calizo enmendado con los dos composts $(A$ y $A+H$, sección 3.1.1) aplicados a tres dosis, equivalentes a 12, 24 y 48 t de materia orgánica total/ha. Paralelamente, se estudió la dinámica del nitrógeno en el suelo control, sin enmendar.

Se añadieron $10 \mathrm{~g}$ de cada mezcla de suelo y compost o de suelo control en matraces erlenmeyer, y, a continuación, se les añadió una disolución nutritiva, para llevar todas las muestras a la humedad equivalente a la capacidad de campo, conteniendo las cantidades de fertilizantes minerales equivalentes a las aplicadas en el primer cultivo, rábano, en el experimento de evaluación agronómica (60kg N/ha, $72 \mathrm{~kg} \mathrm{P}_{2} \mathrm{O}_{5} / \mathrm{ha}$ y $60 \mathrm{~kg} \mathrm{~K} \mathrm{~K}_{2} \mathrm{O}$ ha; Tabla 3.6), según se recoge en la sección 3.4. Posteriormente, se cerraron los matraces con tapones de silicona y se incubaron aeróbicamente en condiciones controladas -humedad constante, $25^{\circ} \mathrm{C}$, y en oscuridad- durante 28 días. A intervalos regulares de tiempo (0, 3, 7, 14, 21 у 28 días) se extrajo el nitrógeno mineral de las mezclas con $\mathrm{KCl} 2 \mathrm{M}$, determinándose éste como la adición de nitrógeno amoniacal $\left(\mathrm{N}^{-} \mathrm{NH}_{4}{ }^{+}\right)$y nítrico $\left(\mathrm{N}-\mathrm{NO}_{3}{ }^{-}\right)$, según Keeney y Nelson (1982), tal como se indica en la sección I.2.4.4 del Anejo de Métodos Analíticos. Se incluyeron tres repeticiones por tratamiento y día de muestreo, que se eliminaban cuando se tomaban las muestras correspondientes para determinar el nitrógeno mineral.

\subsubsection{Efectos de la aplicación de los composts sobre parámetros biológicos y bioquímicos en dos suelos con texturas diferentes (Experimento 2.2)}

Este ensayo de incubación a corto plazo (56 días), en el que se determinaron diferentes parámetros biológicos y bioquímicos en dos suelos con texturas diferentes enmendados con los composts A y A+H, se llevó a cabo en el Dipartimento di Scienze delle Produzioni Vegetali, del Suolo e dell'Ambiente Agroforestale en la Università degli Studi di Firenze (Italia). 


\subsubsection{Materiales utilizados}

Junto al suelo calizo, de textura franco-arcillosa (denominado S1 en el presente ensayo, sección 3.1.2), utilizado a lo largo de esta Tesis Doctoral, se incluyó en este experimento (2.2) un suelo italiano (procedente de Pisa, Italia, S2).

En primer lugar, se caracterizó el suelo S2, determinando su textura, pH, conductividad eléctrica (CE) y contenido en nitrógeno total, nitrógeno mineral, fósforo y potasio asimilables, carbono orgánico, y carbonatos, según las técnicas analíticas que se indican en la sección I.2 (Anejo I). Las características y composición de este suelo S2 se presentan en la sección 4.2.2.2 de Resultados y Discusión.

Tanto los suelos $\mathrm{S} 1$ y $\mathrm{S} 2$ como los composts $\mathrm{A}$ y $\mathrm{A}+\mathrm{H}$ se tamizaron por la malla de luz de $2 \mathrm{~mm}$.

\subsubsection{Diseño experimental}

Se estudió la aplicación de los composts A y A+H (sección 3.1.1) aplicados a la dosis equivalente a $24 \mathrm{t}$ de materia orgánica total/ha en los dos suelos con texturas diferentes ya indicados (S1, franco-arcilloso, sección 3.1.2, y S2, franco arenoso, sección 3.3.3.1). Adicionalmente, se incluyeron en el experimento controles (CO) de ambos suelos sin enmendar, para permitir comparaciones.

En primer lugar, los suelos se humedecieron hasta el 50\% de su capacidad de retención de agua a capacidad de campo y se preincubaron en oscuridad a $25^{\circ} \mathrm{C}$ durante 10 días. A continuación, se añadió el compost de manera homogénea, y se colocaron $100 \mathrm{~g}$ de la mezcla o del suelo control en un recipiente hermético de vidrio de $1 \mathrm{~L}$ de capacidad provisto de una válvula de tres vías.

Se prepararon 3 repeticiones por tratamiento y día de muestreo, para un experimento de 56 días de duración, realizándose 4 muestreos en total (días 0, 7, 28 y 56), y eliminándose las réplicas correspondientes tras cada uno de los muestreos efectuados.

\subsubsection{Parámetros químicos, biológicos y bioquímicos determinados}

En los 4 muestreos realizados se determinó el contenido en nitrógeno mineral, tal y como se indica en la sección I.2.4.4 del Anejo de Métodos Analíticos.

Se determinó el carbono y el nitrógeno de la biomasa microbiana $\left(B_{C}\right.$ y $B_{N}$, 
respectivamente) por el método de extracción-fumigación (Vance et al., 1987; Wu et al., 1990) en cada uno de los momentos de muestreo, y la actividad microbiana mediante respirometría $\left(\mathrm{CO}_{2}\right.$ producido; Blackmer y Bremner, 1977), que se midió semanalmente. En los 4 momentos de muestreo se determinó también la amonificación de la arginina (conversión a $\mathrm{NH}_{4}{ }^{+}$), según Lin y Brookes (1999).

Las actividades enzimáticas fosfomonoesterasa alcalina y ácida (Tabatabai y Bremner, 1969), fosfodiesterasa (Browman y Tabatabai, 1978), ß-glucosidasa (Tabatabai, 1982) y proteasa (Ladd y Butler, 1972), se determinaron los días 0, 7 y 56 del experimento.

En las secciones I.2.5.2 a I.2.5.5 del Anejo de Métodos Analíticos se presentan con detalle los procedimientos utilizados.

\subsection{EVALUACIÓN DE LOS COMPOSTS $A$ Y $A+H$ COMO ENMIENDAS DEL SUELO. EFECTO DIRECTO Y RESIDUAL SOBRE LOS CULTIVOS Y EL SUELO}

\subsubsection{Diseño del experimento de evaluación agronómica}

Se estudiaron -durante 2 años consecutivos (campañas 2006/07 y 2007/08, Años 1 y 2, respectivamente)- 8 tratamientos, resultantes de la combinación factorial de 2 composts (A vs. A+H, sección 3.1.1) x 2 dosis de aplicación de los composts (equivalentes a 12 y 24 t de materia orgánica total/ha, respectivamente) x 2 programas de fertilización mineral (normal o estándar, F1 vs. reducido en nitrógeno [30\% menos que en F1] y en potasio [que no se aplicó], F2; Tabla 3.6). En adición, se prepararon 2 controles (CO) que no recibieron compost, pero fueron abonados con los programas de fertilización mineral F1 y F2 (CO F1 y CO F2, respectivamente).

Tabla 3.6. Programas de fertilización mineral estándar (F1) y reducida (F2) aplicados a los cultivos

\begin{tabular}{lcccc}
\hline & & \multicolumn{3}{c}{ Elemento fertilizante } \\
\cline { 3 - 5 } \multicolumn{1}{c}{ Cultivo } & Programa de fertilización & $\begin{array}{c}\text { Nitrógeno } \\
(\mathrm{N}, \mathrm{kg} / \mathrm{ha})\end{array}$ & $\begin{array}{c}\text { Fósforo } \\
\left(\mathrm{P}_{2} \mathrm{O}_{5}, \mathrm{~kg} / \mathrm{ha}\right)\end{array}$ & $\begin{array}{c}\text { Potasio } \\
\left(\mathrm{K}_{2} \mathrm{O}, \mathrm{kg} / \mathrm{ha}\right)\end{array}$ \\
\hline Rábano & F1 & $60^{z}$ & 72 & 60 \\
& F2 & $42^{z}$ & 72 & 0 \\
\hline Lechuga & F1 & $200^{y}$ & 100 & 150 \\
& F2 & $140^{y}$ & 100 & 0 \\
\hline Judía & F1 & $60^{\mathrm{x}}$ & 60 & 150 \\
& F2 & $42^{\mathrm{x}}$ & 60 & 0 \\
\hline
\end{tabular}

zEl nitrógeno se fraccionó entre fondo (50\%) y una aplicación de cobertera (50\%)

y El nitrógeno se fraccionó entre fondo (12,5\%) y tres aplicaciones de cobertera $(87,5 \%)$

x El nitrógeno se aportó como abono de cobertera en una única aplicación 
El experimento se llevó a cabo en una parcela de $260 \mathrm{~m}^{2}$ de superficie con cubrición de malla de plástico agrotextil, en el Campus de Vera de la Universitat Politècnica de València. Las mezclas de suelo y compost o el suelo control se colocaron en contenedores de cultivo de gran volumen, de plástico negro y forma tronco-cónica, de diámetro $40 \mathrm{~cm}$, altura $31 \mathrm{~cm}$, y $35 \mathrm{~L}$ de capacidad.

Previamente a la realización de las mezclas de suelo y compost, éstos se tamizaron (el suelo por la luz de $10 \mathrm{~mm}$ y los composts a través de $6 \mathrm{~mm}$ ) con objeto de facilitar la homogeneidad de las mezclas resultantes.

En la Tabla 3.7 se presenta la clave de los diez tratamientos estudiados utilizada a lo largo de este experimento.

Tabla 3.7. Clave de los tratamientos estudiados en la evaluación agronómica de los composts $\mathrm{A}$ y $\mathrm{A}+\mathrm{H}$

\begin{tabular}{cccc}
\hline Tratamiento & Compost & $\begin{array}{c}\text { Dosis de compost } \\
(\mathrm{t} / \mathrm{ha})\end{array}$ & Fertilización \\
\hline A D1 F1 & Alperujo & 12 & Estándar \\
A D1 F2 & Alperujo & 12 & Reducida \\
A D2 F1 & Alperujo & 24 & Estándar \\
A D2 F2 & Alperujo & 24 & Reducida \\
A+H D1 F1 & Alperujo+Hidrolizado & 12 & Estándar \\
A+H D1 F2 & Alperujo+Hidrolizado & 12 & Reducida \\
A+H D2 F1 & Alperujo+Hidrolizado & 24 & Estándar \\
A+H D2 F2 & Alperujo+Hidrolizado & 24 & Reducida \\
CO F1 & Control sin enmendar & - & Estándar \\
CO F2 & Control sin enmendar & - & Reducida \\
\hline
\end{tabular}

Tras mezclar homogéneamente el suelo con las cantidades correspondientes de compost, se procedió al llenado de los contenedores desde la base -con los orificios de drenaje- hasta la superficie, de la siguiente manera: capa de grava para drenaje de $3 \mathrm{~cm}$, capa de suelo original puro de $8 \mathrm{~cm}$, y capa de la mezcla de suelo y compost homogeneizada (con el uso de una hormigonera, de $100 \mathrm{~L}$ de capacidad) de $20 \mathrm{~cm}$. Los contenedores se dispusieron según un dispositivo experimental de bloques al azar, con tres repeticiones de 7 contenedores cada una por tratamiento.

Sobre las mezclas de suelo y compost se establecieron tres cultivos de hortalizas (rotación), que se repitieron durante el segundo año: 1) Rábano (Raphanus sativus, cv. “Largo Rojo Escarlata”); 2) Lechuga (Lactuca sativa var. Iongifolia, cv. "Romana de Valladolid”); y, 3) Judía (Phaseolus vulgaris, cv. "Contender"). En rábano y en judía, se 
realizó siembra directa de 45 semillas/contenedor y 2 semillas/contenedor, respectivamente, mientras que en lechuga se preparó un semillero en bandeja, trasplantándose posteriormente 3 plántulas/contenedor. Las labores culturales más relevantes realizadas en las tres especies estudiadas se detallan en la Tabla 3.8. En la Fotografía 3.4 se presentan los cultivos estudiados en el ensayo de evaluación agronómica durante el primer año (Año 1) del experimento.

Tabla 3.8. Labores culturales realizadas y momento de su aplicación en los dos años del experimento

\begin{tabular}{ccccc}
\hline Cultivo & $\begin{array}{c}\text { Siembra } \\
\text { en bandeja }\end{array}$ & Trasplante & $\begin{array}{c}\text { Siembra } \\
\text { directa }\end{array}$ & Recolección \\
\hline Año 1 (Efecto directo) & & & \\
\hline $\begin{array}{c}\text { Rábano } \\
\text { Lechuga }\end{array}$ & $03 / 10 / 2006$ & $23 / 10 / 2006$ & -- & $11 / 07 / 2006$ \\
Judía & - & - & $18 / 04 / 2007$ & $08 / 02 / 2007$ \\
\hline Año 2 (Efecto residual) & - & 25 y 29/07/2007, y 04 y 11/08/2007 \\
\hline Rábano & - & - & $02 / 10 / 2007$ & $04 / 12 / 2007$ \\
Lechuga & $22 / 11 / 2007$ & $13 / 12 / 2007$ & -- & $05 / 03 / 2008$ \\
Judía & -- & - & $06 / 06 / 2008$ & 21,25 y 31/07/2008, y 04/08/2008 \\
\hline
\end{tabular}

Debe indicarse que la aplicación de compost al suelo tuvo lugar en un único aporte, antes de comenzar los dos años del experimento, evaluándose por ello el "efecto directo" durante el primer año, y el "efecto residual” durante el segundo.

Además del aporte de compost, los suelos se abonaron con nitrógeno, fósforo y potasio, aplicados como abonado de fondo y de cobertera, de manera que los contenedores recibieron: 1) la cantidad de abono correspondiente al programa normal o estándar (F1), según Maroto (2002), ó 2) la cantidad correspondiente a un programa reducido (F2) en nitrógeno (30\% menos que en $\mathrm{F} 1$ ) y en potasio (que no se aplicó) (Tabla 3.6). Como fertilizantes nitrogenados se emplearon nitrato cálcico $(15,5 \% \mathrm{~N})$ en rábano y nitrato amónico $(33,5 \% \mathrm{~N})$ en lechuga y judía; y como abono fosfatado y potásico en los tres cultivos se utilizó superfosfato simple $\left(20 \% \mathrm{P}_{2} \mathrm{O}_{5}\right)$ y sulfato de potasa $\left(50 \% \mathrm{~K}_{2} \mathrm{O}\right)$, respectivamente. El fósforo y el potasio se aplicaron como abonos de fondo, mientras que el nitrógeno se aplicó según se ha especificado en la Tabla 3.6.

Los riegos se llevaron a cabo con un sistema por goteo automatizado, en función de los requerimientos de los cultivos.

La recolección de la cosecha de cada cultivo se realizó cuando ésta alcanzó la madurez comercial, determinándose al final de cada cultivo, además, diferentes 
parámetros relacionados con el crecimiento, desarrollo y productividad. En judía, las vainas se cosecharon escalonadamente, efectuándose en total cuatro recolecciones.
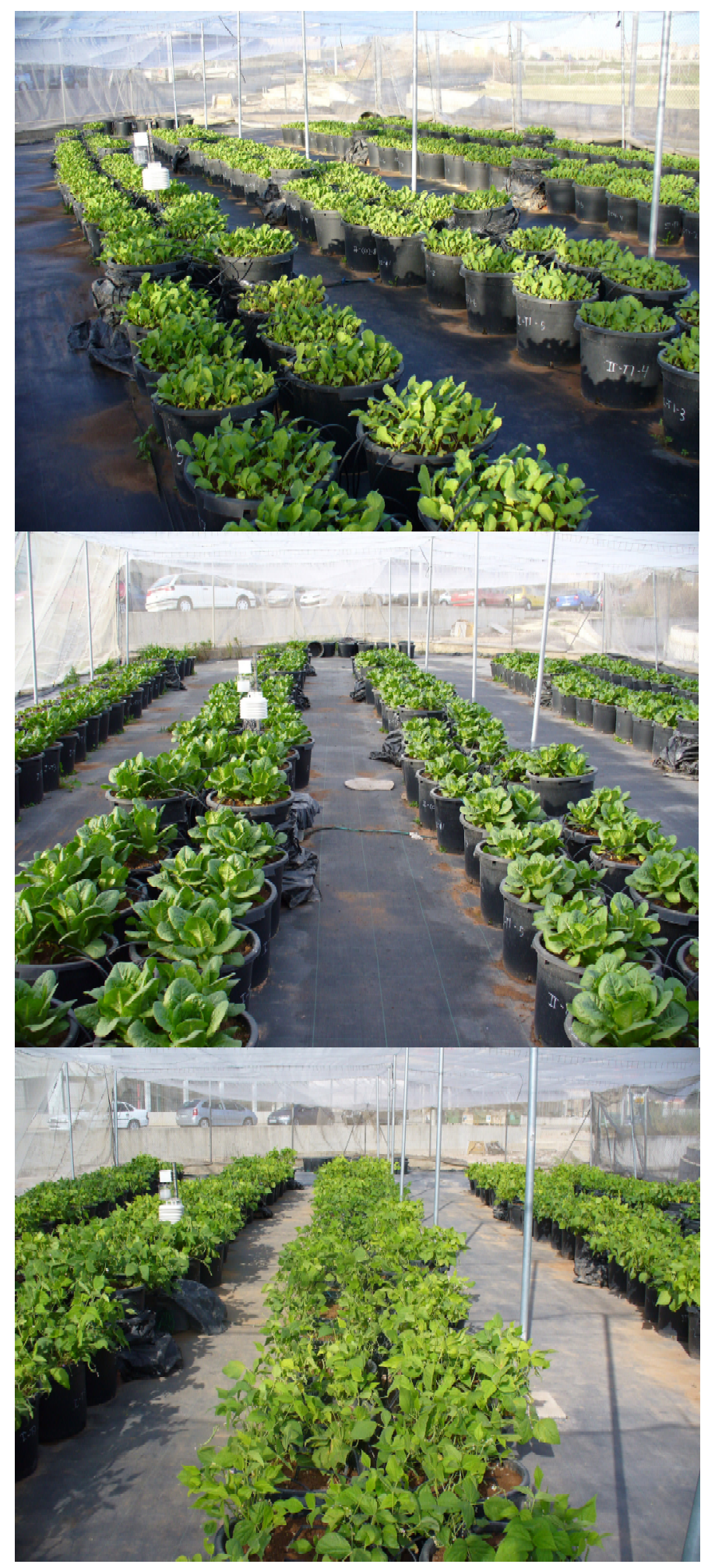

Fotografía 3.4. Vista general de la parcela y los tres cultivos en contenedor estudiados en la evaluación agronómica de los composts $A$ y A+H durante el primer año (Año 1) del experimento. Rábano (arriba), lechuga (centro) y judía (abajo) 


\subsubsection{Parámetros de crecimiento y productividad controlados}

Los parámetros medidos en rábano, lechuga y judía para evaluar su crecimiento, desarrollo y productividad en cada uno de los dos años del estudio se presentan en la Tabla 3.9.

En rábano, y para la determinación de los parámetros número de hojas por planta, área de la hoja más grande, y peso fresco, diámetro y longitud de la raíz, se seleccionaron las diez raíces de mayor tamaño de cada contenedor por ser las que coincidían con, o se aproximaban a la cosecha comercializable.

En el cultivo de lechuga, y para controlar el número de hojas formadas por planta y el área de la hoja de mayor tamaño, se siguió el criterio de tomar el cogollo de peso intermedio de los tres producidos en cada uno de los contenedores.

En judía, los parámetros a controlar se midieron en todas las plantas (2) de cada contenedor.

Para cada uno de los tres cultivos estudiados, así como para cada año del estudio, se midió la superficie $\left(\mathrm{S}\right.$, en $\left.\mathrm{cm}^{2}\right)$ de aquellas hojas cuya área fuera representativa del rango de tamaño observado en el experimento global, con independencia del tratamiento, con un medidor de área foliar (modelo Li-3000A marca LI-COR Inc.), determinándose además sus respectivos valores de longitud (L, en $\mathrm{cm}$ ) y anchura (A, en cm). A partir de dichos datos se realizó un ajuste de regresión no lineal, obteniéndose una ecuación polinómica, que se expresó como:

$$
S=a+b \cdot A+c \cdot A^{2}+d \cdot L+e \cdot L^{2}
$$

donde a, b, c, d y e son coeficientes de regresión.

En las plantas de los diferentes tratamientos experimentales en comparación se midió la longitud (L) y la anchura (A) de la hoja de mayor tamaño, para, a partir de la ecuación ajustada más arriba, calcular la superficie de dicha hoja. Las ecuaciones ajustadas para cada cultivo y cada uno de los dos años estudiados se presentan en la Tabla 3.10. En judía, S, A y L correspondieron al área, anchura y longitud de cada uno de los tres foliolos de la hoja (compuesta) de mayor tamaño, respectivamente, calculándose la superficie (total) de la hoja mediante la suma de las áreas de dichos tres foliolos. 
Tabla 3.9. Parámetros controlados en rábano, lechuga y judía el Año 1 (efecto directo) y el Año 2 (efecto residual) en el experimento de evaluación agronómica

\begin{tabular}{|c|c|}
\hline Cultivo & Parámetro \\
\hline \multirow[t]{10}{*}{ Rábano } & $\mathrm{N}^{\circ}$ hojas/planta \\
\hline & Área de la hoja más desarrollada $\left(\mathrm{cm}^{2}\right)$ \\
\hline & Contenido en clorofila de las hojas (ud. SPAD) \\
\hline & Peso fresco de la raíz (g) \\
\hline & Diámetro de la raíz (mm) \\
\hline & Longitud de la raíz (mm) \\
\hline & Biomasa del vástago (mg materia seca/planta) \\
\hline & Biomasa de la raíz (mg materia seca/planta) \\
\hline & Biomasa total (mg materia seca/planta) \\
\hline & Producción total de raíces (g materia fresca/contenedor) \\
\hline \multirow[t]{7}{*}{ Lechuga } & $\mathrm{N}^{\circ}$ hojas/planta \\
\hline & Área de la hoja más desarrollada $\left(\mathrm{cm}^{2}\right)$ \\
\hline & Contenido en clorofila de las hojas (ud. SPAD) \\
\hline & Biomasa del vástago (g materia seca/planta) \\
\hline & Biomasa de la raíz (g materia seca/planta) \\
\hline & Biomasa total (g materia seca/planta) \\
\hline & Producción total de cogollos (g materia fresca/contenedor) \\
\hline \multirow[t]{18}{*}{ Judía } & $\mathrm{N}^{\circ}$ hojas/planta \\
\hline & Área de la hoja más desarrollada $\left(\mathrm{cm}^{2}\right)$ \\
\hline & Contenido en clorofila de las hojas (ud. SPAD) \\
\hline & Altura del tallo (mm) \\
\hline & Número de vainas/planta \\
\hline & Peso fresco unitario de la vaina $(\mathrm{g})$ \\
\hline & Longitud de la vaina ( $\mathrm{mm})$ \\
\hline & Peso fresco de la raíz (g/planta) \\
\hline & Biomasa de las hojas (g materia seca/planta) \\
\hline & Biomasa del tallo (mg materia seca/planta) \\
\hline & Biomasa de las vainas (g materia seca/planta) \\
\hline & Biomasa de la parte aérea (g materia seca/planta) \\
\hline & Biomasa de la raíz (mg material seca/planta) \\
\hline & Biomasa total (g materia seca/planta) \\
\hline & Producción de vainas en cada recolección (g materia fresca/contenedor) \\
\hline & Número de vainas cosechadas en cada recolección por contenedor \\
\hline & Producción precoz de vainas (g/contenedor) \\
\hline & Producción total de vainas (g/contenedor) \\
\hline
\end{tabular}


Tabla 3.10. Ecuaciones de ajuste de la superficie de la hoja (S, expresada en $\mathrm{cm}^{2}$ ) de mayor tamaño en los cultivos estudiados y los dos años del experimento

\begin{tabular}{lll}
\hline Cultivo & Ecuación de ajuste & $R^{\mathbf{2}}$ \\
\hline Año 1 (Efecto directo) & & 0,982 \\
\hline Rábano & $\mathrm{S}=-0,170828-5,52335 \cdot A+1,55724 \cdot A^{2}+3,702192 \cdot L-0,0365966 \cdot L^{2}$ & 0,974 \\
Lechuga & $S=7,53054-3,72299 \cdot A+1,19533 \cdot A^{2}-0,301865 \cdot L+0,164797 \cdot L^{2}$ & 0,991 \\
Judía z & $S=-0,330625-1,05077 \cdot A+0,943316 \cdot A^{2}+1,95842 \cdot L+0,00159583 \cdot L^{2}$ & 0,972 \\
\hline Año 2 (Efecto residual) & & 0,980 \\
\hline Rábano & $S=-0,330625-1,05077 \cdot A+0,943316 \cdot A^{2+1,95842 \cdot L+0,00159583 \cdot L^{2}}$ & 0,991 \\
Lechuga & $S=-29,0091-9,63929 \cdot A+1,37207 \cdot A^{2}+5,70662 \cdot L+0,0566029 \cdot L^{2}$ & \\
Judíaz & $S=2,61559-1,75193 \cdot A+0,768328 \cdot A^{2}+1,18916 \cdot L+0,0638772 \cdot L^{2}$ &
\end{tabular}

A: anchura de la hoja; L: longitud de la hoja

z S, A y L corresponden a la superficie, anchura y longitud de cada foliolo, respectivamente

Los coeficientes de determinación $\left(\mathrm{R}^{2}\right)$ mostraron un nivel de significación $P \leq 0,001$

Por otra parte, el contenido en clorofila de las hojas se determinó mediante un método no destructivo, utilizando el equipo Chlorophyll Meter SPAD-502, Konica Minolta Business Solutions Spain S.A., expresándose los resultados en unidades SPAD, que están estrechamente relacionadas con el contenido foliar de clorofila (Mak y Yeh, 2001; Rodríguez y Miller, 2000). Para ello, se tomaron 3 lecturas por hoja y 10 hojas por contenedor como unidad de muestreo.

Para la determinación del peso seco del material vegetal, éste se secó en estufa a $65^{\circ} \mathrm{C}$.

\subsubsection{Análisis elemental del material vegetal}

Las muestras para el análisis del material vegetal (foliar) seco a $65^{\circ} \mathrm{C}$ se prepararon mediante homogeneización de las hojas -secas y trituradas- de 10 plantas de rábano, 1 planta de lechuga, y 2 plantas de judía por cada tratamiento y repetición.

El contenido en nitrógeno se determinó siguiendo el método Kjeldahl (Jones, 1991), de acuerdo con lo indicado en la sección I.3.1 del Anejo de Métodos Analíticos.

La determinación de $\mathrm{K}, \mathrm{Ca}, \mathrm{Mg}$ y $\mathrm{Na}$ se realizó mediante digestión nítricoperclórica y posterior análisis en ICP-AES -ver la sección I.3.2 del Anejo de Métodos-, mientras que $P$ se determinó, tras dicha digestión, según el método de Fiske y Subbarow (1925), según se indica en la sección I.3.3 del Anejo de Métodos. Todas las digestiones se realizaron por duplicado, incluido el blanco. Los resultados se expresaron en porcentaje de materia seca (\% ms). 


\subsubsection{Determinación de las características físico-químicas y químicas del suelo cultivado}

Una vez terminada cada una de las dos rotaciones rábano-lechuga-judía, es decir, al final del Año 1 y el Año 2, se tomaron muestras representativas de suelo en los primeros $20 \mathrm{~cm}$ desde la superficie con una sonda manual, y se determinaron en las muestras así obtenidas los siguientes parámetros físico-químicos y químicos: $\mathrm{pH}$, conductividad eléctrica (CE), carbono orgánico, $N$ total, $N$ mineral, $P$ (Olsen y Sommers, 1982) y K, Ca, Mg y Na asimilables, siguiendo las metodologías indicadas en la sección I.2.3 y I.2.4 del Anejo de Métodos Analíticos.

\subsection{EFECTOS DE LA MATERIA ORGÁNICA SOLUBLE EXTRAÍDA DE LOS COMPOSTS A Y $A+H$ SOBRE EL CULTIVO DE ALFALFA Y EL SUELO CALIZO}

\subsubsection{Planteamiento y diseño del experimento}

La materia orgánica soluble (MOS) extraída de los composts A y A+H en medio alcalino (según se ha descrito en la sección 3.1.1) se testó en un estudio de evaluación agronómica con Medicago sativa (ecotipo “Aragón”) y el suelo calizo utilizado a lo largo de esta Tesis Doctoral. Se estudiaron comparativamente 24 tratamientos, como resultado de la combinación factorial de 2 orígenes de la MOS (compost A vs. compost $\mathrm{A}+\mathrm{H}) \times 6$ Dosis de aplicación de las MOS estudiadas (equivalentes a 200, 400, 800, 1600, 3200 y 6400 mg de carbono orgánico total/kg de suelo) $\times 2$ Programas de fertilización mineral (F1 o estándar, equivalente a 25, 110 y $100 \mathrm{~kg} /$ ha de $\mathrm{N}, \mathrm{P}_{2} \mathrm{O}_{5}$ y $\mathrm{K}_{2} \mathrm{O}$, respectivamente [según Del Pozo, 1983]; y, F2 o reducida, en la que se aplicó el $50 \%$ y el $100 \%$ del $\mathrm{N}$ y el $\mathrm{P}_{2} \mathrm{O}_{5}$ en $\mathrm{F} 1$, respectivamente, pero no se aportó $\mathrm{K}_{2} \mathrm{O}$ ). En el estudio se incluyeron, además, dos controles (CO) a los que no se les adicionó MOS, pero fueron abonados con los programas F1 y F2 (CO F1 y CO F2, respectivamente).

El suelo calizo se tamizó por la malla de luz de $10 \mathrm{~mm}$ y se colocó en macetas de plástico de 0,5 L de capacidad, con la base perforada (drenajes), a razón de 600 g de suelo por maceta. Como fertilizantes minerales se utilizaron nitrato amónico (33,5\% $\mathrm{N})$, superfosfato simple $\left(20 \% \mathrm{P}_{2} \mathrm{O}_{5}\right)$ y sulfato de potasa $\left(50 \% \mathrm{~K}_{2} \mathrm{O}\right)$, mezclándose los abonos fosfatado y potásico con el suelo antes del enmacetado (abonado de fondo o pre-siembra), y aplicándose el $\mathrm{N}$ disuelto en agua 45 días después de la siembra. 
Las macetas se colocaron en un invernadero de cristal y temperatura controlada en el Campus de Vera de la Universitat Politècnica de València (Fotografía 3.5), disponiéndose los 26 tratamientos estudiados según un diseño experimental de bloques al azar, a razón de 3 repeticiones de 4 macetas por tratamiento, contabilizándose así un total de 312 macetas en el experimento, que se desarrolló durante los meses comprendidos entre julio de 2008 y enero de 2009.

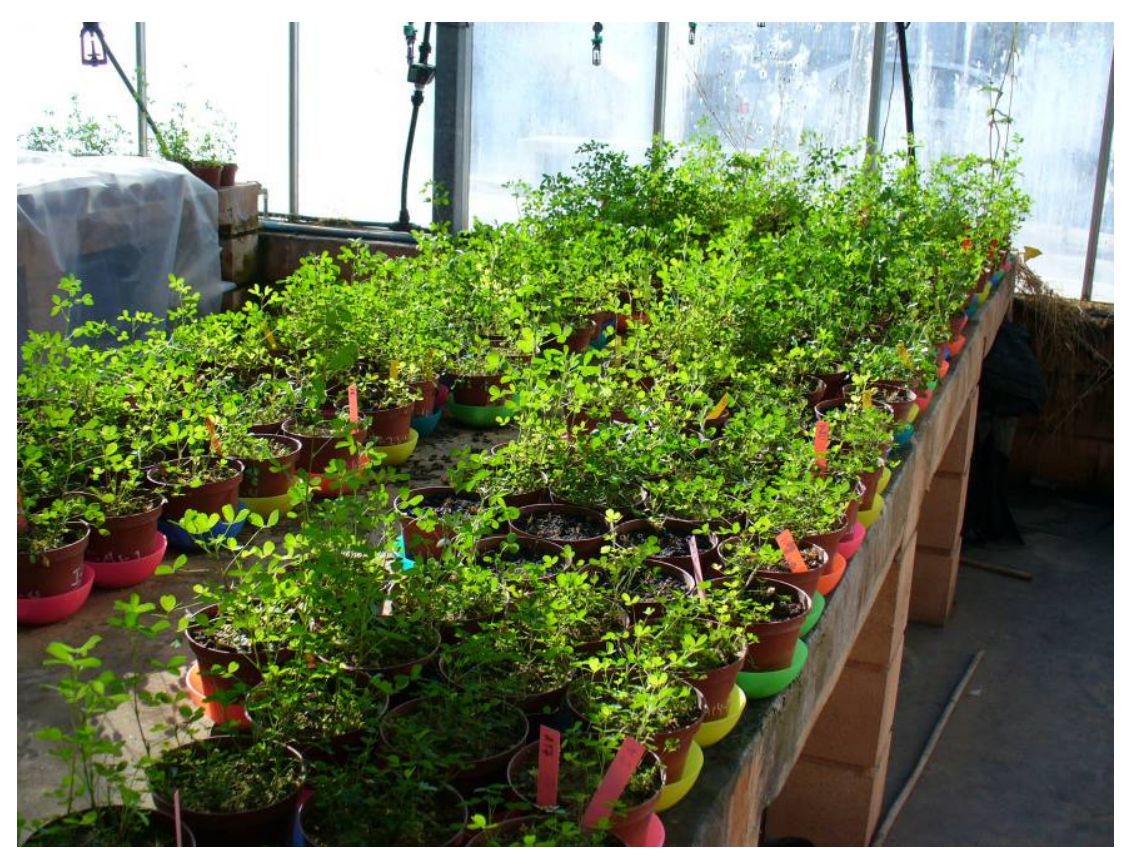

Fotografía 3.5. Vista general de las plantas de alfalfa cultivadas en maceta tras la aplicación de materia orgánica soluble (MOS) al suelo calizo utilizado

Se sembraron 14 semillas de alfalfa (Medicago sativa, ecotipo “Aragón”) por maceta, aclarándose posteriormente con objeto de dejar sólo 8 plántulas por contenedor. Las plantas se regaron mediante nebulizadores aéreos, en función de los requerimientos del cultivo.

Las dosis de MOS señaladas más arriba se fraccionaron -a partes iguales- entre 5 aplicaciones: $1^{\mathrm{a}}$ Aplicación, 1 semana antes de la siembra; $2^{\mathrm{a}}, 1$ mes después de la siembra; $3^{a}$, 2 meses después de la siembra; $4^{a}$, 3 11/2 meses después de la siembra; y $5^{a}, 4 \frac{1}{2}$ meses después de la siembra.

La siega de la alfalfa se realizó en 4 cortes: $1^{\text {er }}$ corte, 3 meses después de la siembra; $2^{\circ}, 4$ meses después de la siembra; $3^{\circ}, 5$ meses después de la siembra; y $4^{\circ}$, 6 meses tras la siembra. 
Para investigar el impacto de la MOS en el suelo, además de las macetas con las plantas (cultivo) de alfalfa, se estudió el efecto de la aplicación de dicha MOS en macetas con suelo sin cultivar, desnudo, examinándose los mismos factores (MOS procedente de los composts A y A+H, Dosis de MOS y Fertilización mineral) y realizándose las mismas labores culturales (fraccionamiento de la MOS, fertilización mineral, y riegos) que en las macetas cultivadas con planta de alfalfa. Asimismo, y además de los tratamientos con MOS, se incluyeron macetas con suelo control (CO), sin adición de materia orgánica soluble.

\subsubsection{Parámetros controlados en las plantas de Medicago sativa}

En cada corte efectuado se controló la producción obtenida (expresándose en g de materia fresca/contenedor), la altura del tallo más largo, el número de hojas (compuestas) formadas por tallo, la biomasa acumulada en la parte aérea (en g de materia seca/contenedor), y el área de los tres foliolos de la hoja de mayor tamaño (en $\mathrm{cm}^{2}$ ), determinándose esta última según se ha indicado en la sección 3.4.2. La ecuación correspondiente al área de cada foliolo fue:

$$
S=0,873073+0,385971 \cdot A+0,0855253 \cdot A^{2}-0,234746 \cdot L+0,223372 \cdot L^{2}
$$

donde $S$ es el área del foliolo $\left(\mathrm{cm}^{2}\right)$, y $\mathrm{A}$ y $\mathrm{L}$ son la anchura y longitud del mismo (en $\mathrm{cm}$ ), respectivamente. La superficie (total) de la hoja se calculó sumando las áreas de los tres foliolos.

Cuando se realizó el último corte $\left(4^{\circ}\right)$, se determinó el peso fresco de la raíz (en $\mathrm{mg} /$ planta), la biomasa acumulada en la misma (en g de materia seca/contenedor), y su volumen (en $\mathrm{mL} /$ planta, mediante el desplazamiento del volumen equivalente de agua al sumergir el conjunto de raíces formadas en una probeta).

Sumando la biomasa aérea de los cuatro cortes realizados se obtuvo la biomasa aérea total, y, mediante adición de esta última a la biomasa de la raíz, se calculó la biomasa total producida por contenedor.

\subsubsection{Parámetros determinados en el suelo cultivado y no cultivado}

Tras el cuarto y último corte realizado, se tomaron muestras de este suelo cultivado de todos los tratamientos estudiados, para su posterior caracterización físico-química y química en el laboratorio, determinándose distintos parámetros: $\mathrm{pH}$, conductividad eléctrica (CE), C orgánico, $\mathrm{N}$ mineral, $\mathrm{P}$ (método Burriel-Hernando), $\mathrm{K}$, 
$\mathrm{Ca}$, Mg y Na asimilables, según los protocolos que se recogen en las secciones I.2.3. y I.2.4 del Anejo de Métodos Analíticos.

En base a los resultados de crecimiento y productividad de alfalfa obtenidos, que revelaron la ausencia de diferencias estadísticamente significativas entre los programas de fertilización mineral F1 y F2, se seleccionaron los tratamientos con el programa de fertilización reducida (F2) para el estudio de las propiedades físicoquímicas y químicas más arriba señaladas en el suelo no cultivado.

\subsection{ESTUDIO IN VITRO E IN VIVO DE LA SUPRESIVIDAD DE LOS COMPOSTS A Y $A+H$}

3.6.1. Aislamiento de actinomicetos y evaluación de sus efectos antagonistas frente a agentes fitopatógenos, e identificación de las cepas supresoras

\subsubsection{Aislamiento de cepas de actinomicetos}

Para el estudio in vitro de las propiedades supresivas de los dos composts de alperujo $(\mathrm{A}$ y $\mathrm{A}+\mathrm{H})$ y las mezclas de suelo y compost preparadas en la sección 3.4, se aislaron cepas de actinomicetos potencialmente supresores de patógenos vegetales mediante diluciones seriadas y posterior cultivo en los medios selectivos SCA (Starch Casein Agar), ISP-5 (Glycerol Asparagine Agar) y AGSA (Arginine Glycerol Salts Agar), todos ellos suplementados con ciclohexamida para evitar contaminación por especies fúngicas. Tras incubar las muestras de los materiales indicados más arriba a $28^{\circ} \mathrm{C}$ durante 14 - 21 días, se aislaron las colonias de actinomicetos cultivadas en el medio ISP-2 (Yeast Extract-Malt Extract) y se conservaron en crioviales con Nutrient Broth $\mathrm{n}^{\circ}$ 2 y $20 \%$ de glicerol a $-80^{\circ} \mathrm{C}$.

3.6.1.2. Evaluación de la inhibición de agentes fitopatógenos por los aislados en ensayos in vitro

Se evaluó la capacidad supresiva mediante cultivo in vitro conjunto de los microorganismos aislados (sección 3.6.1.1) con 5 hongos fitopatógenos procedentes de la Colección Española de Cultivos Tipo (CECT): Fusarium oxysporum f. sp. melonis CECT 20474, Pythium debaryanum CECT 2362, Thanatephorus cucumeris CECT 2813, Sclerotinia sclerotiorum CECT 2823, y Phytophthora cinnamomi CECT 20186. Las características de estos patógenos se relacionan a continuación (Agrios, 1996): 
- Fusarium oxysporum f. sp. melonis: Los hongos del género Fusarium pertenecen a la clase Hyphomycetes, orden Hyphales, que producen marchitamientos vasculares y pudriciones, principalmente en especies anuales y plantas ornamentales, entre otras, y cancrosis en árboles. La mayoría de los hongos de este género son de la especie Fusarium oxysporum. Se han descrito subpoblaciones de elevada especialización patogénica circunscrita a determinadas especies, géneros o grupos de plantas, como es el caso del melón, cuya producción se ve gravemente afectada por F. oxysporum f. sp. melonis.

- Pythium debaryanum: Pertenece al orden de los Peronosporales en la clase de los Oomycetes, incluyéndose en este grupo algunos de los hongos fitopatógenos más importantes que se conocen. El género Pythium causa la pudrición de semillas y de la raíz, la asfixia de las plántulas, y la pudrición blanda de los frutos carnosos y otros órganos vegetales que se encuentran en contacto con el suelo.

- Thanatephorus cucumeris: Es un basidiomiceto del orden Tulasnellales que provoca pudriciones del tallo y de la raíz de muchas plantas anuales, y la mancha del café de los pastos. Es el teleomorfo o estado perfecto del hongo Rhizoctonia solani.

- Sclerotinia sclerotiorum: Ascomiceto que pertenece a la clase Discomycetes, orden Helotiales. Produce enfermedades graves en numerosas plantas hortícolas y ornamentales, así como en algunos arbustos. Entre las enfermedades de las hortalizas se encuentran la podredumbre algodonosa de la zanahoria, la pudrición del tallo de la soja, y la pudrición blanda acuosa de la judía y el pepino.

- Phytophthora cinnamomi: Se encuentra dentro de la clase Oomycetes, en el orden de los Peronosporales. Produce la pudrición de la raíz del aguacate, azalea, castaño, canelo, roble, pino, piña, y otros árboles y arbustos. Primero genera la pudrición de las raíces, para expandirse después por el tallo.

En primer lugar - de acuerdo con las indicaciones de diversos autores, y utilizando varios aislados de actinomicetos y los microorganismos fitopatógenos indicados-, se evaluó la viabilidad de 6 medios de cultivo para la realización de los ensayos in vitro: ISP-2 (Badji et al., 2005), Potato Dextrose Agar (PDA) (Castillo et al., 
2002; Getha et al., 2005), Yeast-Malt Extract Agar (YMA) (Leiva et al., 2004), Bennet Agar (BA) (Bouizgarne et al., 2006), Corn Meal Agar (CMA) (Jiménez-Esquilín y Roane, 2005), y X-Medium (Tripathi et al., 2004).

De entre dichos medios de cultivo, se seleccionaron dos (YMA y PDA), depositando en ellos discos de agar con crecimiento activo de actinomicetos (procedentes de cultivos en ese mismo medio) e incubando en estufa a $28^{\circ} \mathrm{C}$ durante 7 días. Transcurrido este tiempo, se colocó -en el centro de cada placa- un disco de agar con micelio esporulado de cada uno de los 5 hongos fitopatógenos seleccionados, incubándose las placas de nuevo a $28^{\circ} \mathrm{C}$ hasta que el crecimiento de los hongos fue el adecuado para realizar las lecturas de los halos de inhibición, generalmente de 7 a 11 días según el crecimiento de cada especie. La supresividad potencial se evaluó en función de la distancia entre el crecimiento de cada hongo y cada actinomiceto, distinguiéndose 4 categorías: -, +, ++, ó +++, indicando inhibición negativa (no se produce inhibición), mínima (hasta una distancia de $1 \mathrm{~cm}$ ), media (entre 1 y $2 \mathrm{~cm}$ ) o máxima (superior a $2 \mathrm{~cm}$ ), respectivamente.

Además del ensayo de supresividad con los hongos fitopatógenos, se evaluó el efecto inhibidor de las cepas aisladas frente a Agrobacterium tumefaciens. Una vez la bacteria había crecido en Plate Count Agar (PCA) durante 24 horas a $28^{\circ} \mathrm{C}$, se preparó una suspensión en caldo común (Nutrient Broth, NB) de aproximadamente 1,5.108 $\mathrm{UFC} / \mathrm{mL}$ y, tras homogeneizarla, se realizaron diluciones seriadas hasta 1,5.105 UFC/ $\mathrm{mL}$. Se inoculó $1 \mathrm{~mL}$ de cada suspensión a un tubo de ensayo que contenía $19 \mathrm{~mL}$ de PCA estéril (previamente refundido en autoclave y atemperado a $50^{\circ} \mathrm{C}$ ), la mezcla resultante se agitó en vórtex, y su contenido se vertió en una placa petri. Una vez solidificado el medio en las placas, se depositaron 6 discos de agar de $6 \mathrm{~mm}$ de diámetro con crecimiento activo de actinomicetos en YMA y PDA, en disposición equidistante en el medio inoculado, y se incubaron a $28^{\circ} \mathrm{C}$. Transcurridas 24 y 48 horas de incubación, se midieron las zonas de inhibición, considerando para ello el halo de inhibición radial entre el crecimiento de la bacteria y el de los actinomicetos.

\subsubsection{Identificación de cepas mediante técnicas moleculares}

Aquellas cepas que mostraron mayor supresividad in vitro se identificaron a nivel de especie mediante técnicas de biología molecular. Partiendo de un cultivo puro de cada una de las cepas, se procedió a la extracción de DNA siguiendo el protocolo del CTAB (Bromuro de CetilTrimetilAmonio). EI DNA extraído fue amplificado mediante PCR 
(Reacción en Cadena de la Polimerasa), utilizando los iniciadores específicos $27 \mathrm{f}$ y 1515r (Lane, 1991), y, finalmente, los productos obtenidos de la PCR se purificaron, utilizando un kit comercial (GenElute, Sigma), y se secuenciaron con un secuenciador automático Applied Biosystems 3730xI DNA Analyzer.

\section{Extracción de DNA}

Con objeto de disgregar las agrupaciones de hifas de los actinomicetos para conseguir un rendimiento de extracción de DNA apropiado, y evitar, además, la adherencia de las colonias al agar, las cepas de actinomicetos se cultivaron en medio líquido y se agitaron a $28^{\circ} \mathrm{C}$ durante 3-5 días. Una vez había transcurrido este tiempo, se recogieron las células por centrifugación, se lavaron, y se homogeneizaron en tampón TE (Tris-CIH 10 mM, EDTA 1mM) en un tubo eppendorf con perlas de vidrio de $400 \mu$ de diámetro para deshacer agregados de hifas. Tras suspenderlas en $500 \mu \mathrm{L}$ de tampón TE con las perlas de vidrio, se lisaron las células añadiendo $100 \mu \mathrm{L}$ de lisozima $(50 \mathrm{mg} / \mathrm{mL})$, y se incubaron durante 1 hora a $37^{\circ} \mathrm{C}$, agitando cada $5-10$ minutos en vórtex para deshacer agregados y facilitar la acción de la lisozima. A continuación, se añadieron $30 \mu \mathrm{L}$ de dodecil sulfato sódico al $10 \%$ y $3 \mu \mathrm{L}$ de proteinasa $\mathrm{K}(20 \mathrm{mg} / \mathrm{mL})$. Los tubos eppendorf se agitaron y se incubaron 30 minutos a $37^{\circ} \mathrm{C}$.

Después, se añadieron $100 \mu \mathrm{L}$ de $\mathrm{NaCl} 5 \mathrm{M}$ y $80 \mu \mathrm{L}$ de una disolución de $\mathrm{CTAB} / \mathrm{NaCl}$ (CTAB 10\% en $\mathrm{NaCl}$ 0,7 M), y las muestras se agitaron en vórtex y se incubaron a $65^{\circ} \mathrm{C}$ durante 10 minutos.

La purificación del DNA se realizó con la adición de $700 \mu \mathrm{L}$ de fenol/cloroformo/alcohol-isoamílico (25/24/1), agitando y centrifugando a continuación a 12000 rpm durante 5 minutos para eliminar los complejos formados con el CTAB. El sobrenadante se transfirió a un nuevo tubo eppendorf y se añadieron $700 \mu \mathrm{L}$ de cloroformo/alcohol-isoamílico (24/1). Se agitó esta mezcla y se centrifugó a 12000 rpm durante 5 minutos para eliminar los restos de complejos con el CTAB (proteínas y polisacáridos).

A continuación, el sobrenadante -conteniendo los ácidos nucleicos- se transfirió a otro eppendorf y se adicionó el mismo volumen de isopropanol frío para precipitar el DNA. Dicho precipitado se centrifugó a 12000 rpm durante 5 minutos, para eliminar el isopropanol, y se lavó con $500 \mu \mathrm{L}$ de etanol frío al 70\%. Finalmente, se centrifugó, para eliminar el etanol, se secó en secador de vacío durante 15 minutos, y se 
resuspendió en $50 \mu \mathrm{L}$ de tampón TE. Para eliminar los restos de RNA extraído, se añadió $1 \mu \mathrm{L}$ de RNAsa $(25 \mathrm{mg} / \mathrm{mL})$. Las muestras se conservaron a $4^{\circ} \mathrm{C}$ durante 24 horas, tras las cuales se realizó un gel de comprobación de la extracción.

Para comprobar la adecuada extracción del DNA se analizaron las muestras (3 $\mu \mathrm{L}$ de cada una de ellas) mediante electroforesis en gel de agarosa al 1,2\% en tampón TAE 10X (preparado añadiendo 48,9 g de Tris base, 7,44 g de $\mathrm{Na}_{2} E D T A \cdot 2 \mathrm{H}_{2} \mathrm{O}$, y 1,42 $\mathrm{mL}$ de ácido acético glacial a $1000 \mathrm{~mL}$ de agua MiliQ, ajustando el pH a 8,5), aplicando $90 \mathrm{~V}$ durante 45 minutos. Los fragmentos de DNA se visualizaron con un transiluminador de UV tras teñirlos con bromuro de etidio.

Posteriormente, las muestras se conservaron a $-20^{\circ} \mathrm{C}$ hasta su utilización.

\section{Amplificación por PCR}

La amplificación del $16 S$ rDNA se realizó por PCR, utilizando los iniciadores $27 f$ y 1525r (Lane, 1991). La reacción se realizó en un volumen total de $50 \mu \mathrm{L}$, que contenía 1,5 $\mathrm{\mu M}$ de $\mathrm{MgCl}_{2}, 0,2 \mathrm{mM}$ de dNTPs (mezcla equimolar de los cuatro nucleótidos), 0,4 $\mu \mathrm{M}$ de cada iniciador, 1,25 U del enzima Taq polimerasa (Ecogen) con su correspondiente tampón, y $1 \mu \mathrm{L}$ de DNA. En cada reacción de amplificación se incluyó un control negativo en el que el DNA se reemplazó por agua estéril.

A continuación, se realizó la reacción de amplificación, que comenzó con una fase inicial de desnaturalización ( 5 minutos a $95^{\circ} \mathrm{C}$ ), seguida de 30 ciclos compuestos por la desnaturalización ( 1 minuto a $95^{\circ} \mathrm{C}$ ), la unión de iniciadores (1 minuto a $\left.54^{\circ} \mathrm{C}\right), y$ la elongación (1 minuto a $72^{\circ} \mathrm{C}$ ). Por último, se produjo un ciclo final de extensión (10 minutos a $\left.72^{\circ} \mathrm{C}\right)$.

EI DNA generado por la PCR $(5 \mu \mathrm{L})$ se visualizó mediante electroforesis en gel de agarosa del modo descrito anteriormente.

\section{Purificación del DNA}

El 16S rDNA obtenido tras la PCR se purificó utilizando el kit GenElute (Sigma), siguiendo las indicaciones del fabricante. A continuación, los productos purificados (5 $\mu \mathrm{L})$ se visualizaron mediante electroforesis en gel de agarosa según se ha indicado más arriba.

Obtención y análisis de las secuencias del 16S rDNA

La secuenciación de los productos obtenidos tras la PCR se realizó en el Laboratorio de Secuenciación de Sistemas Genómicos S.L. (Paterna, España). Para la 
realización de las reacciones de secuenciación se utilizó el kit $A B I$ PRISM® Big Dye ${ }^{T M}$ Terminator Cycle Sequencing Reaction (versión 3.1). Estas reacciones se sometieron a electroforesis capilar en un secuenciador automático (Applied Biosystems 3730xI DNA Analyzer).

La secuencia de bases de cada fragmento, con una longitud aproximada de 600700 nucleótidos, se obtuvo en un archivo de texto electrónico, desde el electroferograma, mediante la aplicación informática CHROMAS (versión 1.43). Las secuencias de los fragmentos de rDNA se ensamblaron manualmente utilizando el programa informático PHYDIT para generar una secuencia casi completa del gen $16 \mathrm{~S}$. La posible identidad de cada una de ellas se determinó mediante la aplicación informática BLAST (Basic Local Alignment Search Tool) que ofrece el NCBI (National Center for Biotechnology Information, Maryland, USA). Los árboles filogenéticos se elaboraron utilizando el algoritmo del "vecino más cercano", del inglés “neighbourjoining" (Saitou y Nei, 1987), con el paquete informático para análisis filogenético PHYLIP (Phylogenetic Inference Package; Felsenstein, 2004), preparándose las matrices de distancias evolutivas según Jukes y Cantor (1969). Las topologías de los árboles sin raíz obtenidos se evaluaron mediante análisis basado en 1000 remuestreos (“bootstrapping”) de PHYLIP (Felsenstein, 2004).

\subsubsection{Caracterización de las cepas de actinomicetos mediante técnicas} fenotípicas

Adicionalmente, los actinomicetos que mostraron mayor inhibición en el ensayo in vitro se caracterizaron mediante técnicas fenotípicas: determinación de los isómeros del ácido diaminopimélico (DAP), color del micelio aéreo esporulado, morfología de las cadenas de esporas, producción de pigmentos melanoides, y actividad quitinolítica.

Determinación de los isómeros del ácido diaminopimélico (DAP)

Estos isómeros pueden determinarse por análisis del hidrolizado ácido de la célula total y separación por cromatografía en capa fina (Staneck y Roberts, 1974).

Para llevar a cabo dicha determinación, en primer lugar se añadieron $500 \mu \mathrm{L}$ de $\mathrm{HCl} 6 \mathrm{~N}$ a criotubos de $2 \mathrm{~mL}$ conteniendo aproximadamente $100 \mathrm{mg}$ de bolas de vidrio $(<106 \mu \mathrm{m})$. A continuación, y a partir de los cultivos de los actinomicetos en ISP-2, se 
añadió un asa de siembra de cada una de las muestras a cada criotubo, y, tras agitar en vórtex durante 6 minutos, se incubaron en termoblock a $100^{\circ} \mathrm{C}$ durante 4 horas.

Tras estas 4 horas de incubación, los criotubos se centrifugaron a 4000 rpm durante 5 minutos, transfiriéndose el sobrenadante a nuevos tubos eppendorf. Éstos se incubaron en termoblock a $100^{\circ} \mathrm{C}$ hasta el secado del sobrenadante, y, una vez seco, se añadieron $500 \mu \mathrm{L}$ de agua destilada estéril, resuspendiendo la mezcla mediante vórtex. Se centrifugaron las muestras durante 5 minutos a 4000 rpm y el sobrenadante se transfirió a nuevos tubos eppendorf, que se llevaron a incubar a $100^{\circ} \mathrm{C}$ hasta que el sobrenadante se secó por completo. Transcurrido el tiempo necesario para su secado, se redisolvió con $75 \mu \mathrm{L}$ de agua destilada. Una vez preparadas las muestras, se procedió a aplicar $3 \mu \mathrm{L}$ de cada una de ellas y $1 \mu \mathrm{L}$ del control en la placa de celulosa. Realizado esto, la placa se colocó en una cubeta de vidrio conteniendo $50 \mathrm{~mL}$ del disolvente previamente preparado y se mantuvo allí durante 5 horas. Al cabo de estas 5 horas, se dejó secar la placa y se pulverizó con ninhidrina en acetona $(0,2 \%)$. A continuación, se incubó en estufa a $100^{\circ} \mathrm{C}$ durante 5 10 minutos, y se procedió a su lectura.

Caracterización según el protocolo del International Streptomyces Project (ISP)

Los aislados con mayores efectos inhibitorios se sembraron en los medios ISP-2, ISP-3 (Oatmeal Agar), ISP-4 (Inorganic Salts-Starch Agar) e ISP-5 (Glycerol Asparagine Agar) del International Streptomyces Project (ISP), y se incubaron a $28^{\circ} \mathrm{C}$, realizándose observaciones del color de la masa de esporas y del reverso de las colonias a los 7 y 14 días de incubación. Además, en estos medios se observó la producción y el color de pigmentos difusibles, y se estudió su sensibilidad al $\mathrm{pH}$. Para ello, de las cepas productoras de pigmento, se extrajeron dos discos de aproximadamente $2 \mathrm{~cm}$ de diámetro mediante un sacabocados. A continuación, y con ayuda de un bisturí, se eliminó la parte superior con crecimiento activo del actinomiceto y se añadieron dos gotas de $\mathrm{HCl}$ a uno de los discos y 2 gotas de $\mathrm{NaOH}$ al otro, para comprobar si se producía viraje del pigmento a pH ácido o a pH básico.

Para la determinación de la morfología de las cadenas de esporas, las cepas que crecieron en el medio ISP-5 se observaron en placa abierta al microscopio de bajo aumento (10x), examinándose los bordes de las colonias

Para detectar la producción de pigmentos melanoides, las cepas con la máxima actividad inhibidora se sembraron en ISP-6 (Peptone-Yeast Extract Iron Agar) y, tras 7 y 
14 días de incubación a $28^{\circ} \mathrm{C}$, se observó si se producía una coloración parda-negra del medio.

En este estudio, los actinomicetos se hicieron crecer en el medio de cultivo para detectar la actividad de la quitinasa, según Kawase et al. (2004). A partir de cultivo puro en ISP-2, se realizó la siembre en el medio de cultivo indicado mediante una estría simple en el centro de la placa, controlándose la presencia de halos alrededor de los actinomicetos con crecimiento activo.

\subsubsection{Bioensayo de supresividad in vivo frente a Fusarium oxysporum f. sp. melonis}

En los experimentos de supresividad in vivo se siguieron básicamente las técnicas descritas por Larkin y Fravel (1998), con objeto de evaluar la supresividad de los composts $\mathrm{A}$ y $\mathrm{A}+\mathrm{H}$ per se y determinar así su potencialidad para el control biológico de agentes fitopatógenos.

\subsubsection{Patosistema utilizado}

Se utilizaron plantas de melón (Cucumis melo) del cv. 'Rochet', descrito como sensible a la infección por Fusarium oxysporum f. sp. melonis (en adelante FOM) (Marín, 2008).

La infección de las plantas por dicho fitopatógeno se efectuó utilizando la cepa de referencia Fusarium oxysporum f. sp. melonis, procedente de la Colección Española de Cultivos Tipo (CECT 20474).

\subsubsection{Preparación del inóculo de Fusarium oxysporum f. sp. melonis}

Para la obtención del inóculo, se añadieron $4 \mathrm{~mL}$ de una suspensión de esporas del hongo fitopatógeno -obtenida a partir de un cultivo en medio sólido PDA- a un matraz erlenmeyer que contenía $100 \mathrm{~mL}$ de PDB (Potato Dextrose Broth) y, posteriormente, el cultivo se incubó a $28^{\circ} \mathrm{C}$ en agitador orbital a $150 \mathrm{rpm}$ durante 10 días.

Transcurrido dicho período, se procedió a la homogeneización del cultivo de FOM mediante centrifugación a 5000 rpm durante 5 minutos en condiciones de asepsia, recuperándose el sobrenadante resultante. 
Con objeto de determinar la concentración de inóculo, se tomó $1 \mathrm{~mL}$ del matraz indicado anteriormente para el recuento en placa (en superficie) en PDA por medio de diluciones seriadas.

En el Experimento 1 se preparó, con dicha metodología, un inóculo a concentraciones equivalentes a 2,15.10 4 y $1,08 \cdot 10^{5}$ propágulos/contenedor para las dosis mínima (D1) y máxima (D2), respectivamente.

Los inóculos utilizados en el Experimento 2 tuvieron una concentración de $3,40 \cdot 10^{5}$ y $1,70 \cdot 10^{6}$ propágulos/contenedor para las dosis estudiadas (D1 y D2, respectivamente).

\subsubsection{Experimento 1. Ensayo in vivo con los composts $A$ y $A+H$}

Las plántulas de melón se produjeron en bandejas de semillero de 104 alvéolos (4 x 4 ×6,5 cm por alvéolo) rellenos con vermiculita tras un período de 20 días y, posteriormente, se trasplantaron en macetas de plástico de 1,1 $\mathrm{L}$ de capacidad que contenían los sustratos resultantes de la mezcla de una turba Sphagnum rubia lituana sin encalar ni fertilizar (Klasmann-Deilmann $\mathrm{GmbH}$ ) con los dos materiales objeto de estudio, composts A y $\mathrm{A}+\mathrm{H}$, en la proporción 92/8 (\% v/v).

Las macetas se colocaron en un invernadero de cristal ubicado en el Campus de Vera de la Universitat Politècnica de València durante los meses de abril y mayo de 2010, según un diseño experimental de bloques al azar, a razón de 3 repeticiones de 4 macetas con 2 plántulas cada una por tratamiento (sustrato) (Fotografía 3.6).

Se estudiaron 4 tratamientos, resultantes de la combinación factorial de 2 sustratos (preparados con los composts $A \circ A+H) \times 2$ dosis de inoculación de FOM (D1 y D2). En adición, se incluyeron en el ensayo los dos sustratos autoclavados (a $121^{\circ} \mathrm{C}$ durante 15 minutos) como controles positivos del agente fitopatógeno, así como controles negativos no inoculados con este hongo.

Durante los días posteriores a la inoculación del hongo FOM se evaluó la evolución de la enfermedad, controlándose (cada 2-3 días) los síntomas de la infección, tales como clorosis de las hojas, necrosis en el vástago y gomosis, principalmente. Transcurridos 47 días desde la inoculación del hongo, se recolectaron las plantas, controlándose el porcentaje de plantas infectadas, el peso fresco de aquellas (en g/planta), la longitud del tallo $(\mathrm{cm})$ y la proporción de éste afectado por necrosis (expresado en \%), la intensidad del color de la necrosis (puntuación), y el grado de clorosis (puntuación). Las puntuaciones, asignadas por un panel de 4 
expertos a los diferentes grados de intensidad de la necrosis, estuvieron basadas en la coloración de las manchas encontradas en la base del tallo: 1 - manchas de color blanco, 2 - color ocre, 3 - color marrón, y 4 - color negro. El nivel de clorosis se estimó visualmente siguiendo el mismo procedimiento, según la siguiente escala numérica: 1 - menos del 25\% del total de hojas cloróticas; 2 - del 25\% al 50\% de hojas cloróticas; 3 - del 50\% al 75\% de hojas cloróticas; y, 4 - más del 75\% de hojas cloróticas.

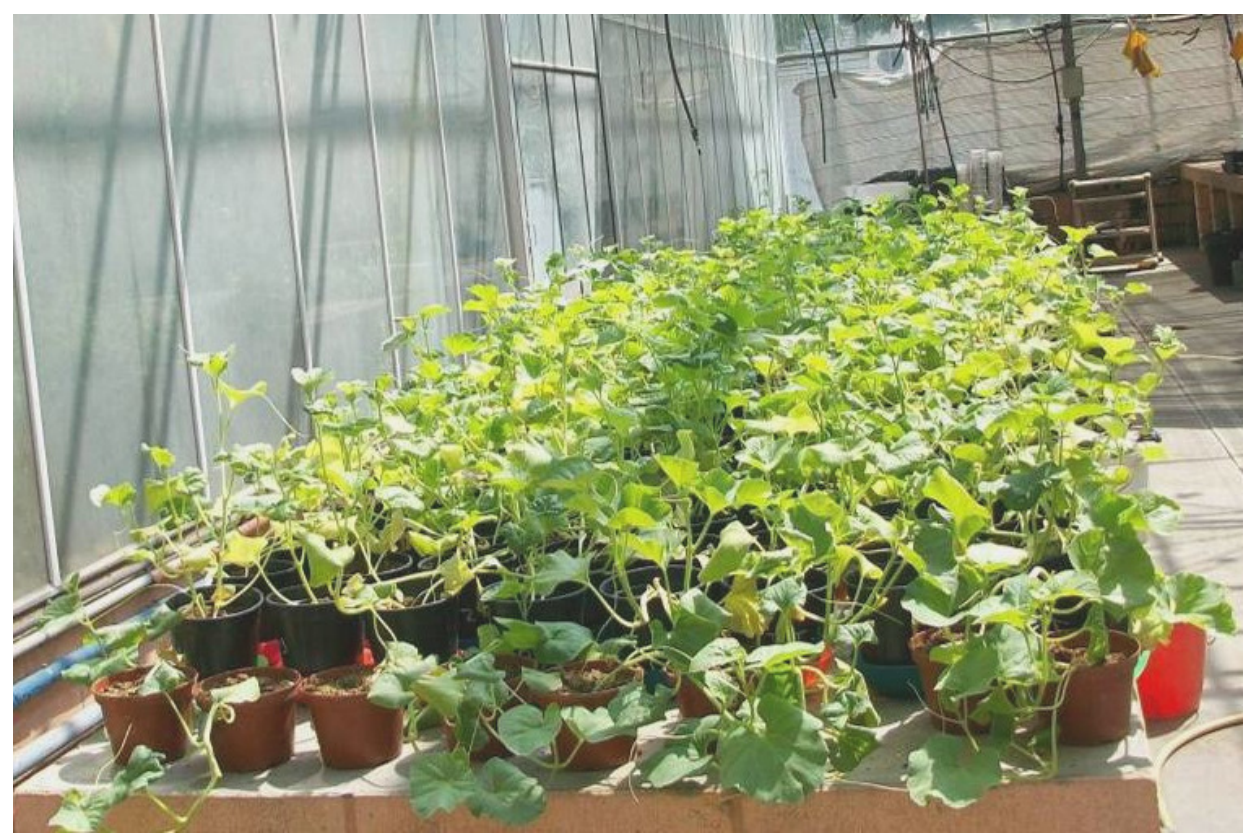

Fotografía 3.6. Vista general de las plantas de melón utilizadas en el bioensayo de supresividad in vivo con los composts $\mathrm{A}$ y $\mathrm{A}+\mathrm{H}$ (Experimento 1 )

Para confirmar la infección por FOM, se sembraron en medio PDA porciones de tallo de cada una de las plantas - desinfectando la superficie de dichas porciones con etanol- para determinar el porcentaje de plántulas infectadas. Las placas se incubaron a $28-30^{\circ} \mathrm{C}$ durante 5 días, identificándose la presencia de FOM mediante examen visual, y evaluándose caracteres fenotípicos tales como aspecto del crecimiento del micelio, textura y coloración, y observación de preparaciones teñidas con azul de metileno mediante microscopía óptica.

\subsubsection{Experimento 2. Efecto del volumen de compost A en la mezcla sobre la} supresividad

Se evaluó la influencia del volumen de compost A en la mezcla (sustrato) en la supresividad potencial de los sustratos de cultivo frente a FOM en un experimento de 47 días de duración. La mezcla con turba Sphagnum se preparó con la proporción de 
compost A utilizada en el Experimento 1 ( $8 \%$ en volumen) y con una proporción del material compostado superior, del 16\%. Las dosis de inóculo (D1 y D2) se han especificado en la sección 3.6.2.2. Al igual que en el Experimento 1, se incluyeron controles no inoculados (controles negativos de la enfermedad) y sustratos autoclavados a $121^{\circ} \mathrm{C}$ durante 15 minutos (esterilizados) e inoculados a la dosis máxima ensayada (D2).

Los parámetros controlados y la metodología seguida a lo largo del experimento y al final del mismo fueron idénticos a los utilizados en el Experimento 1 (sección 3.6.2.3).

\subsection{APLICACIÓN DE COMPOST DE ALPERUJO A DOS SUELOS CONTAMINADOS. INFLUENCIA EN LA BIODISPONIBILIDAD DE METALES PESADOS Y ARSÉNICO, Y EN EL CRECIMIENTO DE PLANTAS DE BRASSICA}

\subsubsection{Suelos, compost y especies vegetales utilizadas}

En este estudio se han utilizado dos suelos contaminados, S1 y S2, y dos suelos no contaminados, SC1 y SC2, estos últimos seleccionados por poseer características similares a S1 y S2, respectivamente, a excepción de la presencia de contaminantes, y poder ser así utilizados como controles de comparación con los suelos contaminados.

El suelo S1 procedía de una parcela dedicada al cultivo de cítricos en el término municipal de Onda (Castellón). En él, las plantas presentaban síntomas foliares de toxicidad por metales pesados. Dicho suelo se seleccionó porque se tenía constancia, además, del vertido de residuos de la industria azulejera y de la presencia de niveles contaminantes de $\mathrm{Pb}$ en dicho emplazamiento.

El suelo SC1 se muestreó de una parcela citrícola próxima a aquella donde se tomó S1, pero que no había recibido vertidos contaminantes.

El suelo S2 fue cedido por el Instituto de Recursos Naturales y Agrobiología de Sevilla (IRNAS), CSIC, y procedía de la ribera del río Guadiamar (Aznalcóllar, Sevilla), que resultó contaminada en 1998 por el vertido accidental de los lodos almacenados en una balsa de una explotación minera de pirita en Aznalcóllar (Cabrera et al., 1999). Este suelo, después de retirar los lodos contaminantes, poseía un pH fuertemente ácido y una elevada contaminación por diversos metales pesados y As.

El suelo SC2 se obtuvo en el término municipal de Sinarcas (Valencia). Se tomó del horizonte B (20-40 cm de profundidad) de un suelo forestal con vegetación de 
pinar y coscoja, siendo seleccionado principalmente por su pH ácido, para poder utilizarlo como control del suelo S2.

Las muestras de todos los suelos, a excepción de SC2, se tomaron de los $20 \mathrm{~cm}$ superficiales de los mismos.

El compost de alperujo utilizado en este experimento fue el compost $A$, utilizado en todos los estudios de la presente Tesis Doctoral, cuya preparación se ha presentado en la sección 3.1.1.

Las especies de Brassica utilizadas, y su procedencia, fueron las siguientes: Brassica carinata (IAS-C101) y Brassica juncea (IASZ1) fueron proporcionadas por el Instituto de Agricultura Sostenible (IAS, CSIC, Córdoba); y, Brassica napus (CCMAVUPV-19937), Brassica oleracea (CCMAV-UPV-22194) y Brassica rapa (CCMAV-UPV19939) procedían del Centro de Conservación y Mejora de la Agrodiversidad Valenciana (COMAV, Universidat Politècnica de València).

\subsubsection{Caracterización física, química y biológica de los suelos}

Para la caracterización de los suelos contaminados y los controles (no contaminados) se seleccionaron distintos parámetros: textura, capacidad de retención de agua útil o disponible (CRAD), pH, conductividad eléctrica (CE), capacidad de intercambio catiónico, contenido en carbonatos, materia orgánica y carbono orgánico, nitrógeno total, fósforo -método Burriel-Hernando- y potasio asimilables, elementos traza totales (mediante digestión con $\mathrm{HClO}_{4}$ y $\mathrm{HNO}_{3}$; Norma ISO 11466, 1995) y biodisponibles (extraíble con $\mathrm{KCl}$ para Al [Matúš et al., 2006]; y extraíbles con EDTA para $\mathrm{Cr}, \mathrm{Cu}, \mathrm{Ni}, \mathrm{Pb}, \mathrm{Zn}$ y As [Romaguera et al., 2008]), así como recuentos de grupos microbianos (bacterias heterótrofas, actinomicetos, y mohos y levaduras) y actividad microbiana (hidrólisis del diacetato de fluoresceína [FDA] y respiración basal $\left[\mathrm{O}_{2}\right.$ consumido]), según las metodologías recogidas en la sección I.2 del Anejo de Métodos Analíticos.

\subsubsection{Fitotoxicidad potencial. Germinación de semillas de cebada}

Se realizó un bioensayo en el que se evaluó el crecimiento de las raíces de plántulas de cebada (Hordeum vulgare, cv. "Nevada") cultivadas en los suelos contaminados, en los suelos control no contaminados, y en arena. Para ello, se siguió 
la metodología descrita en la Norma UNE-77301-1 (1996), que se describe en la sección I.2.5.6 del Anejo de Métodos.

\subsubsection{Descripción del experimento}

Para estudiar el efecto de la aplicación de materia orgánica sobre los suelos contaminados y su idoneidad para el cultivo de diferentes especies del género Brassica, se prepararon 40 tratamientos, resultantes de la combinación factorial de 4 Suelos con diferentes orígenes y grado de contaminación (contaminados [S1 y S2]) vs. no contaminados [SC1 y SC2] $) \times 2$ niveles de Enmienda orgánica de los suelos (aplicación de compost, + vs. no aplicación de compost, -) $\times 5$ Especies de Brassica a cultivar (B. carinata, B. juncea, B. napus, B. oleracea y B. rapa).

Para cada tratamiento/combinación Suelo $\times$ Enmienda $\times$ Especie de Brassica, se dispusieron 12 plantas, repartidas según un diseño de bloques al azar, en tres bloques de cuatro réplicas (macetas) con una planta por cada una de ellas.

En adición, se prepararon macetas con las mezclas de los suelos y la enmienda orgánica, que se dejaron sin cultivar, estudiándose los dos factores restantes: 4 Suelos (S1, S2, SC1 y SC2) y 2 niveles de Enmienda orgánica (+ y -).

El experimento se llevó a cabo entre los meses de octubre de 2007 y enero de 2008 en un invernadero de cristal de la Universitat Politècnica de València, bajo condiciones de temperatura controladas (entre 15 y $30^{\circ} \mathrm{C}$ ).

En primer lugar, se prepararon las mezclas de los suelos con el compost de alperujo A en una proporción tal que se aumentó en un $2 \%$ el contenido en $C$ orgánico de dichos suelos, lo que fue equivalente a unas 100 t de compost/ha. Seguidamente se procedió a abonar los suelos, tanto enmendados como no enmendados, con nitrato cálcico (0,33 g/kg suelo), superfosfato simple $(0,31 \mathrm{~g} / \mathrm{kg}$ suelo) y sulfato de potasa $(0,1 \mathrm{~g} / \mathrm{kg}$ suelo). A continuación se Ilenaron macetas de $1 \mathrm{~L}$ de capacidad con, aproximadamente, $1500 \mathrm{~g}$ de cada uno de los suelos (tratamientos) estudiados.

Las semillas de las 5 especies de Brassica se pregerminaron, desinfectándolas previamente por inmersión en hipoclorito sódico 0,1\% durante 20 minutos, y lavándolas posteriormente con agua destilada. Se colocaron en placas petri de $10 \mathrm{~cm}$ de diámetro sobre 3 capas de papel de filtro humedecidas con agua destilada, y se dejaron en una cámara de germinación a $25^{\circ} \mathrm{C}$ durante 3 días, transcurridos los cuales se seleccionaron aquellas semillas que presentaron una longitud del hipocótilo comprendida entre 0,5 y $1 \mathrm{~cm}$. 
Tras la siembra, el cultivo de Brassica duró 16 semanas, durante las cuales las plantas se regaron manualmente en función de sus necesidades.

\subsubsection{Análisis del suelo al final del experimento}

Una vez finalizado el experimento, se recolectó la parte aérea de las plantas, se eliminaron las raíces, y el suelo se secó al aire y se tamizó por la luz de $2 \mathrm{~mm}$, para, a continuación, determinar el pH, la conductividad eléctrica (CE), el contenido total y biodisponible de $\mathrm{Al}, \mathrm{As}, \mathrm{Pb}$ y $\mathrm{Zn}$, además de realizar recuentos de grupos microbianos y determinar la actividad microbiana (hidrólisis del FDA y respiración basal), según se describe detalladamente en la sección I.2 del Anejo de Métodos Analíticos.

\subsubsection{Parámetros controlados en el material vegetal}

Transcurridas las 16 semanas de cultivo, se contó el número de plantas desarrolladas, calculándose el porcentaje de supervivencia de cada especie de Brassica en cada tratamiento/combinación Suelo $\times$ Enmienda, determinándose además la biomasa del vástago (expresada en g de materia seca) en las plantas que sobrevivieron.

En los suelos calizos S1 y SC1 (enmendados con compost A y sin enmendar) se determinó la concentración ( $\mu \mathrm{g} / \mathrm{g}$ de materia seca) y la acumulación total ( $\mu \mathrm{g} / \mathrm{vástago)}$ de $\mathrm{Pb}$ y $\mathrm{Zn}$ en las cinco especies de Brassica estudiadas, mientras que en los suelos ácidos (S2 y SC2) se determinaron estos dos parámetros (concentración y acumulación total) para $\mathrm{Al}, \mathrm{As}, \mathrm{Pb}$ y $\mathrm{Zn}$ únicamente en las tres especies que sobrevivieron (B. carinata, B. napus y B. oleracea). La preparación, digestión y determinación de los elementos traza en el material vegetal se detalla en la sección I.3.4 del Anejo de Métodos.

El factor de bioconcentración FBC se calculó como la relación entre la concentración del elemento traza en el vástago de la planta y la concentración total de dicho elemento en el suelo (McGrath y Zhao, 2003). En adición, se calculó la relación entre la concentración del elemento traza en el vástago de la planta y la concentración biodisponible del mismo en el suelo, denominándose este factor de bioconcentración como FBC'. 


\subsection{DISMINUCIÓN DEL pH DEL COMPOST DE ALPERUJO MEDIANTE LA ADICIÓN DE AZUFRE ELEMENTAL}

\subsubsection{Experimento de acidificación con el compost}

Para llevar a cabo la acidificación del compost de alperujo (compost A, sección 3.1.1), se obtuvo en primer lugar la curva de valoración de éste, con objeto de determinar las dosis de azufre elemental $\left(\mathrm{S}^{0}\right)$ micronizado a ensayar. A continuación se realizó un ensayo de incubación con dos dosis de enmienda $\left(\mathrm{S}^{0}\right)$, determinándose -a lo largo de dicho experimento- diferentes parámetros físico-químicos y químicos relacionados con el proceso de acidificación, así como la evolución de diferentes grupos microbianos. En adición, durante dicho ensayo se aislaron cepas de bacterias oxidadoras del azufre, que se caracterizaron e identificaron posteriormente.

\subsubsection{Curva de valoración del compost}

La curva de valoración del compost A se obtuvo utilizando un método volumétrico diseñado especialmente para materiales orgánicos (Martínez et al.,1988), con el fin de estudiar la relación entre el descenso de pH del compost y la adición de la disolución valorante (ácido). Para ello, se utilizó una disolución de sulfato ferroso $\left(\mathrm{FeSO}_{4} \cdot 7 \mathrm{H}_{2} \mathrm{O}\right)$ al $2 \%(\mathrm{p} / \mathrm{v})$, que se valoró con permanganato potásico, estandarizado previamente con oxalato potásico. A partir de la disolución ferrosa valorada se prepararon 17 disoluciones, variando la proporción reactivo/agua (Tabla 3.11).

En recipientes de plástico de $300 \mathrm{~mL}$ se introdujeron $40 \mathrm{~mL}$ de compost, $200 \mathrm{~mL}$ de cada una de las disoluciones de sulfato ferroso preparadas, y 3 ó 4 gotas de cloroformo con el fin de evitar fermentaciones que pudieran alterar el $\mathrm{pH}$ de las suspensiones. En todos los casos se utilizó un control sin sustrato.

Los recipientes se incubaron a temperatura ambiente, agitándolos diariamente durante 45 minutos. A partir del cuarto día de incubación se midió el pH de todas las suspensiones cada 24 horas, hasta que no se observaron variaciones importantes (valores de $\mathrm{pH}$ prácticamente constantes). Posteriormente se filtraron las suspensiones, y se determinaron los miliequivalentes (meq) de ácido que quedaron sin reaccionar (o remanentes) en cada una de ellas, expresándolos como meq de $\mathrm{H}^{+}$. 
Tabla 3.11. Proporciones reactivo-agua de las disoluciones utilizadas para obtener la curva de valoración del compost A

\begin{tabular}{|c|c|c|}
\hline Disolución & $\begin{array}{c}\text { Agua destilada } \\
(\mathrm{mL})\end{array}$ & $\begin{array}{c}\mathrm{FeSO}_{4} \cdot 7 \mathrm{H}_{2} \mathrm{O} 2 \%(\mathrm{p} / \mathrm{v}) \\
(\mathrm{mL})\end{array}$ \\
\hline 0 & 200,0 & 0 \\
\hline 1 & 187,5 & 12,5 \\
\hline 2 & 175,0 & 25,0 \\
\hline 3 & 162,5 & 37,5 \\
\hline 4 & 150,0 & 50,0 \\
\hline 5 & 137,5 & 62,5 \\
\hline 6 & 125,0 & 75,0 \\
\hline 7 & 112,5 & 87,5 \\
\hline 8 & 100,0 & 100,0 \\
\hline 9 & 87,5 & 112,5 \\
\hline 10 & 75,0 & 125,0 \\
\hline 11 & 62,5 & 137,5 \\
\hline 12 & 50,0 & 150,0 \\
\hline 13 & 37,5 & 162,5 \\
\hline 14 & 25,0 & 175,0 \\
\hline 15 & 12,5 & 187,5 \\
\hline 16 & 0 & 200,0 \\
\hline
\end{tabular}

La determinación de los meq de $\mathrm{H}^{+}$, tanto adicionados inicialmente como remanentes, se realizó volumétricamente con permanganato potásico. La diferencia entre ambos valores permitió conocer los meq de $\mathrm{H}^{+}$que habían reaccionado en cada una de las suspensiones.

La curva de valoración del compost se obtuvo representando gráficamente el pH final alcanzado (en el eje de ordenadas) frente a los meq de $\mathrm{H}^{+}$que reaccionaron por litro de compost (en el eje de abcisas), para cada una de las proporciones reactivo/agua utilizadas (disoluciones 0 a 16, Tabla 3.11).

\subsubsection{Ensayo de incubación}

A partir de la curva de valoración se determinó la dosis de enmienda ( $D$, en g de S\%/L de compost) necesaria para que el $\mathrm{pH}$ del compost alcanzara el valor de 6 , al considerar que la disponibilidad de los nutrientes del compost -utilizado como sustrato o componente de sustratos de cultivo- es máxima en el intervalo de pH comprendido entre 5,2 y 6,3 (Abad et al., 2004; García de la Fuente et al., 2007). Para ello, se calculó la cantidad de enmienda requerida (azufre elemental, $\mathrm{S}^{\circ}$, micronizado) -a partir de los miliequivalentes de $\mathrm{H}^{+}$, obtenidos de la curva de valoración (meq $\left.\mathrm{H}^{+} / \mathrm{L}\right)$ - para alcanzar el valor de $\mathrm{pH}$ deseado con la siguiente ecuación:

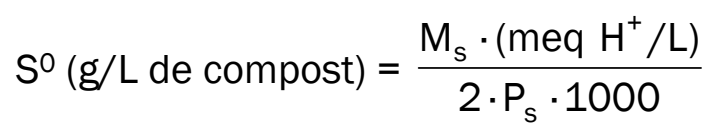


donde $\mathrm{M}_{\mathrm{s}}$ es la masa molar del azufre elemental (32 g) y $\mathrm{P}_{\mathrm{s}}$ es la pureza del azufre elemental micronizado $(0,985)$.

Con el fin de estudiar la evolución de parámetros químicos y biológicos durante el proceso de acidificación, el compost A se enmendó con dos dosis de azufre elemental micronizado: dosis $\mathrm{D}$ (que se ha denominado $1 \mathrm{xD}$ ) y 1,5 veces dicha dosis (1,5xD).

Para que el proceso de acidificación tenga lugar, el material debe estar suficientemente húmedo, pero evitando excesos de agua que puedan impedir la oxidación del azufre. Por ello, el compost se humedeció hasta un $80 \%$ de la capacidad de contenedor (determinada a $1 \mathrm{kPa}$ ). Se colocó, en bandejas rectangulares de 30×20×10 cm de plástico, la mezcla homogénea del compost humedecido (2000 g) con las dosis de $\mathrm{S}^{0}$ a estudiar, así como una muestra control sin enmendar, incubándose en estufa a $28^{\circ} \mathrm{C}$ y humedad constante durante 70 días. La humedad se determinó gravimétricamente cada dos días, restituyéndose las pérdidas de agua por evaporación con la adición de agua destilada estéril.

Los muestreos se efectuaron los días $0,3,9,15,23,36,50$ y 70 del experimento, finalizando la incubación el día 70 del ensayo, en base a lo indicado en otros experimentos previos de acidificación con tres composts de residuos orgánicos, en los que el pH de los materiales enmendados se estabilizó antes de 60 días (García de la Fuente et al., 2007). En cada fecha de muestreo se tomaron -previa homogeneización y en condiciones asépticas- aproximadamente 250 g de material (compost A) con cada una de las dosis de enmienda estudiadas.

\section{Eficiencia de acidificación}

La eficiencia de acidificación (e.a., \%) de la enmienda utilizada (So micronizado) se calculó según Martínez et al. (1988) a partir de la siguiente ecuación:

$$
\text { e.a. }(\%)=\frac{\mathrm{pH}_{\text {final }}-\mathrm{pH}_{\text {inicial }}}{\mathrm{pH}_{\text {esperado }}-\mathrm{pH}_{\text {inicial }}} \cdot 100
$$

donde $\mathrm{pH}_{\text {final }}$ es el $\mathrm{pH}$ alcanzado tras la estabilización, $\mathrm{pH}_{\text {inicial }}$ es el $\mathrm{pH}$ del día 0 de la muestra control sin enmendar, y $\mathrm{pH}_{\text {esperado }}$ es el $\mathrm{pH}$ final esperado según la curva de valoración. 
Parámetros físico-químicos y químicos determinados

En cada una de las muestras tomadas se determinaron el $\mathrm{pH}$ y la conductividad eléctrica (CE), tal y como se recoge en la sección I.1.3 del Anejo de Métodos. A continuación, el material se secó en estufa a $105^{\circ} \mathrm{C}$ y se trituró, para determinar posteriormente el contenido en carbonatos $\left(\mathrm{CaCO}_{3}\right.$, \% en materia seca, ver la sección I.1.4.8 del Anejo de Métodos) y en sulfatos (expresado como $\mathrm{CaSO}_{4}$, en \% en materia seca, sección I.1.4.9 del Anejo de Métodos).

\section{Recuento de grupos microbianos}

En cada uno de los materiales muestreados se realizaron recuentos de cuatro grupos microbianos: bacterias oxidadoras del azufre (autótrofas), bacterias heterótrofas, actinomicetos, y mohos y levaduras, tal y como se explica en la sección I.1.5.1 del Anejo de Métodos. Para el recuento de las bacterias oxidadoras del azufre se utilizó un medio con indicador de pH, el medio de cultivo 152 de la Colección ATCC (American Type Culture Collection) para Thiobacillus, que facilitó el aislamiento de dichos microorganismos. Este medio se elaboró disolviendo $10 \mathrm{~g}$ de $\mathrm{Na}_{2} \mathrm{~S}_{2} \mathrm{O}_{3} \cdot 5 \mathrm{H}_{2} \mathrm{O}, 1$ g de $\mathrm{NH}_{4} \mathrm{Cl}$, 0,5 g de $\mathrm{MgCl}_{2}$, 0,6 g de $\mathrm{K}_{2} \mathrm{HPO}_{4}$, 0,4 g de $\mathrm{KH}_{2} \mathrm{PO}_{4}, 0,02$ g de $\mathrm{FeCl}_{3}, 1$ g de extracto de levadura y $0,016 \mathrm{~g}$ del indicador rojo de clorofenol -que vira a amarillo a $\mathrm{pH}$ inferior a 4,8- en $1 \mathrm{~L}$ de agua destilada y adicionando $15 \mathrm{~g}$ de agar.

\subsubsection{Aislamiento e identificación de cepas oxidadoras del azufre}

Una vez realizados los recuentos del ensayo de acidificación, se seleccionaron 34 colonias crecidas en el medio 152, en virtud del viraje de éste de rojo a amarillo a pH ácido. Estas cepas, susceptibles de ser identificadas como bacterias oxidadoras del azufre, se caracterizaron mediante tinción Gram y las pruebas bioquímicas de la catalasa y la oxidasa. Las 34 cepas aisladas en cultivo puro se congelaron a $-80^{\circ} \mathrm{C}$ para su adecuada conservación. De estas cepas se seleccionaron 8 por su rápida acidificación del medio, al virar éste de rojo a amarillo en un período de tiempo inferior a 48 horas, y también por los resultados obtenidos tras su caracterización.

Para la identificación de los aislados de bacterias oxidadoras del azufre se partió de cultivo puro de cada una de las cepas, procediéndose a: la extracción de DNA según el protocolo del CTAB; la amplificación del DNA mediante PCR; la purificación de los productos obtenidos en esta última; y, la secuenciación y combinación de las secuencias con el programa PHYDIT, para la identificación a nivel de especie con la 
aplicación informática BLAST, tal y como se indicó en la sección 3.6.1.3, pero utilizando los iniciadores universales para eubacterias $27 \mathrm{f}$ y $1492 \mathrm{r}$ en la PCR (Lane, 1991). La reacción de amplificación comenzó con una fase inicial de desnaturalización (5 minutos a $95^{\circ} \mathrm{C}$ ), seguida de 35 ciclos compuestos por la desnaturalización $\left(1\right.$ minuto a $95^{\circ} \mathrm{C}$ ), la unión de iniciadores (1 minuto a $55^{\circ} \mathrm{C}$ ), y la elongación ( 1 minuto a $72^{\circ} \mathrm{C}$ ). Por último, se produjo un ciclo final de extensión (10 minutos a $72^{\circ} \mathrm{C}$ ). Asimismo, se prepararon árboles filogenéticos con el paquete informático PHYLIP, de acuerdo con la metodología descrita anteriormente (ver la sección 3.6.1.3).

Por otro lado, la caracterización fenotípica se llevó a cabo según los procedimientos descritos por Katayama et al. (1995) y Kelly y Wood (2000).

\subsubsection{Evaluación de la eficiencia acidificadora de las cepas de bacterias oxidadoras del azufre}

De las dos dosis $(1 \times D$ y $1,5 \times D)$ de $S^{0}$ aplicadas al compost $A$ en el ensayo anterior, se seleccionó la dosis de mayor eficiencia de acidificación (1,5xD). Tras añadir la enmienda a la cantidad de compost necesaria para obtener $400 \mathrm{~g}$ de material húmedo, se homogeneizó la mezcla resultante y se colocó en recipientes de plástico herméticos de 26,5×16,2×15 cm. A continuación, se realizaron tres ciclos consecutivos de esterilización en autoclave a $110^{\circ} \mathrm{C}$ durante 20 minutos. Se atemperaron los recipientes con el compost estéril, y, en cámara de flujo laminar, éste se humedeció con agua destilada estéril hasta alcanzar un $80 \%$ de la capacidad de contenedor (determinada a $1 \mathrm{kPa}$ ). A continuación se procedió a inocular el compost con las ocho cepas autóctonas seleccionadas por el rápido viraje del medio de cultivo ThCl, así como con las cepas de referencia Halothiobacillus neapolitanus CIP 104769, Thiobacillus denitrificans CIP 104767 y Thiomonas intermedia CIP 104401 de la Colección del Instituto Pasteur, por separado. Para ello, se sembraron los microorganismos en matraces de $50 \mathrm{~mL}$ de medio Thl líquido, agitándose a $100 \mathrm{rpm}$ y en oscuridad durante 24-48 horas. Transcurrido este tiempo, se realizó el recuento de bacterias en el medio por recuento directo con microscopio y se ajustó la densidad del inóculo a unas 3,2.107 UFC/g de compost. Tras verter el inóculo en los recipientes, éstos se taparon herméticamente y se incubaron en estufa a $28^{\circ} \mathrm{C}$ y humedad constante durante 18 días. Cada cepa se preparó e inoculó por triplicado, incluyéndose en el ensayo un control no estéril y otro estéril no inoculado. Al finalizar 
la incubación, se determinó el pH y la conductividad eléctrica (CE), expresándose estos parámetros en relación con el compost original no estéril $(\Delta)$, así como la eficiencia de acidificación (e.a.).

En adición, y para evaluar el efecto de las bacterias oxidadoras del azufre de referencia sobre el proceso de acidificación, se inocularon las cepas de Halothiobacillus neapolitanus, Thiobacillus denitrificans y Thiomonas intermedia arriba indicadas al compost original no autoclavado a una dosis de inóculo de aproximadamente 3,2:107 UFC/g de compost. Tras 25 días de incubación en las mismas condiciones que las anteriormente indicadas, se controlaron los cambios producidos en el pH, la CE y la población de bacterias oxidadoras del azufre cultivadas -en comparación con el compost original no inoculado $(\Delta)-$, y en la eficiencia de acidificación.

\subsection{ANÁLISIS ESTADÍSTICO DE LOS DATOS}

Para el estudio estadístico de los resultados se utilizó el programa Statgraphics@ Plus 5.1 para Windows (Statistical Graphics Corp. 2005).

Los resultados experimentales obtenidos se analizaron mediante técnicas de Análisis de la Varianza (ANOVA). Para determinar la significación de las diferencias entre las medias de los diferentes grupos o niveles, se aplicó el test de StudentNewman-Keuls, considerando un nivel de significación de $P \leq 0,05$.

En los análisis de regresión, el modelo consideró únicamente las variables cuyos coeficientes difirieron significativamente a $P \leq 0,05$.

Para el estudio de las correlaciones existentes entre diferentes parámetros se empleó la correlación bilateral de Pearson y, en base a la matriz de correlación de dichos resultados, se redujo la dimensionalidad del conjunto de datos estudiados aplicando el Análisis de Componentes Principales (ACP). 
4. RESULTADOS Y DISCUSIÓN 


\subsection{CARACTERÍSTICAS, PROPIEDADES Y COMPOSICIÓN DE LOS COMPOSTS A Y A+H}

La aplicación de compost a suelos de cultivo es una de las principales alternativas utilizadas con el fin de elevar y mantener el contenido en materia orgánica del suelo y generar fertilidad sostenible en los agroecosistemas, debido tanto al aprovechamiento de sus nutrientes por los cultivos como a una serie de efectos beneficiosos sobre las características físicas, químicas y biológicas del suelo (Ingelmo y Rubio, 2008; Moral y Muro, 2008). Asimismo, el incremento de los niveles de carbono orgánico del suelo es un objetivo clave en el desarrollo de estrategias sostenibles de manejo del mismo, que permitan atenuar los efectos del cambio climático (Barral et al., 2009; Van-Camp et al., 2004).

Los efectos de las enmiendas orgánicas dependen de las propiedades del medio receptor así como del tipo de material orgánico utilizado, su estabilidad y madurez, y la cantidad aplicada, entre otros factores. En este contexto, cada compost posee unas características específicas y éstas influyen de manera diferencial en las propiedades del suelo y el desarrollo del cultivo y, por consiguiente, en la producción y la calidad de ésta (Courtney y Mullen, 2008; Roe, 2005). Por tanto, el uso de materiales orgánicos como mejoradores del suelo requiere el análisis previo de cada tipo de enmienda (Ortiz, 2001), considerando que la calidad agronómica de dichos materiales incluye parámetros físicos, físico-químicos, químicos y biológicos (Soliva, 2001).

Por otra parte, el uso de composts como enmiendas orgánicas en Agricultura está regulado básicamente por el Real Decreto 824/2005, de 8 de julio, sobre productos fertilizantes, que especifica las características técnicas y los criterios requeridos para que su utilización no produzca efectos nocivos desde el punto de vista sanitario ni medioambiental. La Orden PRE/630/2011, de 23 de marzo, por la que se modifican los Anexos I a VI de dicho Real Decreto, incluye el "Compost de alperujo" en la categoría 09 del grupo 6 "Enmiendas orgánicas" y especifica además los requisitos mínimos que éste debe cumplir, los cuales se han incluido en la Tabla 4.1.1.

Respecto a las propiedades de los dos composts de alperujo objeto de estudio (A y $\mathrm{A}+\mathrm{H})$, resulta de gran interés que éstos reúnan determinadas características cuando vayan a utilizarse como enmiendas del suelo o como abonos orgánicos, tales como ser biológicamente estables, no inmovilizar nitrógeno, estar libres de fitotoxinas y patógenos, no ser excesivamente salinos, etc. Sin embargo, la cantidad aplicada a las dosis habituales (10 - 40 t/ha) representa una concentración muy baja de compost en 
la rizosfera, por efecto de dilución al mezclarse éste con la capa arable, considerándose, además, que su influencia se ve amortiguada por el gran poder tampón de los suelos agrícolas (Carmona y Abad, 2008). Todo esto permite que las exigencias de calidad relativas a sus propiedades físicas, químicas o biológicas en su aplicación como mejoradores de los suelos cultivados sean menores que en su uso como sustratos o componentes de sustratos de cultivo (Masaguer y Benito, 2008).

Tabla 4.1.1. Requisitos que deben cumplir los composts de alperujo, especificados en el Anexo I de la Orden PRE/630/2011, de 23 de marzo, por la que se modifican los anexos I a VI del Real Decreto 824/2005 sobre productos fertilizantes

Requisito

Humedad máxima 40\%

Materia orgánica total $\geq 45 \%$ (mf)

Relación $\mathrm{C} / \mathrm{N}<20$

Contenido máximo en polifenoles $0,8 \%$

No podrán contener impurezas ni inertes de ningún tipo tales como piedras, gravas, metales, vidrios o plásticos

mf: materia fresca

A continuación se presentan los resultados obtenidos en la caracterización de los dos composts objeto de esta Tesis Doctoral.

\subsubsection{Propiedades físicas}

Las propiedades físicas más importantes de los dos composts a base de alperujo estudiados - uno regado con agua de pozo (A) y el otro con hidrolizado enzimático graso de proteínas animales procedente de la industria farmacéutica $(A+H)$ - se muestran en la Tabla 4.1.2.

El contenido de humedad es un parámetro relevante a la hora de manejar el compost y de aplicarlo en campo (Moral y Muro, 2008), y depende fundamentalmente de su origen, del desarrollo del proceso de compostaje, y de las condiciones de almacenamiento (Masaguer y Benito, 2008). El contenido en agua de los composts A y $\mathrm{A}+\mathrm{H}$ fue inferior al máximo tolerado por la legislación vigente (40\%) -con un valor significativamente superior en el compost A-, lo que es beneficioso ya que valores de humedad superiores a dicho umbral incrementan el coste del transporte $\mathrm{y}$, adicionalmente, dificultan su aplicación (Moral y Muro, 2008). 
Tabla 4.1.2. Propiedades físicas seleccionadas de los dos composts estudiados (A y $\mathrm{A}+\mathrm{H})$

\begin{tabular}{lcccc}
\hline \multirow{1}{*}{ Parámetro } & \multicolumn{2}{c}{ Compost } & \multirow{2}{*}{$\boldsymbol{P}$} \\
\cline { 2 - 3 } & $\mathrm{A}$ & $\mathrm{A}+\mathrm{H}$ & \\
\hline Humedad $(\% \mathrm{p} / \mathrm{p})$ & 24,9 & 13,4 & $* * *$ \\
Diámetro medio geométrico $(\mathrm{mm})$ & 1,47 & 1,52 & $\mathrm{~ns}$ \\
Índice de grosor $(\% \mathrm{p} / \mathrm{p})$ & 69 & 71 & $\mathrm{~ns}$ \\
Densidad aparente $\left(\mathrm{kg} / \mathrm{m}^{3}\right)$ & 376 & 490 & $* *$ \\
Densidad de partícula $\left(\mathrm{kg} / \mathrm{m}^{3}\right)$ & 1707 & 1663 & $*$ \\
Porosidad total $(\% \mathrm{v} / \mathrm{v})$ & 78,0 & 70,5 & $* *$ \\
Volumen de agua $(\% \mathrm{v} / \mathrm{v})$ & 66,2 & 77,4 & $* * *$ \\
Volumen de aire $(\% \mathrm{v} / \mathrm{v})$ & 11,8 & 0 & $* * *$ \\
Mojabilidad (minutos) & 368 & 1,5 & $* * *$ \\
Contracción de volumen $(\% \mathrm{v} / \mathrm{v})$ & 15,8 & 7,0 & $* *$ \\
\hline \hline
\end{tabular}

A: compost de alperujo; $\mathrm{A}+\mathrm{H}$ : compost de alperujo más hidrolizado

$P$ : nivel de significación. ns, * $* * y^{*} * *$ indican diferencias no significativas o estadísticamente significativas a $P \leq 0,05, P \leq 0,01$ y $P \leq 0,001$, respectivamente

Con relación a la granulometría de un compost, el estudio de la distribución del tamaño de sus partículas es de utilidad para conocer el grado de degradabilidad de dicho material y determinar sus posibles usos en agricultura (Masaguer y Benito, 2008). Los resultados obtenidos mostraron que los dos composts poseían unas características granulométricas similares, no encontrándose diferencias en el diámetro medio geométrico ni en el índice de grosor entre dichos materiales, cuyos valores oscilaron alrededor de 1,50 mm y 70\% (p/p), respectivamente. En adición, la fracción granulométrica 1-2 mm fue la más abundante en ambos composts, tal y como puede apreciarse en el histograma de frecuencias del tamaño de partícula (Figura 4.1.1), no hallándose, por otra parte, agregados (partículas) con tamaños superiores a la fracción 4-8 mm en ninguno de los dos materiales estudiados. Este comportamiento granulométrico era previsible de antemano, ya que los composts se tamizaron por la malla de diámetro de luz de $6 \mathrm{~mm}$ con objeto de facilitar la homogeneidad de las mezclas de los mismos con los suelos estudiados en diferentes secciones de esta Memoria. Generalmente, los composts se someten a un proceso de cribado final previo a su aplicación agronómica, para evitar así la presencia de partículas de gran tamaño (Masaguer y Benito, 2008; Moral y Muro, 2008; Sullivan y Miller, 2005). Además, una distribución de tamaño de partícula heterogénea condiciona la dinámica del compost en el suelo donde se aplica, habiéndose demostrado que las diferentes fracciones granulométricas de los composts (de diversos orígenes y características) presentan una tasa de mineralización distinta, que 
es tanto mayor cuanto menor es el tamaño de partícula, debido a su distinto contenido en nutrientes así como a su diferente superficie específica (Doublet et al., 2010; Moral y Muro, 2008; Tester et al., 1980).

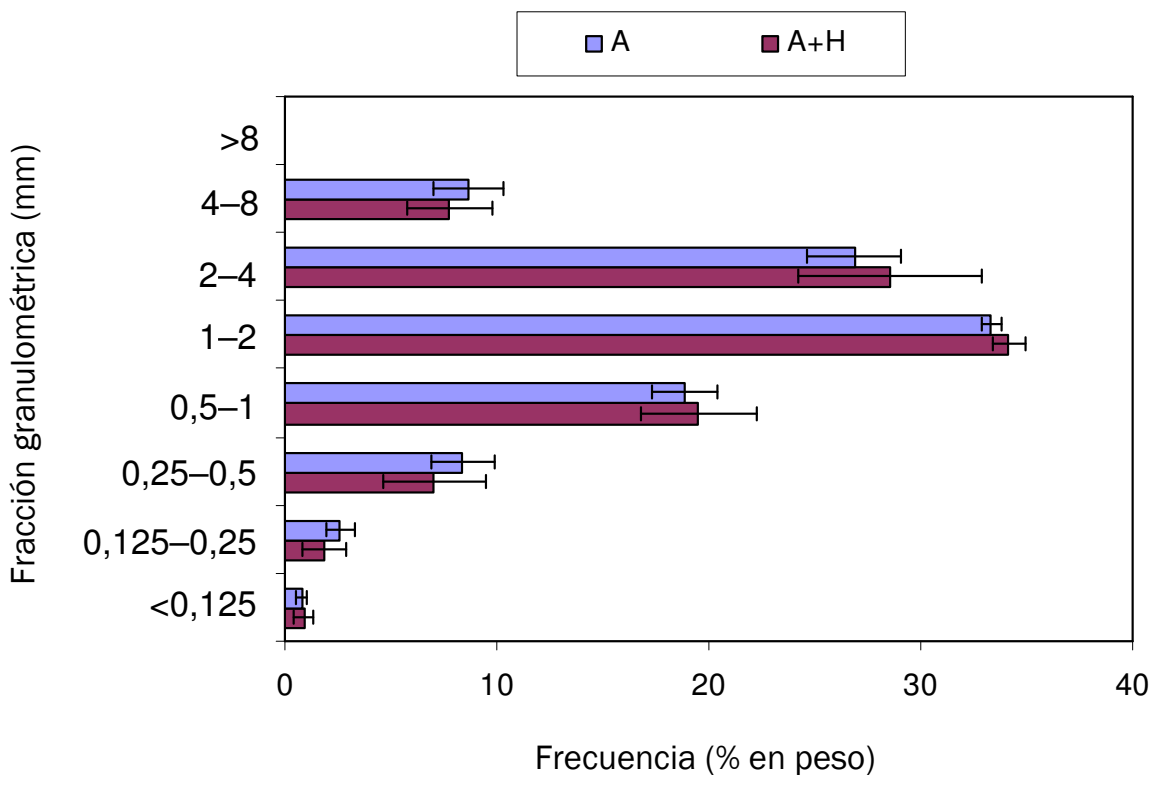

Figura 4.1.1. Histograma de frecuencias del tamaño de partícula de los dos composts estudiados $(\mathrm{A}$ y $\mathrm{A}+\mathrm{H})$

A: compost de alperujo; $A+H$ : compost de alperujo más hidrolizado

Las barras horizontales indican el error estándar

En contraste con los resultados anteriores, se encontraron diferencias marcadas y estadísticamente significativas en las características hidrofísicas entre los dos composts estudiados (Tabla 4.1.2). Así, la densidad de partícula, la porosidad total y el volumen de aire (determinado a $1 \mathrm{kPa}$ de tensión) fueron superiores en $\mathrm{A}$, mientras que la densidad aparente y la capacidad de retención total de agua (volumen de agua, también determinada a $1 \mathrm{kPa}$ ) fueron mayores en $\mathrm{A}+\mathrm{H}$. Aunque el valor de la porosidad total debería corresponderse con la suma del volumen de agua y el volumen de aire, el resultado de la porosidad obtenido en $\mathrm{A}+\mathrm{H}$-de magnitud inferior al volumen de agua- se debe probablemente a que la porosidad total se calculó indirectamente, según especifica la Norma UNE-EN 13041:2001/A1 (2007), utilizando los datos correspondientes a la densidad aparente y la densidad de partícula -esta última calculada mediante una ecuación empírica-, mientras que el volumen de agua se determinó mediante un método directo contemplado en dicha Norma, tras aplicar a la muestra (compost) saturada una presión hidrostática de 1 $\mathrm{kPa}$. 
A pesar de que los valores obtenidos en el análisis granulométrico -diámetro medio geométrico, índice de grosor y fracción más abundante- sugieren una alta capacidad de aireación en los dos composts estudiados - debido a la abundancia de partículas de tamaño superior a $1 \mathrm{~mm}$, que albergan principalmente aire en los poros que quedan entre ellas (interparticulares)-, merece destacarse el bajo volumen de aire encontrado en ambos composts, especialmente en $\mathrm{A}+\mathrm{H}$ en que se observó que la totalidad del espacio (volumen) poroso se mantuvo saturado de agua. En este sentido, varios autores han señalado los efectos deletéreos de los materiales con alto contenido en compuestos de naturaleza lipídica sobre el compostaje de los mismos, que pueden afectar a la capacidad de retención de agua y la difusión de oxígeno en éstos, y llegar incluso a manifestarse en fenómenos de aglomeración y compactación (Cayuela et al., 2010; Ruggieri et al., 2008). Asimismo, este efecto de asociación de partículas en agregados de mayor tamaño es también común en materiales que contienen partículas orgánicas muy finas, manifestándose además con mayor intensidad durante el secado de las muestras (Blok et al., 2008). De este modo, la alta concentración de lípidos encontrada en $\mathrm{A}$ y $\mathrm{A}+\mathrm{H}$ (ver la sección 4.1.2.2) facilita la aglomeración de las partículas de pequeño tamaño que, al humedecerse, retienen gran cantidad de agua en los poros existentes entre ellas y, por tanto, los resultados registrados en el análisis granulométrico no son de utilidad para interpretar las relaciones aire:agua de los dos composts objeto de estudio.

Merece destacarse la facilidad del compost $\mathrm{A}+\mathrm{H}$ para humedecerse inicialmente así como para rehumectarse una vez que se ha secado (mojabilidad), ya que el tiempo necesario para que $10 \mathrm{~mL}$ de agua destilada se infiltraran completamente en una muestra de compost seco a $40^{\circ} \mathrm{C}$ fue inferior a 2 minutos, frente a más de 6 horas en el compost A. La resistencia a la mojabilidad de este último podría atribuirse a una película de aire fuertemente adsorbida, o bien a la deposición de compuestos orgánicos hidrofóbicos, tales como humatos de hierro (Blok et al., 2008; Bunt, 1988). Por otra parte, la facilidad de A+H para humectarse está evidentemente relacionada con la adición del hidrolizado enzimático procedente de la industria farmacéutica, que podría haber actuado como surfactante (humectante) para disminuir la tensión superficial del agua, permitiendo así una mejor infiltración de ésta en el material (Bunt, 1988). 
Por último, el compost $A$ se contrajo dos veces más que $A+H$ cuando ambos se secaron $\left(a 105^{\circ} \mathrm{C}\right)$ tras ser humedecidos bajo condiciones normalizadas (saturación y drenaje posterior a $1 \mathrm{kPa}$ de tensión).

\subsubsection{Características físico-químicas y químicas}

En contraposición con las enmiendas orgánicas convencionales, como los estiércoles, que se mineralizan más o menos rápidamente, los composts efectúan una acción fertilizante a lo largo de un período relativamente largo, por lo que generalmente suelen considerarse fertilizantes "diluidos" y de liberación lenta (Moral y Muro, 2008). Entre los parámetros que pueden utilizarse para evaluar la aptitud de un compost como mejorador del suelo, deben considerarse aquéllos que determinan su calidad química, tales como su contenido en materia orgánica y la madurez/estabilidad de ésta, además de su concentración en fitonutrientes y, finalmente, su contenido en elementos potencialmente tóxicos o contaminantes (Masaguer y Benito, 2008; Soliva, 2001).

\subsubsection{Características físico-químicas}

En relación con las características físico-químicas de los composts, en la Tabla 4.1.3 se presentan los resultados obtenidos para A y A+H así como el intervalo de variación de diferentes composts a base de alperujo estudiados por diversos autores (se han incluido sólo aquellos composts con una proporción de alperujo superior al $60 \%$ en materia seca), dicho alperujo mezclado con distintos materiales -agentes estructurantes- tales como residuos del desmotado del algodón, hojas de olivo, raspón de uva, estiércol fresco de vaca, estiércol de oveja, etc.

Los dos composts objeto de estudio fueron fuertemente alcalinos, con valores de $\mathrm{pH}$ superiores a 9,1 unidades, y comparativamente mayor en $\mathrm{A}+\mathrm{H}$.

Este último mostró una conductividad eléctrica (CE) elevada (806 mS/m), marcadamente superior a la del compost A (365 mS/m).

Estos resultados podrían atribuirse al riego del alperujo con hidrolizado enzimático graso durante el compostaje de $\mathrm{A}+\mathrm{H}$, que incrementó los valores de estos dos parámetros ( $\mathrm{pH}$ y $\mathrm{CE}$ ) en tal magnitud que superaron los valores observados en otros composts preparados con alperujo. De ello derivan algunas repercusiones 
importantes para su aplicación agrícola, ya que ésta podría verse limitada por la elevada salinidad de $\mathrm{A}+\mathrm{H}$.

Con respecto a la capacidad de intercambio catiónico $(\mathrm{ClC})$, que se define como la suma de cationes que pueden ser adsorbidos por unidad de peso de compost, e indica los cationes disponibles para la planta, que no son lixiviados por efecto del riego y la lluvia, ambos materiales presentaron valores similares a los de los estudios referenciados, siendo esta CIC además superior en el compost A (105 meq/100 g ms vs. $75 \mathrm{meq} / 100 \mathrm{~g}$ ms en $\mathrm{A}+\mathrm{H}$ ).

\subsubsection{Características químicas. Composición}

Como puede apreciarse (Tabla 4.1.3), el contenido en materia orgánica total y carbono orgánico oxidable en $\mathrm{A}+\mathrm{H}$ fueron significativamente superiores a los del compost A y, por el contrario, este último presentó un contenido en carbono orgánico total y nitrógeno total comparativamente mayores, obteniéndose valores de relación $\mathrm{C} / \mathrm{N}$ para $\mathrm{A}$ y $\mathrm{A}+\mathrm{H}$ de 11 y 12, respectivamente, similares a los de los estiércoles bien elaborados (Cegarra y Paredes, 2008). Merece destacarse que el valor de este ratio fue inferior al que otros autores suelen atribuir a los composts de alperujo, lo que se debe probablemente a un contenido de lignina inferior al que éstos suelen presentar (como puede observarse más adelante, en la Tabla 4.1.7), ya que éste se trata de un compuesto resistente a la biodegradación, que puede incrementar el valor de la relación $\mathrm{C} / \mathrm{N}$. Además, tanto el compost $\mathrm{A}$ como el $\mathrm{A}+\mathrm{H}$ cumplieron los requerimientos especificados por la legislación vigente, que indica que los composts de alperujo deben poseer un contenido en materia orgánica total (MOT) superior al 45\% en masa del producto (lo que es equivalente al $75 \%$ sobre materia seca, considerando una humedad máxima del 40\%) y una relación C/N inferior a 16 (ver la Tabla 4.1.1).

El carbono orgánico hidrosoluble constituye la fracción más lábil y fácilmente asimilable - por los microorganismos- de la materia orgánica y, por ello, la más activa durante el proceso de compostaje, ya que está formada por gran variedad de compuestos orgánicos simples, como carbohidratos, aminoácidos, péptidos y fenoles, entre otros (Bustamante, 2007; Cayuela, 2004). La evolución del carbono orgánico hidrosoluble durante el compostaje depende del equilibrio entre varios procesos que incrementan o reducen la cantidad de materia orgánica disuelta. Así, ésta puede aumentar por la solubilización de compuestos de la matriz orgánica original y también por la biosíntesis de compuestos de bajo peso molecular; y, por el contrario, puede 
Tabla 4.1.3. Características físico-químicas y composición (sobre materia seca) de los dos composts estudiados $(\mathrm{A}$ y $\mathrm{A}+\mathrm{H})$, y rangos de variación encontrados según diversos autores

\begin{tabular}{|c|c|c|c|c|}
\hline \multirow{2}{*}{ Parámetro } & \multirow[b]{2}{*}{ Rango de variación ${ }^{z}$} & \multicolumn{2}{|c|}{ Compost } & \multirow[b]{2}{*}{$P$} \\
\hline & & A & $A+H$ & \\
\hline $\mathrm{pH}$ & $7,42-9,37$ & 9,17 & 9,59 & $* * *$ \\
\hline Conductividad eléctrica (CE, mS/m) & $195-481^{y}$ & 365,0 & 806,0 & $* * *$ \\
\hline $\mathrm{CIC}$ (meq/100 g ms) & $78-123$ & 105,2 & 74,75 & * \\
\hline Materia orgánica total (g/kg) & $408-912$ & 667,9 & 716,7 & * \\
\hline Carbono orgánico total (g/kg) & $254-435$ & 400,3 & 381,1 & $* *$ \\
\hline$N$ total $(g / k g)$ & $17,4-26,3$ & 37,65 & 32,09 & $* * *$ \\
\hline Relación C/N & $14,6-22,7$ & 10,6 & 11,9 & $* * *$ \\
\hline Carbono orgánico oxidable (g/kg) & $-x$ & 243,8 & 290,7 & $* * *$ \\
\hline Carbono orgánico extraíblew (g/kg) & $87-123$ & 60,39 & 110,4 & ** \\
\hline Carbono de ácidos húmicos (g/kg) & $64-98$ & 43,79 & 90,40 & ** \\
\hline Carbono de ácidos fúlvicos (g/kg) & - & 16,60 & 20,02 & ** \\
\hline Carbono orgánico hidrosoluble (g/kg) & 25-35 & 35,76 & 61,35 & $* * *$ \\
\hline Nitrógeno hidrosoluble (g/kg) & - & 3,74 & 8,18 & $* * *$ \\
\hline $\mathrm{N}-\mathrm{NO}_{3}^{-}-(\mathrm{mg} / \mathrm{kg})$ & $31-550$ & nd & nd & \\
\hline $\mathrm{N}-\mathrm{NH}_{4}{ }^{+}(\mathrm{mg} / \mathrm{kg})$ & $86-185$ & 14,10 & 9,12 & * \\
\hline \multicolumn{5}{|l|}{ Elementos ${ }^{v}$} \\
\hline$P(g / k g)$ & $1,4-2,4$ & 8,00 & 10,13 & * \\
\hline $\mathrm{K}(\mathrm{g} / \mathrm{kg})$ & $13,7-42,7$ & 36,26 & 47,03 & $* * *$ \\
\hline $\mathrm{S}(\mathrm{g} / \mathrm{kg})$ & - & 10,86 & 15,91 & $* * *$ \\
\hline $\mathrm{Ca}(\mathrm{g} / \mathrm{kg})$ & $9,4-29,7$ & 76,13 & 43,75 & $* * *$ \\
\hline $\mathrm{Mg}(\mathrm{g} / \mathrm{kg})$ & $1,9-5,7$ & 22,19 & 15,25 & $* * *$ \\
\hline $\mathrm{Na}(\mathrm{g} / \mathrm{kg})$ & $1,0-4,1$ & 3,51 & 10,60 & $* * *$ \\
\hline $\mathrm{Fe}(\mathrm{mg} / \mathrm{kg})$ & $424-7700$ & 8171 & 6191 & $* * *$ \\
\hline $\mathrm{Zn}(\mathrm{mg} / \mathrm{kg})$ & $38-138$ & 95,34 & 75,74 & $* * *$ \\
\hline $\mathrm{Cu}(\mathrm{mg} / \mathrm{kg})$ & $21-41$ & 46,02 & 31,74 & $* * *$ \\
\hline $\mathrm{Mn}(\mathrm{mg} / \mathrm{kg})$ & $34-98$ & 264,4 & 172,8 & $* * *$ \\
\hline Mo (mg/kg) & - & 11,30 & 7,10 & $* * *$ \\
\hline $\mathrm{B}(\mathrm{mg} / \mathrm{kg})$ & $67-76$ & 128,8 & 93,90 & $* * *$ \\
\hline Carbonatos $\left(\mathrm{CaCO}_{3}, \mathrm{~g} / \mathrm{kg}\right)$ & - & 108,2 & 65,79 & $* * *$ \\
\hline
\end{tabular}

A: compost de alperujo; $\mathrm{A}+\mathrm{H}$ : compost de alperujo más hidrolizado

nd: no detectado

$P$ : nivel de significación. *, ** y *** indican diferencias estadísticamente significativas a $P \leq 0,05, P \leq 0,01$ y $P \leq 0,001$, respectivamente

z Intervalos de variación según Alburquerque et al., 2006a, 2006b, 2006c, 2007, 2009; Altieri y Esposito, 2010; Cayuela, 2004; Cayuela et al., 2008a; Cegarra et al., 2005b, 2006; Walker y Bernal, 2008

y Utilizando un extracto $1 / 10(p / v)$

x no establecido/especificado

wen medio alcalino

v extraídos con agua regia 
disminuir debido a procesos de mineralización de compuestos orgánicos solubles así como mediante procesos de polimerización y condensación, que favorecen la formación de sustancias orgánicas complejas, de baja solubilidad (Said-Pullicino et al., 2007). Respecto al carbono orgánico y el nitrógeno hidrosolubles de los dos composts estudiados, la adición del hidrolizado graso a la mezcla en compostaje provocó un incremento en la concentración de éstos en el compost final obtenido, duplicándose sus niveles en $\mathrm{A}+\mathrm{H}$ respecto a $\mathrm{A}$ y superando considerablemente, además, los valores que usualmente se encuentran en composts de alperujo; estos resultados sugieren la formación de compuestos orgánicos solubles procedentes de moléculas más complejas pertenecientes a la fracción orgánica del material graso añadido con el hidrolizado.

El compostaje se caracteriza por la descomposición del material biodegradable de los residuos y la transformación parcial del material orgánico remanente en sustancias húmicas (Adani et al., 1999; Mondini et al., 2003). En el proceso, a medida que avanza la condensación y polimerización de las moléculas sencillas resultantes de la degradación de la materia orgánica (humificación), se produce un aumento de los ácidos húmicos, mientras que el contenido de ácidos fúlvicos tiende a decrecer (Bernal et al., 2009). En los composts $\mathrm{A}$ y $\mathrm{A}+\mathrm{H}$ se obtuvieron valores de carbono orgánico extraíble (en medio alcalino), carbono de ácidos húmicos y carbono de ácidos fúlvicos próximos a los recogidos en la bibliografía, y significativamente superiores en $\mathrm{A}+\mathrm{H}$, en el que destacó su alto contenido en ácidos húmicos $(90,4 \mathrm{~g} / \mathrm{kg})$. El grado de humificación de la materia orgánica suele relacionarse con su capacidad de intercambio catiónico (CIC), aumentando ésta a medida que la humificación progresa, ya que el incremento en el grado de polimerización conlleva un aumento significativo de la superficie específica de las macromoléculas húmicas y, fundamentalmente, de los grupos carboxílicos (Lax et al., 1986). Como se ha indicado anteriormente, el valor de CIC fue superior en el compost A, aunque el menor contenido en carbono orgánico extraíble y de ácidos húmicos parecía sugerir un grado de humificación inferior. Esto podría explicarse por la inespecificidad de la metodología para determinar sustancias húmicas mediante extracción alcalina, ya que en dicha técnica puede interferir la coextracción de compuestos no humificados o incompletamente humificados, como compuestos derivados de la lignina, quinonas, polifenoles, lípidos, ácidos dibenzocarboxílicos, compuestos alifáticos, alcanos, azúcares, péptidos, etc., por lo 
que podría haberse sobrestimado el contenido en compuestos húmicos de $\mathrm{A}+\mathrm{H}$ (Adani et al., 1995, 1999; Alburquerque et al., 2009; Bernal et al., 2009; Sánchez-Monedero et al., 1999). La fracción orgánica soluble en agua tiene especial relevancia en la evaluación de la madurez y la estabilidad del compost (Bernal et al., 2009), como se estudiará más adelante, en el apartado 4.1.3.

Por otra parte, la determinación de nitrógeno mineral mostró un nivel de nitrógeno en forma amoniacal comparativa y significativamente superior en $A$, mientras que no se detectó la presencia de nitrógeno en forma nítrica en ninguno de los dos composts estudiados.

Con relación al contenido en macro- y micro-elementos solubles en agua regia (Norma UNE-EN 13650) de los composts, los niveles de fósforo, potasio, azufre y sodio fueron muy elevados y comparativamente superiores en $\mathrm{A}+\mathrm{H}$, particularmente sodio, destacando el alto contenido de potasio en los dos composts estudiados (36,3 g/kg y $47,0 \mathrm{~g} / \mathrm{kg}$ de $\mathrm{K}$ en $\mathrm{A}$ y $\mathrm{A}+\mathrm{H}$, respectivamente) $\mathrm{y}$, en general, en los composts de alperujo caracterizados por otros autores. El aumento observado en la concentración de los elementos indicados en $\mathrm{A}+\mathrm{H}$ radica en la adición del residuo enzimático graso, cuya riqueza en estos elementos fue comparativamente superior a la de los dos materiales utilizados para el co-compostaje: alperujo y estiércol de caballo fresco (ver las composiciones de estos materiales en la sección 3.1.1). En contraste con lo anterior, el compost A mostró contenidos significativamente más elevados en calcio, magnesio, hierro, cinc, cobre, manganeso, molibdeno, y boro. Para la mayoría de los elementos determinados en $\mathrm{A}$ y $\mathrm{A}+\mathrm{H}$ se encontraron concentraciones superiores a las observadas por diferentes autores en otros composts de alperujo, lo que podría explicarse por la alta variabilidad registrada en la composición del alperujo fresco, especialmente en calcio, magnesio, hierro y manganeso (Alburquerque et al., 2004). Debe tenerse en cuenta, además, que el alperujo debe ser co-compostado con otros materiales que actúen de agentes estructurantes y aporten también nitrógeno para equilibrar su relación $\mathrm{C} / \mathrm{N}$, lo que sugiere que los composts resultantes pueden llegar a presentar variaciones de gran magnitud en su concentración en macro- y microelementos. Además, si se compara la composición nutricional de los composts $A$ y A+H con el rango de concentración de nutrientes que generalmente se encuentra en materiales compostados de diferentes orígenes y características (Wolf y Snyder, 2003), se observan unos niveles notablemente superiores de nitrógeno, potasio, calcio y magnesio en $\mathrm{A}$ y $\mathrm{A}+\mathrm{H}$. 
Respecto a la riqueza en nutrientes recogida en el Real Decreto 824/2005, sobre productos fertilizantes, merece destacarse que los composts $A$ y $A+H$ cumplieron los requerimientos especificados en dicho Real Decreto (expresados en porcentaje sobre materia fresca) para los abonos orgánicos NPK de origen animal y vegetal $\left(\mathrm{N}+\mathrm{P}_{2} \mathrm{O}_{5}+\mathrm{K}_{2} \mathrm{O} \geq 4 \%\right.$, cada nutriente con una concentración superior al $1 \%$, y $\mathrm{C} / \mathrm{N}<15)$. Por ello, los dos composts estudiados no deben equipararse con una enmienda orgánica convencional, ya que las enmiendas orgánicas de los suelos cultivados se conciben generalmente como grandes aportes de material orgánico -con el fin de mantener o incrementar los niveles de materia orgánica del suelo- con unos contenidos más o menos altos de humedad y bajas concentraciones de N-P-K por tonelada de materia fresca aportada, mientras que los composts suelen contener niveles de humedad más bajos y, además de mantener o corregir la materia orgánica del suelo, aportan nutrientes de forma gradual debido a su alta estabilidad, derivada del tratamiento biológico controlado inherente al propio proceso de compostaje (Moral y Muro, 2008).

En cuanto al nivel de carbonatos de las muestras, ambas presentaron valores inferiores a los encontrados en composts elaborados con residuos de diferente procedencia, tales como agrícolas, ganaderos o forestales (Carrión et al., 2008; García de la Fuente et al., 2007). La presencia de carbonatos en $\mathrm{A}$ y $\mathrm{A}+\mathrm{H}$ fue responsable, en gran medida, del pH fuertemente alcalino de estos dos composts, de acuerdo con lo señalado por los autores anteriormente citados.

Por otro lado, un aspecto de los composts de gran importancia es la determinación del contenido en metales pesados de los mismos, cuya concentración puede limitar su uso agronómico (Pinamonti et al., 1997). Los metales pesados están presentes en el medio natural, alimentos y suelos cultivados, y, además, se utilizan ampliamente en procesos industriales de transformación, pudiendo transferirse consecuentemente a los residuos orgánicos compostados (Lineres, 1992). En la aplicación de compost al suelo, los principales elementos proclives a producir efectos contaminantes son: $\mathrm{Zn}, \mathrm{Cu}, \mathrm{Ni}, \mathrm{Cd}, \mathrm{Pb}, \mathrm{Cr}$ y Hg, suscitando, además, su acumulación a largo plazo gran preocupación, ya que ésta puede perjudicar gravemente a la cadena alimentaria, al crecimiento y desarrollo de las plantas, y a los procesos microbianos del suelo, debiendo tenerse también en consideración el riesgo potencial de contaminación de las aguas subterráneas (Businelli et al., 2009; Paradelo et al., 2007; Smith, 2009). En este contexto, el Real Decreto 824/2005, sobre productos 
fertilizantes, regula el contenido máximo de metales pesados en los productos fertilizantes elaborados con residuos y otros materiales orgánicos, distinguiéndose tres niveles de restricción (clases A, B, y C) en función de la concentración de metales pesados de los mismos. Al examinar los datos de concentración de metales pesados obtenidos en los composts $\mathrm{A}$ y $\mathrm{A}+\mathrm{H}$ (Tabla 4.1.4), puede apreciarse que ambos materiales presentaron valores inferiores a los límites máximos establecidos en la clase A para todos los elementos metálicos estudiados, pudiéndose clasificar estos dos composts, por tanto, como composts clase A, registrándose asimismo mayores niveles de metales pesados en $\mathrm{A}$ que en $\mathrm{A}+\mathrm{H}$.

Tabla 4.1.4. Concentración de metales pesados $(\mathrm{mg} / \mathrm{kg} \mathrm{ms})$ en los dos composts estudiados (A y $A+H)$, y límites máximos de concentración permitidos según el RD $824 / 2005$ sobre productos fertilizantes

\begin{tabular}{|c|c|c|c|c|c|c|}
\hline \multirow{2}{*}{ Metal } & \multicolumn{3}{|c|}{ Límite de concentración } & \multicolumn{2}{|c|}{ Compost } & \multirow[b]{2}{*}{$P$} \\
\hline & Clase $\mathrm{A}$ & Clase B & Clase C & A & $\mathrm{A}+\mathrm{H}$ & \\
\hline $\mathrm{Cd}$ & 0,7 & 2 & 3 & nd & nd & - \\
\hline $\mathrm{Cu}$ & 70 & 300 & 400 & 46,0 & 31,7 & $* * *$ \\
\hline $\mathrm{Ni}$ & 25 & 90 & 100 & 20,0 & 16,0 & ns \\
\hline $\mathrm{Pb}$ & 45 & 150 & 200 & 13,7 & 9,1 & $* * *$ \\
\hline $\mathrm{Zn}$ & 200 & 500 & 1000 & 95,3 & 75,7 & $* * *$ \\
\hline $\mathrm{Hg}$ & 0,4 & 1,5 & 2,5 & nd & nd & - \\
\hline $\mathrm{Cr}$ (total) & 70 & 250 & 300 & 26,3 & 13,7 & ** \\
\hline $\mathrm{Cr}(\mathrm{VI})$ & 0 & 0 & 0 & nd & nd & - \\
\hline
\end{tabular}

A: compost de alperujo; $\mathrm{A}+\mathrm{H}$ : compost de alperujo más hidrolizado

nd: no detectado

$P$ : nivel de significación. ns, ** y *** indican diferencias no significativas o estadísticamente significativas a $P \leq 0,01$ y $P \leq 0,001$, respectivamente

Para el análisis del contenido de los nutrientes disponibles (o asimilables) para las plantas en el medio de cultivo, se han propuesto numerosos extractantes con el fin de evaluar la correlación existente entre la concentración de los elementos extraídos de dicho medio y los niveles determinados en el material vegetal que se ha desarrollado sobre éste (Bunt, 1988). Los nutrientes se hallan fundamentalmente disueltos en la solución del medio/sustrato (compost puro o mezclado con suelo, con otros materiales orgánicos, con materiales minerales naturales o sintéticos, etc.), pero una fracción considerable puede hallarse adsorbida parcialmente por la materia orgánica y otros componentes de distinta naturaleza y, por tanto, no está inmediatamente disponible para las plantas. Sin embargo, éstos pueden ser desorbidos y pasar a formas asimilables posteriormente, lo que ha motivado la realización de estudios sobre extracción con diferentes disoluciones (De Kreij et al., 
1993a, 1993b), destacándose tres tipos: extractantes ácidos, tamponados y de extracción enérgica, como acetato amónico o calcio-lactato-acetato (CAL); extractantes débiles, agua o cloruro cálcico; y, por último, soluciones no tamponadas que contienen agentes quelantes, como la mezcla de cloruro cálcico y ácido dietilentriaminpentaacético (DTPA), entre otras (Alt, 2001). Para la determinación rutinaria de elementos y nutrientes asimilables, la normativa europea especifica la extracción en agua y en cloruro cálcico/DTPA (método CAT) (Normas UNE-EN 13652 y UNE-EN 13651, 2002, respectivamente), incluyéndose también en dichos documentos los resultados obtenidos en sendos ensayos interlaboratorios con diferentes materiales orgánicos (corteza compostada, biorresiduo, lodo compostado, fibra de madera compostada, turba arcillosa fertilizada, y turba gruesa fertilizada) utilizando ambos extractantes. La comparación de los niveles de los elementos minerales obtenidos en ambos extractos en los composts $\mathrm{A}$ y $\mathrm{A}+\mathrm{H}$ se presenta en la Tabla 4.1.5. Merece destacarse que, para todos los elementos solubles determinados, $\mathrm{A}+\mathrm{H}$ registró valores superiores al compost $\mathrm{A}$, exceptuando el nivel de $\mathrm{NO}_{3}{ }^{-}$.

Al evaluar comparativamente la fracción soluble en ambos extractantes (CAT y agua), expresando los niveles de los elementos minerales como porcentaje (\%) respecto al contenido de los elementos solubles en agua regia (Tabla 4.1.6), se observó una proporción más alta de elementos solubles para todos los elementos estudiados, y también para los dos extractantes utilizados, en $\mathrm{A}+\mathrm{H}$ que en $\mathrm{A}$. Debe destacarse aquí, de acuerdo con lo especificado en la Norma UNE-EN 13650 (2001), que el agua regia no disuelve totalmente la mayoría de los materiales orgánicos y que la eficiencia de la extracción difiere de un elemento a otro; tal eficiencia puede también diferir para un mismo elemento entre diferentes materiales. Por lo tanto, los elementos extraíbles con agua regia no pueden describirse como "totales" (ni tampoco pueden considerarse como "biodisponibles", ya que el procedimiento de extracción es demasiado vigoroso).

Por otra parte, la utilización de CAT suele ser recomendable para la extracción de fósforo $(P)$, ya que existe una alta correlación entre la concentración de $P$ soluble determinada con CAT y los niveles absorbidos por la planta; además, la extracción de P con esta disolución corrige las subestimaciones en la determinación del contenido en este elemento cuando ésta se realiza con con agua o con $\mathrm{CaCl}_{2}$ (Alt, 2001). Esto puede corroborarse con los resultados del ensayo interlaboratorios recogidos en las Normas UNE-EN 13651 y 13652, que indican que la extracción con CAT incrementó 


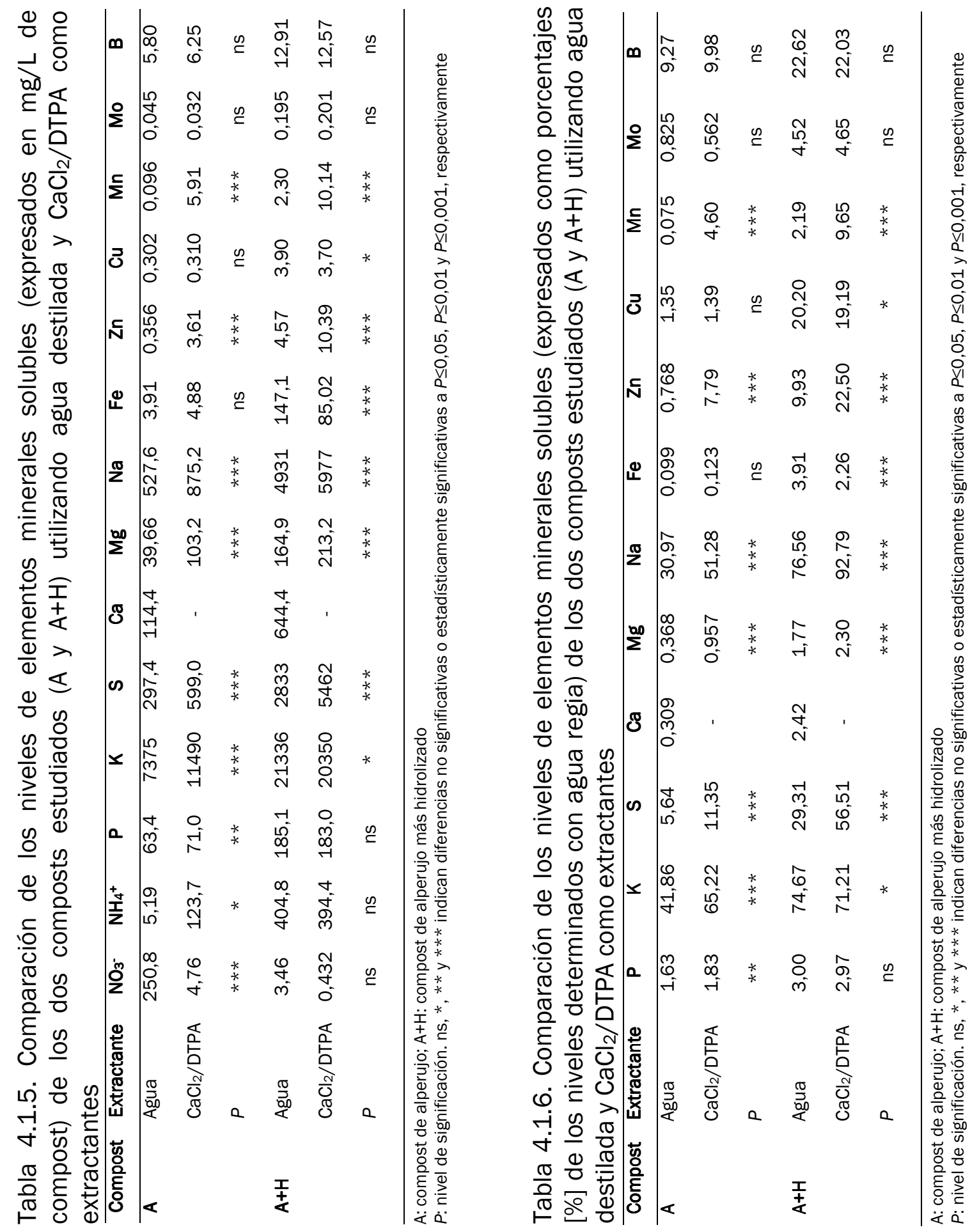


los niveles de $\mathrm{P}$ respecto al soluble en agua. En los materiales estudiados, no existieron diferencias estadísticamente significativas entre ambos extractantes para $\mathrm{A}+\mathrm{H}$, mientras que en A se extrajo una cantidad con CAT significativamente mayor que con agua.

En cuanto a los niveles de potasio, en A se produjo una extracción con $\mathrm{CaCl}_{2}$ /DTPA mayor que con agua, de acuerdo con lo señalado por Alt (2001) y los resultados recogidos en las Normas UNE-EN citadas. Por el contrario, en $\mathrm{A}+\mathrm{H}$ la mayor extracción tuvo lugar con agua, destacando los elevados valores de concentración obtenidos con ambos extractantes y el alto porcentaje de fracción soluble de este elemento (hasta el $75 \%$ en agua).

Respecto al nivel de azufre (S), el ratio S extraído en agua respecto a S extraído en CAT fue cercano a 0,5 en $\mathrm{A}$ y $\mathrm{A}+\mathrm{H}$, mientras que en las Normas anteriormente mencionadas se obtuvieron valores muy similares para los dos extractantes en los materiales estudiados. Asimismo, el S soluble en agua y en CAT de $\mathrm{A}+\mathrm{H}$ se tradujo en una proporción -respecto al contenido determinado con agua regia- unas 5 veces superior a la del compost $A$.

El contenido en magnesio y sodio fue significativamente mayor en los dos composts al extraer con CAT, en coincidencia con los resultados de las Normas UNEEN citadas, llegándose además a extraer más del 50\% y del $90 \%$ del sodio soluble en agua regia en $\mathrm{A}$ y $\mathrm{A}+\mathrm{H}$, respectivamente; a pesar de que $\mathrm{A}$ mostró mayor nivel de magnesio determinado con agua regia (Tabla 4.1.3), el porcentaje de fracción soluble en agua y en CAT fue comparativamente superior en $\mathrm{A}+\mathrm{H}$ (Tablas 4.1 .5 y 4.1.6).

Con relación a los microelementos estudiados (Fe, $\mathrm{Zn}, \mathrm{Cu}, \mathrm{Mn}, \mathrm{Mo} \mathrm{y} \mathrm{B})$, la concentración soluble en agua y en CAT de la mayoría de ellos fue mayor en $\mathrm{A}+\mathrm{H}$ (Tablas 4.1 .5 y 4.1.6), a pesar de que el contenido en agua regia de dichos nutrientes fue superior en el compost A en todos los casos (Tabla 4.1.3). Así, los porcentajes de fracción asimilable respecto al contenido en agua regia mostraron que la proporción de Fe soluble fue 39 y 19 veces mayor en $\mathrm{A}+\mathrm{H}$ que en $\mathrm{A}$ al utilizar agua y CAT, respectivamente, obteniéndose valores de $147 \mathrm{mg} / \mathrm{L}$ compost en $\mathrm{A}+\mathrm{H}$ frente a menos de $4 \mathrm{mg} / \mathrm{L}$ compost en A para la extracción con agua. Además, los porcentajes de Fe extraído con agua y CAT - respecto a la cantidad extraída con agua regia- difirieron significativamente en $\mathrm{A}+\mathrm{H}$, mientras que se obtuvieron valores similares en $\mathrm{A}$. Los niveles de $\mathrm{Zn}$ y Mn mostraron diferencias estadísticamente significativas entre los dos extractantes utilizados -tanto al expresarse en $\mathrm{mg} / \mathrm{L}$ compost como en porcentaje 
respecto al contenido encontrado tras la extracción con agua regia-, registrándose valores superiores en el extracto con CAT, lo que coincide con los resultados presentados en las Normas UNE-EN citadas. De acuerdo con Alt (2001) y Alt et al. (1994), el Zn extraído con CAT y el contenido del mismo en los tejidos vegetales están estrechamente correlacionados, considerándose además que la extracción con agua es demasiado débil y, por tanto, inadecuada para poder determinar concentraciones fitotóxicas de dicho elemento. Por otra parte, varios autores han señalado la sobrestimación que se produce al determinar la concentración de Mn en los extractos preparados con CAT, sugiriendo el extracto con agua para determinar el contenido de este elemento (Alt, 2001; De Kreij et al., 1993a). Por último, Cu, Mo y B mostraron generalmente concentraciones similares con agua y CAT, en coincidencia con lo observado por De Kreij et al. (1993b) y las Normas UNE-EN más arriba mencionadas. Esto parece indicar que ambos extractantes son adecuados para la determinación de la fracción asimilable de estos tres micronutrientes.

De acuerdo con todo lo anterior, se puede concluir que la utilización de CAT es adecuada para determinar simultáneamente los niveles de los macro- y micronutrientes asimilables por las plantas, exceptuando el manganeso, y que el estudio de los nutrientes extraídos con CAT sirve además para complementar la información aportada por la determinación de los elementos realizada tras la digestión con agua regia.

Por otro lado, y con el fin de estudiar la contribución de los iones más abundantes a la salinidad de los composts $A$ y $A+H$, los resultados obtenidos utilizando agua como extractante se sometieron a un análisis de regresión stepwise ("paso a paso"), estudiándose la variación de la conductividad eléctrica (CE) en función de la concentración de $\mathrm{K}^{+}, \mathrm{Ca}^{2+}, \mathrm{Mg}^{2+}, \mathrm{Cl}^{-}, \mathrm{SO}_{4}{ }^{2-}$ y $\mathrm{Na}^{+}$(expresados en meq por litro de extracto) así como de las interacciones binarias entre éstos. La ecuación de regresión obtenida siguiendo este procedimiento fue:

$$
\mathrm{CE}(\mathrm{mS} / \mathrm{m})=61,71\left[\mathrm{~K}^{+}\right]+140,1 ; \mathrm{R}^{2}=0,996 \quad(\mathrm{P} \leq 0,001)
$$

A partir de esta ecuación puede deducirse que la conductividad eléctrica de los dos composts estudiados dependió fundamentalmente de los iones potasio, confirmándose de esta forma la relevancia de la alta concentración de este elemento en los composts elaborados con alperujo y su contribución a la salinidad de los mismos. 
Con objeto de estudiar las principales fracciones que componen la materia orgánica de los composts $\mathrm{A}$ y $\mathrm{A}+\mathrm{H}$, se procedió a determinar el contenido en lignina, hemicelulosa, celulosa, lípidos (grasas), carbohidratos solubles y polifenoles (Tabla 4.1.7). Puede apreciarse que la materia orgánica estuvo formada principalmente por lignina, destacando una mayor proporción de ésta en $A+H$. En el proceso de compostaje, la lignina desempeña un papel fundamental en la humificación de los residuos lignocelulósicos, ya que se considera que la degradación parcial de ésta - por reacciones de oxidación y depolimerización- origina la estructura básica de las sustancias húmicas, produciendo sustancias aromáticas y fenólicas que actúan como precursoras en la formación de dichas estructuras húmicas (Alburquerque et al., 2009; Said-Pullicino et al., 2007; Sánchez-Monedero et al., 1999). El contenido de hemicelulosa y celulosa en $\mathrm{A}$ y $\mathrm{A}+\mathrm{H}$ fue similar al de los composts de alperujo referenciados en la bibliografía, no encontrándose diferencias en el contenido en hemicelulosa entre los dos composts estudiados, mientras que el contenido en celulosa fue comparativamente superior en A. Por otra parte, y aunque un alto contenido en lípidos puede limitar la utilización del alperujo en los suelos agrícolas, varios autores han demostrado la degradación de las grasas de dicho residuo durante el compostaje hasta límites no fitotóxicos (Alburquerque et al., 2006a; Filippi et al., 2002; Madejón et al., 1998), lo que coincide con el bajo contenido en grasas observado en los composts $\mathrm{A}$ y $\mathrm{A}+\mathrm{H}$. Otro tipo de compuestos a los que se les atribuyen propiedades antimicrobianas y fitotóxicas son los polifenoles (Alburquerque et al., 2006), cuya concentración fue baja en $\mathrm{A}(3,72 \mathrm{~g} / \mathrm{kg})$, pero en $\mathrm{A}+\mathrm{H}(18,9 \mathrm{~g} / \mathrm{kg})$ superó los valores habituales en composts de alperujo así como el límite de $8 \mathrm{~g} / \mathrm{kg}$ $(0,8 \%)$ que establece la legislación vigente (Tabla 4.1.1.). Por último, el contenido en carbohidratos solubles fue comparativa y significativamente superior en el compost $\mathrm{A}+\mathrm{H}$, que presentó además valores dentro del rango de variación de los composts analizados en otros trabajos de investigación. 
Tabla 4.1.7. Componentes seleccionados de la materia orgánica de los dos composts estudiados $(\mathrm{A}$ y $\mathrm{A}+\mathrm{H})$, y rangos de variación encontrados según diversos autores

\begin{tabular}{|c|c|c|c|c|}
\hline \multirow[b]{2}{*}{ Componente/Compuesto } & \multirow{2}{*}{$\begin{array}{l}\text { Rango de } \\
\text { variaciónz }\end{array}$} & \multicolumn{2}{|c|}{ Compost } & \multirow[b]{2}{*}{$P$} \\
\hline & & A & $\mathrm{A}+\mathrm{H}$ & \\
\hline Lignina (g/kg) & $266-430$ & 176,6 & 288,8 & $\star \star *$ \\
\hline Hemicelulosa (g/kg) & 118-314 & 133,6 & 134,3 & ns \\
\hline Celulosa (g/kg) & $90-208$ & 173,5 & 105,1 & $* * *$ \\
\hline Grasas (g/kg) & $3,5-13,9$ & 0,950 & 1,67 & ns \\
\hline Polifenoles (ácido p-cumárico, g/kg) & $0,4-4,1$ & 3,72 & 18,9 & ** \\
\hline Carbohidratos solubles (glucosa, g/kg) & $8,1-13,1$ & 4,89 & 9,30 & ** \\
\hline
\end{tabular}

A: compost de alperujo; $\mathrm{A}+\mathrm{H}$ : compost de alperujo más hidrolizado

$P$ : nivel de significación. ns, ** y*** indican diferencias no significativas o estadísticamente significativas a $P \leq 0,01$ y $P \leq 0,001$, respectivamente

z Intervalos de variación según Alburquerque et al., 2006a, 2006b, 2006c, 2007, 2009; Altieri y Esposito, 2010; Cayuela, 2004; Cayuela et al., 2008a; Cegarra et al., 2005b, 2006; Walker y Bernal, 2008

\subsubsection{Propiedades biológicas}

El estudio de las características biológicas de los materiales (residuos) orgánicos se fundamenta en que la actividad metabólica de los microorganismos desempeña un papel clave durante el proceso de descomposición y estabilización de la materia orgánica. De este modo, las poblaciones microbianas que intervienen varían a lo largo del compostaje, integrándose en un proceso dinámico que se caracteriza por la modificación progresiva de las características del material orgánico y las condiciones durante dicho proceso (Iglesias Jiménez et al., 2008; Tiquia, 2005). Por tanto, las determinaciones relacionadas con la biomasa y actividad microbiana aportan información de gran utilidad para evaluar la calidad del producto final obtenido mediante el proceso de compostaje (Mondini et al., 2003). Por otra parte, uno de los criterios más limitantes que condiciona la aplicación potencial de los composts en Agricultura es la presencia de sustancias fitotóxicas, que afectan negativamente el crecimiento de las plantas (Iglesias Jiménez et al., 2008), utilizándose para su determinación diferentes tipos de bioensayos con material vegetal.

\subsubsection{Biomasa y actividad microbiana}

Para cuantificar la presencia de microorganismos en los dos composts estudiados, se utilizó, como técnica microbiológica, el recuento de cuatro poblaciones microbianas cultivadas en placa, empleando medios de cultivo selectivos: bacterias autótrofas, bacterias heterótrofas, actinomicetos, y mohos y levaduras. La población 
de bacterias autótrofas y actinomicetos en el compost $\mathrm{A}+\mathrm{H}$ fue mayor que en $\mathrm{A}$, mientras que los grupos microbianos de heterótrofas, y de mohos y levaduras fue superior en éste último (Tabla 4.1.8).

Tabla 4.1.8. Poblaciones microbianas y actividad microbiana en los dos composts estudiados $(\mathrm{A}$ y $\mathrm{A}+\mathrm{H})$

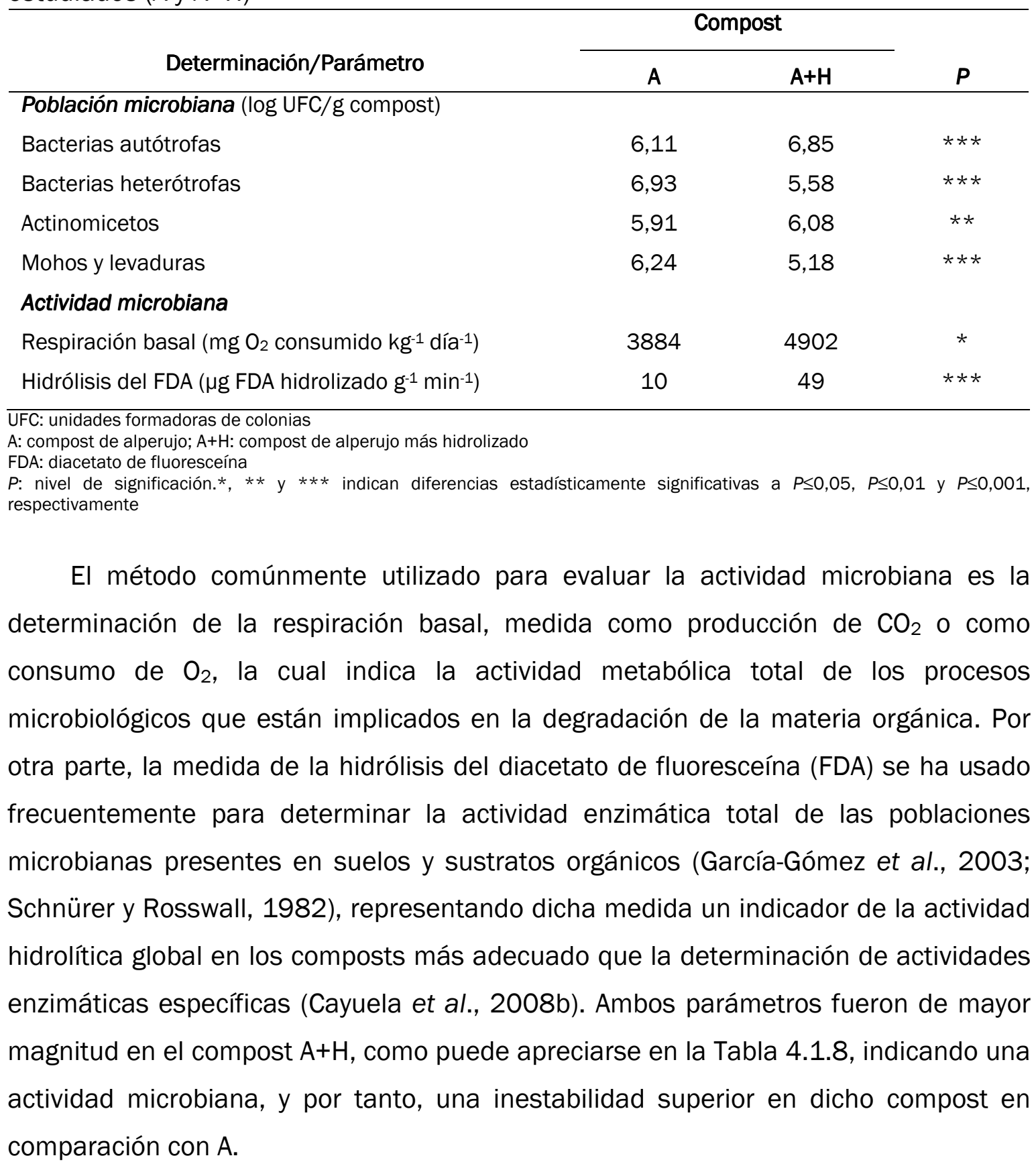

\subsubsection{Bioensayos de germinación y crecimiento}

La fitotoxicidad se define como "el daño o lesión provocado a las plantas por sustancias presentes o producidas en el medio de cultivo, cuando dichos compuestos 
son extraídos de éste y acumulados en los tejidos vegetales" (Araújo y Monteiro, 2005).

En la evaluación de los composts, la utilidad de los bioensayos se basa en la estrecha relación existente entre los resultados obtenidos en éstos y la potencialidad de dichos materiales compostados para ser utilizados en Agricultura (Abad et al., 1992; Zucconi et al., 1981a, 1981b).

Los efectos fitotóxicos de un compost pueden atribuirse a propiedades físicoquímicas y químicas desfavorables para el crecimiento vegetal, destacando salinidad elevada (Aslam et al., 2008), presencia de ácidos alifáticos de cadena corta (Chanyasak et al., 1983; Manios et al., 1989), presencia de fenoles (Alburquerque et al., 2006c), y emisión de amonio (Tiquia y Tam, 1998) así como síntesis de óxido de etileno durante la evolución del compost en el suelo (Wong, 1985), entre otras.

Para la evaluación de dichos efectos deletéreos, pueden realizarse tres tipos de bioensayos: de germinación de semillas en los extractos acuosos obtenidos del compost, de germinación directamente sobre los materiales (sólidos) a testar, y de crecimiento de plantas adultas sobre los materiales colocados en contenedor (maceta). Estos bioensayos se caracterizan tanto por su sencillez y rapidez como por su reproducibilidad y elevada sensibilidad al factor fitotóxico potencial. No obstante, la aplicación e interpretación de estos bioensayos resulta complicada, debido a la ausencia de técnicas estandarizadas, pudiendo encontrarse una amplia diversidad de especies vegetales a ensayar y de procedimientos a aplicar (Aslam et al., 2008). Esto limita el alcance de los resultados obtenidos, ya que algunas especies son más sensibles que otras a las diferentes sustancias tóxicas presentes en el compost y los resultados obtenidos por distintos autores no son, además, coincidentes ni comparables entre sí (Iglesias Jiménez et al., 2008; Paradelo et al., 2010).

En el presente estudio se realizaron bioensayos de germinación en placa petri con los extractos acuosos obtenidos de los composts $A$ y $A+H$, utilizando semillas de berro (Lepidium sativum) (Zucconi et al., 1981a, 1981b), sensible a metales pesados y sustancias orgánicas fitotóxicas (Oleszczuk, 2008), y de lechuga (Lactuca sativa), con elevada sensibilidad a las sales (Choi et al., 1989; Ortega et al., 1996). En adición, se desarrolló un ensayo de crecimiento mediante siembra directa de semillas de berro sobre los dos materiales indicados, siguiendo la norma AFNOR XP U44-165 (2004). 
Respecto al índice de germinación de las semillas en los bioensayos en placa (IG, expresado como porcentaje del control, agua destilada), A mostró un valor significativamente superior a $\mathrm{A}+\mathrm{H}$ en las dos especies estudiadas, $\mathrm{y}$, además, la dilución del extracto incrementó de forma significativa el valor de IG en ambas especies, especialmente en lechuga (Tabla 4.1.9).

Tabla 4.1.9. Efectos principales de los tratamientos estudiados -compost y dilución de los extractos obtenidos- sobre el índice de germinación (IG) de berro y de lechuga en los bioensayos realizados

\begin{tabular}{lcc}
\hline \multicolumn{1}{r}{ Efecto principal del tratamiento } & \multicolumn{2}{c}{ IG (\% del control) } \\
\cline { 2 - 3 } 1. Compost & Berro & Lechuga \\
A & 97 & 86 \\
A+H & 77 & 61 \\
$P$ & $* * *$ & $* * *$ \\
2. Dilución & & \\
100\% (extracto puro) & 77 & 47 \\
25\% & 96 & 101 \\
$P$ & $* * *$ & $* * *$ \\
3. Interacción & & \\
$1 \times 2$ & $* * *$ & $* *$
\end{tabular}

A: compost de alperujo; $\mathrm{A}+\mathrm{H}$ : compost de alperujo más hidrolizado

$P$ : nivel de significación. ** y*** indican diferencias estadísticamente significativas a $P \leq 0,01$ y $P \leq 0,001$, respectivamente

Con el extracto puro de $\mathrm{A}+\mathrm{H}$, el IG fue del $53 \%$ en el bioensayo de berro y del $29 \%$ en el de lechuga (Figura 4.1.2). De acuerdo con lo señalado por Bernal et al. (1998) y Zucconi et al. (1981a, 1981b), un valor de IG en berro superior al 50\% indica que el compost está maduro y no presenta problemas de fitotoxicidad, aunque otros autores refieren un valor mínimo del $80 \%$ para considerar que un material no es fitotóxico (Emino y Warman, 2004; Paradelo et al., 2010). El bajo valor (<30\%) de IG para $\mathrm{A}+\mathrm{H}$ en lechuga pone de manifiesto los riesgos potenciales de la elevada salinidad del mismo, según han señalado Abad et al. (2001). En el compost A, el IG fue de $102 \%$ y $64 \%$ en berro y lechuga, respectivamente, valores significativamente superiores a los de $\mathrm{A}+\mathrm{H}$. En ambos composts, los resultados de IG obtenidos estuvieron más relacionados con la longitud de la radícula de las semillas germinadas que con el porcentaje de germinación de las semillas, que fue igual o superior al $90 \%$ en todos los casos. Estos resultados coinciden con lo indicado por Araújo y Monteiro (2005) y Tiquia (2000), que afirmaron que la longitud de la radícula es un parámetro más sensible a los agentes fitotóxicos que la germinación de las semillas. La dilución 


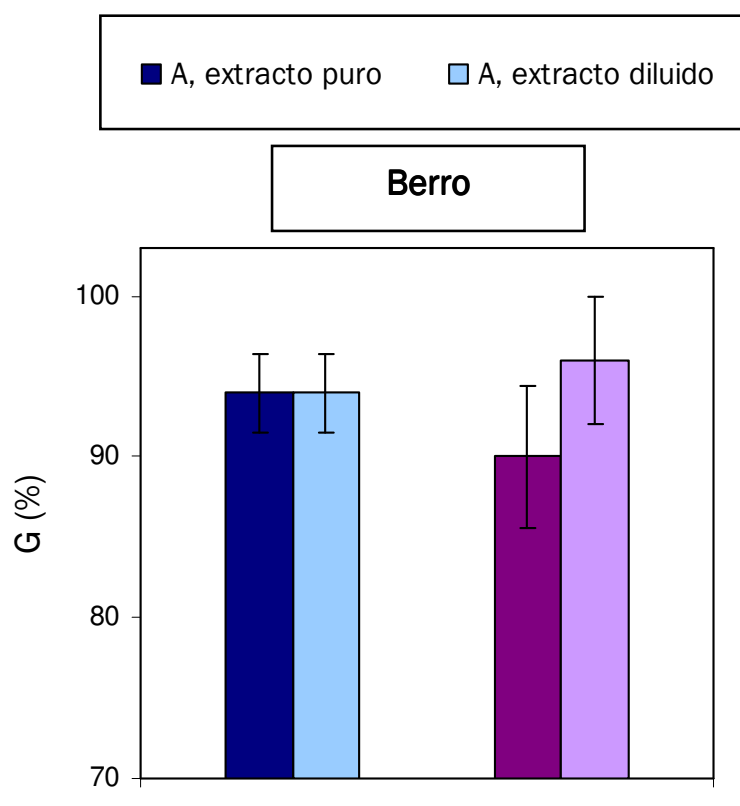

\section{$\mathrm{A}+\mathrm{H}$, extracto puro $\square \mathrm{A}+\mathrm{H}$, extracto diluido}
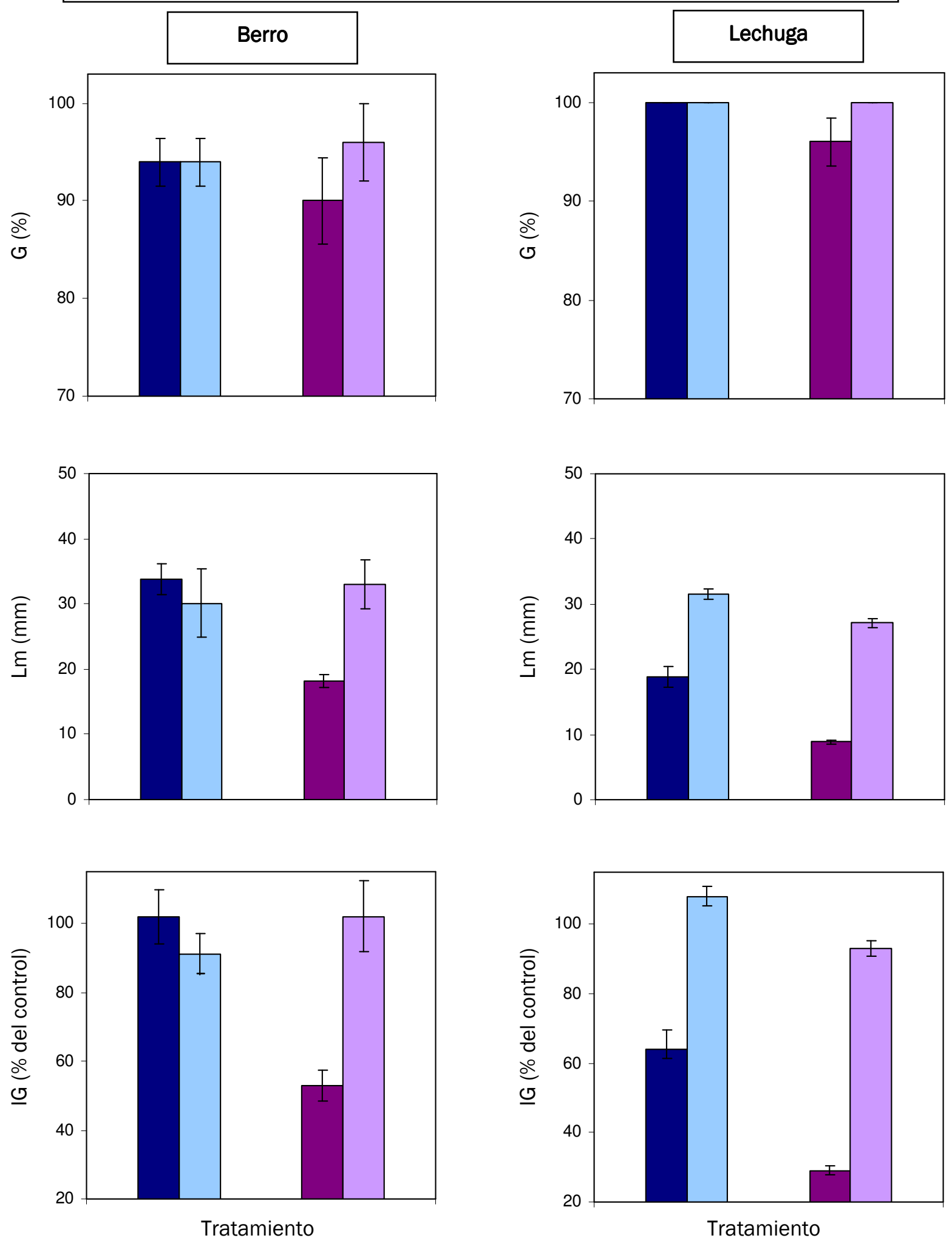

Figura 4.1.2. Parámetros determinados (G, Lm e IG) en los bioensayos de germinación de semillas de berro (izquierda) y de lechuga (derecha) realizados, utilizando los extractos acuosos puros y diluidos (al 25\%) de los dos composts estudiados (A y A+H) G: porcentaje de germinación; Lm: longitud media de radícula; IG: índice de germinación A: compost de alperujo; $\mathrm{A}+\mathrm{H}$ : compost de alperujo más hidrolizado Las barras verticales indican el error estándar 
(con agua destilada) del extracto puro de los composts incrementó significativamente el índice de germinación, especialmente en $\mathrm{A}+\mathrm{H}$, indicando que la aplicación y posterior mezcla (dilución) de dichos composts con el suelo permite eliminar los riesgos potenciales de salinidad de éstos detectados en los bioensayos de germinación realizados.

Con relación al bioensayo de siembra directa de semillas de berro sobre los materiales estudiados (Tabla 4.1.10), se registró un porcentaje de plántulas emergidas en la turba control del orden del $70 \%$ y el $81 \%$ a los 3 y 7 días desde la siembra, respectivamente, mientras que en el compost $A+H$ no emergió plántula alguna a lo largo de los 7 días del ensayo, y en A tan sólo se produjo una emergencia del 10\% durante dichos 7 días. En adición, el peso de la biomasa aérea media acumulada por plántula en A al final del experimento fue notablemente inferior a la turba control (1,7 mg vs. 3,3 mg, respectivamente). Por tanto, este bioensayo puso de manifiesto que ninguno de los dos composts son aptos para ser utilizados como sustratos o componentes de sustratos para el cultivo sin suelo en las proporciones estudiadas, debido a su carácter fitotóxico, lo que ya podía deducirse para el compost $\mathrm{A}+\mathrm{H}$ de los resultados obtenidos en los bioensayos de germinación en placa. Dicha fitotoxicidad podría deberse tanto a los altos niveles de fenoles y sales solubles en este último material como a su nula capacidad de aireación.

Tabla 4.1.10. Parámetros determinados en el bioensayo de siembra directa de semillas de berro en los sustratos preparados con los dos composts estudiados (A y $\mathrm{A}+\mathrm{H})$. Comparación con el sustrato control de turba

\begin{tabular}{lccccc}
\hline \multirow{2}{*}{ Parámetro } & \multicolumn{4}{c}{ Material } & \\
\cline { 2 - 4 } & $\mathrm{A}$ & $\mathrm{A}+\mathrm{H}$ & Turba & P \\
\hline Plántulas emergidas a las 72 horas (\%) & Ob & Ob & $70,3 \mathrm{a}$ & $* * *$ \\
Plántulas normales emergidas tras 7 días (\%) & $9,7 \mathrm{~b}$ & Oc & $80,7 \mathrm{a}$ & $* * *$ \\
Plántulas anormales emergidas tras 7 días (\%) & $0,3 \mathrm{~b}$ & Ob & $5,0 \mathrm{a}$ & $* * *$ \\
Biomasa aérea fresca a los 7 días (mg/plántula) & $16,1 \mathrm{~b}$ & - & $75,9 \mathrm{a}$ & $* * *$ \\
Biomasa aérea seca a los 7 días (mg/plántula) & $1,69 \mathrm{~b}$ & - & $3,31 \mathrm{a}$ & $* * *$ \\
\hline
\end{tabular}

A: compost de alperujo; $\mathrm{A}+\mathrm{H}$ : compost de alperujo más hidrolizado

$P$ : nivel de significación. *** indica diferencias estadísticamente significativas a $P \leq 0,001$

Valores en fila sin letra común difieren estadísticamente a $P \leq 0,05$ (test de Student-Newman-Keuls)

En el caso del compost A, el IG obtenido en los extractos acuosos de éste, utilizando semillas de berro, fue similar al control de agua destilada, mientras que la emergencia y el crecimiento de las plántulas en el ensayo de siembra directa fueron marcadamente inferiores al control de turba; ello parece indicar que cada tipo de 
bioensayo mostró una sensibilidad distinta a la hora de detectar la fitotoxicidad potencial de este compost. Según Araújo y Monteiro (2005) y Emino y Warman (2004), los resultados de los bioensayos de siembra directa sobre los materiales suelen diferir de los de germinación de semillas en los extractos acuosos, debido a que la duración y el procedimiento operacional de aquéllos se asemejan más a las condiciones de campo reales y, por tanto, aportan información más fiable respecto a los potenciales efectos fitotóxicos.

\subsubsection{Análisis de Componentes Principales}

Con el fin de evaluar el grado de asociación existente entre los diferentes parámetros físicos, físico-químicos, químicos y biológicos determinados en los composts $\mathrm{A}$ y $\mathrm{A}+\mathrm{H}$, se construyó una matriz de correlación a partir de las variables estudiadas, que se presenta en el Anejo II. Debido al elevado número de correlaciones altamente significativas encontradas, y considerando además que los parámetros contemplados reúnen información que puede ser redundante, se seleccionó el Análisis de Componentes Principales (ACP) como técnica de análisis estadístico multivariante para simplicar o reducir la dimensión del número de variables estudiadas, facilitando así la interpretación de los resultados obtenidos. De este modo, el conjunto de variables, denominadas variables originales interrelacionadas, se transformó en un nuevo conjunto de éstas, combinación lineal de las originales, llamadas componentes principales (CP) (Batista y Martínez, 1989; Pérez López, 2004).

Según los "eigenvalues" (o autovalores) obtenidos, que miden la variabilidad que explica cada nueva variable (componente principal), y siguiendo el criterio de elección de los componentes que poseen autovalores superiores a 1 como los más representativos, se seleccionaron cuatro componentes principales (CP1 a CP4), que explicaron conjuntamente más del 98\% de la varianza (Tabla 4.1.11); merece destacarse que, considerando únicamente los dos primeros componentes principales extraídos (CP1 y CP2), se explicó el 93,2\% de la varianza. 
Tabla 4.1.11. Componentes principales de las propiedades físicas, las características físico-químicas y químicas, y las propiedades biológicas de los dos composts estudiados ( $\mathrm{A}$ y $\mathrm{A}+\mathrm{H}$ )

\begin{tabular}{cccc}
\hline $\begin{array}{c}\text { Componente principal } \\
\text { (CP) }\end{array}$ & Autovalor & $\begin{array}{c}\text { Varianza explicada } \\
(\%)\end{array}$ & $\begin{array}{c}\text { Varianza acumulada } \\
(\%)\end{array}$ \\
\hline 1 & 47,385 & 86,155 & 86,155 \\
2 & 3,896 & 7,084 & 93,239 \\
3 & 1,595 & 2,900 & 96,139 \\
4 & 1,147 & 2,086 & 98,225 \\
\hline
\end{tabular}

A: compost de alperujo; $\mathrm{A}+\mathrm{H}$ : compost de alperujo más hidrolizado

En la representación gráfica de los componentes principales que se muestra en la Figura 4.1.3 (arriba), puede apreciarse que los dos composts estudiados ( $\mathrm{A}$ y $\mathrm{A}+\mathrm{H}$ ) se separaron en dos grupos claramente diferenciados, en función de las diferentes características, propiedades y composición de éstos. El componente principal 1 (CP1) dispersó ambos materiales sobre el eje de abscisas en base a que $A+H$ presentó valores comparativamente superiores de densidad aparente, volumen de agua, $\mathrm{pH}$, conductividad eléctrica, contenido en lignina, carbono orgánico oxidable e hidrosoluble, carbono de ácidos fúlvicos, polifenoles, carbohidratos, relación $\mathrm{C} / \mathrm{N}$, potasio, sodio, e hidrólisis del FDA, principalmente. Por el contrario, el compost A destacó por su mayor dificultad para humectarse (menor mojabilidad), capacidad de intercambio catiónico superior, además de niveles más elevados de $\mathrm{Ca}$, Fe, y carbonatos, e índices de germinación de semillas más elevados en comparación con el compost $\mathrm{A}+\mathrm{H}$.

Respecto a los pesos de cada componente (Figura 4.1.3, abajo), la mayoría de los parámetros estudiados definieron el CP1, mientras que el CP2 estuvo definido principalmente por el índice de grosor, el diámetro medio geométrico y el contenido en hemicelulosa.

Con relación a las propiedades físicas, el volumen de agua y la densidad aparente estuvieron inversamente correlacionados con el volumen de aire y la porosidad total. En general, se observó una agrupación de componentes de la fracción orgánica -carbono orgánico hidrosoluble, carbohidratos, polifenoles, carbono de ácidos fúlvicos, materia orgánica total, y lignina, entre otros- frente a la asociación de componentes minerales, inversamente correlacionados con aquéllos $-\mathrm{N}^{-} \mathrm{NH}_{4}{ }^{+}, \mathrm{Ca}, \mathrm{Mg}$, $\mathrm{Fe}$, y $\mathrm{CaCO}_{3}$, principalmente-. En cuanto al contenido en polifenoles, se observó una correlación negativa entre éstos y el índice de germinación de las semillas de lechuga y de berro, de acuerdo con los efectos fitotóxicos que les atribuyen diferentes autores 

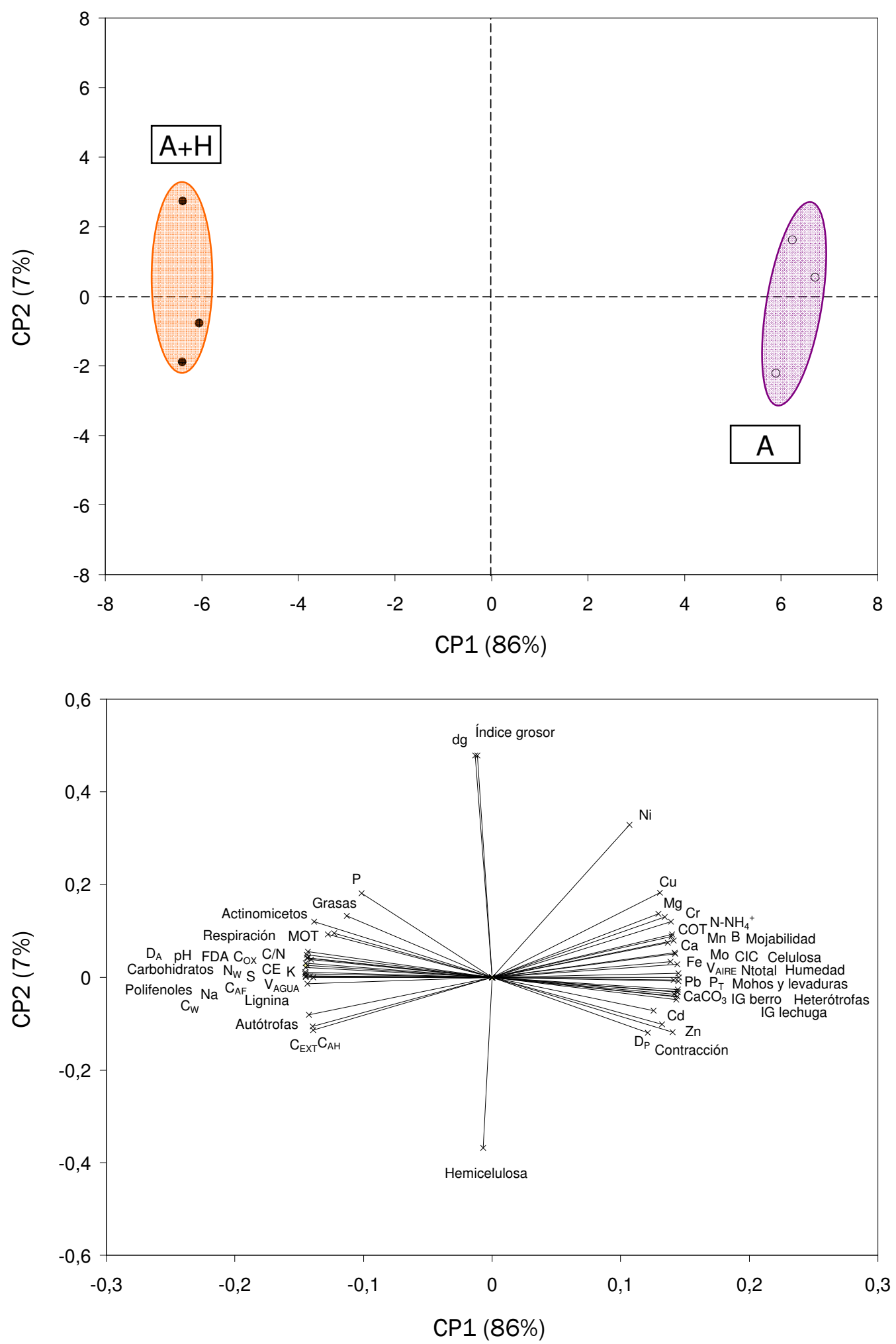

Figura 4.1.3. Distribución ortogonal del análisis de componentes principales (CP1 y CP2) para los composts A y A+H (arriba), y para los parámetros físicos, físico-químicos, químicos y biológicos determinados en éstos (abajo)

A: compost de alperujo; $\mathrm{A}+\mathrm{H}$ : compost de alperujo más hidrolizado

$\mathrm{C}_{\mathrm{AF}}$ : carbono de ácidos fúlvicos; $\mathrm{C}_{\mathrm{AH}}$ : carbono de ácidos húmicos; $\mathrm{C}_{\mathrm{EXT}}$ : carbono orgánico extraíble en medio alcalino; Cox: carbono orgánico oxidable; $\mathrm{C}_{\mathrm{W}}$ : carbono orgánico hidrosoluble; $\mathrm{CE}$ : conductividad eléctrica; CIC: capacidad de intercambio catiónico; COT: carbono orgánico total; $\mathrm{D}_{\mathrm{A}}$ : densidad aparente; dg: diámetro medio geométrico; $\mathrm{D}_{\mathrm{P}}$ : densidad de partícula; FDA: hidrólisis del diacetato de fluoresceína; IG: índice de germinación; MOT: materia orgánica total; $\mathrm{N}_{\mathrm{w}}$ : nitrógeno hidrosoluble; $\mathrm{P}_{\mathrm{T}}$ : porosidad total; $V_{A G U A}$ : volumen de agua; $V_{\text {AIRE: }}$ volumen de aire. Los elementos químicos son los solubles en agua regia 
(Linares et al., 2003; Niaounakis y Halvadakis, 2006; Piotrovska et al., 2011). Asimismo, se apreció una estrecha correlación positiva entre la conductividad eléctrica (CE) y el contenido en $\mathrm{K}$ de los composts, en coincidencia con la ecuación de regresión calculada en la sección 4.1.2.2 para los elementos solubles en agua (mediante análisis de regresión "paso a paso"). Por su parte, la respiración microbiana, la hidrólisis del diacetato de fluoresceína (FDA) y el contenido en carbono orgánico hidrosoluble estuvieron inversamente relacionados con la capacidad de intercambio catiónico, y positivamente con la relación $\mathrm{C} / \mathrm{N}$, en concordancia con los criterios considerados a la hora de evaluar la estabilidad y madurez de los composts, aspectos que se abordan en la siguiente sección 4.1.5.

\subsubsection{Evaluación de la madurez y estabilidad de los composts $\mathrm{A}$ y $\mathrm{A}+\mathrm{H}$}

Madurez y estabilidad son dos condiciones indispensables para la aplicación de materiales compostados al suelo (Bernal et al., 1998, 2009). Aunque ambos términos se utilizan frecuentemente de forma indistinta, cada uno de ellos se refiere a unas características específicas de los composts. Así, la estabilidad se refiere al grado de descomposición biológica de los compuestos orgánicos del compost, siendo dicha estabilidad inversamente proporcional a la actividad microbiana y a la biodisponibilidad de la materia orgánica, mientras que la madurez se relaciona con la ausencia de sustancias fitotóxicas y patógenos, y con el crecimiento potencial de las plantas (Bernal et al., 1998, 2009; Paradelo et al., 2010). No obstante, se puede considerar que el término madurez engloba conceptualmente el de estabilidad, ya que un compost maduro, cuya materia orgánica está altamente humificada y ha evolucionado hacia formas más resistentes a la biodegradación, suele caracterizarse por la ausencia de sustancias fitotóxicas y por estar biológicamente estabilizado. La incorporación al suelo de compost con un grado de madurez inadecuado tiene como consecuencia más destacada la inmovilización del $\mathrm{N}$ asimilable de dicho suelo por las poblaciones de microorganismos, lo que puede generar una deficiencia de $\mathrm{N}$ en la planta y, por tanto, una disminución del desarrollo y el rendimiento de los cultivos; mientras que en composts suficientemente maduros se observa, como resultado global, una mineralización (de N) neta positiva. Por otro lado, la adición de materiales orgánicos no estabilizados puede provocar también la inmovilización de otros nutrientes esenciales, tales como S, P, Ca o Mg, debido al incremento de biomasa microbiana que se produce al adicionar una fuente de carbono lábil al suelo y a la 
competencia de los microorganismos con las plantas por la absorción de estos nutrientes. Asimismo, la intensa y rápida descomposición de un compost inestable provoca una disminución de la concentración de oxígeno a nivel de la raíz y, por tanto, la formación de condiciones fuertemente anaerobias y reductoras, lo que unido al aumento de la temperatura del suelo a nivel radicular, provoca un descenso en la actividad metabólica de la planta (Iglesias-Jiménez et al., 2008). Esta situación se ve agravada además por la producción de sustancias que inhiben el crecimiento y el desarrollo de las plantas (amoníaco, óxido de etileno y ácidos orgánicos, entre otros) durante la descomposición en el suelo del compost inmaduro en el suelo, aunque la fitotoxicidad puede ser también causada por otros factores, como la presencia de metales pesados o sales solubles en exceso. Todo ello limita la eficacia de los tests de fitotoxicidad disponibles para determinar la madurez de los composts (Wu et al., 2000) y justifica que se hayan llevado a cabo numerosas investigaciones con objeto de desarrollar diferentes métodos para evaluar dicha madurez, proponiéndose para tal fin numerosos criterios y procedimientos que necesitan combinarse para poder evaluar así la madurez de los materiales compostados de forma más precisa (Aslam et al., 2008; Bernal et al., 2009; Iglesias-Jiménez et al., 2008; Paradelo et al., 2010; Said-Pullicino et al., 2007). Dichos métodos incluyen parámetros de naturaleza física, química y biológica, así como diversos ratios e índices que están estrechamente vinculados a la madurez de los residuos orgánicos compostados. En la Tabla 4.1.12 se recogen los valores estándar o de referencia de diferentes parámetros e índices que sirven para evaluar la madurez y estabilidad de composts, así como los resultados obtenidos para los dos composts de alperujo estudiados ( $\mathrm{A}$ y $\mathrm{A}+\mathrm{H}$ ).

Uno de los criterios de madurez y humificación utilizados para evaluar la calidad de composts es la capacidad de intercambio catiónico (CIC), que, como se ha mencionado en la sección 4.1.2.2., fue de mayor magnitud en A que en $\mathrm{A}+\mathrm{H}$ (156 meq/100 g MOT y 104 meq/100 g MOT, respectivamente), obteniéndose resultados superiores a los mínimos establecidos por diversos autores para considerar un compost maduro (Harada e Inoko, 1980; Iglesias-Jiménez y Pérez-García, 1992a). Sin embargo, algunos autores han encontrado valores de CIC superiores a $100 \mathrm{meq} / 100$ g MOT en composts inmaduros, por lo que éstos sugirieron como índice más apropiado el ratio $\mathrm{CIC} /$ carbono orgánico total-COT, proponiéndose como valor mínimo de éste $1,7 \mathrm{meq} / \mathrm{g}$ C y 1,9 meq/g C de acuerdo con lo señalado por Roig et al. (1988) e Iglesias-Jiménez y Pérez-García (1992b), respectivamente. En este estudio, los dos 
composts de alperujo superaron dichos umbrales, con un resultado para este índice comparativamente más alto en $\mathrm{A}$.

Tabla 4.1.12. Parámetros e índices utilizados como indicadores de madurez y estabilidad de residuos orgánicos compostados, y niveles de éstos en los dos composts estudiados $(\mathrm{A}$ y $\mathrm{A}+\mathrm{H})$

\begin{tabular}{|c|c|c|c|c|}
\hline \multirow[b]{2}{*}{ Parámetro/Índice } & \multirow[b]{2}{*}{$\begin{array}{l}\text { Valor } \\
\text { óptimo }\end{array}$} & \multirow[b]{2}{*}{ Fuente } & \multicolumn{2}{|c|}{ Compost } \\
\hline & & & A & $\mathrm{A}+\mathrm{H}$ \\
\hline $\mathrm{CIC}$ (meq/100 g MOT) & $\begin{array}{l}>60 \\
>67\end{array}$ & $\begin{array}{l}\text { Harada e Inoko (1980) } \\
\text { Iglesias-Jiménez y } \\
\text { Pérez-García (1992a) }\end{array}$ & 156 & 104 \\
\hline Ratio CIC/COT (meq/g C) & $\begin{array}{l}>1,7 \\
>1,9\end{array}$ & $\begin{array}{l}\text { Roig et al. (1988) } \\
\text { lglesias-Jiménez y Pérez-García } \\
\text { (1992b) }\end{array}$ & 2,61 & 1,95 \\
\hline Ratio COT/NT & $<20$ & $\begin{array}{l}\text { Bernal et al. (1998, 2009); } \\
\text { Iglesias-Jiménez y Pérez-García } \\
(1992 a) \\
\text { Golueke (1981); } \\
\text { Mathur et al. (1993) }\end{array}$ & 10,6 & 11,9 \\
\hline $\mathrm{C}_{\mathrm{w}}(\mathrm{g} / \mathrm{kg})$ & $\begin{array}{l}\leq 4 \\
<5 \\
\leq 10 \\
<17\end{array}$ & $\begin{array}{l}\text { Zmora-Nahum et al. (2005) } \\
\text { García et al. (1992) } \\
\text { Hue y Liu (1995) } \\
\text { Bernal et al. (1998, 2009) }\end{array}$ & 35,8 & 61,3 \\
\hline Ratio $\mathrm{C}_{\mathrm{w}} / \mathrm{N}_{\mathrm{w}}$ & $\begin{array}{l}<6 \\
\leq 16\end{array}$ & $\begin{array}{l}\text { Chansayak y Kubota (1981) } \\
\text { Hue y Liu (1995) }\end{array}$ & 10 & 7 \\
\hline Ratio $\mathrm{C}_{\mathrm{w}} / \mathrm{N}_{\mathrm{T}}$ & $\begin{array}{l}<0,55 \\
\leq 0,70\end{array}$ & $\begin{array}{l}\text { Bernal et al. }(1998,2009) \\
\text { Hue y Liu (1995) }\end{array}$ & 0,95 & 1,91 \\
\hline $\mathrm{N}-\mathrm{NH}_{4}{ }^{+}(\mathrm{g} / \mathrm{kg})$ & $<0,4$ & Zucconi y de Bertoldi (1987) & 0,012 & 0,008 \\
\hline CEXT (g/kg) & $\leq 60$ & Hue y Liu (1995) & 60,4 & 110,4 \\
\hline $\mathrm{C}_{\mathrm{AF}}(\mathrm{g} / \mathrm{kg})$ & $\leq 12,5$ & Hue y Liu (1995) & 16,6 & 20,0 \\
\hline Ratio $\mathrm{C}_{\mathrm{EXT}} / \mathrm{C}_{\mathrm{w}}$ & $\geq 6,0$ & Hue y Liu (1995) & 1,7 & 1,8 \\
\hline Ratio de humificación (RH, \%) & $>7$ & Roletto et al. (1985) & 15 & 29 \\
\hline Indice de humificación (IH, \%) & $>3,5$ & Roletto et al. (1985) & 11 & 24 \\
\hline $\begin{array}{l}\text { Porcentaje de ácidos húmicos } \\
\text { (PAH, \%) }\end{array}$ & $\geq 50$ & Roletto et al. (1985) & 73 & 82 \\
\hline İndice de polimerización (IP) & $\begin{array}{c}>1 \\
>1,9\end{array}$ & $\begin{array}{l}\text { Roletto et al. (1985) } \\
\text { Iglesias-Jiménez y Pérez-García } \\
\text { (1992b) }\end{array}$ & 2,6 & 4,5 \\
\hline IG (\% del control) & $\begin{array}{l}>50 \\
>80\end{array}$ & $\begin{array}{l}\text { Bernal et al. (1998, 2009); } \\
\text { Zucconi et al. (1981a, 1981b) } \\
\text { Emino y Warman }(2004) ; \\
\text { Paradelo et al. (2010) }\end{array}$ & 102 & 53 \\
\hline Emisión de $\mathrm{CO}_{2}\left(\mathrm{mg} \mathrm{CO} 2 \mathrm{~kg}^{-1} \mathrm{~h}^{-1}\right)$ & $\leq 120$ & Hue y Liu (1995) & 223 & 281 \\
\hline
\end{tabular}

Por otro lado, la relación COT/nitrógeno total- $\mathrm{N}_{\mathrm{T}}$ es un indicador utilizado tradicionalmente como criterio de madurez, recomendándose generalmente valores inferiores a 20 (Golueke, 1981; Mathur et al., 1993), o bien restringiendo dicho ratio a un máximo de 12 como criterio más fiable (Bernal et al., 1998, 2009; Iglesias-Jiménez y Pérez-García, 1992a). No obstante, la relación COT/NT presenta gran variabilidad 
entre materiales compostados y, además, pueden encontrarse composts maduros con valores superiores a 20 (cuando una fracción del carbono orgánico está presente en forma de compuestos resistentes a la biodegradación, por ejemplo, lignina, lo que ya se mencionó en la sección 4.1.2.2), o bien composts inmaduros con valores inferiores a 15 (como consecuencia de un alto contenido en nitrógeno respecto a la proporción de carbono en el material original). Por ello, puede deducirse que el ratio $\mathrm{COT} / \mathrm{N}_{\mathrm{T}}$ debe considerarse juntamente con otros criterios que sirvan para determinar la madurez de los composts (Iglesias-Jiménez et al., 2008). La caracterización de los composts A y $\mathrm{A}+\mathrm{H}$ mostró que estos dos materiales presentaron una relación COT/ $\mathrm{N}_{\mathrm{T}}$ inferior a 12 , siendo el valor de este ratio comparativamente menor en $\mathrm{A}$.

La transformación bioquímica de la materia orgánica que desarrollan los microorganismos tiene lugar principalmente en la fase líquida (acuosa) de ésta, por lo que, a efectos prácticos, el estudio de los componentes de la materia orgánica solubles en agua es de particular interés a la hora de evaluar la madurez del compost (Bernal et al., 2009). Como puede observarse en la Tabla 4.1.12, diversos autores han sugerido distintos valores máximos de carbono orgánico hidrosoluble $\left(\mathrm{C}_{\mathrm{w}}\right)$ como índice de madurez, basándose en que, durante el proceso de compostaje, se observa un descenso progresivo del mismo hasta estabilizarse prácticamente. Para simplificar su determinación, se ha propuesto -como método alternativo- la medida de la absorbancia a $465 \mathrm{~nm}$ de un extracto acuoso del compost (Zmora-Nahum et al., 2005), aunque, de forma similar a otros criterios de madurez recogidos en la presente Tesis, los límites recomendados para este parámetro en distintos estudios varían notablemente. En el compost $\mathrm{A}$, el contenido en $\mathrm{C}_{\mathrm{w}}$ duplicó el valor menos restrictivo (17 g/kg), y en $\mathrm{A}+\mathrm{H}$ fue casi cuatro veces superior, lo que indica cierto grado de inestabilidad de los dos composts, ya que el carbono orgánico hidrosoluble es la fracción más activa del carbono (Wu et al., 2000). A pesar de haberse propuesto la relación $\mathrm{C} / \mathrm{N}$ en la fase acuosa $\left(\mathrm{C}_{\mathrm{w}} / \mathrm{N}_{\mathrm{w}}\right)$ como índice de madurez alternativo al ratio equivalente en el material sólido (Chanyasak y Kubota, 1981), la baja concentración de nitrógeno orgánico soluble en agua encontrada generalmente en los materiales orgánicos compostados dificulta su determinación, por lo que se planteó como posible criterio para reemplazarlo el ratio $\mathrm{C}_{\mathrm{w}} / \mathrm{N}_{\mathrm{T}}$, considerándose como límites de éste los valores 0,55 y 0,70 (Bernal et al., 1998, 2009; Hue y Liu, 1995). Como era previsible en vista del alto contenido en carbono orgánico hidrosoluble ( $\mathrm{C}_{\mathrm{w}}$, Tabla 4.1.12), los composts $\mathrm{A}$ y $\mathrm{A}+\mathrm{H}$ superaron los valores máximos recomendados para los dos índices 
señalados $\left(\mathrm{C}_{\mathrm{w}} / \mathrm{N}_{\mathrm{w}}\right.$ y $\mathrm{C}_{\mathrm{w}} / \mathrm{N}_{\mathrm{T}}$, Tabla 4.1.12), destacando la mayor proporción de nitrógeno orgánico soluble en agua $\left(N_{w}\right.$, Tabla 4.3) en el compost $A+H$ respecto al contenido total ( $\mathrm{N}_{\mathrm{T}}$, Tabla 4.3), lo que provocó una disminución en el ratio $\mathrm{C}_{\mathrm{w}} / \mathrm{N}_{\mathrm{w}}$ de dicho material en comparación con A.

Respecto al contenido de nitrógeno en forma amoniacal $\left(\mathrm{N}-\mathrm{NH}_{4}^{+}\right)$, ambos composts presentaron niveles inferiores al límite máximo establecido por Zucconi y de Bertoldi (1987).

Debido a que la formación de sustancias húmicas está estrechamente relacionada con la madurez de los materiales orgánicos compostados, el proceso de humificación ha sido objeto de numerosos estudios (Bernal et al., 2009; Paradelo et al., 2010). Durante el compostaje, la concentración de ácidos húmicos aumenta debido fundamentalmente a la degradación de la lignina, combinándose a posteriori los productos así obtenidos para formar moléculas más complejas (García-Gómez et al., 2005). En este contexto, Hue y Liu (1995) establecieron algunos valores óptimos en relación con las distintas formas de carbono orgánico, concretamente carbono extraíble en medio alcalino $\left(\mathrm{C}_{\mathrm{EXT}}\right)$, carbono de ácidos fúlvicos $\left(\mathrm{C}_{\mathrm{AF}}\right)$ y ratio $\mathrm{C}_{\mathrm{EXT}} / \mathrm{C}_{\mathrm{W}}$. Ninguno de los dos composts estudiados cumplió estos criterios, condición que podría atribuirse a la co-extracción simultánea de compuestos heterogéneos de naturaleza no húmica, o no completamente humificada, durante la extracción alcalina de ácidos húmicos y fúlvicos, tal y como se indicó en el apartado 4.1.2.2. Esto afectaría también a los ratios que relacionan diferentes parámetros de la humificación, que se utilizan como indicadores de madurez y estabilidad: el ratio de humificación $(\mathrm{RH})$, el índice de humificación $(\mathrm{IH})$, el porcentaje de ácidos húmicos (PAH), y el índice de polimerización (IP) (Tabla 4.1.12). A pesar de que los valores de estos cuatro índices en $\mathrm{A}$ y $\mathrm{A}+\mathrm{H}$ superaron los valores mínimos establecidos por Iglesias-Jiménez y Pérez-García (1992b) y Roletto et al. (1985), deberían tomarse en consideración las limitaciones señaladas más arriba del método de extracción alcalina de las sustancias húmicas, prevaleciendo la bondad de otros criterios para evaluar la madurez de los composts. De acuerdo con lo anterior, según Veeken et al. (2000), los índices basados en la determinación del contenido en ácidos húmicos extraídos con hidróxido sódico no pueden servir como criterios de madurez si no se determina, adicionalmente, la naturaleza de la materia orgánica así extraída. 
Respecto al índice de germinación de semillas (IG), en la sección 4.1.3.3 se ha comentado más extensamente la mayor fitotoxicidad potencial del compost $\mathrm{A}+\mathrm{H}$ en comparación con A.

La evaluación de la estabilidad biológica suele relacionarse con la madurez de los composts, sugiriéndose la tasa de respiración aeróbica como un parámetro muy apropiado para evaluar la actividad biológica y, derivada de ésta, la estabilidad de los materiales. En condiciones de aerobiosis, la actividad microbiana libera dióxido de carbono y energía, pudiendo determinarse la tasa de respiración de la población microbiana mediante la emisión de dióxido de carbono, el consumo de oxígeno o el autocalentamiento de la masa del material (Bernal et al., 2009). Un compost insuficientemente maduro presenta una alta demanda de oxígeno y una elevada producción de $\mathrm{CO}_{2}$ y calor, debido al crecimiento y actividad de los microorganismos como consecuencia de la abundancia de compuestos fácilmente biodegradables en el material. Utilizando los tests respirométricos, Hue y Liu (1995) propusieron el valor de $120 \mathrm{mg} \mathrm{CO} \mathrm{kg}^{-1} \mathrm{~h}^{-1}$ como límite máximo aceptable en un compost maduro, lo que es un valor considerablemente inferior a las cifras obtenidas en los composts $\mathrm{A}$ y $\mathrm{A}+\mathrm{H}$ (223 y $281 \mathrm{mg} \mathrm{CO}_{2} \mathrm{~kg}^{-1} \mathrm{~h}^{-1}$, respectivamente), apreciándose por tanto que estos dos materiales no estaban completamente estabilizados/maduros de acuerdo con este criterio.

Según los resultados hasta aquí presentados, puede concluirse que se encontraron diferencias marcadas en las características físicas, químicas y biológicas, en la composición, y en el grado de madurez y estabilidad entre los dos composts estudiados $(\mathrm{A}$ y $\mathrm{A}+\mathrm{H})$, que estuvieron estrechamente relacionadas con el manejo de la mezcla de residuos (alperujo + estiércol de caballo fresco) durante el compostaje de ésta: riego de las pilas sólo con agua (compost A) o con hidrolizado enzimático graso de proteínas animales durante los primeros 38 días del proceso seguido de riegos con agua (compost $A+H$ ).

Al considerar de forma global los criterios de madurez y estabilidad más comúnmente utilizados, se observó que el compost A fue más maduro/estable que $\mathrm{A}+\mathrm{H}$. Aunque los dos materiales estudiados presentaron valores de $\mathrm{CIC}$, relación CIC/COT y relación COT/ $\mathrm{N}_{\mathrm{T}}$ adecuados para ser considerados composts maduros y, por tanto, aptos para su utilización agrícola, los elevados niveles de carbono orgánico hidrosoluble $\left(\mathrm{C}_{\mathrm{W}}\right)$ y la alta tasa de respiración (estimada como producción de $\mathrm{CO}_{2}$ ) encontrados indicaron que dichos composts no eran totalmente estables desde el 
punto de vista biológico. Por otra parte, los bioensayos realizados (germinación de semillas en extracto acuoso de los composts y crecimiento de plántulas mediante siembra directa sobre los materiales sólidos) revelaron cierto grado de fitotoxicidad, particularmente en $\mathrm{A}+\mathrm{H}$, lo que sugiere la realización de ensayos de evaluación agronómica, utilizando los composts $\mathrm{A}$ y $\mathrm{A}+\mathrm{H}$ como mejoradores del suelo (enmiendas húmicas) a las dosis usualmente aplicadas, para averiguar si se manifiestan efectos deletéreos sobre los cultivos ocasionados por dichos composts; los resultados de estos experimentos agronómicos se presentan más adelante, en la sección 4.3. 


\subsection{EFECTOS DE LOS COMPOSTS $A$ Y $A+H$ SOBRE LAS PROPIEDADES FÍSICAS, LAS CARACTERÍSTICAS QUÍMICAS Y LA DINÁMICA DEL NITRÓGENO DE LOS SUELOS ENMENDADOS}

La búsqueda de estrategias alternativas a las convencionales con objeto de incrementar la fertilidad del suelo ha fomentado el interés por la aplicación de residuos orgánicos y composts como insumos de provecho en el contexto de la sostenibilidad y el respeto por el medio ambiente (Montemurro et al., 2004; Montemurro y Maiorana, 2008). En comparación con los materiales orgánicos no estabilizados ni higienizados, los composts presentan diferentes ventajas tales como: ausencia de semillas viables de especies arvenses, ausencia de patógenos, elevada uniformidad en su aplicación en campo por el menor volumen (dosis) requerido y tamaño de partícula más reducido, balance de nutrientes más equilibrado, presencia de materia orgánica madura y estable, y liberación lenta de los nutrientes, entre otras (Moral et al., 2009).

Por otra parte, la degradación y la pérdida de calidad del suelo han sido objeto de numerosos estudios, habiéndose hecho hincapié en la determinación de parámetros que sirvan para evaluar los cambios producidos en éste por distintas técnicas de manejo del mismo. Por ello, el desarrollo de estudios que combinen parámetros físicos, químicos y biológicos es de gran interés a la hora de recabar información relativa al efecto de las alternativas de manejo del suelo (en este caso, aplicación de compost como mejorador o enmienda) sobre la fertilidad de éste (Melero et al., 2008). Diferentes estudios han utilizado parámetros físicos y químicos como indicadores de la calidad del suelo (ver la revisión de Parr y Papendick, 1997), pero distintos autores han señalado que éstos varían lentamente y han propuesto la determinación de parámetros biológicos y bioquímicos para detectar cambios a corto plazo (Melero et al., 2007a, 2007b; Tejada et al., 2009).

En base a lo anterior, en la presente Tesis se han llevado a cabo varios estudios para evaluar la influencia de la aplicación de los composts de alperujo $(A$ y $A+H)$ en el suelo, tal y como se ha descrito en la sección 3.3. Se realizó un experimento de un año de duración (Experimento 1), tras el cual se determinaron parámetros físicos, físico-químicos y químicos seleccionados del suelo, así como también dos ensayos de incubación (Experimento 2) a corto plazo: en uno de ellos (2.1) se estudió la dinámica del nitrógeno orgánico en un suelo calizo enmendado con los dos composts indicados; 
y, en el otro (2.2) se examinó la evolución de parámetros biológicos y bioquímicos en dos suelos con texturas diferentes, a los que se aplicaron dichos materiales orgánicos. Todos estos experimentos se realizaron con suelos no cultivados, con el fin de evaluar la influencia de los composts en los mismos sin la interferencia de cultivos, presentándose a continuación los resultados obtenidos en los mismos.

\subsubsection{Experimento 1. Efectos sobre las propiedades físicas y las características químicas del suelo}

Para evaluar los efectos de los dos composts de alperujo objeto de la presente Tesis sobre las características físicas, físico-químicas y químicas del suelo calizo (ver Materiales y Métodos, sección 3.3.1), se estudiaron un total de 8 tratamientos, resultantes de la combinación factorial de 2 Composts (alperujo, A vs. alperujo más hidrolizado, $\mathrm{A}+\mathrm{H}$ ) $\times 4$ Dosis de aplicación de éstos (equivalentes a 12, 24, 48 y $96 \mathrm{t}$ de materia orgánica total/ha; D1, D2, D3 y D4, respectivamente). Además, se incluyó un control (CO), que no recibió aporte de materia orgánica. Los contenedores con el suelo enmendado y el control se mantuvieron en invernadero, bajo condiciones de humedad controladas (entre el $50 \%$ y el $100 \%$ de la capacidad de campo), durante un año.

Al final del experimento se determinaron parámetros físicos seleccionados, cuyos resultados y correspondiente análisis de la varianza multifactorial se presentan en la Tabla 4.2.1. Únicamente se observaron diferencias estadísticamente significativas entre los dos composts estudiados ( $\mathrm{A}$ y $\mathrm{A}+\mathrm{H}$ ) en el contenido volumétrico de humedad a capacidad de campo $\left(\theta_{v c c}\right)$, siendo el valor de este parámetro ligeramente superior en A. En cuanto al factor Dosis de compost, los resultados obtenidos revelaron que la densidad aparente $\left(\rho^{b}\right)$ fue tanto menor cuanto mayor fue la dosis aplicada, observándose el efecto contrario sobre la porosidad $\left(\varepsilon_{\mathrm{T}}\right)$. Asimismo, las dos dosis más altas (48 y 96 t/ha, D3 y D4, respectivamente) retuvieron mayor volumen de agua (en condiciones de capacidad de campo) que las dosis equivalentes a 12 y $24 \mathrm{t} / \mathrm{ha}$ (D1 y D2, respectivamente). La conductividad hidráulica saturada medida en laboratorio $\left(K_{H S}\right)$ no se vio afectada por la dosis de compost aplicada, mientras que para la conductividad hidráulica determinada con infiltrómetro de minidisco $\left(\mathrm{K}_{\mathrm{H}^{\prime}}{ }^{\prime}\right)$, a la tensión de 0,5 cm, las dos dosis más bajas (D1 y D2, 12 y 24 t/ha, respectivamente) proporcionaron valores significativamente superiores a las restantes, alcanzándose además el valor mínimo de este parámetro con la dosis de 96 t/ha (D4). 
Tabla 4.2.1. Efectos principales de los tratamientos estudiados -Compost (A vs. A+H) y Dosis de aplicación de éste (D1, D2, D3 y D4, equivalente a 12, 24, 48 y 96 t de materia orgánica total/ha, respectivamente)- sobre propiedades físicas seleccionadas del suelo al final del experimento

\begin{tabular}{|c|c|c|c|c|c|c|}
\hline $\begin{array}{l}\text { Efecto principal del } \\
\text { tratamiento }\end{array}$ & $\begin{array}{c}\rho^{\mathbf{b}} \\
\left(\mathrm{kg} / \mathrm{m}^{3}\right)\end{array}$ & $\begin{array}{c}\varepsilon_{\mathrm{T}} \\
\left(\mathrm{m}^{3} / \mathrm{m}^{3}\right)\end{array}$ & $\begin{array}{c}\theta v c c \\
(\% \mathrm{v} / \mathrm{v})\end{array}$ & $\mathrm{K}_{\mathrm{HS}}$ & $(\mathrm{cm} / \mathrm{h})$ & $K_{H^{\prime}}$ \\
\hline \multicolumn{7}{|l|}{ 1. Compost } \\
\hline$A$ & 1028 & 0,607 & 25,5 & 20,7 & & 1,54 \\
\hline$A+H$ & 1032 & 0,605 & 24,6 & 25,9 & & 1,64 \\
\hline$P$ & ns & ns & * & ns & & ns \\
\hline \multicolumn{7}{|l|}{ 2. Dosis de compost } \\
\hline D1 & $1049 a$ & $0,600 c$ & $22,9 b$ & 19,1 & & $1,91 a$ \\
\hline D2 & $1039 b$ & $0,603 c$ & $23,4 b$ & 16,9 & & $1,97 a$ \\
\hline D3 & $1026 c$ & $0,607 b$ & $26,9 a$ & 28,2 & & $1,50 b$ \\
\hline D4 & $1006 d$ & $0,614 a$ & $27,0 a$ & 29,1 & & $0,98 \mathrm{c}$ \\
\hline$P$ & $* * *$ & $* * *$ & $* * *$ & ns & & $* * *$ \\
\hline \multicolumn{7}{|l|}{ 3. Interacción } \\
\hline $1 \times 2$ & ns & ns & * & ns & & * \\
\hline
\end{tabular}

A: compost de alperujo; $\mathrm{A}+\mathrm{H}$ : compost de alperujo más hidrolizado

$\rho^{\mathrm{b}}$ : densidad aparente; $\varepsilon_{\mathrm{T}}$ : porosidad; $\theta_{\mathrm{vcc}}$ : humedad volumétrica a capacidad de campo; KHs: conductividad hidráulica saturada medida en laboratorio; $\mathrm{K}_{\mathrm{H}}$ ': conductividad hidráulica determinada en campo con infiltrómetro de minidisco a succión constante de $0,5 \mathrm{~cm}$

ns, * y *** indican diferencias no significativas o estadísticamente significativas a $P \leq 0,05$ y $P \leq 0,001$, respectivamente Valores en columna sin letra común difieren estadísticamente a $P \leq 0,05$ (test de Student-Newman-Keuls)

La comparación de los controles (CO) con los suelos enmendados (Tabla 4.2.2) puso de manifiesto que solamente la dosis máxima (96 t/ha, D4) de A y A+H resultó en una densidad aparente $\left(\rho^{b}\right)$ inferior a dichos controles; y que, inversamente, dicha dosis aumentó la porosidad del suelo $\left(\varepsilon_{\mathrm{T}}\right)$. En el caso de la humedad volumétrica a capacidad de campo ( $\theta_{\mathrm{vcc}}$ ), las dos dosis más altas (48 y 96 t/ha, D3 y D4, respectivamente) superaron (de manera significativa) el valor del suelo control (CO). No se registraron diferencias estadísticamente significativas en la conductividad hidráulica saturada medida en laboratorio $\left(\mathrm{K}_{\mathrm{HS}}\right)$ entre los tratamientos estudiados, mientras que la conductividad hidraúlica determinada con infiltrómetro de minidisco $\left(K_{H^{\prime}}\right)$ presentó el valor más alto en el control sin enmendar (CO), en comparación con los tratamientos con compost, destacando la disminución máxima en dicho parámetro cuando se aplicó la dosis de 96 t/ha (D4) de A y las dosis de 48 y 96 t/ha (D3 y D4, respectivamente) de $\mathrm{A}+\mathrm{H}$. 
Tabla 4.2.2. Influencia del compost $(\mathrm{A}$ y $\mathrm{A}+\mathrm{H})$ y de la dosis de aplicación de éste (D1, D2, D3 y D4, equivalente a 12, 24, 48 y 96 t de materia orgánica total/ha, respectivamente) en propiedades físicas seleccionadas del suelo al final del experimento. Comparación con el control ( $\mathrm{CO}$, que no recibió compost)

\begin{tabular}{|c|c|c|c|c|c|c|}
\hline Compost & Dosis & $\begin{array}{c}\rho^{\mathbf{b}} \\
\left(\mathrm{kg} / \mathrm{m}^{3}\right)\end{array}$ & $\begin{array}{c}\boldsymbol{\varepsilon}_{\mathbf{T}} \\
\left(\mathrm{m}^{3} / \mathrm{m}^{3}\right)\end{array}$ & $\begin{array}{c}\theta v c c \\
(\% \mathrm{v} / \mathrm{v})\end{array}$ & KHS & $(\mathrm{cm} / \mathrm{h}) \quad$ \\
\hline \multirow[t]{4}{*}{ A } & D1 & $1046 a b$ & $0,600 d$ & $23,2 b$ & 18,7 & $1,68 \mathrm{bc}$ \\
\hline & D2 & $1042 a b c$ & $0,602 \mathrm{~cd}$ & $24,0 b$ & 10,1 & $1,78 \mathrm{bc}$ \\
\hline & D3 & $1023 \mathrm{~cd}$ & $0,609 b c$ & $27,3 a$ & 24,6 & $1,74 \mathrm{bc}$ \\
\hline & D4 & $999 e$ & $0,616 a$ & $27,6 a$ & 29,5 & $0,96 d$ \\
\hline \multirow[t]{4}{*}{$\mathrm{A}+\mathrm{H}$} & D1 & $1052 a$ & $0,599 d$ & $22,6 b$ & 19,6 & $2,14 b$ \\
\hline & D2 & $1036 a b c$ & $0,604 \mathrm{~cd}$ & $22,8 b$ & 23,6 & $2,16 b$ \\
\hline & D3 & $1030 \mathrm{bc}$ & $0,606 \mathrm{bcd}$ & $26,6 a$ & 31,7 & $1,26 \mathrm{~cd}$ \\
\hline & D4 & 1012de & $0,612 a b$ & $26,4 a$ & 28,7 & $1,00 d$ \\
\hline $\mathrm{CO}$ & - & 1040abc & $0,603 \mathrm{~cd}$ & $23,9 b$ & 15,4 & $2,92 a$ \\
\hline$P$ & & $\star \star \star *$ & $* * *$ & $* * *$ & ns & $\star \star \star *$ \\
\hline
\end{tabular}

A: compost de alperujo; $\mathrm{A}+\mathrm{H}$ : compost de alperujo más hidrolizado

$\rho^{\mathrm{b}}$ : densidad aparente; $\varepsilon_{\mathrm{T}}$ porosidad; $\theta_{\mathrm{vcc}}$ : humedad volumétrica a capacidad de campo; KHs: conductividad hidráulica saturada medida en laboratorio; $K_{H}{ }^{\prime}$ : conductividad hidráulica determinada en campo con infiltrómetro de minidisco a succión constante de $0,5 \mathrm{~cm}$

ns $y * * *$ indican diferencias no significativas o estadísticamente significativas a $P \leq 0,001$, respectivamente

Valores en columna sin letra común difieren estadísticamente a $P \leq 0,05$ (test de Student-Newman-Keuls)

Diversos estudios señalan una mejora en las propiedades físicas del suelo -disminución de la densidad aparente e incremento de la porosidad y de la capacidad de retención de agua - tras la aplicación de materiales orgánicos (Erhart y Hartl, 2010; Evanylo et al., 2008), de acuerdo con los resultados encontrados en el presente experimento.

Por otro lado, el estudio del flujo de agua en el suelo requiere la determinación de la velocidad de infiltración y de la conductividad hidráulica. Esta última expresa la capacidad del medio poroso para transmitir agua y otros fluidos a través del mismo; depende de las características intrínsecas de la matriz sólida y porosa del suelo así como de las propiedades del fluido, y puede determinarse tanto en régimen saturado como no saturado (Porta et al., 2003). La zona no saturada tiene gran importancia a efectos prácticos, ya que la mayor parte de los procesos de transferencia de agua en los suelos tienen lugar en régimen no saturado; sin embargo, en estas condiciones es difícil determinar con precisión la conductividad hidráulica, ya que ésta varía según el tipo de suelo y su contenido de humedad (Dirksen, 1991; Porta et al., 2010). 
En el presente experimento no se observaron efectos significativos cuando la conductividad hidráulica saturada se determinó en laboratorio, mientras que los valores calculados a partir de la medida de la infiltración utilizando un infiltrómetro de disco a la succión de 0,5 cm fueron de cuantía comparativamente inferior y difirieron significativamente, además, entre sí. Esto se debe a que el flujo de agua a través de los macroporos está sujeto a una elevada variabilidad espacial, por lo que la infiltración del agua bajo una tensión/succión determinada impide el flujo de ésta a través de los macroporos y proporciona por tanto una medida más consistente (Porta et al., 2003). Así, la aplicación de los composts A y A+H disminuyó la conductividad hidráulica del suelo medida a la succión de 0,5 cm en comparación con el control (CO), particularmente cuando éstos se aplicaron a la dosis máxima (D4, 96 t/ha). Algunos autores han relacionado la repelencia al agua de algunos suelos con el carácter hidrofóbico de los componentes orgánicos de los mismos (Ellerbrock et al., 2005; Ojeda et al., 2010). Dicho fenómeno es tanto más marcado cuanto más baja es la humedad del suelo, considerándose, de forma general, que existe un umbral de humedad a partir del cual los efectos hidrofóbicos desaparecen (Doerr et al., 2000). Por tanto, la influencia de los composts $\mathrm{A}$ y $\mathrm{A}+\mathrm{H}$ en la hidrofobicidad del suelo podría haber repercutido en la determinación de la conductividad hidráulica medida con infiltrómetro de minidisco, habiéndose eliminado dicho efecto en condiciones de saturación en laboratorio. Ello se vería también apoyado por el incremento en la retención de agua a capacidad de campo $\left(\theta_{\mathrm{vcc}}\right)$ observado al aumentar la dosis de compost aplicada (Tabla 4.2.2).

Tanto al inicio como al final de este Experimento 1 se determinaron diferentes características físico-químicas y químicas en las mezclas de suelo y compost, y también en el suelo control (CO) (Tablas 4.2 .3 y 4.2.4).

Los valores de $\mathrm{pH}$ de los suelos que recibieron compost y del control disminuyeron ligera, pero significativamente, durante el ensayo, especialmente en los suelos enmendados con A, mientras que la conductividad eléctrica (CE) aumentó en todos los tratamientos en una cuantía que osciló entre 0,33 (A+H a D4) y 0,96 dS/m (A a D3) (Tabla 4.2.3). 
Tabla 4.2.3. Influencia del compost $(\mathrm{A}$ y $\mathrm{A}+\mathrm{H})$ y de la dosis de aplicación de éste (D1, D2, D3 y D4, equivalente a 12, 24, 48 y 96 t de materia orgánica total/ha, respectivamente) en el $\mathrm{pH}$ y la conductividad eléctrica (CE) del suelo al inicio y al final del experimento, y valores de estos parámetros en el control sin enmendar (CO)

\begin{tabular}{|c|c|c|c|c|c|}
\hline \multirow{2}{*}{ Compost } & \multirow{2}{*}{ Dosis } & \multicolumn{2}{|c|}{$\mathrm{pH}$} & \multicolumn{2}{|c|}{$\begin{array}{c}\mathrm{CE} \\
(\mathrm{dS} / \mathrm{m})\end{array}$} \\
\hline & & Inicial & Final & Inicial & Final \\
\hline \multirow[t]{4}{*}{$A$} & D1 & 8,28 & $8,10^{* * *}$ & 0,26 & $1,04^{* * *}$ \\
\hline & D2 & 8,23 & $8,06^{* * *}$ & 0,33 & $1,13^{* * *}$ \\
\hline & D3 & 8,14 & $8,02^{* * *}$ & 0,43 & $1,39^{* * *}$ \\
\hline & D4 & 8,16 & $7,96^{* * *}$ & 0,66 & $1,54^{* * *}$ \\
\hline \multirow[t]{4}{*}{$A+H$} & D1 & 8,20 & $8,12^{* * *}$ & 0,29 & $1,01^{* * *}$ \\
\hline & D2 & 8,19 & $8,10^{* * *}$ & 0,37 & $1,23^{* * *}$ \\
\hline & D3 & 8,13 & $8,10^{*}$ & 0,54 & $1,26^{* * *}$ \\
\hline & D4 & 8,17 & $8,11^{*}$ & 1,12 & $1,45^{* *}$ \\
\hline $\mathrm{CO}$ & - & 8,49 & $8,22^{* * *}$ & 0,15 & $0,75^{\star * \star}$ \\
\hline
\end{tabular}

A: compost de alperujo; $\mathrm{A}+\mathrm{H}$ : compost de alperujo más hidrolizado

$*, * * y * * *$ indican diferencias -entre valores iniciales y finales- estadísticamente significativas a $P \leq 0,05, P \leq 0,01$ y $P \leq 0,001$, respectivamente

Según los resultados del análisis estadístico realizado (Tabla 4.2.4), el contenido en carbono orgánico (Corg) del suelo al final del experimento fue inferior o similar al inicial en la mayoría de los tratamientos estudiados, encontrándose la disminución más marcada con las dosis más altas de compost (48 y 96 t/ha, D3 y D4 respectivamente), particularmente con la aplicación de $\mathrm{A}+\mathrm{H}$ a 96 t/ha (D4). Esto podría deberse al aporte de carbono orgánico fácilmente biodegradable con el compost, en cuantía comparativamente superior en $\mathrm{A}+\mathrm{H}$, que podría haberse degradado a lo largo del experimento. Respecto a nitrógeno total ( $\mathrm{N}$ total), no se encontraron diferencias significativas entre el contenido inicial y final en la mayoría de los tratamientos, observándose un incremento gradual con el aumento en la dosis de compost $(\mathrm{A}$ y $\mathrm{A}+\mathrm{H})$. Asimismo, la concentración de nitrógeno mineral (Nmin) aumentó en todos los tratamientos con el transcurso del tiempo, siendo este incremento tanto mayor cuanto más elevada fue la dosis de compost aplicada, por lo que el aporte de compost estuvo relacionado con la mineralización del nitrógeno orgánico del mismo; este efecto fue, además, más marcado con A que con $\mathrm{A}+\mathrm{H}$. Con relación al fósforo, el contenido en este elemento al final del experimento fue similar o superior al valor inicial cuando se aplicó A, no encontrándose una tendencia clara de variación con el aporte de $\mathrm{A}+\mathrm{H}$. En potasio, se observó que el contenido en este elemento fue de 
mayor magnitud a medida que aumentó la dosis de compost aplicada, no apreciándose, además, un cambio importante en el control sin enmendar (CO) entre el inicio y el fin del estudio. Merece destacarse el incremento marcado en los niveles de fósforo y de potasio registrado al inicio del experimento, tras aplicar los composts $\mathrm{A}$ y $\mathrm{A}+\mathrm{H}$ al suelo. En el caso de potasio, este efecto podría deberse al aporte directo de este elemento derivado del elevado contenido del mismo en los composts de alperujo (ver la sección 4.1.2.2, características químicas y composición de los composts); respecto a fósforo, algunos autores han relacionado el incremento en el contenido en fósforo asimilable del suelo observado tras la aplicación de compost a los compuestos fenólicos presentes en algunos materiales orgánicos, que aumentaban la disponibilidad de este elemento debido a la interacción de los polifenoles con los óxidos metálicos, especialmente de Al y Fe (Bustamante et al., 2011; Kraus et al., 2003). En todos los tratamientos estudiados se registraron niveles de calcio, magnesio y sodio al final del ensayo superiores a los valores iniciales; este incremento fue de mayor magnitud en el control sin enmendar que en los tratamientos con compost en el caso de calcio, mientras que se registró la situación contraria con magnesio y sodio. El incremento en el contenido de estos elementos y en la CE del suelo está probablemente relacionado con los aportes de agua realizados para mantener el grado de humedad requerido en el suelo a lo largo del año de experimentación.

Con los valores de los parámetros físico-químicos y químicos obtenidos al final del experimento, se realizó el análisis de la varianza multifactorial (Compost y Dosis de compost) y el estudio comparativo de las mezclas de suelo y compost con los controles sin aporte de materia orgánica, presentándose los resultados correspondientes en las Tablas 4.2 .5 y 4.2.6, respectivamente.

Respecto a las características físico-químicas, el análisis de la varianza multifactorial realizado (Tabla 4.2.5) indicó que el compost $A+H$ incrementó el valor de $\mathrm{pH}$ del suelo respecto a $\mathrm{A}$, y que la aplicación de dosis crecientes de compost disminuyó significativa y progresivamente el valor de dicho parámetro. En contraste con lo anterior, se observó un incremento en la conductividad eléctrica (CE) a medida que aumentó la dosis de compost aplicada, con independencia del origen de éste (A vs. $\mathrm{A}+\mathrm{H})$. 


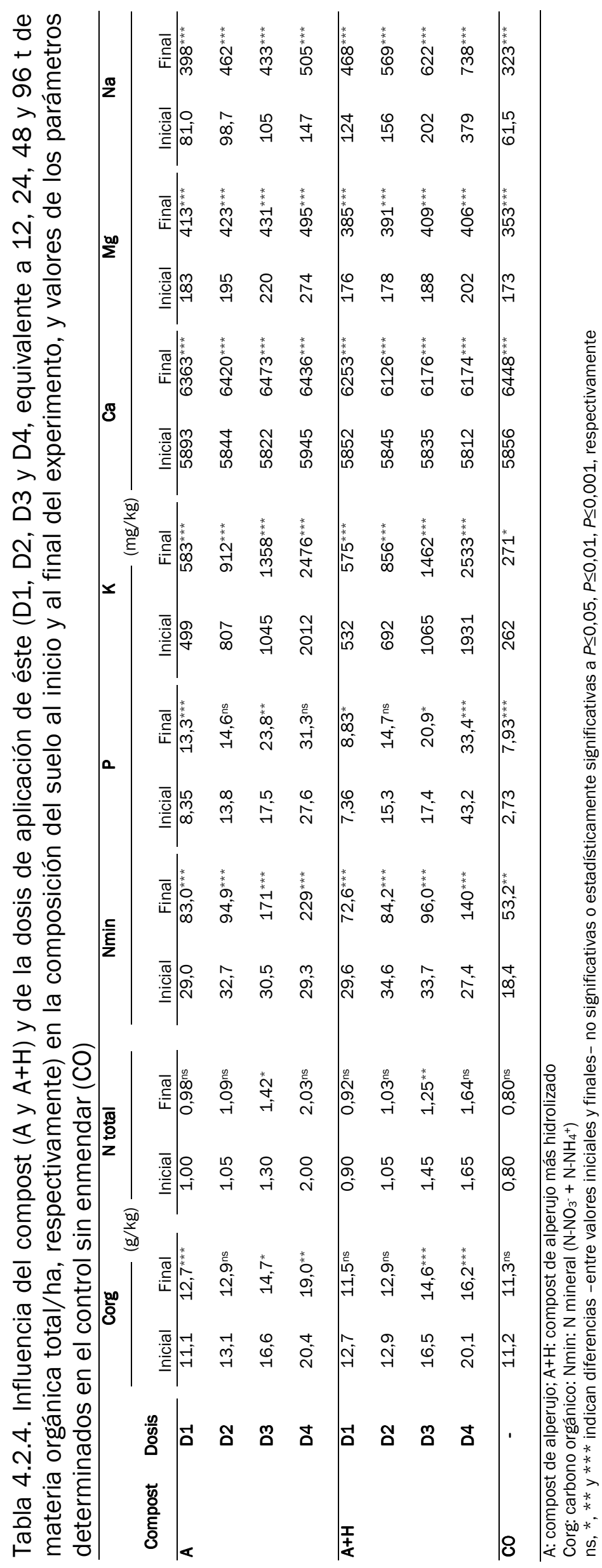




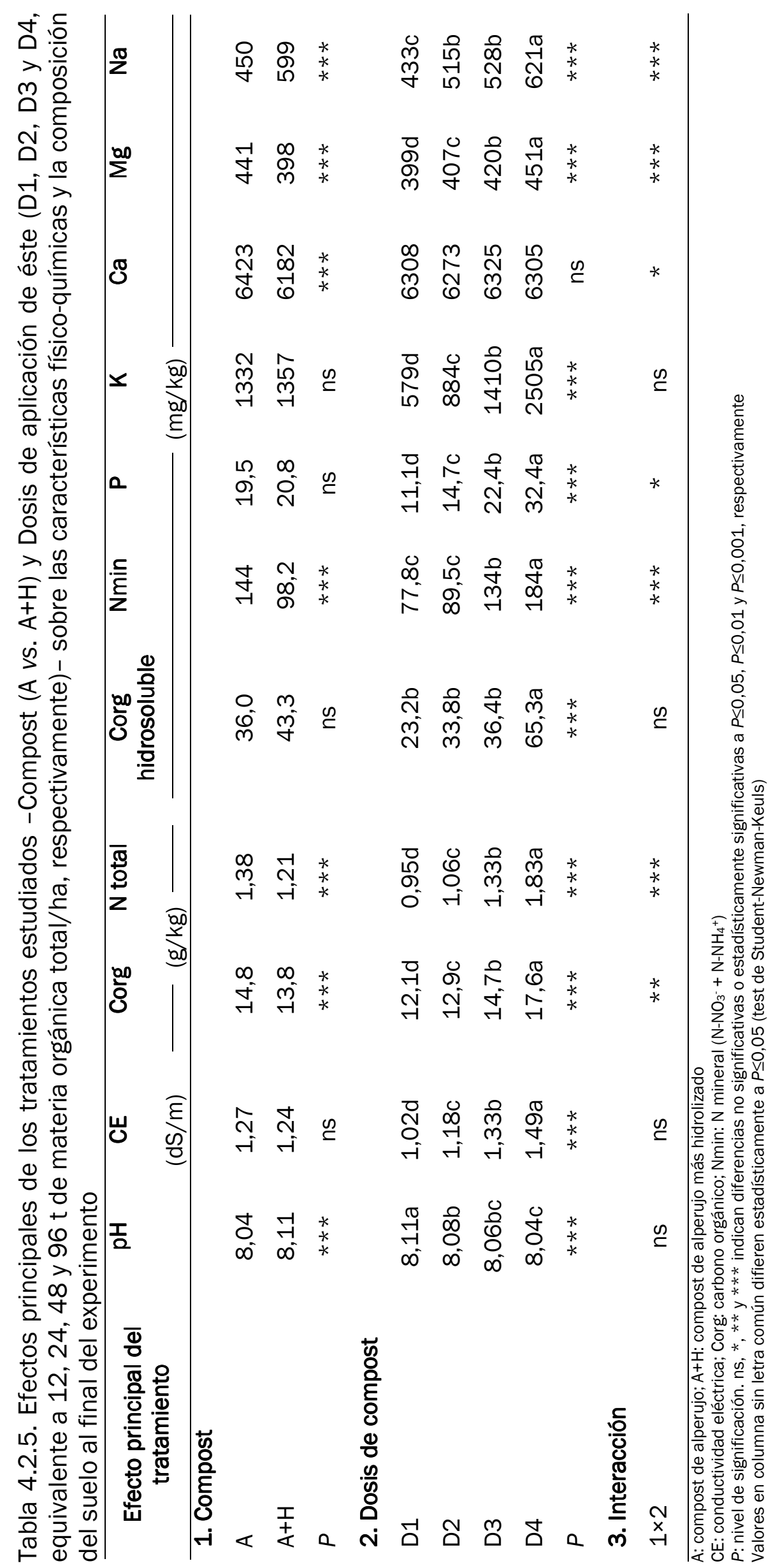


El estudio conjunto de los tratamientos con compost y el control (Tabla 4.2.6) puso de manifiesto que el valor de $\mathrm{pH}$ fue significativamente superior en el suelo que no recibió aporte de materia orgánica ( $\mathrm{CO})$, destacando además la disminución de este parámetro con A a 48 y 96 t/ha (D3 y D4, respectivamente) respecto al resto de tratamientos. A diferencia de lo anterior, la adición de compost provocó un aumento en la CE en comparación con el control, llegándose a duplicar el valor de este parámetro cuando la dosis de aplicación fue de 96 t/ha.

Con relación a la composición del suelo, la aplicación del compost A elevó el contenido en carbono orgánico (Corg), nitrógeno total ( $\mathrm{N}$ total), nitrógeno mineral (Nmin), calcio y magnesio en comparación con $\mathrm{A}+\mathrm{H}, \mathrm{y}$, por el contrario, este último mostró niveles comparativamente más altos de sodio (Tabla 4.2.5), coincidiendo estos resultados con los contenidos en estos elementos registrados en los composts $\mathrm{A}$ y $\mathrm{A}+\mathrm{H}$, tal y como ya se ha indicado en la sección 4.1.2.2. Por otro lado, no se encontraron diferencias en el contenido en carbono orgánico hidrosoluble, fósforo y potasio entre estos dos composts. En general, el aumento en la dosis de compost aplicada provocó un incremento significativo en la concentración de Corg, $\mathrm{N}$ total, Nmin, fósforo, potasio, magnesio y sodio, mientras que dicho factor (Dosis) no influyó en el contenido en calcio, y sólo se registró, además, un aumento significativo en la concentración de carbono orgánico hidrosoluble cuando se aplicó la dosis máxima (D4, 96 t/ha). Todas las interacciones Compost $x$ Dosis resultaron estadísticamente significativas a excepción de las correspondiente a los niveles de carbono orgánico hidrosoluble y potasio.

Al estudiar comparativamente los suelos tratados con compost $(A \circ A+H)$ y el control que no recibió aporte de materia orgánica (Tabla 4.2.6), se registró un incremento significativo en la concentración de $\mathrm{N}$ total con la aplicación de los composts, tanto mayor cuanto más elevada fue la dosis de aplicación. De la misma manera, se observó un aumento notable en el contenido en carbono orgánico hidrosoluble al aplicar las dosis de 48 (D3) y 96 t/ha (D4) de A, y de 24 (D2), 48 (D3) y 96 t/ha (D4) de $A+H$, alcanzándose con este último ( $A+H$ a 96 t/ha) el máximo valor de este parámetro. Asimismo, la aplicación de compost aumentó significativamente la concentración de Corg y fósforo, a excepción de la dosis mínima de A+H (12 t/ha, D1). Por otro lado, los niveles de Nmin, potasio, magnesio y sodio en los tratamientos que recibieron compost fueron superiores a los del suelo control, siendo este incremento más marcado para Nmin y magnesio con $A$, y para sodio con $\mathrm{A}+\mathrm{H}$. 


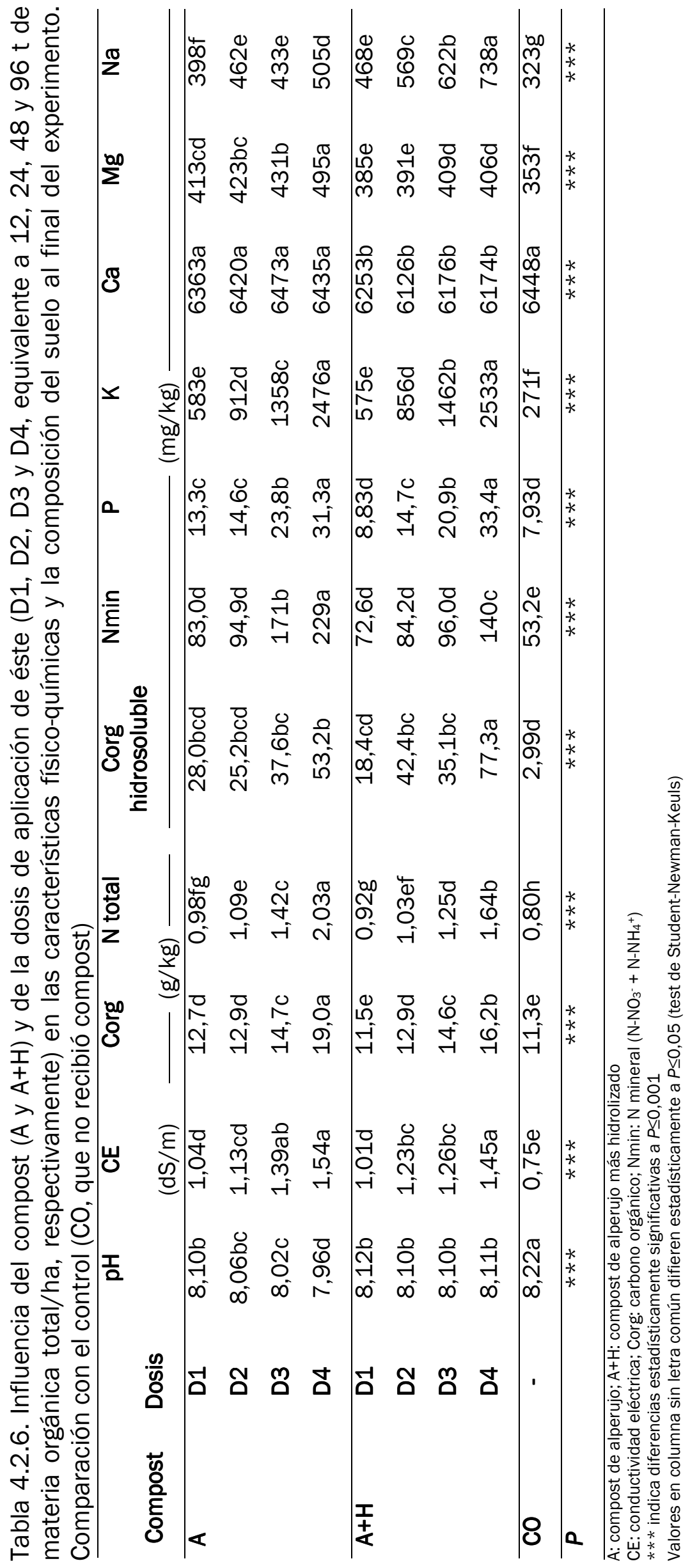


Merecen destacarse los elevados valores de concentración de nitrógeno, fósforo y potasio asimilables, que llegaron a ser cuatro veces superior al control para nitrógeno y fósforo, y nueve veces para potasio, lo que está estrechamente relacionado con el valor fertilizante de los composts de alperujo con vistas a su uso como enmiendas del suelo. En relación con calcio, los tratamientos con A no mostraron diferencias significativas respecto al control, y los de $\mathrm{A}+\mathrm{H}$ fueron inferiores a éste.

La aplicación de los composts A y A+H al suelo calizo estudiado provocó efectos similares a los señalados por otros autores, que indican un efecto variable de los materiales orgánicos sobre el pH así como un incremento en la conductividad eléctrica (CE) (Diacono y Montemurro, 2011; Hargreaves et al., 2008). En adición, en este Experimento 1 se han registrado, en general, aumentos en el contenido en $\mathrm{N}$ total, Corg, Corg hidrosoluble, Nmin, potasio, fósforo y magnesio respecto al control sin aplicación de materia orgánica tras un año de experimentación. Esta mejora en la fertilidad del suelo se ha observado también en otros estudios, especialmente a largo plazo, tras la aplicación regular y continuada de materia orgánica exógena (Erhart y Hartl, 2010; Herencia et al., 2007).

\subsubsection{Experimento 2. Dinámica del nitrógeno en los suelos tratados con los composts} A y $\mathrm{A}+\mathrm{H}$. Caracterización química, bioquímica y microbiológica

El nitrógeno suele ser el elemento limitante del desarrollo de las especies cultivadas, debido a las deficiencias en éste derivadas, principalmente, de la degradación del suelo y la insuficiente restitución del nitrógeno extraído por los cultivos. Esto ha generado un elevado consumo de fertilizantes nitrogenados en los últimos años, provocando perjuicios desde el punto de vista económico y medioambiental (Cordovil et al., 2007; Ramos, 2005).

Durante el proceso de mineralización, los microorganismos del suelo transforman los compuestos orgánicos nitrogenados, hidrolizándolos y convirtiéndolos en formas inorgánicas más sencillas, disponibles para las plantas (nitrato y amonio); mientras que en la inmovilización los microorganismos llevan a cabo la síntesis de proteínas a partir de nitrógeno mineral (Madrid et al., 2011). Los procesos de mineralización e inmovilización del nitrógeno tienen lugar simultáneamente (denominándose este sistema dinámico en inglés como MIT, “mineralizationimmobilization turnover"; Jansson y Persson, 1982), por lo que la 
mineralización/inmovilización neta depende del balance de la reserva de nitrógeno mineral del suelo a lo largo de un período de tiempo definido (Amlinger et al., 2003).

Mediante el compostaje, la concentración de nitrógeno en el material orgánico original se reduce y los compuestos nitrogenados pasan a formas estables, disminuyendo así su disponibilidad para las plantas. Las bajas tasas de mineralización de los composts aplicados al suelo pueden reducir la lixiviación de nitratos -mediante la ralentización de la conversión del nitrógeno orgánico a nitrato- respecto a otros materiales orgánicos que no hayan experimentado dicho proceso de maduración y estabilización (Evanylo et al., 2008; Hadas et al., 1995). El estudio de la dinámica del nitrógeno es de gran interés a la hora de aplicar una dosis de compost -acorde con su capacidad para liberar nitrógeno mineral- que pueda complementar o reemplazar la fertilización mineral y, de este modo, proporcionar parte de la cantidad de nitrógeno requerida por los cultivos (Hadas et al., 2004).

De manera general, una relación $\mathrm{C} / \mathrm{N}$ inferior a 20 se considera como buen indicador de la mineralización neta de nutrientes, mientras que un valor superior de este cociente se relaciona con la inmovilización (Costa et al., 1991; Sikora y Szmidt, 2005), aunque en los últimos años se ha demostrado que este ratio no debe ser el único parámetro a tener en cuenta para predecir la mineralización (Cabrera et al., 2005a; Gabrielle et al., 2004, Tognetti et al., 2008). En lo referente a este aspecto, Amlinger et al. (2003) indicaron que, además de la influencia de factores específicos del cultivo y el lugar de aplicación del compost (características y manejo del suelo, y condiciones ambientales del emplazamiento, principalmente), la dinámica del nitrógeno del suelo tras la aplicación de compost depende de distintos factores: relación $\mathrm{C} / \mathrm{N}$ del material residual (fresco, original) objeto de compostaje, condiciones del proceso, tasa de descomposición/estabilización y duración del compostaje, acondicionamiento posterior del compost, parámetros de calidad del compost final producido (relación $\mathrm{C} / \mathrm{N}$, fracciones biodisponibles de carbono y nitrógeno), y época (momento) de aplicación de este último, entre otros.

Por tanto, y debido a que el proceso de mineralización del nitrógeno orgánico sirve para suministrar nitrógeno a las plantas cultivadas, resulta de gran interés la realización de experimentos que estudien la dinámica del nitrógeno y determinen los efectos de la aplicación de materiales orgánicos sobre la cantidad de nitrógeno disponible para los cultivos a lo largo de un período concreto (Roy et al., 2010), pudiéndose realizar para ello ensayos de incubación en laboratorio bajo condiciones 
controladas o ensayos de campo, y aplicar modelos basados en el estudio de la cinética de mineralización del nitrógeno, principalmente (Amlinger et al., 2003).

\subsubsection{Experimento 2.1. Ensayo de incubación con el suelo calizo}

Para estudiar la dinámica del nitrógeno en el suelo calizo (empleado en el Experimento 1, sección 4.2.1, y a lo largo de toda esta Tesis) tratado con los composts A y $\mathrm{A}+\mathrm{H}$, se realizó un experimento de incubación a corto plazo (28 días), aplicando tres dosis de compost equivalentes a 12, 24 y 48 t de materia orgánica total/kg de suelo (D1, D2 y D3, respectivamente). Tanto las mezclas de suelo y compost como el suelo control recibieron nitrógeno, fósforo y potasio mediante la aplicación de una disolución nutritiva, según se ha señalado en la sección 3.3.2 de Materiales y Métodos. Los resultados de la variación del contenido en nitrógeno mineral, en formas nítrica $\left({\mathrm{N}-\mathrm{NO}_{3}}^{-}\right)$y amoniacal $\left(\mathrm{N}^{-\mathrm{NH}_{4}}{ }^{+}\right)$, en el suelo a lo largo de los 28 días de incubación se presentan en la Figura 4.2.1.

El experimento mostró que la aplicación del compost A incrementó el contenido de nitrato en el suelo a lo largo del período de incubación, siendo la cuantía de este efecto tanto mayor cuanto más elevada fue la dosis de compost aportada. Además, se observó que la forma amoniacal disminuyó progresivamente durante los primeros 7 días del ensayo hasta desaparecer en su totalidad, en coincidencia con el incremento más marcado en la forma nítrica (nitrificación). Asimismo, el contenido inicial de amonio y la disminución de éste con el tiempo fueron tanto mayores cuanto más elevada fue la dosis de A. En el control no enmendado (CO) se observó también un incremento del contenido en nitrógeno en forma nítrica, aunque en cuantía inferior a los tratamientos con A, y un descenso progresivo del nivel de amonio.

En contraste con lo anterior, el compost $\mathrm{A}+\mathrm{H}$ provocó la inmovilización del nitrógeno nítrico durante los primeros 7 días del experimento con la dosis de 12 t/ha, y durante los primeros 21 días con las dosis de 24 y 48 t/ha, incrementándose posteriormente el contenido de $\mathrm{N}^{-N_{3}}$ - con las dos dosis más bajas (12 y 24 t/ha). Además, el contenido en amonio disminuyó hasta desaparecer con mayor rapidez (3 días) que con el compost $A$. De todo ello puede inferirse un efecto inmediato desfavorable de $\mathrm{A}+\mathrm{H}$ sobre el desarrollo vegetal, debido a una menor disponibilidad de nitrógeno mineral, lo que se estudiará más adelante, en la sección 4.3. El aumento del contenido en nitrógeno mineral al final del ensayo con las dosis de 12 y 24 t/ha parece sugerir la posterior mineralización del nitrógeno inmovilizado, lo que podría 
evaluarse en un ensayo similar pero a más largo plazo. Con relación a este último efecto indicado, Madejón et al. (2001c) señalaron que composts de origen agroindustrial (vinazas de remolacha) con una tasa alta de mineralización tenían efectos positivos sobre las plantas inmediatamente después de su aplicación al suelo, mientras que si el material compostado provocaba la inmovilización de nitrógeno tras su adición, los efectos favorables sobre los cultivos se producían después de un largo período de tiempo (> 24 meses).
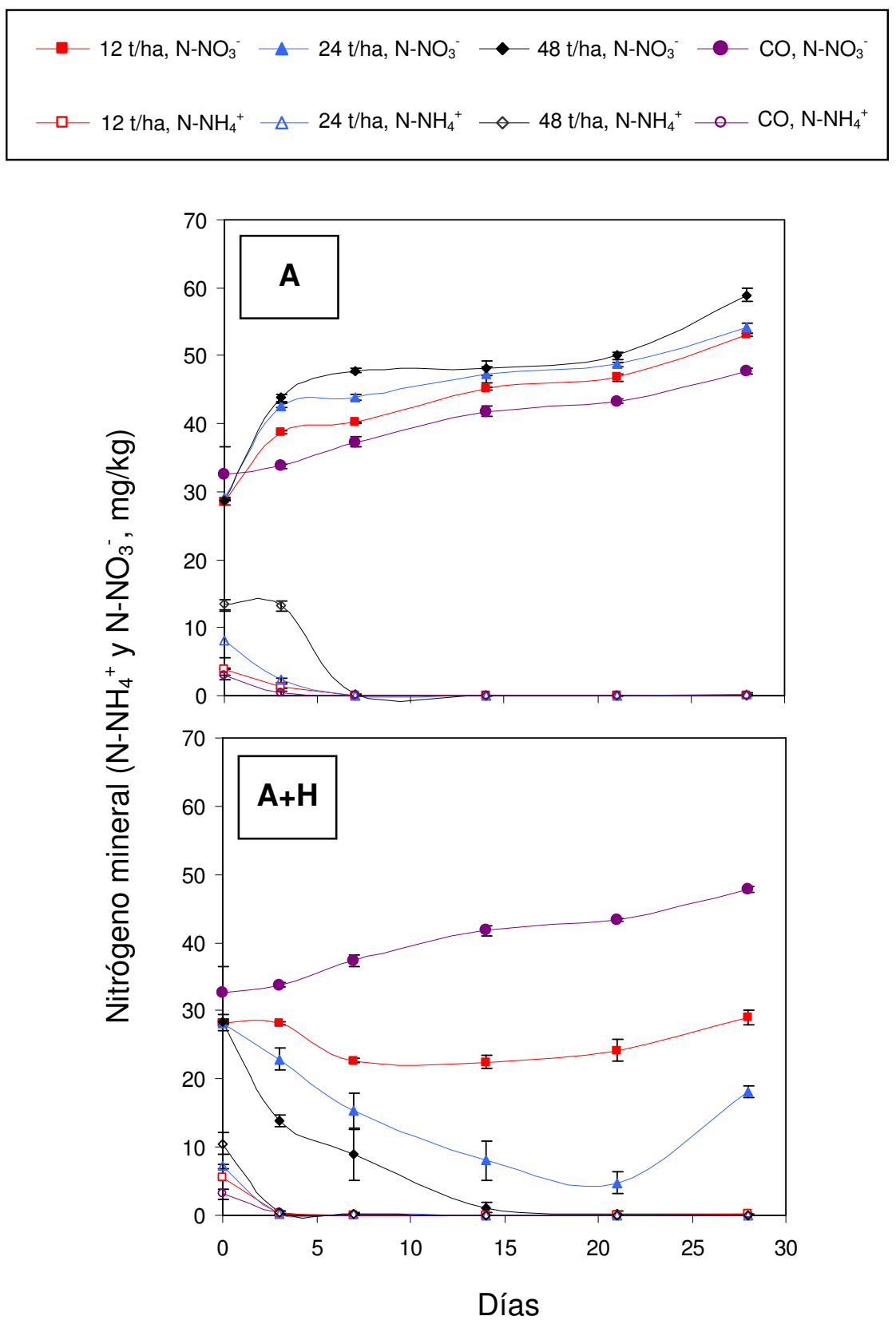

Figura 4.2.1. Variación de la concentración de nitrógeno mineral $\left(\mathrm{N}^{-} \mathrm{NH}_{4}{ }^{+}\right.$y N-NO$\left.{ }_{3}^{-}\right)$en el suelo tratado con los composts $\mathrm{A}$ y $\mathrm{A}+\mathrm{H}$ a las dosis de 12, 24 y $48 \mathrm{t} /$ ha a lo largo del ensayo de incubación. Comparación con el control ( $\mathrm{CO}$, que no recibió compost) $\mathrm{A}$ : compost de alperujo; $\mathrm{A}+\mathrm{H}$ : compost de alperujo más hidrolizado Las barras verticales indican el error estándar 
Asimismo, los resultados obtenidos en este Experimento 2.1 coinciden con otros estudios realizados con alperujo compostado, que señalan que la disponibilidad del nitrógeno del suelo tratado con compost de alperujo es el factor clave del crecimiento de las plantas, por su alta resistencia a la mineralización (Alburquerque et al., 2007), e informan, además, del riesgo de inmovilización inmediatamente después de su aplicación (Cabrera et al., 2005b).

La mineralización neta de nitrógeno se calculó substrayendo al contenido en nitrógeno mineral $\left(\mathrm{N}^{-\mathrm{NH}_{4}}{ }^{+}+\mathrm{N}^{-\mathrm{NO}_{3}}{ }^{-}\right)$de cada tratamiento con compost la concentración de nitrógeno mineral en el control sin enmendar (Figura 4.2.2). Los tratamientos con A mostraron un incremento en los niveles (netos) de nitrógeno mineral al inicio del ensayo de incubación, que fue tanto mayor cuanto más elevada fue la dosis de compost aplicada; posteriormente, la concentración neta de nitrógeno mineral disminuyó en todos los tratamientos con A, y, a partir del día 14 de incubación, este parámetro permaneció estable o aumentó sólo ligeramente. En cuanto a $\mathrm{A}+\mathrm{H}$, se observó el proceso de inmovilización más arriba indicado, llegando a registrarse una disminución en el contenido en nitrógeno mineral, con respecto al control, del orden de $48 \mathrm{mg} / \mathrm{kg}$ suelo.

El uso de modelos para predecir la cantidad de nitrógeno mineralizado a lo largo del tiempo en suelos tratados con materiales orgánicos conlleva ciertas dificultades, no sólo porque intervienen procesos de transformación e intercambio entre las distintas formas de nitrógeno (nitrógeno orgánico resistente a la degradación, nitrógeno orgánico fácilmente biodegradable, y nitrógeno mineral), sino también por las posibles pérdidas debidas a la alta movilidad del nitrógeno mineral en el suelo (Sistani et al., 2008). Dichos modelos se aplican a los resultados obtenidos en los ensayos de incubación controlada a corto o a largo plazo (con o sin lixiviación periódica). La cinética de mineralización del nitrógeno se ha expresado tradicionalmente mediante el ajuste exponencial de primer orden (Stanford y Smith, 1972), aunque posteriormente se han desarrollado otros modelos (Gil et al., 2011) como el doble exponencial de primer orden (Molina et al., 1980; Richter et al., 1980), la combinación del modelo exponencial de orden cero y de primer orden (Bonde y Rosswall, 1987), o los modelos hiperbólico (Juma et al., 1984) y parabólico (Broadbent, 1986), principalmente. 


\begin{tabular}{|lll|}
\hline$--\mathrm{A}, 12 \mathrm{t}$ /ha & $-\mathrm{A}, 24$ tha & $-\mathrm{A}, 48$ tha \\
- & $\mathrm{A}+\mathrm{H}, 12$ tha & $\mathrm{A}+\mathrm{H}, 24$ tha \\
\hline
\end{tabular}

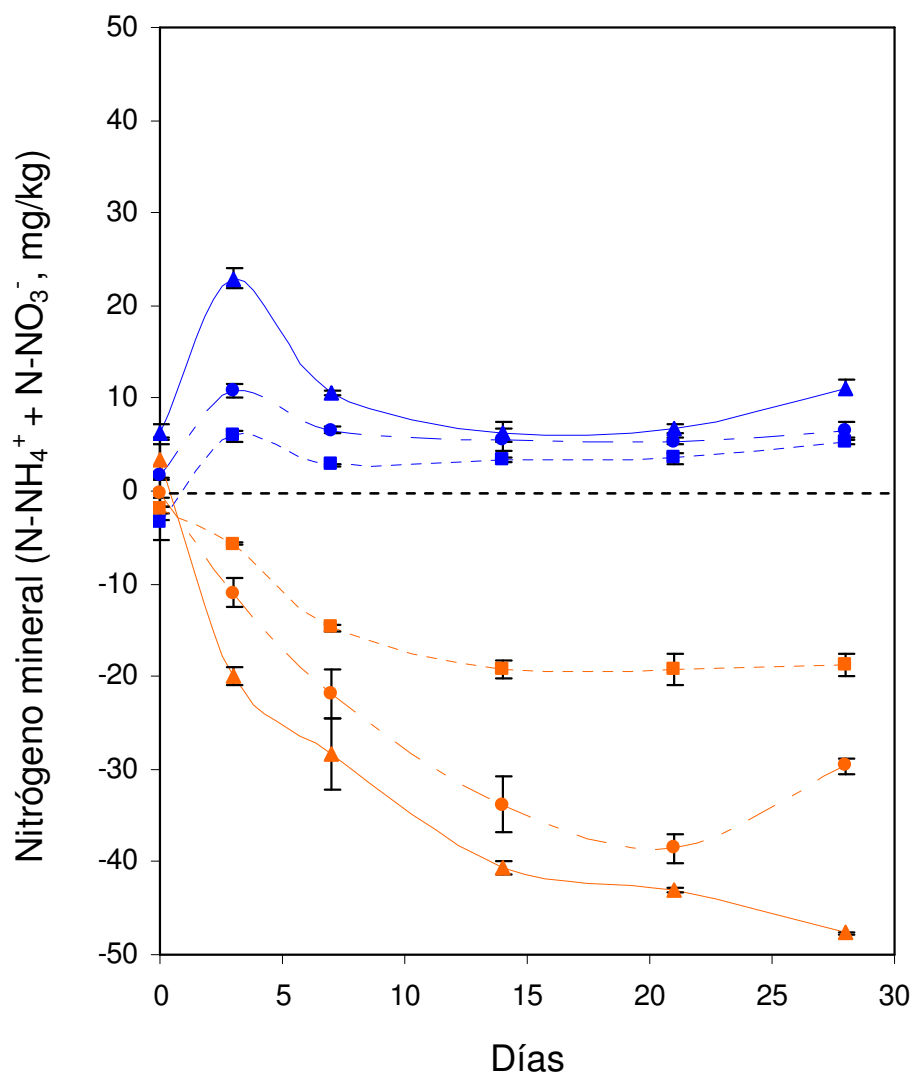

Figura 4.2.2. Mineralización/inmovilización neta $\left(\mathrm{N}^{-\mathrm{NH}_{4}}{ }^{+}+\mathrm{N}-\mathrm{NO}_{3}{ }^{-}\right)$del nitrógeno orgánico en el suelo -tratado con los composts A y A+H a las dosis de 12, 24 y 48 t/ha- a lo largo del ensayo de incubación (resultados obtenidos restando los valores en el control)

A: compost de alperujo; $\mathrm{A}+\mathrm{H}$ : compost de alperujo más hidrolizado Las barras verticales indican el error estándar

En este Experimento 2.1 se ajustó la evolución de la mineralización neta de nitrógeno a lo largo del ensayo a los modelos indicados (datos no presentados), obteniéndose la mayor bondad de ajuste para el modelo hiperbólico en A, y para el modelo parabólico en $\mathrm{A}+\mathrm{H}$ (Tabla 4.2.7). El ajuste a los modelos utilizados comúnmente en los estudios de dinámica del nitrógeno se ha visto dificultado en los tratamientos con A, debido al incremento en el contenido de nitrógeno mineral inicial, y a la posterior disminución de éste, además de la estabilización de los valores al final del ensayo. 
Tabla 4.2.7. Cinética de la concentración neta de nitrógeno mineral (nítrico + amoniacal) en el suelo tratado con los composts $\mathrm{A}$ y $\mathrm{A}+\mathrm{H}$ a las dosis de 12, 24 y 48 t/ha en el ensayo de incubación

\begin{tabular}{lccccc}
\hline \multicolumn{1}{c}{ Compost } & $\begin{array}{c}\text { Dosis } \\
(\mathrm{t} / \mathrm{ha})\end{array}$ & Modelo de ajuste & \multicolumn{2}{c}{ Parámetro } & $\mathrm{R}^{\mathbf{2}}$ \\
\hline $\mathrm{A}$ & & & $\mathrm{No}$ & $\mathrm{b}$ & \\
\hline & 12 & \multirow{2}{*}{$\mathrm{N}_{\min }=\frac{\mathrm{N}_{0} \mathrm{t}}{\left(\mathrm{bN}_{0}+\mathrm{t}\right)}$} & 3,45310 & $-0,337801$ & 0,608 \\
& 48 & & 7,24968 & $-0,282689$ & 0,686 \\
\hline $\mathrm{A}+\mathrm{H}$ & & & $\mathrm{A}$ & $\mathrm{b}$ & \\
\hline & 12 & \multirow{2}{*}{$\mathrm{N}_{\min }=\mathrm{At}^{\mathrm{b}}$} & $-6,19404$ & 0,366695 & 0,837 \\
& 24 & & $-10,32860$ & 0,381952 & 0,837 \\
& 48 & & $-13,82440$ & 0,378004 & 0,967 \\
\hline
\end{tabular}

A: compost de alperujo; $\mathrm{A}+\overline{\mathrm{H}}$ : compost de alperujo más hidrolizado

Nmin: concentración neta de nitrógeno mineral (respecto al contenido inicial en el control) en el tiempo t

$\mathrm{N}_{0}$ : nitrógeno potencialmente mineralizable

t: tiempo de incubación (días)

A, b: coeficientes de regresión

Los coeficientes de determinación $\left(\mathrm{R}^{2}\right)$ mostraron un nivel de significación de al menos $P \leq 0,05$

Los dos composts utilizados en el presente estudio mostraron una dinámica del nitrógeno orgánico aplicado al suelo (exógeno) distinta. Ambos poseen una relación $\mathrm{C} / \mathrm{N}$ inferior a 20 (11 y 12 para $\mathrm{A}$ y $\mathrm{A}+\mathrm{H}$, respectivamente), indicativa de una mineralización neta del nitrógeno orgánico, por lo que los resultados de este ensayo confirman que dicho ratio no es adecuado por sí solo, y que debería considerarse juntamente con otros parámetros para conocer la dinámica del nitrógeno orgánico del suelo. El comportamiento diferencial de los composts A y A+H en relación con la tasa de mineralización del nitrógeno orgánico -mineralización neta al aplicar A al suelo, e inmovilización tras el aporte de $\mathrm{A}+\mathrm{H}$ - podría atribuirse a la menor estabilidad y madurez de este último compost, que puede inferirse de algunas de las características químicas y biológicas de dicho material, tales como su elevado contenido en carbono orgánico hidrosoluble, su actividad microbiana superior, y su mayor fitotoxicidad (ver las secciones 4.1.2, 4.1.3 y 4.1.5).

Asimismo, el proceso de inmovilización de nitrógeno observado con A+H podría estar asociado al elevado contenido en polifenoles solubles registrado en este material orgánico (18,9 g/kg ms; Tabla 4.1.7). Dichos compuestos no sólo pueden provocar la inmovilización del nitrógeno mineral, sino también retrasar la mineralización del nitrógeno orgánico (Chaves et al., 2005; Constantinides y Fownes, 1994; Hättenschwiler y Vitousek, 2000; MacKenzie et al., 2006). Los compuestos fenólicos son tóxicos para algunos microorganismos (bacterias y hongos, entre otros) 
involucrados en las reacciones de mineralización del nitrógeno orgánico, y, además, los fenoles presentan una gran capacidad de unión con las proteínas, por su alta afinidad por los grupos amida -estos últimos relacionados con la formación de nitrógeno amoniacal-, formando complejos no disponibles para los microorganismos (Capasso et al., 1995). Por tanto, el efecto de los fenoles sobre la disponibilidad de nitrógeno no sólo corresponde a la inmovilización del nitrógeno mineral, sino también a la inhibición de la mineralización del nitrógeno orgánico mediante los mecanismos más arriba señalados (Chaves et al., 2005). No obstante, los fenómenos de inmovilización que ocasionan los compuestos fenólicos son transitorios (Piotrowska et al., 2006; Saadi et al., 2007; Sierra et al., 2007), y la degradación y/o eliminación de éstos hasta concentraciones no perjudiciales suprime su impacto negativo sobre el suelo (Alfano et al., 2008; Piotrowska et al., 2011). Otros experimentos realizados con alperujos compostados no observaron fenómenos de inmovilización de nitrógeno, debido, fundamentalmente, a que los niveles de los compuestos fenólicos disminuyeron progresiva y significativamente durante el proceso de compostaje, hasta alcanzar valores de concentración no tóxicos (Alburquerque et al., 2006b, 2007).

En base a los resultados hasta aquí presentados, el uso del compost $\mathrm{A}+\mathrm{H}$ como mejorador del suelo requerirá retrasar la siembra/plantación/trasplante de los cultivos cierto período de tiempo tras la aplicación de este compost al suelo, particularmente el primero inmediato a su adición, o bien -en el caso de cultivos leñosos - aplicar dicho compost en períodos que no coincidan con una alta demanda de nitrógeno por el cultivo, en coincidencia con las indicaciones de otros autores sobre el uso de materiales orgánicos cuya aplicación al suelo provoca inmovilización de nitrógeno mineral (Flavel et al., 2005; Madrid et al., 2011).

Además, debe indicarse que las condiciones de los experimentos de incubación en laboratorio corresponden a condiciones controladas y favorables para la actividad microbiana, por lo que, en la aplicación de compost en condiciones de campo, la dinámica de mineralización/inmovilización del nitrógeno estará sujeta a variaciones respecto a las conclusiones obtenidas en este tipo de ensayos (Hadas et al., 2004). Por estos motivos, se consideró de gran interés realizar un estudio de evaluación agronómica, aplicando los composts $\mathrm{A}$ y $\mathrm{A}+\mathrm{H}$ al suelo a las dosis comúnmente utilizadas en el ámbito agrícola, cuyos resultados se presentan en la sección 4.3. 


\subsubsection{Experiment 2.2. Short-term incubation assay with a Spanish clay loam soil and an Italian sandy loam soil}

Studies on the impact of compost on soil have mainly considered physical and chemical parameters involved in plant productivity (crop yield) in long-term experiments, although organic amendments can influence not only soil structure and nutrient content, but also soil microbiota (Crecchio et al., 2001; Pérez-Piqueres et al., 2006; Ros et al., 2003).

Microbiological and biochemical parameters are highly sensitive to small changes produced by soil management practices (Diacono and Montemurro, 2011). Soil microorganisms play a key role in organic matter degradation, nutrient cycling, and other significant biochemical transformations (Murphy et al., 2007). In this context, elements from organic compounds are transformed into inorganic, mineral forms, and afterwards they are either immobilized and used in microbial biomass synthesis or released into the soil mineral pool (Baldock and Nelson, 2000). Hence, biological determinations are useful tools to assess the influence of organic matter application on soil characteristics.

A short-term incubation assay, using two different textured soils, was carried out in order to elucidate the biochemical and microbiological processes involved in nitrogen dynamics after these soils were amended with compost.

Together with the Spanish, calcareous, clay loam soil (S1) used throughout this $\mathrm{PhD}$ Thesis, an Italian soil (S2) was also studied in the experiment. The latter was a sandy loam soil -sampled from Pisa (Tuscany, Italy)-, slightly alkaline $(\mathrm{pH}=7.50)$ and with an electrical conductivity of $3.1 \mathrm{dS} \mathrm{m}^{-1}$. This soil also showed the following composition: organic carbon $28.9 \mathrm{~g} \mathrm{~kg}^{-1}$, total nitrogen $2.79 \mathrm{~g} \mathrm{~kg}^{-1}$, mineral nitrogen $146 \mathrm{mg} \mathrm{kg-1}$, available phosphorus $79.5 \mathrm{mg} \mathrm{kg}^{-1}$, available potassium 383 mg kg-1, and carbonates $\left(\mathrm{CaCO}_{3}\right) 2.2 \%$ (on dry weight).

Both soils were moistened to $50 \%$ of their water holding capacity at field capacity and preincubated at $25^{\circ} \mathrm{C}$ during 10 days. Afterwards, they were amended with composts A (two-phase olive mill waste compost, TPOMW) and $\mathrm{A}+\mathrm{H}$ (compost from TPOMW+animal fatty-proteinaceous waste) at a rate equivalent to $24 \mathrm{Mg}$ total organic matter (TOM) ha-1 prior to their incubation at $25^{\circ} \mathrm{C}$ during 56 days. Control soils (CO), which did not receive organic matter application, were also included in the experiment 
(see section 3.3.3). Neither compost-amended soils nor control soils received additional, extra mineral fertilizers in contrast to Experiment 2.1 where all treatments studied (both soils amended with composts and controls) were fed with mineral nitrogen, phosphorus and potassium.

Results for variations with time in chemical, biological and biochemical parameters determined in every experimental treatment tested as well as for the factorial analysis of variance -Compost factor (A vs. A+H) and Soil factor (S1 vs. S2)applied to these parameters are presented in Figures 4.2.3 to 4.2.9 and in Tables 4.2.8 and 4.2.10, respectively.

Changes in soil mineral $\mathrm{N}$ content (expressed as $\mathrm{NO}_{3}-\mathrm{N}+\mathrm{NH}_{4}{ }^{+}-\mathrm{N}$ ) throughout the incubation period are presented in Figure 4.2.3 and Table 4.2.8. Higher values were observed in S2 in comparison with S1; control soils (CO) underwent less pronounced variations than amended soils, showing an increase at the beginning of the incubation period (S1) or a decrease on day 28 (S2).

When amended with compost $\mathrm{A}$, soil mineral $\mathrm{N}$ concentration evolved similarly to $\mathrm{CO}$ (controls), except for a comparatively lower $\mathrm{N}$ content on day 7 after $\mathrm{A}$ was added to S2, and a higher decrease on day 28 in S1.

Application of compost $\mathrm{A}+\mathrm{H}$ resulted in a strong $\mathrm{N}$ immobilization process in both soils, this effect being higher in magnitude in S2 (40 mg kg-1, S2 vs. $17 \mathrm{mg} \mathrm{kg}^{-1}$, S1, in comparison with control soils [CO] on day 28). Nevertheless, and considering the initial values of mineral $\mathrm{N}$, the decrease in mineral $\mathrm{N}$ content in $\mathrm{S} 1$ was proportionally larger than in S2, thus emphasizing that no mineral $\mathrm{N}$ was recorded on day 28 in soil S1. From day 28 to day 56, both soils amended with $\mathrm{A}+\mathrm{H}$ exhibited a slight $\mathrm{N}$ increase, which could be related with the subsequent mineralization of the organic $\mathrm{N}$ formerly immobilized.

Other authors (Amlinger et al., 2003; Cabrera et al., 2005b) have reported differences in compost mineralization rates between different textured soils, a comparatively lower mineralization being observed in clay soils -due to the high protection of organic matter by the humus-clay complex, which hinders microbial attack-, and reversely for sandy soils, i.e. a comparatively larger mineralization. Madrid et al. (2011) studied nitrogen dynamics in two soils with different texture (clay and sandy) amended with municipal solid waste (MSW) compost and found a similar $\mathrm{N}$ immobilization after the addition of this compost in both soils, followed by the mineralization of organic $\mathrm{N}$, which was significantly higher in the sandy soil. 


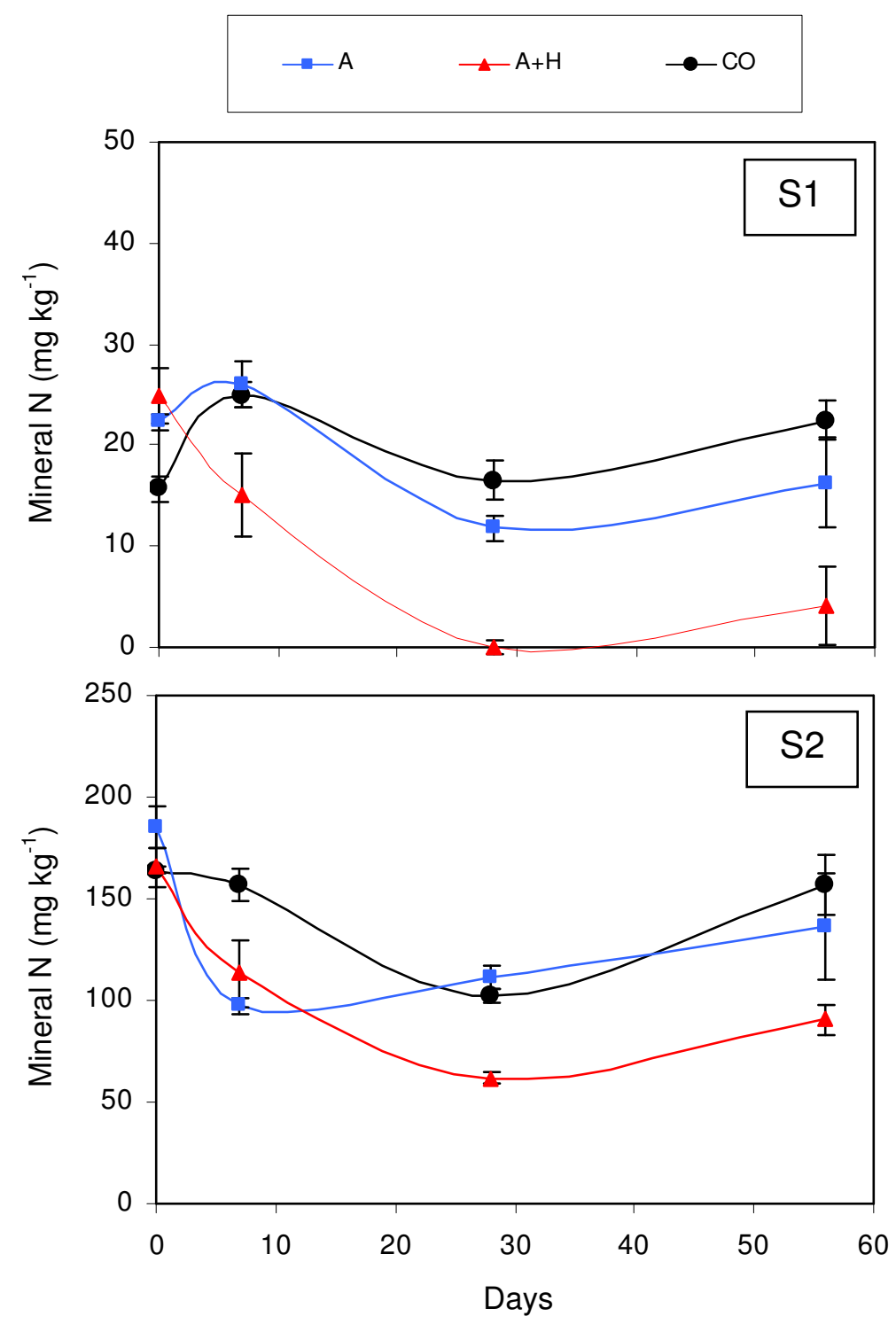

Figure 4.2.3. Influence of compost application ( $\mathrm{A}$ and $\mathrm{A}+\mathrm{H}$ at $24 \mathrm{Mg}$ total organic matter ha-1) to two different textured soils (S1 and S2) on soil mineral nitrogen concentration $\left(\mathrm{NO}_{3}-\mathrm{N}+\mathrm{NH}_{4}{ }^{+}-\mathrm{N}\right)$ throughout the incubation experiment

A: two-phase olive mill waste (TPOMW) compost; $\mathrm{A}+\mathrm{H}$ : compost from TPOMW+animal fatty-proteinaceous waste; CO: control, unamended

S1: clay loam soil; S2: sandy loam soil

Vertical bars show the standard error

Several methods have been developed to determine soil microbial biomass, the most widely used being the fumigation with chloroform. The chloroform fumigationextraction method involves the extraction and subsequent quantification of microbial constituents ( $\mathrm{C}$ and $\mathrm{N}$ ) immediately following soil chloroform fumigation (Kandeler, 2007; Smith et al., 1993). As shown in Figure 4.2.4, microbial biomass in compostamended soils increased remarkably during the first days of incubation and decreased slowly later on, as indicated by the evolution of microbial biomass $\mathrm{C}$ and $\mathrm{N}$ throughout the experiment (results expressed in relation to the initial values for each treatment). 
These changes were more remarkable in $\mathrm{A}+\mathrm{H}$ - than in A-amended soils. On the other hand, changes observed in these two parameters in unamended soils (controls, CO) were small and a decrease was even recorded in S2.

Table 4.2.8. Main effects of the experimental treatments tested -Compost ( $\mathrm{A}$ vs. $A+H$ ) and Soil (S1 vs. S2) - on chemical characteristics and on biological properties studied in compost-amended soils at selected intervals from the beginning of the incubation assay

\begin{tabular}{|c|c|c|c|}
\hline Treatment main effect & $\begin{array}{c}\text { Mineral N } \\
\left(\mathrm{mg} \mathrm{kg}^{-1}\right)\end{array}$ & $\begin{array}{c}\text { Basal respiration } \\
\left(\mathrm{mg} \mathrm{CO}_{2}-\mathrm{C} \mathrm{kg}^{-1} \text { day-1}^{-1}\right)\end{array}$ & $\begin{array}{l}\text { Arginine ammonification } \\
\quad\left(\mu \mathrm{g} \mathrm{NH} 4^{+}-\mathrm{Ng}^{-1} \mathrm{~h}^{-1}\right)\end{array}$ \\
\hline \multicolumn{4}{|l|}{ Day 0} \\
\hline \multicolumn{4}{|l|}{ 1. Compost } \\
\hline A & 103,6 & - & 5,427 \\
\hline $\mathrm{A}+\mathrm{H}$ & 95,36 & - & 5,356 \\
\hline$P$ & ns & & ns \\
\hline \multicolumn{4}{|l|}{ 2. Soil } \\
\hline S1 & 23,55 & - & 8,751 \\
\hline S2 & 175,4 & - & 2,031 \\
\hline$P$ & $* * *$ & & $* * *$ \\
\hline \multicolumn{4}{|l|}{ 3. Interaction } \\
\hline $1 \times 2$ & ns & & ns \\
\hline \multicolumn{4}{|l|}{ Day 7} \\
\hline \multicolumn{4}{|l|}{ 1. Compost } \\
\hline A & 61,63 & 19,17 & 2,543 \\
\hline $\mathrm{A}+\mathrm{H}$ & 64,09 & 36,67 & 0,920 \\
\hline$P$ & ns & $* * *$ & ns \\
\hline \multicolumn{4}{|l|}{ 2. Soil } \\
\hline S1 & 20,52 & 17,22 & 1,541 \\
\hline S2 & 105,2 & 38,62 & 1,923 \\
\hline$P$ & $* * *$ & $* * *$ & ns \\
\hline \multicolumn{4}{|l|}{ 3. Interaction } \\
\hline $1 \times 2$ & ns & $* * *$ & ns \\
\hline \multicolumn{4}{|l|}{ Day 28} \\
\hline \multicolumn{4}{|l|}{ 1. Compost } \\
\hline A & 61,53 & 17,67 & 0 \\
\hline$A+H$ & 30,70 & 27,73 & 0 \\
\hline$P$ & $* * *$ & $* * *$ & ns \\
\hline \multicolumn{4}{|l|}{ 2. Soil } \\
\hline S1 & 5,653 & 12,03 & 0 \\
\hline S2 & 86,57 & 33,37 & 0 \\
\hline \multirow{2}{*}{\multicolumn{4}{|c|}{ 3. Interaction }} \\
\hline & & & \\
\hline $1 \times 2$ & $* * *$ & $* * *$ & ns \\
\hline \multicolumn{4}{|l|}{ Day 56} \\
\hline \multicolumn{4}{|l|}{ 1. Compost } \\
\hline A & 76,22 & 16,06 & 0,885 \\
\hline$A+H$ & 47,37 & 17,87 & 1,574 \\
\hline$P$ & ns & ns & ns \\
\hline \multicolumn{4}{|l|}{ 2. Soil } \\
\hline S1 & 10,21 & 7,850 & 0,548 \\
\hline S2 & 113,4 & 26,08 & 1,910 \\
\hline$P$ & $* * *$ & $* * *$ & $*$ \\
\hline \multicolumn{4}{|l|}{ 3. Interaction } \\
\hline $1 \times 2$ & ns & $* * *$ & ns \\
\hline
\end{tabular}




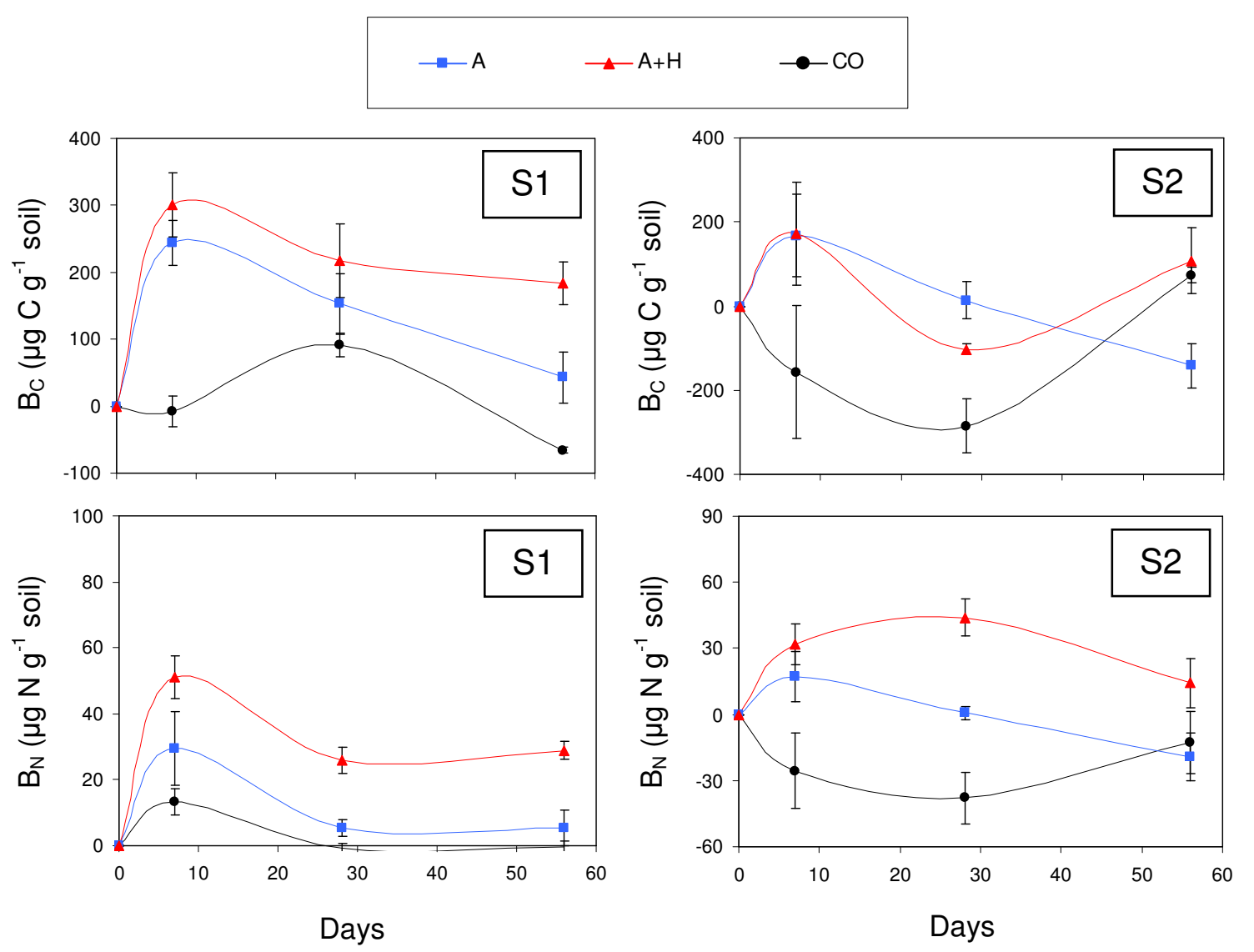

Figure 4.2.4. Influence of compost application (A and $\mathrm{A}+\mathrm{H}$ at $24 \mathrm{Mg}$ total organic matter ha-1) to two different textured soils (S1 and S2) on soil microbial biomass carbon $\left(B_{C}\right)$ and on soil microbial biomass nitrogen $\left(B_{N}\right)$ throughout the incubation experiment. Results are expressed as changes with regard to the initial values for each treatment

A: two-phase olive mill waste (TPOMW) compost; $\mathrm{A}+\mathrm{H}$ : compost from TPOMW+animal fatty-proteinaceous waste; CO: control, unamended

S1: clay loam soil; S2: sandy loam soil

Vertical bars show the standard error

Soil respiration reflects soil biological activity, and it can be determined as $\mathrm{CO}_{2}$ release or oxygen consumption resulting from soil microorganisms' metabolism (Hernández y García, 2003). As regards microbial activity in the treatments tested, basal respiration, measured weekly and expressed as $\mathrm{CO}_{2}-\mathrm{C}$ production (Figure 4.2.5), was enhanced in compost-amended soils compared to unamended controls, respiration in $\mathrm{S} 2$ being significantly higher than in $\mathrm{S} 1$ (Table 4.2.8). Values for $\mathrm{CO}_{2}-\mathrm{C}$ release varied slightly throughout the incubation period in controls (CO) and in treatments with compost $\mathrm{A}$, whereas $\mathrm{CO}_{2}-\mathrm{C}$ release progressively decreased throughout the experiment when compost $\mathrm{A}+\mathrm{H}$ was applied to soils $\mathrm{S} 1$ and $\mathrm{S} 2$, thus showing an inhibition in microbial activity throughout the period studied (around 15 
and $20 \mathrm{mg} \mathrm{CO}_{2}-\mathrm{C} \mathrm{kg}^{-1}$ soil day-1 on day 56 less than on day 7 for S1 and S2, respectively; Figure 4.2.5). Net cumulative quantities of $\mathrm{CO}_{2}-\mathrm{C}$ produced (calculated by the successive addition of the values obtained in each measurement and the subtraction of the control values; Figure 4.2.6) were fitted to a first-order kinetic model $\left(C_{\min }=C_{0}\left[1-e^{-k t}\right]\right)$, this model explaining more than $99 \%$ of the experimental data variance (Table 4.2.9). The potentially mineralisable carbon $\left(\mathrm{C}_{0}\right)$ in $\mathrm{S} 2$ was remarkably higher than in $\mathrm{S} 1$, just like compost $A$ was in comparison with $\mathrm{A}+\mathrm{H}$. Carbon dioxide evolution with time is an indicator of microbial activity, and it is affected by changes in the physiology and composition of microbial populations as well as in the environmental conditions (Sánchez-Monedero et al., 2008). An increase in soil respiration was expected after compost application due to biodegradable organic matter addition, soil respiration showing a comparatively higher increase with $\mathrm{A}+\mathrm{H}$, which showed larger amounts of easily-available C (particularly water-soluble organic carbon fractions) and lower stability degree than compost $A$, as presented in section 4.1 of Results and Discussion.

Microorganisms catabolise arginine -one of the twenty essential amino acids- by means of different pathways, releasing ammonium as end-product, which can be easily nitrified in soil (Mishra and Misra, 1991). Reactions responsible for arginine ammonification belong to two cathegories: arginine deamination (or deimination) followed by an immediate release of $\mathrm{NH}_{4}^{+}$; and, arginase activity with urea production, which can be rapidly hydrolysed by urease activity with ammonium release (Bonde et al., 2001). Several studies have correlated arginine ammonification with both microbial activity (Alef and Kleiner, 1986) and microbial biomass (Alef and Kleiner, 1987; Lin and Brookes, 1999) in soils. Bonde et al. (2001) proposed the determination of arginine ammonification for assessing gross $\mathrm{N}$ mineralization in the short-term even under fluctuating soil temperature and soil water content conditions. Smith and Hughes (2004) also demonstrated that experiments involving arginine ammonification can provide valuable information on nitrogen status in composted materials to assess their potential risks for microbial $\mathrm{N}$ immobilisation. 


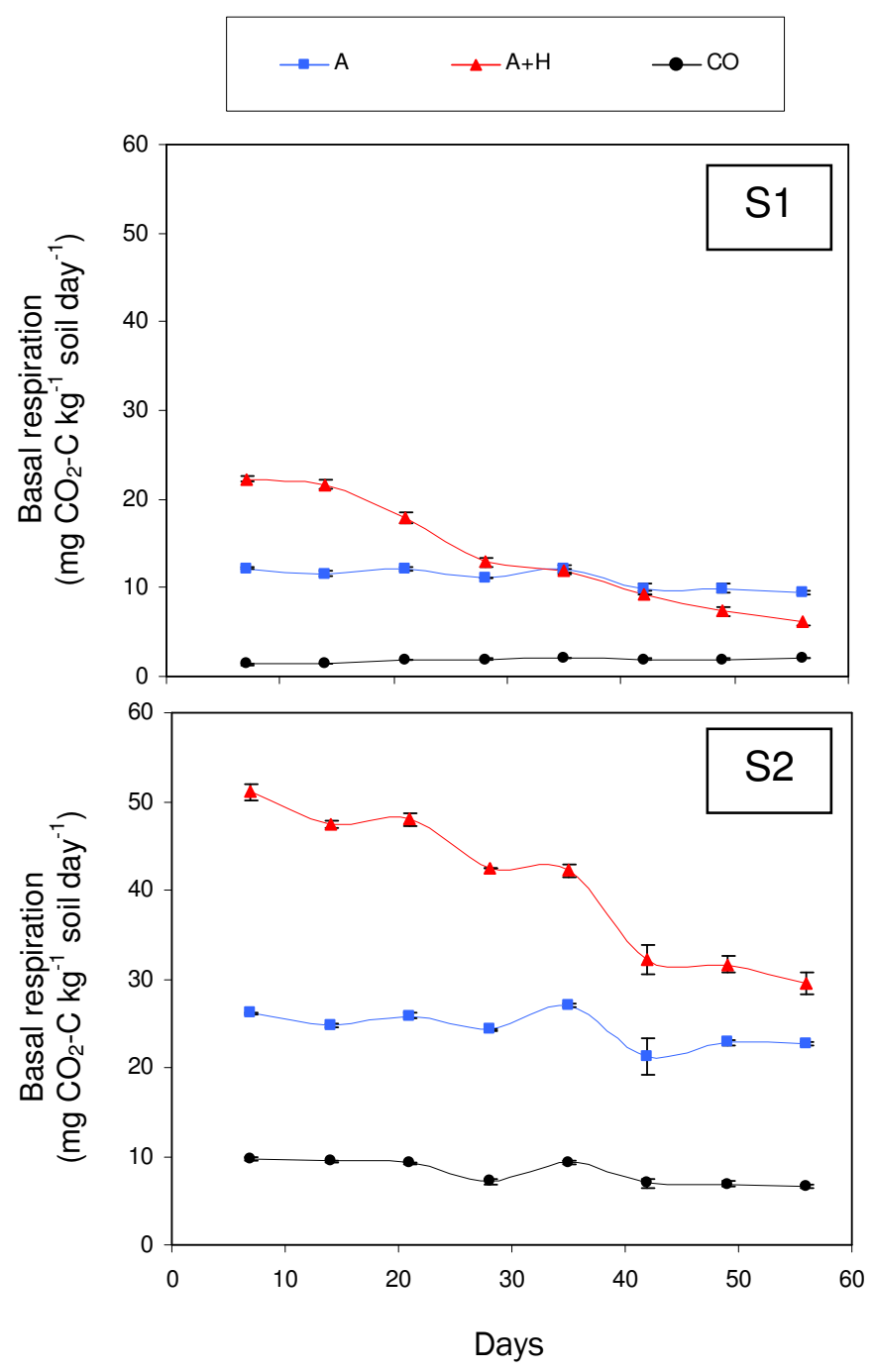

Figure 4.2.5. Influence of compost application (A and $\mathrm{A}+\mathrm{H}$ at $24 \mathrm{Mg}$ total organic matter ha-1) to two different textured soils (S1 and $S 2$ ) on soil basal respiration throughout the incubation experiment

A: two-phase olive mill waste (TPOMW) compost; A+H: compost from TPOMW+animal fatty-proteinaceous waste; CO: control, unamended

S1: clay loam soil; S2: sandy loam soil

Vertical bars show the standard error 

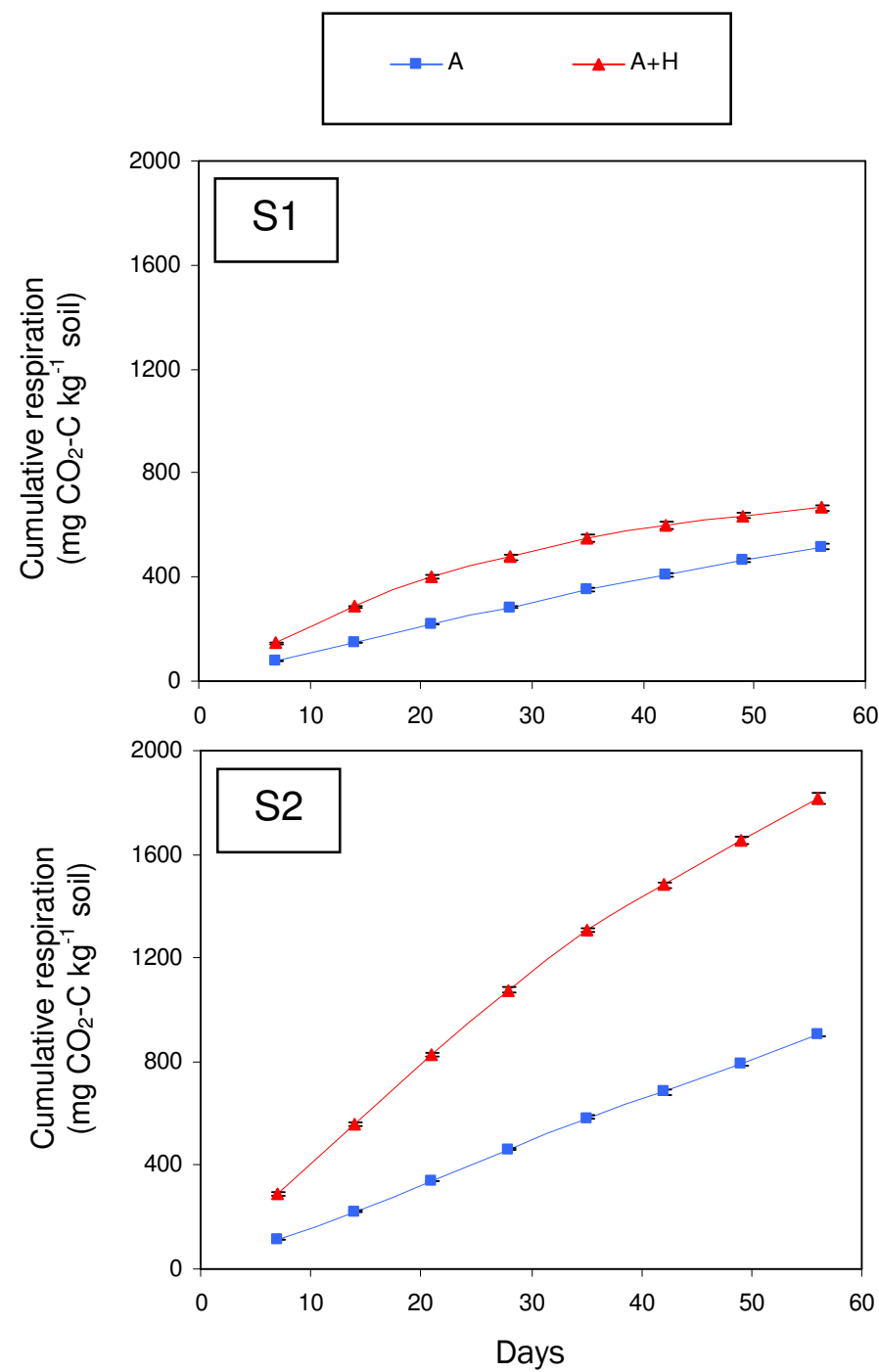

Figure 4.2.6. Influence of compost application ( $\mathrm{A}$ and $\mathrm{A}+\mathrm{H}$ at $24 \mathrm{Mg}$ total organic matter ha-1) to two different textured soils (S1 and S2) on net cumulative values of soil respiration (control values substracted) throughout the incubation experiment

A: two-phase olive mill waste (TPOMW) compost; $\mathrm{A}+\mathrm{H}$ : compost from TPOMW+animal fatty-proteinaceous waste S1: clay loam soil; S2: sandy loam soil

Vertical bars show the standard error

Table 4.2.9. Parameters for the first-order kinetic model $\left(\mathrm{C}_{\min }=\mathrm{C}_{0}\left[1-\mathrm{e}^{-\mathrm{kt}}\right]\right)$ adjusted to the net cumulative values (control values substracted) of $\mathrm{CO}_{2}-\mathrm{C}$ released from soils $\mathrm{S} 1$ and S2 amended with composts $\mathrm{A}$ and $\mathrm{A}+\mathrm{H}$ at $24 \mathrm{Mg}$ total organic matter ha-1

\begin{tabular}{ccccc}
\hline \multirow{2}{*}{ Compost } & & \multicolumn{2}{c}{ Parameter } & \multirow{2}{*}{$\mathbf{R}^{2}$} \\
\cline { 3 - 4 } & Soil & $\mathrm{C}_{0}$ & $\mathrm{k}$ & 0.997 \\
& $\mathrm{~S} 1$ & 1595 & 0.00702 & 0.998 \\
\hline $\mathrm{A}+\mathrm{H}$ & $\mathrm{S} 2$ & 5666 & 0.00307 & 0.992 \\
& $\mathrm{~S} 1$ & 806.8 & 0.03183 & 0.998
\end{tabular}

$\mathrm{C}_{\text {min: }}$ : carbon mineralised on time $\mathrm{t}$; $\mathrm{C}_{0}$ : potentially mineralisable carbon $\left(\mathrm{mg} \mathrm{kg}^{-1}\right)$; $\mathrm{k}$ : mineralization constant rate (day-1) A: two-phase olive mill waste (TPOMW) compost; $\mathrm{A}+\mathrm{H}$ : compost from TPOMW+animal fatty-proteinaceous waste Coefficients of determination $\left(\mathrm{R}^{2}\right)$ showed a level of significance of $P \leq 0.001$ 
In our study, a drop in arginine ammonification was recorded in all treatments tested from the beginning of the incubation until day 28 (Figure 4.2.7; Table 4.2.8), followed by a slight increase to the end of the experiment, which were in parallel to the mineral $\mathrm{N}$ evolution observed throughout the incubation period -particularly in $\mathrm{A}+\mathrm{H}$ treatments (Figure 4.2.3)-, thus reflecting also $\mathrm{N}$ dynamics in $\mathrm{A}$ - and $\mathrm{A}+\mathrm{H}$-amended soils. Alef and Kleiner (1987) suggested that arginine ammonification was a useful and valuable indicator for soil microbial biomass assessment due to the positive actual correlation between both parameters. Nevertheless, in the present experiment an increase in both microbial biomass and activity was recorded, whereas a drop in arginine ammonification was observed. In this situation, Lin and Brookes (1999) indicated that arginine ammonification should not be used to estimate microbial biomass in soils which are immobilizing inorganic $\mathrm{N}$ during the early phase of organic matter decomposition.

Enzymes are specialized protein catalysts which combine with a specific substrate and promote the occurrence of reactions without undergoing permanent alteration (Dick and Tabatabai, 1993; Kandeler, 2007). Enzyme activities can develop within the cytoplasm or periplasmic space of proliferating and non-proliferating microbial, animal and plant cells, attached to dead cells, or even released from lysed cells (Nannipieri et al., 2002; Renella et al., 2006). In addition, an important activity is associated with enzymes which are secreted by living cells during normal cell growth and division, known as extracellular enzymes, whose location can be usually inferred from their function (Pascual et al., 2002). Soil enzymes, like enzymes from other ecosystems, are strongly dependent on $\mathrm{pH}$, ionic strength, temperature, and the presence (or absence) of inhibitors (Burns, 1978; Pascual et al., 2002). Standardized methods for the determination of a broad range of enzyme activities have been described by Tabatabai (1994), Alef and Nannipieri (1995), and Schinner et al. (1996). These determinations measure maximum potential -rather than actual- activities of enzymes, since experimental conditions for enzyme assays are selected to ensure optimum catalysis rates (Alef and Nannipieri, 1995). Soil enzyme activities are substrate-specific and they are then unable to reflect the total nutrient status of soil; therefore, the simultaneous determination of several enzyme activities and other selected biological parameters may better predict soil fertility (Dick and Tabatabai, 1993; Ros et al., 2003). 


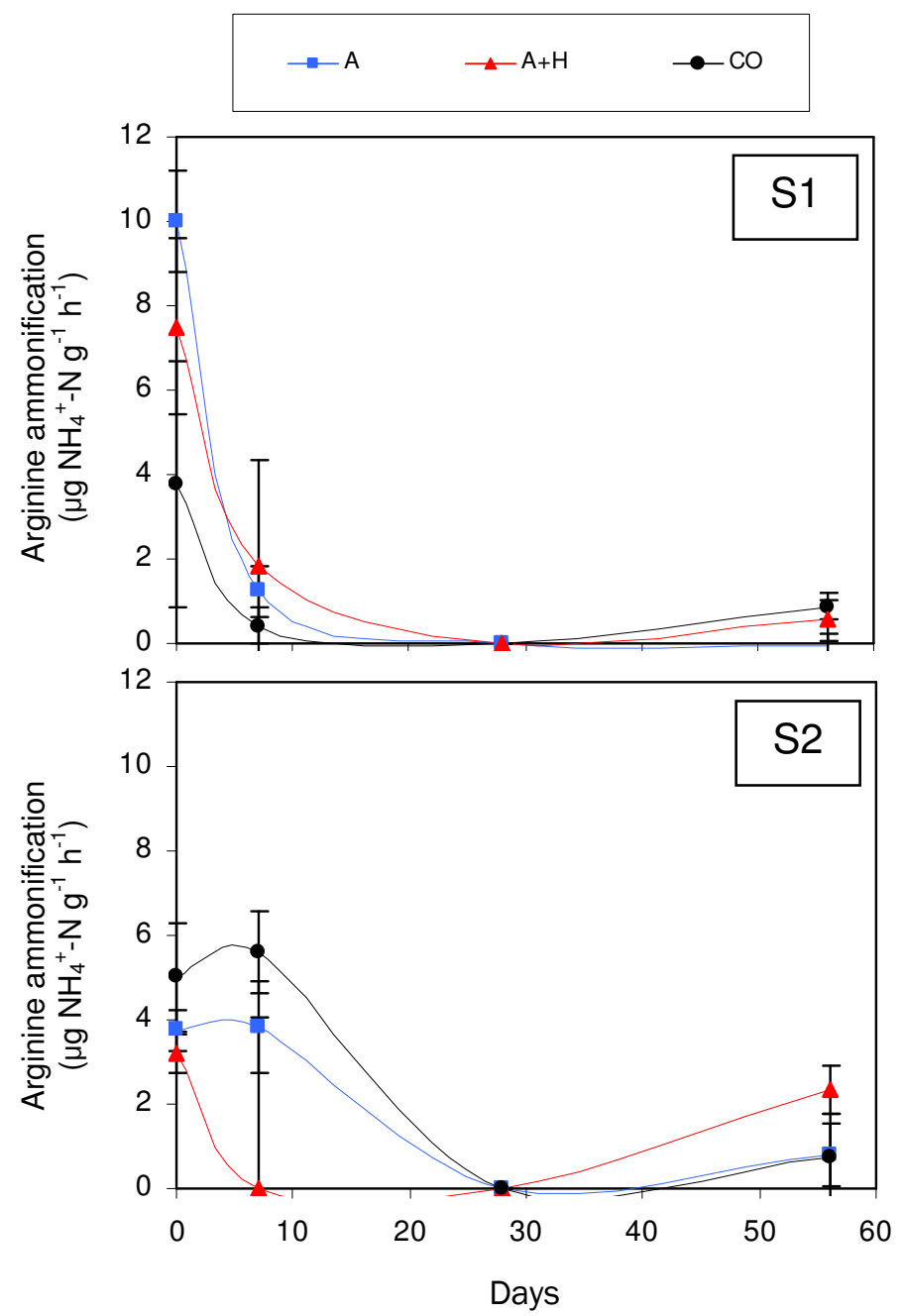

Figure 4.2.7. Influence of compost application ( $\mathrm{A}$ and $\mathrm{A}+\mathrm{H}$ at $24 \mathrm{Mg}$ total organic matter ha-1) to two different textured soils (S1 and S2) on arginine ammonification throughout the incubation experiment

A: two-phase olive mill waste (TPOMW) compost; $\mathrm{A}+\mathrm{H}$ : compost from TPOMW+animal fatty-proteinaceous waste; CO: control, unamended

S1: clay loam soil; S2: sandy loam soil

Vertical bars show the standard error

In this PhD Thesis, enzymes involved in phosphorus (phosphatases), carbon ( $\beta$ glucosidases) and nitrogen (proteases) cycles were determined in both control (unamended) and compost-amended (with $A$ and $A+H$ ) soils on days 0,7 and 56 of incubation.

Phosphatases is a term used to appoint a broad group of enzymes that hydrolyse phosphate esters and anhydrides, capable of acting on a number of different structurally-related substrates, but at widely differential rates (Alef and Nannipieri, 1995). Among enzymes whose mechanism acts on ester linkages, phosphoric 
monoester hydrolases have received much attention, followed by phosphoric diester hydrolases (Trasar-Cepeda et al., 2003). Phosphomonoesterases have been extensively studied in soils due to the hydrolysis of organic phosphomonoester to inorganic phosphorus which can be then uptaken by plants. According to their optimum $\mathrm{pH}$, they are classified as acid, neutral or alkaline phosphatases, being acid and alkaline phosphomonoesterases extensively studied in soils as they are strongly related to plant nutrition. It is widely accepted that acid phosphatase prevails in acid soils, while alkaline phosphatase is predominant in alkaline soils (Eivazi and Tabatabai, 1977). The activity of phosphomonoesterases is strongly affected not only by $\mathrm{pH}$, but also by organic matter content, soil moisture, and oxygen diffusion rate. Phosphodiesterases include nucleases, which hydrolyse ribo- and deoxyribo-nucleic acids to nucleotides, and phospholipases, which hydrolyse phospholipids (Alef and Nannipieri, 1995). Phosphodiesterase activity has been detected in microorganisms, plants and animals, and it has been significantly correlated with soil organic matter content. The methods currently used to determine phosphomonoesterase and phosphodiesterase activities are based on $p$-nitrophenol release after soil incubation with $p$-nitrophenyl phosphate or bis-p-nitrophenyl phosphate, respectively.

In relation to phosphatase activity in the experiment carried out (Figure 4.2.8; Table 4.2.10), higher values were observed in soil S2 in comparison with S1. The former (S2) showed a similar trend of variation in compost-amended and in unamended (control, CO) soils (a slight increase until day 7 of incubation), thus treatments with $\mathrm{A}$ and $\mathrm{A}+\mathrm{H}$ registering small and non-significant changes in acid and alkaline phosphomonoesterases as well as in phosphodiesterase activity in comparison with soil $\mathrm{CO}$. On the other hand, a noticeable increase in phosphatase activities was observed during the first week of incubation when composts were applied to the clay loam soil (S1), this effect being significantly higher with A for alkaline phosphomonoesterase and phosphodiesterase in comparison with $\mathrm{A}+\mathrm{H}$. Moreover, and for both composts studied $(A$ and $A+H)$, the enhancement of phosphatase activities lasted until the end of the incubation period, thereby resulting in an effect with long persistence. 

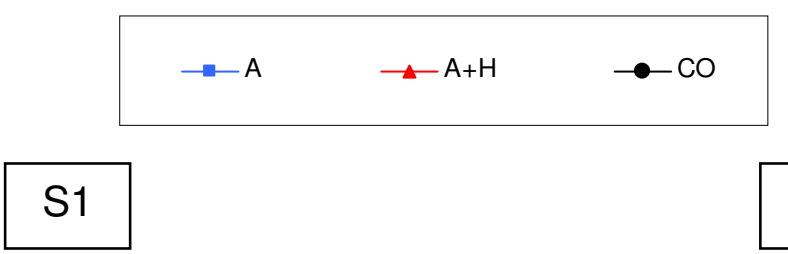

Alkaline phosphomonoesterase
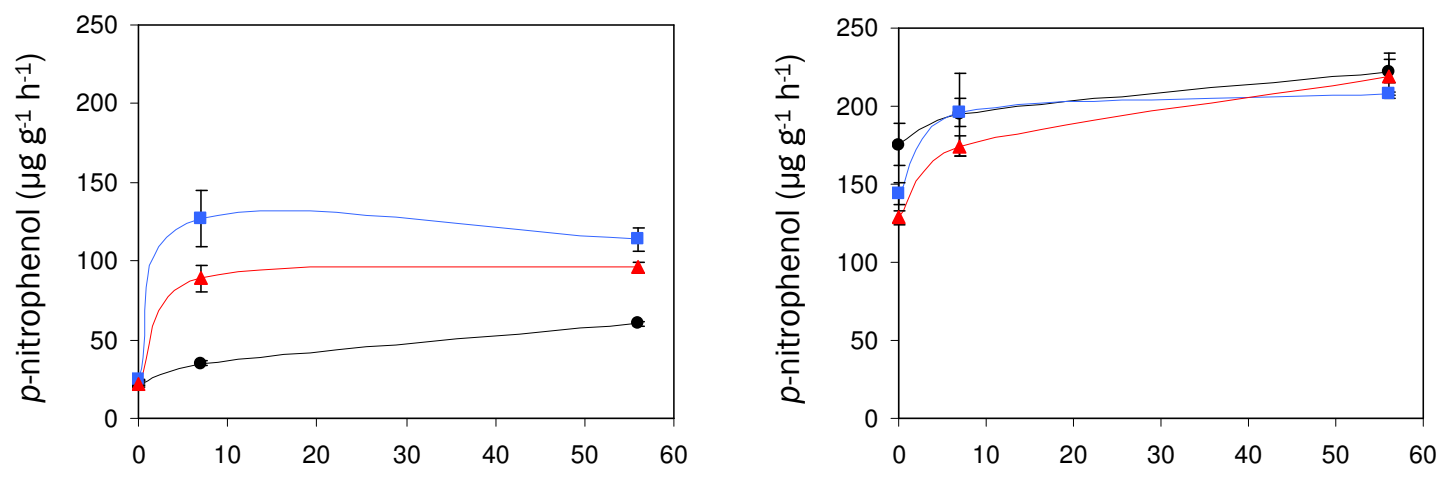

Acid phosphomonoesterase
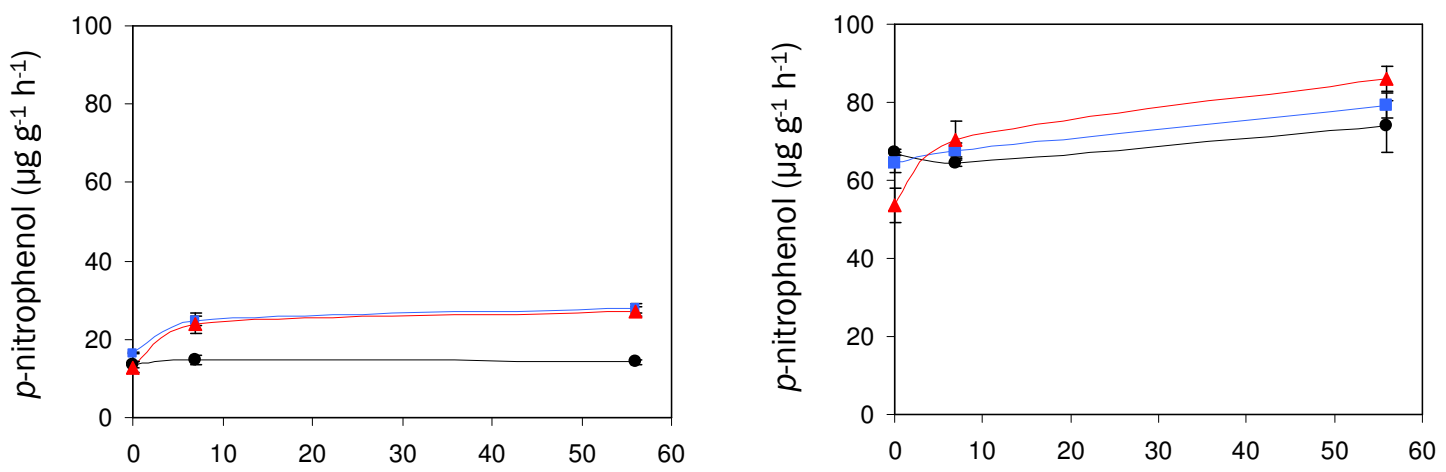

\section{Phosphodiesterase}
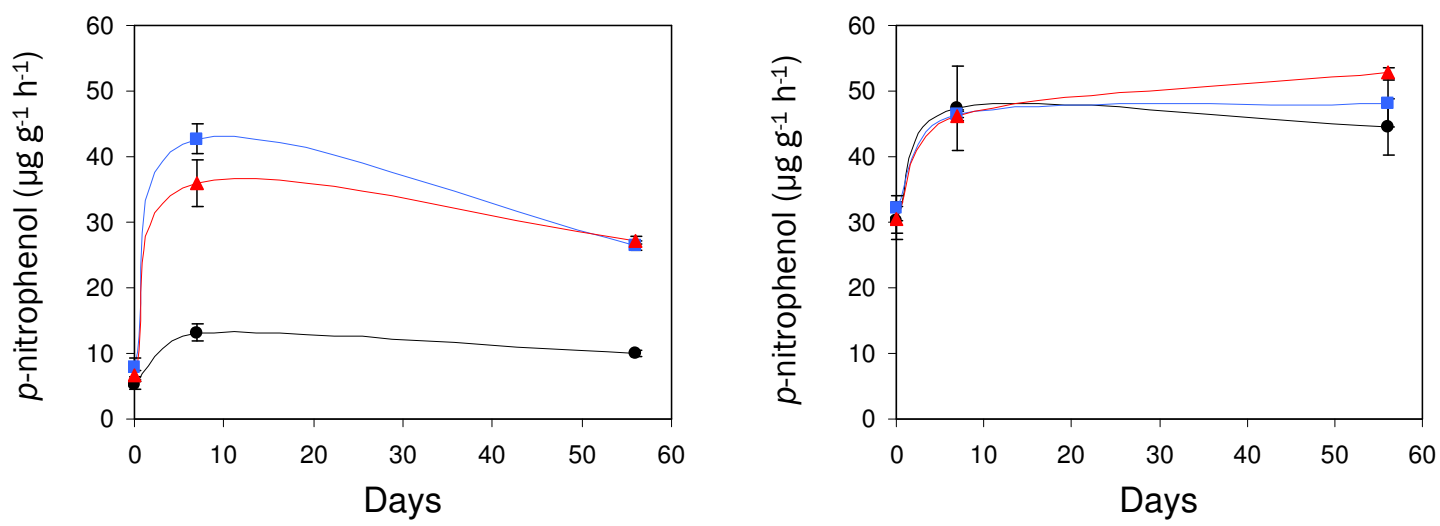

Figure 4.2.8. Influence of compost application ( $\mathrm{A}$ and $\mathrm{A}+\mathrm{H}$ at $24 \mathrm{Mg}$ total organic matter ha-1) to two different textured soils (S1, left and S2, right) on alkaline and acid phosphomonoesterase activities and on phosphodiesterase activity throughout the incubation experiment

A: two-phase olive mill waste (TPOMW) compost; A+H: compost from TPOMW+animal fatty-proteinaceous waste; CO: control, unamended

S1: clay loam soil; S2: sandy loam soil

Vertical bars show the standard error 
Table 4.2.10. Main effects of the experimental treatments tested -Compost (A vs. $\mathrm{A}+\mathrm{H}$ ) and Soil (S1 vs. S2)- on enzyme activities studied in compost-amended soils at selected intervals from the beginning of the incubation assay

\begin{tabular}{|c|c|c|c|c|c|}
\hline $\begin{array}{l}\text { Treatment main } \\
\text { effect }\end{array}$ & $\begin{array}{c}\text { Alkaline } \\
\text { phosphomonoesterase }\end{array}$ & $\begin{array}{c}\text { Acid } \\
\text { phosphomonoesterase } \\
(\mu \mathrm{g} p \text {-nitropheno }\end{array}$ & $\begin{array}{l}\text { Phosphodiesterase } \\
\left(\mathrm{g}^{-1} \mathrm{~h}^{-1}\right)\end{array}$ & $\beta$-glucosidase & $\begin{array}{c}\text { Protease } \\
\left(\mu g \mathrm{NH}_{4}{ }^{+}-\mathrm{N} \mathrm{g}^{-1} \mathrm{~h}^{-1}\right)\end{array}$ \\
\hline \multicolumn{6}{|l|}{ Day 0} \\
\hline \multicolumn{6}{|l|}{ 1. Compost } \\
\hline A & 75,25 & 40,51 & 20,02 & 41,91 & 57,24 \\
\hline $\mathrm{A}+\mathrm{H}$ & 84,41 & 33,29 & 18,53 & 34,99 & 77,89 \\
\hline$P$ & ns & * & ns & ns & ns \\
\hline \multicolumn{6}{|l|}{ 2. Soil } \\
\hline S1 & 23,29 & 14,66 & 7,23 & 6,712 & 14,76 \\
\hline S2 & 136,4 & 59,13 & 31,33 & 70,19 & 120,4 \\
\hline$P$ & $* \star *$ & $* \star *$ & $* * *$ & $* * *$ & $* * *$ \\
\hline \multicolumn{6}{|l|}{ 3. Interaction } \\
\hline $1 \times 2$ & ns & ns & ns & ns & ns \\
\hline \multicolumn{6}{|l|}{ Day 7} \\
\hline \multicolumn{6}{|l|}{ 1. Compost } \\
\hline A & 161,5 & 46,12 & 44,60 & 47,26 & 41,40 \\
\hline $\mathrm{A}+\mathrm{H}$ & 131,6 & 47,31 & 41,10 & 48,50 & 48,73 \\
\hline$P$ & * & ns & ns & ns & ns \\
\hline \multicolumn{6}{|l|}{ 2. Soil } \\
\hline S1 & 108,1 & 24,37 & 39,33 & 14,24 & 7,36 \\
\hline S2 & 185,0 & 69,05 & 46,37 & 81,52 & 82,77 \\
\hline$P$ & $* * *$ & $* * *$ & * & $* * *$ & $* * *$ \\
\hline \multicolumn{6}{|l|}{ 3. Interaction } \\
\hline $1 \times 2$ & ns & ns & ns & ns & ns \\
\hline \multicolumn{6}{|l|}{ Day 56} \\
\hline \multicolumn{6}{|l|}{ 1. Compost } \\
\hline A & 160,9 & 53,48 & 37,26 & 59,13 & 50,44 \\
\hline $\mathrm{A}+\mathrm{H}$ & 157,7 & 56,62 & 39,97 & 66,37 & 91,61 \\
\hline$P$ & ns & ns & ns & ns & $* * *$ \\
\hline \multicolumn{6}{|l|}{ 2. Soil } \\
\hline S1 & 104,8 & 27,53 & 26,81 & 16,34 & 19,06 \\
\hline S2 & 213,8 & 82,57 & 50,42 & 109,2 & 122,99 \\
\hline$P$ & $* * *$ & $* * *$ & $* * *$ & $* * *$ & $* * *$ \\
\hline \multicolumn{6}{|l|}{ 3. Interaction } \\
\hline $1 \times 2$ & ns & ns & ns & ns & ns \\
\hline
\end{tabular}

The enzyme $\beta$-glucosidase, as other glucosidases and galactosidases, is included in the group of glycosidases. They play a key role in soil carbohydrate degradation and, therefore, in the energy input of soil microorganisms (Jiménez y Bonmatí, 2003). From among glycosidases, $\beta$-glucosidase is the most important since it is involved in the microbial degradation of cellulose to glucose. The method used in this experiment to determine this enzyme activity in the soils tested measures the release of $p$ nitrophenol from $p$-nitrophenyl- $\beta$-D-glucoside added to soil as a substrate. 
As can be observed in Figure 4.2.9 and Table 4.2.10, a larger $\beta$-glucosidase activity was measured in soil S2 compared to S1, and no significant differences in this activity were recorded between controls and compost-amended soils.

Proteases catalyse the hydrolysis of proteins to peptides, and peptides to amino acids. Nearly all soil microorganisms are capable of protein degradation, which generally entails ammonium release at the end of the catabolic pathway. Soil proteases are present in living and dead cells, as free enzymes, and adsorbed on organic, inorganic and organo-mineral particles (Alef and Nannipieri, 1995). The determination of protease activity differs depending on the type of substrate and the conditions selected to perform the incubation procedure $(\mathrm{pH}$, temperature, and so forth). In the present study, N-benzoyl-L-arginine amide was used as substrate for protease determination.

As can be seen (Figure 4.2.9 and Table 4.2.10), protease activity in soil S2 was higher than in $\mathrm{S} 1$, and in addition it was enhanced by compost $\mathrm{A}+\mathrm{H}$ in both soils until day 56 , whereas no statistical differences, or even a small decrease, were observed in A treatments when compared with control soils (CO).

Many authors have reported a positive effect of organic fertilization on hydrolyse activities, thus stimulating soil microorganisms to synthesize enzymes related to the dynamics of the most important nutrients (Madejón et al., 2001b; Marschner et al., 2003). In this PhD Thesis, a great increase in phosphatase activities was found when S1 was amended with compost A or A+H. According to Tejada et al. (2006), a supply of readily-metabolisable $\mathrm{C}$ is likely to enhance soil phosphatase activities. In our study, and due to the differential behaviour of both soils, this effect could be related to the texture of S1, as clay minerals and humic-clay complexes contribute to the accumulation and survival of soil enzymes by means of stabilisation and protective effects (Gianfreda and Bollag, 1996; Renella et al., 2007; Tabatabai, 1994). Since composts are in general slowly decomposed in soil, the continuous release of nutrients can sustain the microbial population biomass for lengthy periods of time (Diacono and Montemurro, 2011), which could explain the persistence of compost effects on phosphatase activities. 


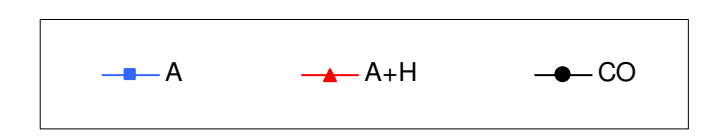

\section{S1}

\section{S2}

B-glucosidase
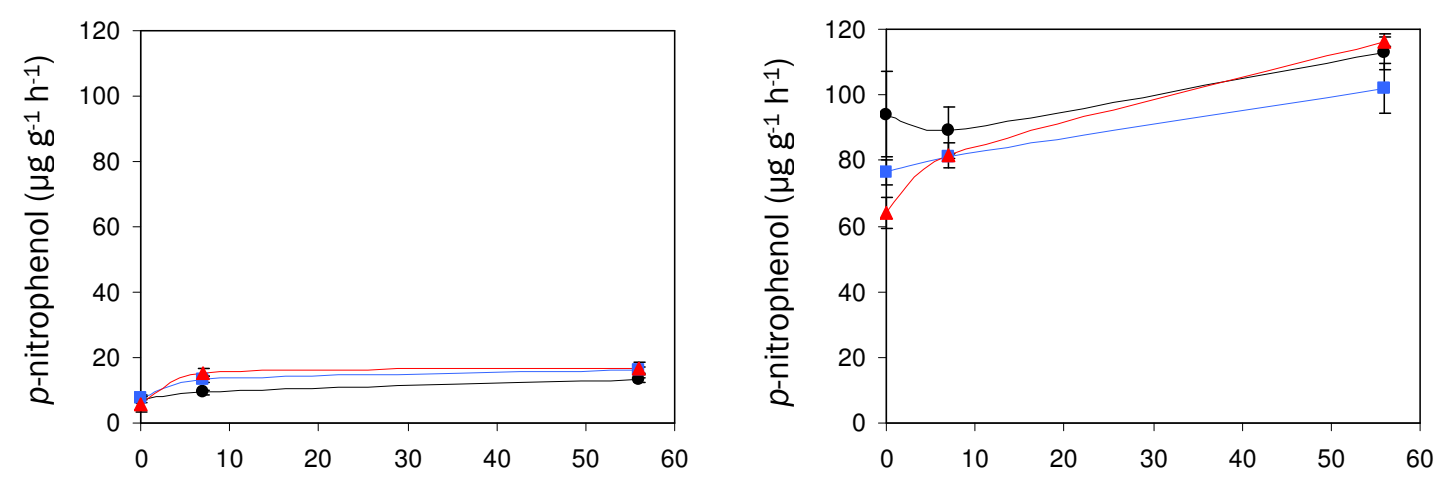

\section{Protease}
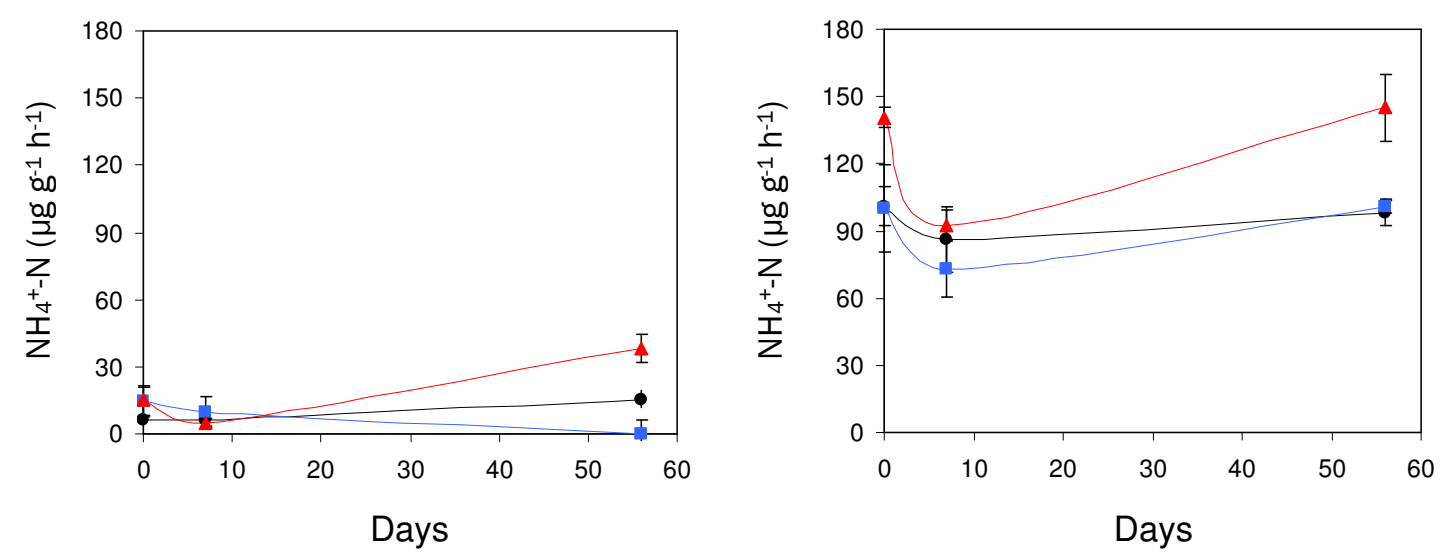

Figure 4.2.9. Influence of compost application (A and $\mathrm{A}+\mathrm{H}$ at $24 \mathrm{Mg}$ total organic matter ha-1) to two different textured soils (S1, left and S2, right) on $\beta$-glucosidase and on protease activities throughout the incubation experiment

A: two-phase olive mill waste (TPOMW) compost; $\mathrm{A}+\mathrm{H}$ : compost from TPOMW+animal fatty-proteinaceous waste; CO: control, unamended

S1: clay loam soil; S2: sandy loam soil

Vertical bars show the standard error

In relation to $\beta$-glucosidase, some authors demonstrated a positive correlation of this enzyme activity with organic carbon and microbial biomass (Böhme et al., 2005; Turner et al., 2002), whereas others found no relationship between $\beta$-glucosidase and organic or microbial biomass carbon (Badiane et al., 2001). In this context, Melero et al. (2007b) did not find significant differences between agricultural soils treated with organic or inorganic fertilizers in the short-term. 
Regarding protease activity, the increase undergone in both soils (S1 and S2) when amended with $\mathrm{A}+\mathrm{H}$, particularly at the end of the experiment, could be explained by the progressive depletion of mineral nitrogen caused by soil microorganisms, that could have induced thereby the activation of proteases in the presence of a substrate (N-benzoyl-L-arginine) that can be degraded as an alternative $\mathrm{N}$ source (Geisseler et al., 2010).

Both soils exhibited $\mathrm{N}$ immobilization throughout the incubation experiment here described when compost $\mathrm{A}+\mathrm{H}$ was applied, this process leading to a complete mineral $\mathrm{N}$ depletion in the clay loam soil (S1). In addition, the sandy loam soil (S2) showed larger mineral $\mathrm{N}$ contents, higher basal respiration, greater arginine ammonification (particularly during the first days of incubation), and higher enzyme activities than soil S1. The differences between soils S1 and S2 agree with other studies, which reported lower $\mathrm{C}$ and $\mathrm{N}$ mineralization rates in soils with high clay contents (Amlinger et al., 2003; Cabrera et al., 2005b; Madrid et al., 2011) together with a lower rate of enzyme production by microbial biomass (Melero et al., 2007b).

\subsubsection{Recapitulación}

En el experimento de un año de duración (Experimento 1), los dos composts estudiados mejoraron las propiedades físicas del suelo calizo utilizado, disminuyendo la densidad aparente e incrementando la porosidad y la humedad volumétrica a capacidad de campo, y aumentaron la fertilidad del mismo, destacando el incremento en los niveles de carbono orgánico, nitrógeno mineral, fósforo y potasio asimilables. Además, los resultados obtenidos mostraron que el efecto de la dosis aplicada fue más marcado que el del origen del compost ( $A$ vs. $A+H)$.

Adicionalmente, los dos ensayos de incubación realizados (Experimentos 2.1 y 2.2) revelaron que $A+H$ inmovilizó nitrógeno mineral tras su aplicación a los dos suelos estudiados (S1 y S2) y que la actividad microbiana -esta última determinada como respiración basal y diferentes actividades enzimáticas-, así como el contenido en nitrógeno mineral fueron superiores en el suelo de textura más gruesa (S2) en comparación con el de textura más fina (S1). 


\subsection{EVALUACIÓN AGRONÓMICA DE LOS COMPOSTS A Y A+H COMO ENMIENDAS ORGÁNICAS. INFLUENCIA EN LOS CULTIVOS Y EL SUELO: EFECTO DIRECTO $Y$ RESIDUAL}

Con objeto de evaluar la viabilidad de los composts de alperujo como mejoradores del suelo, se estudiaron 8 tratamientos, resultantes de la combinación factorial de:

- 2 Composts (alperujo, A vs. alperujo más hidrolizado, $\mathrm{A}+\mathrm{H}$ ) por $(x)$

- 2 Dosis de aplicación de los composts (equivalentes a 12 y 24 t de materia orgánica total/ha; D1 y D2, respectivamente) por (x)

- 2 Programas de fertilización mineral (estándar, F1 vs. reducida en nitrógeno [con un 30\% menos que F1] y sin aporte de potasio, F2; ver Materiales y Métodos, sección 3.4.1).

Adicionalmente, se incluyeron 2 controles, que no recibieron aporte de materia orgánica, pero que se fertilizaron con los programas F1 y F2 (CO F1 y CO F2, respectivamente).

Sobre las distintas mezclas de suelo y compost (y programa de fertilización mineral aplicado) se establecieron sucesivamente tres especies hortícolas, que se cultivaron durante dos años consecutivos: rábano (Raphanus sativus, cv. "Largo Rojo Escarlata”), lechuga (Lactuca sativa var. longifolia, cv. "Romana de Valladolid”) y judía (Phaseolus vulgaris, cv. "Contender").

Debe señalarse que la incorporación de compost al suelo se realizó en una única aplicación al principio del experimento, con el fin de evaluar el efecto enmendante, o mejorador, de éste a corto plazo (primer año, Año 1) así como su efecto residual (segundo año, Año 2) sobre dichos cultivos (secciones 4.3 .1 y 4.3 .2 ) y el propio suelo (sección 4.3.3).

A continuación se presentan los resultados obtenidos en la evaluación agronómica realizada con los dos composts objeto de estudio de esta Tesis Doctoral. 


\subsubsection{Influencia de los composts y su interacción con la fertilización mineral en el crecimiento, desarrollo y productividad de las tres especies hortícolas estudiadas. Efecto directo (a corto plazo) y residual}

\subsubsection{Efecto directo}

\section{Rábano}

En el cultivo de rábano se controlaron diferentes parámetros relacionados con el crecimiento, el desarrollo y la morfología de la parte aérea y la raíz, examinándose los efectos principales de los tratamientos experimentales estudiados (Compost, Dosis de compost y Programa de fertilización mineral) y la interacción de éstos, así como su comparación con los controles (Figura 4.3.1; Tabla 4.3.1).

Respecto a las características de las hojas, el compost A incrementó el área de la hoja respecto a $\mathrm{A}+\mathrm{H}$, así como la dosis equivalente a 12 t/ha en comparación con la de 24 t/ha. Además, la aplicación del plan de fertilización estándar (F1) tuvo mayor efecto que el programa de fertilización reducida (F2) sobre el área de la hoja, el número total de hojas formadas por planta, y el contenido en clorofila de éstas. En cuanto al desarrollo del sistema radical, estimado por el peso fresco unitario, el diámetro y la longitud de la raíz, se encontraron diferencias significativas en peso fresco y longitud de la misma entre los dos composts estudiados, con valores superiores con A. El factor Dosis de compost proporcionó raíces de diámetro comparativamente superior cuando el material compostado se añadió a la dosis de 24 t/ha, mientras que las raíces de mayor longitud se produjeron con la dosis de 12 t/ha. En adición, algunas interacciones de los factores estudiados relacionadas con el área de la hoja, el peso fresco y la longitud de la raíz resultaron estadísticamente significativas. 


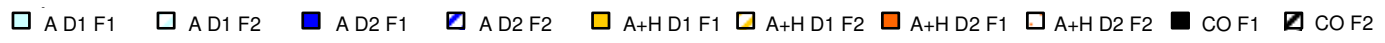

Hoja
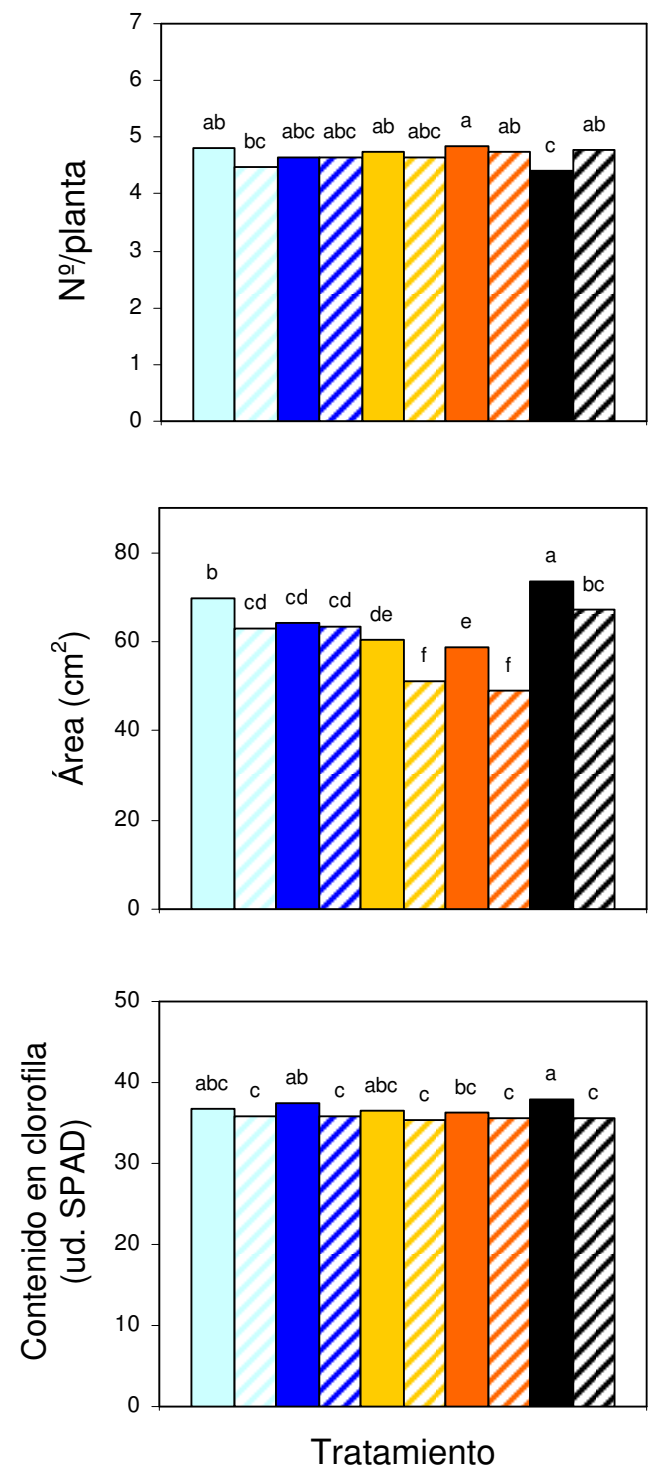

Raíz
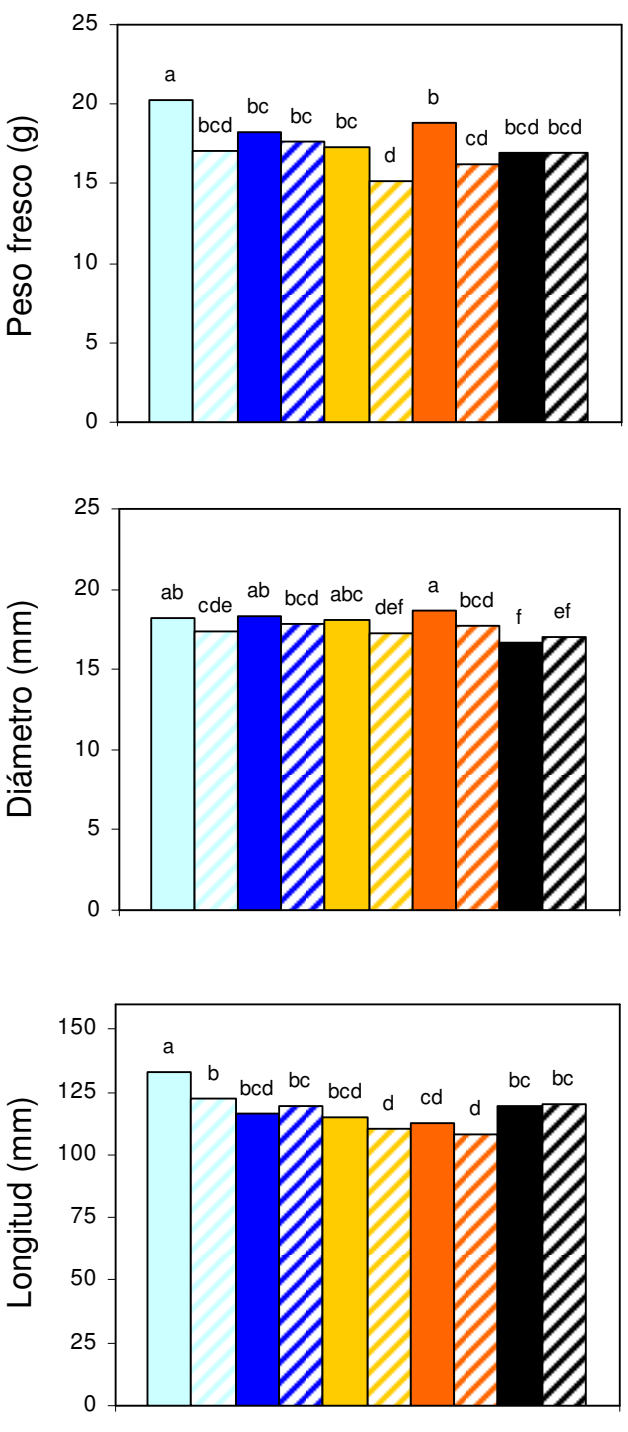

Tratamiento

Figura 4.3.1. Influencia del compost (A y A+H), la dosis de aplicación de éste (D1 y D2, equivalentes a 12 y 24 t de materia orgánica total/ha, respectivamente) y el programa de fertilización mineral (estándar, F1 y reducida, F2) en el crecimiento vegetativo (hojas y raíz) de rábano. Comparación con los controles ( $\mathrm{CO}$, que no recibieron compost). Primer año del experimento (Año 1)

$\mathrm{A}$ : compost de alperujo; $\mathrm{A}+\mathrm{H}$ : compost de alperujo más hidrolizado

Barras sin letra común difieren estadísticamente a $P \leq 0,05$ (test de Student-Newman-Keuls) 
Tabla 4.3.1. Análisis factorial de la varianza $(P)$ para los efectos de los tratamientos estudiados -Compost (alperujo vs. alperujo más hidrolizado), Dosis de aplicación de éste (12 vs. 24 t de materia orgánica total/ha) y Programa de fertilización mineral (estándar vs. reducida) - sobre el crecimiento vegetativo (hojas y raíz) de rábano. Primer año del experimento (Año 1)

\begin{tabular}{|c|c|c|c|c|c|c|}
\hline \multirow[b]{2}{*}{ Fuente de variación } & \multicolumn{3}{|c|}{ Hoja } & \multicolumn{3}{|c|}{ Raíz } \\
\hline & $\begin{array}{c}\mathrm{N} \% \\
\text { planta }\end{array}$ & Área & $\begin{array}{l}\text { Contenido en } \\
\text { clorofila }\end{array}$ & $\begin{array}{l}\text { Peso } \\
\text { fresco }\end{array}$ & Diámetro & Longitud \\
\hline 1. Compost & ns & $\star \star \star *$ & ns & $\star \star \star$ & ns & $\star \star \star *$ \\
\hline 2. Dosis de compost & ns & ** & ns & ns & $\star \star$ & $* * *$ \\
\hline 3. Fertilización mineral & * & $\star \star \star$ & $* * *$ & ns & $* * *$ & $\star *$ \\
\hline \multicolumn{7}{|l|}{ 4. Interacción } \\
\hline $1 \times 2$ & ns & ns & ns & $\star *$ & ns & * \\
\hline $1 \times 3$ & ns & $* \star \star$ & ns & ns & ns & ns \\
\hline $2 \times 3$ & ns & ns & ns & ns & ns & * \\
\hline $1 \times 2 \times 3$ & ns & * & ns & * & ns & * \\
\hline
\end{tabular}

$P$ : nivel de significación. ns, * ** $\mathrm{y} * * *$ indican diferencias no significativas o estadísticamente significativas a $P \leq 0,05, P \leq 0,01$ y $P \leq 0,001$, respectivamente

Cuando los tratamientos con compost se compararon con los controles (Figura 4.3.1), se apreció que aquellos con $\mathrm{A}$ y $\mathrm{A}+\mathrm{H}$ resultaron en un número de hojas similar o superior a dichos controles. Tanto estos últimos como las mezclas de suelo y compost experimentaron un incremento en el área de la hoja cuando se fertilizaron con el programa estándar (F1) en comparación con la fertilización reducida (F2). Todos los tratamientos con $\mathrm{A}+\mathrm{H}$ proporcionaron valores de dicho parámetro inferiores a los controles; los suelos con A no difirieron de su control cuando se aplicó la fertilización reducida (F2), pero mostraron resultados comparativamente inferiores con el programa estándar (F1). Por otro lado, la adición de compost al suelo no influyó en el contenido en clorofila de las hojas, que dependió únicamente del programa de fertilización aplicado. La comparación de las mezclas de suelo y compost con los controles reveló que los tratamientos con $\mathrm{A}+\mathrm{H}$ en combinación con la fertilización reducida resultaron en un peso fresco y una longitud de la raíz inferiores a dichos controles, mientras que con A se obtuvieron valores para estos parámetros similares 0 superiores, destacando la magnitud de estas diferencias con A a 12 t/ha junto con el programa de fertilización estándar. Además, dicho programa de abonado y la dosis de 24 t/ha incrementaron el valor del diámetro de la raíz en los tratamientos con compost $(\mathrm{A}$ y $\mathrm{A}+\mathrm{H})$ frente a los controles. 
Los resultados del análisis factorial de la varianza correspondientes a la producción de biomasa en raíz, hojas y planta entera -expresada en mg de materia seca/planta- se presentan en la Figura 4.3.2 y la Tabla 4.3.2. Todos los parámetros de biomasa estudiados fueron comparativamente superiores cuando se aplicó el compost $A$, alcanzando los incrementos respecto a $A+H$ valores en torno al $50 \%$. Este efecto está relacionado probablemente con la inmovilización de nitrógeno mineral provocada por este último compost, de acuerdo con el estudio de dinámica del nitrógeno orgánico que se ha presentado en la sección 4.2.2. Asimismo, el programa de fertilización estándar (F1) mostró valores de peso seco de raíz, hojas y planta entera superiores al plan reducido en nitrógeno y potasio (F2), mientras que el factor Dosis de compost no tuvo efecto alguno sobre la biomasa producida. Las interacciones de los factores objeto de estudio tampoco resultaron estadísticamente significativas.

La comparación de las mezclas de suelo y compost con los controles mostró que el crecimiento (biomasa) de la raíz, hojas (vástago) y planta entera (total) siguió una pauta similar a las descritas hasta ahora, esto es, los tratamientos con A no difirieron de los controles, mientras que la aplicación de $\mathrm{A}+\mathrm{H}$ disminuyó el crecimiento de la planta y la producción de biomasa en hojas y raíz, especialmente cuando se aplicó juntamente con el plan de fertilización reducido (F2).

Por último, la productividad del cultivo, expresada como producción de raíces en g de materia fresca/contenedor, mostró la misma tendencia que la producción de biomasa cuando se estudiaron los efectos principales de los tratamientos experimentales (Compost, Dosis de aplicación de éste y Programa de fertilización mineral; Tabla 4.3.2). De este modo, el compost A y la fertilización mineral estándar (F1) incrementaron la producción de raíces en comparación con $\mathrm{A}+\mathrm{H}$ y el programa de fertilización reducida (F2), respectivamente, no encontrándose diferencias significativas para las interacciones de los efectos principales estudiados.

La comparación con los controles (Figura 4.3.3) reveló que A proporcionó, en general, un peso de raíces (producción total) superior a dichos controles, mientras que los tratamientos con $\mathrm{A}+\mathrm{H}$ no difirieron de éstos (Fotografía 4.3.1). 
$\square$ AD1F1 $\square$ AD1F2 $\square$ AD2F1 $\square$ AD2 F2 $\square$ A+HD1F1 $\square$ A+HD1F2 $\square$ A+HD2F1 $\square$ A+HD2 F2 $\square$ COF1 $\square$ COF2

\section{Biomasa (mg materia seca/planta)}
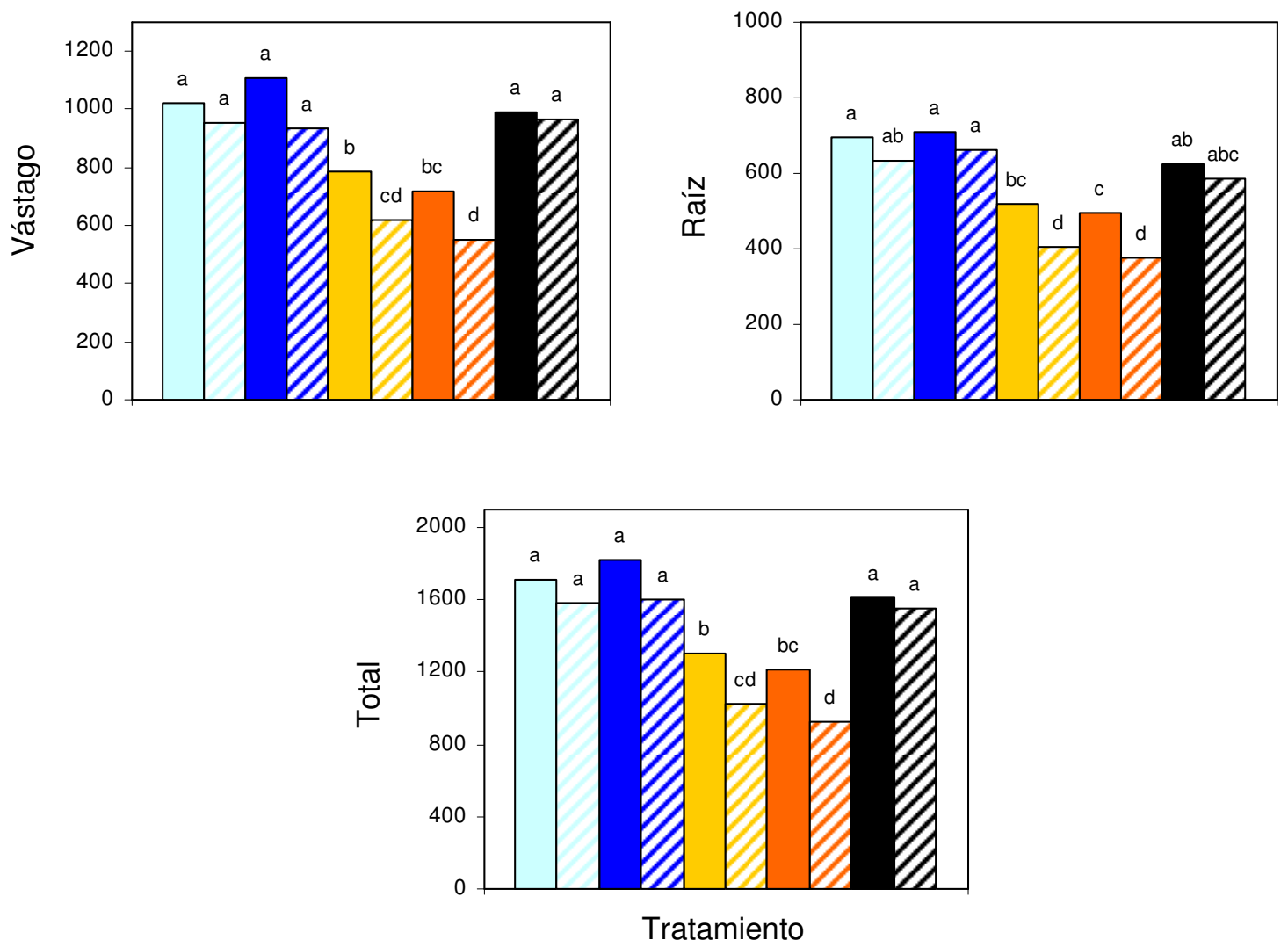

Figura 4.3.2. Influencia del compost (A y A+H), la dosıs de aplicación de éste (D1 y D2, equivalentes a 12 y 24 t de materia orgánica total/ha, respectivamente) y el programa de fertilización mineral (estándar, F1 y reducida, F2) en la acumulación y distribución de biomasa en rábano. Comparación con los controles ( $\mathrm{CO}$, que no recibieron compost). Año 1

A: compost de alperujo; $A+H$ : compost de alperujo más hidrolizado

Barras sin letra común difieren estadísticamente a $P \leq 0,05$ (test de Student-Newman-Keuls)

\section{Lechuga}

Según los resultados recogidos en la Figura 4.3.4 y la Tabla 4.3.3 -donde se presentan los parámetros controlados en relación con el crecimiento y desarrollo de la parte aérea de lechuga (número de hojas/planta, área de la hoja y contenido en clorofila de ésta)-, tanto el área de la hoja como el contenido en clorofila de la misma fueron superiores en los tratamientos que habían recibido el compost $\mathrm{A}+\mathrm{H}$ en comparación con $A$, no encontrándose diferencias en el número de hojas formadas por planta entre ambos composts. En lo que se refiere al factor Dosis de compost, la dosis de 12 t/ha incrementó el contenido en clorofila y redujo el área de la hoja en 
comparación con la dosis equivalente a 24 t/ha. Los dos programas de fertilización estudiados (F1 y F2) no afectaron al número de hojas formadas ni al área de éstas, mientras que el contenido foliar en clorofila fue superior con el programa reducido en nitrógeno y potasio (F2). Las interacciones estudiadas no fueron significativas para la mayoría de los parámetros controlados.

Tabla 4.3.2. Análisis factorial de la varianza $(P)$ para los efectos de los tratamientos estudiados -Compost (alperujo vs. alperujo más hidrolizado), Dosis de aplicación de éste (12 vs. 24 t de materia orgánica total/ha) y Programa de fertilización mineral (estándar, F1 vs. reducida, F2)- sobre la acumulación y distribución de biomasa, y sobre la producción total de raíces en rábano. Año 1

\begin{tabular}{lcccc}
\hline \multirow{2}{*}{ Fuente de variación } & \multicolumn{3}{c}{ Biomasa } & \multirow{2}{*}{ Producción total } \\
\cline { 2 - 4 } & Vástago & Raíz & Total & $* * *$ \\
1. Compost & $* * *$ & $* * *$ & $* * *$ & ns \\
2. Dosis de compost & $\mathrm{ns}$ & $\mathrm{ns}$ & $\mathrm{ns}$ & $* *$ \\
3. Fertilización mineral & $* * *$ & $* * *$ & $* * *$ & \\
4. Interacción & & & & $\mathrm{ns}$ \\
$1 \times 2$ & $\mathrm{~ns}$ & $\mathrm{~ns}$ & $\mathrm{~ns}$ & $\mathrm{~ns}$ \\
$1 \times 3$ & $\mathrm{~ns}$ & $\mathrm{~ns}$ & $\mathrm{~ns}$ & $\mathrm{~ns}$ \\
$2 \times 3$ & $\mathrm{~ns}$ & $\mathrm{~ns}$ & $\mathrm{~ns}$ & $\mathrm{~ns}$ \\
$1 \times 2 \times 3$ & $\mathrm{~ns}$ & $\mathrm{~ns}$ & $\mathrm{~ns}$ &
\end{tabular}

$\bar{P}$ : nivel de significación. ns, ** y *** indican diferencias no significativas o estadísticamente significativas a $P \leq 0,01$ y $P \leq 0,001$, respectivamente

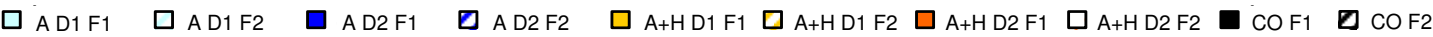

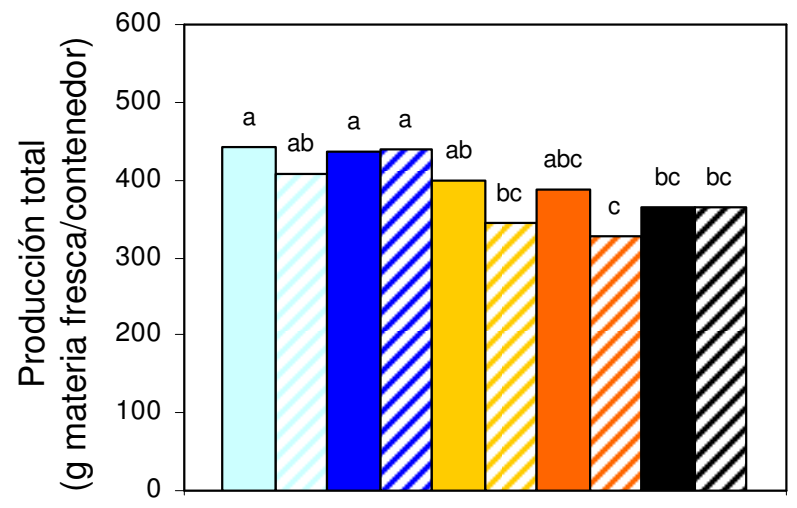

Tratamiento

Figura 4.3.3. Influencia del compost (A y A+H), la dosis de aplicación de éste (D1 y D2, equivalentes a 12 y 24 t de materia orgánica total/ha, respectivamente) y el programa de fertilización mineral (estándar, F1 y reducida, F2) en la producción total de raíces en rábano. Comparación con los controles (CO, que no recibieron compost). Año 1 A: compost de alperujo; $A+H$ : compost de alperujo más hidrolizado Barras sin letra común difieren estadísticamente a $P \leq 0,05$ (test de Student-Newman-Keuls) 


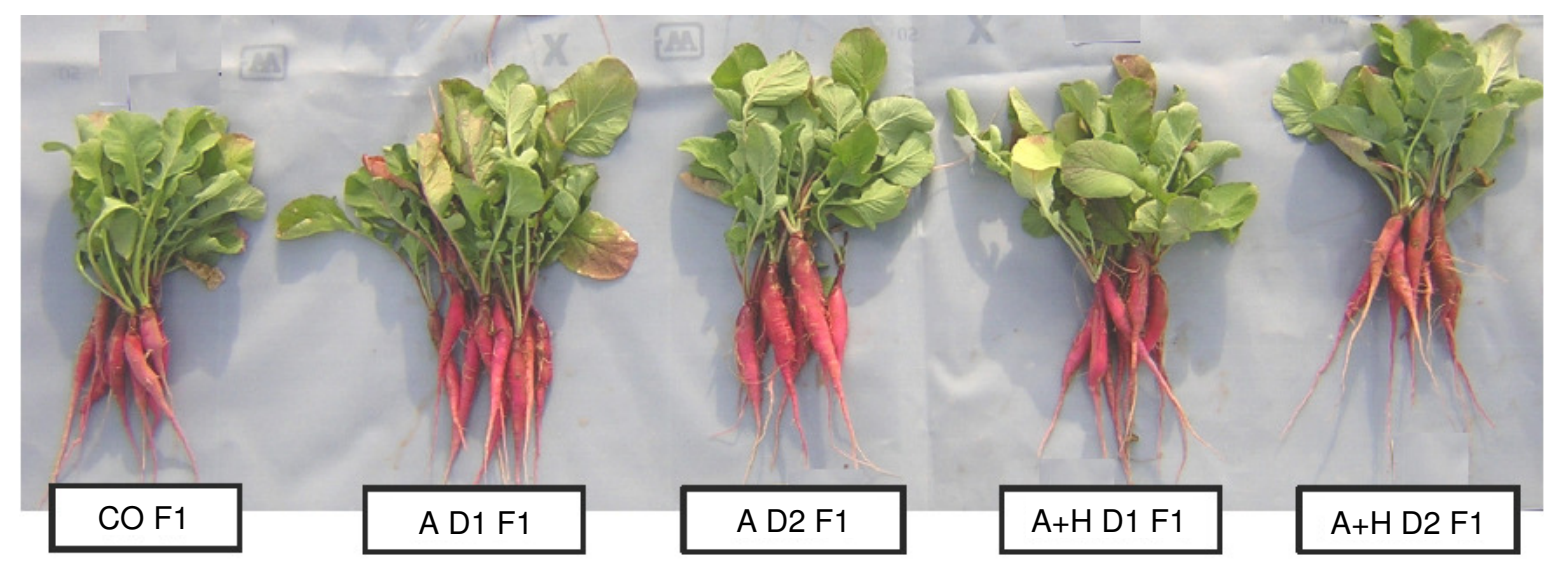

Fotografía 4.3.1. Imagen que compara las plantas de rábano producidas en los tratamientos (mezclas de suelo) con los composts $\mathrm{A}$ y $\mathrm{A}+\mathrm{H}$, aplicados a las dosis $\mathrm{D} 1 \mathrm{y}$ D2 (equivalentes a 12 y 24 t materia orgánica total/ha, respectivamente), junto con el programa de fertilización mineral estándar (F1), y en el control ( $\mathrm{CO}$, que no recibió aporte de materia orgánica) con idéntica fertilización mineral. Año 1 del experimento

Por lo que se refiere a la comparación entre los tratamientos con compost y los controles (Figura 4.3.4), debe señalarse que la adición de compost no influyó en el número de hojas formadas por planta, pero se tradujo en un incremento en la superficie foliar cuando se aplicó A a 24 t/ha, o A+H a cualquiera de las dos dosis estudiadas en el experimento. En contraste con lo anterior, la aplicación de compost disminuyó el contenido foliar de clorofila respecto a los controles, exceptuando el tratamiento $\mathrm{A}+\mathrm{H}$ a $12 \mathrm{t} / \mathrm{ha}$.

De acuerdo con el análisis estadístico (factorial) de los efectos principales de los tratamientos experimentales estudiados sobre la producción de biomasa (Figura 4.3.5; Tabla 4.3.4), no se encontraron diferencias en peso seco de la parte aérea, raíz y planta entera entre los dos composts. Sin embargo, la dosis de 24 t/ha incrementó de manera altamente significativa la acumulación y distribución de biomasa en este cultivo en comparación con la dosis de 12 t/ha, especialmente cuando se abonó con el programa mineral estándar (F1). En adición, y según reveló dicho análisis de la varianza multifactorial, este plan de abonado (F1) aumentó el peso seco de la raíz y de la planta entera respecto al programa de fertilización reducido en nitrógeno y potasio (F2). En los parámetros peso seco de las hojas (vástago) y de la planta entera (total), la interacción de los factores Dosis de compost y Fertilización mineral fue altamente significativa. 
$\square$ AD1F1 $\square$ AD1F2 $\square$ AD2F1 $\square$ AD2F2 $\square$ A+HD1F1 $\square$ A+HD1F2 $\square$ A+HD2F1 $\square$ A+HD2 F2 $\square$ COF1 $\square$ COF2
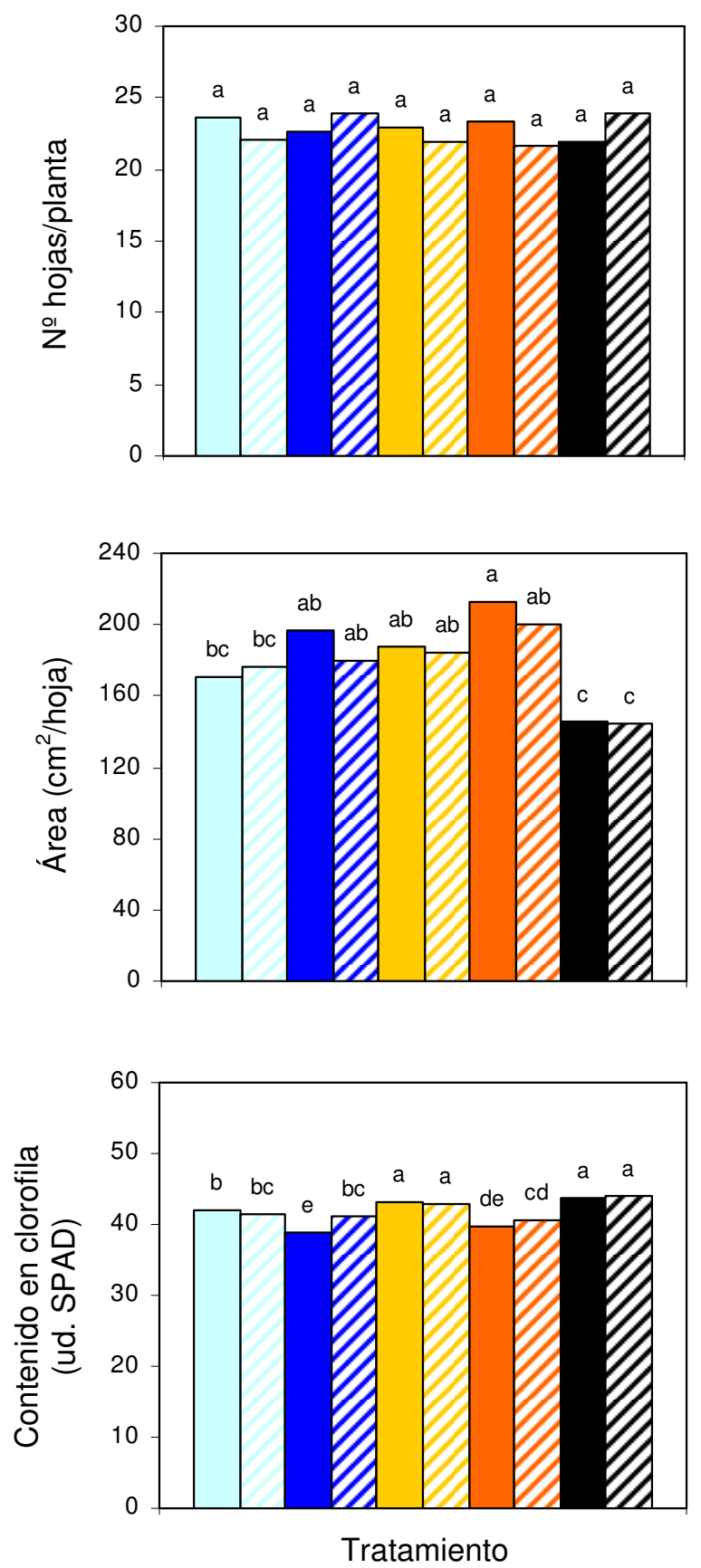

Figura 4.3.4. Influencia del compost (A y A+H), la dosis de aplicación de éste (D1 y D2, equivalentes a 12 y 24 t de materia orgánica total/ha, respectivamente) y el programa de fertilización mineral (estándar, F1 y reducida, F2) en el desarrollo de la hoja de lechuga. Comparación con los controles ( $\mathrm{CO}$, que no recibieron compost). Año 1 A: compost de alperujo; $\mathrm{A}+\mathrm{H}$ : compost de alperujo más hidrolizado

Barras sin letra común difieren estadísticamente a $P \leq 0,05$ (test de Student-Newman-Keuls) 
Tabla 4.3.3. Análisis factorial de la varianza $(P)$ para los efectos de los tratamientos estudiados -Compost (alperujo vs. alperujo más hidrolizado), Dosis de aplicación de éste (12 vs. 24 t de materia orgánica total/ha) y Programa de fertilización mineral (estándar vs. reducida)- sobre el desarrollo de la hoja en lechuga. Año 1

\begin{tabular}{lccc}
\hline \multirow{2}{*}{ Fuente de variación } & \multicolumn{3}{c}{ Hoja } \\
\cline { 2 - 4 } 1. Compost & No/planta & Área & Contenido en clorofila \\
2. Dosis de compost & $\mathrm{ns}$ & $* *$ & $* *$ \\
3. Fertilización mineral & $\mathrm{ns}$ & $\mathrm{ns}$ & $*$ \\
4. Interacción & $\mathrm{ns}$ & & \\
$1 \times 2$ & & $\mathrm{~ns}$ & \\
$1 \times 3$ & $\mathrm{~ns}$ & $\mathrm{~ns}$ & $\mathrm{~ns}$ \\
$2 \times 3$ & $\mathrm{~ns}$ & $\mathrm{~ns}$ & $* * *$ \\
$1 \times 2 \times 3$ & $\mathrm{~ns}$ & $\mathrm{~ns}$ & $\mathrm{~ns}$
\end{tabular}

$P$ : nivel de significación. ns, ${ }^{*},{ }^{* *} \mathrm{y} * * *$ indican diferencias no significativas o estadísticamente significativas a $P \leq 0,05, P \leq 0,01$ y $P \leq 0,001$, respectivamente

La comparación entre los tratamientos con compost y los suelos control puso de manifiesto que la mayoría de los tratamientos a los que se aplicó alperujo compostado produjeron cantidades de biomasa en vástago, raíces y planta entera (total) mayores que los controles. Así, todos los tratamientos con $\mathrm{A}$ o $\mathrm{A}+\mathrm{H}$ que recibieron el plan de fertilización estándar (F1) se tradujeron en un peso seco de los parámetros controlados superiores al control correspondiente (CO F1), particularmente cuando el compost se incorporó a la dosis de 24 t/ha. Con relación a los tratamientos con compost que fueron abonados con el programa mineral reducido (F2), únicamente aquellos en los que el compost se aplicó a la dosis de 24 t/ha difirieron del control con plan de abonado mineral equivalente (CO F2).

En referencia a la productividad (producción total, Figura 4.3.6), el análisis factorial realizado (Tabla 4.3.4) mostró que: el factor Compost no fue estadísticamente significativo; la Dosis de compost equivalente a 24 t/ha aumentó notablemente la producción respecto a la dosis de 12 t/ha; y, el programa de fertilización estándar (F1) proporcionó rendimientos superiores al plan reducido (F2).

En la comparación de los tratamientos con compost y los controles (Figura 4.3.6) merece destacarse que todos los tratamientos que incluían compost produjeron una cosecha significativamente superior a dichos controles, destacando $A+H$ a $24 \mathrm{t} / \mathrm{ha}$ más fertilización estándar (F1) (Fotografía 4.3.2), que proporcionó la productividad máxima del ensayo (1012 g/contenedor). 


\section{$\square$ AD1F1 $\square$ AD1F2 $\square$ AD2F1 $\square$ AD2 F2 $\square$ A+HD1F1 $\square$ A+HD1F2 $\square$ A+HD2F1 $\square$ A+HD2 F2 $\square$ COF1 $\boldsymbol{\square}$ COF2}

\section{Biomasa (g materia seca/planta)}
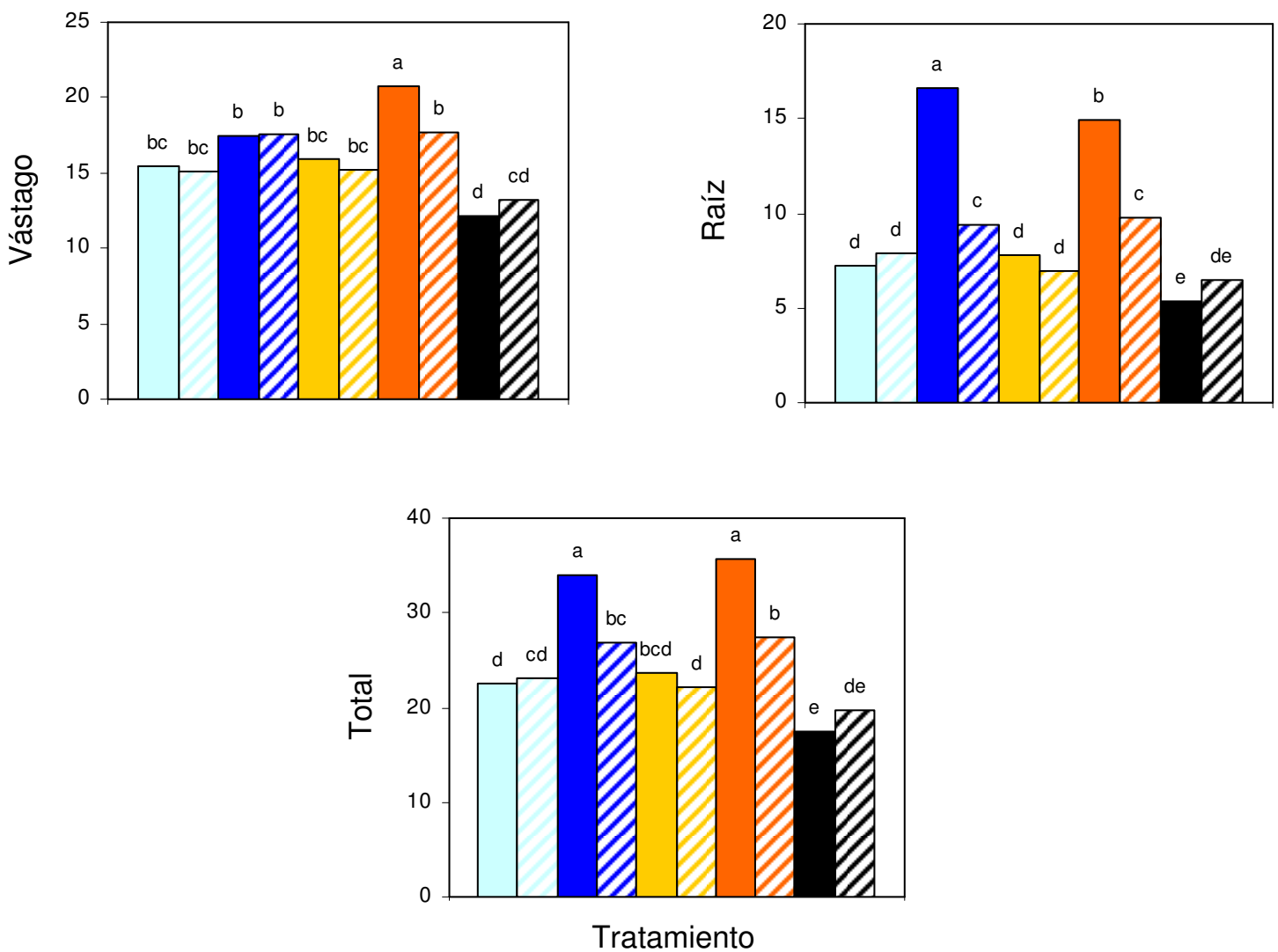

Figura 4.3.5. Influencia del compost (A y A+H), la dosis de aplicación de éste (D1 y D2, equivalentes a 12 y 24 t de materia orgánica total/ha, respectivamente) y el programa de fertilización mineral (estándar, F1 y reducida, F2) en la acumulación y distribución de biomasa en lechuga. Comparación con los controles ( $\mathrm{CO}$, que no recibieron compost). Año 1

A: compost de alperujo; $\mathrm{A}+\mathrm{H}$ : compost de alperujo más hidrolizado

Barras sin letra común difieren estadísticamente a $P \leq 0,05$ (test de Student-Newman-Keuls) 
Tabla 4.3.4. Análisis factorial de la varianza $(P)$ para los efectos de los tratamientos estudiados -Compost (alperujo vs. alperujo más hidrolizado), Dosis de aplicación de éste (12 vs. 24 t de materia orgánica total/ha) y Programa de fertilización mineral (estándar vs. reducida)- sobre la acumulación y distribución de biomasa, y sobre la producción total de cogollos en lechuga. Año 1

\begin{tabular}{lcccc}
\hline \multirow{2}{*}{ Fuente de variación } & \multicolumn{3}{c}{ Biomasa } & \multirow{2}{*}{ Producción total } \\
\cline { 2 - 4 } & Vástago & Rá́z & Total & ns \\
1. Compost & $\mathrm{ns}$ & $\mathrm{ns}$ & $\mathrm{ns}$ & $* * *$ \\
2. Dosis de compost & $* * *$ & $* * *$ & $* * *$ & $*$ \\
3. Fertilización mineral & $\mathrm{ns}$ & $* * *$ & $* * *$ & \\
4. Interacción & & & & $\mathrm{ns}$ \\
$1 \times 2$ & $\mathrm{~ns}$ & $\mathrm{~ns}$ & $\mathrm{~ns}$ & $\mathrm{~ns}$ \\
$1 \times 3$ & $\mathrm{~ns}$ & $\mathrm{~ns}$ & $\mathrm{~ns}$ & $\mathrm{~ns}$ \\
$2 \times 3$ & $* * *$ & $\mathrm{~ns}$ & $* * *$ & $\mathrm{~ns}$ \\
$1 \times 2 \times 3$ & $\mathrm{~ns}$ & $\mathrm{~ns}$ & $*$ &
\end{tabular}

$P$ : nivel de significación. ns, * $y^{* * *}$ indican diferencias no significativas o estadísticamente significativas a $P \leq 0,05$ y $P \leq 0,001$, respectivamente

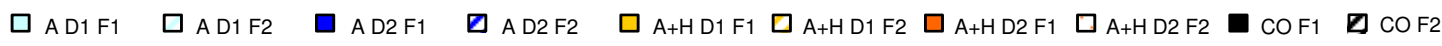

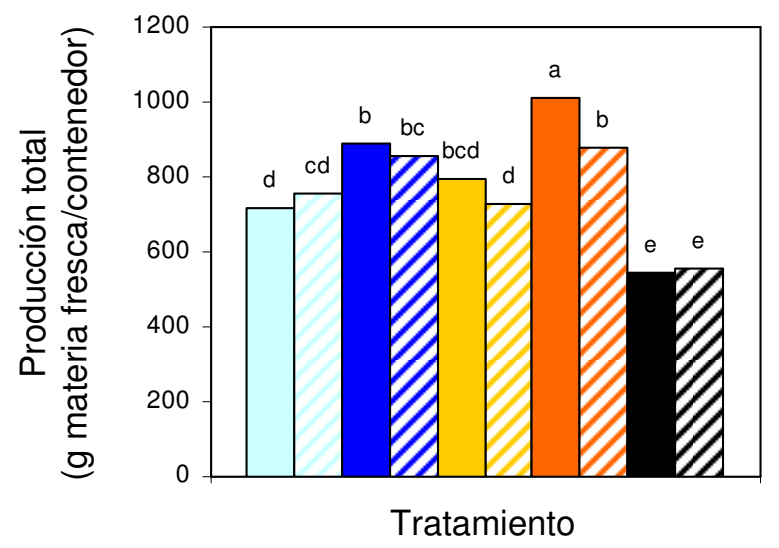

Figura 4.3.6. Influencia del compost $(A$ y $A+H)$, la dosis de aplicación de éste (D1 y D2, equivalentes a 12 y 24 t de materia orgánica total/ha, respectivamente) y el programa de fertilización mineral (estándar, F1 y reducida, F2) en la producción total de cogollos de lechuga. Comparación con los controles ( $\mathrm{CO}$, que no recibieron compost). Año 1 A: compost de alperujo; $\mathrm{A}+\mathrm{H}$ : compost de alperujo más hidrolizado Barras sin letra común difieren estadísticamente a $P \leq 0,05$ (test de Student-Newman-Keuls) 


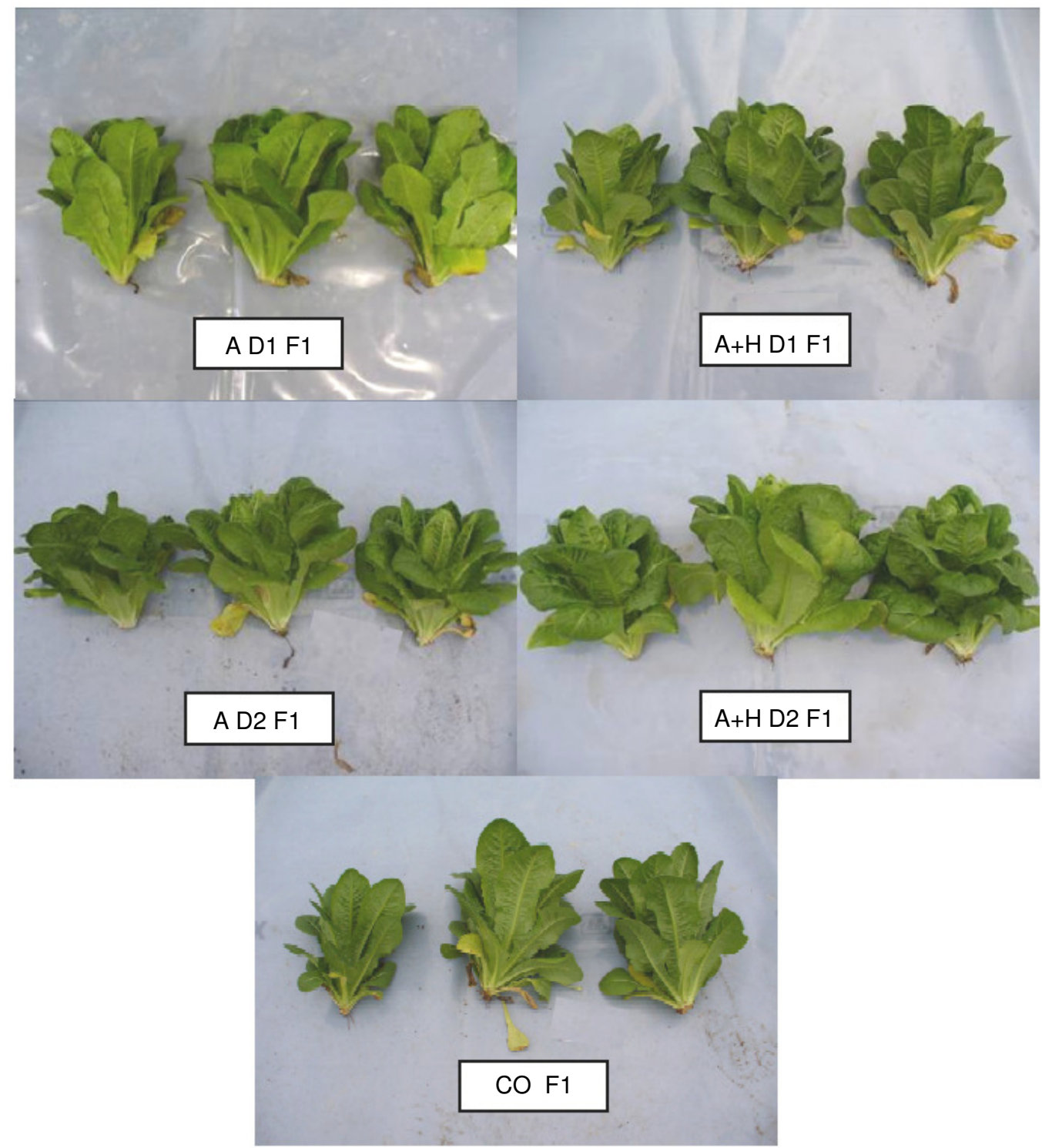

Fotografía 4.3.2. Imagen que compara las piezas de lechuga producidas en los tratamientos (mezclas de suelo) con los composts $A$ y $A+H$, aplicados a las dosis D1 y D2 (equivalentes a 12 y 24 t materia orgánica total/ha, respectivamente), junto con el programa de fertilización mineral estándar (F1), y en el control (CO, que no recibió aporte de materia orgánica) con idéntica fertilización mineral. Año 1 del experimento

\section{Judía}

Con relación al cultivo de judía, en la Figura 4.3.7 y la Tabla 4.3.5 se presentan los resultados del estudio comparativo -tratamientos con compost vs. controles- de diferentes parámetros relacionados con la morfología y el desarrollo del vástago (diferenciando tallo y hojas), las vainas y el sistema radical así como el nivel de significación $(P)$ del análisis de la varianza multifactorial para los efectos de los tratamientos experimentales estudiados sobre dichos parámetros, respectivamente. 

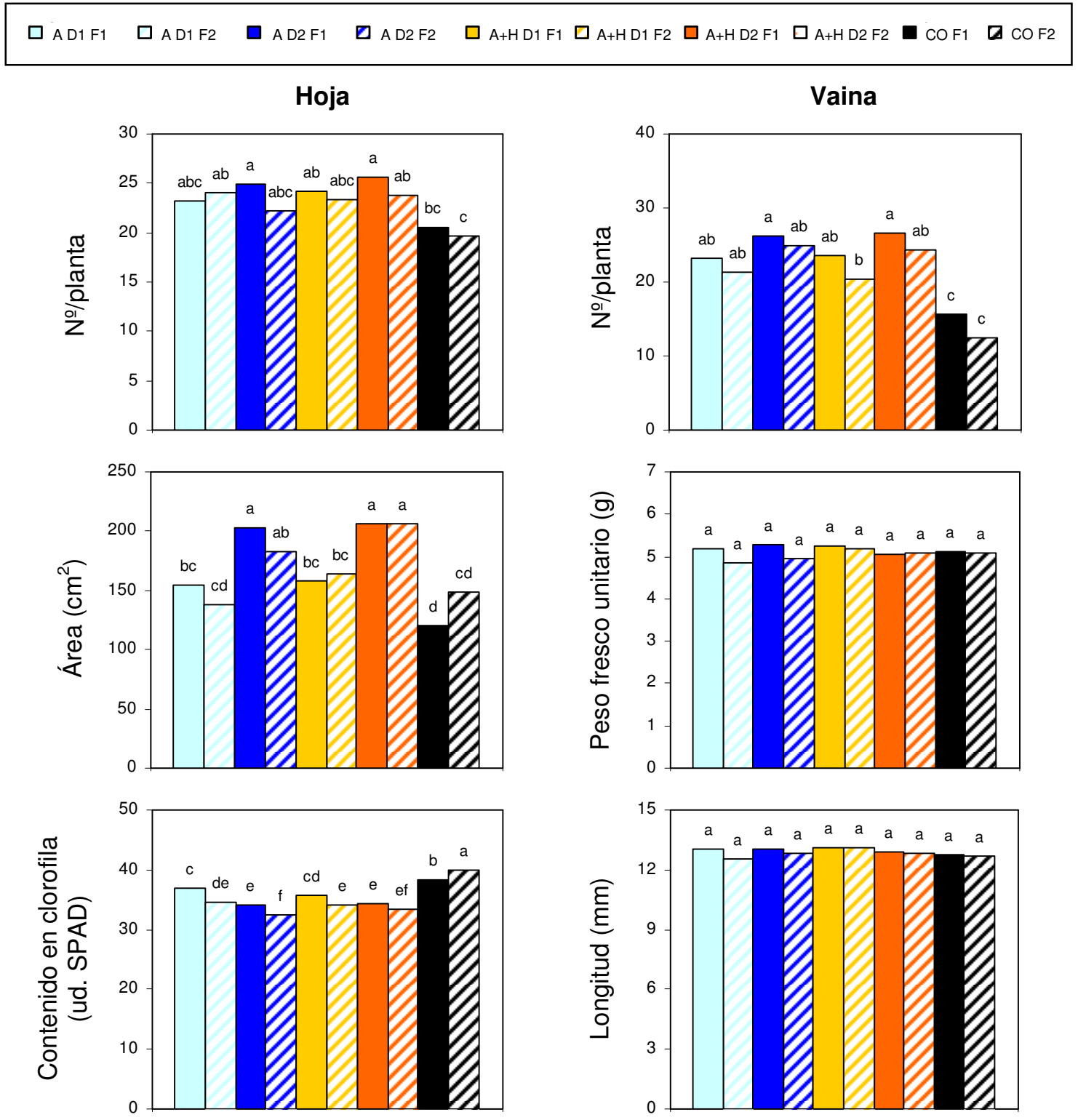

Tallo

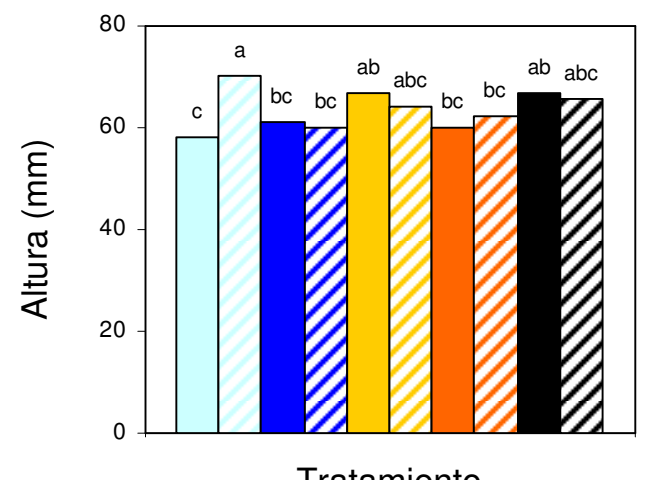

Raíz

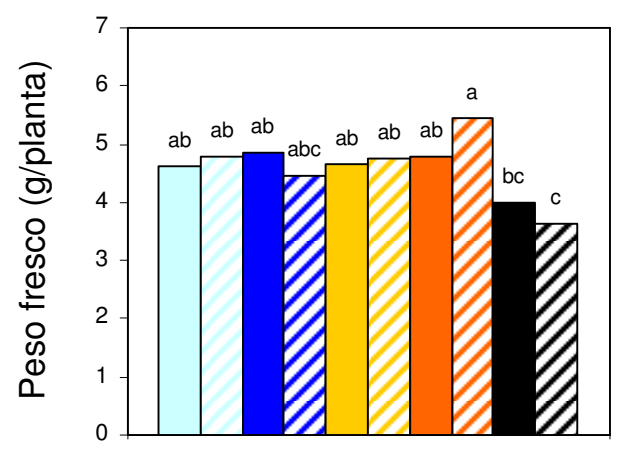

Tratamiento

Figura 4.3.7. Influencia del compost $(A$ y $A+H)$, la dosis de aplicación de éste (D1 y D2, equivalentes a 12 y 24 t de materia orgánica total/ha, respectivamente) y el programa de fertilización mineral (estándar, F1 y reducida, F2) en el crecimiento vegetativo (tallo, hojas y raíz) y el desarrollo reproductivo (vainas) de judía. Comparación con los controles (CO, que no recibieron compost). Año 1

A: compost de alperujo; $\mathrm{A}+\mathrm{H}$ : compost de alperujo más hidrolizado

Barras sin letra común difieren estadísticamente a $P \leq 0,05$ (test de Student-Newman-Keuls) 
Tabla 4.3.5. Análisis factorial de la varianza $(P)$ para los efectos de los tratamientos estudiados -Compost (alperujo vs. alperujo más hidrolizado), Dosis de aplicación de éste (12 vs. 24 t de materia orgánica total/ha) y Programa de fertilización mineral (estándar vs. reducida)- sobre el crecimiento vegetativo y el desarrollo reproductivo de judía. Año 1

\begin{tabular}{|c|c|c|c|c|c|c|c|c|}
\hline \multirow[b]{2}{*}{ Fuente de variación } & \multirow[b]{2}{*}{$\begin{array}{c}\text { Altura } \\
\text { tallo }\end{array}$} & \multicolumn{3}{|c|}{ Hoja } & \multicolumn{3}{|c|}{ Vaina } & \multirow[b]{2}{*}{$\begin{array}{c}\text { Peso fresco } \\
\text { raíz }\end{array}$} \\
\hline & & $\begin{array}{l}\mathrm{N} \% \\
\text { planta }\end{array}$ & Área & $\begin{array}{l}\text { Contenido } \\
\text { en clorofila }\end{array}$ & $\begin{array}{c}\mathrm{N} \% \\
\text { planta }\end{array}$ & $\begin{array}{c}\text { Peso fresco } \\
\text { unitario }\end{array}$ & Longitud & \\
\hline 1. Compost & ns & ns & * & ns & ns & ns & ns & ns \\
\hline 2. Dosis de compost & ** & ns & $* * *$ & $* * *$ & ** & ns & ns & ns \\
\hline 3. Fertilización mineral & * & ns & ns & $* * *$ & * & ns & ns & ns \\
\hline \multicolumn{9}{|l|}{ 4. Interacción } \\
\hline $1 \times 2$ & ns & ns & ns & * & ns & ns & ns & ns \\
\hline $1 \times 3$ & * & ns & ns & ns & ns & ns & ns & ns \\
\hline $2 \times 3$ & ns & ns & ns & ns & ns & ns & ns & ns \\
\hline $1 \times 2 \times 3$ & *** & ns & ns & ns & ns & ns & ns & ns \\
\hline
\end{tabular}

$P$ : nivel de significación. ns, * ${ }^{*}{ }^{*} \mathrm{y} * * *$ indican diferencias no significativas o estadísticamente significativas a $P \leq 0,05, P \leq 0,01 \mathrm{y}$ $P \leq 0,001$, respectivamente

Ninguno de los tres factores estudiados (Compost, Dosis de compost y Fertilización mineral) influyó significativamente en el número de hojas formadas por planta, el peso fresco unitario y la longitud de las vainas, y el peso fresco de la raíz, así como tampoco la mayoría de las interacciones de éstos (Tabla 4.3.5). Respecto al resto de parámetros controlados, el compost $A+H$ aumentó el área de la hoja en comparación con A (Figura 4.3.7); la dosis de compost equivalente a 12 t/ha incrementó la altura del tallo y el contenido en clorofila de la hoja, mientras que la dosis de 24 t/ha aumentó el área de la hoja y el número de vainas producidas por planta; y, finalmente, en cuanto al factor Fertilización mineral, el programa reducido (F2) se tradujo en una altura del tallo superior al plan estándar (F1), mientras que este último provocó un aumento tanto del contenido foliar en clorofila como del número de vainas formadas por planta.

El estudio comparativo de los tratamientos con compost y los controles (Figura 4.3.7) mostró que el número de hojas formadas por planta fue superior en la mayoría de los tratamientos que recibieron compost, encontrándose las diferencias más marcadas en los tratamientos en que éste se aplicó a la dosis de 24 t/ha en combinación con el plan estándar de fertilización (F1). En todos los tratamientos que recibieron el programa de fertilización mineral estándar (F1) el área de la hoja fue superior al control (CO F1), mientras que en los que incluían el plan de fertilización reducida (F2) el valor de dicho parámetro superó al control equivalente (CO F2) sólo cuando el compost se aplicó a la dosis de 24 t/ha. La incorporación de compost al 
suelo disminuyó el contenido en clorofila de las hojas, encontrándose que la cuantía de este efecto fue tanto más elevada cuanto mayor fue el desarrollo de la planta (número de hojas formadas, área de la hoja, número de vainas producidas, etc.). El análisis de los parámetros relacionados con las vainas recolectadas (número, peso fresco unitario y longitud) indicó que los tratamientos experimentales estudiados proporcionaron como único efecto estadísticamente significativo el incremento en el número de vainas producidas por planta en todos los que recibieron compost, en comparación con los controles, efecto que fue más acusado con la dosis máxima (24 t/ha) juntamente con la fertilización mineral estándar (F1). Por otra parte, este estudio comparativo con los controles no detectó influencia alguna de la adición de compost en la altura del tallo; en cuanto a la raíz, la aplicación del programa de fertilización reducida incrementó significativamente el peso fresco de ésta en la mayoría de los tratamientos.

De acuerdo con la Figura 4.3.8 y la Tabla 4.3.6, que recogen los resultados de acumulación de biomasa en las diferentes partes anatómicas y en la planta entera de judía, únicamente se encontraron diferencias estadísticamente significativas para el factor Compost en el peso seco del tallo, cuyo valor fue comparativamente superior cuando se aplicó $A+H$. En relación con la dosis de compost, la biomasa producida fue más alta con la dosis máxima (24 t/ha) en todos los parámetros medidos, a excepción del peso seco de las raíces, en que el factor Dosis de compost no resultó significativo. El programa de fertilización mineral estándar (F1) aumentó el peso de la biomasa en vainas, parte aérea completa y planta entera (total) respecto al plan reducido (F2).

Asimismo, el estudio comparativo de los tratamientos que recibieron compost y los controles (Figura 4.3.8) presentó una tendencia de variación clara, siendo los valores de biomasa obtenidos, en general, significativamente mayores en los suelos enmendados (Fotografía 4.3.3). Así, todos los tratamientos proporcionaron un peso seco del tallo superior a los controles, exceptuando el compost A a la dosis de $12 \mathrm{t} / \mathrm{ha}$ en combinación con el plan de fertilización estándar (F1). En la producción de biomasa en las hojas destacaron el tratamiento con A a la dosis de 24 t/ha en combinación con el programa de fertilización estándar (F1), y los de A+H a dicha dosis (y con los dos planes de fertilización mineral estudiados, F1 y F2). El crecimiento de las vainas fue comparativamente superior cuando los composts se aplicaron a la dosis de 24 t/ha junto con la fertilización mineral estándar (F1). Además, la mayoría de tratamientos con $\mathrm{A}$ y $\mathrm{A}+\mathrm{H}$ produjeron un peso de la raíz mayor que los controles. El 
desarrollo tanto de la parte aérea como de la planta entera (biomasa total) fue más alto en los tratamientos con $\mathrm{A}$ y $\mathrm{A}+\mathrm{H}$ a la dosis máxima juntamente con el plan de abonado estándar (F1), y en el caso de la aplicación de A+H también con el programa de fertilización reducido (F2).

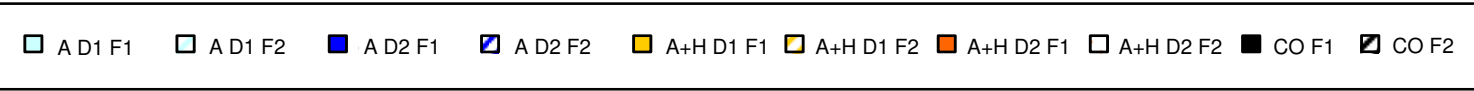

\section{Biomasa}
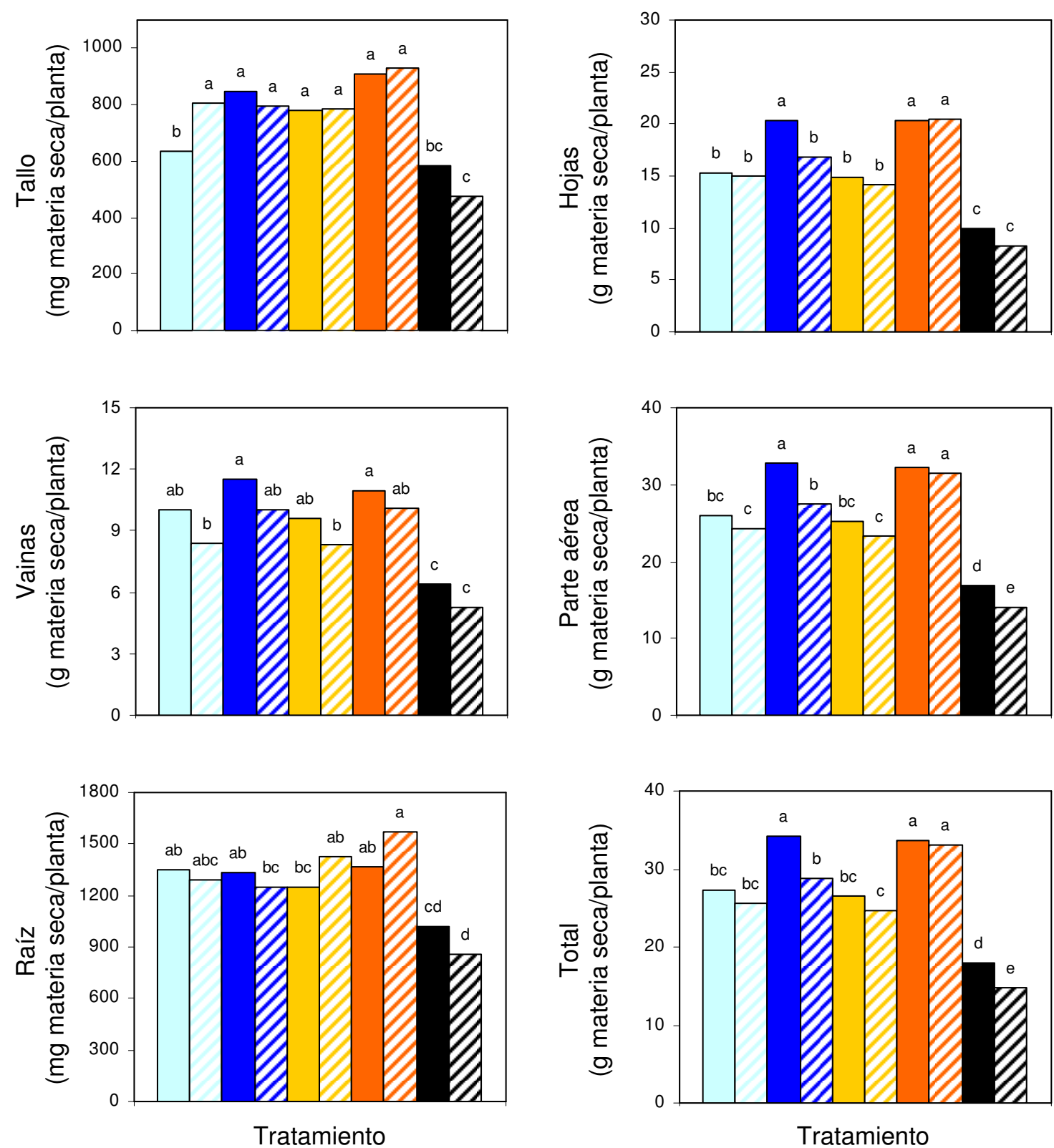

Figura 4.3.8. Influencia del compost (A y A+H), la dosis de aplicación de éste (D1 y D2, equivalentes a 12 y 24 t de materia orgánica total/ha, respectivamente) y el programa de fertilización mineral (estándar, F1 y reducida, F2) en la acumulación y distribución de biomasa en judía. Comparación con los controles ( $\mathrm{CO}$, que no recibieron compost). Año 1

A: compost de alperujo; $\mathrm{A}+\mathrm{H}$ : compost de alperujo más hidrolizado

Barras sin letra común difieren estadísticamente a $P \leq 0,05$ (test de Student-Newman-Keuls) 
Tabla 4.3.6. Análisis factorial de la varianza $(P)$ para los efectos de los tratamientos estudiados -Compost (alperujo vs. alperujo más hidrolizado), Dosis de aplicación de éste (12 vs. 24 t de materia orgánica total/ha) y Programa de fertilización mineral (estándar vs. reducida)- sobre la acumulación y distribución de biomasa en judía. Año 1

\begin{tabular}{|c|c|c|c|c|c|c|}
\hline \multirow[b]{2}{*}{ Fuente de variación } & \multicolumn{6}{|c|}{ Biomasa } \\
\hline & Tallo & Hojas & Vainas & $\begin{array}{l}\text { Parte } \\
\text { aérea }\end{array}$ & Raíz & Total \\
\hline 1. Compost & $\star \star$ & ns & ns & ns & ns & ns \\
\hline 2. Dosis de compost & $* * *$ & $* * *$ & $* * *$ & $* * *$ & ns & $\star \star \star$ \\
\hline 3. Fertilización mineral & ns & ns & $\star \star$ & $\star \star *$ & ns & * \\
\hline \multicolumn{7}{|l|}{ 4. Interacción } \\
\hline $1 \times 2$ & ns & ns & ns & ns & ns & ns \\
\hline $1 \times 3$ & ns & ns & ns & ns & * & * \\
\hline $2 \times 3$ & ns & ns & ns & ns & ns & ns \\
\hline $1 \times 2 \times 3$ & ns & ns & ns & ns & ns & ns \\
\hline
\end{tabular}

P: nivel de significación. ns, * ${ }^{*} * \mathrm{y} * * *$ indican diferencias no significativas o estadísticamente significativas a $P \leq 0,05, P \leq 0,01 \mathrm{y}$ $P \leq 0,001$, respectivamente

La cosecha de las vainas de judía se realizó en cuatro recolecciones sucesivas, cuyos resultados de producción (comercial, de acuerdo con el tamaño de las vainas) expresada en g de legumbre fresca/contenedor y en número de vainas/contenedor se recogen en la Tabla 4.3.7. Puede apreciarse que los tres factores estudiados tuvieron efectos estadísticamente significativos solamente en las dos primeras recolecciones, destacando la influencia positiva y más marcada de $\mathrm{A}+\mathrm{H}$ respecto a $\mathrm{A}$ en la producción en peso y en número de vainas de la segunda recolección. El factor Dosis de compost reveló que los mejores resultados de producción (en peso y en número de vainas) se alcanzaron con la aplicación a 24 t/ha (en comparación con la de 12 t/ha). Por su parte, el plan de abonado estándar (F1) incrementó el valor de los dos parámetros estudiados (peso y número de vainas) cuando se comparó con la fertilización del programa reducido (F2).

El estudio comparativo de los parámetros relacionados con la producción de judía -en cada recolección- entre los tratamientos que recibieron compost y los controles puso de manifiesto que la aplicación de compost al suelo provocó un aumento en la producción de vainas en la primera recolección, tanto en el peso obtenido como en el número de legumbres recogidas, particularmente con la dosis de 24 t/ha y el plan de fertilización estándar (F1). En la segunda recolección destacaron, por su mayor productividad, el tratamiento con el compost A a la dosis máxima (24 t/ha junto con el plan estándar de fertilización (F1), y también aquellos con A+H a 24 
t/ha con los dos programas de fertilización estudiados (F1 y F2) y a 12 t/ha en combinación con la fertilización estándar (F1). En cuanto a la tercera recolección, los tratamientos con compost proporcionaron generalmente producciones superiores a los controles (en número y en peso de las vainas), especialmente cuando los composts se aplicaron a la dosis de 24 t/ha juntamente con el plan de abonado estándar (F1). La última recolección, de cuantía más elevada que las anteriores, particularmente en los controles (CO F1 y CO F2), arrojó resultados similares a los descritos en las cosechas anteriores, pero las diferencias entre los distintos tratamientos no llegaron a alcanzar los niveles de significación estadística.

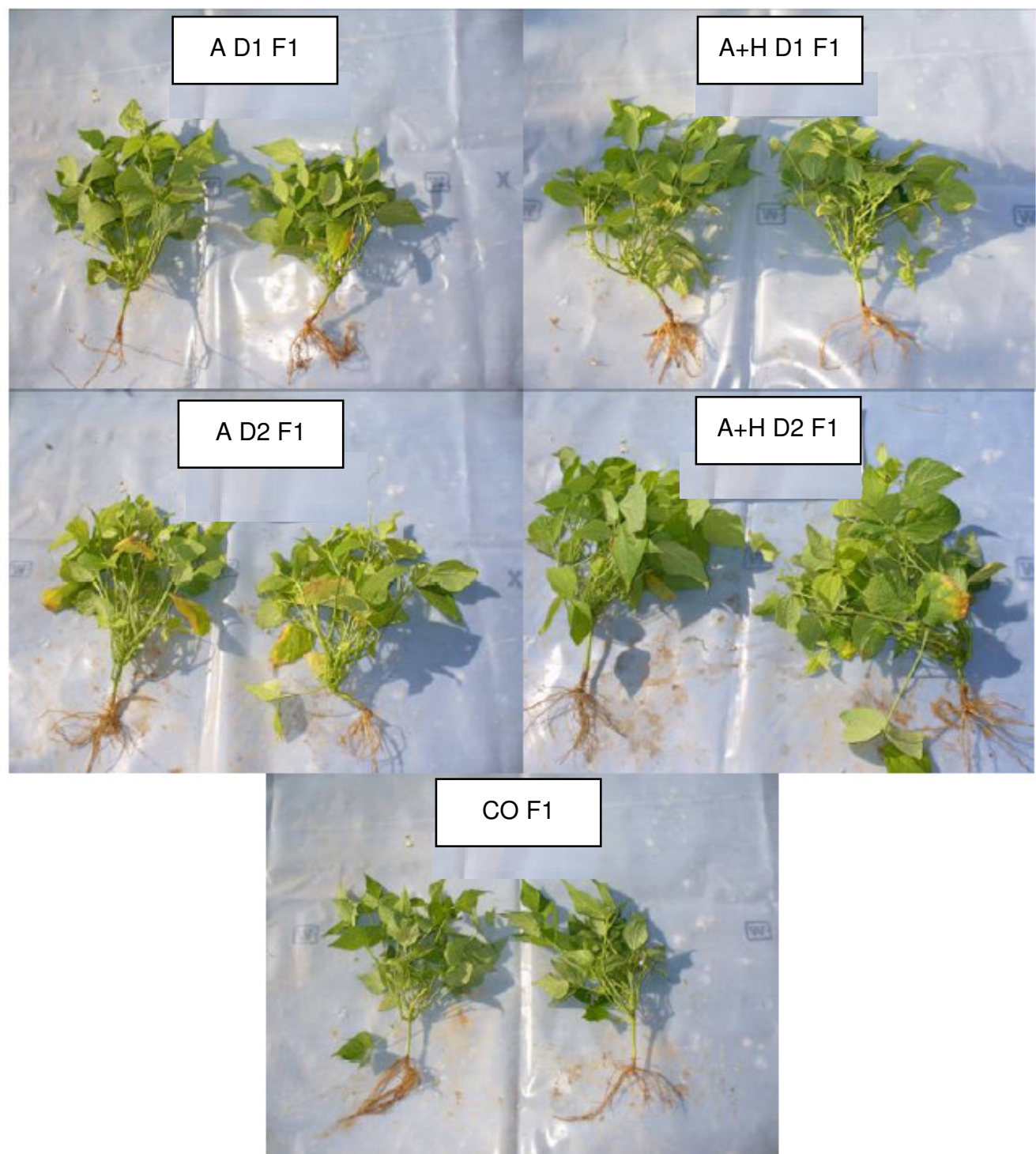

Fotografía 4.3.3. Imagen que compara las plantas de judía producidas en los tratamientos (mezclas de suelo) con los composts $\mathrm{A}$ y $\mathrm{A}+\mathrm{H}$, aplicados a las dosis D1 y D2 (equivalentes a 12 y 24 t materia orgánica total/ha, respectivamente), junto con el programa de fertilización mineral estándar (F1), y en el control (CO, que no recibió aporte de materia orgánica) con idéntica fertilización mineral. Año 1 del experimento 


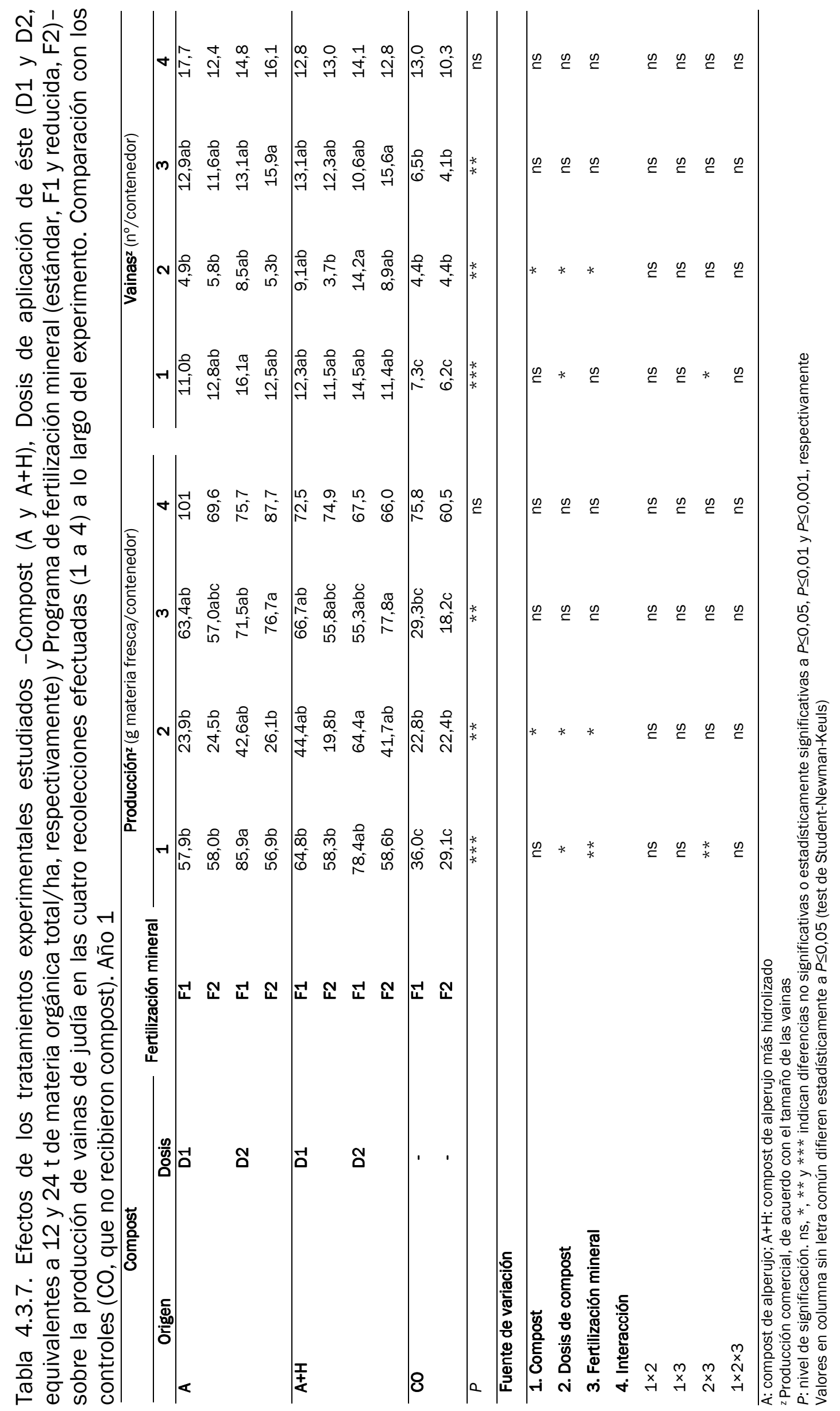


La producción acumulada de vainas a lo largo del experimento (Figura 4.3.9), expresada como porcentaje de la producción total (comercial + no comercial) obtenida en el experimento completo, es un indicador de la precocidad de la cosecha. Se apreció mayor diferencia en los valores de este parámetro entre los tratamientos que fueron fertilizados con el programa estándar (F1) que entre los que recibieron el plan de fertilización reducida (F2). En la segunda y tercera recolección (días 49 y 54 desde la siembra, respectivamente), el programa de fertilización estándar (F1) se tradujo en un porcentaje (en peso) de vainas en los tratamientos con $\mathrm{A}+\mathrm{H}$ o $\mathrm{A}$ a $24 \mathrm{t} /$ ha superior a aquellos con A a 12 t/ha y el control (CO F1). Por otra parte, en la primera y segunda recolección en los tratamientos con plan de abonado reducido (F2) se obtuvo un porcentaje de cosecha, respecto a la total producida, similar en todos los tratamientos estudiados, observándose en la tercera recolección mayores diferencias entre los tratamientos con compost y el control (CO F2).

De acuerdo con los resultados de producción recogidos en la Tabla 4.3.8, los composts $\mathrm{A}$ y $\mathrm{A}+\mathrm{H}$ proporcionaron valores de cosecha precoz -es decir, la producida en las primeras dos recolecciones- y cosecha total (comercial + no comercial en el experimento completo) similares. En contraste con lo anterior, se registró un incremento significativo en la producción con la dosis máxima de compost (24 t/ha) y el programa de fertilización estándar (F1) en comparación con la dosis de 12 t/ha y la fertilización reducida (F2), respectivamente. Ninguna de las interacciones de los factores estudiados tuvo efectos estadísticamente significativos.

Al estudiar comparativamente los tratamientos con compost y los controles se observó un incremento en la producción precoz de vainas cuando se aplicó A a 24 t/ha en combinación con el programa de fertilización estándar (F1) y cualquiera de los tratamientos con $\mathrm{A}+\mathrm{H}$ (a excepción de la dosis de 12 t/ha en combinación con el plan de fertilización reducido, F2). Los resultados de este análisis estadístico estuvieron estrechamente relacionados con los valores de número de días transcurridos desde la siembra hasta alcanzar el 50\% de la producción total, obtenidos del ajuste de los datos de producción acumulada a ecuaciones polinómicas de segundo grado (Figura 4.3.9, datos no presentados), observándose que cuanto mayor fue la producción precoz (en g/contenedor) tanto menor fue el número de días necesarios para alcanzar el $50 \%$ de la producción total. 


\begin{tabular}{|c|c|c|c|c|}
\hline A D1 & - A D2 & $\triangle \mathrm{A}+\mathrm{H} \mathrm{D} 1$ & $\triangle \mathrm{A}+\mathrm{H} \mathrm{D} 2$ & - $\mathrm{CO}$ \\
\hline
\end{tabular}

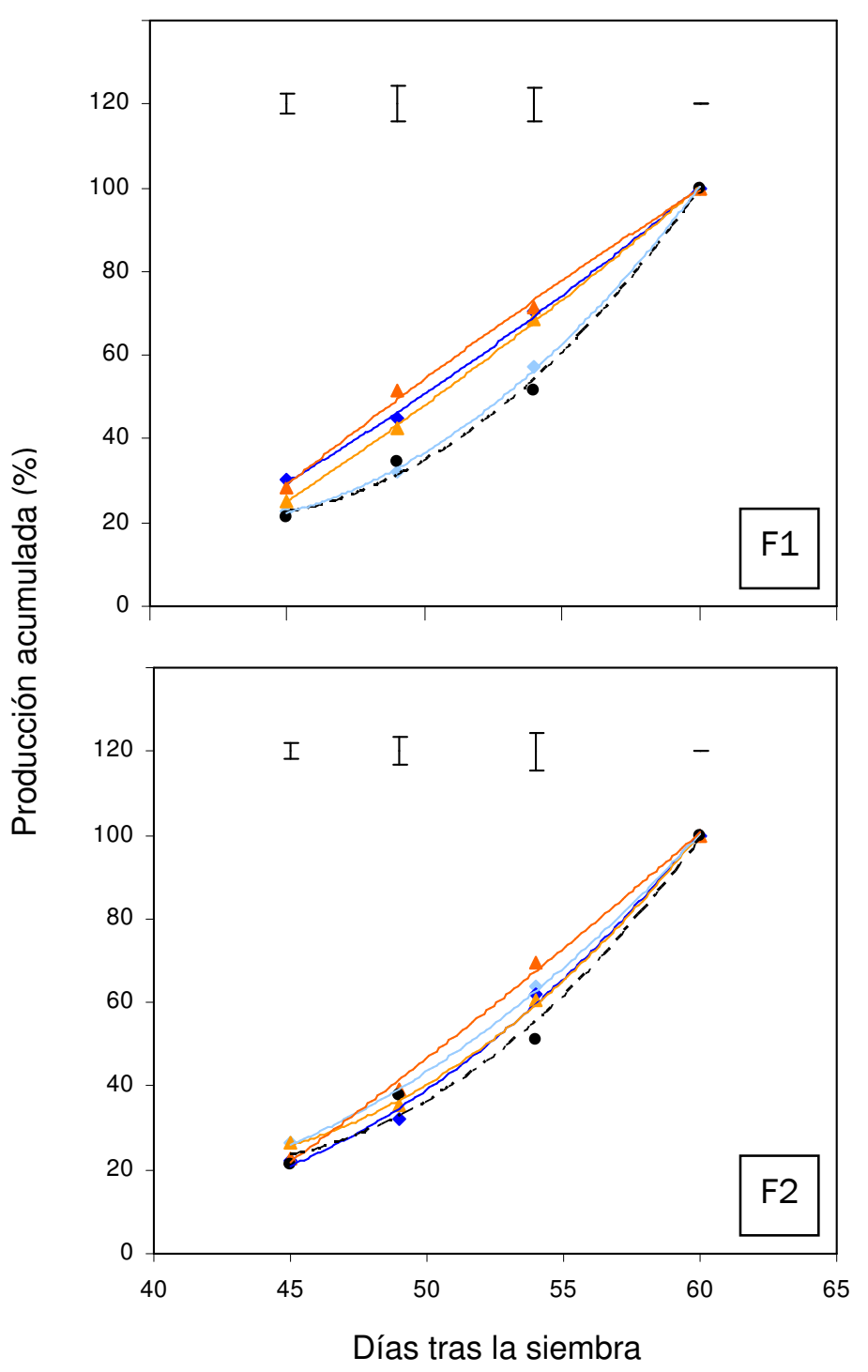

Figura 4.3.9. Evolución temporal de la producción acumulada de vainas de judía (expresada como porcentaje [\%] de la producción total obtenida en las cuatro recolecciones realizadas) en los tratamientos con los composts $\mathrm{A}$ y $\mathrm{A}+\mathrm{H}$ a las dosis D1 y D2 (equivalentes a 12 y 24 t de materia orgánica total/ha, respectivamente) en combinación con la fertilización mineral (programa F1, estándar, arriba y F2, reducida, abajo). Comparación con los controles (CO, que no recibieron compost). Año 1

A: compost de alperujo; $\mathrm{A}+\mathrm{H}$ : compost de alperujo más hidrolizado

Las barras verticales indican el error estándar 
Tabla 4.3.8. Efectos de los tratamientos experimentales estudiados -Compost (A y $A+H)$, Dosis de aplicación de éste (D1 y D2, equivalentes a 12 y 24 t de materia orgánica total/ha, respectivamente) y Programa de fertilización mineral (estándar, F1 y reducida, F2) - sobre la producción precoz y total de vainas de judía, y sobre los días transcurridos hasta alcanzar el $50 \%$ de la producción total obtenida. Comparación con los controles (CO, que no recibieron compost). Año 1

\begin{tabular}{|c|c|c|c|c|c|}
\hline \multicolumn{2}{|c|}{ Compost } & \multirow{2}{*}{$\begin{array}{c}\text { Fertilización } \\
\text { mineral }\end{array}$} & \multirow{2}{*}{$\begin{array}{c}\text { Producción } \\
\text { precoz }^{z} \\
\text { (g/contenedor) }\end{array}$} & \multirow{2}{*}{$\begin{array}{c}\text { Días hasta el } 50 \% \\
\text { de la producción } \\
\text { total }\end{array}$} & \multirow{2}{*}{$\begin{array}{c}\text { Producción } \\
\text { totaly } \\
\text { (g/contenedor) }\end{array}$} \\
\hline Origen & Dosis & & & & \\
\hline \multirow[t]{4}{*}{ A } & D1 & F1 & $81,79 \mathrm{cde}$ & $53 a$ & $254,1 a b$ \\
\hline & & F2 & $82,42 \mathrm{cde}$ & $51 a b c$ & $217,6 b$ \\
\hline & D2 & F1 & $128,5 a b$ & $50 b c$ & $284,5 a$ \\
\hline & & F2 & $82,98 \mathrm{cde}$ & $52 a b$ & $257,9 a b$ \\
\hline \multirow[t]{4}{*}{$\mathrm{A}+\mathrm{H}$} & D1 & F1 & $109,2 a b c$ & $50 b c$ & $256,5 a b$ \\
\hline & & F2 & $78,11 \mathrm{cde}$ & $52 a b$ & $220,9 b$ \\
\hline & D2 & F1 & $142,9 a$ & $49 c$ & $277,3 a$ \\
\hline & & F2 & $100,2 \mathrm{bcd}$ & $51 a b c$ & $256,0 a b$ \\
\hline \multirow[t]{2}{*}{$\mathrm{CO}$} & - & F1 & 58,83de & $53 a$ & $170,9 c$ \\
\hline & - & $\mathrm{F} 2$ & $51,50 e$ & $53 a$ & $135,9 d$ \\
\hline$P$ & & & $\star * \star$ & * & $\star \star \star *$ \\
\hline \multicolumn{6}{|c|}{ Fuente de variación } \\
\hline 1. Compos & & & ns & ns & ns \\
\hline 2. Dosis de & & & ** & ns & ** \\
\hline 3. Fertilizac & eral & & ** & ns & $\star *$ \\
\hline \multicolumn{6}{|c|}{ 4. Interacción } \\
\hline $1 \times 2$ & & & ns & ns & ns \\
\hline $1 \times 3$ & & & ns & ns & ns \\
\hline $2 \times 3$ & & & ns & ns & ns \\
\hline $1 \times 2 \times 3$ & & & ns & ns & ns \\
\hline
\end{tabular}

A: compost de alperujo; $\mathrm{A}+\mathrm{H}$ : compost de alperujo más hidrolizado

z Producción comercial, de acuerdo con el tamaño de las vainas

y Producción comercial + no comercial

$P$ : nivel de significación. ns, * ** $y * * *$ indican diferencias no significativas o estadísticamente significativas a $P \leq 0,05, P \leq 0,01$ y $P \leq 0,001$, respectivamente

Valores en columna sin letra común difieren estadísticamente a $P \leq 0,05$ (test de Student-Newman-Keuls)

La distribución temporal de la cosecha constituye una estimación de la precocidad distinta de la producción precoz (la obtenida en las primeras dos recolecciones). Aquel parámetro es de naturaleza fisiológica y se refiere al ciclo biológico propio de la planta (cultivo), mientras que este último es de carácter agronómico, eligiéndose una fecha determinada por razones económicas. Dicho índice temporal de la precocidad, que como ya se ha indicado se estimó como el número de días transcurridos entre la siembra y la recolección del $50 \%$ de la cosecha total producida (por contenedor), fue tanto menor cuanto más acusada fue la anticipación de la producción a las primeras recolecciones. 
Finalmente, se apreció que los controles rindieron una producción total marcadamente inferior a los tratamientos con compost, especialmente cuando éstos se incorporaron a la dosis de 24 t/ha junto con el programa de fertilización estándar (F1).

\section{Recapitulación}

A modo de resumen del efecto directo (es decir, a corto plazo, durante el primer año) de los composts sobre los cultivos estudiados, debe señalarse que los parámetros medidos en rábano fueron significativamente superiores en el suelo al que se aplicó compost $A$ en comparación con A+H. En cuanto a las dosis de compost aplicadas, no se encontraron efectos significativos de éstas sobre la mayoría de los parámetros estudiados. En contraste con lo anterior, el programa de fertilización estándar (F1) se tradujo en un crecimiento de la planta y una producción de raíces significativamente superiores al programa reducido (F2). Por otro lado, los tratamientos con compost A proporcionaron un peso de raíces superior a los controles, mientras que los que recibieron $\mathrm{A}+\mathrm{H}$ no difirieron de éstos.

En lechuga y judía no se encontraron diferencias en peso seco (biomasa) de la planta entera ni en cosecha (producción) entre los dos composts estudiados. Sin embargo, la dosis de 24 t/ha incrementó de manera significativa el desarrollo y la productividad de estos dos cultivos en comparación con la dosis de 12 t/ha, especialmente cuando se fertilizó con el programa F1 (estándar). Al estudiar comparativamente los tratamientos con compost y los controles sin enmendar, se observó que estos últimos produjeron una biomasa total y una producción marcadamente inferiores a las que proporcionaron los composts.

Las diferencias en la respuesta a la aplicación de compost encontradas entre los cultivos estudiados -rábano, por un lado, y lechuga y judía, por otro- podrían estar relacionadas con la distinta evolución (biodegradación) de los composts $\mathrm{A}$ y $\mathrm{A}+\mathrm{H}$ tras ser aplicados al suelo utilizado. Como ya se ha señalado en la sección 4.2.2.1, la descomposición del compost $\mathrm{A}$ transcurrió con una mineralización neta de nitrógeno orgánico, mientras que A+H provocó una inmovilización de nitrógeno mineral debido al menor grado de madurez y estabilidad observado en este último compost, de acuerdo con los resultados que se han presentado en la sección 4.1. Este proceso de inmovilización observado con $\mathrm{A}+\mathrm{H}$ fue transitorio y reversible, comenzando la mineralización del nitrógeno orgánico del suelo que recibió dicho compost antes del 
establecimiento del cultivo de lechuga y prolongándose, además, durante el de judía, comportándose entonces $\mathrm{A}+\mathrm{H}$ (al igual que $\mathrm{A}$ desde su incorporación al suelo) como una fuente adicional de nutrientes para los cultivos, comúnmente descritos como "de liberación lenta o progresiva" (Alburquerque et al., 2006b, 2007). Adicionalmente, el efecto deletéreo sobre el crecimiento, desarrollo y productividad de rábano encontrado tras la aplicación de $\mathrm{A}+\mathrm{H}$ podría atribuirse también a un fenómeno de fitotoxicidad, asociado con el elevado contenido en polifenoles solubles registrado en este material orgánico $(18,88 \mathrm{~g} / \mathrm{kg}$ ms; Tabla 4.1.7), de acuerdo con lo señalado por varios autores para los residuos y subproductos de la industria extractiva del aceite de oliva, especialmente alperujos (Ait Baddi et al., 2004; Alburquerque et al., 2006a, 2006b, 2006c; Paredes et al., 2002; Piotrowska et al., 2011).

\subsubsection{Efecto residual}

Una vez finalizado el primer año de evaluación agronómica (Año 1), en el que se estudió el efecto directo (a corto plazo) de la aplicación de compost, se procedió a repetir una secuencia (sucesión) ordenada de cultivos hortícolas (rotación) idéntica durante el año siguiente, con objeto de valorar el efecto residual (Año 2) de la aplicación de compost de alperujo sobre dichos cultivos.

\section{Rábano}

Los datos experimentales relacionados con el crecimiento y la morfología de la hoja y la raíz de rábano en el segundo año se recogen en la Figura 4.3 .10 y la Tabla 4.3.9. Con respecto al factor Compost, y según el análisis de la varianza multifactorial realizado, únicamente se encontraron efectos estadísticamente significativos para el contenido foliar de clorofila y el diámetro de la raíz, observándose que el compost $A+H$ aumentó el valor de estos dos parámetros en comparación con A. Por otro lado, la dosis de compost equivalente a 12 t/ha incrementó comparativa y significativamente la magnitud de varios parámetros estudiados, tales como el número de hojas formadas por planta, el área de la hoja, el contenido foliar en clorofila y la longitud de la raíz. De acuerdo con los resultados presentados, el plan de fertilización mineral estándar (F1) elevó de manera altamente significativa los valores de todos los parámetros medidos respecto al programa reducido (F2). En adición, la mayoría de las interacciones estudiadas no fueron estadísticamente significativas. 


\section{$\square A D 1 F 1 \quad \square A D 1 F 2 \quad \square A D 2 F 1 \quad \square$ AD2 F2 $\quad \square$ A+HD1F1 $\square$ A+HD1F2 $\square$ A+HD2F1 $\square$ A+HD2F2 $\square$ COF1 $\square$ COF2}
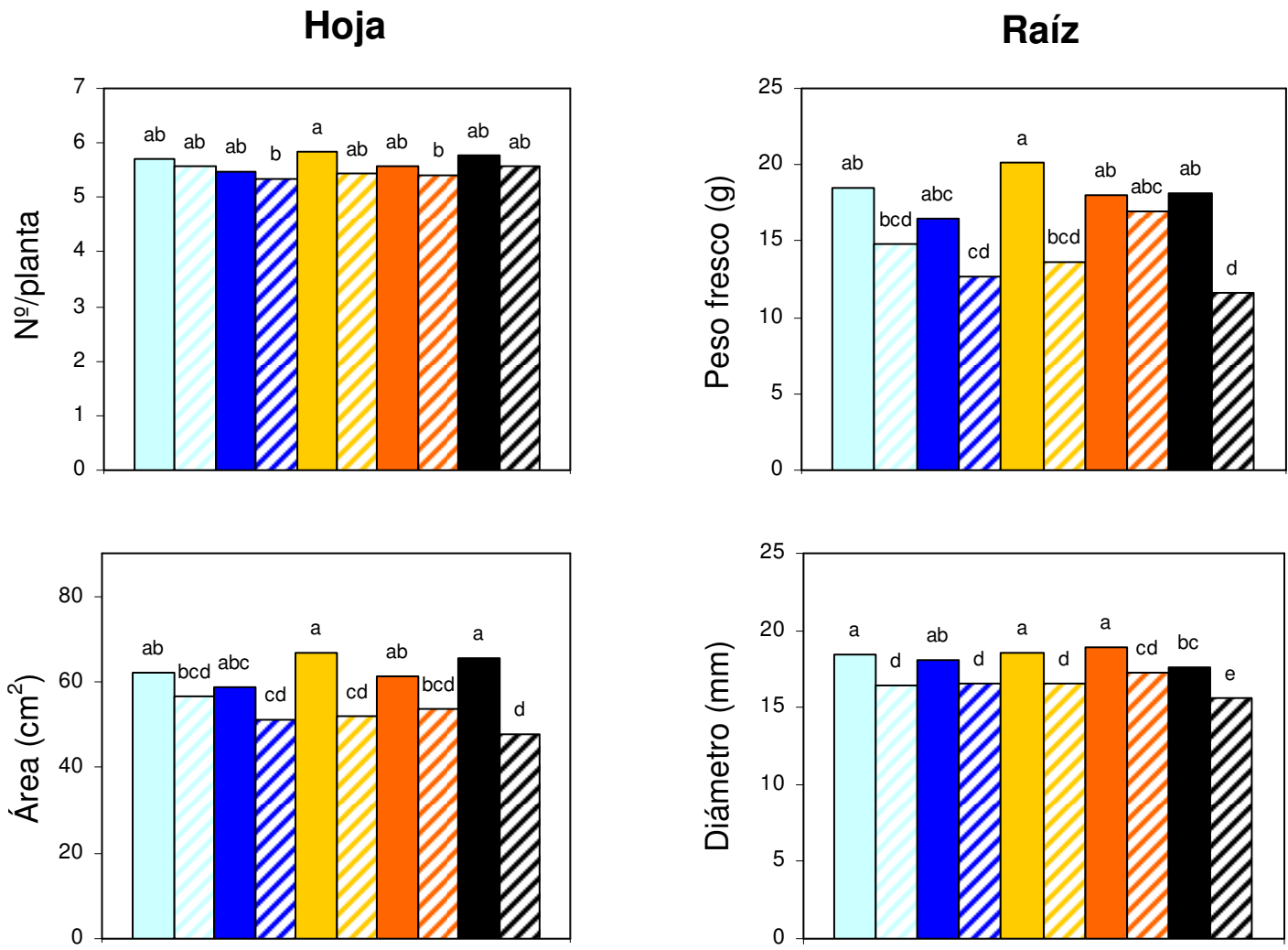

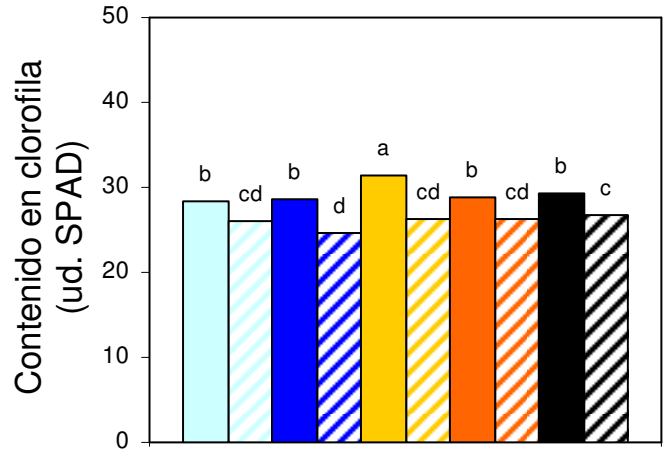

Tratamiento

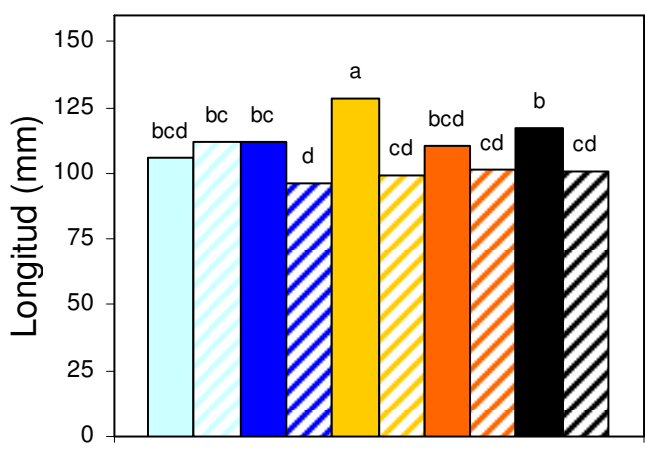

Tratamiento

Figura 4.3.10. Influencia del compost (A y A+H), la dosis de aplicación de éste (D1 y D2, equivalentes a 12 y 24 t de materia orgánica total/ha, respectivamente) y el programa de fertilización mineral (estándar, F1 y reducida, F2) en el crecimiento vegetativo (hojas y raíz) de rábano. Comparación con los controles (CO, que no recibieron compost). Segundo año del experimento (Año 2)

A: compost de alperujo; $\mathrm{A}+\mathrm{H}$ : compost de alperujo más hidrolizado

Barras sin letra común difieren estadísticamente a $P \leq 0,05$ (test de Student-Newman-Keuls) 
Tabla 4.3.9. Análisis factorial de la varianza $(P)$ para los efectos de los tratamientos estudiados -Compost (alperujo vs. alperujo más hidrolizado), Dosis de aplicación de éste (12 vs. 24 t de materia orgánica total/ha) y Programa de fertilización mineral (estándar vs. reducida)- sobre el crecimiento vegetativo (hojas y raíz) de rábano. Segundo año del experimento (Año 2)

\begin{tabular}{|c|c|c|c|c|c|c|}
\hline \multirow[b]{2}{*}{ Fuente de variación } & \multicolumn{3}{|c|}{ Hoja } & \multicolumn{3}{|c|}{ Raíz } \\
\hline & $\begin{array}{c}\mathrm{N} \% \\
\text { planta }\end{array}$ & Área & $\begin{array}{l}\text { Contenido en } \\
\text { clorofila }\end{array}$ & $\begin{array}{l}\text { Peso } \\
\text { fresco }\end{array}$ & Diámetro & Longitud \\
\hline 1. Compost & ns & ns & $\star \star \star *$ & ns & * & ns \\
\hline 2. Dosis de compost & $* *$ & * & ** & ns & ns & * \\
\hline 3. Fertilización mineral & $* *$ & $\star * *$ & $* * *$ & $\star * *$ & $* * *$ & $\star * *$ \\
\hline \multicolumn{7}{|l|}{ 4. Interacción } \\
\hline $1 \times 2$ & ns & ns & ns & ns & ns & ns \\
\hline $1 \times 3$ & ns & ns & ns & ns & ns & ** \\
\hline $2 \times 3$ & ns & ns & ns & ns & ns & ns \\
\hline $1 \times 2 \times 3$ & ns & ns & ** & ns & ns & $\star * *$ \\
\hline
\end{tabular}

$P$ : nivel de significación. $\mathrm{ns},{ }^{*}, * * \mathrm{y} * * *$ indican diferencias no significativas o estadísticamente significativas a $P \leq 0,05, P \leq 0,01$ y $P \leq 0,001$, respectivamente

Al comparar los tratamientos que recibieron compost con los controles sin enmendar (Figura 4.3.10) no se encontraron diferencias estadísticamente significativas entre los mismos en el número de hojas formadas por planta y en el área de la hoja, ni tampoco entre la mayoría de los tratamientos con compost y los controles en el contenido foliar en clorofila, el peso fresco de la raíz y la longitud de ésta. El diámetro de la raíz en las mezclas de suelo y compost fue mayor que en los controles, a excepción del tratamiento con el compost A a 24 t/ha en combinación con el programa estándar de fertilización (F1). Se registró un aumento marcado en el valor de los parámetros estudiados cuando se aplicó el programa estándar de fertilización (F1), en comparación con el plan reducido (F2), en la mayoría de los tratamientos incluídos en el experimento, especialmente los que recibieron el compost $\mathrm{A}+\mathrm{H}$ y los controles.

De acuerdo con los resultados de acumulación y distribución de biomasa presentados en la Figura 4.3.11 y la Tabla 4.3.10, la aplicación de A+H se tradujo en un peso seco de raíz y planta entera mayor que cuando se adicionó A. Al igual que en el estudio del crecimiento de las hojas y la raíz, destacó la gran influencia de la fertilización mineral en la producción de biomasa. Así, el programa de fertilización estándar (F1) provocó un incremento en el peso seco del vástago, la raíz y la planta entera respecto al plan reducido (F2). No se encontraron diferencias en el peso del vástago, la raíz y total entre la mayoría de los tratamientos a base de compost y sus 
controles correspondientes, aunque los tratamientos con $\mathrm{A}+\mathrm{H}$ fertilizados con el plan reducido (F2) superaron a su control (CO F2) en el peso de la raíz, y de la planta entera cuando el compost se aplicó a la dosis de 24 t/ha.

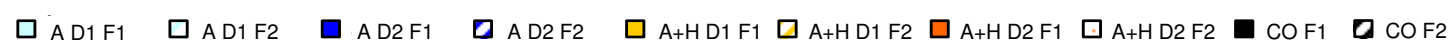

Biomasa (mg materia seca/planta)
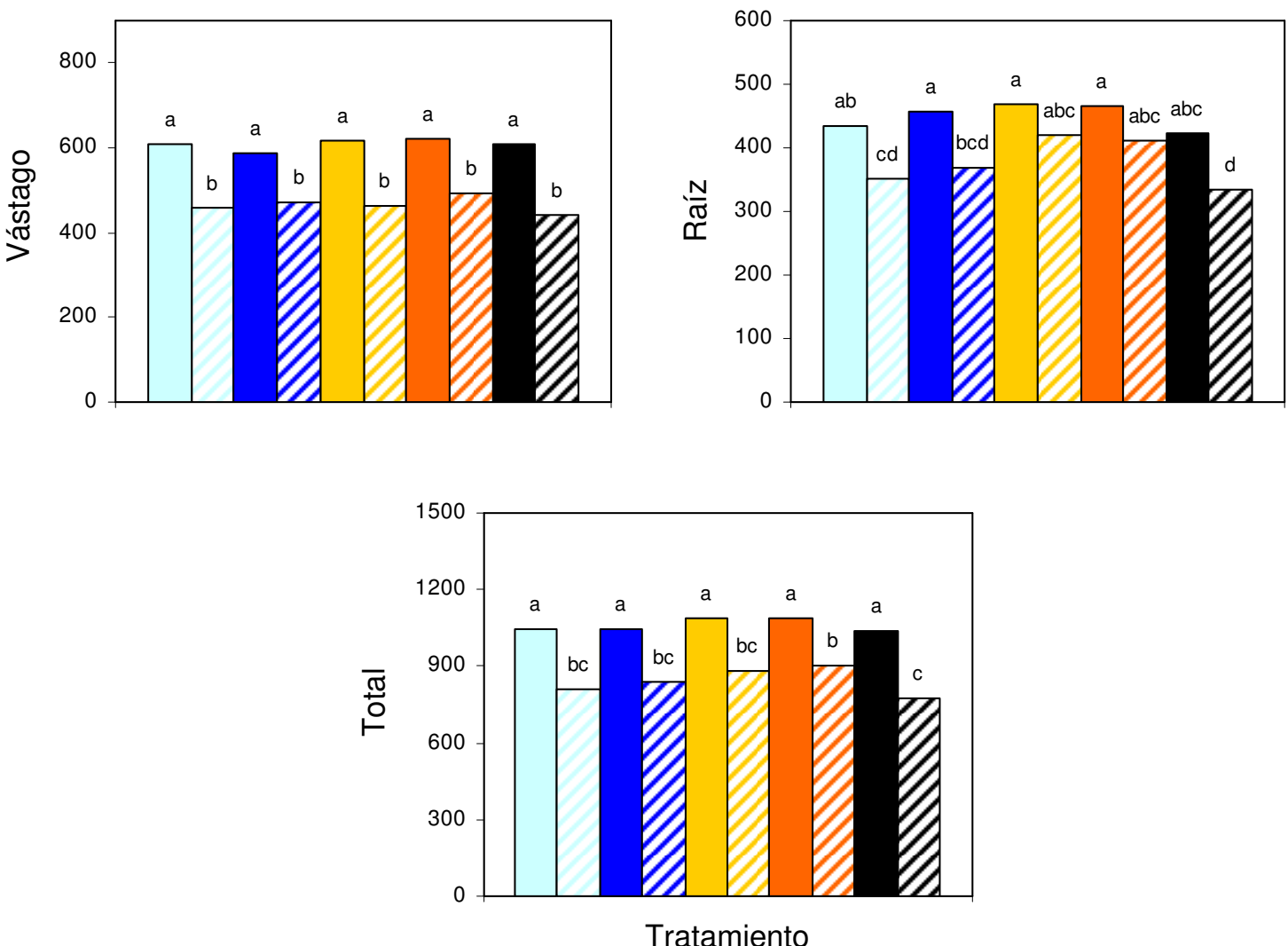

Figura 4.3.11. Influencia del compost $(\mathrm{A}$ y $\mathrm{A}+\mathrm{H})$, la dosis de aplicación de éste (D1 y D2, equivalentes a 12 y 24 t de materia orgánica total/ha, respectivamente) y el programa de fertilización mineral (estándar, F1 y reducida, F2) en la acumulación y distribución de biomasa en rábano. Comparación con los controles (CO, que no recibieron compost). Año 2

A: compost de alperujo; $\mathrm{A}+\mathrm{H}$ : compost de alperujo más hidrolizado

Barras sin letra común difieren estadísticamente a $P \leq 0,05$ (test de Student-Newman-Keuls)

Por otro lado, la producción total de raíces (Tabla 4.3.10 y Figura 4.3.12) -expresada en gramos de materia fresca/contenedor- siguió una pauta similar a la observada en la producción de biomasa. Así, la productividad de rábano con $\mathrm{A}+\mathrm{H}$ y el programa estándar de fertilización (F1) fue mayor que con A y el plan de fertilización reducido (F2), respectivamente. El estudio comparativo de los tratamientos con compost y los controles mostró que el único tratamiento que difirió de su 
correspondiente control fue el que recibió $\mathrm{A}+\mathrm{H}$ a la dosis de $24 \mathrm{t} /$ ha juntamente con el plan de abonado reducido (F2).

Finalmente, no se encontraron diferencias estadísticamente significativas para ninguna de las interacciones estudiadas en los parámetros relacionados con biomasa y producción.

Tabla 4.3.10. Análisis factorial de la varianza $(P)$ para los efectos de los tratamientos estudiados -Compost (alperujo vs. alperujo más hidrolizado), Dosis de aplicación de éste (12 vs. 24 t de materia orgánica total/ha) y Programa de fertilización mineral (estándar vs. reducida)- sobre la acumulación y distribución de biomasa, y sobre la producción total de raíces de rábano. Año 2

\begin{tabular}{lcccc}
\hline \multirow{2}{*}{ Fuente de variación } & \multicolumn{3}{c}{ Biomasa } & \multirow{2}{*}{ Producción total } \\
\cline { 2 - 4 } & Vástago & Raíz & Total & $*$ \\
1. Compost & $\mathrm{ns}$ & $*$ & $*$ & $\mathrm{~ns}$ \\
2. Dosis de compost & $\mathrm{ns}$ & $\mathrm{ns}$ & $\mathrm{ns}$ & $* * *$ \\
3. Fertilización mineral & $* * *$ & $* * *$ & $* * *$ & \\
4. Interacción & & & & $\mathrm{ns}$ \\
$1 \times 2$ & $\mathrm{~ns}$ & $\mathrm{~ns}$ & $\mathrm{~ns}$ & $\mathrm{~ns}$ \\
$1 \times 3$ & $\mathrm{~ns}$ & $\mathrm{~ns}$ & $\mathrm{~ns}$ & $\mathrm{~ns}$ \\
$2 \times 3$ & $\mathrm{~ns}$ & $\mathrm{~ns}$ & $\mathrm{~ns}$ & $\mathrm{~ns}$ \\
$1 \times 2 \times 3$ & $\mathrm{~ns}$ & $\mathrm{~ns}$ & $\mathrm{~ns}$ &
\end{tabular}

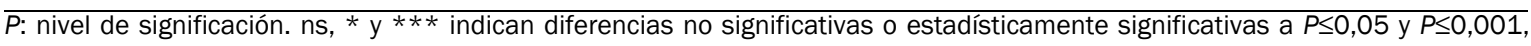
respectivamente

$\square$ AD1F1 $\square$ AD1F2 $\square$ AD2F1 $\quad$ AD2 F2 $\square$ A+HD1F1 $\square$ A+HD1F2 $\square$ A+HD2F1 $\square$ A+HD2 F2 $\quad$ COF1 $\square$ COF2

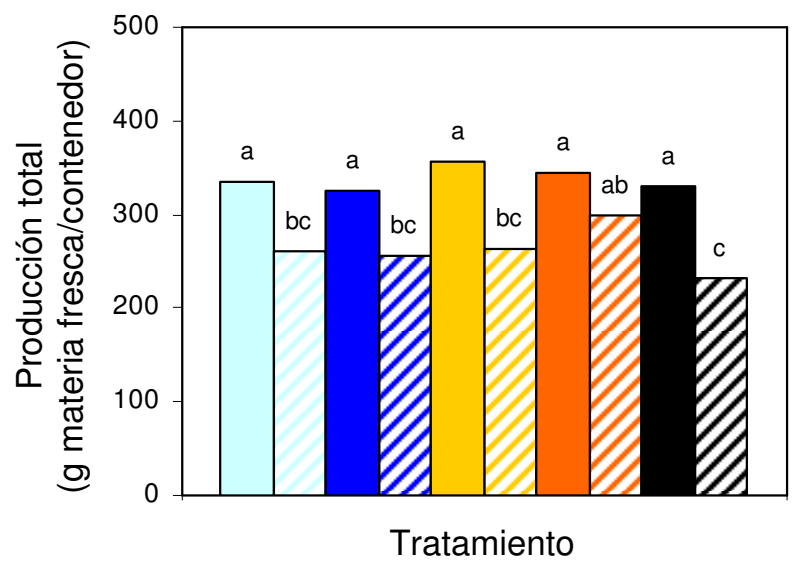

Figura 4.3.12. Influencia del compost $(A$ y $A+H)$, la dosis de aplicación de éste (D1 y D2, equivalentes a 12 y 24 t de materia orgánica total/ha, respectivamente) y el programa de fertilización mineral (estándar, F1 y reducida, F2) en la producción total de raíces en rábano. Comparación con los controles (CO, que no recibieron compost). Año 2

A: compost de alperujo; $\mathrm{A}+\mathrm{H}$ : compost de alperujo más hidrolizado

Barras sin letra común difieren estadísticamente a $P \leq 0,05$ (test de Student-Newman-Keuls) 


\section{Lechuga}

Se controlaron diferentes parámetros relativos a las características de las hojas (Figura 4.3.13 y Tabla 4.3.11), observándose que ninguno de los factores estudiados tuvo efecto sobre el número de hojas formadas por planta, mientras que la dosis de compost de 12 t/ha incrementó el contenido foliar de clorofila en relación con la de 24 t/ha; la fertilización mineral estándar (F1) aumentó el área de la hoja y el contenido foliar en clorofila respecto al programa reducido (F2).

Al comparar los tratamientos con compost y los controles (Figura 4.3.13) no se encontraron diferencias estadísticamente significativas en el número de hojas formadas por planta. Los tratamientos con compost que recibieron el plan de abonado estándar (F1) aumentaron el tamaño (área) de la hoja en comparación con el control con idéntico programa de fertilización (CO F1), mientras que la aplicación de compost en combinación con el plan de fertilización mineral reducida (F2) se tradujo, en general, en una disminución en el contenido en clorofila de las hojas respecto al control correspondiente (CO F2).

La evaluación de los efectos principales de los tratamientos experimentales estudiados sobre la producción de biomasa (Figura 4.3.14 y Tabla 4.3.12) reveló que el compost $\mathrm{A}+\mathrm{H}$ aumentó el peso seco de la raíz en comparación con el compost $\mathrm{A}$, y que en el resto de los parámetros de acumulación y distribución de biomasa, se observó una tendencia definida: por un lado, la dosis de 24 t/ha favoreció el crecimiento de la parte aérea así como del sistema radical y el total (planta entera) comparativamente con la de 12 t/ha; y, por otro, el plan de fertilización estándar (F1) estimuló el crecimiento de la planta (parte aérea, raíz y planta entera) frente al plan reducido (F2). Todas las interacciones de los tres factores estudiados fueron estadísticamente significativas para el parámetro de acumulación de biomasa en raíz. 


\section{$\square$ AD1F1 $\square$ AD1F2 $\square$ AD2F1 $\square$ AD2 F2 $\square$ A+HD1F1 $\square$ A+HD1 F2 $\square$ A+HD2 F1 $\square$ A+HD2 F2 $\quad$ COF1 $\square$ COF2}
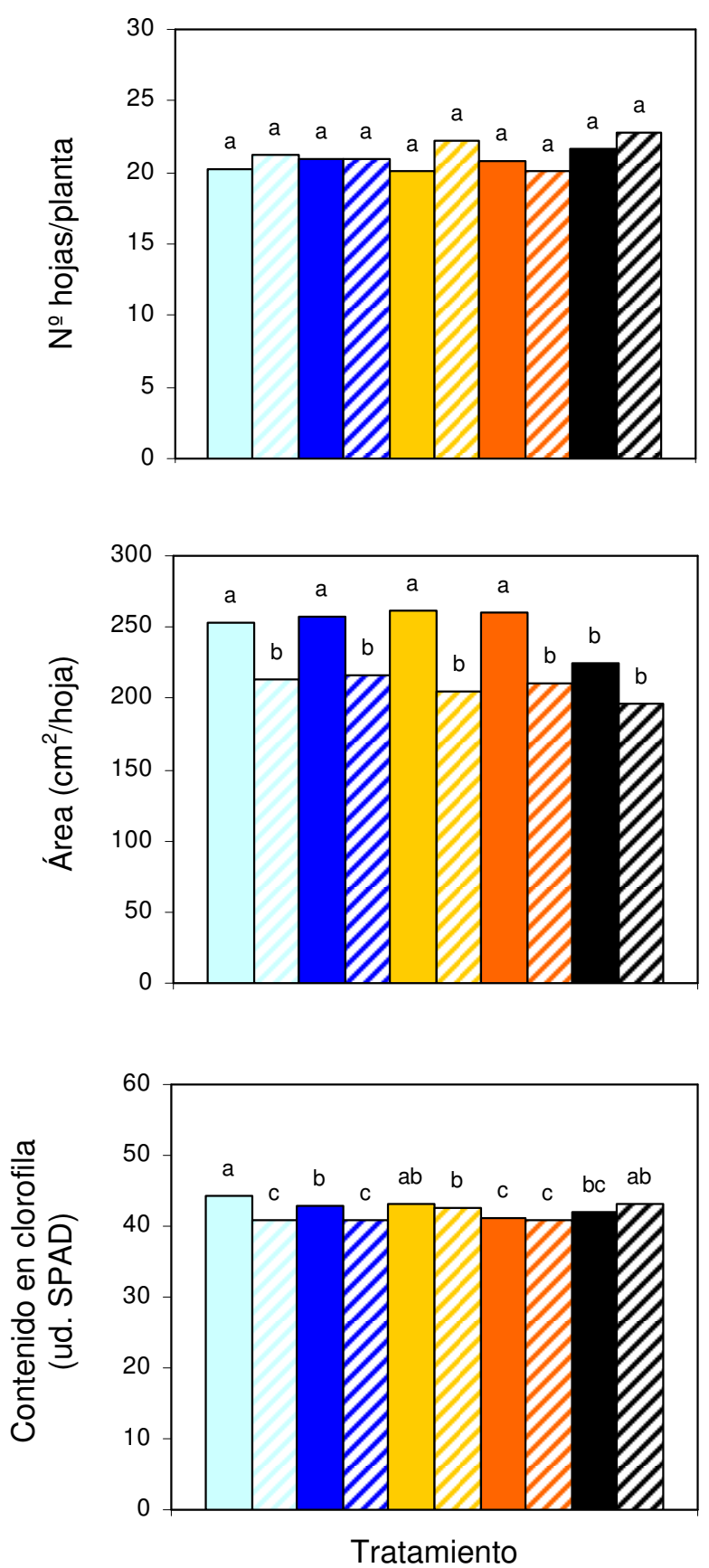

Figura 4.3.13. Influencia del compost $(\mathrm{A}$ y $\mathrm{A}+\mathrm{H})$, la dosis de aplicación de éste (D1 y D2, equivalentes a 12 y 24 t de materia orgánica total/ha, respectivamente) y el programa de fertilización mineral (estándar, F1 y reducida, F2) en el desarrollo de la hoja en lechuga. Comparación con los controles ( $\mathrm{CO}$, que no recibieron compost). Año 2

A: compost de alperujo; $\mathrm{A}+\mathrm{H}$ : compost de alperujo más hidrolizado

Barras sin letra común difieren estadísticamente a $P \leq 0,05$ (test de Student-Newman-Keuls) 
Tabla 4.3.11. Análisis factorial de la varianza $(P)$ para los efectos de los tratamientos estudiados -Compost (alperujo vs. alperujo más hidrolizado), Dosis de aplicación de éste (12 vs. 24 t de materia orgánica total/ha) y Programa de fertilización mineral (estándar vs. reducida)- sobre el desarrollo de la hoja en lechuga. Año 2

\begin{tabular}{lccc}
\hline \multirow{2}{*}{ Fuente de variación } & \multicolumn{3}{c}{ Hoja } \\
\cline { 2 - 4 } 1. Compost & No/planta & Área & Contenido en clorofila \\
2. Dosis de compost & $\mathrm{ns}$ & $\mathrm{ns}$ & $\mathrm{ns}$ \\
3. Fertilización mineral & $\mathrm{ns}$ & $* * *$ & $* * *$ \\
4. Interacción & $\mathrm{ns}$ & & \\
$1 \times 2$ & & $\mathrm{~ns}$ & $*$ \\
$1 \times 3$ & $\mathrm{~ns}$ & $\mathrm{~ns}$ & $* * *$ \\
$2 \times 3$ & $\mathrm{~ns}$ & $\mathrm{~ns}$ & $\mathrm{~ns}$ \\
$1 \times 2 \times 3$ & $\mathrm{~ns}$ & $\mathrm{~ns}$ & $\mathrm{~ns}$
\end{tabular}

$P$ : nivel de significación. $\mathrm{ns},{ }^{*} \mathrm{y} * * *$ indican diferencias no significativas o estadísticamente significativas a $P \leq 0,05$ y $P \leq 0,001$, respectivamente

Los tratamientos con compost proporcionaron, en la mayoría de los casos, valores de biomasa del vástago y de la raíz superiores a los controles, y, en adición, aquellos se tradujeron también en un peso seco de la planta entera (total) más elevado que en los controles, destacando, para los tres parámetros de biomasa estudiados (peso seco del vástago, de la raíz y total), los valores máximos obtenidos cuando se aplicaron los composts se aplicaron a la dosis de 24 t/ha en combinación con el plan de fertilización estándar (F1).

Finalmente, la producción total de cogollos mostró el mismo comportamiento que la producción de biomasa total (ver Tabla 4.3.12 y Figura 4.3.15), esto es, la dosis de compost de 24 t/ha produjo un peso de piezas superior a la dosis de 12 t/ha, y la aplicación del programa de fertilización estándar (F1) se tradujo en una productividad más elevada que la obtenida con el programa reducido (F2). Cuando se compararon con los controles, todos los tratamientos que recibieron compost proporcionaron un peso de cogollos superior a dichos controles, particularmente con la dosis de $24 \mathrm{t} / \mathrm{ha}$ juntamente con el plan de abonado estándar (F1). 


\section{$\square$ AD1F1 $\square$ AD1F2 $\square$ AD2F1 $\square$ AD2 F2 $\square$ A+HD1F1 $\square$ A+HD1F2 $\square$ A+HD2 F1 $\square$ A+HD2 F2 $\square$ COF1 $\square$ COF2}

\section{Biomasa (g materia seca/planta)}
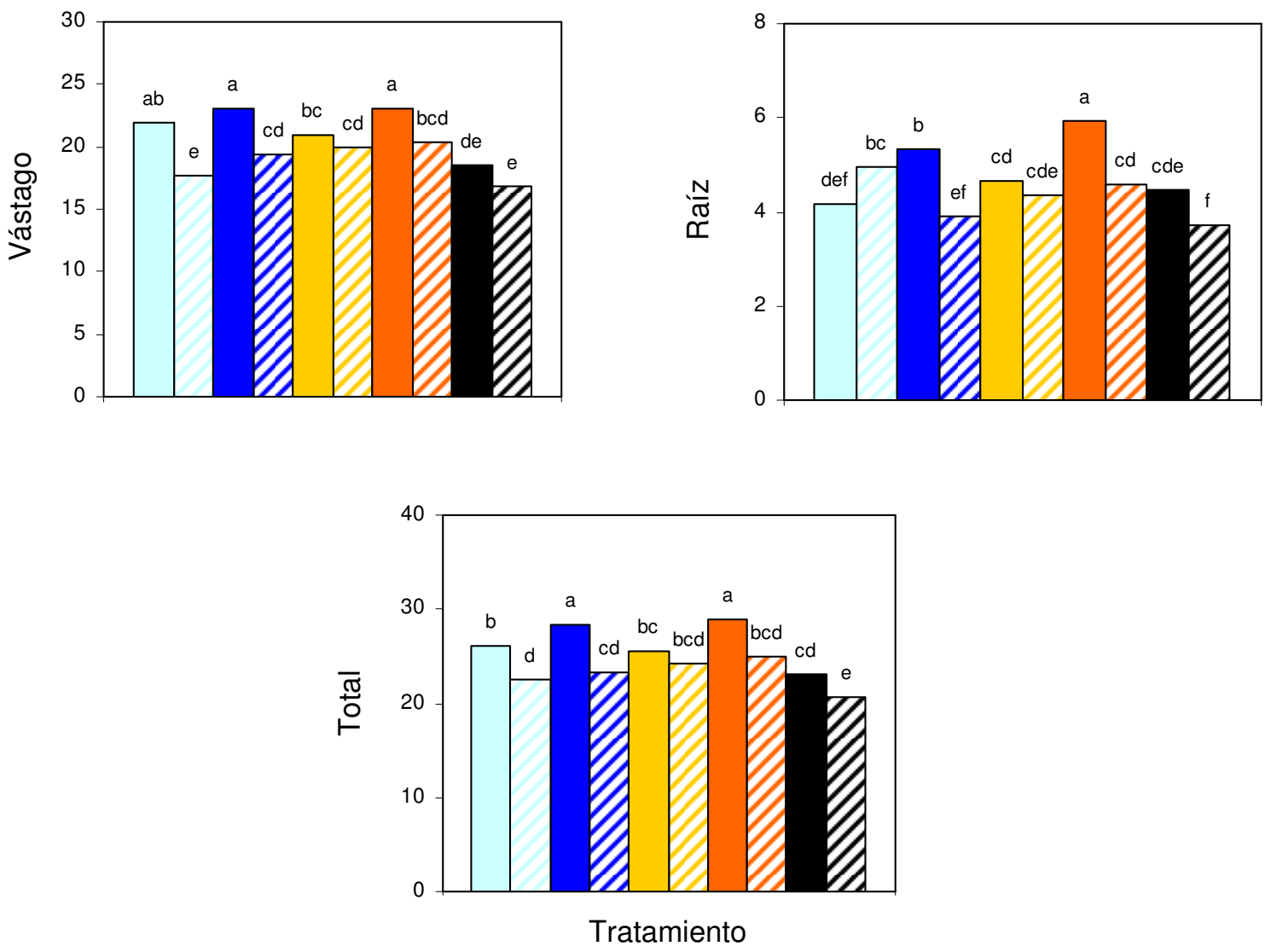

Figura 4.3.14. Influencia del compost (A y $A+H)$, la dosis de aplicación de éste (D1 y D2, equivalentes a 12 y 24 t de materia orgánica total/ha, respectivamente) y el programa de fertilización mineral (estándar, F1 y reducida, F2) en la acumulación y distribución de biomasa en lechuga. Comparación con los controles ( $\mathrm{CO}$, que no recibieron compost). Año 2

A: compost de alperujo; $\mathrm{A}+\mathrm{H}$ : compost de alperujo más hidrolizado

Barras sin letra común difieren estadísticamente a $P \leq 0,05$ (test de Student-Newman-Keuls) 
Tabla 4.3.12. Análisis factorial de la varianza $(P)$ para los efectos de los tratamientos estudiados -Compost (alperujo vs. alperujo más hidrolizado), Dosis de aplicación de éste (12 vs. 24 t de materia orgánica total/ha) y Programa de fertilización mineral (estándar vs. reducida)- sobre la acumulación y distribución de biomasa, y sobre la producción total de cogollos en lechuga. Año 2

\begin{tabular}{lcccc}
\hline \multirow{2}{*}{ Fuente de variación } & \multicolumn{3}{c}{ Biomasa } & \multirow{2}{*}{ Producción total } \\
\cline { 2 - 4 } 1. Compost & Vástago & Raíz & Total & ns \\
2. Dosis de compost & ns & $*$ & ns & $* * *$ \\
3. Fertilización mineral & $* * *$ & $* * *$ & $* * *$ & $* * *$ \\
4. Interacción & $* * *$ & $* * *$ & $* * *$ & \\
$1 \times 2$ & & & & $n$ \\
$1 \times 3$ & $n s$ & $* *$ & $n s$ & $n s$ \\
$2 \times 3$ & $* *$ & $*$ & $n s$ & $n s$ \\
$1 \times 2 \times 3$ & $n s$ & $* * *$ & $*$ & $n s$
\end{tabular}

$P$ : nivel de significación. ns, * ** $\mathrm{y} * * *$ indican diferencias no significativas o estadísticamente significativas a $P \leq 0,05, P \leq 0,01$ y $P \leq 0,001$, respectivamente

$\square$ AD1F1 $\square$ AD1F2 $\square$ AD2F1 $\square$ AD2 F2 $\square$ A+HD1F1 $\square$ A+HD1F2 $\square$ A+HD2F1 $\square$ A+HD2 F2 $\square$ COF1 $\square$ COF2

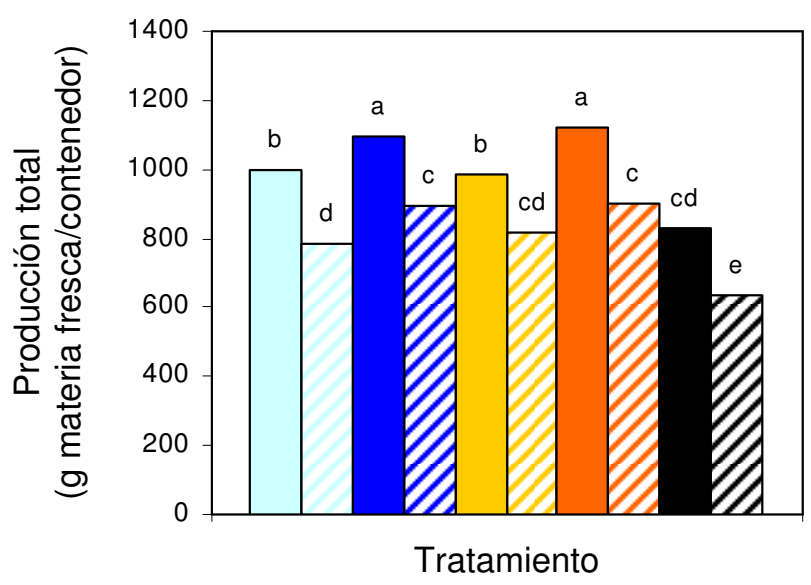

Figura 4.3.15. Influencia del compost $(\mathrm{A}$ y $\mathrm{A}+\mathrm{H})$, la dosis de aplicación de éste (D1 y D2, equivalentes a 12 y 24 t de materia orgánica total/ha, respectivamente) y el programa de fertilización mineral (estándar, F1 y reducida, F2) en la producción total de cogollos de lechuga. Comparación con los controles ( $\mathrm{CO}$, que no recibieron compost). Año 2

A: compost de alperujo; $\mathrm{A}+\mathrm{H}$ : compost de alperujo más hidrolizado

Barras sin letra común difieren estadísticamente a $P \leq 0,05$ (test de Student-Newman-Keuls) 
Judía

Según los resultados recopilados acerca de las características del tallo, hojas, vainas y raíces (Figura 4.3.16 y Tabla 4.3.13), el tipo de compost aplicado no resultó estadísticamente significativo y la dosis de éste únicamente tuvo efecto sobre el contenido foliar en clorofila, el peso fresco de la raíz y el número de vainas cosechadas por planta, apreciándose que la dosis de 24 t/ha aumentó comparativamente el valor de estos parámetros. En relación con el efecto del programa de fertilización mineral aplicado, el estándar (F1) aumentó el número de hojas y de vainas por planta, mientras que el reducido (F2) incrementó ligeramente la longitud de la vaina. El análisis de la varianza multifactorial realizado reveló que la mayor parte de las interacciones de los factores principales estudiados no resultaron estadísticamente significativas.

La comparación de los tratamientos con compost y los controles reveló algunas diferencias significativas en el contenido foliar en clorofila y en el número de vainas formadas por planta, aunque al comparar cada control (abonado con F1 ó F2, CO F1 y CO F2, respectivamente) con los tratamientos que poseían el mismo programa de fertilización, no se identificó, en general, un efecto importante de la aplicación de los composts.

En cuanto a la producción de biomasa, se recogieron los datos relativos a biomasa del tallo, hojas y vainas (y de la parte aérea por adición de los mismos), y raíz, determinándose a partir de todos ellos la biomasa total de la planta entera (Figura 4.3.17 y Tabla 4.3.14). El análisis estadístico realizado mostró que la aplicación de compost a 24 t/ha aumentó el peso seco de la parte aérea y de la planta entera en comparación con la dosis de 12 t/ha. Por otro lado, la aplicación del programa estándar de fertilización (F1) provocó un incremento en la biomasa de vainas, parte aérea y total respecto al plan reducido (F2). Algunas interacciones de los factores estudiados resultaron estadísticamente significativas.

Con respecto al estudio conjunto de los tratamientos con compost y los controles, merece destacarse que la aplicación de $\mathrm{A}+\mathrm{H}$ con la fertilización reducida (F2), y de A a 24 t/ha en combinación con el plan reducido (F2), proporcionó valores de biomasa aérea y total superiores al control con dicho programa de fertilización. 


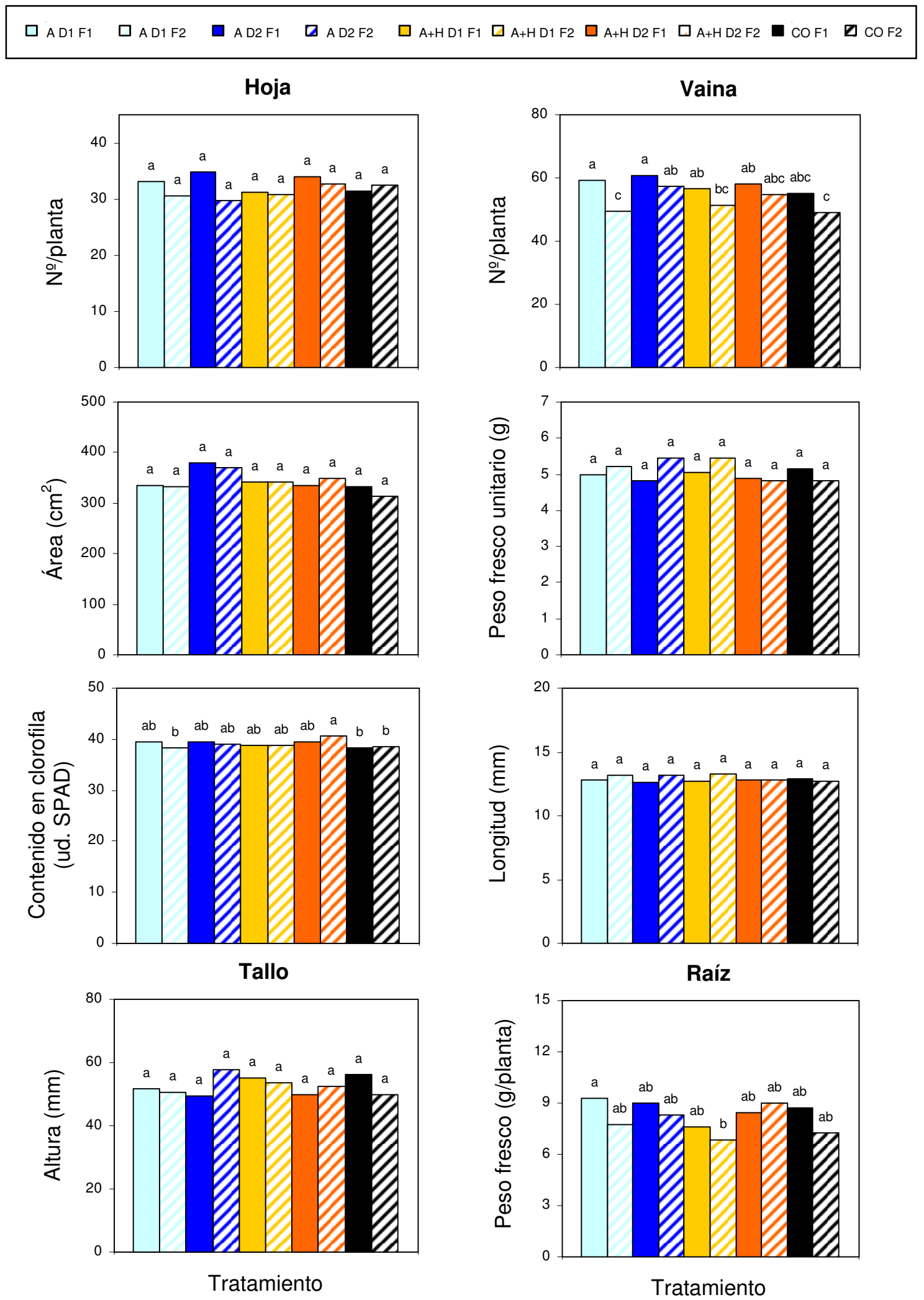

Figura 4.3.16. Influencia del compost $(\mathrm{A}$ y $\mathrm{A}+\mathrm{H})$, la dosis de aplicación de éste (D1 y D2, equivalentes a 12 y 24 t de materia orgánica total/ha, respectivamente) y el programa de fertilización mineral (estándar, F1 y reducida, F2) en el crecimiento vegetativo (tallo, hojas y raíz) y el desarrollo reproductivo (vainas) de judía. Comparación con los controles (CO, que no recibieron compost). Año 2

A: compost de alperujo; $\mathrm{A}+\mathrm{H}$ : compost de alperujo más hidrolizado

Barras sin letra común difieren estadísticamente a $P \leq 0,05$ (test de Student-Newman-Keuls) 
Tabla 4.3.13. Análisis factorial de la varianza $(P)$ para los efectos de los tratamientos estudiados -Compost (alperujo vs. alperujo más hidrolizado), Dosis de aplicación de éste (12 vs. 24 t de materia orgánica total/ha) y Programa de fertilización mineral (estándar vs. reducida)- sobre el crecimiento vegetativo (tallo, hojas y raíz) y el desarrollo reproductivo (vainas) de judía. Año 2

\begin{tabular}{|c|c|c|c|c|c|c|c|c|}
\hline \multirow[b]{2}{*}{ Fuente de variación } & \multirow[b]{2}{*}{$\begin{array}{c}\text { Altura } \\
\text { tallo }\end{array}$} & \multicolumn{3}{|c|}{ Hoja } & \multicolumn{3}{|c|}{ Vaina } & \multirow{2}{*}{$\begin{array}{c}\text { Peso } \\
\text { fresco } \\
\text { raíz }\end{array}$} \\
\hline & & $\begin{array}{c}\mathrm{N}^{\circ} / \\
\text { planta }\end{array}$ & Área & $\begin{array}{l}\text { Contenido } \\
\text { en clorofila }\end{array}$ & $\begin{array}{c}\mathrm{N} \% \\
\text { planta }\end{array}$ & $\begin{array}{c}\text { Peso fresco } \\
\text { unitario }\end{array}$ & Longitud & \\
\hline 1. Compost & ns & ns & ns & ns & ns & ns & ns & ns \\
\hline 2. Dosis de compost & ns & ns & ns & * & ** & ns & ns & * \\
\hline 3. Fertilización mineral & ns & $* *$ & ns & ns & $* * *$ & ns & * & ns \\
\hline \multicolumn{9}{|l|}{ 4. Interacción } \\
\hline $1 \times 2$ & ns & ns & * & ns & ns & ns & ns & ns \\
\hline $1 \times 3$ & ns & ns & ns & * & ns & ns & ns & ns \\
\hline $2 \times 3$ & ns & ns & ns & ns & ns & ns & ns & ns \\
\hline $1 \times 2 \times 3$ & ns & ns & ns & ns & ns & ns & ns & ns \\
\hline
\end{tabular}

$P$ : nivel de significación. $n s, *, * * y * * *$ indican diferencias no significativas o estadísticamente significativas a $P \leq 0,05, P \leq 0,01$ y $P \leq 0,001$, respectivamente

De manera similar a lo mostrado para el cultivo de judía del primer año (Año 1), la evolución temporal de la producción de vainas se estudió tomando en consideración las cuatro recolecciones efectuadas a lo largo del ciclo productivo, determinándose en cada una de ellas el peso de vainas cosechadas y el número de vainas producidas por contenedor (producción comercial, de acuerdo con el tamaño de las legumbres recolectadas; Tabla 4.3.15). Puede apreciarse que en el factor Dosis de compost la aplicación de 12 t/ha aumentó el peso de la cosecha de la cuarta recolección en comparación con la dosis de 24 t/ha, mientras que se observó el efecto contrario para el número de vainas recogidas en la tercera recolección. Además, el plan de fertilización estándar (F1) aumentó la producción y el número de vainas cosechadas en la primera recolección respecto al programa reducido (F2). El tipo de compost ( $\mathrm{A}$ vs. $\mathrm{A}+\mathrm{H}$ ) no tuvo una influencia significativa en la recolección de legumbres en este segundo año del estudio, tal y como puede observarse al comparar los tratamientos con compost y los controles. 


\section{$\square$ AD1F1 $\square$ AD1F2 $\square$ AD2F1 $\square$ AD2F2 $\square$ A+HD1F1 $\square$ A+HD1F2 $\square$ A+HD2F1 $\square$ A+HD2F2 $\square$ COF1 $\quad$ COF2}

\section{Biomasa}
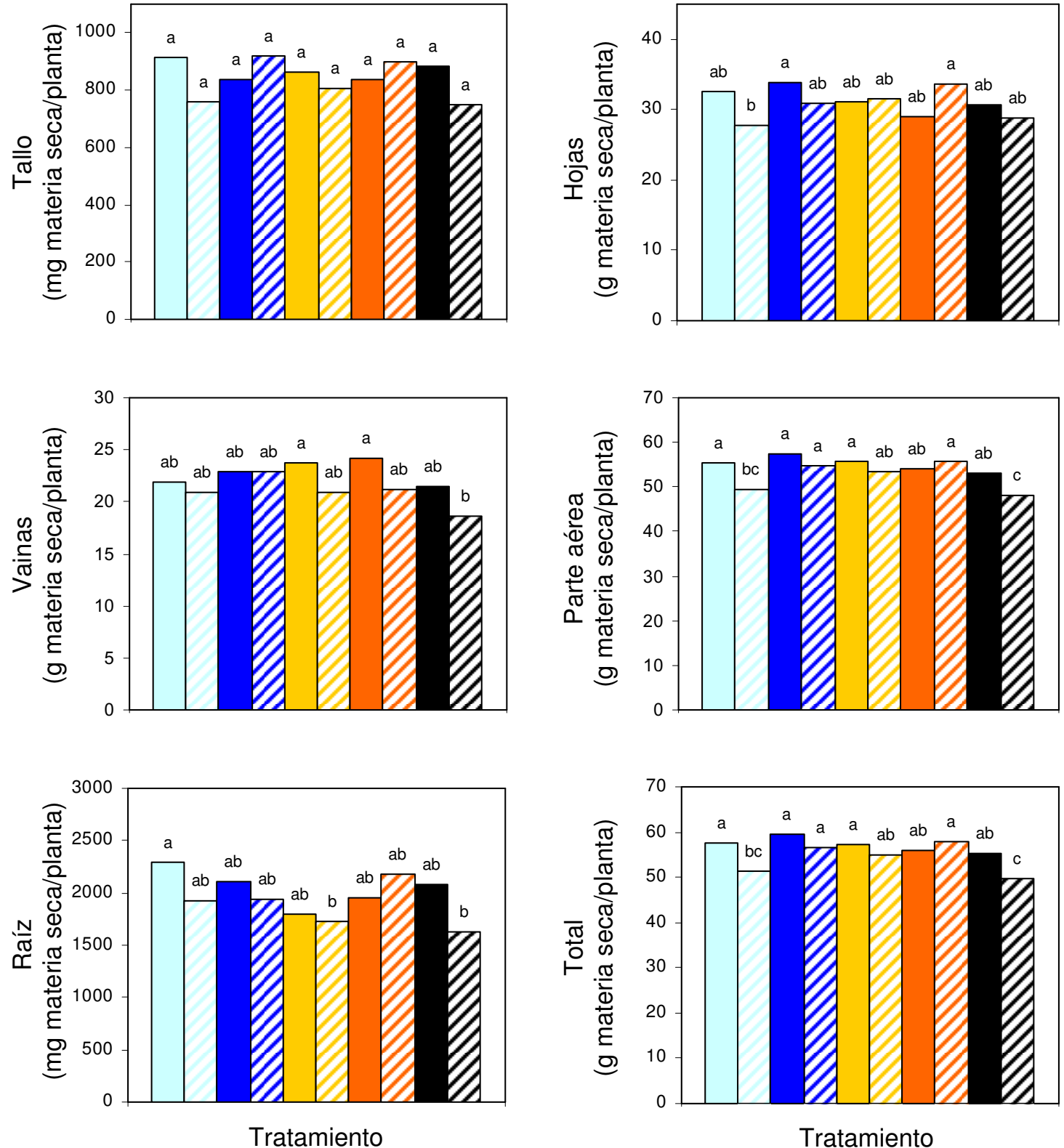

Figura 4.3.17. Influencia del compost (A y A+H), la dosis de aplicación de éste (D1 y D2, equivalentes a 12 y $24 \mathrm{t}$ de materia orgánica total/ha, respectivamente) y el programa de fertilización mineral (estándar, F1 y reducida, F2) en la acumulación y distribución de biomasa en judía. Comparación con los controles ( $\mathrm{CO}$, que no recibieron compost). Año 2

$\mathrm{A}$ : compost de alperujo; $\mathrm{A}+\mathrm{H}$ : compost de alperujo más hidrolizado

Barras sin letra común difieren estadísticamente a $P \leq 0,05$ (test de Student-Newman-Keuls) 
Tabla 4.3.14. Análisis factorial de la varianza $(P)$ para los efectos de los tratamientos estudiados -Compost (alperujo vs. alperujo más hidrolizado), Dosis de aplicación de éste (12 vs. 24 t de materia orgánica total/ha) y Programa de fertilización mineral (estándar vs. reducida)- sobre la acumulación y distribución de biomasa en judía. Año 2

\begin{tabular}{lcccccc}
\hline \multicolumn{1}{c}{ Fuente de variación } & \multicolumn{7}{c}{ Biomasa } \\
\cline { 2 - 7 } & Tallo & Hojas & Vainas & $\begin{array}{c}\text { Parte } \\
\text { aérea }\end{array}$ & Raíz & Total \\
\hline 1. Compost & $\mathrm{ns}$ & $\mathrm{ns}$ & $\mathrm{ns}$ & $\mathrm{ns}$ & $\mathrm{ns}$ & $\mathrm{ns}$ \\
2. Dosis de compost & $\mathrm{ns}$ & $\mathrm{ns}$ & $\mathrm{ns}$ & $*$ & $\mathrm{~ns}$ & $*$ \\
3. Fertilización mineral & $\mathrm{ns}$ & $\mathrm{ns}$ & $*$ & $*$ & $\mathrm{~ns}$ & $*$ \\
4. Interacción & & & & & & \\
$1 \times 2$ & $\mathrm{~ns}$ & $\mathrm{~ns}$ & $\mathrm{~ns}$ & $\mathrm{~ns}$ & $*$ & $\mathrm{~ns}$ \\
$1 \times 3$ & $\mathrm{~ns}$ & $* * *$ & $\mathrm{~ns}$ & $*$ & $\mathrm{~ns}$ & $*$ \\
$2 \times 3$ & $* *$ & $\mathrm{~ns}$ & $\mathrm{~ns}$ & $\mathrm{~ns}$ & $\mathrm{~ns}$ & $*$ \\
$1 \times 2 \times 3$ & $\mathrm{~ns}$ & $\mathrm{~ns}$ & $\mathrm{~ns}$ & $\mathrm{~ns}$ & $\mathrm{~ns}$ & $\mathrm{~ns}$
\end{tabular}

$P$ : nivel de significación. ns, * ${ }^{*} * y * * *$ indican diferencias no significativas o estadísticamente significativas a $P \leq 0,05, P \leq 0,01$ y $P \leq 0,001$, respectivamente

En este contexto, y tras examinar la evolución temporal de la producción acumulada de legumbres recolectadas (Figura 4.3.18), debe señalarse que no se hallaron diferencias estadísticamente significativas en el número de días transcurridos hasta alcanzar el 50\% de la producción total, la cosecha precoz -es decir, la obtenida en las primeras dos recolecciones- ni la producción total de vainas (Tabla 4.3.16), entre los distintos tratamientos estudiados, al considerar tanto el análisis factorial de la varianza como la comparación entre los controles y los tratamientos con compost. Únicamente destacó que la aplicación de A a 24 t/ha juntamente con el plan de fertilización reducido (F2) incrementó la producción total de vainas respecto al control correspondiente (CO F2). 


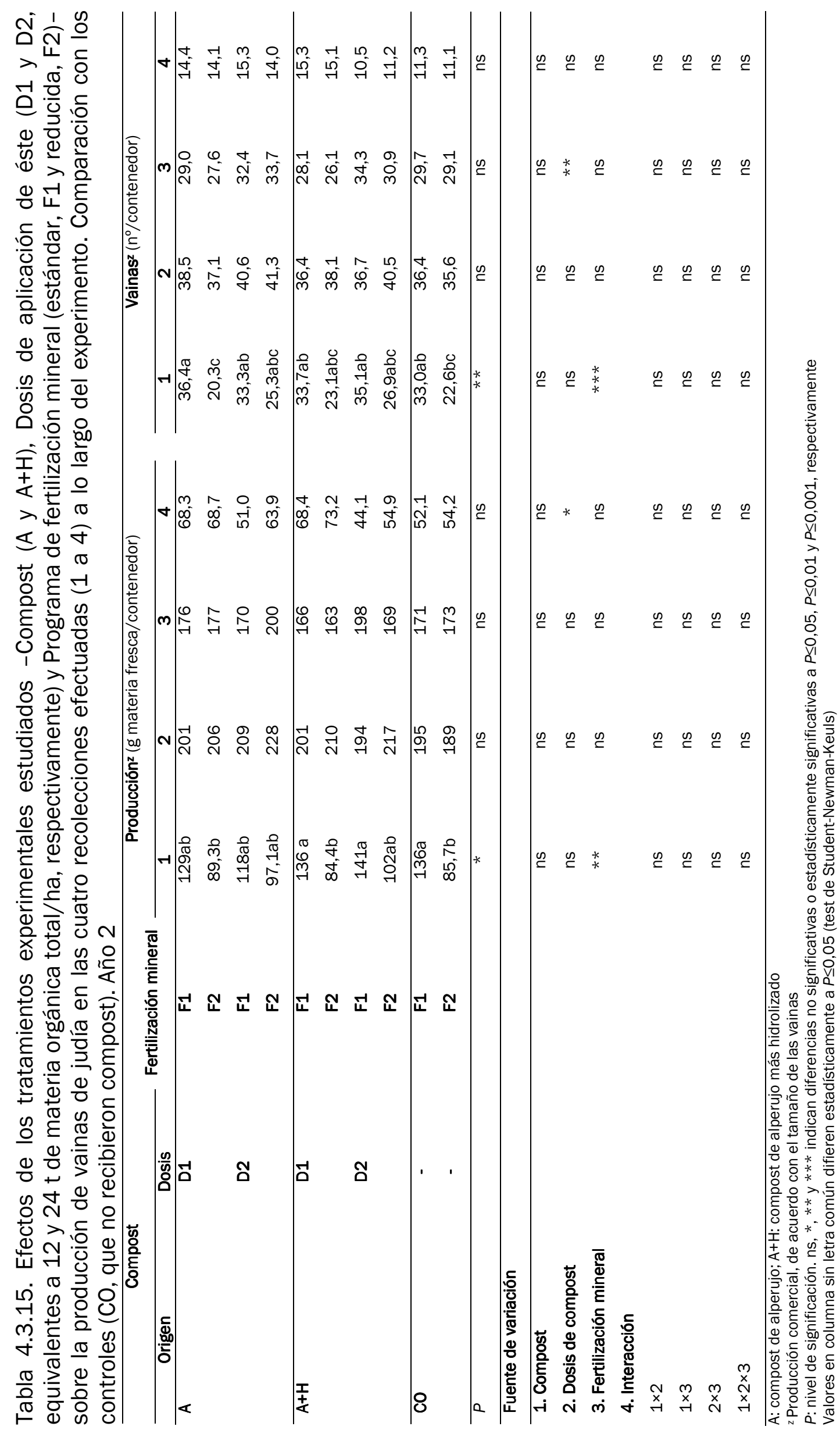




\begin{tabular}{llll}
\hline AD1 & AD2 & $\triangle \mathrm{A}+\mathrm{HD} 1 \quad \mathrm{~A}+\mathrm{HD} 2 \quad \mathrm{CO}$ \\
\hline
\end{tabular}

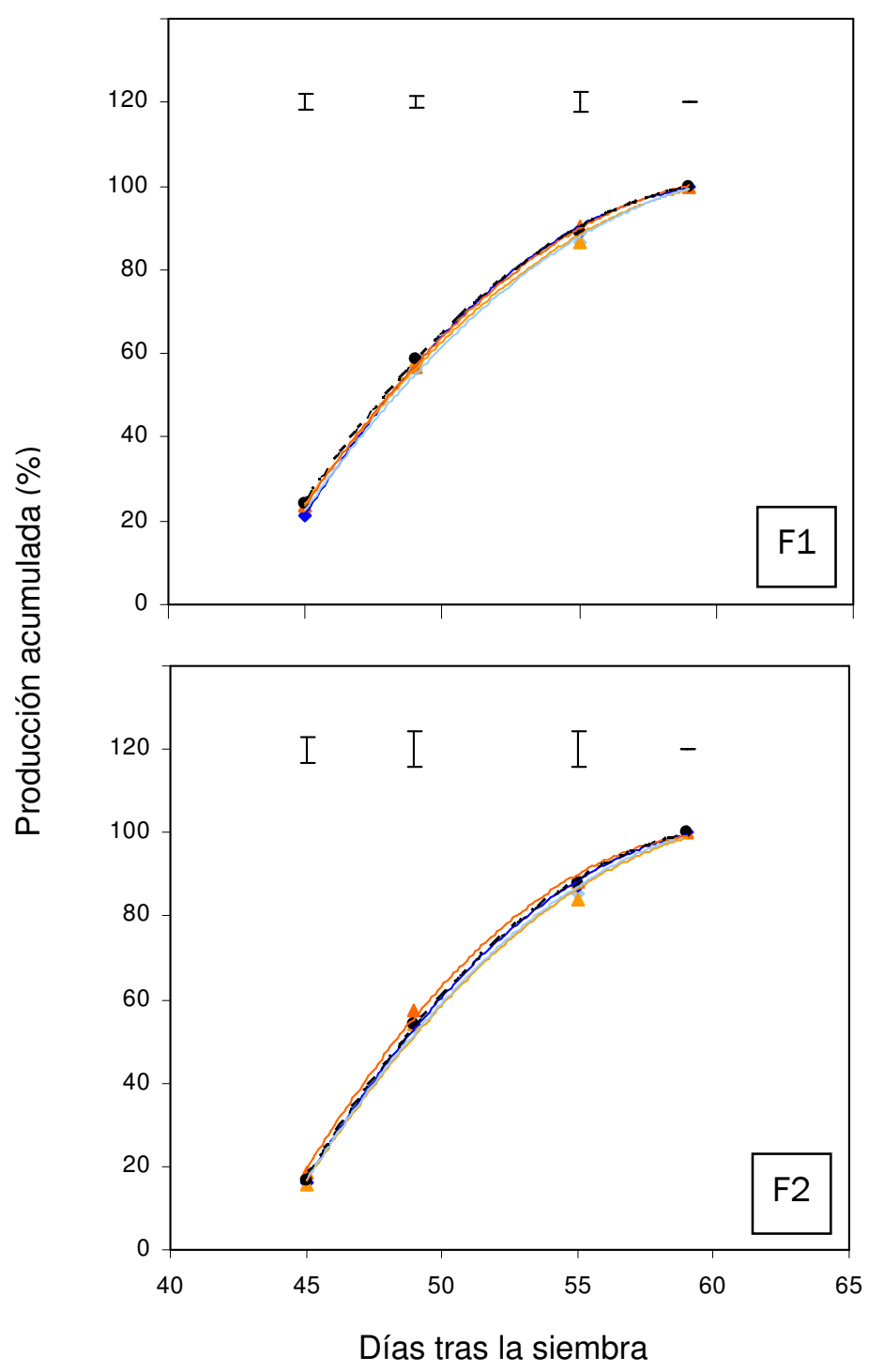

Figura 4.3.18. Evolución temporal de la producción acumulada de vainas de judía (expresada como porcentaje [\%] de la producción total obtenida en las cuatro recolecciones realizadas) en los tratamientos con los composts $\mathrm{A}$ y $\mathrm{A}+\mathrm{H}$ a las dosis $\mathrm{D} 1$ y D2 (equivalentes a 12 y 24 t de materia orgánica total/ha, respectivamente) en combinación con la fertilización mineral (programa F1, estándar, arriba y F2, reducida, abajo). Comparación con los controles (CO, que no recibieron compost). Año 2

A: compost de alperujo; $\mathrm{A}+\mathrm{H}$ : compost de alperujo más hidrolizado

Las barras verticales indican el error estándar 
Tabla 4.3.16. Efectos de los tratamientos experimentales estudiados -Compost (A y $A+H$ ), Dosis de aplicación de éste (D1 y D2, equivalentes a 12 y 24 t de materia orgánica total/ha, respectivamente) y Programa de fertilización mineral (estándar, F1 y reducida, F2) - sobre la producción precoz y total de vainas de judía, y sobre los días transcurridos hasta alcanzar el $50 \%$ de la producción total obtenida. Comparación con los controles (CO, que no recibieron compost). Año 2

\begin{tabular}{|c|c|c|c|c|c|}
\hline \multicolumn{2}{|c|}{ Compost } & \multirow{2}{*}{$\begin{array}{l}\text { Fertilización } \\
\text { mineral }\end{array}$} & \multirow{2}{*}{$\begin{array}{c}\text { Producción } \\
\text { precoz } \\
\text { (g/contenedor) }\end{array}$} & \multirow{2}{*}{$\begin{array}{c}\text { Días hasta el } 50 \% \\
\text { de la producción } \\
\text { total }\end{array}$} & \multirow{2}{*}{$\begin{array}{c}\text { Producción } \\
\text { totaly } \\
\text { (g/contenedor) }\end{array}$} \\
\hline Origen & Dosis & & & & \\
\hline \multirow[t]{4}{*}{ A } & D1 & F1 & 330,4 & 48 & $586,6 a b$ \\
\hline & & $\mathrm{F} 2$ & 295,6 & 49 & $551,9 a b$ \\
\hline & D2 & F1 & 327,2 & 48 & $559,4 a b$ \\
\hline & & F2 & 325,0 & 49 & $599,9 a$ \\
\hline \multirow[t]{4}{*}{$\mathrm{A}+\mathrm{H}$} & D1 & F1 & 337,3 & 48 & $581,3 a b$ \\
\hline & & $\mathrm{F} 2$ & 294,4 & 49 & $544,7 a b$ \\
\hline & D2 & F1 & 334,9 & 48 & $591,1 a$ \\
\hline & & $\mathrm{F} 2$ & 318,8 & 48 & $553,0 a b$ \\
\hline \multirow[t]{2}{*}{$\mathrm{CO}$} & - & F1 & 330,6 & 48 & $563,3 a b$ \\
\hline & - & $\mathrm{F} 2$ & 275,0 & 49 & $509,5 b$ \\
\hline$P$ & & & ns & ns & * \\
\hline \multicolumn{6}{|c|}{ Fuente de variación } \\
\hline \multicolumn{2}{|l|}{ 1. Compost } & & ns & ns & ns \\
\hline \multicolumn{2}{|c|}{ 2. Dosis de compost } & & ns & ns & ns \\
\hline \multicolumn{2}{|c|}{ 3. Fertilización mineral } & & ns & ns & ns \\
\hline \multicolumn{6}{|c|}{ 4. Interacción } \\
\hline \multicolumn{2}{|l|}{$1 \times 2$} & & ns & ns & ns \\
\hline \multicolumn{2}{|l|}{$1 \times 3$} & & ns & ns & ns \\
\hline \multicolumn{2}{|l|}{$2 \times 3$} & & ns & ns & ns \\
\hline \multicolumn{2}{|l|}{$1 \times 2 \times 3$} & & ns & ns & ns \\
\hline
\end{tabular}

A: compost de alperujo; $\mathrm{A}+\mathrm{H}$ : compost de alperujo más hidrolizado

z Producción comercial, de acuerdo con el tamaño de las vainas

y Producción comercial + no comercial

$P$ : nivel de significación. ns y * indican diferencias no significativas o estadísticamente significativas a $P \leq 0,05$, respectivamente

Valores en columna sin letra común difieren estadísticamente a $P \leq 0,05$ (test de Student-Newman-Keuls)

La evaluación global del efecto residual de la aplicación de los composts permite concluir que el cultivo de rábano mostró la importancia del efecto de la fertilización mineral sobre el crecimiento de la raíz y la productividad, observándose como única diferencia significativa respecto al control la productividad del tratamiento con compost $\mathrm{A}+\mathrm{H}$ a $24 \mathrm{t} / \mathrm{ha}$ en combinación con la fertilización reducida (F2). La aplicación de compost mejoró el crecimiento, la producción y la calidad de los cogollos de lechuga en todos los tratamientos estudiados, particularmente cuando $\mathrm{A}$ y $\mathrm{A}+\mathrm{H}$ se añadieron a 24 t/ha juntamente con el programa de fertilización reducida (F2). En el último cultivo, judía, la influencia del compost en los parámetros medidos fue escasa, 
principalmente en los relacionados con la cuantía de la cosecha. Los resultados hasta aquí presentados parecen sugerir que el efecto residual, durante el segundo año, de la aplicación de los composts de alperujo sobre el crecimiento, desarrollo y productividad de las tres especies cultivadas podría depender críticamente tanto de la evolución (descomposición) de los composts en el suelo como de los requerimientos nutricionales específicos de los cultivos estudiados.

\subsubsection{Estudio comparativo del efecto directo y residual de la aplicación de} compost sobre la rotación rábano-lechuga-judía

Con objeto de estudiar comparativamente el efecto directo (Año 1) y residual (Año 2) de los composts $A$ y $A+H$ aplicados a las dosis de 12 y 24 t de materia orgánica total/ha (en combinación con los programas de fertilización mineral F1, estándar y F2, reducida) sobre el desarrollo y la producción de los tres cultivos hortícolas estudiados, para cada parámetro controlado en éstos se calculó el ratio (cociente) entre el valor medido en el tratamiento con compost y el control sin enmendar que recibió idéntico programa de fertilización mineral.

Los resultados en rábano (Tabla 4.3.17) en el primer año (Año 1) pusieron de manifiesto que el peso fresco unitario de la raíz fue similar o superior al control en los tratamientos con el compost $A$, mientras que los valores de este parámetro fueron inferiores al control -aunque sin llegar a diferir significativamente de éste-cuando se aplicó $A+H$ en combinación con el programa de fertilización reducida (F2). Respecto al segundo año (Año 2), el valor de este ratio con el plan de fertilización reducida (F2) fue superior al de los tratamientos con el programa estándar (F1), aunque sólo se encontraron diferencias estadísticamente significativas respecto al control con $\mathrm{A}+\mathrm{H}$ a 24 t/ha. La cantidad de biomasa producida con A (parte aérea y raíz) no difirió de los controles el Año 1 (efecto directo) ni el Año 2 (efecto residual). Sin embargo, la aplicación de A se tradujo en un incremento en la producción total de raíces en el primer año, pero dicho efecto desapareció en el segundo. Como resultado del efecto directo de la aplicación de $\mathrm{A}+\mathrm{H}$, los tratamientos experimentaron una disminución respecto a los controles tanto en la biomasa tanto del vástago como de la raíz, particularmente cuando aquellos habían recibido el programa de fertilización mineral reducido (F2). No obstante, la producción total de raíces no se vio afectada significativamente por dicho efecto el primer año, llegando a igualarse con, e incluso a 
superar, la producción total y la biomasa del sistema radical en comparación con los controles en el segundo.

Tabla 4.3.17. Efecto directo (Año 1) y residual (Año 2) de la aplicación de los composts $\mathrm{A}$ y $\mathrm{A}+\mathrm{H}$ a las dosis D1 y D2 (equivalentes a 12 y 24 t materia orgánica total/ha, respectivamente) -junto con los programas de fertilización mineral F1 y F2 (estándar y reducida, respectivamente)- sobre el crecimiento, la acumulación y distribución de biomasa, y la productividad en rábano. En cada parámetro, las cifras indican el ratio calculado como cociente entre el valor medido en el tratamiento con compost y el control sin enmendar que recibió idéntico programa de fertilización mineral

\begin{tabular}{|c|c|c|c|c|c|c|}
\hline \multicolumn{2}{|c|}{ Compost } & \multirow{2}{*}{$\begin{array}{l}\text { Fertilización } \\
\text { mineral }\end{array}$} & \multirow{2}{*}{$\begin{array}{c}\text { Peso fresco } \\
\text { raíz }\end{array}$} & \multicolumn{2}{|c|}{ Biomasa } & \multirow[t]{2}{*}{ Producción total } \\
\hline Origen & Dosis & & & Vástago & Raíz & \\
\hline Año 1 & & & & & & \\
\hline \multirow[t]{4}{*}{ A } & D1 & F1 & 1,20 * & 1,03 & 1,11 & $1,21^{*}$ \\
\hline & & F2 & 1,01 & 0,99 & 1,08 & 1,11 \\
\hline & D2 & F1 & 1,08 & 1,12 & 1,14 & $1,20 *$ \\
\hline & & F2 & 1,04 & 0,97 & 1,13 & $1,20 *$ \\
\hline \multirow[t]{4}{*}{$\mathrm{A}+\mathrm{H}$} & D1 & F1 & 1,02 & $0,80 *$ & 0,83 & 1,09 \\
\hline & & F2 & 0,89 & $0,64 *$ & $0,69 *$ & 0,94 \\
\hline & D2 & F1 & 1,12 & $0,73 *$ & $0,79 *$ & 1,06 \\
\hline & & F2 & 0,96 & $0,57 *$ & $0,65^{*}$ & 0,90 \\
\hline
\end{tabular}

\begin{tabular}{lcccccc}
\hline Año 2 & & & & & & \\
\hline A & D1 & F1 & 1,02 & 1,00 & 1,03 & 1,01 \\
& & F2 & 1,27 & 1,04 & 1,06 & 1,13 \\
& D2 & F1 & 0,91 & 0,96 & 1,08 & 0,99 \\
& & F2 & 1,08 & 1,07 & 1,11 & 1,10 \\
A+H & D1 & F1 & 1,11 & 1,02 & 1,11 & 1,08 \\
& & F2 & 1,17 & 1,05 & $1,26^{*}$ & 1,14 \\
& D2 & F1 & 0,99 & 1,02 & 1,10 & 1,04 \\
& & F2 & $1,45^{*}$ & 1,12 & $1,23^{*}$ & $1,29 *$ \\
\hline
\end{tabular}

A: compost de alperujo; $\mathrm{A}+\mathrm{H}$ : compost de alperujo más hidrolizado

* indica diferencias estadísticamente significativas del tratamiento respecto al control con idéntico programa de fertilización mineral a $P \leq 0,05$ (test de Student-Newman-Keuls)

El estudio comparativo del efecto directo y residual del compost sobre lechuga (ver Tabla 4.3.18) puso de manifiesto un efecto positivo generalizado de la aplicación de compost, tanto el primer año como el segundo. El efecto directo fue de mayor magnitud que el residual, particularmente sobre la biomasa acumulada en la raíz y la producción total de cogollos, siendo además superior en los tratamientos que recibieron la dosis de 24 t/ha junto con el programa de abonado estándar (F1). 
Tabla 4.3.18. Efecto directo (Año 1) y residual (Año 2) de la aplicación de los composts A y $\mathrm{A}+\mathrm{H}$ a las dosis D1 y D2 (equivalentes a 12 y 24 t materia orgánica total/ha, respectivamente) -junto con los programas de fertilización mineral F1 y F2 (estándar y reducida, respectivamente)- sobre el crecimiento, la acumulación y distribución de biomasa, y la productividad en lechuga. En cada parámetro, las cifras indican el ratio calculado como cociente entre el valor medido en el tratamiento con compost y el control sin enmendar que recibió idéntico programa de fertilización mineral

\begin{tabular}{|c|c|c|c|c|c|c|}
\hline \multicolumn{2}{|c|}{ Compost } & \multirow{2}{*}{$\begin{array}{c}\text { Fertilización } \\
\text { mineral }\end{array}$} & \multirow[t]{2}{*}{ Área foliar } & \multicolumn{2}{|c|}{ Biomasa } & \multirow[t]{2}{*}{ Producción total } \\
\hline Origen & Dosis & & & Vástago & Raíz & \\
\hline \multicolumn{7}{|l|}{ Año 1} \\
\hline \multirow[t]{4}{*}{$\bar{A}$} & D1 & F1 & 1,16 & $1,27^{*}$ & $1,35^{*}$ & $1,32 *$ \\
\hline & & F2 & 1,22 & 1,15 & 1,22 & $1,36 *$ \\
\hline & D2 & F1 & $1,35^{*}$ & $1,44 *$ & $3,10 *$ & $1,63 *$ \\
\hline & & F2 & $1,24 *$ & $1,33 *$ & $1,44 *$ & $1,54 *$ \\
\hline \multirow[t]{4}{*}{$\mathrm{A}+\mathrm{H}$} & D1 & F1 & $1,28 *$ & $1,31 *$ & $1,45^{*}$ & $1,46 *$ \\
\hline & & F2 & 1,27 * & 1,15 & 1,07 & $1,31 *$ \\
\hline & D2 & F1 & $1,46 *$ & $1,71 *$ & $2,79 *$ & $1,86 *$ \\
\hline & & F2 & $1,38^{*}$ & $1,34 *$ & $1,51^{*}$ & $1,58 *$ \\
\hline \multicolumn{7}{|l|}{ Año 2} \\
\hline \multirow[t]{4}{*}{$A$} & D1 & F1 & $1,13^{*}$ & $1,18^{*}$ & 0,93 & $1,21^{*}$ \\
\hline & & F2 & 1,09 & 1,05 & $1,33 *$ & $1,24 *$ \\
\hline & D2 & F1 & $1,15^{*}$ & $1,24 *$ & $1,19 *$ & $1,33^{*}$ \\
\hline & & F2 & 1,10 & $1,15^{*}$ & 1,05 & $1,42 *$ \\
\hline \multirow[t]{4}{*}{$A+H$} & D1 & F1 & $1,17 *$ & $1,13^{*}$ & 1,04 & $1,19 *$ \\
\hline & & F2 & 1,04 & $1,18^{*}$ & $1,17 *$ & $1,29 *$ \\
\hline & D2 & F1 & $1,16 *$ & $1,25 *$ & $1,32 *$ & $1,36 *$ \\
\hline & & F2 & 1,07 & $1,21^{*}$ & $1,23 *$ & $1,42 *$ \\
\hline
\end{tabular}

A: compost de alperujo; $\mathrm{A}+\mathrm{H}$ : compost de alperujo más hidrolizado

* indica diferencias estadísticamente significativas del tratamiento respecto al control con idéntico programa de fertilización mineral a $P \leq 0,05$ (test de Student-Newman-Keuls)

En cuanto a judía, cuyos resultados de área la hoja, biomasa (acumulada en la parte aérea y en la raíz) y producción total de vainas se presentan en la Tabla 4.3.19, se registró -como efecto directo- un incremento (respecto a los controles) en el valor de los parámetros estudiados de cuantía similar para ambos composts ( $\mathrm{A}$ y $A+H)$, pero comparativamente superior en los tratamientos en que éstos se aplicaron a $24 \mathrm{t} / \mathrm{ha}$ en combinación con el plan de fertilización reducida (F2). El efecto positivo observado el primer año desapareció el segundo, encontrándose únicamente algunas diferencias significativas respecto a los controles en los tratamientos correspondientes a la dosis de 24 t/ha junto con la fertilización mineral reducida (F2). 
Tabla 4.3.19. Efecto directo (Año 1) y residual (Año 2) de la aplicación de los composts A y $\mathrm{A}+\mathrm{H}$ a las dosis D1 y D2 (equivalentes a 12 y 24 t materia orgánica total/ha, respectivamente) -junto con los programas de fertilización mineral F1 y F2 (estándar y reducida, respectivamente)- sobre el crecimiento, la acumulación y distribución de biomasa, y la productividad en judía. En cada parámetro, las cifras indican el ratio calculado como cociente entre el valor medido en el tratamiento con compost y el control sin enmendar que recibió idéntico programa de fertilización mineral

\begin{tabular}{|c|c|c|c|c|c|c|}
\hline \multicolumn{2}{|c|}{ Compost } & \multirow{2}{*}{$\begin{array}{l}\text { Fertilización } \\
\text { mineral }\end{array}$} & \multirow{2}{*}{$\begin{array}{l}\text { No vainas } \\
\text { /planta }\end{array}$} & \multicolumn{2}{|c|}{ Biomasa } & \multirow[t]{2}{*}{ Producción total } \\
\hline Origen & Dosis & & & Parte aérea & Raíz & \\
\hline \multicolumn{7}{|l|}{ Año 1} \\
\hline \multirow[t]{4}{*}{ A } & D1 & F1 & $1,49 *$ & $1,53^{*}$ & $1,32^{*}$ & $1,49 *$ \\
\hline & & F2 & $1,70 *$ & $1,73^{*}$ & $1,50 *$ & $1,60 *$ \\
\hline & D2 & F1 & $1,68 *$ & $1,94 *$ & $1,31 *$ & $1,66 *$ \\
\hline & & F2 & $1,99 *$ & $1,97 *$ & $1,46^{*}$ & $1,90 *$ \\
\hline \multirow[t]{4}{*}{$A+H$} & D1 & F1 & $1,52 *$ & $1,50 *$ & 1,22 & $1,50 *$ \\
\hline & & F2 & $1,62 *$ & $1,67 *$ & $1,66^{*}$ & $1,63^{*}$ \\
\hline & D2 & F1 & $1,71^{*}$ & $1,91^{*}$ & $1,34 *$ & $1,62 *$ \\
\hline & & F2 & $1,94 *$ & $2,25 *$ & $1,83^{*}$ & $1,89 *$ \\
\hline \multicolumn{7}{|l|}{ Año 2} \\
\hline \multirow[t]{4}{*}{ A } & D1 & F1 & 1,07 & 1,04 & 1,10 & 1,04 \\
\hline & & F2 & 1,01 & 1,03 & 1,18 & 1,08 \\
\hline & D2 & F1 & 1,10 & 1,08 & 1,01 & 0,99 \\
\hline & & F2 & $1,16 *$ & $1,14 *$ & 1,19 & $1,18^{*}$ \\
\hline \multirow[t]{4}{*}{$\mathrm{A}+\mathrm{H}$} & D1 & F1 & 1,03 & 1,05 & 0,86 & 1,03 \\
\hline & & F2 & 1,04 & $1,10 *$ & 1,06 & 1,07 \\
\hline & D2 & F1 & 1,06 & 1,02 & 0,93 & 1,05 \\
\hline & & F2 & 1,11 & $1,16^{*}$ & 1,33 & 1,09 \\
\hline
\end{tabular}

A: compost de alperujo; A+H: compost de alperujo más hidrolizado

z Producción comercial + no comercial

* indica diferencias estadísticamente significativas del tratamiento respecto al control con idéntico programa de fertilización mineral a $P \leq 0,05$ (test de Student-Newman-Keuls)

En conclusión, el compost A tuvo un efecto inmediato -a corto plazo- estimulador del crecimiento, desarrollo y productividad de las especies hortícolas estudiadas, que se mantuvo durante los tres ciclos de cultivo del primer año. Con relación a $\mathrm{A}+\mathrm{H}$, el efecto directo de su aplicación fue perjudicial para el crecimiento y desarrollo de rábano, pero dicha situación revertió al cabo de 4 meses, provocando un aumento en la producción de lechuga y de judía en el primer año. 
La evaluación del efecto residual de la aplicación de compost (Año 2) reveló que la influencia de $\mathrm{A}$ y $\mathrm{A}+\mathrm{H}$ en el desarrollo y la producción de los tres cultivos estudiados disminuyó notablemente respecto al primer año (o efecto directo). Por tanto, el efecto residual fue similar con ambos composts $(A$ y $A+H)$, registrándose únicamente un incremento en el desarrollo y la productividad de lechuga con las mezclas de compost y suelo en comparación con los controles.

\subsubsection{Influencia de los composts y su interacción con la fertilización mineral en el estado nutricional de las tres especies hortícolas estudiadas. Efecto directo y residual}

\subsubsection{Efecto directo}

Rábano

En rábano (Figura 4.3.19 y Tabla 4.3.20), el compost A aumentó el contenido foliar de fósforo $(P)$, potasio $(K)$ y magnesio $(M g)$ respecto a $A+H$, encontrándose el efecto opuesto en calcio (Ca) y sodio ( $\mathrm{Na}$ ). En el factor Dosis de compost, la aplicación a $12 \mathrm{t} /$ ha se tradujo en un incremento en los niveles de Ca y Mg en comparación con la de 24 t/ha. En cuanto a la fertilización mineral, el plan de abonado reducido (F2) elevó los niveles de $\mathrm{P}$ y $\mathrm{Mg}$ en relación con el programa estándar (F1). Las interacciones del factor Compost con los otros dos factores estudiados (Dosis de compost y Programa de fertilización mineral) fueron estadísticamente significativas para la mayoría de los elementos determinados.

En adición, las aplicaciones de compost incrementaron el contenido en $\mathrm{K}$ de las hojas con respecto a los controles, principalmente cuando el suelo se trató con A. En general, la aplicación de A en combinación con la fertilización mineral estándar (F1) disminuyó la concentración de $\mathrm{Ca}, \mathrm{y} \mathrm{A}+\mathrm{H}$ la de $\mathrm{Mg}$, en comparación con dichos controles. Por otro lado, los tratamientos con compost no afectaron los niveles de $\mathrm{N}$ y $\mathrm{P}$ frente a los controles, y, por lo que se refiere a $\mathrm{Na}$, sólo se apreció un incremento en su concentración cuando se aplicó $\mathrm{A}+\mathrm{H}$ en combinación con el plan de fertilización reducida (F2). 

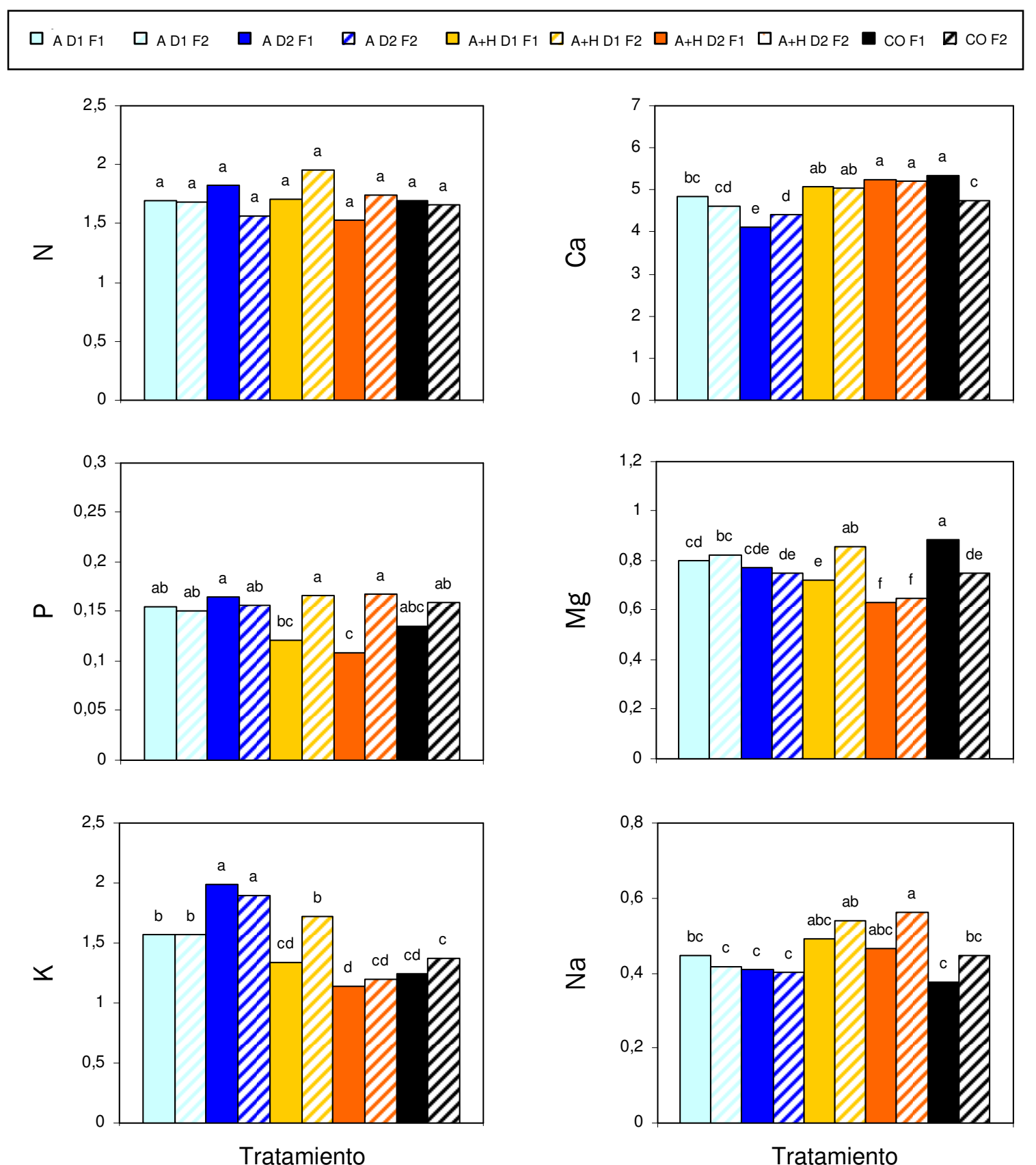

Figura 4.3.19. Influencia del compost $(\mathrm{A}$ y $\mathrm{A}+\mathrm{H})$, la dosis de aplicación de éste (D1 y D2, equivalentes a 12 y 24 t de materia orgánica total/ha, respectivamente) y el programa de fertilización mineral (estándar, F1 y reducida, F2) en el contenido foliar de nutrientes (expresado en \% de materia seca) en rábano. Comparación con los controles (CO, que no recibieron compost). Primer año del experimento (Año 1)

A: compost de alperujo; $\mathrm{A}+\mathrm{H}$ : compost de alperujo más hidrolizado

Barras sin letra común difieren estadísticamente a $P \leq 0,05$ (test de Student-Newman-Keuls) 
Tabla 4.3.20. Análisis factorial de la varianza $(P)$ para los efectos de los tratamientos estudiados -Compost (alperujo vs. alperujo más hidrolizado), Dosis de aplicación de éste (12 vs. 24 t de materia orgánica total/ha) y Programa de fertilización mineral (estándar vs. reducida)- sobre el contenido foliar de nutrientes en rábano. Primer año del experimento (Año 1)

\begin{tabular}{|c|c|c|c|c|c|c|}
\hline Fuente de variación & $\mathrm{N}$ & $\mathbf{P}$ & $\mathrm{K}$ & $\mathrm{Ca}$ & Mg & $\mathrm{Na}$ \\
\hline 1. Compost & ns & * & $\star * \star$ & $* * *$ & $* * *$ & $* \star \star$ \\
\hline 2. Dosis de compost & ns & ns & ns & * & $* * *$ & ns \\
\hline 3. Fertilización mineral & ns & $\star \star$ & ns & ns & $\star \star$ & ns \\
\hline \multicolumn{7}{|l|}{ 4. Interacción } \\
\hline $1 \times 2$ & ns & ns & $* * *$ & $* * *$ & $* * *$ & ns \\
\hline $1 \times 3$ & $*$ & $* * *$ & $\star \star$ & ns & $\star \star$ & * \\
\hline $2 \times 3$ & ns & ns & * & * & $\star *$ & ns \\
\hline $1 \times 2 \times 3$ & ns & ns & ns & * & ns & ns \\
\hline
\end{tabular}

\section{Lechuga}

De acuerdo con los resultados presentados en la Figura 4.3.20 y la Tabla 4.3.21, el efecto principal del factor Compost puso de manifiesto que la aplicación de $\mathrm{A}+\mathrm{H}$ incrementó las concentraciones foliares de $\mathrm{P}$ y $\mathrm{Mg}$, mientras que $\mathrm{A}$ aumentó los niveles de Ca y Na. Además, cuando el compost se aplicó a la dosis de 12 t/ha aumentaron los niveles de N, Mg y Na (en comparación con la de 24 t/ha), mientras que con la de 24 t/ha se apreció un aumento de $\mathrm{P}$ y K (con respecto a 12 t/ha). En cuanto a los efectos de la fertilización mineral aplicada, hay que señalar que los niveles de $\mathrm{N}$ y $\mathrm{K}$ se elevaron con el plan estándar (F1) en comparación con el reducido (F2), y que los contenidos en $\mathrm{Mg}$ y $\mathrm{Na}$ experimentaron un incremento con el programa reducido (F2) respecto al estándar (F1). En base a los resultados obtenidos, la mayoría de las interacciones de los factores estudiados fueron estadísticamente significativas, especialmente las correspondientes a los niveles de $\mathrm{P}$ y Mg. 


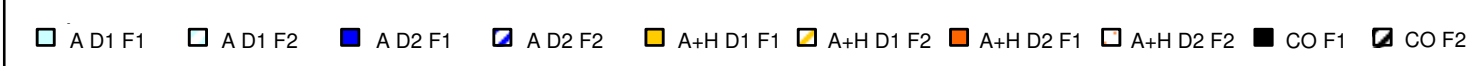
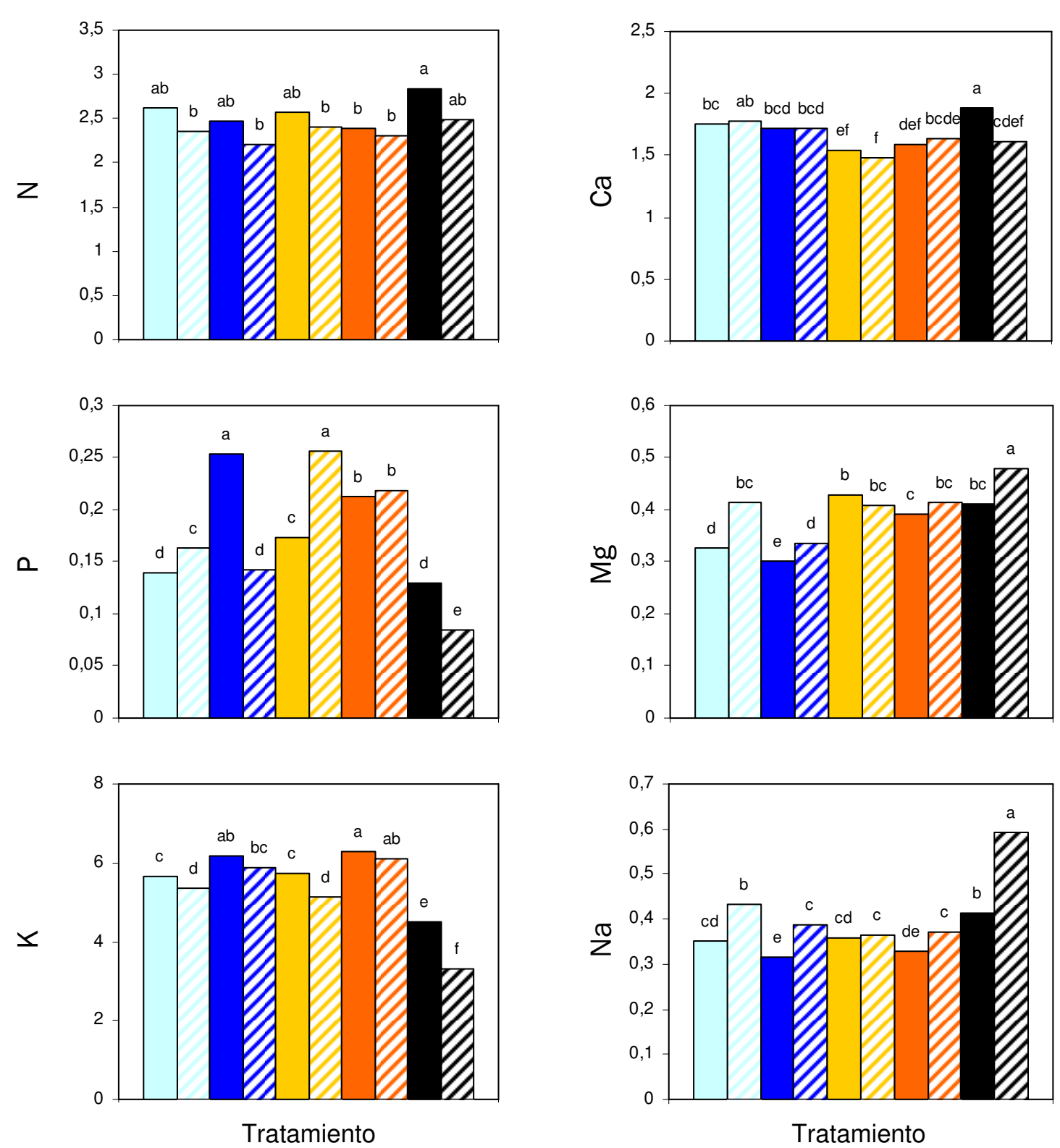

Figura 4.3.20. Influencia del compost $(\mathrm{A}$ y $\mathrm{A}+\mathrm{H})$, la dosis de aplicación de éste (D1 y D2, equivalentes a 12 y 24 t de materia orgánica total/ha, respectivamente) y el programa de fertilización mineral (estándar, F1 y reducida, F2) en el contenido foliar de nutrientes (expresado en \% de materia seca) en lechuga. Comparación con los controles (CO, que no recibieron compost). Año 1

$\mathrm{A}$ : compost de alperujo; $\mathrm{A}+\mathrm{H}$ : compost de alperujo más hidrolizado

Barras sin letra común difieren estadísticamente a $P \leq 0,05$ (test de Student-Newman-Keuls) 
Tabla 4.3.21. Análisis factorial de la varianza $(P)$ para los efectos de los tratamientos estudiados -Compost (alperujo vs. alperujo más hidrolizado), Dosis de aplicación de éste (12 vs. 24 t de materia orgánica total/ha) y Programa de fertilización mineral (F1 vs. reducida)- sobre el contenido foliar de nutrientes en lechuga. Año 1

\begin{tabular}{|c|c|c|c|c|c|c|}
\hline Fuente de variación & $\mathbf{N}$ & $P$ & $\mathrm{~K}$ & $\mathrm{Ca}$ & $\mathrm{Mg}$ & $\mathrm{Na}$ \\
\hline 1. Compost & ns & $\star \star \star *$ & ns & 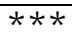 & $\star \star \star$ & * \\
\hline 2. Dosis de compost & $* * *$ & $\star \star *$ & $\star * \star$ & ns & $\star \star *$ & $\star \star \star$ \\
\hline 3. Fertilización mineral & $* * *$ & ns & $\star * \star$ & ns & $\star \star \star$ & $\star \star *$ \\
\hline \multicolumn{7}{|l|}{ 4. Interacción } \\
\hline $1 \times 2$ & ns & $\star \star *$ & ns & $\star \star \star$ & $\star \star$ & * \\
\hline $1 \times 3$ & ns & $\star \star *$ & ns & ns & $\star * *$ & $\star \star \star$ \\
\hline $2 \times 3$ & ns & $\star \star *$ & ns & ns & ns & ns \\
\hline $1 \times 2 \times 3$ & ns & $\star *$ & ns & ns & $* * *$ & ns \\
\hline
\end{tabular}

Con relación al status nutricional de lechuga en los controles frente a los tratamientos con compost, no se encontraron diferencias significativas en el nivel de $\mathrm{N}$, mientras que casi todos los tratamientos que recibieron compost aumentaron los niveles de P y K, destacando en este último elemento la dosis de 24 t/ha. Con Mg y Ca (en este último particularmente con el plan de abonado estándar, F1) se presentó generalmente la situación contraria (control > compost), de manera similar a lo señalado anteriormente en rábano. Por último, las aplicaciones de compost junto con la fertilización mineral disminuyeron los niveles de $\mathrm{Na}$ en comparación con los controles.

Judía

El análisis de la varianza multifactorial realizado mostró que A resultó en un contenido foliar de $\mathrm{Mg}$ superior a $\mathrm{A}+\mathrm{H}$, mientras que este último incrementó comparativamente los valores de $\mathrm{K}$, Ca y Na (Tabla 4.3.22 y Figura 4.3.21). La dosis equivalente a 24 t/ha aumentó los niveles de $\mathrm{K}$ y $\mathrm{Na}$, y disminuyó el de $\mathrm{Mg}$, en comparación con la de 12 t/ha. En relación con el factor Fertilización mineral, el plan reducido (F2) aumentó la concentración de P, Ca y Mg, y disminuyó el contenido de K, respecto al programa estándar (F1). En relación con las interacciones estudiadas, 
debe señalarse que las concentraciones de $\mathrm{Ca}$ y $\mathrm{Na}$ registraron niveles de significación $(P)$ altamente significativos.

$\square$ AD1F1 $\square A D 1 F 2 \quad \square A D 2 F 1 \quad \square A D 2 F 2 \quad \square A+H D 1 F 1 \quad \square A+H D 1 F 2 \quad \square A+H D 2 F 1 \quad \square A+H D 2 F 2 \square C O F 1 \quad \square C O F 2$
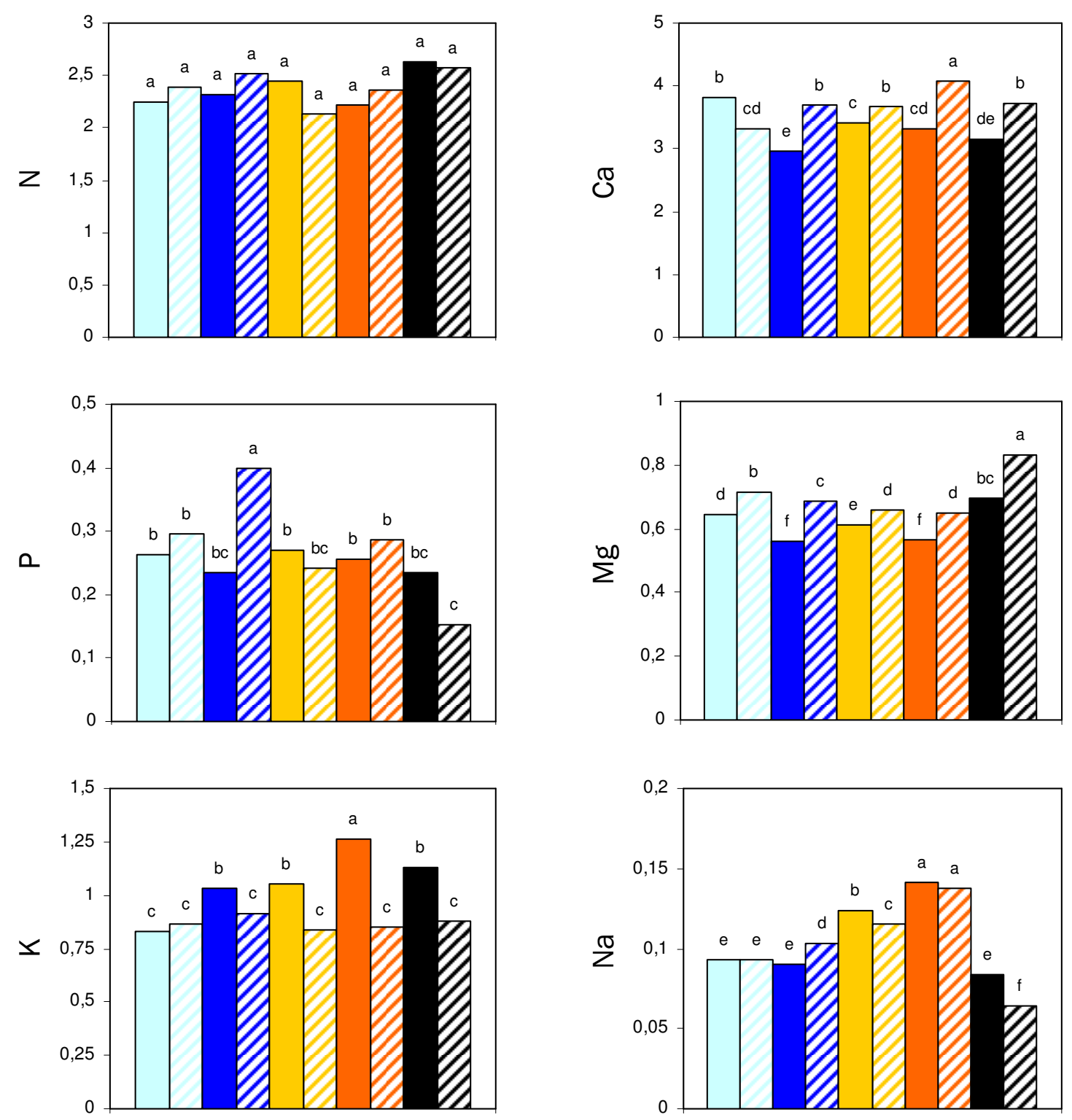

Tratamiento

Tratamiento

Figura 4.3.21. Influencia del compost (A y A+H), la dosis de aplicación de éste (D1 y D2, equivalentes a 12 y 24 t de materia orgánica total/ha, respectivamente) y el programa de fertilización mineral (estándar, F1 y reducida, F2) en el contenido foliar de nutrientes (expresado en \% de materia seca) en judía. Comparación con los controles (CO, que no recibieron compost). Año 1

A: compost de alperujo; $\mathrm{A}+\mathrm{H}$ : compost de alperujo más hidrolizado

Barras sin letra común difieren estadísticamente a $P \leq 0,05$ (test de Student-Newman-Keuls) 
Tabla 4.3.22. Análisis factorial de la varianza $(P)$ para los efectos de los tratamientos estudiados -Compost (alperujo vs. alperujo más hidrolizado), Dosis de aplicación de éste (12 vs. 24 t de materia orgánica total/ha) y Programa de fertilización mineral (estándar vs. reducida)- sobre el contenido foliar de nutrientes en judía. Año 1

\begin{tabular}{lcccccc}
\multicolumn{1}{c}{ Fuente de variación } & $\mathrm{N}$ & $\mathrm{P}$ & $\mathrm{K}$ & $\mathrm{Ca}$ & $\mathrm{Mg}$ & $\mathrm{Na}$ \\
\hline 1. Compost & $\mathrm{ns}$ & $\mathrm{ns}$ & $* * *$ & $* * *$ & $* * *$ & $* * *$ \\
2. Dosis de compost & $\mathrm{ns}$ & $\mathrm{ns}$ & $* * *$ & $\mathrm{~ns}$ & $* * *$ & $* * *$ \\
3. Fertilización mineral & $\mathrm{ns}$ & $*$ & $* * *$ & $* * *$ & $* * *$ & $\mathrm{~ns}$ \\
4. Interacción & & & & & & \\
$1 \times 2$ & $\mathrm{~ns}$ & $\mathrm{~ns}$ & $\mathrm{~ns}$ & $* * *$ & $\mathrm{~ns}$ & $* * *$ \\
$1 \times 3$ & $\mathrm{~ns}$ & $*$ & $* * *$ & $* * *$ & $*$ & $* *$ \\
$2 \times 3$ & $\mathrm{~ns}$ & $*$ & $* * *$ & $* * *$ & $* * *$ & $* *$ \\
$1 \times 2 \times 3$ & $\mathrm{~ns}$ & $\mathrm{~ns}$ & $\mathrm{~ns}$ & $* * *$ & $\mathrm{~ns}$ & $\mathrm{~ns}$ \\
\hline $\begin{array}{l}P: \text { nivel de significación. } \mathrm{ns},{ }^{*}, * * \mathrm{y} * * * \\
P \leq 0,001, \text { indican diferencias no significativas o estadísticamente significativas a } P \leq 0,05, P \leq 0,01 \mathrm{y}\end{array}$
\end{tabular}

Al igual que en los dos cultivos anteriores, los tratamientos con compost y los controles sin enmendar no difirieron en el contenido en N. Asimismo, merece destacarse que la aplicación de compost juntamente con el plan de fertilización reducida (F2) incrementó la concentración de $\mathrm{P}$. En K, únicamente $\mathrm{A}+\mathrm{H}$ a la dosis de 24 t/ha en combinación con el plan de fertilización estándar (F1) superó al contenido de este elemento en el control con idéntica fertilización mineral (CO F1). Además, la mayoría de los tratamientos con compost disminuyeron comparativamente el nivel de Mg. Finalmente, la aplicación de compost no tuvo un efecto consistente sobre el nivel Ca.

\subsubsection{Efecto residual}

Rábano

La Figura 4.3.22 y la Tabla 4.3.23 recogen los resultados del estudio estadístico de los niveles foliares de los nutrientes en rábano en el segundo año tras la aplicación de los composts 

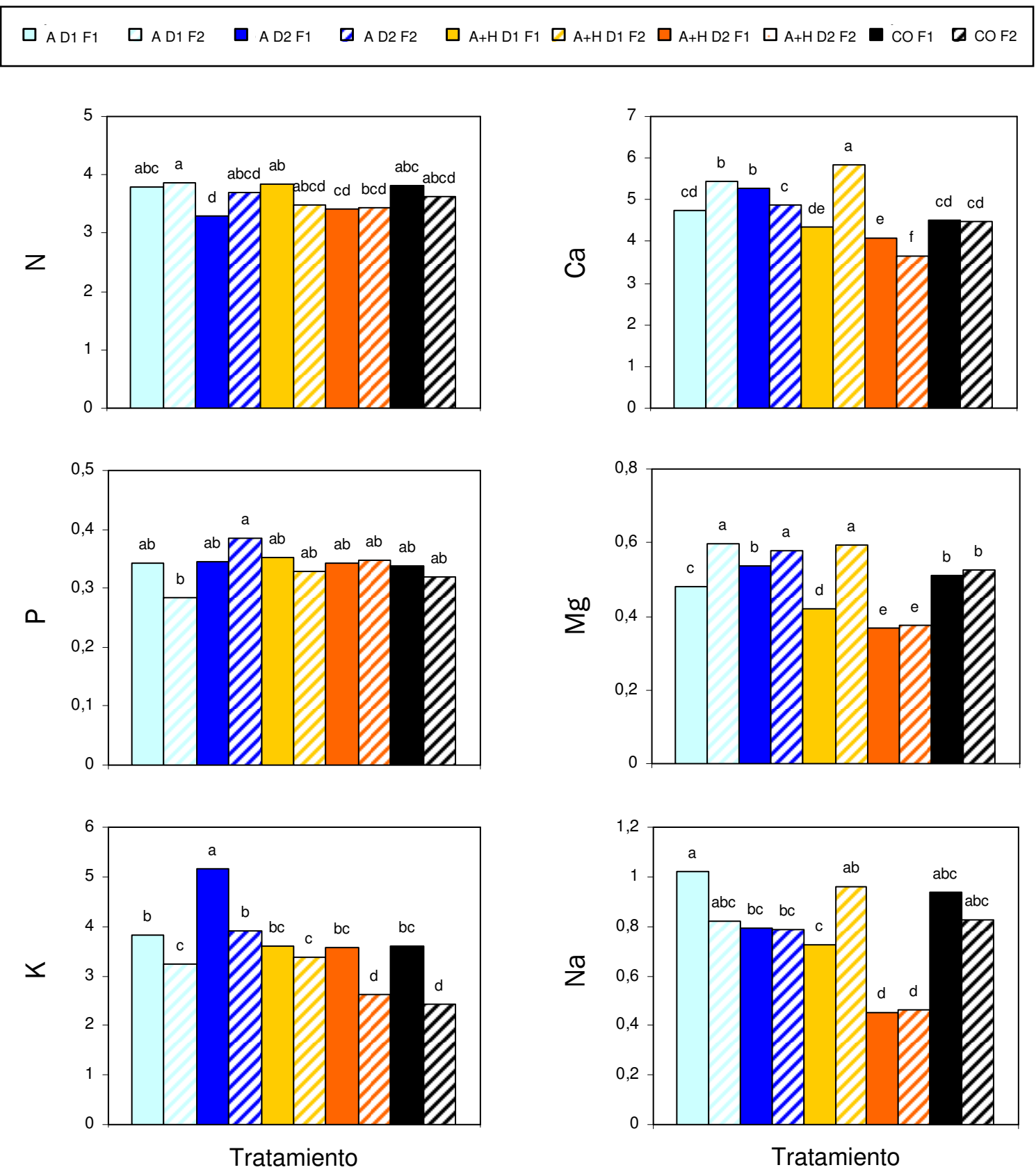

Figura 4.3.22. Influencia del compost $(\mathrm{A}$ y $\mathrm{A}+\mathrm{H})$, la dosis de aplicación de éste (D1 y D2, equivalentes a 12 y 24 t de materia orgánica total/ha, respectivamente) y el programa de fertilización mineral (estándar, F1 y reducida, F2) en el contenido foliar de nutrientes (expresado en \% de materia seca) en rábano. Comparación con los controles (CO, que no recibieron compost). Segundo año del experimento (Año 2) A: compost de alperujo; $\mathrm{A}+\mathrm{H}$ : compost de alperujo más hidrolizado Barras sin letra común difieren estadísticamente a $P \leq 0,05$ (test de Student-Newman-Keuls) 
Tabla 4.3.23. Análisis factorial de la varianza $(P)$ para los efectos de los tratamientos estudiados -Compost (alperujo vs. alperujo más hidrolizado), Dosis de aplicación de éste (12 vs. 24 t de materia orgánica total/ha) y Programa de fertilización mineral (estándar vs. reducida)- sobre el contenido foliar de nutrientes en rábano. Segundo año del experimento (Año 2)

\begin{tabular}{|c|c|c|c|c|c|c|}
\hline Fuente de variación & $\mathrm{N}$ & $\mathbf{P}$ & $\mathrm{K}$ & $\mathrm{Ca}$ & $\mathrm{Mg}$ & $\mathrm{Na}$ \\
\hline 1. Compost & ns & ns & $\star \star \star$ & $\star \star \star *$ & $\star \star \star$ & $\star \star \star *$ \\
\hline 2. Dosis de compost & $\star \star$ & * & $\star \star \star$ & $\star * *$ & $\star \star *$ & $* \star *$ \\
\hline 3. Fertilización mineral & ns & ns & $\star \star \star$ & $\star \star *$ & $\star \star *$ & ns \\
\hline \multicolumn{7}{|l|}{ 4. Interacción } \\
\hline $1 \times 2$ & ns & ns & $\star \star \star$ & $\star \star *$ & $\star \star *$ & $\star \star$ \\
\hline $1 \times 3$ & ns & ns & * & * & ns & $\star \star$ \\
\hline $2 \times 3$ & ns & * & $* * *$ & $* \star *$ & $\star \star *$ & ns \\
\hline $1 \times 2 \times 3$ & ns & ns & ns & * & $* *$ & $\star \star$ \\
\hline
\end{tabular}

El factor Compost tuvo un efecto altamente significativo, observándose que $A$ aumentó los niveles de $\mathrm{K}, \mathrm{Ca}, \mathrm{Mg}$ y $\mathrm{Na}$ respecto a $\mathrm{A}+\mathrm{H}$. La aplicación de compost a la dosis de 12 t/ha incrementó la concentración de N, Ca, Mg y Na comparativamente con la de 24 t/ha, mientras que esta última aumentó el contenido en $\mathrm{P}$ y $\mathrm{K}$. Con referencia a la fertilización mineral, el plan estándar (F1) aumentó el nivel de K, y disminuyó los de Ca y Mg, en comparación con F2 (reducido). Tanto la interacción Compost $\mathrm{x}$ Dosis de compost como Dosis de compost $\mathrm{x}$ Fertilización mineral fueron altamente significativas en la mayoría de los elementos analizados.

El estudio conjunto de las mezclas de suelo+compost y los controles no enmendados indicó que prácticamente no existieron diferencias en los niveles de $\mathrm{N}$ y $P$ entre los tratamientos en comparación. Los tratamientos con compost mostraron un contenido en $\mathrm{K}$ similar o superior a los controles, particularmente elevado cuando A se aplicó a la dosis de 24 t/ha. Con respecto a los restantes nutrientes, los tratamientos con $\mathrm{A}+\mathrm{H}$ a la dosis de $24 \mathrm{t} /$ ha presentaron niveles de $\mathrm{Ca}, \mathrm{Mg}$ y $\mathrm{Na}$ inferiores a los controles, apreciándose en el resto de tratamientos que las concentraciones de estos tres elementos fueron generalmente del mismo orden que (e incluso superiores a) los suelos control. 


\section{Lechuga}

Al examinar los resultados obtenidos (Figura 4.3.23 y Tabla 4.3.24), se apreció que el compost A incrementó la concentración foliar de K, Ca, Mg y Na, y disminuyó la de $\mathrm{P}$, respecto a $\mathrm{A}+\mathrm{H}$. En cuanto al factor Dosis de compost (12 vs. $24 \mathrm{t} / \mathrm{ha}$ ), la adición de la dosis máxima aumentó los niveles de $\mathrm{P}, \mathrm{K}$ y $\mathrm{Ca}$, pero disminuyó el de $\mathrm{Na}$, en comparación con la dosis mínima. El programa de fertilización estándar (F1) incrementó los niveles de $\mathrm{N}$ y $\mathrm{K}$, mientras que los de $\mathrm{Mg}$ y $\mathrm{Na}$ aumentaron en mayor cuantía con el plan reducido (F2). En este cultivo destacó el elevado número de interacciones ternarias con alto nivel de significación estadística.

De forma análoga al cultivo de lechuga del primer año (efecto directo), no se observaron diferencias importantes entre los controles y los tratamientos con compost en el contenido foliar de $\mathrm{N}$. Por otro lado, los tratamientos con $\mathrm{A}$ y $\mathrm{A}+\mathrm{H}$ aumentaron los niveles de $\mathrm{P}-\mathrm{A}$ a la dosis de $24 \mathrm{t} / \mathrm{ha}, \mathrm{y} \mathrm{A}+\mathrm{H}$ a cualquiera de las dos dosis estudiadasy de $\mathrm{K}$, destacando el elevado (máximo) valor alcanzado en $\mathrm{K}$ con A y $\mathrm{A}+\mathrm{H}$ a $24 \mathrm{t} / \mathrm{ha}$ junto con el programa estándar de fertilización F1. La determinación de Ca y Mg reveló que la aplicación de $\mathrm{A}+\mathrm{H}$ proporcionó, en general, niveles de estos elementos inferiores a los controles. Con respecto a $\mathrm{Na}$, y a excepción de los tratamientos con $\mathrm{A}$ en combinación con el programa de fertilización reducida (F2), los restantes tratamientos difirieron de los controles, mostrando aquéllos concentraciones inferiores.

\section{Judía}

Conforme a lo expuesto en la Figura 4.3.24 y la Tabla 4.3.25, que corresponde al estado nutricional de este cultivo en el segundo año (efecto residual), hay que señalar que el compost A proporcionó un nivel de $\mathrm{Mg}$ superior a $\mathrm{A}+\mathrm{H}$, mientras que este último resultó en una concentración de Ca comparativamente superior. En cuanto a la dosis de compost aplicada, la equivalente a 12 t/ha se tradujo en un contenido en $\mathrm{Ca}$, Mg y $\mathrm{Na}$ más elevado que la de 24 t/ha, encontrándose en $\mathrm{K}$ el efecto contrario. La aplicación del plan de fertilización estándar F1 aumentó la concentración de K, pero se tradujo en un contenido de Mg más bajo en comparación con el plan de abonado reducido F2. Se encontraron gran número de interacciones estadísticamente significativas (a excepción de N y P). 


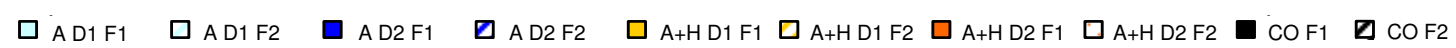
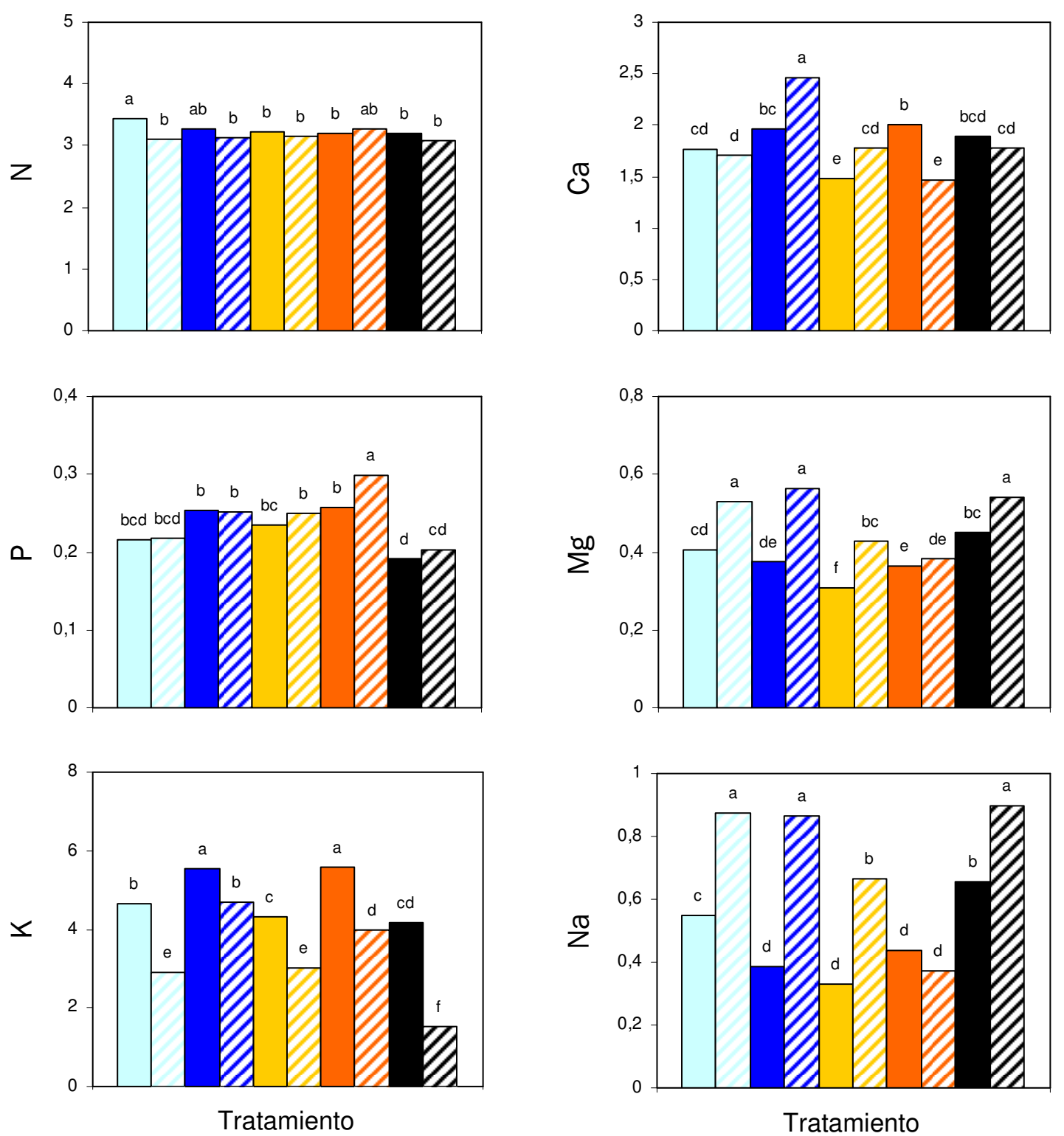

Figura 4.3.23. Influencia del compost (A y A+H), la dosis de aplicación de éste (D1 y D2, equivalentes a 12 y 24 t de materia orgánica total/ha, respectivamente) y el programa de fertilización mineral (estándar, F1 y reducida, F2) en el contenido foliar de nutrientes (expresado en \% de materia seca) en lechuga. Comparación con los controles (CO, que no recibieron compost). Año 2

A: compost de alperujo; $\mathrm{A}+\mathrm{H}$ : compost de alperujo más hidrolizado

Barras sin letra común difieren estadísticamente a $P \leq 0,05$ (test de Student-Newman-Keuls) 
Tabla 4.3.24. Análisis factorial de la varianza $(P)$ para los efectos de los tratamientos estudiados -Compost (alperujo vs. alperujo más hidrolizado), Dosis de aplicación de éste (12 vs. 24 t de materia orgánica total/ha) y Programa de fertilización mineral (estándar vs. reducida)- sobre el contenido foliar de nutrientes en lechuga. Año 2

\begin{tabular}{|c|c|c|c|c|c|c|}
\hline Fuente de variación & $\mathrm{N}$ & $P$ & $\mathrm{~K}$ & $\mathrm{Ca}$ & $\mathrm{Mg}$ & $\mathrm{Na}$ \\
\hline 1. Compost & ns & $\star \star$ & $* *$ & $* * *$ & $* * *$ & $* * *$ \\
\hline 2. Dosis de compost & ns & $* * *$ & $* \star *$ & $\star * *$ & ns & $\star \star *$ \\
\hline 3. Fertilización mineral & $\star \star$ & ns & $* * *$ & ns & $\star \star \star$ & $\star * *$ \\
\hline \multicolumn{7}{|l|}{ 4. Interacción } \\
\hline $1 \times 2$ & ns & ns & ns & $\star * *$ & ns & ns \\
\hline $1 \times 3$ & $* *$ & ns & ns & $\star * *$ & $* * *$ & $* * *$ \\
\hline $2 \times 3$ & * & ns & * & ns & ns & $* *$ \\
\hline $1 \times 2 \times 3$ & ns & ns & $* * *$ & $\star * *$ & $\star * *$ & $* * *$ \\
\hline
\end{tabular}

El estudio conjunto de los tratamientos que recibieron compost y los controles (sin aplicación de materia orgánica) puso de manifiesto que los diferentes tratamientos no difirieron entre sí en lo que se refiere al contenido en N y P. A partir de los resultados obtenidos se puede concluir que la aplicación de $\mathrm{A}$ y $\mathrm{A}+\mathrm{H}$ junto con el programa de fertilización estándar F1 (y en el caso de A únicamente cuando se utilizó a la dosis de 24 t/ha) incrementó comparativamente el nivel de K. En relación con Ca, merece destacarse que la mayoría de los tratamientos con compost mostraron niveles inferiores a los controles, mientras que en Mg esta situación sólo se presentó cuando los composts se aplicaron en combinación con el plan de fertilización reducido F2. Por último, el nivel de $\mathrm{Na}$ fue inferior al control cuando $\mathrm{A}$ y $\mathrm{A}+\mathrm{H}$ se aplicaron a $24 \mathrm{t} / \mathrm{ha}$ junto con el plan de fertilización reducida F2. 


\section{$\square$ AD1F1 $\square$ AD1F2 $\square$ AD2F1 $\square$ AD2F2 $\square$ A+HD1F1 $\square$ A+HD1F2 $\square$ A+HD2F1 $\square$ A+HD2 2 COF1 $\square$ COF2}
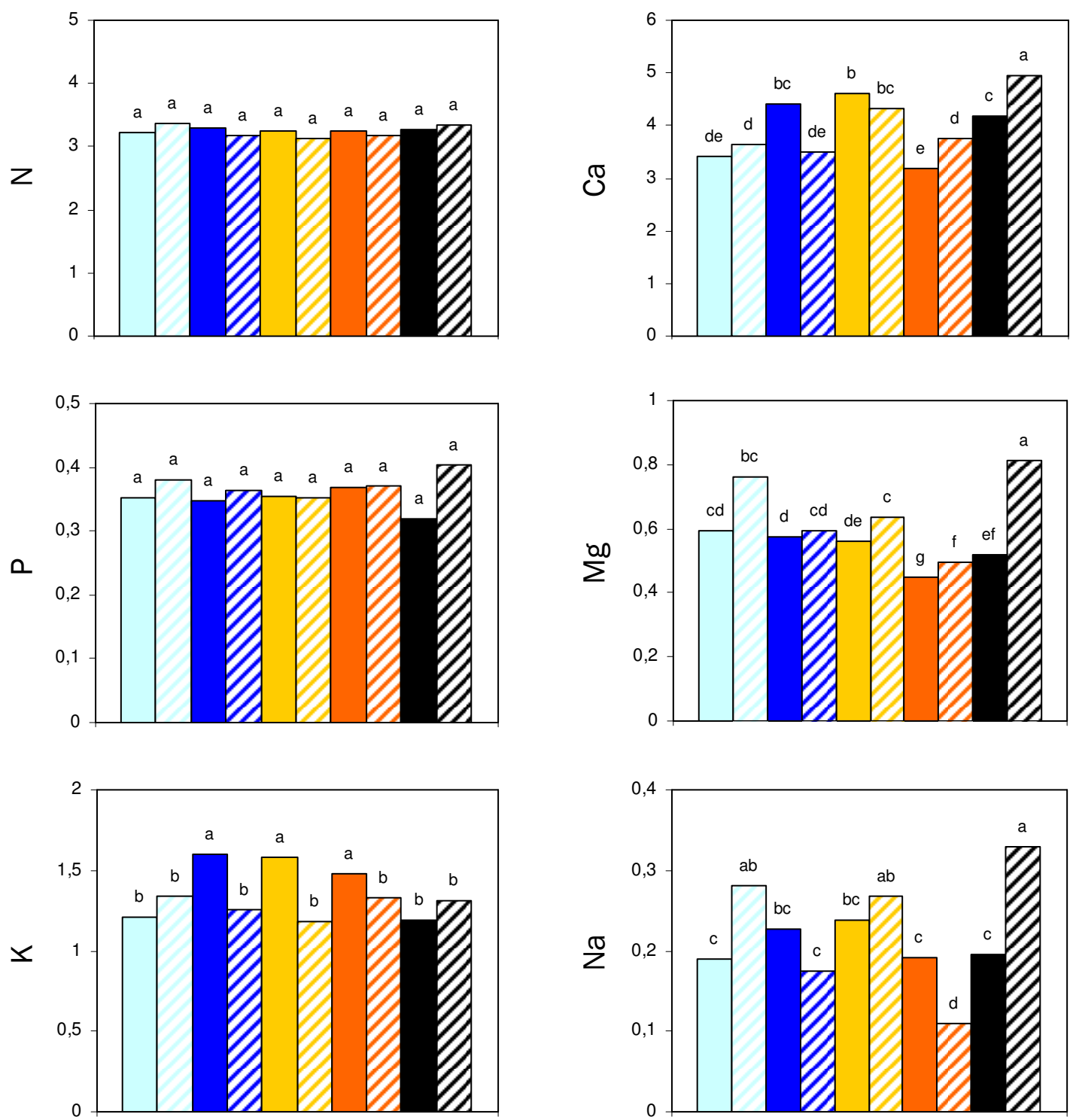

Tratamiento

Tratamiento

Figura 4.3.24. Influencia del compost $(\mathrm{A}$ y $\mathrm{A}+\mathrm{H})$, la dosis de aplicación de éste (D1 y D2, equivalentes a 12 y 24 t de materia orgánica total/ha, respectivamente) y el programa de fertilización mineral (estándar, F1 y reducida, F2) en el contenido foliar de nutrientes (expresado en \% de materia seca) en judía. Comparación con los controles (CO, que no recibieron compost). Año 2

A: compost de alperujo; $\mathrm{A}+\mathrm{H}$ : compost de alperujo más hidrolizado

Barras sin letra común difieren estadísticamente a $P \leq 0,05$ (test de Student-Newman-Keuls) 
Tabla 4.3.25. Análisis factorial de la varianza $(P)$ para los efectos de los tratamientos estudiados -Compost (alperujo vs. alperujo+hidrolizado), Dosis de aplicación de éste (12 vs. 24 t de materia orgánica total/ha, respectivamente) y Programa de fertilización mineral (estándar vs. reducida)- sobre el contenido foliar de nutrientes en judía. Año 2

\begin{tabular}{|c|c|c|c|c|c|c|}
\hline Fuente de variación & $\mathbf{N}$ & $P$ & $\mathrm{~K}$ & $\mathrm{Ca}$ & $\mathrm{Mg}$ & $\mathrm{Na}$ \\
\hline 1. Compost & ns & ns & ns & $\star \star * *$ & $\star \star \star *$ & ns \\
\hline 2. Dosis de compost & ns & ns & $* *$ & $* * *$ & $* * *$ & $* * *$ \\
\hline 3. Fertilización mineral & ns & ns & $* * *$ & ns & $* * *$ & ns \\
\hline \multicolumn{7}{|l|}{ 4. Interacción } \\
\hline $1 \times 2$ & ns & ns & * & $* * *$ & ns & ** \\
\hline $1 \times 3$ & ns & ns & $* *$ & $* * *$ & ns & ns \\
\hline $2 \times 3$ & ns & ns & ns & ns & $* * *$ & $* * *$ \\
\hline $1 \times 2 \times 3$ & ns & ns & $* * *$ & $* * *$ & $* *$ & ns \\
\hline
\end{tabular}

De acuerdo con los resultados hasta aquí presentados, la aplicación de compost no provocó variaciones significativas en el contenido foliar de $\mathrm{N}$ en ninguno de los cultivos ni en los períodos estudiados (Años 1 y 2). Esto podría deberse a una lenta mineralización del nitrógeno orgánico de los composts aplicados (considerando, además, el proceso de inmovilización inmediato tras la aplicación de $\mathrm{A}+\mathrm{H}$ ) (ver sección 4.2.2.1). En este contexto, Alburquerque et al. (2007) y Cabrera et al. (2005b) han señalado la alta resistencia a la mineralización de diferentes residuos de almazara compostados tras ser aplicados a suelos calizos, haciendo además hincapié en la naturaleza lignocelulósica de dichos composts y la presencia de nitrógeno en éstos fundamentalmente en forma orgánica.

En relación con los niveles de $\mathrm{P}$, la aplicación de compost aumentó el contenido de este elemento en lechuga en los dos ciclos de cultivo estudiados, y en judía en el primer año (cuando se combinó con el plan de fertilización reducida). El efecto positivo del compost sobre el contenido de P en lechuga está relacionado probablemente con el aumento en la asimilabilidad de este nutriente en el suelo calizo estudiado. Esta mayor disponibilidad vendría facilitada por diferentes procesos como: la formación de complejos fosfo-húmicos; el recubrimiento de los coloides inorgánicos del suelo, evitándose así la adsorción de fosfato; o, la formación de quelatos de Ca a partir de fosfatos de calcio insolubles, lo que aumentaría las formas de fósforo solubles en el suelo, entre otros (Alburquerque et al., 2007; Stevenson, 1994).

Asimismo, se registró un incremento en los niveles de $K$ cuando se cultivó rábano en los tratamientos con compost A el Año 1 y el Año 2 (efecto directo y 
residual), lechuga sobre las mezclas de suelo con $\mathrm{A}$ y $\mathrm{A}+\mathrm{H}$ en los dos ciclos de cultivo, y judía en el segundo año en los tratamientos con compost (juntamente con el plan de fertilización estándar). El efecto positivo de los dos composts de alperujo estudiados sobre el contenido en potasio en las tres especies cultivadas coincide con lo señalado por Alburquerque et al. (2007), Cegarra et al. (1996) y Walker y Bernal (2008) para diferentes tipos de residuos del sector oleícola en cultivos distintos a los aquí presentados, poniendo de manifiesto la elevada eficacia de estos materiales orgánicos para suministrar potasio a las plantas.

En cuanto a los niveles foliares de $\mathrm{Ca}$ y $\mathrm{Mg}$, se observó, en general, una disminución en la mayoría de los cultivos estudiados, tanto por efecto inmediato (a corto plazo, directo) como por efecto residual tras la aplicación de compost. Esta situación podría atribuirse bien a un efecto antagonista con el potasio (antagonismo iónico) o bien al efecto quelante de la materia orgánica del compost sobre estos dos elementos, formándose quelatos poco solubles y por tanto no disponibles (Alburquerque et al., 2007; Nogales et al., 1984).

Según los intervalos óptimos de los niveles de los nutrientes en hoja establecidos por Maynard y Hochmuth (2007), únicamente se detectaron deficiencias de nutrientes en el cultivo de rábano del primer año, particularmente en $\mathrm{N}$ y $\mathrm{P}$, con independencia del tratamiento, lo que pudo estar relacionado con la baja fertilidad inicial del suelo, procedente de una antigua explotación no cultivada durante varios años.

4.3.3. Influencia de los composts en combinación con la fertilización mineral y los cultivos en la fertilidad del suelo. Efecto directo y residual

\subsubsection{Efecto directo sobre las características físico-químicas y químicas}

Una vez finalizado el primer año (Año 1) de evaluación agronómica con los tres cultivos hortícolas estudiados, se muestreó el suelo de los contenedores con objeto de evaluar el efecto directo de la aplicación de $\mathrm{A}$ y $\mathrm{A}+\mathrm{H}$-en combinación con el programa de fertilización mineral aplicado y los cultivos implantados- sobre la fertilidad del suelo. 
Respecto a la influencia de los tratamientos experimentales estudiados en las características físico-químicas del suelo (Figura 4.3.25 y Tabla 4.3.26), los factores Compost y Dosis de compost no tuvieron efecto significativo sobre el $\mathrm{pH}$, mientras que el plan de abonado estándar (F1) incrementó ligera, pero significativamente, el valor de dicho parámetro. Por otro lado, la aplicación de compost a 12 t/ha aumentó la conductividad eléctrica (CE) del suelo respecto a la dosis de 24 t/ha, al igual que ocurrió con el programa de abonado reducido (F2) en comparación con el estándar (F1), debido probablemente a la acumulación de elementos minerales en el suelo derivada del menor crecimiento de las plantas cultivadas durante el primer año. La interacción Compost x Fertilización mineral fue altamente significativa para este parámetro y la interacción ternaria presentó, además, niveles de significación estadística del 1\% no sólo para la CE, sino también para el pH del suelo.

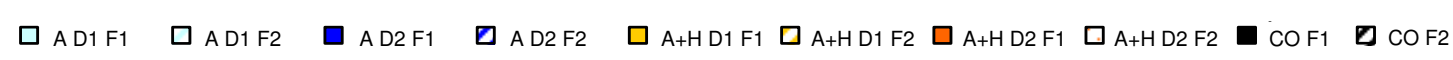

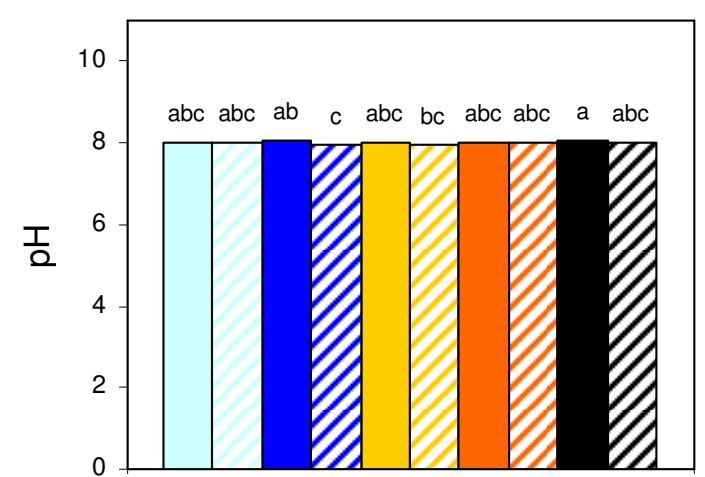

Tratamiento

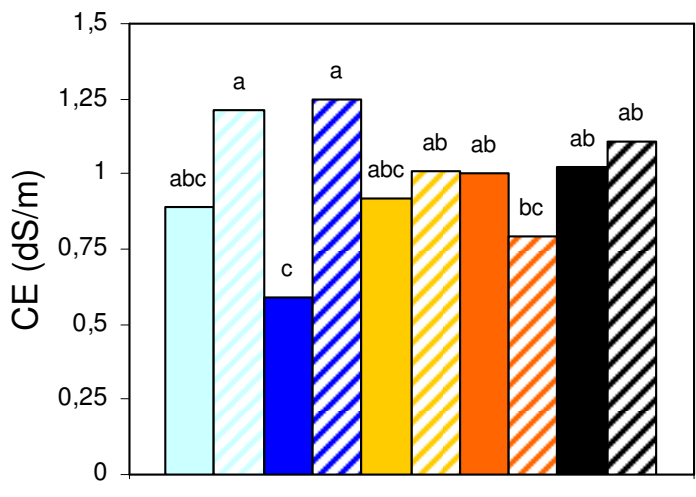

Tratamiento

Figura 4.3.25. Influencia del compost $(\mathrm{A}$ y $\mathrm{A}+\mathrm{H})$, la dosis de aplicación de éste (D1 y D2, equivalentes a 12 y $24 \mathrm{t}$ de materia orgánica total/ha, respectivamente) y el programa de fertilización mineral (estándar, F1 y reducida, F2) en el pH y la conductividad eléctrica (CE) del suelo al final del primer año del experimento (Año 1). Comparación con los controles (CO, que no recibieron compost)

A: compost de alperujo; $\mathrm{A}+\mathrm{H}$ : compost de alperujo más hidrolizado

Barras sin letra común difieren estadísticamente a $P \leq 0,05$ (test de Student-Newman-Keuls) 
Tabla 4.3.26. Análisis factorial de la varianza $(P)$ para los efectos de los tratamientos estudiados -Compost (alperujo vs. alperujo más hidrolizado), Dosis de aplicación de éste (12 vs. 24 t de materia orgánica total/ha) y Programa de fertilización mineral (estándar vs. reducida)- sobre el pH y la conductividad eléctrica (CE) del suelo al final del primer año del experimento (Año 1)

\begin{tabular}{lcc}
\hline \multicolumn{1}{c}{ Fuente de variación } & $\mathrm{pH}$ & $\mathrm{CE}$ \\
\hline 1. Compost & $\mathrm{ns}$ & $\mathrm{ns}$ \\
2. Dosis de compost & $\mathrm{ns}$ & $*$ \\
3. Fertilización mineral & $* * *$ & $* * *$ \\
4. Interacción & & \\
$1 \times 2$ & $\mathrm{~ns}$ & $\mathrm{~ns}$ \\
$1 \times 3$ & $\mathrm{~ns}$ & $* * *$ \\
$2 \times 3$ & $\mathrm{~ns}$ & $\mathrm{~ns}$ \\
$1 \times 2 \times 3$ & $* *$ & $* *$ \\
\hline P: nivel de significación. $\mathrm{ns},{ }^{*}, * * \mathrm{y} * * *$ indican diferencias no significativas o estadísticamente significativas a $P \leq 0,05, P \leq 0,01 \mathrm{y}$
\end{tabular}

En lo referente a la composición química del suelo (Figura 4.3.26 y Tabla 4.3.27), el análisis factorial de la varianza realizado puso de manifiesto contenidos en carbono orgánico (Corg), Ca y Mg superiores, y concentraciones de $\mathrm{P}$ y $\mathrm{K}$ inferiores, con el compost $\mathrm{A}$ respecto a $\mathrm{A}+\mathrm{H}$. Estos efectos de los composts estuvieron estrechamente relacionados con la composición de los mismos (ver la sección 4.1), coincidiendo, por tanto, la mayor concentración de cada uno de los elementos minerales en $\mathrm{A}$ o en $\mathrm{A}+\mathrm{H}$ con el nivel superior de éstos en los suelos a los que se aplicaron dichos composts. Los resultados del factor Dosis de compost mostraron que la dosis equivalente a 12 t/ha aumentó la concentración de Ca y Mg, mientras que la máxima (24 t/ha) elevó los niveles de Corg, $\mathrm{N}$ total y $\mathrm{K}$. En relación con el programa de fertilización mineral estudiado, el plan reducido (F2) incrementó los niveles de $\mathrm{N}$ mineral $\left(\mathrm{N}-\mathrm{NO}_{3}{ }^{-}+\mathrm{N}^{-} \mathrm{NH}_{4}{ }^{+}\right)$, P, Ca y Mg en comparación con el plan estándar (F1), registrándose el efecto opuesto, es decir disminución, sobre el contenido en $\mathrm{K}$. La mayor cantidad de $\mathrm{N}$ mineral y $\mathrm{P}$ encontrada en los suelos tratados con el programa de fertilización mineral reducida podría deberse a que el desarrollo y la producción de los tres cultivos establecidos fue comparativamente inferior, en general, con este plan de abonado, lo que podría haber provocado un menor agotamiento de la reserva de estos dos nutrientes en el suelo. Por otra parte, en los tres factores estudiados (Compost, Dosis de aplicación de éste, y Fertilización mineral) se observó que el mayor nivel de $\mathrm{K}$ coincidió con la menor 
concentración de $\mathrm{Ca}$ y Mg. Este efecto está vinculado probablemente con el alto suministro de $\mathrm{K}$ aportado por los composts de alperujo aplicados, pudiendo entonces los iones $\mathrm{K}^{+}$reemplazar a los iones $\mathrm{Ca}^{2+}$ y $\mathrm{Mg}^{2+}$ retenidos como bases de cambio (cambiables), facilitando así su lixiviación por efecto de la lluvia y los riegos (Bolan et al., 2005).

En cuanto al estudio comparativo de los tratamientos con compost y los controles sin enmendar, debe señalarse que la aplicación de A aumentó el contenido en Corg, particularmente cuando se añadió a la dosis de 24 t/ha, y que ambos composts elevaron la concentración de $\mathrm{N}$ total al aportarse a la dosis máxima. $\mathrm{A}+\mathrm{H}$ aumentó el nivel de $\mathrm{P}$ en comparación con los controles, mientras que A manifestó dicho efecto sólo cuando se aplicó con el programa de fertilización reducida. Dado que el programa de abono reducido (F2) no aportó potasio, existió una diferencia notable en $\mathrm{K}$ asimilable entre los dos suelos control, de más de $100 \mathrm{mg} / \mathrm{kg}$. Una diferencia similar se encontró entre los programas de fertilización estándar (F1) y reducida (F2) en los tratamientos donde se incorporó compost. La aplicación de compost aumentó considerablemente los niveles de fertilidad potásica del suelo, especialmente A+H y la dosis de 24 t/ha para ambos materiales. La mayoría de los tratamientos con compost mostró niveles de Mg similares a los controles, mientras que en el caso de Ca las únicas diferencias significativas respecto a dichos controles se observaron en los tratamientos con el menor contenido en $\mathrm{K}(\mathrm{A}$ y $\mathrm{A}+\mathrm{H}$ a $12 \mathrm{t} / \mathrm{ha}$ en combinación con el plan de abonado reducido F2) y en los que se registró el máximo nivel de este último elemento ( $\mathrm{A}+\mathrm{H}$ a $24 \mathrm{t} / \mathrm{ha}$ ), demostrándose así la estrecha relación existente entre $\mathrm{K}$ y Ca en el suelo (Bolan et al., 2005). Por último, los tratamientos con el programa de fertilización reducida presentaron un contenido en Na más alto que los controles, a excepción de $\mathrm{A}+\mathrm{H}$ a $24 \mathrm{t} / \mathrm{ha}$, con valores significativamente inferiores a los suelos sin enmendar. 

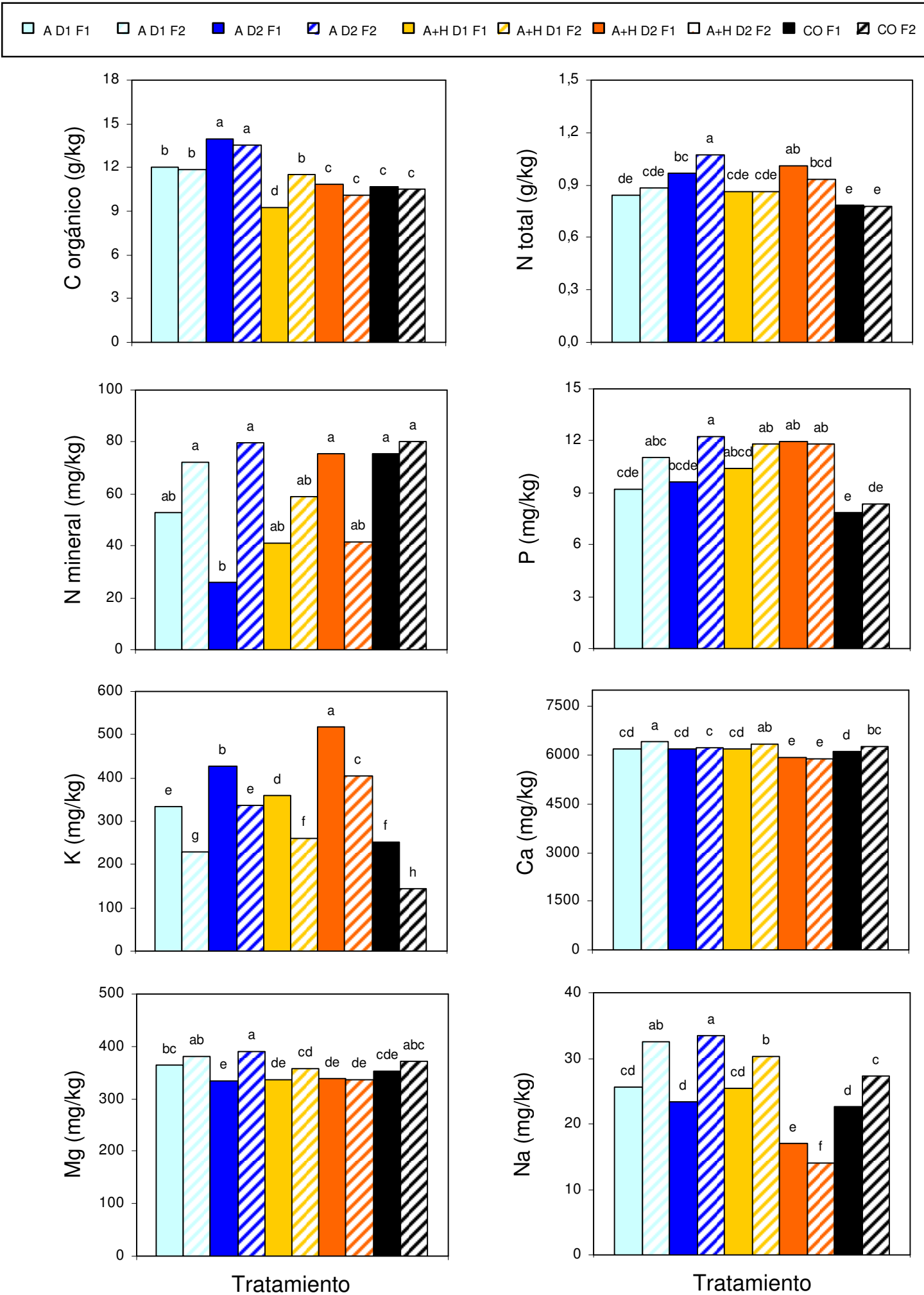

Figura 4.3.26. Influencia del compost $(A$ y $A+H)$, la dosis de aplicación de éste (D1 y D2, equivalentes a 12 y 24 t de materia orgánica total/ha, respectivamente) y el programa de fertilización mineral (estándar, F1 y reducida, F2) en la composición química del suelo al final del primer año del experimento (Año 1). Comparación con los controles (CO, que no recibieron compost)

A: compost de alperujo; $\mathrm{A}+\mathrm{H}$ : compost de alperujo más hidrolizado

Barras sin letra común difieren estadísticamente a $P \leq 0,05$ (test de Student-Newman-Keuls) 
Tabla 4.3.27. Análisis factorial de la varianza $(P)$ para los efectos de los tratamientos estudiados -Compost (alperujo vs. alperujo más hidrolizado), Dosis de aplicación de éste (12 vs. 24 t de materia orgánica total/ha) y Programa de fertilización mineral (estándar vs. reducida) - sobre la composición química del suelo al final del primer año del experimento (Año 1)

\begin{tabular}{|c|c|c|c|c|c|c|c|c|}
\hline Fuente de variación & Corg & $\mathrm{N}$ total & $\begin{array}{c}\mathrm{N} \\
\text { mineral }\end{array}$ & $P$ & $\mathrm{~K}$ & $\mathrm{Ca}$ & $\mathrm{Mg}$ & $\mathrm{Na}$ \\
\hline 1. Compost & $* * *$ & ns & ns & * & $* * \star$ & $* * *$ & $\star * *$ & ns \\
\hline 2. Dosis de compost & $* * *$ & $* * *$ & ns & ns & $* * *$ & $* * *$ & $* *$ & $* * *$ \\
\hline 3. Fertilización mineral & ns & ns & * & $* * *$ & $* * *$ & $* * *$ & $* * *$ & $* * *$ \\
\hline \multicolumn{9}{|l|}{ 4. Interacción } \\
\hline $1 \times 2$ & $* * *$ & ns & ns & ns & $* \star *$ & $* * *$ & ns & $* * *$ \\
\hline $1 \times 3$ & ** & * & ** & * & ns & ** & $* * *$ & $* * *$ \\
\hline $2 \times 3$ & $* * *$ & ns & ns & ns & ns & $* * *$ & ns & $* * *$ \\
\hline $1 \times 2 \times 3$ & $* * *$ & ns & * & ns & ns & ns & $* * *$ & ns \\
\hline
\end{tabular}

\subsubsection{Efecto residual sobre las características y la composición del suelo}

Los análisis de los suelos muestreados tras el cultivo de judía del segundo año (efecto residual) (Figura 4.3.27 y Tabla 4.3.28) mostraron que el compost A elevó ligeramente y con un bajo nivel de significación- el valor de $\mathrm{pH}$ respecto a $\mathrm{A}+\mathrm{H}$, al igual que la dosis equivalente a $12 \mathrm{t} / \mathrm{h}$ a respecto a la de $24 \mathrm{t} / \mathrm{ha}$. De modo similar, el programa de fertilización reducida (F2) aumentó el pH en comparación con el plan de abonado estándar (F1). Con relación a la salinidad del suelo, la dosis máxima de compost (24 t/ha) y el programa de fertilización estándar (F1) aumentaron la CE en comparación con la dosis de 12 t/ha y el programa de fertilización reducida (F2), respectivamente. No obstante, el análisis de la varianza realizado para comparar los tratamientos que recibieron compost con los controles sin enmendar reveló que ninguno de los dos parámetros físico-químicos estudiados presentaron, en general, diferencias estadísticamente significativas entre las mezclas de suelo+compost y los controles que recibieron el mismo programa de fertilización mineral. 


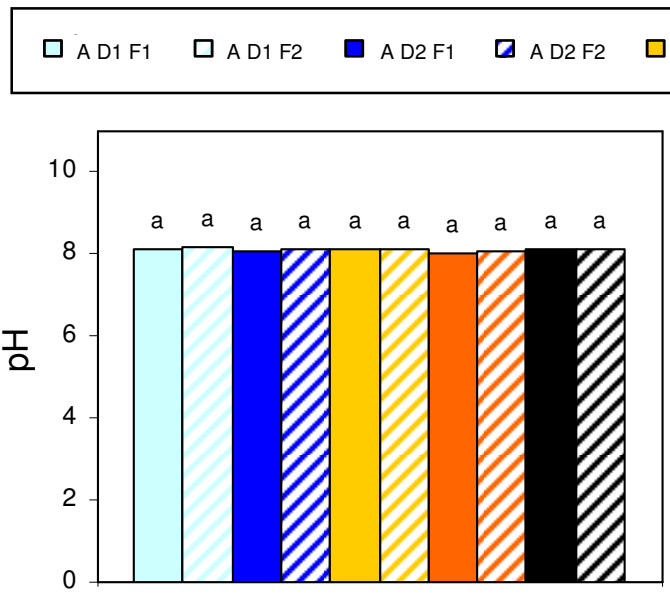

Tratamiento

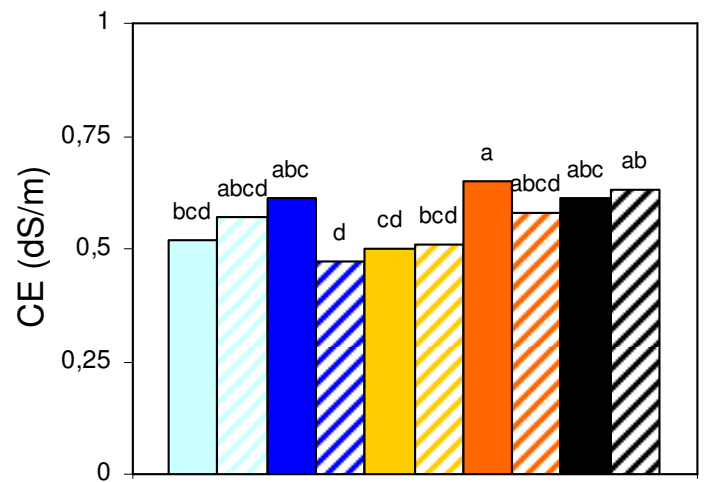

Tratamiento

Figura 4.3.27. Influencia del compost $(A$ y $A+H)$, la dosis de aplicación de éste (D1 y D2, equivalentes a 12 y 24 t de materia orgánica total/ha, respectivamente) y el programa de fertilización mineral (estándar, F1 y reducida, F2) en el pH y la conductividad eléctrica (CE) del suelo al final del segundo año del experimento (Año 2). Comparación con los controles ( $\mathrm{CO}$, que no recibieron compost)

$\mathrm{A}$ : compost de alperujo; $\mathrm{A}+\mathrm{H}$ : compost de alperujo más hidrolizado

Barras sin letra común difieren estadísticamente a $P \leq 0,05$ (test de Student-Newman-Keuls)

Tabla 4.3.28. Análisis factorial de la varianza $(P)$ para los efectos de los tratamientos estudiados -Compost (alperujo vs. alperujo más hidrolizado), Dosis de aplicación de éste (12 vs. 24 t de materia orgánica total/ha) y Programa de fertilización mineral (estándar vs. reducida)- sobre el pH y la conductividad eléctrica (CE) del suelo al final del segundo año del experimento (Año 2)

\begin{tabular}{lcc}
\hline \multicolumn{1}{c}{ Fuente de variación } & $\mathrm{pH}$ & $\mathrm{CE}$ \\
\hline 1. Compost & $*$ & $\mathrm{~ns}$ \\
2. Dosis de compost & $*$ & $* *$ \\
3. Fertilización mineral & $*$ & \\
4. Interacción & & $* *$ \\
$1 \times 2$ & $\mathrm{~ns}$ & $\mathrm{~ns}$ \\
$1 \times 3$ & $\mathrm{~ns}$ & $* * *$ \\
$2 \times 3$ & $\mathrm{~ns}$ & $\mathrm{~ns}$
\end{tabular}

$\overline{P: \text { nivel de significación. } \mathrm{ns}, ~ *, * *} \mathrm{y} * * *$ indican diferencias no significativas o estadísticamente significativas a $P \leq 0,05, P \leq 0,01$ y $P \leq 0,001$, respectivamente 
De acuerdo con la Figura 4.3.28 y la Tabla 4.3.29, que presentan los resultados de los análisis estadísticos relativos a la composición química del suelo al final del segundo año (Año 2) del experimento, el compost A incrementó los niveles de Corg, N total y $\mathrm{Mg}$ en comparación con $\mathrm{A}+\mathrm{H}$, mientras que este último elevó comparativamente el nivel de Ca. En cuanto al factor Dosis de compost, la dosis de 24 t/ha aumentó la magnitud de todos los elementos objeto de estudio, a excepción de $\mathrm{Na}$ cuyo nivel fue superior con la dosis de 12 t/ha. El programa de fertilización aplicado no afectó de manera significativa a la mayoría de los elementos estudiados; en contraste con lo anterior, el plan de abonado estándar incrementó el nivel de K, mientras que el programa reducido aumentó el de Mg y Na. Por último, y en relación con las interacciones estudiadas, hay que señalar que todas las interacciones binarias, así como la ternaria, fueron significativas en $\mathrm{K}$, Ca y Mg.

El estudio comparativo de los tratamientos con compost y los suelos control mostró que la aplicación de compost se tradujo en un aumento en el nivel de Corg del suelo, especialmente cuando el compost se aplicó a la dosis de 24 t/ha. Asimismo, la dosis de 24 t/ha incrementó la concentración de $\mathrm{N}$ total respecto a los controles. Los tratamientos que recibieron compost mostraron una concentración de $\mathrm{K}$ más alta que los controles (a excepción del tratamiento $\mathrm{A}+\mathrm{H}$ a 12 t/ha con fertilización mineral reducida), alcanzándose el incremento de mayor magnitud con $\mathrm{A}+\mathrm{H}$ a la dosis de 24 t/ha juntamente con el plan de abonado estándar (F1). En Ca, Mg y $\mathrm{Na}$ no se observaron tendencias de variación definidas, a pesar de que los distintos tratamientos difirieron significativamente entre sí.

A modo de valoración global de la influencia de los composts de alperujo junto con la fertilización mineral y los cultivos en el suelo estudiado (efecto directo y residual), merece destacarse que no se encontraron diferencias en los valores de $\mathrm{pH}$ ni de conductividad eléctrica entre los tratamientos con compost y los controles sin enmendar en ninguno de los dos años del estudio, registrándose únicamente un descenso en la conductividad eléctrica entre los dos años considerados. 


\section{$\square$ AD1F1 $\square$ AD1F2 $\square$ AD2F1 $\square$ AD2 F2 $\square$ A+HD1F1 $\square$ A+HD1F2 $\square$ A+HD2F1 $\square$ A+HD2 F2 $\square$ COF1 $\square$ COF2}
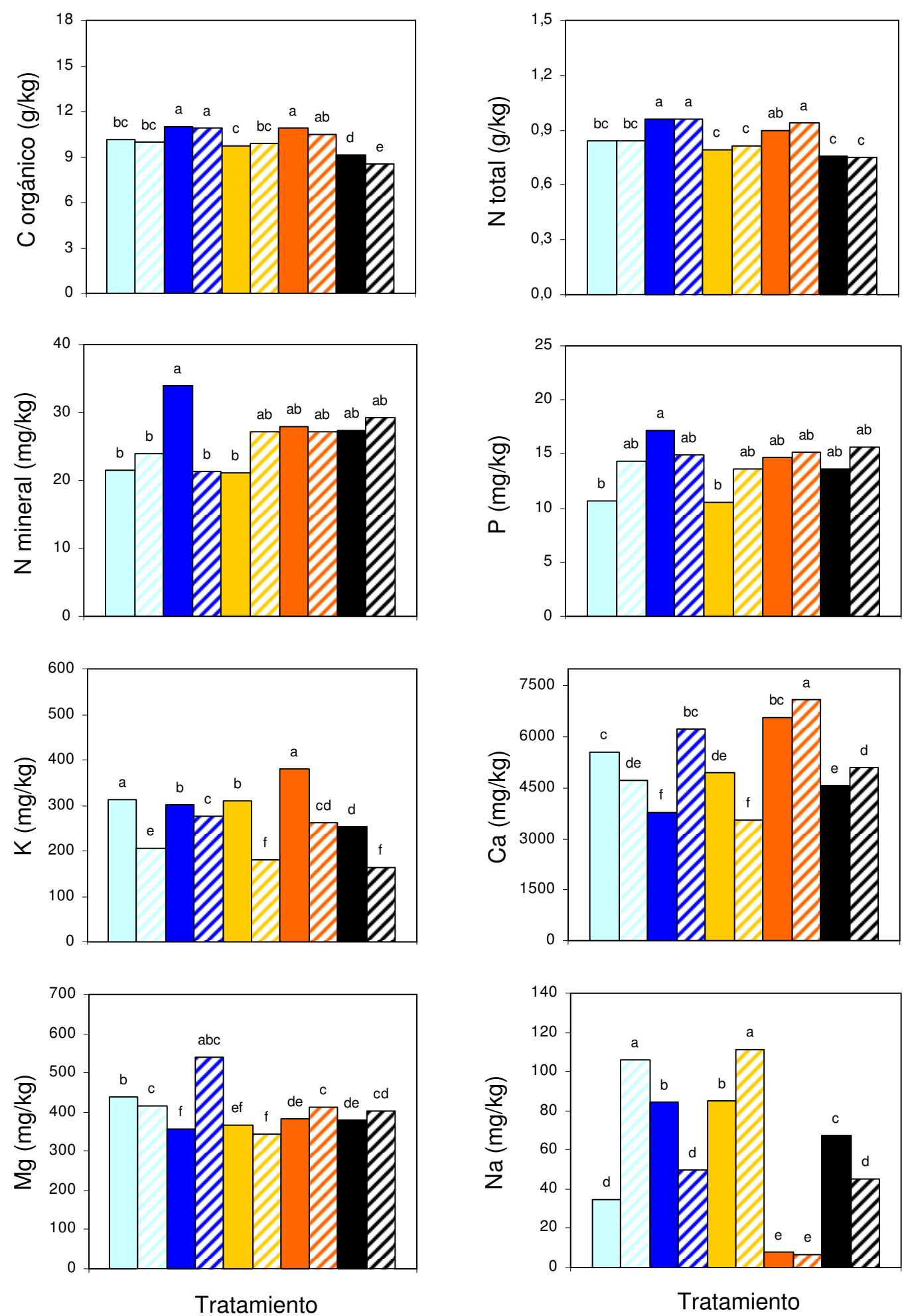

Figura 4.3.28. Influencia del compost $(\mathrm{A}$ y $\mathrm{A}+\mathrm{H})$, la dosis de aplicación de éste (D1 y $\mathrm{D} 2$, equivalentes a 12 y $24 \mathrm{t}$ de materia orgánica total/ha, respectivamente) y el programa de fertilización mineral (estándar, F1 y reducida, F2) en la composición química del suelo al final del segundo año del experimento (Año 2). Comparación con los controles ( $\mathrm{CO}$, que no recibieron compost)

A: compost de alperujo; $\mathrm{A}+\mathrm{H}$ : compost de alperujo más hidrolizado

Barras sin letra común difieren estadísticamente a $P \leq 0,05$ (test de Student-Newman-Keuls) 
Tabla 4.3.29. Análisis factorial de la varianza $(P)$ para los efectos de los tratamientos estudiados -Compost (alperujo vs. alperujo más hidrolizado), Dosis de aplicación de éste (12 vs. 24 t de materia orgánica total/ha) y Programa de fertilización mineral (estándar vs. reducida)- sobre la composición química del suelo al final del segundo año del experimento (Año 2)

\begin{tabular}{|c|c|c|c|c|c|c|c|c|}
\hline Fuente de variación & Corg & $\mathrm{N}$ total & $\begin{array}{c}\mathrm{N} \\
\text { mineral }\end{array}$ & $P$ & $\bar{K}$ & $\mathrm{Ca}$ & Mg & $\mathrm{Na}$ \\
\hline 1. Compost & * & * & ns & ns & ns & $\star * \star$ & $\star * \star$ & $\star \star *$ \\
\hline 2. Dosis de compost & $\star \star \star$ & $\star \star *$ & $\star * *$ & $* \star *$ & $\star \star *$ & $\star * *$ & $\star \star$ & $\star * *$ \\
\hline 3. Fertilización mineral & ns & ns & ns & ns & $\star * *$ & ns & $\star * *$ & $\star \star *$ \\
\hline \multicolumn{9}{|l|}{ 4. Interacción } \\
\hline $1 \times 2$ & ns & ns & ns & ns & $* * *$ & $\star * *$ & * & $\star * *$ \\
\hline $1 \times 3$ & ns & ns & ** & ns & $* * *$ & $\star * *$ & $* \star *$ & ns \\
\hline $2 \times 3$ & ns & ns & $* * *$ & ** & $* * *$ & $\star * *$ & $\star * \star$ & $\star * *$ \\
\hline $1 \times 2 \times 3$ & ns & ns & ns & ns & $* * *$ & ** & $* * *$ & $\star * *$ \\
\hline
\end{tabular}

Corg: carbono orgánico

$P$ : nivel de significación. ns, * $* *$ y *** indican diferencias no significativas o estadísticamente significativas a $P \leq 0,05, P \leq 0,01$ y $P \leq 0,001$, respectivamente

Asimismo, se observó que la aplicación de los composts A y A+H elevó notablemente el nivel de $\mathrm{K}$ asimilable del suelo, particularmente tras el primer año del experimento, destacando la aplicación a la dosis de 24 t/ha en combinación con el programa de fertilización estándar (F1). Al evaluar el efecto residual, se apreció que el efecto descrito sobre la fertilidad potásica se mantuvo en la mayoría de los tratamientos, aunque la magnitud de dicho efecto fue comparativamente menor. Según datos de Villalbí y Vidal (1988), el suelo calizo original tenía un contenido “normal” en potasio, pasando a "alto" (240-307 mg/kg) o "muy alto" (>307 mg/kg) en la mayoría de las mezclas suelo+compost.

Del mismo modo, la aplicación del compost A aumentó los niveles de Corg del suelo el primer año del estudio, especialmente a la dosis de $24 \mathrm{t} / \mathrm{ha}$. Tras el segundo año, ambos composts incrementaron el contenido en Corg, destacando igualmente la dosis de 24 t/ha, aunque en menor cuantía que el compost A en el Año 1 (efecto directo). Sin embargo, y según los niveles de referencia señalados por Villalbí y Vidal (1988) para el contenido en materia orgánica del suelo (valor obtenido multiplicando el contenido en Corg por el factor 1,72), los valores de este parámetro continuaron siendo bajos, a pesar del incremento experimentado en el mismo tras la aplicación de los dos composts de alperujo.

En lo que respecta a nitrógeno total, las mezclas de suelo y compost a la dosis de $24 \mathrm{t} /$ ha se tradujeron en un aumento en los niveles de este elemento, tanto por 
efecto directo como residual, difiriendo de los controles en una cuantía similar durante los dos años de cultivo. Sin embargo, el incremento en nitrógeno total encontrado no fue de gran magnitud, ya que la concentración final, tras el segundo año, de dicho elemento en los tratamientos con y sin aplicación de compost se encontraron dentro del rango clasificado como "bajo" (entre 0,6 y 1,0 g N total/kg) (Fuentes-Yagüe, 1999).

El efecto directo (Año 1) del compost sobre el contenido en $P$ asimilable del suelo, que aumentó con la aplicación de A y A+H en comparación con los controles sin enmendar (especialmente con $\mathrm{A}+\mathrm{H}$ ), desapareció cuando se estudió el efecto residual (Año 2). Respecto a los niveles estándar o de referencia, todos los tratamientos se mantuvieron durante los dos años del experimento dentro del intervalo considerado como "bajo" (entre 5 y 15 mg P/kg), según indican Villalbí y Vidal (1988) y FuentesYagüe (1999).

A modo de recapitulación, puede señalarse que se encontraron diferencias notables entre los dos composts estudiados en el primer cultivo establecido tras la aplicación de dichos composts al suelo (rábano, Año 1), con valores constante y significativamente mayores para el compost $A$; estas diferencias desaparecieron en los siguientes dos cultivos de la rotación, lechuga y judía (en el Año 1). La dosis de aplicación de 24 t/ha y la fertilización estándar (F1) proporcionaron resultados superiores en comparación con la dosis de 12 t/ha y la fertilización reducida (F2), respectivamente. Los efectos descritos disminuyeron con el tiempo, siendo éstos de mayor magnitud en el Año 1 (efecto directo) que en el Año 2 (efecto residual). Adicionalmente, tanto $\mathrm{A}$ como $\mathrm{A}+\mathrm{H}$ incrementaron la fertilidad del suelo -sobre todo la potásica- el Año 1 del estudio en comparación con los controles sin enmendar, especialmente cuando se aplicaron a 24 t/ha junto con la fertilización estándar (F1), manteniéndose este efecto durante el Año 2 aunque en una cuantía comparativamente inferior.

Por último, y en relación con la influencia de los composts en las propiedades del suelo y en la productividad y la calidad de las cosechas, debe indicarse que dichos materiales deberían aplicarse de manera repetida para poder llegar a manifestar efectos más notables, destacando el incremento en el contenido de carbono orgánico. En este contexto, experimentos realizados a largo plazo han demostrado una mineralización lenta y continua del nitrógeno orgánico acumulado, además de un aumento en potasio y fósforo asimilables, así como una mejora global de las 
propiedades físicas y biológicas de los suelos, y un incremento en el rendimiento de los cultivos. 


\subsection{EFECTOS DE LA MATERIA ORGÁNICA SOLUBLE (MOS) EXTRAÍDA DE LOS COMPOSTS A Y A+H SOBRE MEDICAGO SATIVA Y EL SUELO CALIZO}

Durante el proceso de compostaje, parte de la materia orgánica original se mineraliza y la fracción residual se transforma en nuevos materiales orgánicos, que están sujetos a procesos de humificación, produciéndose así las denominadas sustancias húmicas (Campitelli et al., 2006).

Las sustancias húmicas son materiales naturales ubícuos, que se encuentran en suelos, sedimentos y aguas como productos de la transformación química y biológica de restos de plantas y animales (Janoš, 2003), y ejercen una función esencial en la fertilidad global del suelo (Stevenson, 1994). Están constituidas por moléculas heterogéneas y complejas, de distinta masa molecular y grado de solubilidad, y producen diferentes efectos morfológicos, fisiológicos y bioquímicos en las plantas, habiéndose reconocido ampliamente sus efectos beneficiosos sobre el suelo y los cultivos (Eyheraguibel et al., 2008; Varanini y Pinton, 2006).

Para extraer las sustancias húmicas de los materiales orgánicos pueden utilizarse diversos extractantes. Los más utilizados y de mayor poder de extracción son las disoluciones de hidróxidos alcalinos, tales como $\mathrm{NaOH}$ y $\mathrm{KOH}$ (Varanini y Pinton, 2006), aunque también se usan disoluciones de sales neutras, por ejemplo $\mathrm{Na}_{4} \mathrm{P}_{2} \mathrm{O}_{7}, \mathrm{y}$ disolventes orgánicos, como dimetilformamida y dimetilsulfóxido (Gonzálvez, 2005).

De entre las diferentes estrategias a emplear para incrementar la calidad y la fertilidad del suelo, la aplicación de materia orgánica líquida (soluble) es una alternativa de gran interés como fuente de materia orgánica y nutrientes (Kohler et al., 2008), y también por sus efectos favorables sobre el crecimiento de las plantas y/o las propiedades del suelo (Chen y Aviad, 1990). Diferentes experimentos han registrado una influencia positiva de la aplicación de sustancias húmicas en el desarrollo vegetal, manifestándose en un aumento en el crecimiento de raíces y vástagos, y en la germinación de semillas (Piccolo et al., 1993). Generalmente se observa un incremento progresivo en el crecimiento de la planta a medida que aumenta la concentración de sustancias húmicas aplicada, aunque una cantidad elevada de materiales húmicos puede provocar una disminución del desarrollo vegetal (Chen y Aviad, 1990). Ese efecto bioestimulante de las sustancias húmicas a concentraciones relativamente bajas ha sido atribuido por numerosos autores a un 
efecto directo, de naturaleza hormonal, sobre la planta así como a una acción indirecta sobre el metabolismo de los microorganismos del suelo, la dinámica de absorción de los nutrientes y las propiedades o características del propio suelo (Atiyeh et al., 2002; Nardi et al., 2002).

En la presente Tesis se han estudiado los efectos de la materia orgánica soluble (MOS) extraída de los composts $A$ y $A+H$ en medio alcalino ( $K O H 1 M)$, según la metodología descrita en la sección 3.5, aplicada a dosis de 200, 400, 800, 1600, 3200 y $6400 \mathrm{mg}$ de carbono orgánico total (COT)/kg de suelo, sobre las características y la composición del suelo calizo - no cultivado, desnudo- descrito en Materiales y Métodos (sección 3.1.2). En adición, se ha evaluado la influencia de dicha MOS en combinación con dos programas de fertilización mineral (F1 o estándar y F2 o reducida en nitrógeno y sin aporte de potasio, ver la sección 3.5.1) en un cultivo de Medicago sativa y en el suelo donde se estableció esta leguminosa forrajera. En ambos casos, suelo no cultivado y suelo cultivado, la adición de la MOS se fraccionó en 5 aplicaciones, en los siguientes momentos: 7 días antes de la siembra y a los 30, 60,105 y 135 días tras la siembra, respectivamente.

Seguidamente se presentan los resultados obtenidos en los dos experimentos realizados en la evaluación agronómica de las dos MOS estudiadas.

\subsubsection{Efectos de la materia orgánica soluble (MOS) sobre el cultivo de Medicago sativa y su interacción con la fertilización mineral}

Con objeto de valorar la materia orgánica soluble (MOS) extraída de los composts A y $\mathrm{A}+\mathrm{H}$, ésta se utilizó como producto fertilizante líquido en un cultivo de alfalfa (Medicago sativa) en contenedor, según la metodología descrita en la sección 3.5. Se estudiaron un total de 24 tratamientos, resultantes de la combinación factorial de 2 MOS (procedentes de los composts A y A+H) x 6 dosis de aplicación de la MOS (200 $6400 \mathrm{mg}$ COT/kg) x 2 programas de fertilización mineral (F1 o estándar y F2 o reducida). Para permitir comparaciones, se incluyeron también 2 controles, que no recibieron aportes de materia orgánica pero que fueron abonados con los programas de fertilización mineral estándar o reducida indicados, y que se han denominado en el texto CO F1 y CO F2, respectivamente. Se realizaron un total de cuatro cortes (siegas) de la parte aérea, efectuándose éstos a los tres, cuatro, cinco y seis meses desde la siembra, respectivamente. Tras el último corte, se recogieron muestras de suelo de 
las macetas para la posterior determinación de parámetros físico-químicos y químicos seleccionados en dichos suelos.

Cada vez que se realizaron cortes de parte aérea, se determinaron diferentes parámetros relacionados con el crecimiento y desarrollo de las plantas, controlándose el peso fresco y seco (biomasa) de la parte aérea, la altura y el número de hojas del tallo más alto, y el área de la hoja de mayor tamaño.

La Tabla 4.4.1 presenta los efectos principales de los factores estudiados (Origen [compost] de la MOS, Dosis de MOS y Fertilización mineral) sobre los parámetros peso fresco de la parte aérea cosechada, altura y número de hojas del tallo, y área foliar en el primer corte, observándose que la dosis equivalente a 6400 $\mathrm{mg}$ COT/kg incrementó el peso fresco de alfalfa en comparación con las dosis inferiores, mientras que el resto de factores estudiados (Origen de la MOS y Fertilización mineral) no influyeron en el peso de la parte aérea de la plantas. Asimismo, no se encontraron diferencias estadísticamente significativas en ninguno de los factores analizados para el resto de parámetros estudiados, exceptuando la interacción de los factores Origen de la MOS x Fertilización para la altura del tallo.

Con relación a la comparación entre los tratamientos en los que se aplicó MOS y los controles que no recibieron materia orgánica (Tabla 4.4.2) en el primer corte realizado, se observó que la MOS sólo aumentó significativamente el peso de materia fresca de la parte aérea cosechada (producción) respecto al control con fertilización reducida (CO F2) cuando aquella se aplicó a las dosis de 6400 mg COT/kg del compost A y $3200 \mathrm{mg}$ COT/kg del compost $\mathrm{A}+\mathrm{H}$.

Respecto al segundo corte realizado (Tabla 4.4.3), los resultados obtenidos mostraron que no existieron diferencias entre los valores de todos los parámetros controlados para los factores Origen (compost) de la MOS y Fertilización mineral, mientras que la Dosis de MOS influyó significativamente en la producción de biomasa aérea cosechada y en la altura del tallo, observándose una disminución en el valor de dichos parámetros cuando se aplicó MOS a la dosis máxima. 
Tabla 4.4.1. Efectos principales de los tratamientos estudiados -Materia orgánica soluble (MOS) extraída del compost (A vs. A+H), Dosis de aplicación de la MOS (en mg de carbono orgánico total/kg de suelo) y Programa de fertilización mineral (estándar, F1 vs. reducida, F2)- sobre el crecimiento y la producción de Medicago sativa en el primer corte (siega) realizado

\begin{tabular}{|c|c|c|c|c|}
\hline Efecto principal del tratamiento & $\begin{array}{l}\text { Producción } \\
\text { (g materia fresca } \\
\text { /contenedor) }\end{array}$ & $\begin{array}{l}\text { Altura } \\
\text { tallo } \\
(\mathrm{cm})\end{array}$ & $\begin{array}{l}\mathrm{N}^{\circ} \text { de hojas } \\
\text { /tallo }\end{array}$ & $\begin{array}{c}\text { Área hoja } \\
\left(\mathrm{cm}^{2}\right)\end{array}$ \\
\hline \multicolumn{5}{|l|}{ 1. Origen (compost) de la MOS } \\
\hline A & 5,25 & 27,61 & 18,0 & 5,92 \\
\hline $\mathrm{A}+\mathrm{H}$ & 5,56 & 28,59 & 19,7 & 5,86 \\
\hline$P$ & ns & ns & ns & ns \\
\hline \multicolumn{5}{|l|}{ 2. Dosis de MOS } \\
\hline 200 & $5,35 b c$ & 28,72 & 18,3 & 5,73 \\
\hline 400 & $4,92 \mathrm{c}$ & 27,63 & 18,0 & 5,80 \\
\hline 800 & $5,15 b c$ & 28,29 & 17,7 & 6,04 \\
\hline 1600 & $5,10 c$ & 28,16 & 19,0 & 5,90 \\
\hline 3200 & $5,78 a b$ & 29,37 & 21,0 & 5,77 \\
\hline 6400 & $6,14 a$ & 26,45 & 19,3 & 6,10 \\
\hline$P$ & ** & ns & ns & ns \\
\hline \multicolumn{5}{|l|}{ 3. Fertilización mineral } \\
\hline $\mathrm{F} 1$ & 5,33 & 27,86 & 18,3 & 5,86 \\
\hline $\mathrm{F} 2$ & 5,49 & 28,34 & 19,3 & 5,92 \\
\hline$P$ & ns & ns & ns & ns \\
\hline \multicolumn{5}{|l|}{ 4. Interacción } \\
\hline $1 \times 2$ & ns & ns & ns & ns \\
\hline $1 \times 3$ & ns & * & ns & ns \\
\hline $2 \times 3$ & ns & ns & ns & ns \\
\hline $1 \times 2 \times 3$ & ns & ns & ns & ns \\
\hline
\end{tabular}

A: compost de alperujo; $\mathrm{A}+\mathrm{H}$ : compost de alperujo más hidrolizado
$P$ : nivel de significación. $\mathrm{ns}, \mathrm{y}^{* *}$ indican diferencias no significativas o estadísticamente significativas a $P \leq 0,05$ y $P \leq 0,01$, respectivamente

Valores en columna sin letra común difieren estadísticamente a $P \leq 0,05$ (test de Student-Newman-Keuls)

El estudio comparativo de los tratamientos examinados en el segundo corte -aplicación de MOS vs. controles (CO) sin aplicación de la misma (Tabla 4.4.4)- puso de manifiesto que los tratamientos con MOS de A proporcionaron resultados similares a los controles, y que los tratamientos con MOS procedente de $\mathrm{A}+\mathrm{H}$ incrementaron la producción (en g materia fresca/contenedor) en varios casos (dosis y programa de fertilización), siendo este aumento significativo para las dosis de 200, 1600 y 3200 mg COT/kg con el programa de fertilización reducida (F2), mientras que la aplicación de $6400 \mathrm{mg}$ COT/kg se tradujo en una disminución marcada en el peso de materia fresca cosechada y en la altura del tallo. 
Tabla 4.4.2. Influencia de la materia orgánica soluble (MOS) extraída de los composts A y $\mathrm{A}+\mathrm{H}$, la dosis de aplicación de ésta (en $\mathrm{mg}$ de carbono orgánico total/kg de suelo) y el programa de fertilización mineral (estándar, F1 y reducida, F2) en el crecimiento y la producción de Medicago sativa en el primer corte (siega) realizado. Comparación con los controles (CO, que no recibieron MOS)

\begin{tabular}{|c|c|c|c|c|c|c|}
\hline \multicolumn{2}{|c|}{ MOS } & \multirow{2}{*}{$\begin{array}{c}\text { Fertilización } \\
\text { mineral }\end{array}$} & \multirow{2}{*}{$\begin{array}{l}\text { Producción } \\
\text { (g materia fresca } \\
\text { /contenedor) }\end{array}$} & \multirow{2}{*}{$\begin{array}{l}\text { Altura } \\
\text { tallo } \\
(\mathrm{cm})\end{array}$} & \multirow{2}{*}{$\begin{array}{l}\mathrm{N}^{\circ} \text { de hojas } \\
\text { /tallo }\end{array}$} & \multirow{2}{*}{$\begin{array}{c}\text { Área hoja } \\
\left(\mathrm{cm}^{2}\right)\end{array}$} \\
\hline $\begin{array}{c}\text { Origen } \\
\text { (compost) }\end{array}$ & Dosis & & & & & \\
\hline \multirow[t]{12}{*}{$A$} & 200 & F1 & $4,62 \mathrm{ef}$ & 28,45 & 17,7 & 5,87 \\
\hline & & F2 & $5,52 \mathrm{bcdef}$ & 29,48 & 18,0 & 5,84 \\
\hline & 400 & F1 & $4,84 \mathrm{cdef}$ & 25,48 & 15,7 & 5,68 \\
\hline & & $\mathrm{F} 2$ & $5,21 \mathrm{cdef}$ & 28,95 & 17,0 & 5,76 \\
\hline & 800 & F1 & $5,18 \mathrm{cdef}$ & 28,60 & 16,7 & 6,46 \\
\hline & & F2 & $5,35 \mathrm{bcdef}$ & 27,72 & 16,0 & 5,90 \\
\hline & 1600 & F1 & $4,94 \mathrm{cdef}$ & 26,25 & 16,3 & 5,40 \\
\hline & & F2 & 4,68def & 29,01 & 18,7 & 6,00 \\
\hline & 3200 & F1 & $4,92 \mathrm{cdef}$ & 26,35 & 17,3 & 5,48 \\
\hline & & F2 & $5,26 \mathrm{cdef}$ & 29,03 & 21,0 & 6,35 \\
\hline & 6400 & F1 & $5,94 a b c d$ & 25,99 & 22,0 & 6,20 \\
\hline & & $\mathrm{F} 2$ & $6,57 a b$ & 27,09 & 19,3 & 6,14 \\
\hline \multirow[t]{12}{*}{$\mathrm{A}+\mathrm{H}$} & 200 & F1 & 5,42 bcdef & 28,64 & 18,3 & 5,73 \\
\hline & & F2 & 5,84abcde & 28,31 & 19,0 & 5,48 \\
\hline & 400 & F1 & 5,37 bcdef & 28,78 & 17,7 & 5,95 \\
\hline & & $\mathrm{F} 2$ & $4,27 f$ & 27,30 & 21,0 & 5,82 \\
\hline & 800 & F1 & $4,61 \mathrm{ef}$ & 28,86 & 20,3 & 5,87 \\
\hline & & F2 & 5,46 bcdef & 28,00 & 17,3 & 5,95 \\
\hline & 1600 & F1 & $5,41 \mathrm{bcdef}$ & 26,73 & 17,7 & 5,87 \\
\hline & & F2 & $5,38 \mathrm{bcdef}$ & 30,65 & 23,3 & 6,33 \\
\hline & 3200 & F1 & $6,06 a b c$ & 31,46 & 22,3 & 5,50 \\
\hline & & F2 & $6,89 a$ & 31,63 & 23,0 & 5,73 \\
\hline & 6400 & F1 & 6,61ab & 29,76 & 17,7 & 6,32 \\
\hline & & F2 & 5,47 bcdef & 22,94 & 19,0 & 5,72 \\
\hline \multirow[t]{2}{*}{$\mathrm{CO}$} & - & F1 & 5,61abcde & 30,90 & 23,3 & 6,02 \\
\hline & - & $\mathrm{F} 2$ & $4,63 e f$ & 27,74 & 14,3 & 5,44 \\
\hline$P$ & & & ** & ns & ns & ns \\
\hline
\end{tabular}

A: compost de alperujo; $\mathrm{A}+\mathrm{H}$ : compost de alperujo más hidrolizado

$P$ : nivel de significación. ns $y * *$ indican diferencias no significativas o estadísticamente significativas a $P \leq 0,01$, respectivamente Valores en columna sin letra común difieren estadísticamente a $P \leq 0,05$ (test de Student-Newman-Keuls) 
Tabla 4.4.3. Efectos principales de los tratamientos estudiados -Materia orgánica soluble (MOS) extraída del compost (A vs. A+H), Dosis de aplicación de la MOS (en mg de carbono orgánico total/kg de suelo) y Programa de fertilización mineral (estándar, F1 vs. reducida, F2)- sobre el crecimiento y la producción de Medicago sativa en el segundo corte realizado

\begin{tabular}{|c|c|c|c|c|}
\hline Efecto principal del tratamiento & $\begin{array}{c}\text { Producción } \\
\text { (g materia fresca } \\
\text { /contenedor) }\end{array}$ & $\begin{array}{l}\text { Altura } \\
\text { tallo } \\
(\mathrm{cm}) \\
\end{array}$ & $\begin{array}{l}\mathrm{N}^{\circ} \text { de hojas } \\
\text { /tallo }\end{array}$ & $\begin{array}{c}\text { Área hoja } \\
\left(\mathrm{cm}^{2}\right)\end{array}$ \\
\hline \multicolumn{5}{|l|}{ 1. Origen (compost) de la MOS } \\
\hline A & 2,99 & 23,50 & 12,1 & 5,36 \\
\hline$A+H$ & 3,01 & 24,51 & 12,8 & 5,50 \\
\hline$P$ & ns & ns & ns & ns \\
\hline \multicolumn{5}{|l|}{ 2. Dosis de MOS } \\
\hline 200 & $3,35 a$ & $26,10 a$ & 12,2 & 5,65 \\
\hline 400 & $2,94 b$ & $24,58 a b$ & 13,3 & 5,30 \\
\hline 800 & $2,89 b$ & $23,10 b$ & 12,0 & 5,34 \\
\hline 1600 & $2,93 b$ & $24,86 a b$ & 12,9 & 5,34 \\
\hline 3200 & $3,41 a$ & $25,08 a b$ & 12,4 & 5,51 \\
\hline 6400 & $2,47 \mathrm{c}$ & $20,31 c$ & 11,7 & 5,42 \\
\hline$P$ & $* * *$ & $* * *$ & ns & ns \\
\hline \multicolumn{5}{|l|}{ 3. Fertilización mineral } \\
\hline F1 & 2,97 & 23,70 & 12,1 & 5,42 \\
\hline $\mathrm{F} 2$ & 3,02 & 24,30 & 12,7 & 5,44 \\
\hline$P$ & ns & ns & ns & ns \\
\hline \multicolumn{5}{|l|}{ 4. Interacción } \\
\hline $1 \times 2$ & ** & * & ns & ns \\
\hline $1 \times 3$ & ns & ns & ns & ns \\
\hline $2 \times 3$ & ns & ns & ns & ns \\
\hline $1 \times 2 \times 3$ & ns & * & $\mathrm{ns}$ & ns \\
\hline
\end{tabular}

A: compost de alperujo; $\mathrm{A}+\mathrm{H}$ : compost de alperujo más hidrolizado

$P$ : nivel de significación. ns, * ** y*** indican diferencias no significativas o estadísticamente significativas a $P \leq 0,05, P \leq 0,01$ y $P \leq 0,001$, respectivamente

Valores en columna sin letra común difieren estadísticamente a $P \leq 0,05$ (test de Student-Newman-Keuls)

De forma análoga a los resultados obtenidos en los dos primeros cortes, el estudio estadístico factorial realizado tras el tercer corte (Tabla 4.4.5) reveló que no existieron diferencias estadísticamente significativas en los cuatro parámetros estudiados para los factores Origen (compost) de la MOS y Fertilización mineral, mientras que la dosis máxima de MOS (6400 mg COT/kg) redujo la producción de materia fresca de la parte aérea, la altura del tallo y el área de la hoja. 
Tabla 4.4.4. Influencia de la materia orgánica soluble (MOS) extraída de los composts A y $\mathrm{A}+\mathrm{H}$, la dosis de aplicación de ésta (en $\mathrm{mg}$ de carbono orgánico total/kg de suelo) y el programa de fertilización mineral (estándar, F1 y reducida, F2) en el crecimiento y la producción de Medicago sativa en el segundo corte realizado. Comparación con los controles (CO, que no recibieron MOS)

\begin{tabular}{|c|c|c|c|c|c|c|}
\hline \multicolumn{2}{|c|}{ MOS } & \multirow{2}{*}{$\begin{array}{c}\text { Fertilización } \\
\text { mineral }\end{array}$} & \multirow{2}{*}{$\begin{array}{l}\text { Producción } \\
\text { (g materia fresca } \\
\text { /contenedor) }\end{array}$} & \multirow{2}{*}{$\begin{array}{l}\text { Altura } \\
\text { tallo } \\
(\mathrm{cm})\end{array}$} & \multirow{2}{*}{$\begin{array}{l}\text { NNo de hojas }^{\text {/tallo }}\end{array}$} & \multirow{2}{*}{$\begin{array}{c}\text { Área hoja } \\
\left(\mathrm{cm}^{2}\right)\end{array}$} \\
\hline $\begin{array}{c}\text { Origen } \\
\text { (compost) }\end{array}$ & Dosis & & & & & \\
\hline \multirow[t]{12}{*}{ A } & 200 & F1 & 3,21abcdefgh & $25,63 a b c$ & 12,0 & 5,74 \\
\hline & & F2 & 3,34abcdef & 26,33ab & 12,0 & 5,36 \\
\hline & 400 & F1 & 2,76defghi & $23,06 a b c$ & 10,3 & 4,80 \\
\hline & & $\mathrm{F} 2$ & 2,98bcdefgh & $24,45 a b c$ & 14,7 & 5,35 \\
\hline & 800 & F1 & 3,02bcdefgh & $22,78 a b c$ & 11,3 & 5,44 \\
\hline & & F2 & 3,07abcdefgh & $22,37 a b c$ & 9,7 & 5,25 \\
\hline & 1600 & F1 & 2,85cdefghi & $22,72 a b c$ & 14,3 & 5,18 \\
\hline & & $\mathrm{F} 2$ & 2,58hij & $25,23 a b c$ & 12,7 & 5,18 \\
\hline & 3200 & F1 & 3,37abcde & $21,66 a b c$ & 13,0 & 5,04 \\
\hline & & $\mathrm{F} 2$ & 3,04abcdefgh & $24,03 a b c$ & 11,7 & 5,66 \\
\hline & 6400 & F1 & 2,96bcdefgh & $21,28 a b c$ & 11,7 & 5,44 \\
\hline & & F2 & 2,68fghij & $22,43 a b c$ & 12,0 & 5,60 \\
\hline \multirow[t]{12}{*}{$\mathrm{A}+\mathrm{H}$} & 200 & F1 & 3,31abcdefg & $25,64 a b c$ & 12,0 & 5,83 \\
\hline & & $\mathrm{F} 2$ & $3,56 a b$ & $26,83 a b$ & 13,0 & 5,68 \\
\hline & 400 & F1 & 2,96bcdefgh & $26,58 a b$ & 14,0 & 5,58 \\
\hline & & F2 & 3,07abcdefgh & $24,22 a b c$ & 14,3 & 5,47 \\
\hline & 800 & F1 & 2,82defghi & $24,87 a b c$ & 14,7 & 5,58 \\
\hline & & F2 & 2,63ghij & $22,38 a b c$ & 12,3 & 5,10 \\
\hline & 1600 & F1 & 2,85 cdefghi & $23,18 a b c$ & 11,0 & 5,25 \\
\hline & & F2 & 3,43abcd & $28,32 a$ & 13,7 & 5,75 \\
\hline & 3200 & F1 & $3,53 a b c$ & $27,89 a$ & 11,0 & 5,70 \\
\hline & & F2 & $3,72 a$ & $26,72 a b$ & 14,0 & 5,63 \\
\hline & 6400 & F1 & $2,06 \mathrm{j}$ & $19,18 b c$ & 11,0 & 5,44 \\
\hline & & F2 & $2,18 \mathrm{ij}$ & $18,35 c$ & 12,3 & 4,98 \\
\hline \multirow[t]{2}{*}{$\mathrm{CO}$} & - & F1 & 3,20abcdefgh & $26,13 a b$ & 10,0 & 5,54 \\
\hline & - & F2 & 2,71efghij & $25,78 a b c$ & 10,0 & 5,03 \\
\hline$P$ & & & * & *; & $\mathrm{ns}$ & $\mathrm{ns}$ \\
\hline
\end{tabular}

A: compost de alperujo; $\mathrm{A}+\mathrm{H}$ : compost de alperujo más hidrolizado

$P$ : nivel de significación. ns $y * * *$ indican diferencias no significativas o estadísticamente significativas a $P \leq 0,001$, respectivamente

Valores en columna sin letra común difieren estadísticamente a $P \leq 0,05$ (test de Student-Newman-Keuls)

La Tabla 4.4.6 presenta la comparación entre los tratamientos en los que se aplicó MOS y los suelos control (sin materia orgánica, CO) en el tercer corte, mostrándose cómo la aplicación de MOS disminuyó el peso de materia fresca cosechada cuando se aplicó a la concentración más elevada (6400mg COT/kg), 
independientemente de su origen (compost) y el programa de fertilización aplicado. En contraste con lo anterior, la adición de MOS de A+H a las dosis de 200 y 1600 mg COT/kg en combinación con el programa de fertilización reducida (F2) incrementó la producción de materia fresca en comparación con el control equivalente (CO F2).

Tabla 4.4.5. Efectos principales de los tratamientos estudiados -Materia orgánica soluble (MOS) extraída del compost (A vs. A+H), Dosis de aplicación de la MOS (en mg de carbono orgánico total/kg de suelo) y Programa de fertilización mineral (estándar, F1 vs. reducida, F2) - sobre el crecimiento y la producción de Medicago sativa en el tercer corte realizado

\begin{tabular}{|c|c|c|c|c|}
\hline Efecto principal del tratamiento & $\begin{array}{l}\text { Producción } \\
\text { (g materia fresca } \\
\text { /contenedor) }\end{array}$ & $\begin{array}{l}\text { Altura } \\
\text { tallo } \\
(\mathrm{cm})\end{array}$ & $\begin{array}{c}\mathrm{N}^{\circ} \text { de hojas } \\
\text { /tallo }\end{array}$ & $\begin{array}{c}\text { Área hoja } \\
\left(\mathrm{cm}^{2}\right)\end{array}$ \\
\hline \multicolumn{5}{|l|}{ 1. Origen (compost) de la MOS } \\
\hline A & 2,21 & 18,60 & 11,7 & 4,87 \\
\hline$A+H$ & 2,14 & 18,72 & 12,3 & 4,90 \\
\hline$P$ & ns & ns & ns & ns \\
\hline \multicolumn{5}{|l|}{ 2. Dosis de MOS } \\
\hline 200 & $2,70 a$ & $21,06 a$ & 12,3 & $5,09 a$ \\
\hline 400 & $2,19 b$ & $18,72 b$ & 12,0 & $4,92 a$ \\
\hline 800 & $2,24 b$ & $19,10 a b$ & 11,3 & $4,97 a$ \\
\hline 1600 & $2,42 a b$ & $19,59 a b$ & 13,3 & $4,98 a$ \\
\hline 3200 & $2,38 a b$ & $20,09 a b$ & 11,7 & $4,96 a$ \\
\hline 6400 & $1,11 \mathrm{c}$ & $13,41 \mathrm{c}$ & 11,3 & $4,39 b$ \\
\hline$P$ & $* * *$ & $* * *$ & ns & $* * *$ \\
\hline \multicolumn{5}{|l|}{ 3. Fertilización mineral } \\
\hline F1 & 2,12 & 18,21 & 12,3 & 4,85 \\
\hline F2 & 2,23 & 19,11 & 12,0 & 4,92 \\
\hline$P$ & ns & ns & ns & ns \\
\hline \multicolumn{5}{|l|}{ 4. Interacción } \\
\hline $1 \times 2$ & * & ns & ns & ns \\
\hline $1 \times 3$ & ns & ns & ns & ns \\
\hline $2 \times 3$ & ns & ns & ns & ns \\
\hline $1 \times 2 \times 3$ & ns & ns & ns & * \\
\hline
\end{tabular}

A: compost de alperujo; $\mathrm{A}+\mathrm{H}$ : compost de alperujo más hidrolizado

$P$ : nivel de significación. ns, * y *** indican diferencias no significativas o estadísticamente significativas a $P \leq 0,05$ y $P \leq 0,001$, respectivamente

Valores en columna sin letra común difieren estadísticamente a $P \leq 0,05$ (test de Student-Newman-Keuls) 
Tabla 4.4.6. Influencia de la materia orgánica soluble (MOS) extraída de los composts A y $\mathrm{A}+\mathrm{H}$, la dosis de aplicación de ésta (en mg de carbono orgánico total/kg de suelo) y el programa de fertilización mineral (estándar, F1 y reducida, F2) en el crecimiento y la producción de Medicago sativa en el tercer corte realizado. Comparación con los controles (CO, que no recibieron MOS)

\begin{tabular}{|c|c|c|c|c|c|c|}
\hline \multicolumn{2}{|c|}{ MOS } & \multirow{2}{*}{$\begin{array}{c}\text { Fertilización } \\
\text { mineral }\end{array}$} & \multirow{2}{*}{$\begin{array}{l}\text { Producción } \\
\text { (g materia fresca } \\
\text { /contenedor) }\end{array}$} & \multirow{2}{*}{$\begin{array}{c}\text { Altura } \\
\text { tallo } \\
(\mathrm{cm})\end{array}$} & \multirow{2}{*}{$\begin{array}{l}\mathrm{N}^{\circ} \text { de hojas } \\
\text { /tallo }\end{array}$} & \multirow{2}{*}{$\begin{array}{c}\text { Área hoja } \\
\left(\mathrm{cm}^{2}\right)\end{array}$} \\
\hline $\begin{array}{c}\text { Origen } \\
\text { (compost) }\end{array}$ & Dosis & & & & & \\
\hline \multirow[t]{12}{*}{ A } & 200 & F1 & 2,56abcd & $20,28 a b$ & 12,0 & $4,92 a b$ \\
\hline & & F2 & $2,75 a b c$ & $22,64 a$ & 12,3 & $5,34 a$ \\
\hline & 400 & F1 & 2,01de & $18,82 a b$ & 9,7 & 4,94ab \\
\hline & & F2 & 2,17cde & $18,08 a b$ & 12,0 & 4,89ab \\
\hline & 800 & F1 & $2,54 \mathrm{abcd}$ & $18,88 a b$ & 13,3 & 4,84ab \\
\hline & & F2 & 2,43abcd & $19,41 \mathrm{ab}$ & 11,0 & $5,19 a b$ \\
\hline & 1600 & F1 & 2,09 cde & $17,78 a b$ & 14,3 & $4,87 a b$ \\
\hline & & F2 & $2,31 \mathrm{bcd}$ & $20,15 a b$ & 12,3 & 4,64ab \\
\hline & 3200 & F1 & $2,50 a b c d$ & 19,31ab & 11,3 & 4,66ab \\
\hline & & F2 & $2,27 \mathrm{bcd}$ & $19,54 a b$ & 11,7 & 4,97ab \\
\hline & 6400 & F1 & $1,31 \mathrm{fg}$ & $12,18 b$ & 9,7 & 4,52ab \\
\hline & & F2 & $1,54 \mathrm{efg}$ & $16,13 a b$ & 10,7 & $5,05 a b$ \\
\hline \multirow[t]{12}{*}{$\mathrm{A}+\mathrm{H}$} & 200 & F1 & 2,62abcd & $20,26 a b$ & 12,7 & $5,23 a b$ \\
\hline & & F2 & $2,85 a b$ & $21,09 a$ & 12,0 & $4,87 a b$ \\
\hline & 400 & F1 & $2,26 \mathrm{bcd}$ & 18,83ab & 13,0 & $4,76 a b$ \\
\hline & & F2 & 2,33abcd & $19,14 a b$ & 13,7 & $5,09 a b$ \\
\hline & 800 & F1 & $2,00 \mathrm{de}$ & 19,31ab & 11,7 & 4,88ab \\
\hline & & F2 & 1,98def & 18,81ab & 10,0 & 4,96ab \\
\hline & 1600 & F1 & $2,28 \mathrm{bcd}$ & $18,07 a b$ & 12,3 & 4,92ab \\
\hline & & F2 & $3,00 a$ & $22,35 a$ & 14,3 & $5,49 a$ \\
\hline & 3200 & F1 & $2,76 a b c$ & $22,24 a$ & 13,0 & $5,38 a$ \\
\hline & & F2 & 1,99de & $19,27 a b$ & 11,0 & 4,80ab \\
\hline & 6400 & F1 & $0,54 \mathrm{~h}$ & $12,57 b$ & 13,3 & $4,24 b$ \\
\hline & & F2 & 1,06gh & $12,76 b$ & 11,7 & $4,17 b$ \\
\hline \multirow[t]{2}{*}{$\mathrm{CO}$} & - & F1 & $2,38 a b c d$ & $18,30 a b$ & 15,3 & $4,75 a b$ \\
\hline & - & F2 & 2,11cde & 18,93ab & 12,3 & 4,92ab \\
\hline$P$ & & & $\star \star \star \star$ & $\star \star \star \star$ & $\mathrm{ns}$ & ** \\
\hline
\end{tabular}

A: compost de alperujo; $\mathrm{A}+\mathrm{H}$ : compost de alperujo más hidrolizado

$P$ : nivel de significación. ns, ** y *** indican diferencias no significativas o estadísticamente significativas a $P \leq 0,01$ y $P \leq 0,001$, respectivamente

Valores en columna sin letra común difieren estadísticamente a $P \leq 0,05$ (test de Student-Newman-Keuls)

En cuanto al cuarto corte realizado, cuyo análisis factorial se muestra en la Tabla 4.4.7, hay que señalar que el efecto Dosis de MOS mostró una tendencia similar al tercer corte para los parámetros estudiados, siendo el efecto deletéreo de la dosis de $6400 \mathrm{mg}$ COT/kg comparativamente más marcado y encontrándose, además, con la 
aplicación de $3200 \mathrm{mg}$ COT/kg valores de peso de materia fresca (producción) y altura del tallo notablemente inferiores a los registrados para las dosis comprendidas entre 200 y $1600 \mathrm{mg}$ COT/kg.

Tabla 4.4.7. Efectos principales de los tratamientos estudiados -Materia orgánica soluble (MOS) extraída del compost (A vs. A+H), Dosis de aplicación de la MOS (en mg de carbono orgánico tota/kg de suelo) y Programa de fertilización mineral (estándar, F1 vs. reducida, F2)- sobre el crecimiento y producción de Medicago sativa en el cuarto corte realizado

\begin{tabular}{|c|c|c|c|c|}
\hline Efecto principal del tratamiento & $\begin{array}{l}\text { Producción } \\
\text { (g materia fresca } \\
\text { /contenedor) }\end{array}$ & $\begin{array}{l}\text { Altura } \\
\text { tallo } \\
(\mathrm{cm})\end{array}$ & $\begin{array}{l}\mathrm{N}^{\circ} \text { de hojas } \\
\text { /tallo }\end{array}$ & $\begin{array}{c}\text { Área hoja } \\
\left(\mathrm{cm}^{2}\right)\end{array}$ \\
\hline \multicolumn{5}{|l|}{ 1. Origen (compost) de la MOS } \\
\hline A & 2,00 & 15,72 & 17,0 & 4,66 \\
\hline $\mathrm{A}+\mathrm{H}$ & 2,09 & 16,32 & 17,3 & 4,75 \\
\hline$P$ & ns & ns & ns & ns \\
\hline \multicolumn{5}{|l|}{ 2. Dosis de MOS } \\
\hline 200 & $2,61 a$ & $19,32 a$ & 16,7 & $4,93 a$ \\
\hline 400 & $2,44 a b$ & $17,35 a b$ & 17,3 & $4,86 a b$ \\
\hline 800 & $2,11 a b$ & $15,02 \mathrm{bcd}$ & 18,3 & $4,62 b c$ \\
\hline 1600 & $2,27 a b$ & $16,80 b c$ & 18,3 & $4,80 a b$ \\
\hline 3200 & $1,98 b$ & $14,64 \mathrm{~cd}$ & 17,3 & $4,62 b c$ \\
\hline 6400 & $0,89 c$ & $13,00 d$ & 15,3 & $4,41 c$ \\
\hline$P$ & $* * *$ & $* * *$ & ns & * \\
\hline \multicolumn{5}{|l|}{ 3. Fertilización mineral } \\
\hline $\mathrm{F} 1$ & 1,98 & 15,67 & 17,7 & 4,70 \\
\hline $\mathrm{F} 2$ & 2,12 & 16,38 & 17,0 & 4,72 \\
\hline$P$ & ns & ns & ns & ns \\
\hline \multicolumn{5}{|l|}{ 4. Interacción } \\
\hline $1 \times 2$ & ** & ns & ns & ns \\
\hline $1 \times 3$ & ns & ns & ns & ns \\
\hline $2 \times 3$ & * & ns & ns & ns \\
\hline $1 \times 2 \times 3$ & ns & ns & ns & ns \\
\hline
\end{tabular}

A: compost de alperujo; A+H: compost de alperujo más hidrolizado

$P$ : nivel de significación. ns, * ** $y * * *$ indican diferencias no significativas o estadísticamente significativas a $P \leq 0,05, P \leq 0,01$ y $P \leq 0,001$, respectivamente

Valores en columna sin letra común difieren estadísticamente a $P \leq 0,05$ (test de Student-Newman-Keuls)

Los resultados del análisis estadístico correspondientes al cuarto y último corte, en el que se compararon los tratamientos con MOS y los controles sin aplicación de ésta (Tabla 4.4.8), mostraron que el peso de materia fresca de la parte aérea cosechada en los tratamientos que recibieron MOS - de ambos composts- a la dosis de $6400 \mathrm{mg}$ COT/kg, fue significativamente inferior a los controles, con independencia 
del programa de fertilización aplicado, así como el tratamiento con MOS de $\mathrm{A}+\mathrm{H}$ a la dosis de $3200 \mathrm{mg}$ COT/kg y fertilización mineral reducida (F2).

Tabla 4.4.8. Influencia de la materia orgánica soluble (MOS) extraída de los composts A y $\mathrm{A}+\mathrm{H}$, la dosis de aplicación de ésta (en $\mathrm{mg}$ de carbono orgánico total/ $\mathrm{kg}$ de suelo) y el programa de fertilización mineral (estándar, F1 y reducida, F2) en el crecimiento y la producción de Medicago sativa en el cuarto corte realizado. Comparación con los controles (CO, que no recibieron MOS)

\begin{tabular}{|c|c|c|c|c|c|c|}
\hline \multicolumn{2}{|c|}{ MOS } & \multirow{2}{*}{$\begin{array}{c}\text { Fertilización } \\
\text { mineral }\end{array}$} & \multirow{2}{*}{$\begin{array}{l}\text { Producción } \\
\text { (g materia fresca } \\
\text { /contenedor) }\end{array}$} & \multirow{2}{*}{$\begin{array}{l}\text { Altura } \\
\text { tallo } \\
(\mathrm{cm})\end{array}$} & \multirow{2}{*}{$\begin{array}{l}\mathrm{N}^{\circ} \text { de hojas } \\
\text { /tallo }\end{array}$} & \multirow{2}{*}{$\begin{array}{c}\text { Área hoja } \\
\left(\mathrm{cm}^{2}\right)\end{array}$} \\
\hline $\begin{array}{c}\text { Origen } \\
\text { (compost) }\end{array}$ & Dosis & & & & & \\
\hline \multirow[t]{12}{*}{ A } & 200 & F1 & $2,84 a b c$ & $20,13 a b c$ & 19,0 & 4,91 \\
\hline & & F2 & $2,64 \mathrm{abcd}$ & $20,97 a b c$ & 17,7 & 5,02 \\
\hline & 400 & F1 & 1,86def & 15,48 abcde & 17,3 & 4,79 \\
\hline & & F2 & $2,28 \mathrm{bcde}$ & 16,75 abcde & 16,3 & 4,84 \\
\hline & 800 & F1 & 2,04 def & $13,44 \mathrm{de}$ & 22,3 & 4,55 \\
\hline & & F2 & $2,11 \mathrm{cdef}$ & 14,41bcde & 15,3 & 4,54 \\
\hline & 1600 & F1 & $1,94 \mathrm{def}$ & $14,45 b c d e$ & 19,7 & 4,59 \\
\hline & & F2 & 1,86def & 16,00 abcde & 18,3 & 4,59 \\
\hline & 3200 & F1 & $2,26 \mathrm{bcde}$ & 15,17 abcde & 16,3 & 4,55 \\
\hline & & F2 & $1,97 \mathrm{def}$ & $13,98 \mathrm{cde}$ & 16,0 & 4,59 \\
\hline & 6400 & F1 & $0,86 \mathrm{gh}$ & 12,18de & 12,0 & 4,22 \\
\hline & & F2 & $1,40 f g$ & 15,68 abcde & 15,7 & 4,74 \\
\hline \multirow[t]{12}{*}{$\mathrm{A}+\mathrm{H}$} & 200 & F1 & 2,52abcd & $18,44 a b c d$ & 14,7 & 4,88 \\
\hline & & F2 & $2,45 \mathrm{bcd}$ & 17,73abcde & 15,0 & 4,92 \\
\hline & 400 & F1 & 2,58abcd & 16,97 abcde & 17,0 & 4,83 \\
\hline & & F2 & $3,05 a b$ & $20,19 a b c$ & 18,3 & 4,96 \\
\hline & 800 & F1 & $2,29 b c d$ & 15,93abcde & 20,3 & 4,76 \\
\hline & & F2 & 1,98def & 16,30abcde & 15,7 & 4,66 \\
\hline & 1600 & F1 & 1,99def & 16,56 abcde & 16,0 & 4,88 \\
\hline & & F2 & $3,28 a$ & $20,21 a b c$ & 19,0 & 5,13 \\
\hline & 3200 & F1 & $2,19 \mathrm{cdef}$ & $16,89 a b c d e$ & 16,3 & 4,94 \\
\hline & & $\mathrm{F} 2$ & 1,49efg & $12,53 \mathrm{de}$ & 21,3 & 4,40 \\
\hline & 6400 & F1 & $0,40 \mathrm{~h}$ & $12,37 \mathrm{de}$ & 20,0 & 4,48 \\
\hline & & F2 & 0,88gh & $11,76 \mathrm{e}$ & 13,3 & 4,20 \\
\hline \multirow[t]{2}{*}{$\mathrm{CO}$} & - & F1 & $2,60 a b c d$ & 16,08 abcde & 15,3 & 4,62 \\
\hline & - & F2 & $2,54 a b c d$ & $21,25 a$ & 16,0 & 5,00 \\
\hline$P$ & & & $* * *$ & ** & ns & ns \\
\hline
\end{tabular}

A: compost de alperujo; $\mathrm{A}+\mathrm{H}$ : compost de alperujo más hidrolizado

$P$ : nivel de significación. ns, ** y*** indican diferencias no significativas o estadísticamente significativas a $P \leq 0,01$ y $P \leq 0,001$, respectivamente

Valores en columna sin letra común difieren estadísticamente a $P \leq 0,05$ (test de Student-Newman-Keuls) 
Al final del experimento, es decir tras haber realizado el cuarto corte, se procedió a la toma de muestras de suelo, para su posterior análisis, y a la separación de las raíces, determinándose entonces el peso fresco de las mismas -expresado en mg/raíz- y su volumen -expresado en mL/raíz-. La Tabla 4.4 .9 muestra los resultados del análisis factorial de la varianza para los efectos principales de los tratamientos experimentales estudiados (Origen [compost] de la MOS, Dosis de MOS y Fertilización mineral) sobre los parámetros arriba indicados. De manera similar a los resultados obtenidos en los cuatro cortes realizados, solamente se encontraron diferencias significativas para el factor Dosis de MOS; la dosis equivalente a $200 \mathrm{mg}$ COT/kg proporcionó el mayor peso fresco y volumen de la raíz, mientras que la dosis de $6400 \mathrm{mg}$ COT/kg se tradujo en el menor crecimiento de ésta.

Cuando se compararon el peso fresco y el volumen de la raíz de los tratamientos en los que se aplicó MOS con los controles que no recibieron ésta (Tabla 4.4.10), se observó que los suelos control (CO) sólo difirieron de los tratados con MOS a la dosis de $6400 \mathrm{mg} \mathrm{COT} / \mathrm{kg}$, tanto de $\mathrm{A}$ como de $\mathrm{A}+\mathrm{H}$, con valores significativamente superiores en dichos controles.

Con objeto de determinar la influencia de la MOS en la acumulación y distribución de la biomasa producida por Medicago sativa (expresada en g de materia seca/contenedor), a lo largo del experimento, se estudió el efecto de cada uno de los factores examinados (Origen [compost] de la MOS, Dosis de MOS y Fertilización mineral) sobre la producción de: la biomasa aérea cosechada en cada uno de los cuatro cortes efectuados $\left(1^{\circ}\right.$ a $\left.4^{\circ}\right)$, la biomasa aérea total producida en el experimento completo (cortes $1^{\circ}+2^{\circ}+3^{\circ}+4^{\circ}$ ), la biomasa acumulada en las raíces al finalizar éste, y la biomasa total de las plantas enteras (parte aérea+raíces) acumulada durante todo el experimento (Tabla 4.4.11). Los resultados obtenidos revelaron que el compost (A vs. $A+H)$ del que se extrajo la MOS y el programa de fertilización mineral aplicado (F1 vs. F2) no influyeron en la producción de materia seca de la parte aérea, las raíces y la planta entera (total). En contraste con lo anterior, la dosis de MOS mostró diferencias significativas en todos los parámetros y momentos controlados, a excepción del primer corte, debido probablemente a que la fracción de MOS aplicada hasta dicho corte, que representó el $60 \%$ del total, fue insuficiente para provocar diferencias entre las dosis estudiadas. En el resto de los cortes efectuados $\left(2^{\circ}\right.$ a $\left.4^{\circ}\right)$, así como en la suma de todos los cortes realizados $\left(1^{\circ}+2^{\circ}+3^{\circ}+4^{\circ}\right)$, se apreció que la dosis de MOS de 
$200 \mathrm{mg} \mathrm{COT/kg} \mathrm{produjo} \mathrm{el} \mathrm{mayor} \mathrm{peso} \mathrm{seco} \mathrm{de} \mathrm{la} \mathrm{raíz} \mathrm{y} \mathrm{total} \mathrm{(parte} \mathrm{aérea} \mathrm{+} \mathrm{raíz),}$ mientras que la aplicación de $6400 \mathrm{mg}$ COT/kg provocó la máxima reducción en la magnitud de dichos parámetros. Además, merece destacarse que la interacción del factor Origen (compost) de la MOS y Dosis de MOS resultó estadísticamente significativa en la biomasa aérea cosechada en los tres últimos cortes realizados, en la biomasa aérea total producida, y en la biomasa total acumulada por la planta entera en el experimento completo.

Tabla 4.4.9. Efectos principales de los tratamientos estudiados -Materia orgánica soluble (MOS) extraída del compost (A vs. A+H), Dosis de aplicación de la MOS (en mg de carbono orgánico total/kg de suelo) y Programa de fertilización mineral (estándar, F1 vs. reducida, F2) - sobre el crecimiento de la raíz de Medicago sativa al finalizar el experimento

\begin{tabular}{lcc}
\hline \multicolumn{1}{c}{ Efecto principal del tratamiento } & $\begin{array}{c}\text { Peso fresco } \\
(\mathrm{mg})\end{array}$ & $\begin{array}{c}\text { Volumen } \\
(\mathrm{mL})\end{array}$ \\
\hline 1. Origen (compost) de la MOS & 583 & 4,70 \\
A & 543 & 4,50 \\
A+H & $\mathrm{ns}$ & $\mathrm{ns}$ \\
$P$ & & \\
2. Dosis de MOS & $732 \mathrm{a}$ & $5,88 \mathrm{a}$ \\
200 & $596 \mathrm{~b}$ & $4,91 \mathrm{~b}$ \\
400 & $604 \mathrm{~b}$ & $4,83 \mathrm{~b}$ \\
800 & $643 \mathrm{ab}$ & $5,14 \mathrm{ab}$ \\
1600 & $557 \mathrm{~b}$ & $4,60 \mathrm{~b}$ \\
3200 & $246 \mathrm{c}$ & $2,27 \mathrm{c}$ \\
6400 & $* * *$ & $* * *$ \\
$P$ & & \\
3. Fertilización mineral & & 4,40 \\
F1 & 543 & $\mathrm{~ns}$ \\
F2 & 583 & $\mathrm{~ns}$ \\
$P$ & $\mathrm{~ns}$ & $\mathrm{~ns}$ \\
4. Interacción & & $\mathrm{ns}$ \\
$1 \times 2$ & $\mathrm{~ns}$ & $\mathrm{~ns}$ \\
$1 \times 3$ & $\mathrm{~ns}$ &
\end{tabular}

A: compost de alperujo; $\mathrm{A}+\mathrm{H}$ : compost de alperujo más hidrolizado

$P$ : nivel de significación. ns $y_{* * *}$ indican diferencias no significativas o estadísticamente significativas a $P \leq 0,001$, respectivamente

Valores en columna sin letra común difieren estadísticamente a $P \leq 0,05$ (test de Student-Newman-Keuls) 
Tabla 4.4.10. Influencia de la materia orgánica soluble (MOS) extraída de los composts $\mathrm{A}$ y $\mathrm{A}+\mathrm{H}$, la dosis de aplicación de ésta (en mg de carbono orgánico total /kg de suelo) y el programa de fertilización mineral (estándar, F1 y reducida, F2) en el crecimiento de la raíz de Medicago sativa al finalizar el experimento. Comparación con los controles (CO, que no recibieron MOS)

\begin{tabular}{|c|c|c|c|c|}
\hline \multicolumn{2}{|c|}{ MOS } & \multirow{2}{*}{$\begin{array}{c}\text { Fertilización } \\
\text { mineral }\end{array}$} & \multirow{2}{*}{$\begin{array}{c}\text { Peso fresco } \\
\text { (mg/raíz) }\end{array}$} & \multirow{2}{*}{$\begin{array}{l}\text { Volumen } \\
\text { (mL/raíz) }\end{array}$} \\
\hline $\begin{array}{c}\text { Origen } \\
\text { (compost) }\end{array}$ & Dosis & & & \\
\hline \multirow[t]{12}{*}{ A } & 200 & F1 & $787 a$ & $6,21 a$ \\
\hline & & F2 & $696 a b$ & $5,58 a b$ \\
\hline & 400 & F1 & 499abc & $4,23 a b c d$ \\
\hline & & F2 & $656 a b$ & 5,33ab \\
\hline & 800 & F1 & $697 a b$ & $5,38 a b$ \\
\hline & & F2 & $638 a b$ & 4,92abc \\
\hline & 1600 & F1 & 552abc & 4,42abcd \\
\hline & & F2 & $669 a b$ & 5,52ab \\
\hline & 3200 & F1 & $615 a b$ & $4,64 a b c d$ \\
\hline & & F2 & $587 a b$ & $5,00 a b c$ \\
\hline & 6400 & F1 & $245 \mathrm{~cd}$ & $2,17 \mathrm{de}$ \\
\hline & & F2 & $360 \mathrm{bcd}$ & $3,07 \mathrm{bcde}$ \\
\hline \multirow[t]{12}{*}{$\mathrm{A}+\mathrm{H}$} & 200 & F1 & 691ab & $5,78 a b$ \\
\hline & & F2 & $754 a$ & 5,93ab \\
\hline & 400 & F1 & 579ab & 4,64abcd \\
\hline & & F2 & $650 a b$ & 5,43ab \\
\hline & 800 & F1 & $542 a b c$ & 4,43abcd \\
\hline & & F2 & $537 a b c$ & $4,59 \mathrm{abcd}$ \\
\hline & 1600 & F1 & $585 a b$ & $4,45 a b c d$ \\
\hline & & F2 & $767 a$ & $6,17 a$ \\
\hline & 3200 & F1 & $597 a b$ & 4,98abc \\
\hline & & F2 & $428 a b c$ & 3,77abcd \\
\hline & 6400 & F1 & $125 d$ & $1,50 \mathrm{e}$ \\
\hline & & F2 & $255 \mathrm{~cd}$ & $2,33 \mathrm{cde}$ \\
\hline \multirow[t]{2}{*}{$\mathrm{CO}$} & - & F1 & $660 a b$ & $5,58 \mathrm{ab}$ \\
\hline & - & F2 & $672 a b$ & 5,74ab \\
\hline
\end{tabular}

A: compost de alperujo; $\mathrm{A}+\mathrm{H}$ : compost de alperujo más hidrolizado

$P$ : nivel de significación. *** indica diferencias estadísticamente significativas a $P \leq 0,001$

Valores en columna sin letra común difieren estadísticamente a $P \leq 0,05$ (test de Student-Newman-Keuls) 
Por otra parte, cuando los tratamientos con MOS y fertilización mineral se compararon con los controles (Tablas 4.4 .12 y 4.4.13; Fotografía 4.4.1), no se observaron diferencias estadísticamente significativas en el peso seco de la biomasa de la parte aérea en el primer corte, mientras que en el resto de cortes para dicho parámetro, para la biomasa de las raíces, y para la biomasa total producida (planta entera) los tratamientos con la dosis de $200 \mathrm{mg} \mathrm{COT} / \mathrm{kg}$ de MOS (de A y A+H), fertilizados tanto con el programa estándar (F1) como el reducido (F2), generaron -como tendencia general- resultados iguales o superiores a los controles. Por otro lado, la aplicación de MOS a $6400 \mathrm{mg}$ COT/kg proporcionó un peso seco de la biomasa aérea en cada uno de los últimos tres cortes, de la biomasa aérea total, de la biomasa de las raíces, y de la biomasa total producida (planta entera) notablemente inferior a los controles y al resto de tratamientos con MOS, especialmente cuando la MOS procedía de A+H y se fertilizó, además, con el programa estándar (F1).

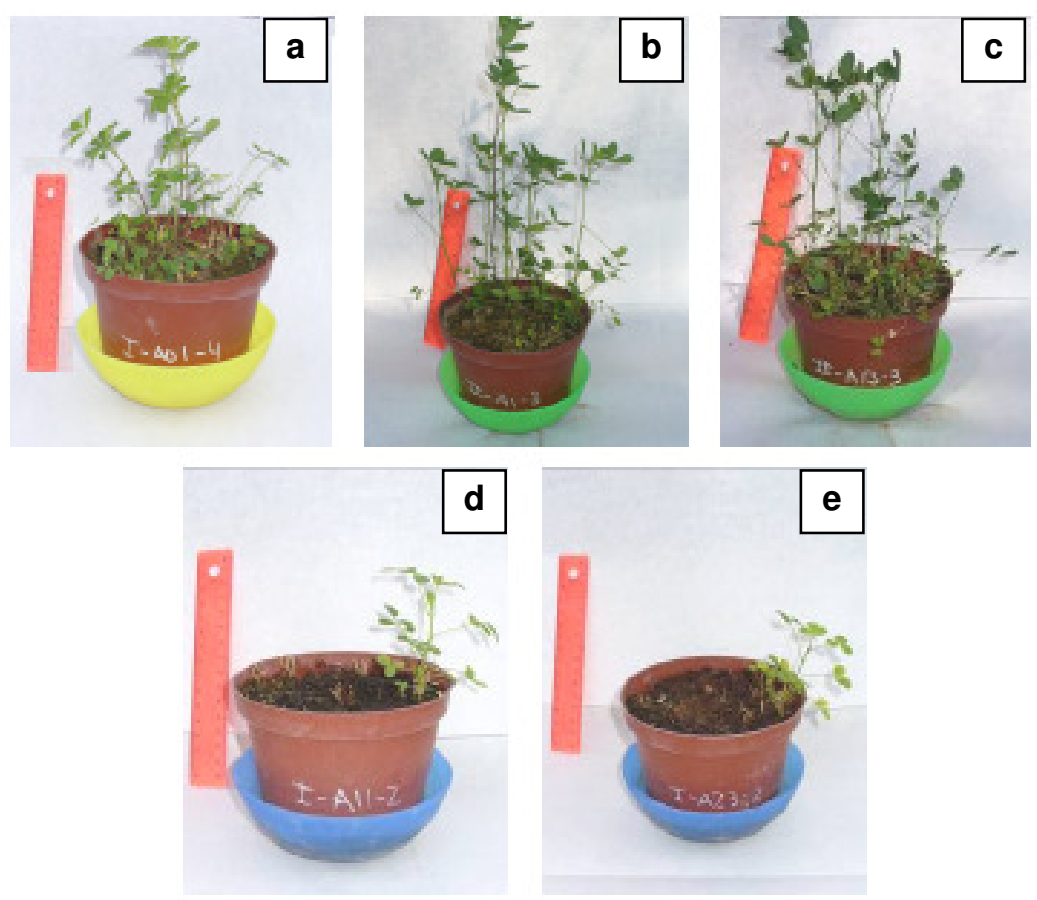

Fotografía 4.4.1. Crecimiento de plantas de alfalfa en maceta inmediatamente antes de realizar el cuarto corte (o siega) en el experimento de evaluación agronómica de la materia orgánica soluble (MOS) extraída de los composts $\mathrm{A}$ y $\mathrm{A}+\mathrm{H}$

a: control (que no recibió MOS) con el programa de fertilización mineral reducida, F2; b y c: tratamientos con la dosis mínima de MOS (200 mg carbono orgánico total/kg suelo) de $\mathrm{A}$ y $\mathrm{A}+\mathrm{H}$, respectivamente; d y e: tratamientos con la dosis máxima de MOS (6400 mg carbono orgánico total/kg suelo) de $\mathrm{A}$ y $\mathrm{A}+\mathrm{H}$, respectivamente. Los tratamientos con MOS recibieron el mismo programa de fertilización mineral que el control (F2) 
Tabla 4.4.11. Efectos principales de los tratamientos estudiados -Materia orgánica soluble (MOS) extraída del compost (A vs. A+H), Dosis de aplicación de la MOS (en mg de carbono orgánico total/kg de suelo) y Programa de fertilización mineral (estándar, F1 vs. reducida, F2) - sobre la acumulación y distribución de la biomasa producida (expresada en g de materia seca/contenedor) por Medicago sativa a lo largo del experimento

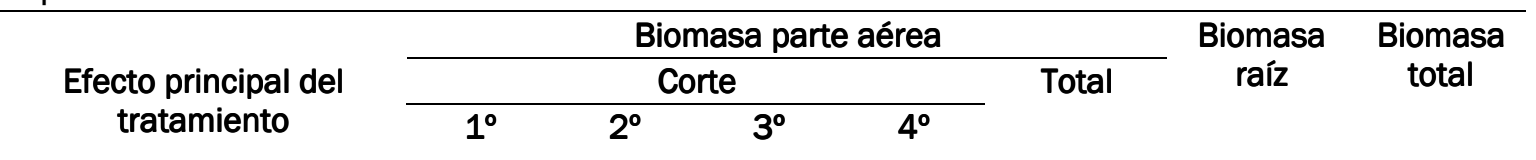

\section{Origen (compost) de la MOS}

$\begin{array}{lccccccc}\text { A } & 1,25 & 0,47 & 0,38 & 0,40 & 2,50 & 0,78 & 3,28 \\ \mathrm{~A}+\mathrm{H} & 1,30 & 0,48 & 0,38 & 0,40 & 2,56 & 0,73 & 3,29 \\ P & \mathrm{~ns} & \mathrm{~ns} & \mathrm{~ns} & \mathrm{~ns} & \mathrm{~ns} & \mathrm{~ns} & \mathrm{~ns}\end{array}$

\section{Dosis de MOS}

$\begin{array}{lccccccc}200 & 1,33 & 0,53 a & 0,49 a & 0,53 a & 2,88 a & 1,03 a & 3,91 a \\ 400 & 1,22 & 0,46 b & 0,40 b & 0,46 a b & 2,54 b & 0,79 b & 3,33 b \\ 800 & 1,22 & 0,46 b & 0,38 b & 0,40 b & 2,46 b & 0,75 b & 3,21 b \\ 1600 & 1,24 & 0,46 b & 0,43 b & 0,44 b & 2,57 b & 0,85 b & 3,42 b \\ 3200 & 1,35 & 0,54 a & 0,41 b & 0,39 b & 2,69 a b & 0,76 b & 3,45 b \\ 6400 & 1,32 & 0,39 c & 0,18 c & 0,16 c & 2,05 c & 0,34 c & 2,39 c \\ P & n s & * * * & * * * & * * * & * * * & * * * & * * *\end{array}$

\section{Fertilización mineral}

$\begin{array}{lccccccc}\text { F1 } & 1,27 & 0,47 & 0,37 & 0,38 & 2,49 & 0,75 & 3,24 \\ \text { F2 } & 1,29 & 0,48 & 0,39 & 0,42 & 2,58 & 0,76 & 3,34 \\ P & \text { ns } & \text { ns } & \text { ns } & \text { ns } & \text { ns } & \text { ns } & \text { ns }\end{array}$

\section{Interacción}

$1 \times 2$

$1 \times 3$

$2 \times 3$

$1 \times 2 \times 3$

$\begin{array}{lll}\text { ns } & * * & * \star \\ \text { ns } & \text { ns } & \text { ns } \\ \text { ns } & \text { ns } & \text { ns } \\ \text { ns } & \text { ns } & \text { ns }\end{array}$

\section{$* *+2$}

ns

$* *$

ns

$* *$
ns
ns
ns

ns

$\star \star$

ns ns

A: compost de alperujo; $\mathrm{A}+\mathrm{H}$ : compost de alperujo más hidrolizado

$P$ : nivel de significación. ns, ** y*** indican diferencias no significativas o estadísticamente significativas a $P \leq 0,01$ y $P \leq 0,001$, respectivamente

Valores en columna sin letra común difieren estadísticamente a $P \leq 0,05$ (test de Student-Newman-Keuls) 
Tabla 4.4.12. Influencia de la materia orgánica soluble (MOS) extraída de los composts $\mathrm{A}$ y $\mathrm{A}+\mathrm{H}$, la dosis de aplicación de ésta (en mg de carbono orgánico total/kg de suelo) y el programa de fertilización mineral (estándar, F1 y reducida, F2) en la acumulación de biomasa en la parte aérea de Medicago sativa (expresada en g de materia seca/contenedor) en los cuatros cortes efectuados $\left(1^{\circ}\right.$ a $\left.4^{\circ}\right)$ a lo largo del experimento. Comparación con los controles (CO, que no recibieron MOS)

\begin{tabular}{|c|c|c|c|c|c|c|}
\hline \multicolumn{2}{|c|}{ MOS } & \multirow{2}{*}{$\begin{array}{l}\text { Fertilización } \\
\text { mineral }\end{array}$} & \multicolumn{4}{|c|}{ Biomasa parte aérea } \\
\hline $\begin{array}{c}\text { Origen } \\
\text { (compost) }\end{array}$ & Dosis & & $1^{\circ}$ & $2^{\circ}$ & $3^{\circ}$ & $4^{\circ}$ \\
\hline \multirow[t]{12}{*}{ A } & 200 & F1 & 1,17 & 0,51abcdefgh & $0,46 a b c d$ & $0,55 a b c$ \\
\hline & & F2 & 1,38 & $0,53 a b c d e f$ & $0,51 a b$ & $0,56 a b c$ \\
\hline & 400 & $\mathrm{~F} 1$ & 1,17 & 0,44defghi & $0,35 \mathrm{de}$ & $0,35 \mathrm{ef}$ \\
\hline & & F2 & 1,22 & $0,47 \mathrm{bcdefgh}$ & $0,39 \mathrm{bcde}$ & $0,45 \mathrm{bcde}$ \\
\hline & 800 & F1 & 1,32 & 0,48 bcdefgh & $0,43 a b c d$ & $0,41 \mathrm{cdef}$ \\
\hline & & F2 & 1,23 & 0,49abcdefgh & $0,41 \mathrm{bcd}$ & $0,41 \mathrm{cdef}$ \\
\hline & 1600 & F1 & 1,16 & 0,45 cdefghi & $0,35 \mathrm{de}$ & $0,36 \mathrm{ef}$ \\
\hline & & F2 & 1,11 & $0,41 \mathrm{hij}$ & $0,40 \mathrm{bcd}$ & 0,36 def \\
\hline & 3200 & F1 & 1,28 & 0,53abcde & $0,43 a b c d$ & 0,49abcde \\
\hline & & F2 & 1,20 & 0,48abcdefgh & 0,39 cde & 0,38 def \\
\hline & 6400 & F1 & 1,34 & $0,47 \mathrm{bcdefgh}$ & $0,21 \mathrm{fg}$ & $0,14 \mathrm{gh}$ \\
\hline & & $\mathrm{F} 2$ & 1,44 & 0,42fghij & $0,27 \mathrm{ef}$ & $0,28 f g$ \\
\hline \multirow[t]{12}{*}{$A+H$} & 200 & $\mathrm{~F} 1$ & 1,29 & 0,52abcdefg & $0,49 a b c$ & 0,51abcde \\
\hline & & F2 & 1,45 & $0,56 a b$ & $0,51 \mathrm{abc}$ & $0,52 \mathrm{abcd}$ \\
\hline & 400 & $\mathrm{~F} 1$ & 1,38 & $0,47 \mathrm{bcdefgh}$ & $0,41 \mathrm{bcd}$ & $0,45 \mathrm{bcde}$ \\
\hline & & F2 & 1,10 & 0,49abcdefgh & $0,43 a b c d$ & $0,59 a b$ \\
\hline & 800 & $\mathrm{~F} 1$ & 1,11 & 0,45 cdefghi & $0,35 \mathrm{de}$ & $0,43 \mathrm{bcdef}$ \\
\hline & & F2 & 1,21 & 0,42ghij & $0,35 \mathrm{de}$ & $0,36 \mathrm{ef}$ \\
\hline & 1600 & $\mathrm{~F} 1$ & 1,24 & 0,45 cdefghi & $0,41 \mathrm{bcd}$ & $0,38 \mathrm{def}$ \\
\hline & & F2 & 1,43 & $0,54 a b c d$ & $0,55 a$ & $0,65 a$ \\
\hline & 3200 & $\mathrm{~F} 1$ & 1,40 & $0,56 a b c$ & $0,46 a b c d$ & 0,40cdef \\
\hline & & F2 & 1,56 & $0,59 a$ & $0,35 \mathrm{de}$ & $0,28 f g$ \\
\hline & 6400 & $\mathrm{~F} 1$ & 1,34 & 0,32j & $0,09 g$ & $0,07 \mathrm{~h}$ \\
\hline & & F2 & 1,13 & $0,34 \mathrm{ij}$ & $0,17 f g$ & $0,15 g h$ \\
\hline \multirow[t]{2}{*}{$\mathrm{CO}$} & - & $\mathrm{F} 1$ & 1,38 & 0,51abcdefgh & $0,44 a b c d$ & 0,50abcde \\
\hline & - & F2 & 1,12 & 0,43efghij & $0,40 \mathrm{bcd}$ & 0,50abcde \\
\hline$P$ & & & ns & $* * *$ & $* * *$ & $* * *$ \\
\hline
\end{tabular}

A: compost de alperujo; $\mathrm{A}+\mathrm{H}$ : compost de alperujo más hidrolizado

$P$ : nivel de significación. ns $y * * *$ indican diferencias no significativas 0 estadísticamente significativas a $P \leq 0,001$, respectivamente

Valores en columna sin letra común difieren estadísticamente a $P \leq 0,05$ (test de Student-Newman-Keuls) 
Tabla 4.4.13. Influencia de la materia orgánica soluble (MOS) extraída de los composts $\mathrm{A}$ y $\mathrm{A}+\mathrm{H}$, la dosis de aplicación de ésta (en mg de carbono orgánico total/kg de suelo) y el programa de fertilización mineral (estándar, F1 y reducida, F2) en la acumulación y distribución de la biomasa producida (expresada en g de materia seca/contenedor) por Medicago sativa en el experimento. Comparación con los controles (CO, que no recibieron MOS)

\begin{tabular}{|c|c|c|c|c|c|}
\hline \multicolumn{2}{|l|}{ MOS } & \multirow{2}{*}{$\begin{array}{l}\text { Fertilización } \\
\text { mineral }\end{array}$} & \multicolumn{3}{|c|}{ Biomasa } \\
\hline Origen (compost) & Dosis & & Parte aérea & Raíz & Total \\
\hline \multirow[t]{12}{*}{ A } & 200 & F1 & 2,68abcdef & $1,09 a$ & 3,77abcde \\
\hline & & $\mathrm{F} 2$ & $2,98 a b c$ & $1,02 a b c$ & 4,00abc \\
\hline & 400 & F1 & 2,31 efgh & 0,69defg & $3,00 f g$ \\
\hline & & F2 & 2,53cdefg & 0,83 abcdef & $3,36 \mathrm{cdef}$ \\
\hline & 800 & F1 & 2,64bcdefg & 0,93 abcde & 3,57 abcdef \\
\hline & & $\mathrm{F} 2$ & $2,54 \mathrm{cdefg}$ & $0,78 \mathrm{bcdefg}$ & 3,32cdef \\
\hline & 1600 & F1 & 2,32efgh & 0,74cdefg & $3,06 \mathrm{efg}$ \\
\hline & & $\mathrm{F} 2$ & 2,29fghi & $0,80 a b c d e f$ & 3,09defg \\
\hline & 3200 & F1 & 2,74abcdef & $0,89 a b c d e$ & 3,63abcdef \\
\hline & & $\mathrm{F} 2$ & $2,45 \mathrm{defg}$ & $0,73 \mathrm{cdefg}$ & 3,18defg \\
\hline & 6400 & F1 & 2,15ghi & 0,36hij & $2,51 \mathrm{gh}$ \\
\hline & & F2 & $2,42 \mathrm{defg}$ & 0,50ghi & $2,92 \mathrm{fg}$ \\
\hline \multirow[t]{12}{*}{$\mathrm{A}+\mathrm{H}$} & 200 & F1 & 2,82abcde & 0,94abcde & 3,76abcde \\
\hline & & $\mathrm{F} 2$ & $3,04 a b$ & $1,06 a b$ & $4,10 a b$ \\
\hline & 400 & F1 & $2,70 a b c d e f$ & 0,82 abcdef & 3,52abcdef \\
\hline & & F2 & $2,60 \mathrm{bcdefg}$ & 0,81 abcdef & $3,41 \mathrm{bcdef}$ \\
\hline & 800 & F1 & 2,34defg & 0,67 efg & $3,01 \mathrm{fg}$ \\
\hline & & F2 & 2,33defgh & 0,65efgh & $2,98 f g$ \\
\hline & 1600 & F1 & 2,49 cdefg & 0,87 abcdef & $3,36 \mathrm{cdef}$ \\
\hline & & $\mathrm{F} 2$ & $3,18 a$ & $0,99 a b c d$ & $4,17 a$ \\
\hline & 3200 & F1 & 2,81abcde & 0,83 abcdef & $3,64 a b c d e f$ \\
\hline & & F2 & 2,77abcdef & 0,58fghi & $3,35 \mathrm{cdef}$ \\
\hline & 6400 & F1 & $1,83 \mathrm{hi}$ & $0,17 j$ & $2,00 \mathrm{~h}$ \\
\hline & & $\mathrm{F} 2$ & $1,80 \mathrm{i}$ & $0,35 \mathrm{ij}$ & $2,15 \mathrm{~h}$ \\
\hline \multirow[t]{2}{*}{$\mathrm{CO}$} & - & F1 & 2,83abcd & $0,97 \mathrm{abcd}$ & 3,80abcd \\
\hline & - & $\mathrm{F} 2$ & 2,45defg & 0,86 abcdef & 3,31cdef \\
\hline
\end{tabular}

A: compost de alperujo; $\mathrm{A}+\mathrm{H}$ : compost de alperujo más hidrolizado

$P$ : nivel de significación. *** indica diferencias estadísticamente significativas a $P \leq 0,001$

Valores en columna sin letra común difieren estadísticamente a $P \leq 0,05$ (test de Student-Newman-Keuls) 
El mecanismo de acción de las sustancias húmicas puede estar relacionado, por una parte, con efectos directos de éstas, que resultan en un incremento de la fotosíntesis, la síntesis de proteínas y la permeabilidad de las membranas celulares de la raíz, provocando un efecto similar a las hormonas vegetales; y por otra, con efectos indirectos, de solubilización de macro- y micro-elementos, e incremento del metabolismo microbiano, entre otros (Arancon et al., 2006; Chen y Aviad, 1990; Valdrighi et al., 1996). Por tanto, el incremento del desarrollo de las plantas y la productividad tras la aplicación de productos orgánicos líquidos al suelo se debe a mecanismos distintos a un mero suministro de nutrientes (Senesi, 1989).

Diversos autores han indicado que la aplicación de sustancias húmicas en presencia de niveles de fertilización mineral adecuados influye positivamente en el crecimiento vegetal (Chen y Aviad, 1990), observándose generalmente un efecto más marcado sobre el crecimiento radical -produciéndose además proliferación de raíces laterales- que sobre el desarrollo de la parte aérea (Arancon et al., 2006; Atiyeh et al., 2002; Canellas et al., 2002; Eyheraguibel et al., 2008; Rodda et al., 2006).

Los efectos de las sustancias húmicas sobre los cultivos descritos en la literatura se manifiestan en: la estimulación de la germinación de las semillas; la acumulación de biomasa y nitrógeno; el incremento en la absorción de nutrientes; el aumento de la biosíntesis de proteínas y glúcidos, de la fotosíntesis y de la respiración; y, finalmente, efectos de detoxificación y adaptación a factores abióticos perjudiciales (exceso de nutrientes minerales, salinidad, estrés hídrico, $\mathrm{pH}$ desfavorable, presencia de xenobióticos, etc.) (Kulikova et al., 2005). Con relación al efecto directo de las sustancias húmicas sobre el metabolismo vegetal, los compuestos húmicos de bajo peso molecular pueden penetrar en las plantas cuando éstos se aplican por vía radical o bien por vía foliar (Kulikova et al., 2005; Nardi et al., 2002; Quaggiotti et al., 2004). A pesar de que los mecanismos precisos por los que las sustancias húmicas influyen en la fisiología de la planta son relativamente desconocidos, numerosos trabajos sugieren la participación de actividades tanto de tipo hormonal (Kulikova et al., 2005; Quaggiotti et al., 2004; Trevisan et al., 2010) como de la $\mathrm{H}^{+}$-ATPasa de la membrana plasmática, enzima responsable del transporte de protones al apoplasto celular (Canellas et al., 2002; Pinton et al., 2009).

Respecto a otros experimentos de aplicación de sustancias húmicas, Valdrighi et al. (1996) indicaron que la incorporación al suelo de ácidos húmicos extraídos de un 
compost de origen vegetal incrementó el crecimiento de endivia cuando éstos se aplicaron a una dosis igual o superior a $1000 \mathrm{mg} / \mathrm{kg}$ de suelo. Por otro lado, Arancon et al. (2003) y Atiyeh et al. (2002) observaron un aumento en el crecimiento de las plántulas de diferentes especies hortícolas al aplicar una concentración de ácidos húmicos de 50 a $500 \mathrm{mg} / \mathrm{kg}$ de sustrato, mientras que las dosis comprendidas entre 500 y 1000 mg/kg inhibían significativamente el desarrollo vegetal. Selim et al. (2009) aplicaron sustancias húmicas a un suelo salino cultivado con patata a dosis de 187,5 y $375 \mathrm{mg} / \mathrm{kg}$ de suelo, encontrando un incremento en el crecimiento y la calidad de los tubérculos, así como en la concentración de macro- y micro-elementos en el suelo tras el cultivo, especialmente con la dosis de $375 \mathrm{mg} / \mathrm{kg}$ de suelo.

De manera similar al experimento descrito en esta Tesis, Caravaca et al. (2006) y Kohler et al. (2008) extrajeron -con KOH- la materia orgánica soluble de un compost preparado con alperujo y estiércol de vaca, utilizando la materia orgánica así extraída como producto fertilizante líquido, que aplicaron en dosis equivalentes a 0, 50, 100 y $300 \mathrm{mg}$ de COT/kg de sustrato (suelo+vermiculita) en cultivos de Retama sphaerocarpa y Medicago sativa, respectivamente. En ambos experimentos se observó que la aplicación de materia orgánica soluble incrementó significativamente la biomasa aérea producida, pero no se encontraron diferencias entre las dosis empleadas; en adición, la incorporación de materia orgánica soluble no provocó cambios en las características físico-químicas y químicas de los sustratos (suelo+vermiculita) utilizados.

Los resultados encontrados a lo largo del experimento de aplicación de MOS extraída en medio alcalino de los composts $A$ y $A+H$ en esta Tesis pusieron de manifiesto la disminución en el desarrollo de la Medicago sativa a partir del segundo corte (siega de la parte aérea) con la aplicación de la MOS a concentración elevada, llegándose incluso a producir la muerte de algunas plantas. Este efecto fitotóxico de la dosis de MOS más elevada podría deberse al incremento en la salinidad del suelo producido por el aporte de sales en exceso asociado a la aplicación de la MOS (que se extrajo con $\mathrm{KOH} 1 \mathrm{M}$ ), tal y como se indica más adelante (sección 4.4.2). Por otro lado, la aplicación de MOS - procedente de cualquiera de los dos composts- a la dosis mínima (200 mg COT/kg) en combinación con la fertilización mineral reducida (F2) incrementó el valor de los parámetros de desarrollo y producción de biomasa estudiados en comparación con los controles que no recibieron MOS. 
A la vista de los resultados obtenidos, en nuestro experimento sólo se puso de manifiesto el efecto beneficioso -esperable- de la adición de MOS cuando ésta se administró a las dosis más bajas junto con el programa de fertilización reducida, condiciones que evitaron un incremento significativo en la salinidad del suelo (ver la sección 4.4.2). En dichas condiciones, el efecto estimulador sobre la acumulación de biomasa producido por la MOS no parece ser de naturaleza nutricional, ya que no se encontraron diferencias significativas debidas al programa de fertilización aplicado, por lo que habría que investigar un efecto directo, estimulador del crecimiento para entender la respuesta de la planta. Probablemente, y de haberse seguido un procedimiento de extracción de la MOS más suave, con una disolución de $\mathrm{KOH}$ de menor concentración que la utilizada, el producto a estudiar hubiera presentado una concentración salina comparativamente inferior para la misma concentración de carbono orgánico total (COT), pudiéndose aplicar, por tanto, a dosis más elevadas sin llegar a manifestarse los efectos fitotóxicos registrados en el presente experimento.

No obstante lo anterior, la obtención de resultados con alto grado de variabilidad, que no revelan una tendencia clara en la respuesta de las plantas a la aplicación de MOS, es un rasgo característico de los experimentos realizados con productos orgánicos líquidos, impidiendo así que el alcance de los resultados encontrados pueda generalizarse a condiciones (sistemas suelo-planta) diferentes a las estudiadas (Senesi et al., 2007). En relación con esto, Senesi (1989), Kulikova et al. (2005), y Trevisan et al. (2010) indicaron que la variabilidad en los resultados obtenidos puede radicar en la amplia diversidad encontrada en: la composición y características del material orgánico utilizado, la dosis aportada, el método de aplicación empleado, las características del suelo, los requerimientos de la especie cultivada, y las condiciones geoclimáticas, entre otros factores. En el caso del uso de sustancias húmicas extraídas de materiales (residuos) orgánicos tratados y estabilizados, hay que añadir además la contribución del proceso de tratamiento utilizado (compostaje o vermicompostaje) como fuente de variabilidad adicional del propio procedimiento empleado para extraer la materia orgánica soluble (Atiyeh et al., 2002). 


\subsubsection{Efecto conjunto de la materia orgánica soluble (MOS) y el cultivo de Medicago sativa sobre las características físico-químicas y químicas del suelo}

En base a que los resultados de los análisis estadísticos realizados para evaluar los efectos de los programas de fertilización mineral estándar (F1) y reducida (F2) sobre el desarrollo y la producción de Medicago sativa revelaron que no existieron diferencias significativas entre ambos programas de abonado, las determinaciones realizadas para estudiar las características físico-químicas y la composición del suelo tras el cuarto y último corte de alfalfa se llevaron a cabo solamente sobre las muestras a las que se aplicó la fertilización reducida (F2). En la Tabla 4.4.14 se presentan los parámetros físico-químicos y químicos determinados en las muestras de suelo indicadas, tomadas al finalizar el experimento.

El valor de pH del suelo fue ligeramente más alto cuando se aplicó MOS extraída de A, mientras que la conductividad eléctrica (CE) fue superior en el suelo al que se aportó MOS procedente de $\mathrm{A}+\mathrm{H}$. Respecto al factor Dosis de MOS, los valores de $\mathrm{pH}$ y CE obtenidos fueron generalmente tanto más elevados cuanto mayor fue la dosis de MOS aplicada.

La comparación con los controles (Tabla 4.4.15) mostró que las dosis de 3200 y $6400 \mathrm{mg}$ COT/kg de MOS extraída de A y la de $6400 \mathrm{mg}$ COT/kg de MOS procedente de $\mathrm{A}+\mathrm{H}$ incrementaron el $\mathrm{pH} ; \mathrm{y}$, que las dosis comprendidas entre 1600 y $6400 \mathrm{mg}$ COT/kg de MOS de A+H, y las de 3200 y 6400 mg COT/kg de MOS de A, aumentaron la CE.

Con relación a las características químicas (composición) del suelo, se apreció que los niveles de carbono orgánico (Corg) fueron superiores cuando se aplicó MOS de A, mientras que los de potasio, calcio y sodio fueron mayores cuando se aportó MOS de $\mathrm{A}+\mathrm{H}$. Al aplicar las dosis crecientes de MOS se observó un incremento gradual en el nivel de potasio, mientras que los contenidos de Corg, nitrógeno mineral (Nmin) y fósforo aumentaron de manera más marcada cuando la MOS se añadió a las dosis más elevadas, particularmente 3200 y 6400 mg COT/kg.

Con referencia al resto de nutrientes estudiados, la aplicación de la dosis máxima de MOS provocó una disminución significativa del contenido en magnesio, mientras que incrementó el nivel de sodio. 


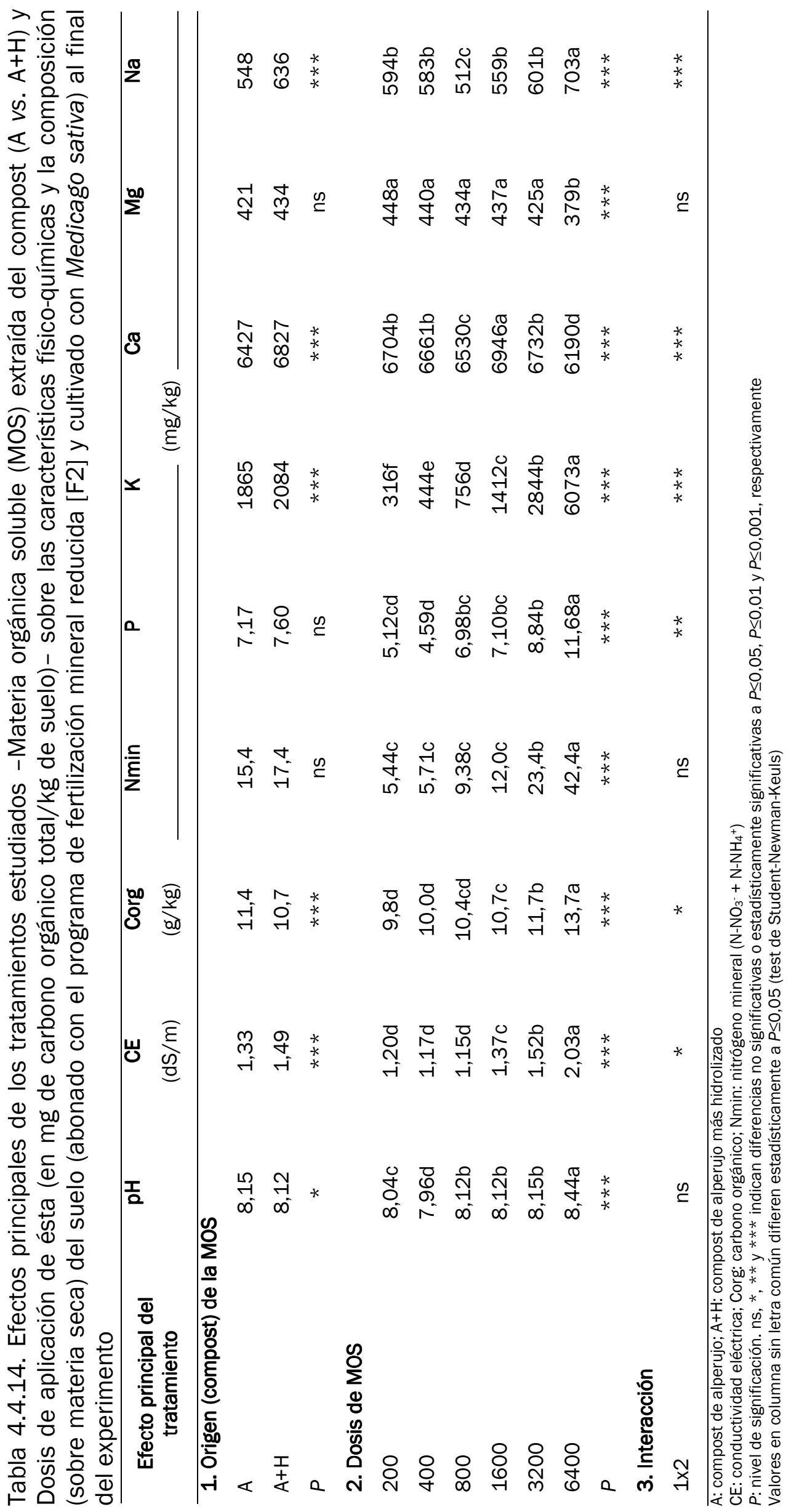




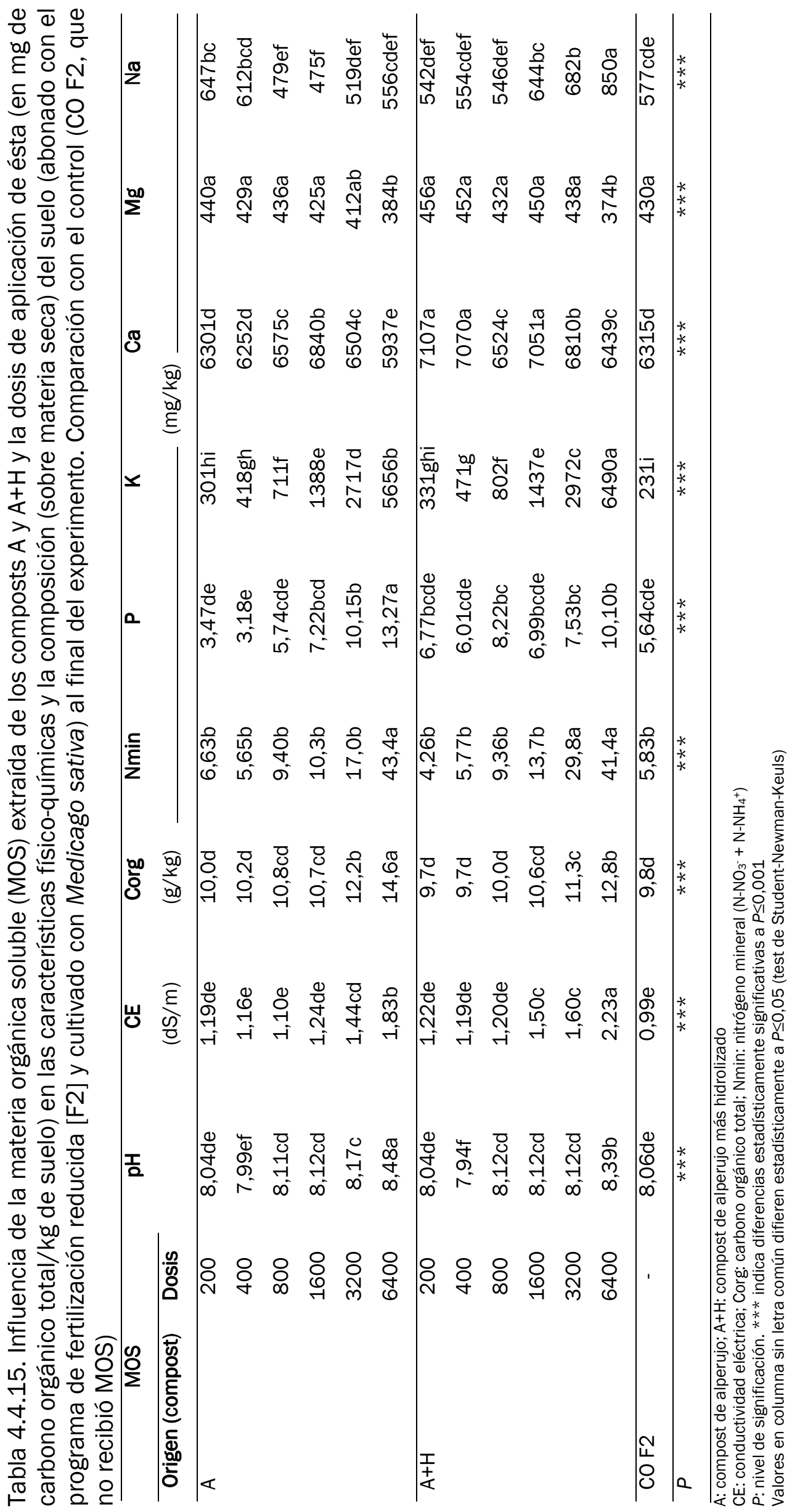


El análisis de la varianza realizado para comparar los tratamientos que recibieron MOS y el control (CO F2) sin aporte orgánico (Tabla 4.4.15) reveló que la aplicación de MOS extraída de los dos composts elevó marcadamente el contenido de potasio asimilable en comparación con los otros elementos estudiados, siendo este efecto de mayor magnitud cuando la cantidad de MOS añadida fue más elevada. Por otro lado, la aplicación de MOS a la dosis de 6400 mg COT/kg aumentó notablemente los niveles de Corg, Nmin, y fósforo, pero disminuyó la concentración de magnesio. Asimismo, la dosis de $3200 \mathrm{mg}$ COT/kg de MOS extraída de A aumentó el contenido en Corg y fósforo, mientras que la MOS procedente de $\mathrm{A}+\mathrm{H}$ aplicada a la misma dosis se tradujo en un aumento tanto en el nivel de Corg como en el de Nmin. También se observaron aumentos en el contenido en calcio, que, aunque no fueron de gran magnitud, fueron significativos para la mayoría de las dosis de MOS aplicadas, especialmente las de $\mathrm{A}+\mathrm{H}$. Adicionalmente, el contenido en sodio sufrió un aumento tras la aplicación de MOS de A+H a las dosis equivalentes a 3200 y 6400 mg COT/kg.

\subsubsection{Efecto de la materia orgánica soluble (MOS) sobre las características físico- químicas y químicas del suelo no cultivado}

Con el fin de evitar la interferencia del cultivo de Medicago sativa, se realizó un experimento adicional con el suelo desnudo, no cultivado, aplicándose al mismo las MOS y las dosis de éstas indicadas al principio de esta sección 4.4 de Resultados y Discusión, estudiándose así un total de 12 tratamientos (2 orígenes [composts]) de la MOS, A vs. A+H x 6 dosis de MOS, 200-6400 mg COT/kg). Adicionalmente se incluyó un control que no recibió aporte de materia orgánica. Todos los tratamientos experimentales estudiados -con aplicación de MOS y control- recibieron únicamente el programa de fertilización mineral reducida F2.

En las Tablas 4.4.16 y 4.4 .17 se recogen los resultados del análisis factorial de la varianza correspondientes a las características físico-químicas y químicas del suelo al finalizar el experimento, y la comparación de los tratamientos que recibieron MOS y el control (CO F2) sin aporte orgánico, respectivamente. Respecto a las propiedades físico-químicas, no se observaron diferencias significativas en el $\mathrm{pH}$ ni en la conductividad eléctrica (CE) entre las dos MOS estudiadas, lo que podría estar relacionado con los valores similares de $\mathrm{pH}$ y CE de las dos MOS aplicadas (alrededor de 13,2 unidades y 51,7 dS/m, respectivamente; ver Materiales y Métodos, sección 3.1.1). Por otra parte, la adición de dosis crecientes de MOS se tradujo en niveles de 


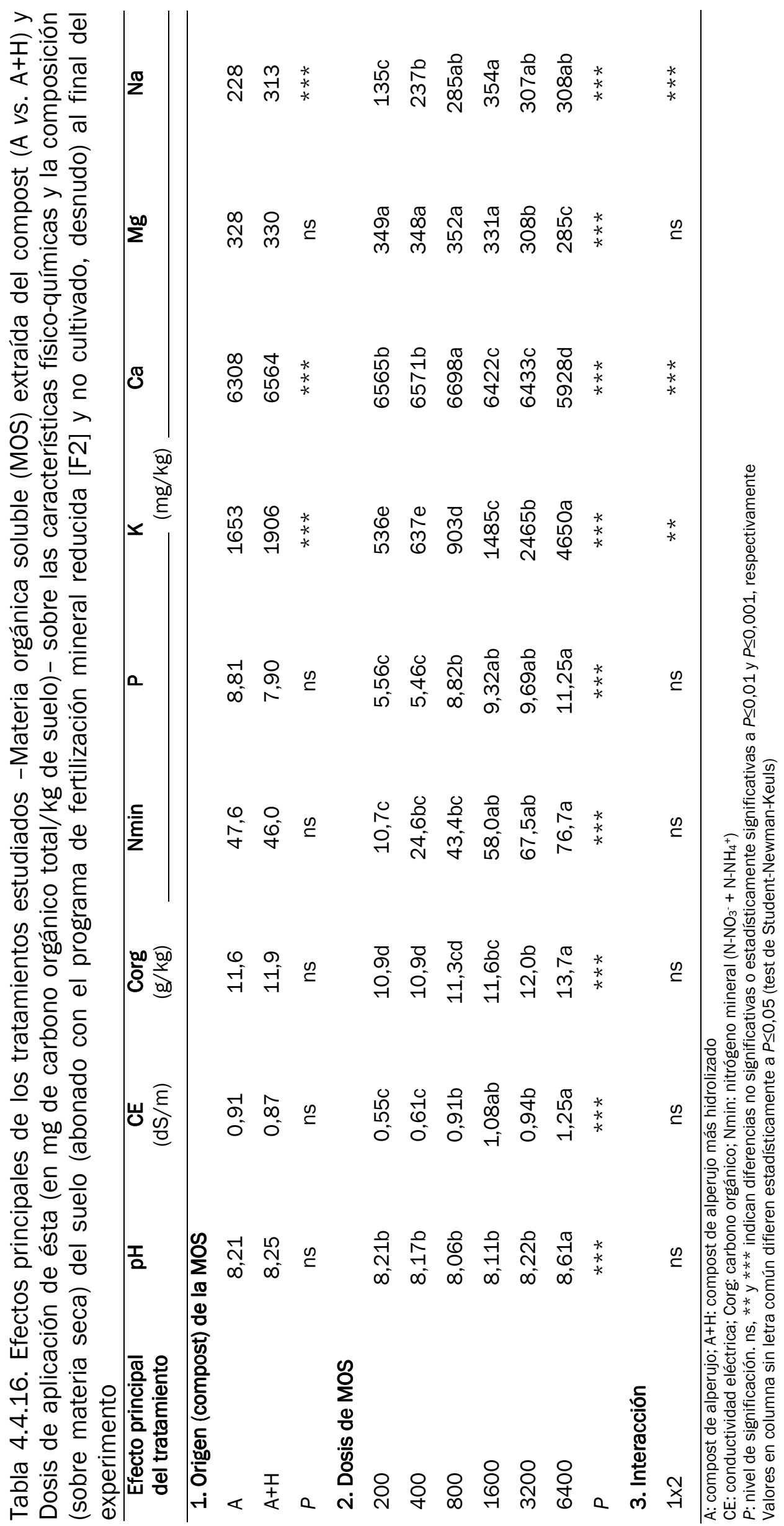




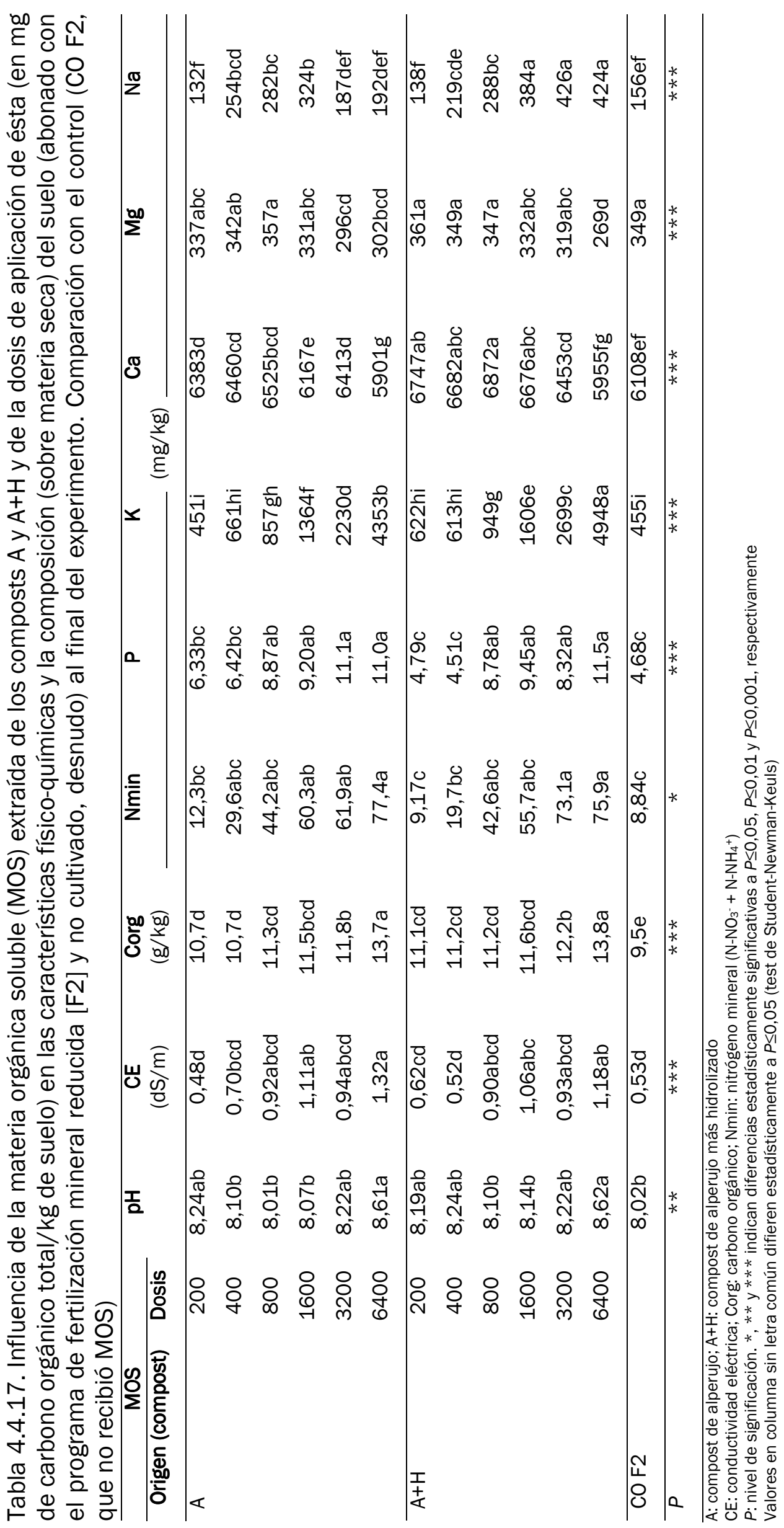


pH y CE comparativa y significativamente superiores al aplicar la dosis máxima (6400 mg COT/kg), obteniéndose valores de 8,61 unidades y 1,25 dS/m para el pH y la CE, respectivamente. En general, cuanto mayor fue la dosis de MOS aplicada tanto más elevada fue la CE del suelo, registrándose un incremento de 0,70 dS/m entre las dosis mínima y máxima, es decir entre 200 y 6400 mg COT/kg.

Con relación al resto de parámetros estudiados, los niveles de carbono orgánico (Corg), nitrógeno mineral (Nmin), fósforo y magnesio no difirieron significativamente cuando se estudió el factor Origen (compost) de la MOS, mientras que el suelo al que se había aplicado MOS de A+H mostró niveles superiores de potasio, calcio y sodio en comparación con el que recibió MOS de A. En cuanto al efecto del factor Dosis de MOS, los resultados obtenidos revelaron una tendencia al aumento progresivo en la concentración de Nmin, fósforo, potasio y sodio, así como una disminución de los niveles de calcio y magnesio, según se incrementó la dosis de MOS.

El estudio comparativo de los tratamientos a los que se adicionó MOS y los controles sin incorporación de materia orgánica (Tabla 4.4.17) reveló que la aplicación de MOS aumentó de manera altamente significativa el pH y la CE del suelo, particularmente en los tratamientos correspondientes a la dosis máxima añadida. De manera similar, el contenido de Corg del suelo aumentó cuando se incrementó la dosis de MOS aplicada. En el caso de Nmin, todos los tratamientos estudiados mostraron un contenido superior al control, aunque sólo se observaron diferencias significativas con las dosis equivalentes a 3200 y $6400 \mathrm{mg}$ COT/kg para ambas MOS (de $\mathrm{A}$ y $\mathrm{A}+\mathrm{H}$ ) y, adicionalmente, con la dosis de $1600 \mathrm{mg}$ COT/kg para la MOS de A. La aplicación de MOS incrementó notablemente el contenido de potasio asimilable del suelo, difiriendo del control las dosis superiores a 800 mg COT/kg; por el contrario, la adición de MOS se tradujo en una disminución en la concentración de magnesio cuando se aplicó a la dosis más alta y, en el caso de la MOS extraída de A, también con la dosis de $3200 \mathrm{mg}$ COT/kg. En general, los niveles de calcio del suelo con MOS de $\mathrm{A}+\mathrm{H}$ fueron superiores a los controles; con relación al sodio, los tratamientos a los que se aplicó MOS de $\mathrm{A}+\mathrm{H}$ mostraron un incremento en su concentración en función de la dosis añadida. En contraste con lo anterior, los suelos que recibieron MOS de A no mostraron un patrón de comportamiento definido cuando se estudió su contenido en calcio y sodio. El aumento en la concentración de sodio en el suelo en que se aplicó MOS de $\mathrm{A}+\mathrm{H}$ pudo estar relacionado con el mayor contenido de este elemento en la MOS extraída de A+H en comparación con A (ver la sección 3.1.1). 


\subsubsection{Comparación de las características físico-químicas y químicas entre el suelo cultivado y el no cultivado}

Con la finalidad de estudiar la interacción de la aplicación de MOS y el cultivo de Medicago sativa sobre la fertilidad del suelo, se analizó conjuntamente la influencia de los factores Origen (compost) de la MOS, Dosis de MOS y Cultivo (presente, + vs. ausente, -) en las características físico-químicas y químicas del suelo, tal y como se presenta en la Tabla 4.4.18.

Merece destacarse que la MOS extraída del compost A elevó ligeramente el contenido de carbono orgánico (Corg) en comparación con $\mathrm{A}+\mathrm{H}$, mientras que la MOS procedente de este último incrementó la concentración de potasio, calcio y sodio.

En general, el factor Dosis de MOS se tradujo en un aumento progresivo en los valores de $\mathrm{pH}, \mathrm{CE}$, Corg, nitrógeno mineral (Nmin), fósforo, potasio y sodio paralelo al incremento en la dosis de MOS aplicada, siendo las diferencias entre las distintas dosis estudiadas comparativamente superiores en el contenido de potasio. El efecto contrario, aunque no tan marcado, se observó en los niveles de calcio y magnesio, registrándose una disminución para calcio con la dosis máxima y con las dosis de 3200 y 6400 mg COT/kg para magnesio.

Por otra parte, el suelo no cultivado (-) presentó valores más altos de pH, Corg, Nmin y fósforo, mientras que el suelo cultivado con Medicago sativa (+) mostró resultados de mayor magnitud para CE, potasio, calcio, magnesio y sodio. En este contexto, el efecto estimulador del desarrollo vegetal provocado por la aplicación de MOS se relaciona comúnmente con un aumento en la absorción de macronutrientes por la planta, destacándose como patrón general un incremento en la absorción de fósforo y potasio. En adición, se considera que la MOS mejora la disponibilidad del hierro para la planta, al contribuir a la formación de complejos (quelatos) de hierro y mantener así a este elemento soluble y/o en formas disponibles (Abad et al., 1991; Varanini y Pinton, 2006). La capacidad de la MOS para formar complejos de hierro influye, a su vez, en la nutrición fosfatada, al facilitar la fijación reversible de los iones fosfato a las sustancias húmicas a través de "puentes" de hierro y poner así dichos iones fosfato más fácilmente a disposición de la planta (Varanini y Pinton, 2006). Asimismo, debe tomarse también en consideración que la adición de MOS afecta a la absorción de algunos elementos nutritivos por la planta, al influir positivamente en la tasa de liberación de elementos minerales fijados en el suelo, como por ejemplo 


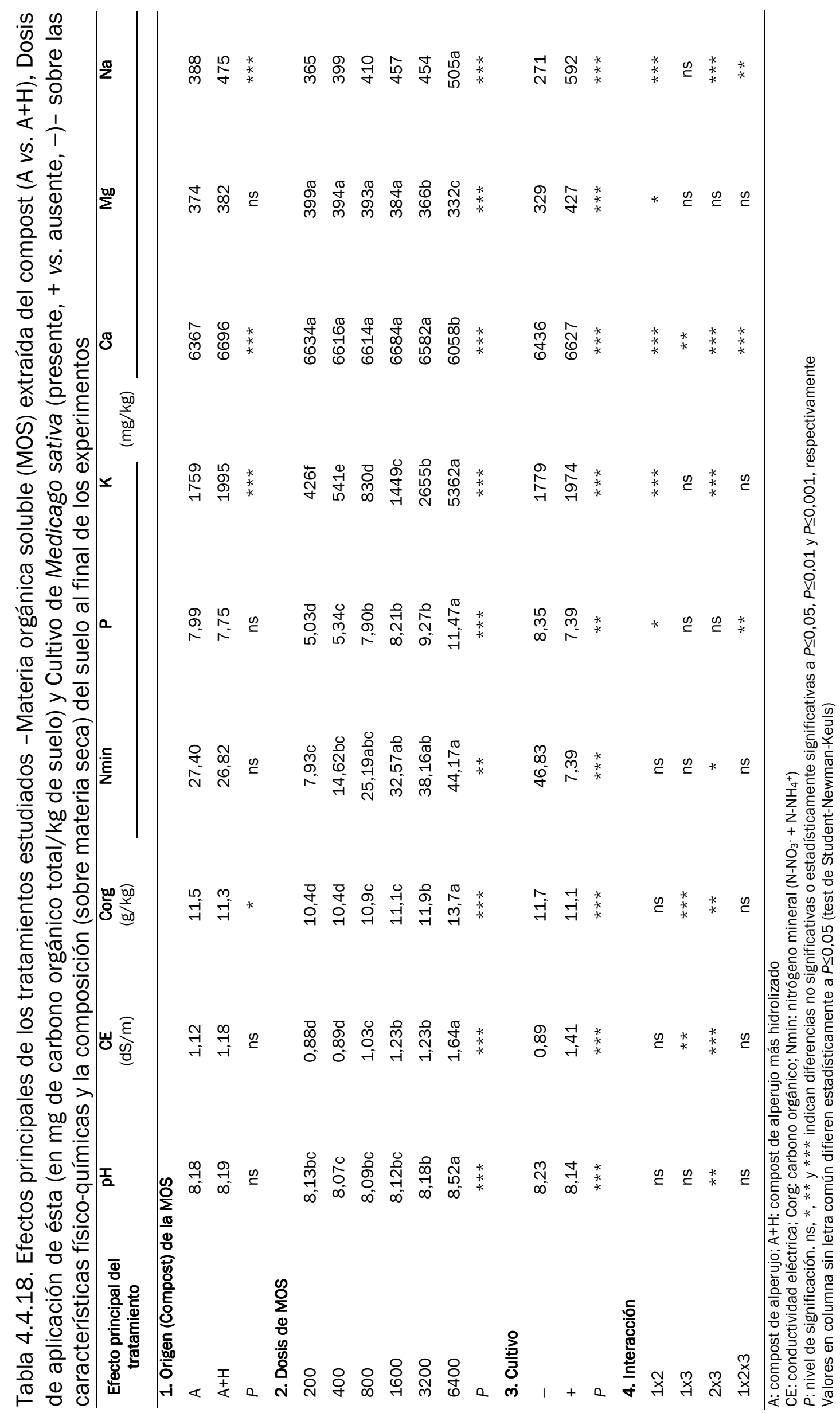


potasio (Chen y Aviad, 1990). En esta Tesis, el menor contenido en nitrógeno y en fósforo encontrado en el suelo cultivado debería responder a su incorporación en la biomasa vegetal. A su vez, el sistema radical de las plantas estimuló probablemente la actividad microbiana del suelo, que podría así mineralizar parte de la materia orgánica de éste, disminuyendo por tanto su contenido en Corg. Respecto al potasio, calcio y magnesio (que son también absorbidos por las plantas), y al estar éstos presentes en los dos suelos estudiados (cultivado y no cultivado) en gran cantidad, es difícil interpretar qué parte pudo haberse incorporado en la biomasa vegetal y qué fracción pudo perderse por lixiviación con los riegos. Por último, el sodio -que no es absorbido por las plantas- apareció en mayor cantidad en el suelo cultivado que en el no cultivado; esta situación podría interpretarse, de acuerdo con lo indicado anteriormente, porque su pérdida por lixiviación fue comparativamente inferior cuando hubo plantas presentes, absorbiendo y transpirando agua del suelo a lo largo del periodo de crecimiento.

De acuerdo con los resultados hasta aquí presentados, se puede concluir que, de los tres factores estudiados -Origen (compost) de la MOS, Dosis de aplicación de ésta, y Programa de fertilización mineral-, la dosis de aplicación de la MOS fue el que tuvo efectos más consistentes y significativos sobre los parámetros determinados en el cultivo y en los suelos, observándose una respuesta diferencial a las distintas dosis aplicadas y registrándose los mejores resultados con las dosis bajas de MOS, es decir las comprendidas en el intervalo 200-3200 mg de carbono orgánico total/kg de suelo, especialmente con $200 \mathrm{mg}$ COT/kg, de acuerdo con el rango de dosis utilizadas en esta Memoria.

Finalmente, las investigaciones sobre el uso eficiente de MOS, tanto desde el punto de vista agronómico como medioambiental, requerirían la estandarización de los procedimientos experimentales a utilizar para alcanzar este objetivo y la realización de análisis que proporcionasen información molecular, estructural y funcional de la fracción húmica de la MOS, para poder complementar los estudios de evaluación agronómica realizados y establecer así criterios consistentes con respecto al alcance de los efectos de la MOS sobre el sistema suelo-planta. 


\subsection{EVALUACIÓN DE LAS PROPIEDADES SUPRESIVAS DE LOS COMPOSTS A Y $A+H$ MEDIANTE ESTUDIOS IN VITRO E IN VIVO}

Existe actualmente un interés creciente por utilizar alternativas a las estrategias convencionales de control de las enfermedades de los cultivos (variedades resistentes y productos fitosanitarios de síntesis, principalmente), habiéndose propuesto para tal fin el uso de composts y otros materiales orgánicos (Bonanomi et al., 2010; Martin, 2003). De este modo, la sustitución total o parcial de turba Sphagnum por compost en los sustratos de cultivo permitiría obtener no sólo beneficios económicos y ambientales debido a la reducción en el consumo de turba, sino también un incremento en el valor añadido de dichos composts derivado del control de agentes fitopatógenos (Loffredo y Senesi, 2009). De acuerdo con todo lo anterior, se ha estudiado la utilización de composts de diferentes orígenes y características, aplicados como enmiendas del suelo o sustratos de cultivo, con objeto de evaluar la supresividad potencial de estos materiales frente a distintos agentes fitopatógenos pertenecientes a diversos géneros, tales como Pythium, Phytophthora, Rhizoctonia y Fusarium, entre otros (Borrero et al., 2004; Cotxarrera et al., 2002; Scheuerell et al., 2005; Termorshuizen et al., 2006).

La actividad supresiva se ha atribuido fundamentalmente a la presencia en los composts de microorganismos antagonistas de los agentes fitopatógenos, como determinadas bacterias de los géneros Bacillus y Streptomyces, u hongos de los géneros Glyocladium y Trichoderma, entre otros (Siddiqui et al., 2008; Trillas et al., 2006). Sin embargo, la supresividad suele ser generalmente un efecto poco consistente e impredecible, dificultando el uso de composts en la práctica y motivando así la búsqueda de parámetros que sirvan para predecir el uso de dichos materiales para inhibir el desarrollo de enfermedades (Janvier et al., 2007; Noble y Coventry, 2005). Bonanomi et al. (2010) encontraron una estrecha relación entre las actividades enzimáticas y microbiológicas de los composts y la inhibición de agentes fitopatógenos, pero no observaron efectos consistentes del grado de descomposición ni de otras propiedades físicas y químicas de dichos composts sobre la supresividad. Entre los parámetros biológicos y bioquímicos más relacionados con la inhibición de enfermedades, destacan la hidrólisis del diacetato de fluoresceína y la respiración y biomasa microbiana. No obstante, la complejidad de los mecanismos de supresividad de los composts sugiere que la predicción de los efectos supresivos debe evaluarse 
mediante el uso simultáneo de diversos parámetros, que pueden variar en función del patógeno estudiado.

Algunos autores han realizado experimentos con alpechín fresco y desecado (Bonanomi et al., 2006; Kotsou et al., 2004), pero los estudios sobre las propiedades supresivas de composts de residuos de almazara son todavía muy escasos. En este contexto, Aviani et al. (2010) observaron -en la infección de plantas de melón por Fusarium oxysporum f. sp. melonis- efectos supresivos en sustratos preparados con compost de alpechín más orujo de aceituna mezclado con perlita (en las proporciones $1 / 2$ y $1 / 3$ en volumen) mayores que en los controles correspondientes (mezclas de turba y perlita en idénticas proporciones).

\subsubsection{Experimento de supresividad in vitro}

Considerando que la supresividad se debe fundamentalmente a factores de tipo biológico, distintos autores han realizado experimentos in vitro con microorganismos aislados de suelos, composts y suelos enmendados con materiales orgánicos para evaluar sus efectos inhibidores frente a agentes fitopatógenos, considerando dichos materiales como fuentes de antagonistas naturales, eficaces y de gran valor (Adesina et al., 2007; Landa et al., 1997; Roberts et al., 2005; Suárez-Estrella et al., 2007).

El presente estudio se centró en el aislamiento e identificación de actinomicetos con actividad antagonista a partir de diferentes tipos de materiales (compost y suelo enmendado, principalmente). Los actinomicetos constituyen un grupo de microorganismos formado por bacterias generalmente aerobias, Gram positivas y con alto contenido en $G+C$ (guanina y citosina). Muchas especies forman filamentos ramificados o hifas, y esporas asexuales. Por su morfología general presentan gran similitud con los hongos, probablemente como consecuencia de la adaptación a los mismos hábitats.

En este grupo de microorganismos, morfológicamente muy variados, dominan dos tipos principales: los nocardioformes, cuyas hifas se fragmentan en elementos cortos generadores de nuevos filamentos miceliares, y los esporoactinomicetos, en los que se diferencia una parte del micelio completo para formar esporas.

El interés por los actinomicetos surge a raíz de la capacidad de estos microorganismos para producir antibióticos, productos del metabolismo secundario microbiano que inhiben el proceso de crecimiento de otros microorganismos, incluso cuando se utilizan a bajas concentraciones (Theilleux, 2000). Los antibióticos que 
producen son de estructura química muy diversa y ejercen actividades muy variadas, que pueden ser de tipo antibacteriano, antifúngico, antiparasitario, antiviral, y de interés agroquímico, principalmente (Bentley, 1997).

El género Streptomyces fue propuesto por Waksman y Henrici en 1943, y clasificado en la familia Streptomycetaceae basándose en su morfología y su tipo de pared celular. En los últimos 30 años este género ha sufrido grandes cambios, y se han descrito numerosas especies nuevas, contabilizándose en la actualidad más de 2000 especies (Anderson y Wellington, 2001; Lechevalier y Lechevalier, 1980).

El trabajo realizado en el marco del "International Streptomyces Project" permitió la descripción -mediante métodos normalizados- de más de 450 especies de Streptomyces y suministró, además, una base coherente y unificada para el establecimiento de claves con vistas a la clasificación de nuevas especies (Shirling y Gottlieb, 1966). La clave más empleada es la descrita en la $1^{a}$ edición del Bergey's Manual of Systematic Bacteriology (Williams et al., 1989), donde se hace amplia referencia a los trabajos del "International Streptomyces Project". Esta clave se basa en caracteres tales como morfología de las cadenas de esporas, apariencia y color de las mismas, pigmentación del micelio, producción de melanina, actividad antimicrobiana, actividad enzimática, resistencia a antibióticos, temperatura y $\mathrm{pH}$ de crecimiento, y fuentes de nitrógeno y carbono, entre otros (Williams et al., 1983). En base a estos caracteres, Streptomyces se sitúa en la sección 29 del Manual (Streptomyces y géneros relacionados), con géneros cuyas hifas aéreas se dividen en un solo plano para formar cadenas de 3 a 50 conidiosporas inmóviles, y colonias con textura superficial que oscila entre lisa, espinosa y verrugosa. Todos ellos tienen pared celular tipo I -es decir, poseen principalmente ácido diaminopimélico en forma L- y un contenido en $\mathrm{G}+\mathrm{C}$ elevado (Lechevalier y Lechevalier, 1980). El micelio, cuando está presente, no presenta fragmentación. En conjunto, los miembros de la sección reciben el nombre de estreptomicetos, del griego, streptos, doblados o torcidos, y myces, hongo.

\subsubsection{Aislamiento de cepas de actinomicetos}

Para llevar a cabo el estudio in vitro de las propiedades supresivas de los dos composts de alperujo $(A$ y $A+H)$ y el suelo calizo enmendado con los composts indicados (a las dosis de 12 y 24 t de materia orgánica total/ha), se aislaron cepas de actinomicetos potencialmente supresores de agentes fitopatógenos mediante cultivo 
en los medios selectivos SCA (Starch Casein Agar), ISP-5 (Glycerol Asparagine Agar) y AGSA (Arginine Glycerol Salts Agar), y posterior aislamiento en cultivo puro en ISP-2 (Yeast Extract-Malt Extract). Una vez realizado el aislamiento, se seleccionaron aquellas cepas que se correspondían con la morfología macro- y microscópica típica de los actinomicetos, obteniéndose así una colección de 49 cepas de actinomicetos, cuya descripción macroscópica en base a su aspecto, color y producción de micelio se presenta en la Tabla 4.5.1. Dichas cepas se incluyeron en un experimento de inhibición frente a una bacteria y cinco hongos fitopatógenos.

\subsubsection{Ensayo de antagonismo de las cepas de actinomicetos aisladas frente a cinco hongos fitopatógenos}

A modo de estudio previo, se evaluaron distintos medios de cultivo con vistas a su uso en el ensayo in vitro, determinándose su aptitud para el crecimiento y antagonismo de los actinomicetos y los hongos fitopatógenos. De los 6 medios testados -Potato Dextrose Agar (PDA), ISP-2, Yeast-Malt extract Agar (YMA), Bennet Agar, Corn Meal Agar, y X-medium (ver la sección 3.6.1.2 de Materiales y Métodos)-, se seleccionaron el PDA y el YMA como los más apropiados para el experimento de supresividad, de manera similar a lo indicado en otros estudios de antagonismo (Castillo et al., 2002; Getha et al., 2005; Leiva et al., 2004). El medio PDA fue óptimo para el crecimiento de los hongos; y el YMA permitió el crecimiento de los actinomicetos y la producción de antibióticos, observándose además los mayores halos de inhibición para todos los hongos ensayados en comparación con el resto de medios de cultivo examinados (datos no presentados).

Se estudió la capacidad supresiva de las cepas obtenidas mediante cultivo in vitro conjunto de los actinomicetos aislados con cinco hongos fitopatógenos seleccionados, procedentes de la Colección Española de Cultivos Tipo (CECT): Fusarium oxysporum f. sp. melonis CECT 20474, Phytophthora cinnamomi CECT 20186, Sclerotinia sclerotiorum CECT 2823, Pythium debaryanum CECT 2362, y Thanatephorus cucumeris CECT 2813 (ver la metodología utilizada en la sección 3.6.1.2). 
Tabla 4.5.1. Descripción macroscópica de las cepas de actinomicetos aisladas (en el medio ISP-2) de los composts $\mathrm{A}$ y $\mathrm{A}+\mathrm{H}$ y del suelo calizo enmendado con dichos composts

\begin{tabular}{|c|c|}
\hline Aislado & Descripción \\
\hline A-6 & Granate con micelio blanco, lisa \\
\hline$A-7$ & Granate sin micelio, lisa \\
\hline $\mathrm{CO} 2-2$ & Ocre-amarillo, rugosa \\
\hline CO2-6 & Naranja claro, rugosa \\
\hline CO2-9 & Ocre con micelio blanco. Produce pigmento azul \\
\hline $\mathrm{CO} 2-10$ & Marrón con micelio blanco, rugosa. Oscurece el agar \\
\hline $\mathrm{co2}-11$ & Marrón oscura con micelio gris, rugosa. Oscurece el agar \\
\hline $\mathrm{CO} 2-16$ & Naranja oscuro con micelio naranja claro \\
\hline $\mathrm{CO} 2-19$ & Ocre con micelio blanco. Forma pequeñas colonias \\
\hline $\mathrm{CO} 2-21$ & Ocre, rugosa \\
\hline $\mathrm{CO} 2-29$ & Blanca-ocre, con surcos radiales \\
\hline $\mathrm{H}-1$ & Blanca-gris pulverulenta, rugosa, con exudación acuosa \\
\hline $\mathrm{H}-3$ & Blanca rugosa \\
\hline S-1 & Amarilla. Forma colonias pequeñas con bordes regulares \\
\hline S-2 & Naranja muy rugosa, bordes irregulares \\
\hline S-3 & Naranja con micelio, rugosa \\
\hline S-5 & Marrón muy oscuro con micelio blanco-gris, rugosa \\
\hline S-6 & Blanca-amarilla con micelio blanco \\
\hline S-7 & Amarilla-ocre sin micelio, rugosa \\
\hline S-9 & Roja con micelio gris-azul, con surcos radiales. Forma colonias grandes redondeadas \\
\hline T2-3 & Blanca rugosa \\
\hline T2-6 & Marrón con surcos radiales \\
\hline T2-10 & Roja con micelio blanco-azul, con surcos radiales \\
\hline T2-12 & Negra con micelio gris, con surcos radiales. Oscurece el agar \\
\hline T2-15 & Marrón con micelio gris y blanco \\
\hline T2-18 & Ocre sin micelio, rugosa con surcos radiales \\
\hline T2-19 & Ocre sin micelio, rugosa \\
\hline T2-20 & Ocre-blanca, muy rugosa \\
\hline T2-21 & Ocre muy rugosa \\
\hline T2-25 & Ocre con micelio blanco, con surcos radiales \\
\hline T2-26 & Marrón-ocre, rugosa \\
\hline T4-1 & Micelio abundante, gris y blanco \\
\hline T4-8 & Ocre con micelio blanco, rugosa \\
\hline T4-10 & Ocre con micelio blanco, muy rugosa \\
\hline $\mathrm{T} 4-13$ & Blanca-gris, con surcos radiales \\
\hline T4-19 & Marrón rugosa. Oscurece el agar \\
\hline T4-22 & Marrón con micelio gris. Oscurece el agar \\
\hline T6-19 & Rosa. Forma colonias grandes y redondas \\
\hline T6-21 & Amarilla con micelio blanco, rugosa \\
\hline T6-23 & Amarilla-rosa con micelio blanco, rugosa \\
\hline T6-25 & Ocre amarillenta, rugosa \\
\hline T6-26 & Blanca rugosa \\
\hline T6-32 & Marrón oscuro, con surcos radiales \\
\hline T6-33 & Ocre con micelio blanco, rugosa \\
\hline T8-2 & Blanca, rugosa \\
\hline T8-22 & Blanca-gris, pastosa \\
\hline T8-34 & Marrón, rugosa. Oscurece el agar \\
\hline T8-35 & Marrón, con surcos radiales \\
\hline T8-37 & Ocre-marrón, rugosa \\
\hline
\end{tabular}

A: compost de alperujo; $\mathrm{A}+\mathrm{H}$ : compost de alperujo más hidrolizado 
Los resultados obtenidos en el co-cultivo de los actinomicetos y los hongos fitopatógenos indicados en YMA y PDA se muestran en las Tablas 4.5.2. y 4.5.3, respectivamente, pudiendo apreciarse que, de las 49 cepas aisladas, 12 presentaron una elevada eficacia para inhibir el crecimiento de dichos hongos (aislados C02-9, C02-16, S-1, S-2, S-3, S-5, S-6, S-7, T2-10, T2-19, T6-32, y T8-2). Por tanto, se obtuvieron $24,5 \%$ de aislados con efectos antagonistas marcados, proporción similar a la indicada por otros autores (Larkin y Fravel, 1998). De entre ellos, merece destacarse que 7 cepas (CO2-16, S-1, S-2, S-3, S-5, S-6, y T8-2) manifestaron una alta supresividad frente a las 5 cepas fitopatógenas, y que los 5 aislados restantes (CO2-9, S-7, T2-10, T2-19, y T6-32) registraron una elevada actividad antagonista frente a 2 4 hongos de referencia.

\subsubsection{Estudio de antagonismo de las cepas de actinomicetos aisladas frente a}

\section{Agrobacterium tumefaciens}

El ensayo con Agrobacterium tumefaciens reveló que 3 cepas de actinomicetos S-6, T2-10 y T8-2- poseían actividad antibacteriana importante frente a esta especie (Tabla 4.5.4). Además, los halos de inhibición medidos tras 48 horas de incubación en el medio Plate Count Agar (PCA) fueron, en general, de mayor magnitud que los registrados tras 24 horas (datos no presentados), lo que sugiere que los actinomicetos continuaron produciendo antibióticos entre ambas mediciones. La distancia comprendida entre el crecimiento de los actinomicetos y la bacteria tras 48 horas se presenta en la Tabla 4.5.4. Puede observarse que los halos de inhibición fueron comparativamente mayores en YMA para la cepa S-6, mientras que para T2-10 y T8-2 el radio de la zona de inhibición en PDA fue igual o mayor que en aquel, lo que pone de manifiesto la importancia de una selección apropiada de los medios de cultivo en relación con los resultados obtenidos en un estudio de evolución temporal de efectos antagonistas. 


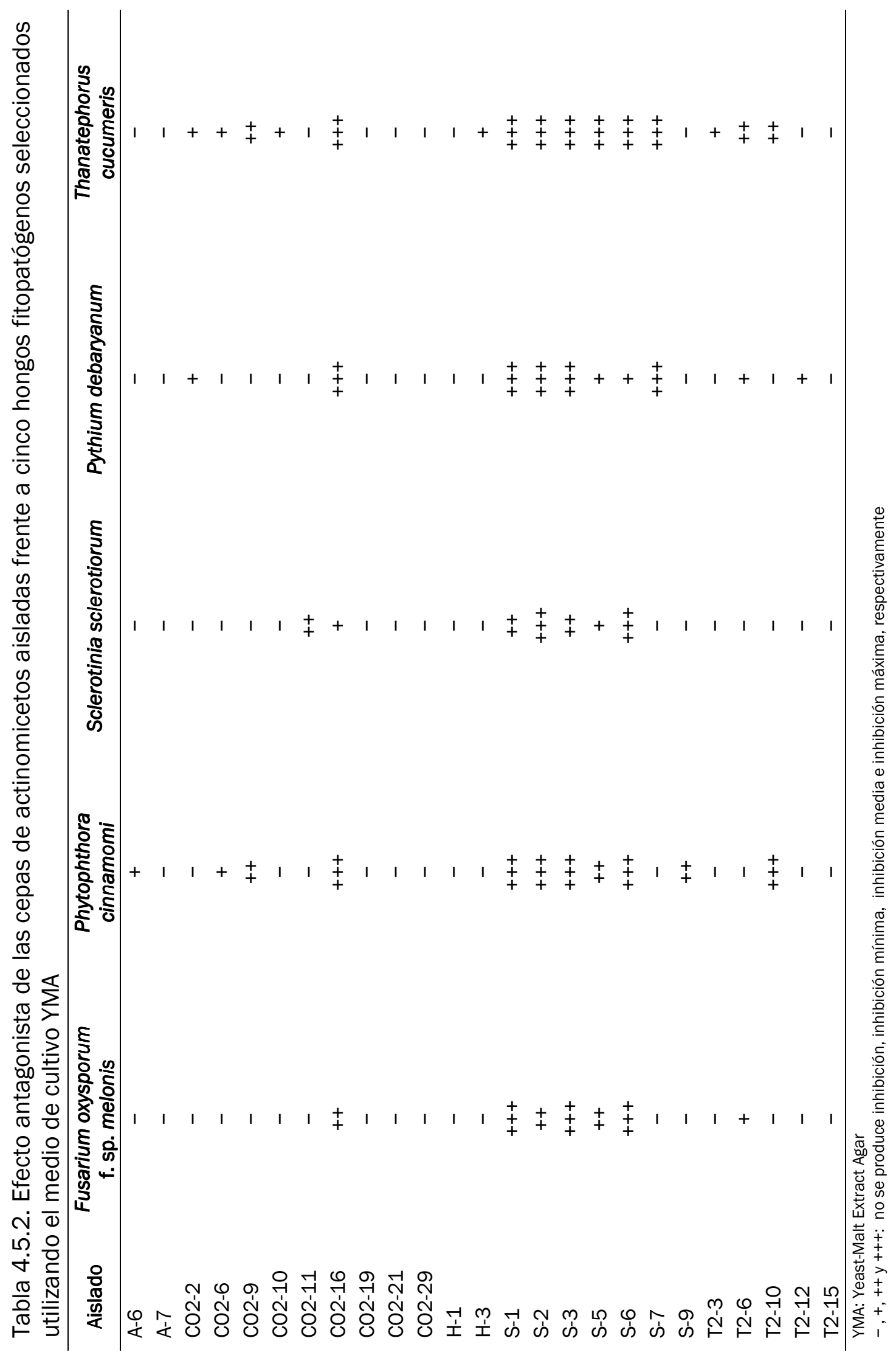




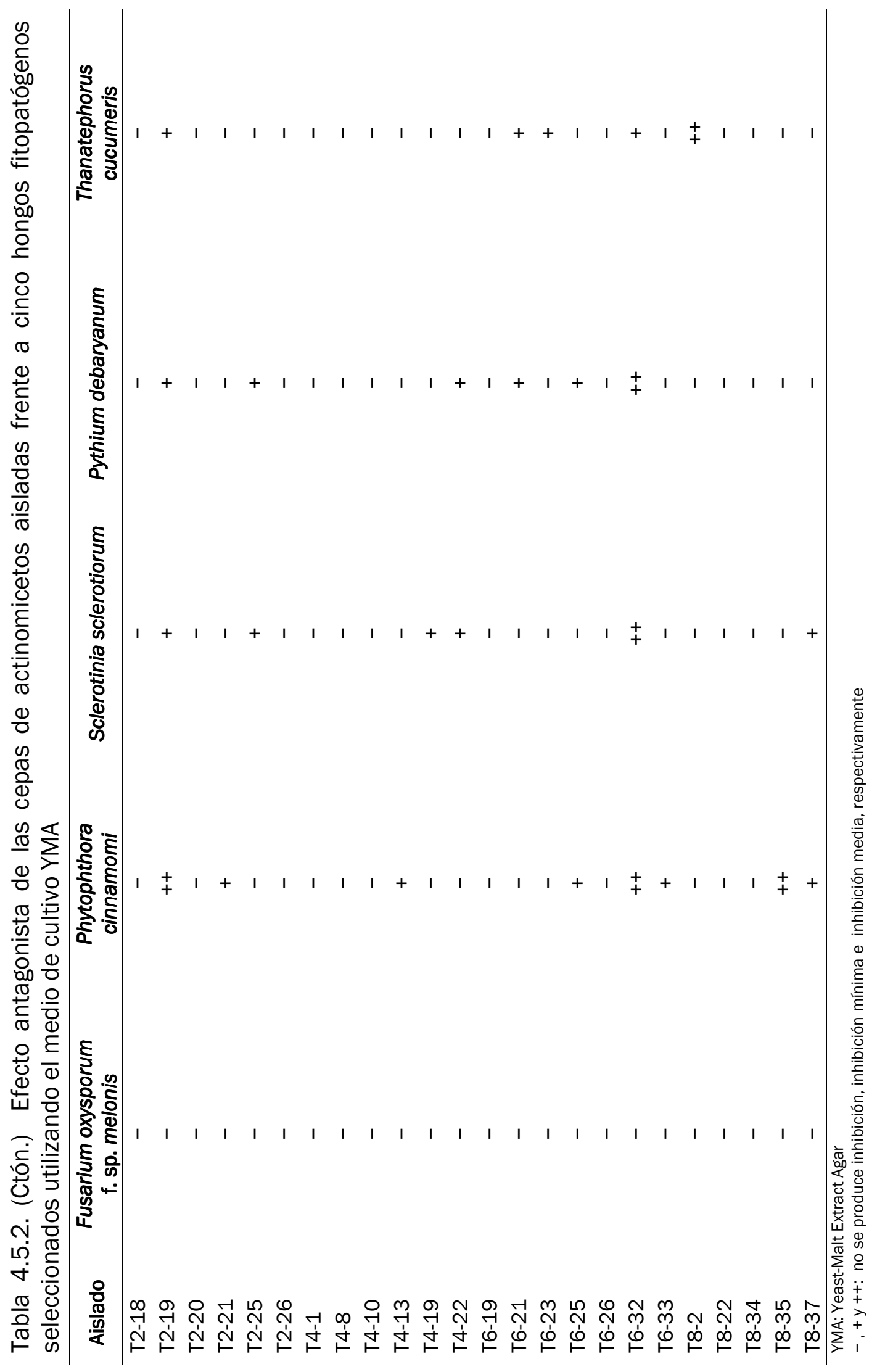




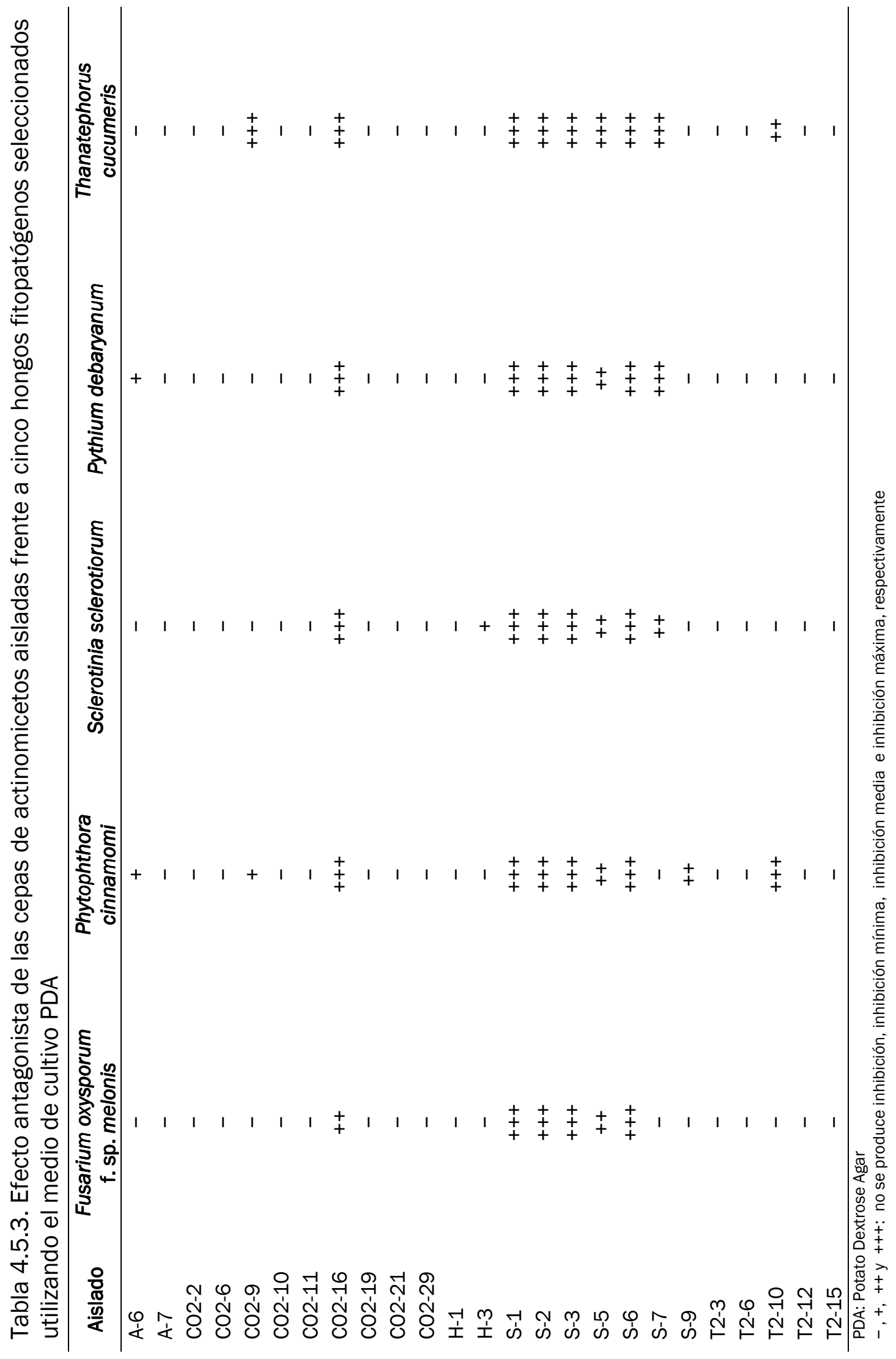




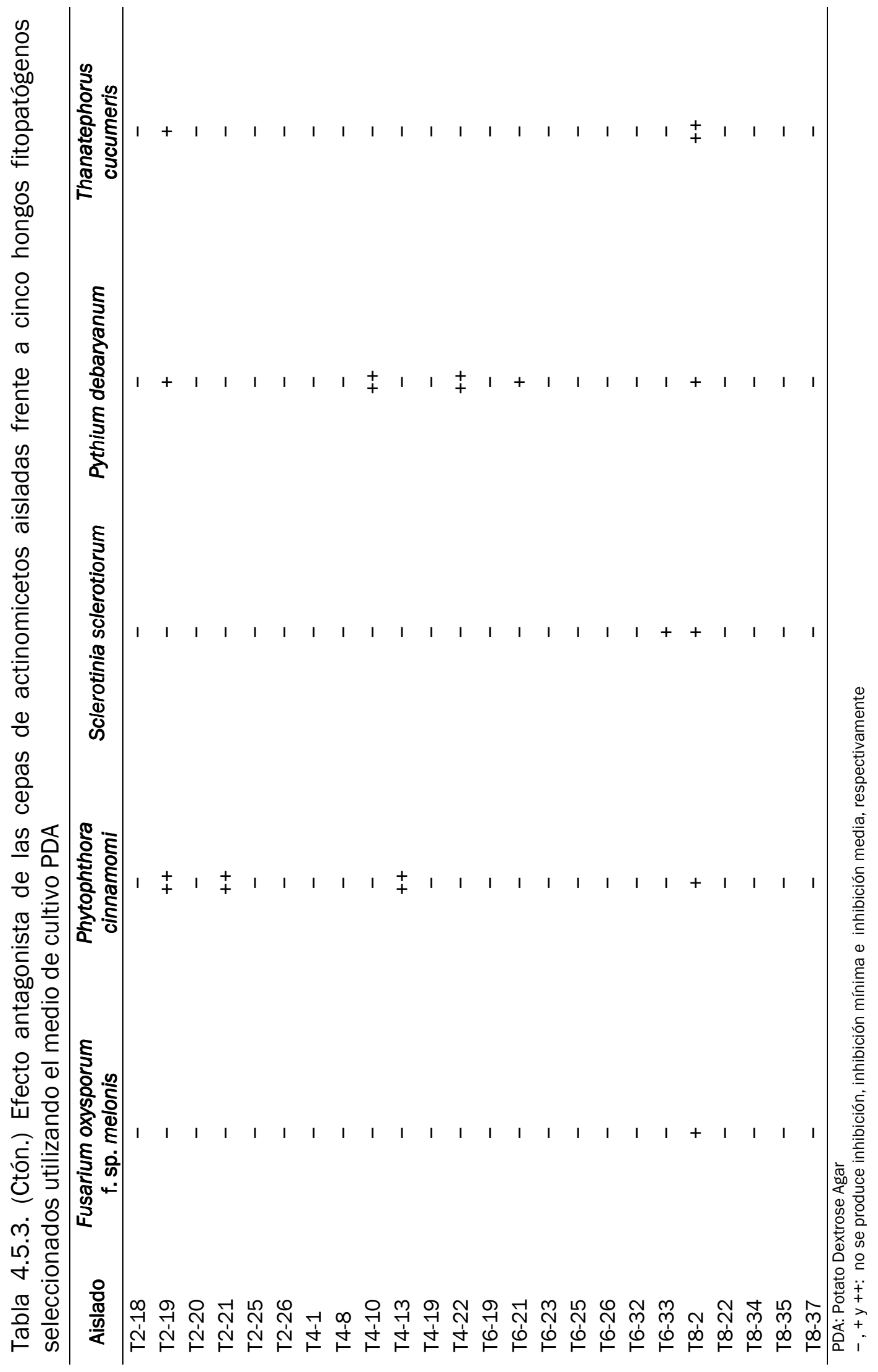


Tabla 4.5.4. Radio (en $\mathrm{mm}$ ) de los halos de inhibición entre el crecimiento de Agrobacterium tumefaciens (en tres concentraciones, equivalentes a 1,5.107, 1,5.106 y $1,5 \cdot 10^{5} \mathrm{UFC} / \mathrm{mL}$ ) y las cepas de actinomicetos cultivadas previamente en los medios YMA y PDA tras 48 horas de incubación en medio PCA

\begin{tabular}{|c|c|c|c|c|c|c|}
\hline \multirow[b]{3}{*}{ Aislado } & \multicolumn{6}{|c|}{ Concentración de inóculo bacteriano (UFC/mL) } \\
\hline & \multicolumn{2}{|c|}{$1,5 \cdot 10^{7}$} & \multicolumn{2}{|c|}{$1,5 \cdot 10^{6}$} & \multicolumn{2}{|c|}{$1,5 \cdot 10^{5}$} \\
\hline & YMA & PDA & YMA & PDA & YMA & PDA \\
\hline S-6 & 3 & $-z$ & 4 & - & 6 & - \\
\hline $\mathrm{T} 2-10$ & 2 & 2 & 3,5 & 3,5 & 2 & 3,5 \\
\hline T8-2 & 1 & 3 & 5 & 5 & 1 & 2 \\
\hline
\end{tabular}

En la Figura 4.5.1 se presentan imágenes con ejemplos de la incubación conjunta de las cepas de actinomicetos aisladas y los microorganismos seleccionados, causantes de enfermedades de tipo fúngico (Fusarium oxysporum f. sp. melonis [A], Phytophthora cinnamomi [B], Sclerotinia sclerotiorum [C], Pythium debaryanum [D], y Thanathephorus cucumeris $[\mathrm{E}]$ ) o bacteriano (Agrobacterium tumefaciens [F]), mostrándose distintos niveles de inhibición (efecto antagonista).

\subsubsection{Identificación de las cepas de actinomicetos con mayor supresividad mediante técnicas moleculares y fenotípicas}

En base a su morfología y la pigmentación de sus colonias, todas las cepas seleccionadas por su elevado antagonismo (12, secciones 4.5.1.2 y 4.5.1.3) frente a los 6 fitopatógenos estudiados se clasificaron como especies pertenecientes al género Streptomyces, excepto la T2-19, que se identificó como Lechevalieria sp.

Tal y como se indica en la Tabla 4.5.5, la identificación a nivel de especie realizada a partir de las secuencias del gen 16S rDNA demostró que 11 aislados pertenecieron al género Streptomyces, distinguiéndose 8 especies: 3 cepas se identificaron como Streptomyces variegatus (S-1, S-2 y S-3, Figura 4.5.2A), 2 como Streptomyces griseoruber (S-5 y T6-32, Figura 4.5.2B), 1 como Streptomyces Iusitanus (S-6, Figura 4.5.2C), 1 como Streptomyces lincolnensis (CO2-9, Figura 4.5.2B), 1 como Streptomyces aureoverticillatus (CO2-16, Figura 4.5.2D), 1 como Streptomyces olivochromogenes (S-7, Figura 4.5.2E), 1 como Streptomyces coeruleorubidus (T2-10, Figura 4.5.2F), y 1 como Streptomyces albogriseolus (T8-2, Figura 4.5.2B). Se obtuvo una similitud en la secuencia de nucleótidos entre los Streptomyces aislados y las 
cepas de referencia correspondientes que osciló desde 99,43\% (para S-1) hasta 100\% (para T2-10 y T8-2), según se indica en los árboles filogenéticos de la Figura 4.5.2. El predominio de especies del género Streptomyces confirma la importancia de los estreptomicetos como agentes de biocontrol, ya que éstos se aislan regularmente y producen antibióticos de gran interés comercial (Anderson and Wellington, 2001; ElTarabily y Sivasithamparam, 2006).

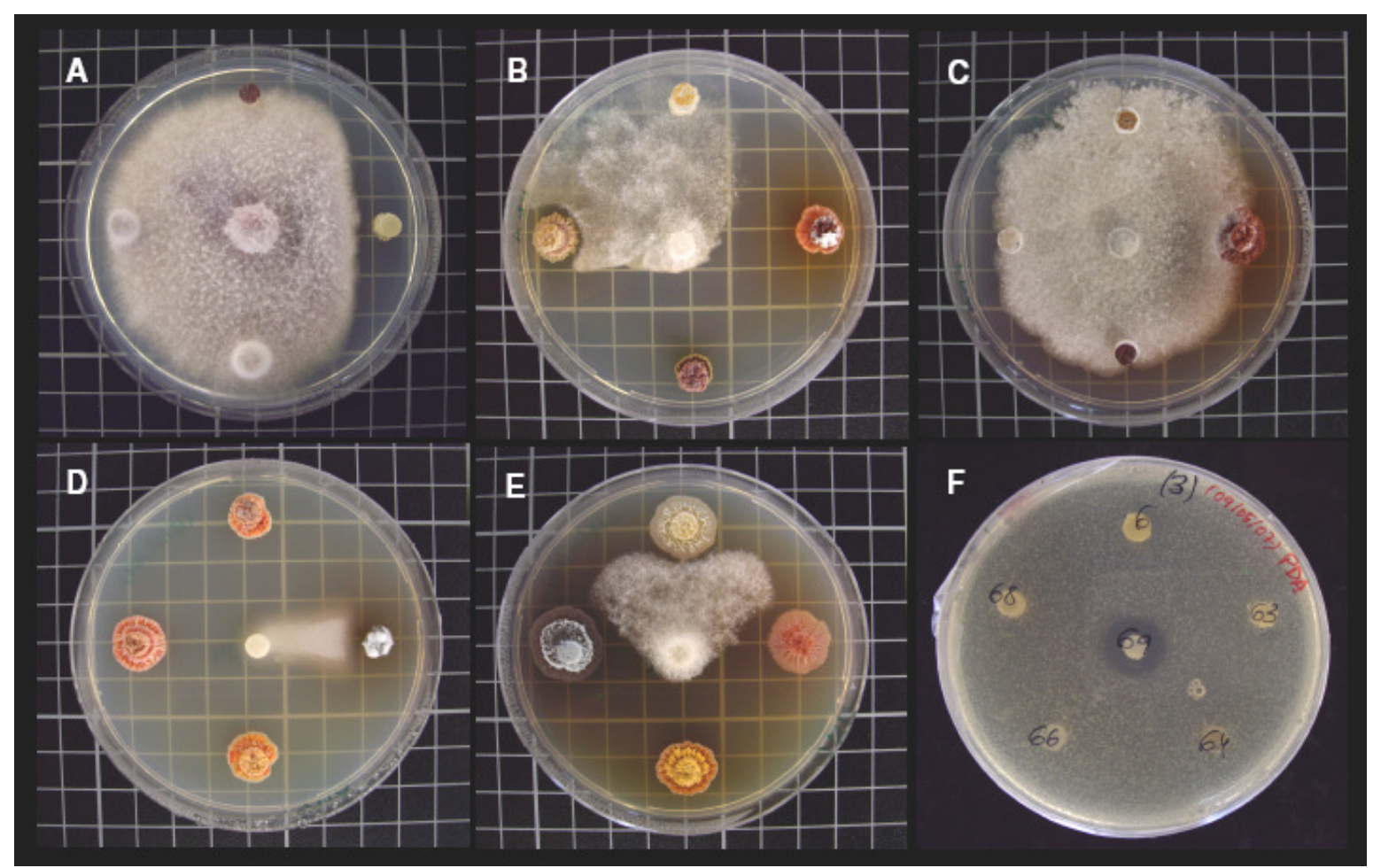

Figura 4.5.1. Imágenes de los efectos supresivos de cepas de actinomicetos aisladas frente a los agentes fitopatógenos seleccionados

A: Tres cepas no inhibidoras (parte superior, inferior e izquierda) e inhibición mínima (derecha) frente a Fusarium oxysporum f. sp. melonis (en el centro)

B: Cepa no inhibidora (parte superior), inhibición mínima (izquierda) e inhibición máxima (derecha e inferior) frente a Phytophthora cinnamomi (en el centro)

C: Cuatro cepas (en el borde externo) que no mostraron efectos antagonistas frente a Sclerotinia sclerotiorum (en el centro)

D: Inhibición mínima (a la derecha) e inhibición máxima (parte superior, inferior e izquierda) frente a Pythium debaryanum (en el centro)

E: Inhibición mínima (parte superior), media (derecha e izquierda) y máxima (inferior) frente a Thanatephorus cucumeris (en el centro)

F: Actinomiceto con antagonismo (en el centro) frente a Agrobacterium tumefaciens y cinco cepas sin efecto supresivo (en el borde externo). Bacteria inoculada homogéneamente en el medio de cultivo 
Tabla 4.5.5. Identificación de los aislados de actinomicetos mediante análisis 16S rDNA y características fenotípicas de los mismos

\begin{tabular}{|c|c|c|c|c|c|c|c|}
\hline Aislado & Especie & $\begin{array}{l}\text { Isómero } \\
\text { del DAP }\end{array}$ & $\begin{array}{c}\text { Color micelio } \\
\text { aéreo } \\
\text { esporulado }\end{array}$ & $\begin{array}{c}\text { Producción } \\
\text { melanina }\end{array}$ & $\begin{array}{c}\text { Producción } \\
\text { pigmentos } \\
\text { difusibles }\end{array}$ & $\begin{array}{l}\text { Morfología } \\
\text { cadena de } \\
\text { esporas }\end{array}$ & $\begin{array}{c}\text { Producción } \\
\text { quitinasa }\end{array}$ \\
\hline CO2-9 & S. lincolnensis & $\mathrm{L}$ & Verde claro & $+z$ & $+z$ & $\mathrm{RF}^{\mathrm{y}}$ & $-z$ \\
\hline $\mathrm{CO} 2-16$ & S. aureoverticillatus & L & Naranja oscuro & + & - & RF & - \\
\hline S-1 & S. variegatus & $\mathrm{L}$ & Naranja oscuro & + & - & $\mathrm{RF}$ & $-z$ \\
\hline S-2 & S. variegatus & L & Rojo-naranja & + & - & RF & - \\
\hline S-3 & S. variegatus & $\mathrm{L}$ & Naranja claro & + & - & $\mathrm{RF}$ & - \\
\hline S-5 & S. griseoruber & $\mathrm{L}$ & Verde-azul & + & + & $S$ & - \\
\hline S-6 & S. lusitanus & $\mathrm{L}$ & Amarillo oscuro & - & - & RF & - \\
\hline S-7 & S. olivochromogenes & $\mathrm{L}$ & Gris claro & - & - & $S$ & - \\
\hline $\mathrm{T} 2-10$ & S. coeruleorubidus & L & Verde-blanco & + & + & $S$ & - \\
\hline T2-19 & Lechevalieria sp. & Meso & NDx & - & - & NDx & + \\
\hline T6-32 & S. griseoruber & $\mathrm{L}$ & Verde-azul & - & + & $S$ & - \\
\hline T8-2 & S. albogriseolus & $\mathrm{L}$ & Verde-azul & + & - & $S$ & - \\
\hline
\end{tabular}

DAP: ácido diaminopimélico

z+,-: producción o no producción, respectivamente

yF, S: Rectus-Flexibilis o Spira, respectivamente

xND: no determinado

La cepa T2-19 fue el único aislado que no perteneció al género Streptomyces, correspondiendo al género Lechevalieria. Su posición filogénetica se situó entre Lechevalieria xinjiangensis (Wang et al., 2007) y el grupo formado por Lechevalieria atacamensis, Lechevalieria roselyniae y Lechevalieria deserti (Okoro et al., 2010), según puede apreciarse en la Figura 4.5.3, siendo la similitud de las secuencias entre T2-19 y L. atacamensis, L. xinjiangensis, L. roselyniae, y L. deserti de 99,41\%, 99,19\%, 99,19\%, y 99,04\%, respectivamente.

En cuanto a las características fenotípicas estudiadas (Tabla 4.5.5), todos los aislados fueron bacterias Gram positivas, aeróbicas y con micelio no fragmentado. Las cepas de Streptomyces produjeron micelio aéreo de moderado a abundante, mientras que Lechevalieria sp. mostró un micelio escaso y poco desarrollado. 
A
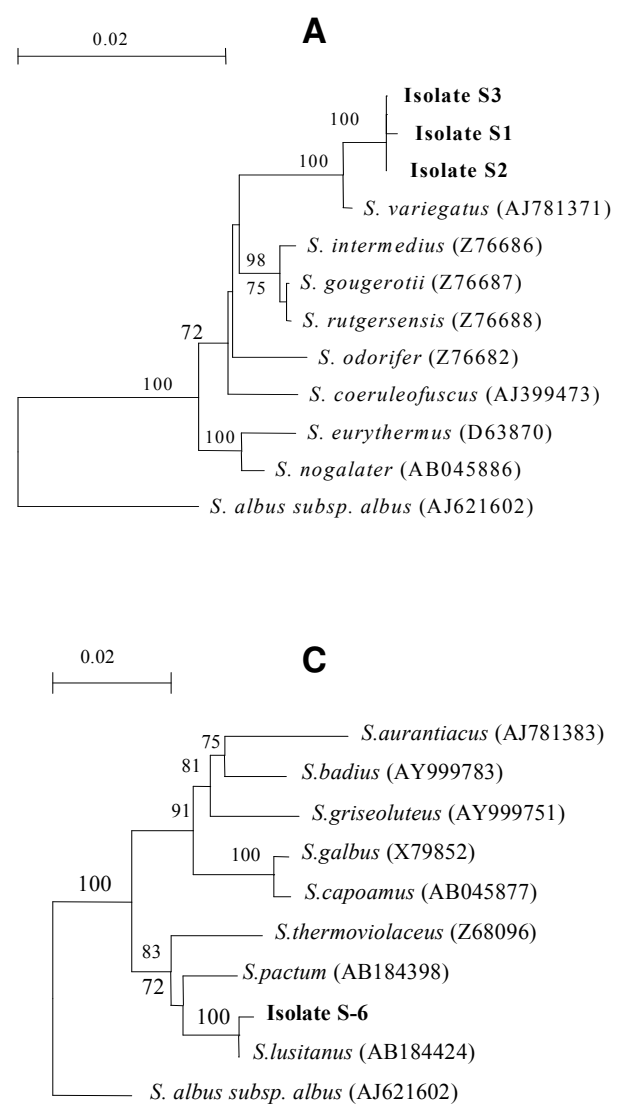

E

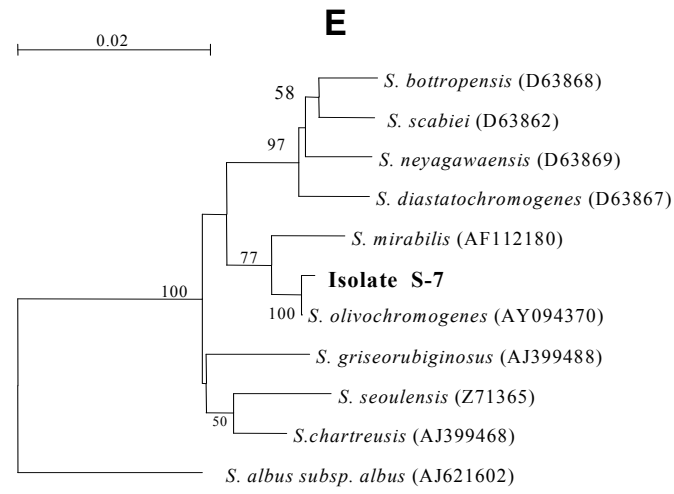

B
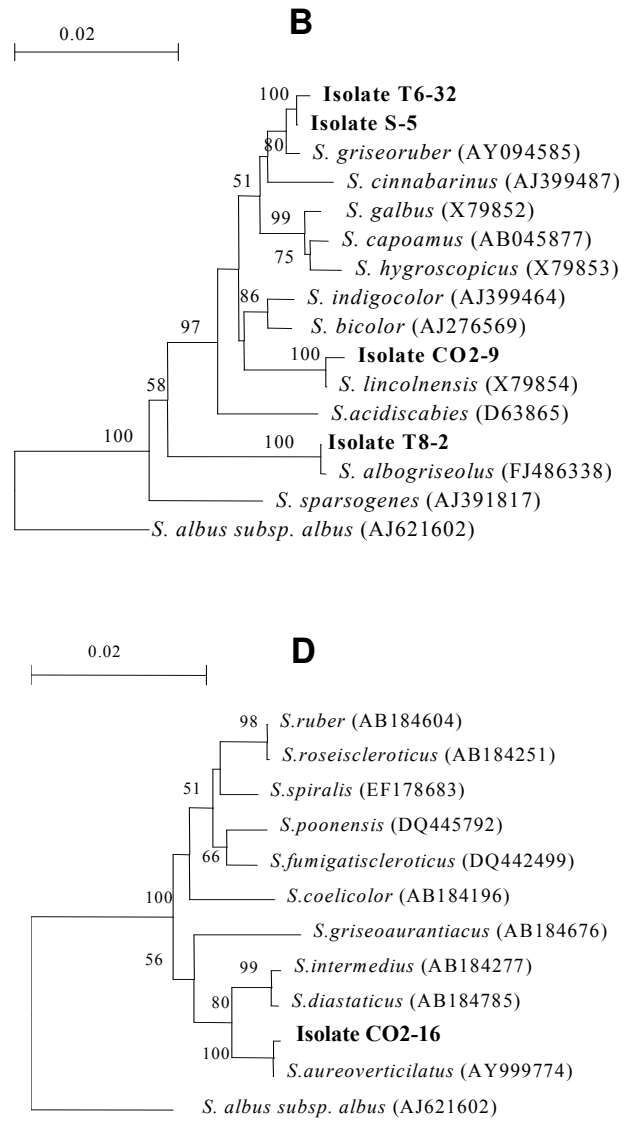

$0.02 \quad \mathbf{F}$

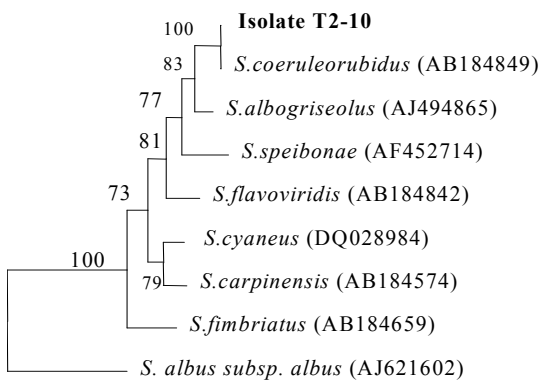

Figura 4.5.2. Árboles filogenéticos basados en las secuencias del gen 16S rDNA, mostrando la relación entre los once Streptomyces aislados y las cepas de referencia de dicho género. Las cifras en los nodos indican el valor obtenido en 1000 remuestreos (bootstrapping). Sólo se muestran los valores superiores al 50\%. La escala indica 0,02 sustituciones por nucleótido

Isolate: aislado 


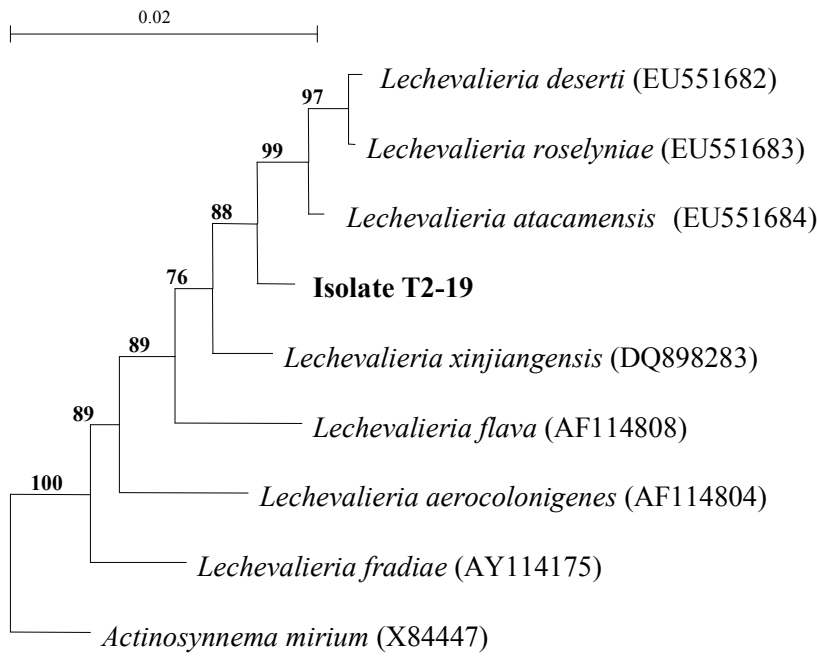

Figura 4.5.3. Árbol filogenético basado en las secuencias del gen $16 S$ rDNA, mostrando la relación entre la cepa de Lechevalieria sp. aislada (T2-19) y las cepas de referencia de dicho género. Las cifras en los nodos indican el valor obtenido en 1000 remuestreos (bootstrapping). Sólo se muestran los valores superiores al 50\%. La escala indica 0,02 sustituciones por nucleótido Isolate: aislado

Además, los estreptomicetos se caracterizaron por poseer ácido diaminopimélico (DAP) en forma L en su pared celular (tipo I), mientras que Lechevalieria sp. estuvo provista de pared celular con ácido meso-diaminopimélico (tipo III).

Las cepas C02-9, S-5, T2-10, y T6-32 produjeron pigmentos difusibles, detectándose pardeamiento del medio ISP-6 (Peptone-Yeast Extract Iron Agar) -como consecuencia de la producción de melanina- en 8 cepas (CO2-9, C02-16, S-1, S-2, S3, S-5, T2-10, у T8-2).

Según la morfología de las cadenas de esporas observada en microscopio óptico, C02-9, C02-16, S-1, S-2, S-3 y S-6, se clasificaron en la serie Rectus-Flexibilis (cadenas rectas o flexuosas), mientras que S-5, S-7, T2-10, T6-32 y T8-2 se agruparon en la serie Spira (cadenas helicoidales).

En lo que respecta a la actividad quitinasa, Lechevalieria sp. fue el único aislado en que se detectó capacidad para degradar quitina, manifestando así efectos inhibidores del crecimiento de hongos fitopatógenos, ya que la quitina es el principal polisacárido de la pared celular de muchos de éstos. No obstante, y debido a que dos de los hongos que manifestaron los mayores efectos antagonistas frente a dicha cepa pertenecieron a la clase de los Oomycetes, cuya pared celular no contiene quitina, el efecto inhibidor de Lechevalieria podría estar también relacionado con la producción de antibióticos, al igual que en el caso de los Streptomyces. 
Se puede recapitular por tanto que, de las 49 cepas aisladas, 12 mostraron un antagonismo medio-alto frente a la mayoría de los agentes fitopatógenos estudiados, identificándose éstas posteriormente mediante técnicas moleculares y fenotípicas. Los aislados se identificaron como Streptomyces, excepto una cepa que perteneció al género Lechevalieria. El análisis de las secuencias del gen 16S rDNA proporcionó una identificación rápida y a nivel de especie, arrojando además resultados que estuvieron de acuerdo con las características fenotípicas estudiadas. Se considera que el aislamiento e identificación de microorganismos con efectos inhibidores de enfermedades es una etapa previa de gran interés para el desarrollo de experimentos in vivo, que puedan facilitar posteriormente un control biológico eficiente a nivel comercial.

\subsubsection{Experimentos de supresividad in vivo frente a Fusarium oxysporum f. $\mathrm{sp}$. melonis}

En la presente Tesis se evaluó la supresividad potencial propia de los composts de alperujo $(\mathrm{A}$ y $\mathrm{A}+\mathrm{H})$ frente a Fusarium oxysporum f. $\mathrm{sp}$. melonis (procedente de la Colección Española de Cultivos Tipo - CECT 20474), que se denominó con el acrónimo FOM, utilizando plantas de melón (Cucumis melo) del cv. "Rochet", sensible a su infección, mediante dos experimientos in vivo. La importancia de dicha enfermedad vascular transmitida desde el suelo radica en que existen diversas "formae specialis" de Fusarium oxysporum, con alta especificidad por la planta hospedante, que ocasionan graves daños en una amplia gama de cultivos (huéspedes), entre ellos el melón, provocando grandes pérdidas económicas (Borrero et al., 2004; Schumann y D’Arcy, 2006; Suárez-Estrella et al., 2004).

\subsubsection{Experimento 1. Ensayo in vivo con los composts $A$ y $A+H$ como} componentes de los sustratos de cultivo estudiados

Para evaluar la supresividad potencial de los composts A y A+H per se, se cultivaron plantas de melón en un experimento de 47 días de duración, utilizando sustratos preparados con 92\% de turba Sphagnum (que aseguró buenas condiciones físicas y químicas para el crecimiento de las plantas), material considerado conductivo (Maher et al., 2008; Yogev et al., 2006), es decir, que permite y facilita la propagación de enfermedades, y $8 \%$ (en volumen) de $\mathrm{A}$ o $\mathrm{A}+\mathrm{H}$, inoculándose el hongo fitopatógeno 
FOM a dos dosis, D1 y D2, equivalentes a 2,15.104 y 1,08.105 propágulos por contenedor, respectivamente. Como patrón de comparación se estudiaron controles no inoculados (controles negativos de la enfermedad) y sustratos autoclavados a $121^{\circ} \mathrm{C}$ durante 15 minutos (esterilizados) e inoculados con la dosis D2. Este último control permitió determinar la capacidad de la microbiota natural (nativa u original) de los composts para inhibir el desarrollo de la enfermedad en las mezclas de turba y compost estudiadas.

En la Figura 4.5.4 se presentan los resultados obtenidos de porcentaje de plantas infectadas, peso fresco de las plantas y longitud del tallo de las mismas. Para cada una de las dosis de inóculo aplicadas (D1 y D2), los tratamientos (sustratos) con el compost $\mathrm{A}+\mathrm{H}$ mostraron un porcentaje de plantas infectadas mayor que los que contenían compost A y la misma dosis de inóculo, llegando casi a duplicarse el número de plantas que manifestaron la enfermedad en los sustratos con $\mathrm{A}+\mathrm{H}$ no esterilizados cuando se aplicó la dosis D2 respecto a D1. Además, la esterilización del sustrato preparado con A incrementó significativamente la incidencia de la infección, alcanzándose hasta un 50\% de plantas afectadas, mientras que en $\mathrm{A}+\mathrm{H}$ no existieron diferencias estadísticamente significativas entre los materiales infectados -a la dosis D2- no esterilizados y autoclavados. Diversos autores (Amir y Alabouvette, 1993; Hoitink y Fahy, 1986) indican que la supresividad de los composts puede deberse tanto a la contribución de factores de naturaleza biótica como a factores abióticos, como el pH o la conductividad eléctrica. Los efectos inhibidores de FOM señalados en el sustrato elaborado con el compost A podrían deberse fundamentalmente a su microbiota antagonista, mientras que los resultados de $\mathrm{A}+\mathrm{H}$ sugieren que este compost no posee una capacidad supresora de enfermedades detectable en las condiciones ensayadas.

Respecto a los parámetros del crecimiento controlados en las plantas de melón, peso fresco y longitud del tallo (Figura 4.5.4), se observaron diferencias significativas entre ambos composts, siendo el peso y la longitud de las plantas notablemente superiores en $\mathrm{A}$. Esto indica que $\mathrm{A}+\mathrm{H}$ debilitó el vigor de las plantas, lo que facilitaría su infección por el agente patógeno (FOM), afectando así a un número de plantas mayor que en A. Sin embargo, la semejanza entre el peso fresco de los controles no inoculados con FOM ( $\mathrm{A}-\mathrm{O}$ y $\mathrm{A}+\mathrm{H}-\mathrm{O})$ y las plantas que habían crecido sobre los sustratos inoculados con FOM en $\mathrm{A}$ y $\mathrm{A}+\mathrm{H}$, puso de manifiesto una baja velocidad de progreso de la enfermedad, que no llegó a afectar al desarrollo vegetal. 

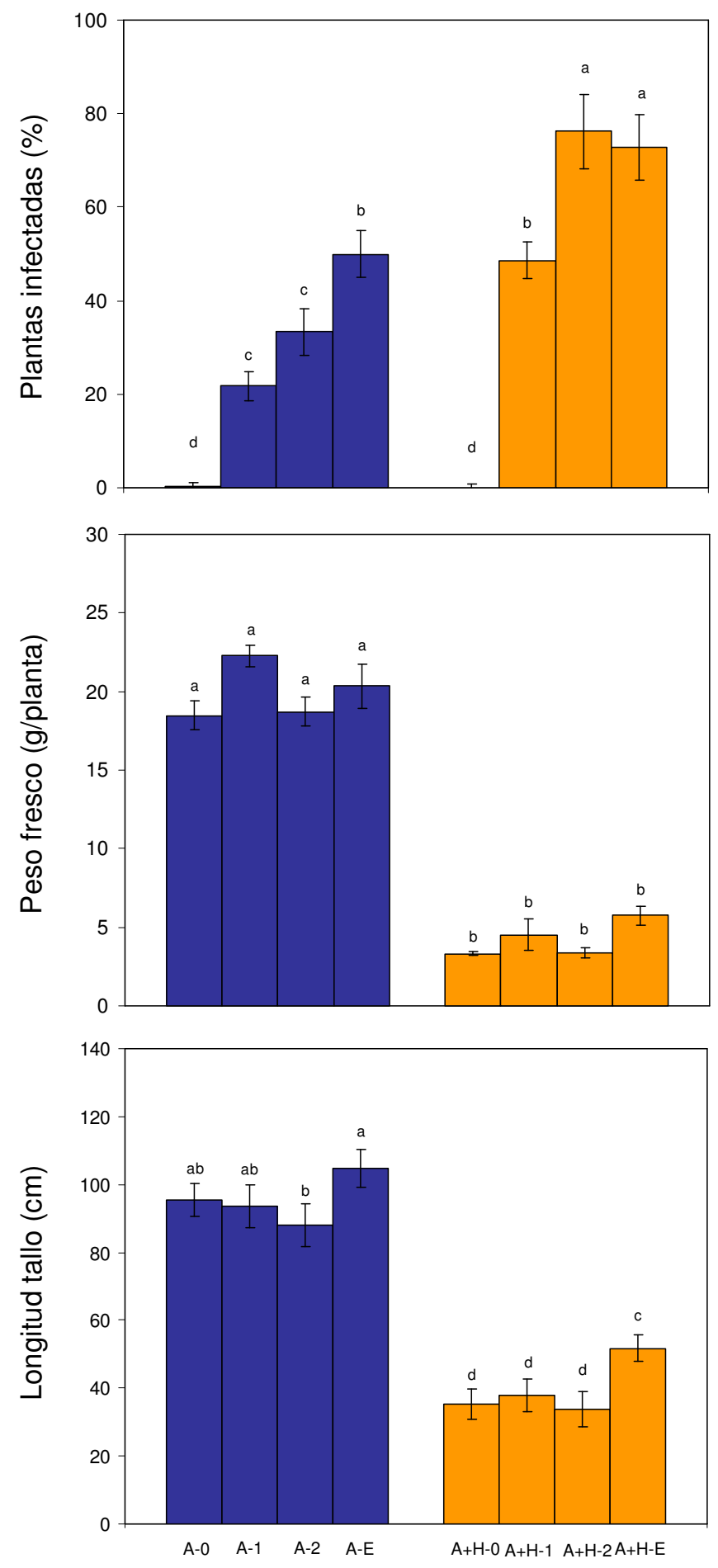

Sustrato

Figura 4.5.4. Porcentaje de plantas infectadas, peso fresco y longitud del tallo en plantas de melón cultivadas en sustratos preparados con los composts $A$ y $A+H$ infectados con diferentes dosis de inóculo de Fusarium oxysporum f. sp. melonis

A: compost de alperujo; $\mathrm{A}+\mathrm{H}$ : compost de alperujo más hidrolizado

0,1 y 2: no inoculado o inoculado con la dosis D1 (2,15.104 propágulos/contenedor) y D2 (1,08.105 propágulos/contenedor), respectivamente; E: autoclavado e inoculado con la dosis D2

Las líneas verticales indican el error estándar. Barras sin letra común difieren estadísticamente a $P \leq 0,05$ (test de StudentNewman-Keuls) 
Durante este experimento de supresividad in vivo, se controló periódicamente la evolución de la enfermedad, determinándose caractarerísticas propias de la sintomatología típica de la fusariosis del melón: amarilleo (clorosis) de las hojas, color verde pálido de las nervaduras de las hojas, y necrosis longitudinal y gomosis del tallo, principalmente (Koike et al., 2007; Messiaen et al., 1994).

En el ámbito de la fitopatología, se considera de gran interés el incremento de la patogeneidad a lo largo del tiempo, lo que se representó en una curva de progresión de la enfermedad (Figura 4.5.5), expresándose la incidencia de ésta como porcentaje de plantas infectadas en función del tiempo transcurrido tras la inoculación del fitopatógeno (FOM). En A pudo apreciarse que el porcentaje de plantas afectadas por la infección en A-1 y A-2 (dosis de inóculo correspondientes a D1 y D2, respectivamente), a partir del día 15 del ensayo, fue menor que en el material autoclavado (A-E), mostrando además el tratamiento con D1 (A-1) una evolución de la enfermedad paralela a la que presentó la dosis de infección máxima D2 (A-2), pero con una cuantía de plantas infectadas significativamente inferior. En el caso de $\mathrm{A}+\mathrm{H}$, la semejanza entre los distintos tratamientos estudiados respecto a la evolución de la enfermedad fue mayor que en A, y, a partir del día 31, los dos sustratos con la dosis máxima de inóculo D2 (tanto autoclavado $[\mathrm{A}+\mathrm{H}-\mathrm{E}]$ como no autoclavado $[\mathrm{A}+\mathrm{H}-2]$ ) presentaron porcentajes similares de plantas con síntomas de la enfermedad, pero significativamente superiores al tratamiento con D1 $(A+H-1)$.

Los datos de porcentaje de plantas afectadas se han utilizado para calcular el parámetro denominado "área bajo la curva de progresión de la enfermedad" (AUDPC, Area Under the Disease-Progress Curve), que integra los aspectos de la evolución de la enfermedad en relación con el crecimiento del huésped y su desarrollo. Las técnicas para su determinación abarcan desde fórmulas simples de cálculo de áreas hasta aplicaciones informáticas de integración de ecuaciones (Jeger y Viljanen-Rollinson, 2001; Yogev et al., 2009). En este experimento se utilizó la fórmula propuesta por Shaner y Finney (1977):

$$
\text { AUDPC }=\sum_{i=1}^{n}\left[\left(Y_{i+1}+Y_{i}\right) / 2\right] \cdot\left[X_{i+1}-X_{i}\right]
$$

donde $Y_{i}$ es la severidad de la enfermedad expresada como porcentaje de plantas afectadas en la observación i, $X_{i}$ los días (desde la inoculación) correspondientes a la observación i, y n el número total de observaciones realizadas. 


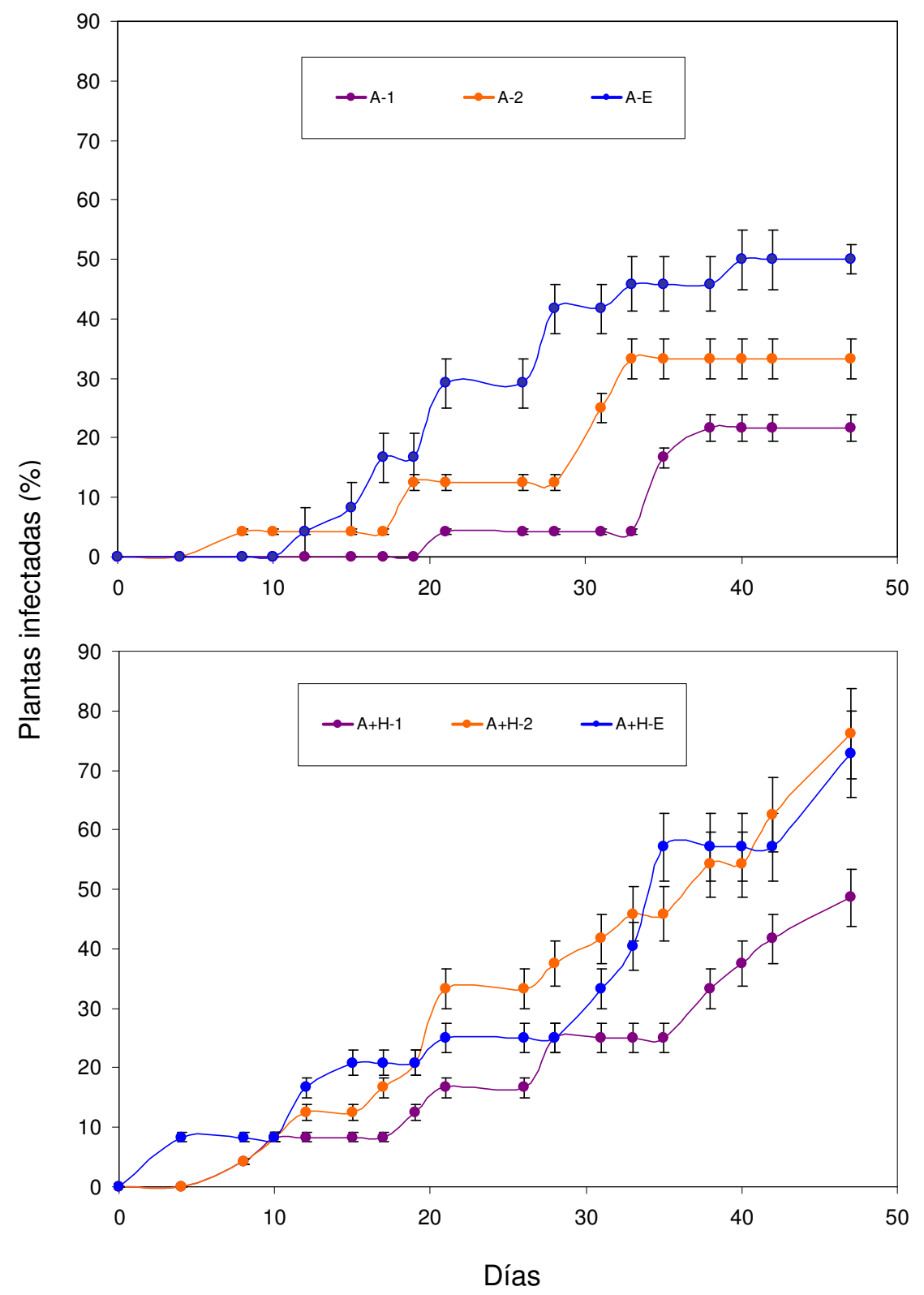

Figura 4.5.5. Curva de progresión de la enfermedad en plantas de melón cultivadas en sustratos preparados con los composts $\mathrm{A}$ y $\mathrm{A}+\mathrm{H}$ infectados con diferentes dosis de inóculo de Fusarium oxysporum f. sp. melonis

A: compost de alperujo; $\mathrm{A}+\mathrm{H}$ : compost de alperujo más hidrolizado

1 y 2: inoculado con la dosis D1 (2,15.104 propágulos/contenedor) y D2 (1,08.105 propágulos/contenedor), respectivamente; E: autoclavado e inoculado con la dosis D2

Las líneas verticales indican el error estándar

Los efectos principales de los factores Compost (A y A+H) y Dosis de FOM (D1 y D2) sobre el AUDPC y sobre diferentes parámetros controlados al final del experimento (porcentaje de plantas infectadas, longitud de tallo afectado, valor -puntuación- de la clorosis de las hojas y del color de la necrosis del tallo), indicadores todos ellos de la severidad de la enfermedad ocasionada por FOM, se muestran en la Tabla 4.5.6. Como puede apreciarse, se encontraron diferencias estadísticamente significativas entre los dos composts para todas las 
determinaciones realizadas, obteniéndose con $\mathrm{A}+\mathrm{H}$ una mayor incidencia de la enfermedad y una manifestación más severa de la sintomatología típica de la infección por FOM. Esto se observó principalmente en el porcentaje de tallo afectado por la necrosis, que en $\mathrm{A}+\mathrm{H}$ alcanzó un valor 20 veces mayor que en A. Además, el valor de AUDPC y el porcentaje de plantas infectadas en el compost $A+H$ fue considerablemente mayor que en los sustratos con compost A (87,3 vs. 34,0 para AUDPC, y $63,1 \%$ vs. $27,5 \%$ para número de plantas infectadas, respectivamente). Con relación a la dosis de inóculo aplicada, el aumento en la concentración de FOM se tradujo en un incremento en el porcentaje de plantas infectadas, el AUDPC, y la intensidad del color de la herida necrótica, mientras que dicha dosis de FOM no influyó significativamente en los parámetros fracción de tallo afectado por la necrosis ni grado de clorosis de las hojas.

Tabla 4.5.6. Efectos principales de los tratamientos estudiados -Compost (A vs. A+H) y Dosis de inóculo (D1 vs. D2)- sobre parámetros seleccionados, indicadores de la severidad de la enfermedad ocasionada por Fusarium oxysporum f. sp. melonis (FOM) en plantas de melón

\begin{tabular}{|c|c|c|c|c|c|}
\hline $\begin{array}{l}\text { Efecto principal del } \\
\text { tratamiento }\end{array}$ & AUDPC & $\begin{array}{c}\text { Plantas } \\
\text { infectadas } \\
(\%)\end{array}$ & $\begin{array}{l}\text { Longitud de tallo } \\
\text { afectado } \\
(\%)\end{array}$ & $\begin{array}{l}\text { Intensidad } \\
\text { color necrosis } \\
\text { (puntuación) }\end{array}$ & $\begin{array}{c}\text { Clorosis } \\
\text { (puntuación) }\end{array}$ \\
\hline \multicolumn{6}{|l|}{ 1. Compost } \\
\hline A & 34,0 & 27,5 & 2,23 & 1,47 & 3,23 \\
\hline $\mathrm{A}+\mathrm{H}$ & 87,3 & 63,1 & 47,8 & 3,13 & 3,98 \\
\hline$P$ & $* * *$ & $* * *$ & $* * *$ & $* * *$ & $* * *$ \\
\hline \multicolumn{6}{|c|}{ 2. Dosis de inóculo (FOM) } \\
\hline D1 & 45,8 & 35,9 & 20,5 & 2,01 & 3,52 \\
\hline D2 & 75,5 & 54,8 & 29,5 & 2,59 & 3,68 \\
\hline$P$ & $* * *$ & * & ns & * & ns \\
\hline \multicolumn{6}{|l|}{ 3. Interacción } \\
\hline $1 \times 2$ & * & ns & ns & ns & ns \\
\hline
\end{tabular}

A: compost de alperujo; $\mathrm{A}+\mathrm{H}$ : compost de alperujo más hidrolizado

D1: 2,15·10 ${ }^{4}$ propágulos/contenedor; D2: 1,08-105 propágulos/contenedor

AUDPC: área bajo la curva de progresión de la enfermedad

$P$ : nivel de significación. ns, * y *** indican diferencias no significativas o estadísticamente significativas a $P \leq 0,05$ y $P \leq 0,001$, respectivamente

El estudio comparativo de estos sustratos con los que fueron esterilizados e inoculados con la dosis D2, A-E y A+H-E (Tabla 4.5.7), reveló que el máximo valor de AUDPC correspondió al compost $A+H$ esterilizado o no $(A+H-E$ y $A+H-2)$, con valores significativamente superiores al sustrato con $\mathrm{A}+\mathrm{H}$ no autoclavado e inoculado con la dosis D1 $(\mathrm{A}+\mathrm{H}-1)$. Respecto al compost $\mathrm{A}$, el parámetro AUDPC del sustrato no esterilizado e inoculado con la dosis mínima D1 (A-1) fue significativamente inferior al 
resto de sustratos elaborados con dicho compost, en ambos casos con la dosis D2 de inóculo. Merece destacarse que los dos tratamientos con el compost A no esterilizado (A-1 y $A-2)$, y el de $A+H$ a la dosis mínima D1 $(A+H-1)$, presentaron un porcentaje de plantas infectadas significativamente inferior al sustrato elaborado con A esterilizado (A-E), y a los preparados con $A+H$ e inoculados con D2 (esterilizados o no). Además, en todos los tratamientos con A se registró una proporción de tallo con necrosis y un grado de clorosis de las hojas significativamente inferiores a los sustratos que contenían $\mathrm{A}+\mathrm{H}$.

Tabla 4.5.7. Parámetros indicadores de la severidad de la enfermedad ocasionada por Fusarium oxysporum f. sp. melonis en plantas de melón cultivadas en sustratos preparados con los composts $\mathrm{A}$ y $\mathrm{A}+\mathrm{H}$

\begin{tabular}{lccccc}
\hline Sustrato & AUDPC & $\begin{array}{c}\text { Plantas } \\
\text { infectadas } \\
(\%)\end{array}$ & $\begin{array}{c}\text { Longitud de tallo } \\
\text { afectado } \\
(\%)\end{array}$ & $\begin{array}{c}\text { Intensidad color } \\
\text { necrosis } \\
\text { (puntuación) }\end{array}$ & $\begin{array}{c}\text { Clorosis } \\
\text { (puntuación) }\end{array}$ \\
\hline $\mathrm{A}-\mathrm{E}$ & $52,1 \mathrm{c}$ & $50,0 \mathrm{ab}$ & $0,88 \mathrm{c}$ & $2,17 \mathrm{~b}$ & $3,29 \mathrm{bc}$ \\
$\mathrm{A}-1$ & $24,2 \mathrm{~d}$ & $21,7 \mathrm{c}$ & $1,72 \mathrm{c}$ & $1,31 \mathrm{c}$ & $3,04 \mathrm{c}$ \\
$\mathrm{A}-2$ & $43,8 \mathrm{c}$ & $33,3 \mathrm{~b}$ & $2,73 \mathrm{c}$ & $1,94 \mathrm{bc}$ & $3,42 \mathrm{~b}$ \\
$\mathrm{~A}+\mathrm{H}-\mathrm{E}$ & $111 \mathrm{a}$ & $72,7 \mathrm{a}$ & $24,3 \mathrm{~b}$ & $2,58 \mathrm{ab}$ & $4,00 \mathrm{a}$ \\
$\mathrm{A}+\mathrm{H}-1$ & $67,3 \mathrm{~b}$ & $48,6 \mathrm{ab}$ & $36,9 \mathrm{ab}$ & $3,03 \mathrm{a}$ & $4,00 \mathrm{a}$ \\
$\mathrm{A}+\mathrm{H}-2$ & $107 \mathrm{a}$ & $76,2 \mathrm{a}$ & $56,3 \mathrm{a}$ & $3,24 \mathrm{a}$ & $3,95 \mathrm{a}$ \\
$P$ & $* * *$ & $* * *$ & $* * *$ & $* * *$ & $* * *$ \\
\hline
\end{tabular}

A: compost de alperujo; $\mathrm{A}+\mathrm{H}$ : compost de alperujo más hidrolizado

AUDPC: área bajo la curva de progresión de la enfermedad

1 y 2: inoculado con la dosis D1 (2,15.104 propágulos/contenedor) y D2 (1,08.105 propágulos/contenedor), respectivamente; E: autoclavado e inoculado con la dosis D2

$P$ : nivel de significación. *** indica diferencias estadísticamente significativas a $P \leq 0,001$

Valores en columna sin letra común difieren estadísticamente a $P \leq 0,05$ (test de Student-Newman-Keuls)

Puesto que los resultados obtenidos en este Experimento 1 revelaron unos efectos antagonistas frente a la infección de FOM en los sustratos preparados con el compost $\mathrm{A}$ más marcados que con $\mathrm{A}+\mathrm{H}$, se consideró de gran interés profundizar en el estudio de los efectos supresivos de dicho material orgánico (A) con vistas a su potencial uso en el ámbito del control biológico a nivel comercial.

4.5.2.2. Experimento 2. Efecto del volumen de compost $A$ en la mezcla sobre las propiedades supresivas de los sustratos estudiados

Se evaluó el efecto del volumen de compost A en la mezcla sobre la supresividad potencial de los sustratos de cultivo preparados en dicho compost frente a Fusarium oxysporum f. sp. melonis (FOM) en un experimento de 47 días de duración. En este experimento, la mezcla con turba Sphagnum se elaboró utilizando la proporción de 
compost A estudiada en el Experimento 1 ( $8 \%$ en volumen, tratamiento A1) y una proporción de este material compostado del 16\% (A2). El hongo fitopatógeno se inoculó a dos dosis, utilizándose en este Experimento 2 una dosis mínima (D1) del mismo orden que la dosis máxima del experimento anterior (Experimento 1) y una

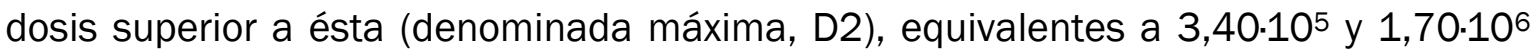
propágulos por contenedor, respectivamente. Asimismo, se incluyeron controles no inoculados (controles negativos de la enfermedad) y sustratos autoclavados a $121^{\circ} \mathrm{C}$ durante 15 minutos (esterilizados) e inoculados con la dosis D2.

Respecto al estudio comparativo del porcentaje de plantas infectadas, peso fresco y longitud del tallo de la planta (Figura 4.5.6), pudo apreciarse que los dos volúmenes de compost presentes en la mezcla (A1 y A2) provocaron una reducción en el porcentaje de plantas infectadas respecto a los sustratos esterilizados (E) cuando FOM se inoculó a la dosis mínima D1, y que la proporción más alta de compost en el sustrato se tradujo en una menor incidencia de la enfermedad en comparación con el sustrato esterilizado cuando el hongo fitopatógeno se inoculó a la dosis máxima D2 (A2-2 vs. A2-E). En general, el peso fresco de la planta disminuyó en las mezclas de compost $\mathrm{A}$ al $16 \%$ en comparación con las del $8 \%$, particularmente en los controles no infectados con FOM (A2-0 vs. A1-0), siendo este efecto similar para la longitud del tallo. Un crecimiento y desarrollo de las plantas de melón comparativamente más elevado en la mezcla con compost al 8\% (A1) sugiere que esta proporción de compost y turba resulta más adecuada para el cultivo en los sustratos preparados con dicho compost A.

Con relación a la evolución de la enfermedad a lo largo del experimento (Figura 4.5.7), el sustrato autoclavado con $8 \%$ de compost (A1-E) manifestó un aumento significativo en el porcentaje de plantas infectadas respecto a las mezclas equivalentes no esterilizadas (A1-1 y A1-2) a partir del día 27 del ensayo, mostrando la mezcla con compost (también al 8\%) inoculada con la dosis D2 de FOM mayores niveles de infección que el correspondiente a D1 desde el día 35 del experimento (A21 y A2-2). De igual modo, el sustrato autoclavado conteniendo $16 \%$ de compost (A2-E) provocó mayor precocidad y magnitud de la infección que los materiales no autoclavados (A2-1 y A2-2), ya desde el día 13 del ensayo; y, por el contrario, la evolución de la infección en estos dos últimos sustratos transcurrió de forma similar en cuanto a número de plantas infectadas y tiempo transcurrido desde la inoculación de FOM, con independencia de la dosis de patógeno inoculado. 

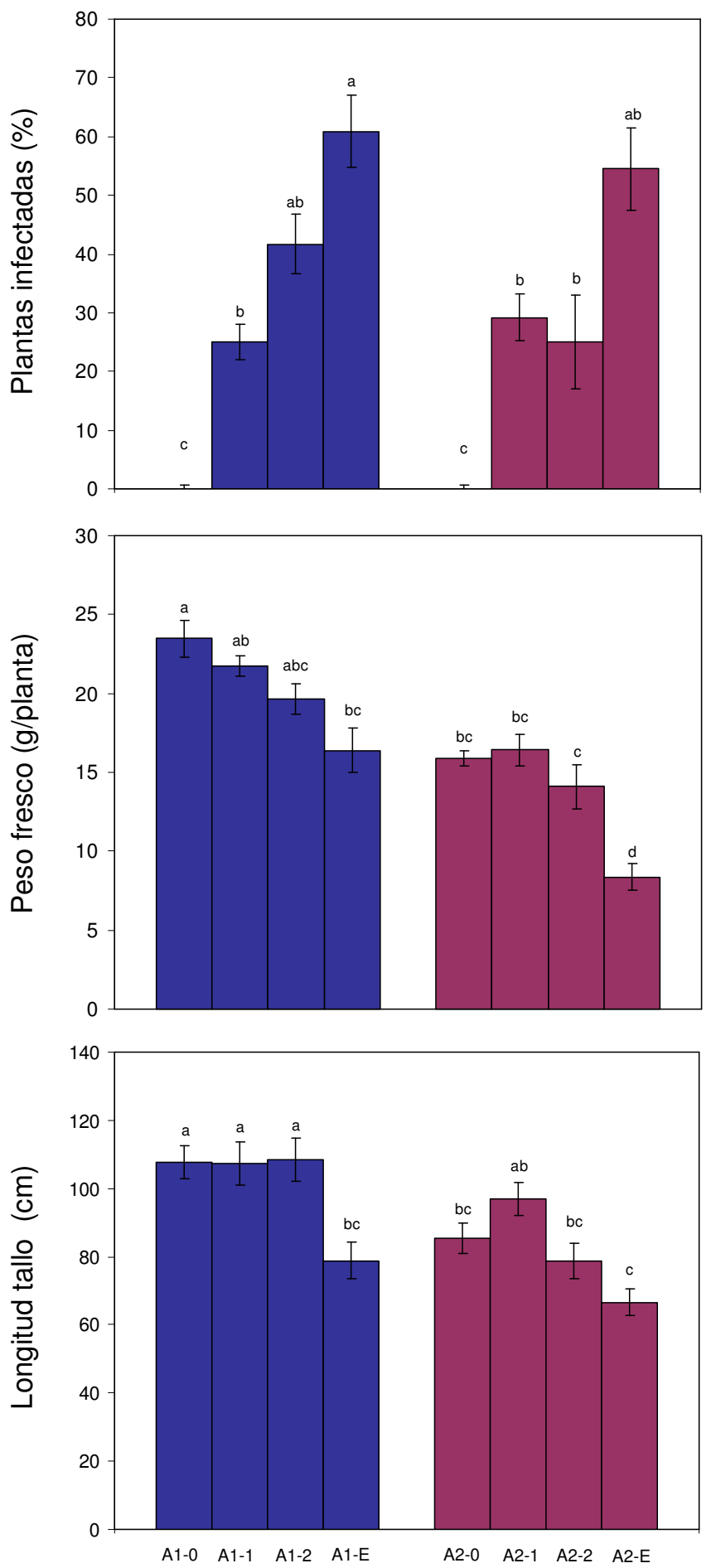

Sustrato

Figura. 4.5.6. Porcentaje de plantas infectadas, peso fresco y longitud del tallo en plantas de melón cultivadas en sustratos preparados con el compost A infectados con diferentes dosis de inóculo de Fusarium oxysporum f. sp. melonis

A1: mezcla de compost (de alperujo) al 8\% (en volumen); A2: mezcla de compost al 16\%

0, 1 y 2: no inoculado o inoculado con la dosis D1 (3,40.105 propágulos/contenedor) y D2 (1,70.106 propágulos/contenedor), respectivamente; E: autoclavado e inoculado con la dosis D2

Las líneas verticales indican el error estándar. Barras sin letra común difieren estadísticamente a $P \leq 0,05$ (test de StudentNewman-Keuls) 


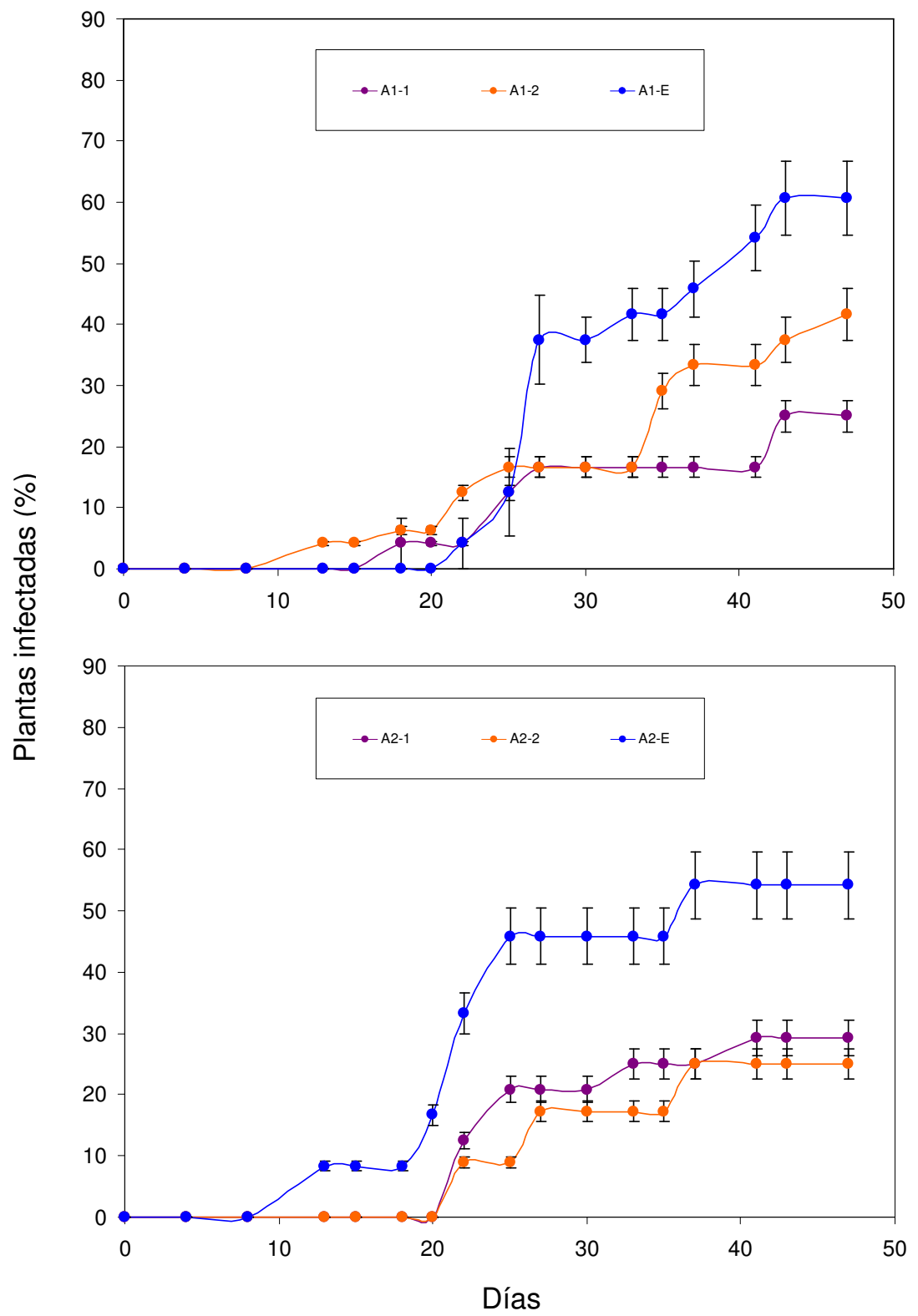

Figura 4.5.7. Curva de progresión de la enfermedad en plantas de melón cultivadas en sustratos preparados con el compost A infectados con diferentes dosis de inóculo de Fusarium oxysporum f. sp. melonis

A1: mezcla de compost (de alperujo) al $8 \%$ (en volumen); A2: mezcla de compost al $16 \%$

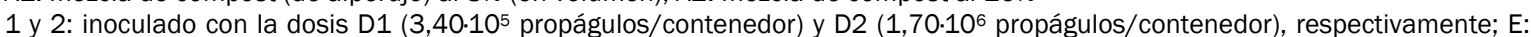
autoclavado e inoculado con la dosis D2

Las líneas verticales indican el error estándar

Según el análisis de la varianza multifactorial realizado (Tabla 4.5.8), la mezcla con compost al 8\% incrementó el parámetro AUDPC y la intensidad del color de la necrosis del tallo, mientras que la mezcla al 16\% provocó un aumento en la clorosis de las hojas, no observándose efecto estadísticamente significativo del factor Mezcla ( $8 \%$ vs. $16 \%$ ) sobre el porcentaje de plantas infectadas ni sobre la longitud del tallo afectado por la necrosis. Además, la Dosis de inóculo (D1 vs. D2) no influyó en ninguno de los parámetros relacionados con la severidad de la enfermedad. 
Tabla 4.5.8. Efectos principales de los tratamientos estudiados -Mezcla (con A, 8\% vs. 16\%) y Dosis de inóculo (D1 vs. D2)- sobre parámetros seleccionados, indicadores de la severidad de la enfermedad ocasionada por Fusarium oxysporum f. sp. melonis (FOM) en plantas de melón

\begin{tabular}{lccccc}
\hline $\begin{array}{c}\text { Efecto principal del } \\
\text { tratamiento }\end{array}$ & AUDPC & $\begin{array}{c}\text { Plantas } \\
\text { infectadas } \\
(\%)\end{array}$ & $\begin{array}{c}\text { Longitud de tallo } \\
\text { afectado } \\
(\%)\end{array}$ & $\begin{array}{c}\text { Intensidad } \\
\text { color necrosis } \\
\text { (puntuación) }\end{array}$ & $\begin{array}{c}\text { Clorosis } \\
\text { (puntuación) }\end{array}$ \\
\hline 1. Mezcla (en volumen) & & & & & \\
8\% & 43,2 & 33,3 & 6,65 & 2,32 & 3,17 \\
16\% & 32,3 & 27,1 & 1,02 & 2,09 & 3,23 \\
$P$ & $* *$ & $\mathrm{~ns}$ & $\mathrm{~ns}$ & $* * *$ & $* * *$ \\
2. Dosis de inóculo (FOM) & & & & & \\
D1 & 35,4 & 27,1 & 3,19 & 2,38 & 3,19 \\
D2 & 40,1 & 33,3 & 4,49 & 2,03 & 3,22 \\
$P$ & $\mathrm{~ns}$ & $\mathrm{~ns}$ & $\mathrm{~ns}$ & $\mathrm{~ns}$ & $\mathrm{~ns}$ \\
3. Interacción & & & & & $\mathrm{ns}$ \\
$1 \times 2$ & $* * *$ & $\mathrm{~ns}$ & $\mathrm{~ns}$ & & $\mathrm{~ns}$ \\
\hline A. & & & & &
\end{tabular}

A: compost de alperujo

D1: $3,40 \cdot 10^{5}$ propágulos/contenedor; D2: 1,70.106 propágulos/contenedor

AUDPC: área bajo la curva de progresión de la enfermedad

$P$ : nivel de significación. ns, ** y *** indican diferencias no significativas o estadísticamente significativas a $P \leq 0,01$ y $P \leq 0,001$, respectivamente

El estudio conjunto de las mezclas con compost esterilizadas y sin esterilizar (Tabla 4.5.9) reveló que los sustratos autoclavados (E) presentaron valores de AUDPC y porcentajes de planta infectada significativamente más elevados que el resto de las mezclas cuando el compost se mezcló al 8\% y al 16\%. Los sustratos con A al 16\% (A21 y A2-2) mostraron los menores valores de AUDPC, mientras que las mezclas al 8\% (A1-1 y A1-2) presentaron valores intermedios. Además, en el sustrato autoclavado y con A al 16\% (A2-E) se observó un grado de clorosis superior al resto de tratamientos ensayados. Por último, los distintos tratamientos estudiados no difirieron en la longitud de tallo afectado ni en la intensidad del color de las heridas necróticas en éste.

A modo de conclusión, puede indicarse que los ensayos in vivo de supresividad de los composts evidenciaron una inhibición de FOM con A mayor que con $\mathrm{A}+\mathrm{H}$ en las mezclas estudiadas (compost al 8\% + turba al 92\%) en el Experimento 1, presentando $\mathrm{A}+\mathrm{H}$ valores más bajos de los parámetros de crecimiento y desarrollo controlados, y más elevados de incidencia y severidad de la enfermedad, en comparación con A. Al comparar los efectos supresivos del compost $A$ en las mezclas con turba al $8 \%$ y al 16\% (Experimento 2), se observó una reducción de la infección similar en ambos sustratos al inocular la dosis D1 de FOM (A1-1 vs. A2-1) -alrededor del 50\% respecto 
Tabla 4.5.9. Parámetros indicadores de la severidad de la enfermedad ocasionada por Fusarium oxysporum f. sp. melonis en plantas de melón cultivadas en sustratos preparados con el compost A

\begin{tabular}{lccccc}
\hline Sustrato & AUDPC & $\begin{array}{c}\text { Plantas } \\
\text { infectadas } \\
(\%)\end{array}$ & $\begin{array}{c}\text { Longitud de tallo } \\
\text { afectado } \\
(\%)\end{array}$ & $\begin{array}{c}\text { Intensidad color } \\
\text { necrosis } \\
\text { (puntuación) }\end{array}$ & $\begin{array}{c}\text { Clorosis } \\
\text { (puntuación) }\end{array}$ \\
\hline A1-E & $75,3 \mathrm{a}$ & $60,9 \mathrm{a}$ & 0,85 & 2,09 & $3,35 \mathrm{~b}$ \\
$\mathrm{~A} 1-1$ & $31,3 \mathrm{~cd}$ & $25,0 \mathrm{~b}$ & 5,86 & 2,33 & $3,17 \mathrm{~b}$ \\
$\mathrm{~A} 1-2$ & $55,2 \mathrm{~b}$ & $41,7 \mathrm{ab}$ & 7,45 & 2,30 & $3,18 \mathrm{~b}$ \\
A2-E & $72,9 \mathrm{a}$ & $54,5 \mathrm{a}$ & 3,19 & 2,42 & $4,00 \mathrm{a}$ \\
A2-1 & $39,6 \mathrm{c}$ & $29,2 \mathrm{~b}$ & 0,52 & 2,43 & $3,21 \mathrm{~b}$ \\
A2-2 & 25, Od & $25,0 \mathrm{~b}$ & 1,53 & 1,75 & $3,25 \mathrm{~b}$ \\
$P$ & $* * *$ & $*$ & $\mathrm{~ns}$ & $\mathrm{~ns}$ & $* * *$ \\
\hline AUDPC: área bajo la curva de progresión de la enfermedad & & &
\end{tabular}

A1: mezcla de compost (de alperujo) al $8 \%$ (en volumen); A2: mezcla de compost al $16 \%$

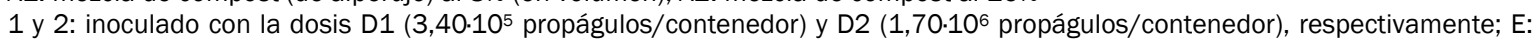
autoclavado e inoculado con la dosis D2

$P$ : nivel de significación. ns, * y *** indican diferencias no significativas o estadísticamente significativas a $P \leq 0,05$ y $P \leq 0,001$, respectivamente

Valores en columna sin letra común difieren estadísticamente a $P \leq 0,05$ (test de Student-Newman-Keuls)

a las mezclas estériles (A1-E y A2-E) - y una disminución significativa del número de plantas infectadas únicamente con la proporción del 16\% cuando el sustrato se inoculó con la dosis máxima del patógeno D2 (A2-2) en comparación con el sustrato autoclavado con idéntica proporción de compost y turba (A2-E). No obstante, el crecimiento y desarrollo de las plantas fue menor cuando se aumentó la proporción de compost en la mezcla, debido probablemente a unas propiedades físicas, físicoquímicas y químicas menos favorables, lo que indica la necesidad de considerar diferentes factores y estudiar in vivo -en ensayos preliminares- los potenciales efectos supresivos de los materiales orgánicos compostados. Además, la adición de microorganismos autóctonos o nativos de los composts a sustratos de cultivo y suelos agrícolas es una alternativa de gran interés para abordar futuras líneas de investigación, pudiéndose plantear incluso la comercialización de aislados de dichos materiales como agentes de biocontrol (Minuto et al., 2006; Postma et al., 2003). 


\subsection{EFECTOS DEL COMPOST DE ALPERUJO SOBRE LA BIODISPONIBILIDAD DE METALES PESADOS Y ARSÉNICO, Y SOBRE EL CRECIMIENTO DE PLANTAS DE BRASSICA EN DOS SUELOS CONTAMINADOS}

Muchas acciones antropogénicas como la actividad industrial, la combustión de combustibles fósiles, la minería, y la ganadería y la agricultura intensivas, conducen a la contaminación de los suelos.

La fitorremediación es una solución emergente para el tratamiento y la recuperación de estos suelos contaminados (Pilon-Smits, 2005). Entre las diferentes alternativas englobadas en el concepto de fitorremediación destacan dos, la fitoestabilización y la fitoextracción. Fitoestabilización significa el uso de plantas para estabilizar los contaminantes en el suelo, mientras que la fitoextracción consiste en el uso de plantas para retirar o extraer los contaminantes. En esta última alternativa, los contaminantes serían absorbidos por las plantas y acumulados preferentemente en sus tejidos aéreos, que serían cosechados, y, de este modo, los contaminantes serían retirados del suelo (Pilon-Smits, 2005; Prasad y Freitas, 2003). Las plantas hiperacumuladoras tienen la capacidad de acumular concentraciones elevadas de metales en sus tejidos, pero presentan una capacidad de crecimiento muy limitada (Roger et al., 2000) además de ser selectivas para un metal específico (Baker y Brooks, 1989), lo que las hace poco útiles para programas de fitorremediación. Para que las especies sean útiles como fitoextractoras deben: ser capaces de acumular, preferentemente en su parte aérea, y tolerar los contaminantes que se desean retirar del suelo; tener un potencial de crecimiento y acumulación de biomasa elevados; y, ser fácilmente cultivables y cosechables, entre otras características (Chaney et al., 2000). Entre las especies que podrían cumplir todas estas condiciones, algunas pertenecientes al género Brassica han recibido especial atención, ya que muchas de las especies hiperacumuladoras que se han descrito pertenecen a la familia Brassicaceae (Prasad y Freitas, 2003). Entre ellas, una de las especies no hiperacumuladoras más prometedoras para la extracción de metales pesados de suelos contaminados es Brassica juncea, aunque también se ha investigado con otras especies de Brassica como son B. campestris, B. carinata, B. napus, B. nigra, B. oleracea, y B. rapa (Gisbert et al., 2006; Kumar et al., 1995; Marchiol et al., 2004; Meers et al., 2005). 
Además de las características antedichas, las plantas destinadas a ser utilizadas en programas de fitorremediación deben tolerar las condiciones desfavorables para el cultivo que acompañan generalmente a los contaminantes, es decir, pHs ácidos o alcalinos, salinidad elevada, pobre estructura, etc.

En este sentido, la enmienda con materia orgánica suele mejorar globalmente las características y la fertilidad del suelo, incluidas la proliferación de microorganismos (Bünemann et al., 2006), la actividad bioquímica (Alvarenga et al., 2009b) y las condiciones de crecimiento de las plantas. La mejora de las propiedades biológicas del suelo tiene gran importancia, ya que tanto el número de microorganismos como su actividad son índices valiosos que se utilizan para determinar el grado de degradación y recuperación de los suelos (Pankhurst et al., 1995).

Es también sabido que la materia orgánica puede disminuir la biodisponibilidad de los metales pesados, haciendo que éstos pasen de las formas solubles e intercambiables a la fracción insoluble (Walker et al., 2003). Este último efecto es dependiente del pH. Así, en suelos calizos, con pH alcalino -condiciones que favorecen las formas insolubles de los metales pesados (Jahiruddin et al., 1985)-, la adición de materia orgánica inmadura puede aumentar la solubilidad de los elementos metálicos por medio del efecto acidificante que acompaña a la descomposición de esta materia orgánica inestable (Santibáñez et al., 2008). En los suelos ácidos, el pH bajo hace que los metales se encuentren en formas más solubles (Blaylock y Huang, 2000), y la adición de materia orgánica, a través de su efecto tamponador y neutralizador del pH, provoca entonces una disminución en dicha solubilidad (Alvarenga et al., 2009a).

\subsubsection{Caracterización de los suelos contaminados y los respectivos controles no contaminados}

\subsubsection{Parámetros físicos, fisico-químicos y composición}

Las características de los suelos contaminados (S1 y S2), y las de sus respectivos controles (SC1 y SC2) utilizados a lo largo de este experimento, se presentan en la Tabla 4.6.1. 
Tabla 4.6.1. Características físicas y físico-químicas seleccionadas, y composición (sobre materia seca) de los suelos contaminados (S1 y S2) y sus respectivos suelos control no contaminados (SC1 y SC2). Valores expresados como la media \pm la desviación estándar

\begin{tabular}{|c|c|c|c|c|}
\hline \multirow[b]{2}{*}{ Parámetroz } & \multicolumn{4}{|c|}{ Suelo } \\
\hline & S1 & SC1 & S2 & SC2 \\
\hline Arena (\%) & 38 & 41 & 49 & 83 \\
\hline Limo (\%) & 52 & 41 & 38 & 15 \\
\hline Arcilla (\%) & 10 & 18 & 13 & 2 \\
\hline Textura & Franco-limoso & Franco & Franco & Arenoso \\
\hline CRAD (\%) & $18,5 \pm 0,4$ & $19,9 \pm 1,4$ & $16,6 \pm 0,4$ & $16,4 \pm 0,7$ \\
\hline $\mathrm{pH}$ & $7,93 \pm 0,01$ & $8,01 \pm 0,02$ & $3,79 \pm 0,02$ & $3,82 \pm 0,03$ \\
\hline $\mathrm{CE}(\mathrm{dS} / \mathrm{m})$ & $0,32 \pm 0,01$ & $0,27 \pm 0,01$ & $0,97 \pm 0,08$ & $0,03 \pm 0$ \\
\hline $\mathrm{CIC}(\mathrm{cmol} / \mathrm{kg})$ & $24,6 \pm 1,3$ & $23,8 \pm 1,2$ & $17,8 \pm 0,7$ & $13,3 \pm 0,3$ \\
\hline Corg (g/kg) & $9,4 \pm 0,9$ & $13,3 \pm 0,6$ & $13,5 \pm 1,1$ & $2,4 \pm 0,4$ \\
\hline Materia orgánica (\%) & $1,61 \pm 0,13$ & $2,29 \pm 0,11$ & $2,33 \pm 0,18$ & $0,42 \pm 0,13$ \\
\hline $\mathrm{N}$ total $(\mathrm{g} / \mathrm{kg})$ & $1,32 \pm 0,10$ & $2,59 \pm 0,12$ & $1,14 \pm 0,10$ & $0,51 \pm 0,03$ \\
\hline $\mathrm{P}$ asimilable (mg/kg) & $21,7 \pm 0,4$ & $23,1 \pm 0,3$ & $21,8 \pm 0,7$ & $21,5 \pm 0,6$ \\
\hline K asimilable (mg/kg) & $150 \pm 7$ & $268 \pm 4$ & $22,4 \pm 2,8$ & $55,2 \pm 4,6$ \\
\hline Carbonatos $\left(\mathrm{CaCO}_{3}, \%\right)$ & $4,9 \pm 0,1$ & $7,7 \pm 0,5$ & nd & nd \\
\hline
\end{tabular}

z CRAD: capacidad de retención de agua disponible; CE: conductividad eléctrica; CIC: capacidad de intercambio catiónico; Corg: carbono orgánico

nd: no detectado

Los suelos S1 y SC1 fueron básicos, siendo el contenido en carbonatos (caliza total) y el pH en el suelo control más elevados que en el contaminado. El suelo S1 fue franco-limoso, mientras que SC1 tuvo una textura franca, presentando el primero una capacidad de retención de agua disponible o útil (18,5\%) parecida al segundo (19,9\%). Ambos fueron suelos no salinos, con una conductividad eléctrica (CE) media de 0,3 dS/m, una capacidad de intercambio catiónico similar (en torno a 24,2 $\mathrm{cmol}_{\mathrm{c}} / \mathrm{kg}$ ), y niveles de materia orgánica y nutrientes ( $\mathrm{N}, \mathrm{P}$ y $\mathrm{K}$ ) comunes en suelos agrícolas de la Comunidad Valenciana.

Por su parte, S2 y SC2 mostraron valores de pH ácido, de aproximadamente 3,8 unidades. S2 presentó una textura franca y SC2 arenosa, ambos con una capacidad de retención de agua disponible de alrededor de 16,5\%. Una diferencia marcada entre S2 y su control SC2, aparte del hecho contaminante, fue la elevada salinidad del primero $(\mathrm{CE}=0,97 \mathrm{dS} / \mathrm{m})$ frente a la muy baja del segundo $(\mathrm{CE}=0,03 \mathrm{dS} / \mathrm{m})$. La capacidad de intercambio catiónico del suelo S2 también fue mayor que la del SC2, siendo en ambos casos inferior a la de los suelos básicos. SC2, al proceder del horizonte $B$ de un suelo forestal, presentó un contenido en materia orgánica bajo en comparación con los otros tres suelos estudiados. Los suelos S2 y SC2 presentaron 
niveles de $\mathrm{N}$ total y $\mathrm{K}$ asimilable inferiores a los de los suelos básicos S1 y SC1, siendo su contenido en $\mathrm{P}$ asimilable similar al de estos dos últimos, por lo que su potencial nutricional fue inferior.

\subsubsection{Contenido y biodisponibilidad de los elementos traza}

La concentración total (determinada tras digestión nítrico-perclórica) y biodisponible (extraíble con EDTA para metales pesados y As, o con $\mathrm{KCl}$ para Al) así como la fracción biodisponible (expresada como porcentaje [\%] de la concentración total) de los siete elementos traza determinados (Al, $\mathrm{As}, \mathrm{Cr}, \mathrm{Cu}, \mathrm{Ni}, \mathrm{Pb}$ y $\mathrm{Zn}$ ) en los cuatro suelos estudiados se presentan en la Tabla 4.6.2. Lo más destacable fueron los elevados niveles totales de $\mathrm{Cu}, \mathrm{Pb}$ y $\mathrm{Zn}$ en el suelo $\mathrm{S} 1$, y de As y Pb en el suelo S2, notablemente superiores a los valores máximos permisibles (según Crommentuijn et al., 1997). También fue destacable el alto contenido en $\mathrm{Zn}$ de S2, aunque quedó por debajo del máximo tolerado. Sin embargo, y más que el contenido total de elementos traza en un suelo, lo que tiene significado funcional y fisiológico es la cantidad de las formas biodisponibles de éstos, que estará accesible a las plantas para su absorción y que también contribuirá en mayor medida a la contaminación del medio. De los contaminantes señalados anteriormente, los que presentaron mayor biodisponibilidad fueron $\mathrm{Pb}(64 \%)$ y Zn (62\%) en S1, y Zn en S2 (76\%). En este último suelo, el Pb se presentó en formas insolubles, debido al pH extremadamente ácido. Por la misma razón, pero en sentido contrario, se observó que la concentración de Al biodisponible en los suelos ácidos S2 y SC2 fue mucho mayor que en los suelos básicos S1 y SC1, en los que este elemento estuvo prácticamente insoluble.

\subsubsection{Poblaciones y actividad microbiana}

En la Tabla 4.6.3 se presentan las poblaciones microbianas, determinadas mediante enumeración de los microorganismos cultivables pertenecientes a los principales grupos microbianos (bacterias heterótrofas, actinomicetos, y mohos y levaduras), y su actividad, medida como consumo de $\mathrm{O}_{2}$ a través del proceso respiratorio y también mediante hidrólisis del diacetato de fluoresceína (FDA), en los cuatro suelos estudiados. 
Tabla 4.6.2. Concentración total, concentración biodisponible y fracción biodisponible de los elementos traza determinados en los suelos contaminados (S1 y S2) y en sus respectivos suelos control no contaminados (SC1 y SC2). Valores expresados como la media \pm la desviación estándar

\begin{tabular}{|c|c|c|c|c|c|}
\hline \multirow[b]{2}{*}{ Elemento/Parámetro } & \multicolumn{4}{|c|}{ Suelo } & \multirow{2}{*}{$\begin{array}{c}\text { Concentración } \\
\text { (total) máxima } \\
\text { permisible }\end{array}$} \\
\hline & S1 & SC1 & S2 & SC2 & \\
\hline \multicolumn{6}{|l|}{ Aluminio (Al) } \\
\hline Total (mg/kg) & $36500 \pm 1800$ & $25748 \pm 1750$ & $30094 \pm 1150$ & $23778 \pm 450$ & ne \\
\hline Biodisponible $(\mathrm{mg} / \mathrm{kg})$ & $5,3 \pm 0,5$ & nd & $226 \pm 5$ & $280 \pm 2$ & \\
\hline Fracción (\% del total) & 0,015 & - & 0,751 & 1,18 & \\
\hline \multicolumn{6}{|l|}{ Arsénico (As) } \\
\hline Total (mg/kg) & nd & nd & $60 \pm 10$ & nd & 34 \\
\hline Biodisponible (mg/kg) & - & - & $3,6 \pm 0,4$ & - & \\
\hline Fracción (\% del total) & - & - & 6 & - & \\
\hline \multicolumn{6}{|l|}{ Cromo (Cr) } \\
\hline Total (mg/kg) & $33 \pm 6$ & $24 \pm 1$ & $22 \pm 2$ & $24 \pm 0,1$ & 100 \\
\hline Biodisponible $(\mathrm{mg} / \mathrm{kg})$ & $3,9 \pm 0,3$ & nd & $1,8 \pm 0,4$ & nd & \\
\hline Fracción (\% del total) & 12 & - & 8 & - & \\
\hline \multicolumn{6}{|l|}{ Cobre (Cu) } \\
\hline Total (mg/kg) & $46 \pm 20$ & $20 \pm 1$ & $35 \pm 12$ & $0,3 \pm 0$ & 40 \\
\hline Biodisponible (mg/kg) & $8,3 \pm 0,6$ & $8,7 \pm 0,4$ & $30 \pm 3$ & nd & \\
\hline Fracción (\% del total) & 18 & 44 & 86 & - & \\
\hline \multicolumn{6}{|l|}{ Níquel (Ni) } \\
\hline Total (mg/kg) & $4 \pm 1$ & $24 \pm 0,6$ & $8 \pm 1$ & $16 \pm 0,1$ & 38 \\
\hline Biodisponible $(\mathrm{mg} / \mathrm{kg})$ & $4 \pm 1$ & $0,7 \pm 0,3$ & $3 \pm 0,7$ & nd & \\
\hline Fracción (\% del total) & 100 & 3 & 38 & - & \\
\hline \multicolumn{6}{|l|}{ Plomo (Pb) } \\
\hline Total (mg/kg) & $1215 \pm 28$ & $42 \pm 0,2$ & $229 \pm 6$ & $46 \pm 0,1$ & 140 \\
\hline Biodisponible (mg/kg) & $773 \pm 11$ & $9,5 \pm 1,7$ & $8 \pm 1$ & nd & \\
\hline Fracción (\% del total) & 64 & 23 & 4 & - & \\
\hline \multicolumn{6}{|l|}{ Zinc (Zn) } \\
\hline Total (mg/kg) & $273 \pm 8$ & $60 \pm 3$ & $113 \pm 15$ & $34 \pm 0,1$ & 160 \\
\hline Biodisponible $(\mathrm{mg} / \mathrm{kg})$ & $170 \pm 49$ & $0,8 \pm 0,1$ & $86 \pm 16$ & nd & \\
\hline Fracción (\% del total) & 62 & 1,33 & 76 & - & \\
\hline
\end{tabular}

zSegún Crommentuijn et al. (1997); ne: no establecido nd: no detectado

Se apreció que el suelo con mayor población microbiana global (destacando el número de bacterias heterótrofas) y mayores índices de respiración y actividad hidrolítica (FDA) fue el control alcalino SC1. El suelo $\mathrm{S} 1$, pese a la presencia de metales pesados contaminantes, presentó poblaciones elevadas de actinomicetos, mohos y levaduras, mientras que el número de colonias de bacterias heterótrofas fue bajo, debido probablemente a una mayor sensibilidad de estos microorganismos a la 
presencia de elementos tóxicos. Los suelos ácidos (S2 y SC2) presentaron poblaciones de microorganismos más reducidas en comparación con los suelos básicos, particularmente S2, que estuvo contaminado por metales pesados y As. Por ello, S2 y SC2 presentaron también los niveles más bajos de actividad microbiana. El efecto deletéreo de los metales pesados sobre los microorganismos del suelo puede perdurar durante muchos años (Abaye et al., 2005), aunque también se han señalado incrementos en la tolerancia de las poblaciones bacterianas y fúngicas a los metales pesados cuando éstas están expuestas a elementos potencialmente tóxicos (EPTs) durante largos períodos de tiempo (Bååth et al., 1998; Del Val et al., 1999).

Tabla 4.6.3. Principales poblaciones microbianas (bacterias heterótrofas, actinomicetos, y mohos y levaduras) y su actividad respiratoria e hidrolítica en los suelos contaminados (S1 y S2) y en sus respectivos suelos control no contaminados (SC1 y SC2)

\begin{tabular}{|c|c|c|c|c|c|}
\hline \multirow{2}{*}{ Determinación/Parámetro } & \multicolumn{4}{|c|}{ Suelo } & \multirow{2}{*}{$P$} \\
\hline & S1 & SC1 & S2 & SC2 & \\
\hline \multicolumn{6}{|l|}{ Población microbiana (log UFC/g) } \\
\hline Bacterias heterótrofas & $5,11 b$ & $6,60 a$ & $4,90 b$ & $5,11 b$ & $* * *$ \\
\hline Actinomicetos & $5,90 a$ & $5,70 a$ & $3,30 \mathrm{~b}$ & $5,30 a$ & *** \\
\hline Mohos y levaduras & $5,00 a$ & $3,70 \mathrm{~b}$ & $3,60 \mathrm{~b}$ & $3,11 b$ & *** \\
\hline \multicolumn{6}{|l|}{ Actividad microbiana } \\
\hline Respiración basal ( $\mathrm{mg} \mathrm{O}_{2}$ consumido $\mathrm{kg}^{-1}$ día $^{-1}$ ) & $100 \mathrm{~b}$ & $186 a$ & $100 \mathrm{~b}$ & $100 \mathrm{~b}$ & *** \\
\hline Hidrólisis del FDA ( $\mu \mathrm{g}$ FDA hidrolizado $\mathrm{g}^{-1} \mathrm{~min}^{-1}$ ) & $0,35 b$ & $0,54 a$ & $0,12 \mathrm{c}$ & $0,08 \mathrm{c}$ & ** \\
\hline
\end{tabular}

UFC: unidades formadoras de colonias; FDA: diacetato de fluoresceína

$P$ : nivel de significación. $* *$ y $* * *$ indican diferencias estadísticamente significativas a $P \leq 0,01$ y $P \leq 0,001$, respectivamente Valores en fila sin letra común difieren estadísticamente a $P \leq 0,05$ (test de Student-Newman-Keuls)

\subsubsection{Fitotoxicidad potencial}

Los resultados del bioensayo realizado con cebada (Hordeum vulgare) para evaluar la fitotoxicidad de los suelos, se recogen en la Tabla 4.6.4. El estudio demostró que los suelos control SC1 y SC2 habían sido seleccionados adecuadamente, ya que no mostraron fitotoxicidad en comparación con el control de arena, creciendo las raíces de las plántulas de cebada en ambos suelos, además, en una cuantía similar. Los suelos contaminados S1 y S2 redujeron (significativamente, $P \leq 0,001)$ el crecimiento de las raíces de cebada de un modo parecido, por lo que presentaron un nivel de fitotoxicidad similar en las condiciones de este bioensayo. 
Tabla 4.6.4. Resultados del bioensayo de crecimiento de raíces de cebada (Hordeum vulgare) en los suelos contaminados (S1 y S2) en comparación con sus respectivos suelos control no contaminados (SC1 y SC2) y un control adicional de arena

\begin{tabular}{|c|c|c|c|c|}
\hline \multirow[b]{2}{*}{ Suelo/Sustrato } & \multirow[b]{2}{*}{$\begin{array}{l}\text { Longitud raíz } \\
(\mathrm{mm})\end{array}$} & \multicolumn{3}{|c|}{ Longitud raíz (fracción de los controles) } \\
\hline & & SC1 & SC2 & Arena \\
\hline S1 & $41 b$ & 0,69 & - & 0,75 \\
\hline SC1 & $59 a$ & - & - & 1,07 \\
\hline S2 & $42 b$ & - & 0,79 & 0,76 \\
\hline $\mathrm{SC} 2$ & $53 a$ & - & - & 0,96 \\
\hline Arena & $55 a$ & - & - & - \\
\hline$P$ & $* * *$ & & & \\
\hline
\end{tabular}

\subsubsection{Efecto de la aplicación de compost sobre las características físico-químicas y la biodisponibilidad de los principales contaminantes en los suelos estudiados}

Como ya se indicó en la sección 3.7.4 de Materiales y Métodos, el diseño del experimento de fitorremediación realizado incluyó controles de los suelos no enmendados y enmendados con el compost de alperujo, en los que no se cultivaron plantas. Estos controles se fertilizaron (con abonos minerales) y recibieron un régimen de riegos igual que los tratamientos -suelos enmendados y no enmendados- en los que se cultivaron plantas. Los resultados que se presentan a continuación hacen referencia a los efectos del compost sobre los suelos indicados después de 16 semanas de duración del experimento, por lo que no tienen que coincidir necesariamente con los valores obtenidos en la caracterización inicial de dichos suelos. El compost utilizado en los experimentos de fitorremediación realizados (sin o con cultivo de plantas; presente sección 4.6.2 y siguiente sección 4.6.3, respectivamente) fue el que se ha denominado compost A (de alperujo) a lo largo de esta Tesis Doctoral.

La Tabla 4.6.5 recoge el efecto de la enmienda con este compost sobre algunas características físico-químicas relevantes de los suelos, y sobre la concentración total y biodisponible así como sobre la fracción biodisponible (como porcentaje [\%] de la concentración total) de los elementos traza determinados en los suelos contaminados (S1 y S2) y en sus respectivos suelos control no contaminados (SC1 y SC2). 


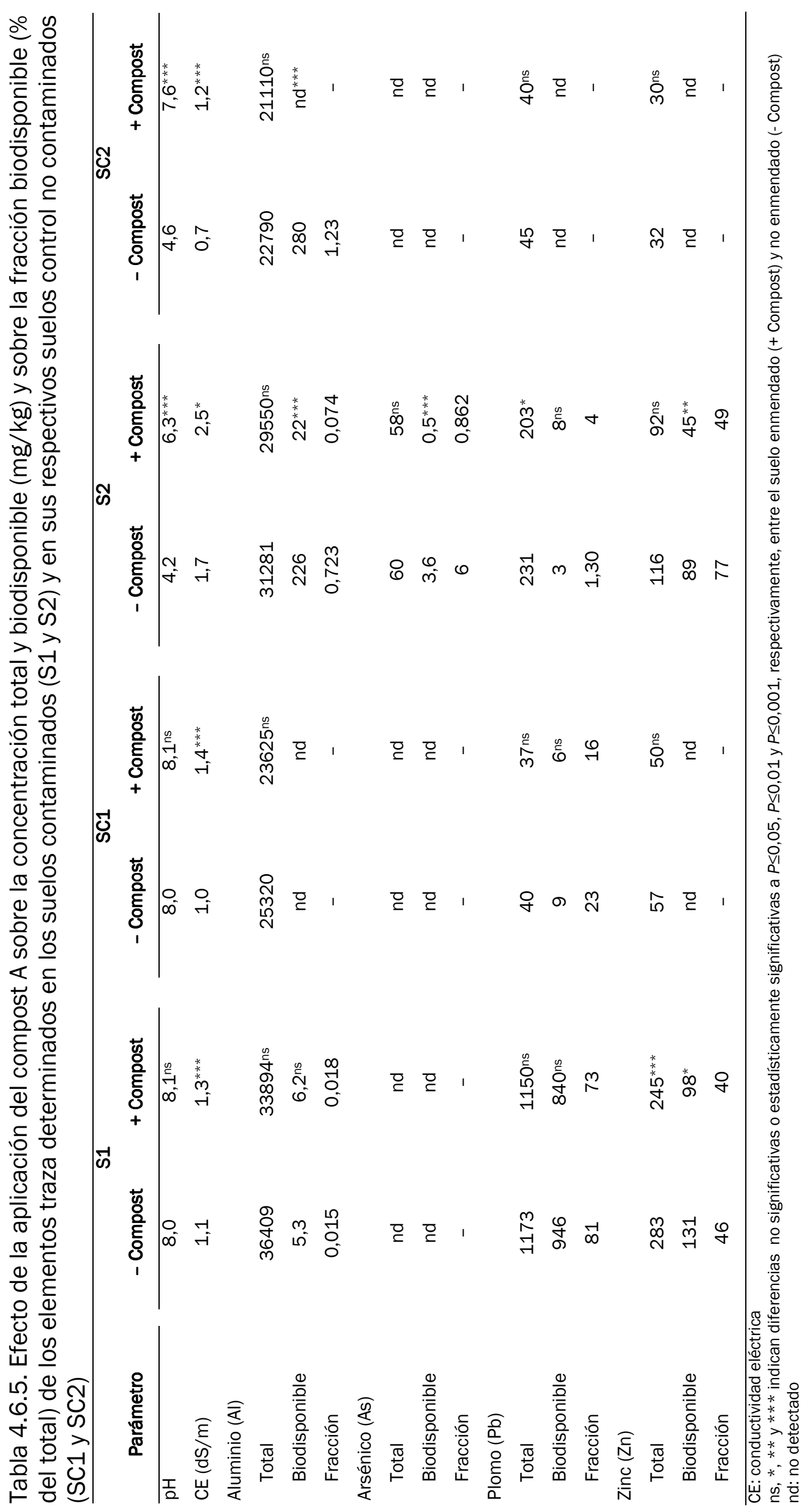


Como era de esperar, la enmienda con el compost $A$, que era fuertemente alcalino (ver la sección 4.1.2.1), afectó de manera diferente a los suelos básicos (S1 y SC1) y a los suelos ácidos (S2 y SC2). Así, el pH de los suelos ácidos aumentó -en 2,1 unidades en S2 y en 3 unidades en SC2-, mientras que en los suelos básicos el pH no varió significativamente, de acuerdo con lo observado por Alburquerque et al. (2011) con la aplicación de un compost de alperujo a un suelo ácido y a otro con pH próximo a la neutralidad. Por otra parte, la conductividad eléctrica (CE) de los cuatro suelos aumentó notablemente debido a la alta salinidad del compost de alperujo aplicado (ver sección 4.1.2.1).

Por otro lado, y como se ha indicado en la sección 4.6.2, el contenido inicial en Al biodisponible (extraíble con KCl) fue elevado en los suelos ácidos S2 y SC2 (226 y 280 $\mathrm{mg} / \mathrm{kg}$, respectivamente), mientras que éste fue prácticamente despreciable en los suelos básicos S1 y SC1; en condiciones de acidez del suelo $(\mathrm{pH}<5)$, la solubilidad y toxicidad del Al limita el crecimiento de las plantas (Sigel y Sigel, 1988). El incremento de $\mathrm{pH}$ hasta valores cercanos a la neutralidad provocado por la aplicación del compost A a los suelos ácidos, fue el responsable de la disminución de la concentración de Al asimilable en dichos suelos y, por tanto, de la marcada disminución en su fracción biodisponible (Tabla 4.6.5). Por otra parte, algunos autores han atribuido esta disminución a la presencia de ácidos húmicos y fúlvicos en las enmiendas orgánicas aplicadas, que afectaron tanto a la solubilidad del Al como a su fitotoxicidad (Tan y Binger, 1986; Tang et al., 2007).

Como ya se ha indicado, los suelos contaminados S1 y S2 presentaron contenidos en $\mathrm{Pb}$ y $\mathrm{Zn}$ superiores a sus respectivos suelos control SC1 y SC2. S1 fue el que presentó mayor contenido total en $\mathrm{Pb}(1173 \mathrm{mg} / \mathrm{kg})$ y Zn (283 mg/kg), estando en la fracción biodisponible el $81 \%$ y el $46 \%$ de los mismos, respectivamente, lo que indica niveles probablemente tóxicos para las plantas (Pichtel y Salt, 1998). En el suelo S2, los contenidos en $\mathrm{Pb}$ y $\mathrm{Zn}$ fueron menores que en S1, con la particularidad de que el Zn se encontró en forma biodisponible en porcentaje elevado (77\%), pudiendo tener así un efecto tóxico sobre las plantas, mientras que el Pb se presentó en formas insolubles y, por tanto, no inmediatamente tóxicas. Esta inmovilización del $\mathrm{Pb}$ en el suelo S2 era de esperar, ya que es bien sabido que este metal es insoluble y muy poco móvil en condiciones ácidas, en las que, además, forma compuestos insolubles al reaccionar con algunos aniones comunes en los suelos, como fosfatos, sulfatos y cloruros. 
Por otra parte, el suelo S2 presentó un elevado contenido en As (60 mg/kg), que, aunque estuvo principalmente en formas no biodisponibles, fue presumiblemente contaminante, considerando los niveles máximos tolerados en diferentes países (20 $\mathrm{mg} / \mathrm{kg}$, Alemania; $10 \mathrm{mg} / \mathrm{kg}$, Reino Unido; $14 \mathrm{mg} / \mathrm{kg}$, Estados Unidos; ver KabataPendias, 2001).

La enmienda con el compost A redujo ligeramente la concentración total de $\mathrm{Pb}$ y Zn en S1 y S2 debido probablemente a un efecto de dilución. La biodisponibilidad de los contaminantes resultó afectada por el compost únicamente en el suelo ácido S2, reduciéndose la de As del 6\% al 0,9\%, y la de $\mathrm{Zn}$ del $77 \%$ al $49 \%$, no viéndose influenciada significativamente la de $\mathrm{Pb}$. La marcada disminución del Zn biodisponible en S2 estuvo relacionada con el incremento de $\mathrm{pH}$ observado. El $\mathrm{pH}$ del suelo es un factor clave en el control de la movilidad del Zn (McBride et al., 1997), disminuyendo la solubilidad de éste a valores de pH básicos. La materia orgánica per se no afectó a la solubilidad del Zn, como se desprende de los valores no significativos obtenidos en el suelo S1 (alrededor del 43\% del total en el suelo enmendado y el no enmendado), donde el pH no experimentó variaciones estadísticamente significativas; en adición, y como indicaron Grimes et al. (1999) indicaron que la adsorción de Zn por la materia orgánica fue baja en comparación con otros metales como $\mathrm{Pb}, \mathrm{Cu}$ o Cd. La disminución en la biodisponibilidad del As en el suelo S2 enmendado fue relevante, dado su elevado potencial de toxicidad. La disminución observada es difícil de explicar, ya que el As se disuelve en la solución del suelo por los iones hidroxilo (Carbonell-Barrachina et al., 1999), y, tal como se ha visto en los resultados obtenidos, la aplicación del compost A aumentó el pH en el suelo S2.

\subsubsection{Efectos de la aplicación de compost de alperujo sobre las poblaciones y actividades microbianas en los suelos estudiados}

El efecto sobre las poblaciones de bacterias heterótrofas, actinomicetos, y mohos y levaduras, cuando el compost A se añadió a los cuatro suelos objeto de estudio, se presenta en la Figura 4.6.1. 

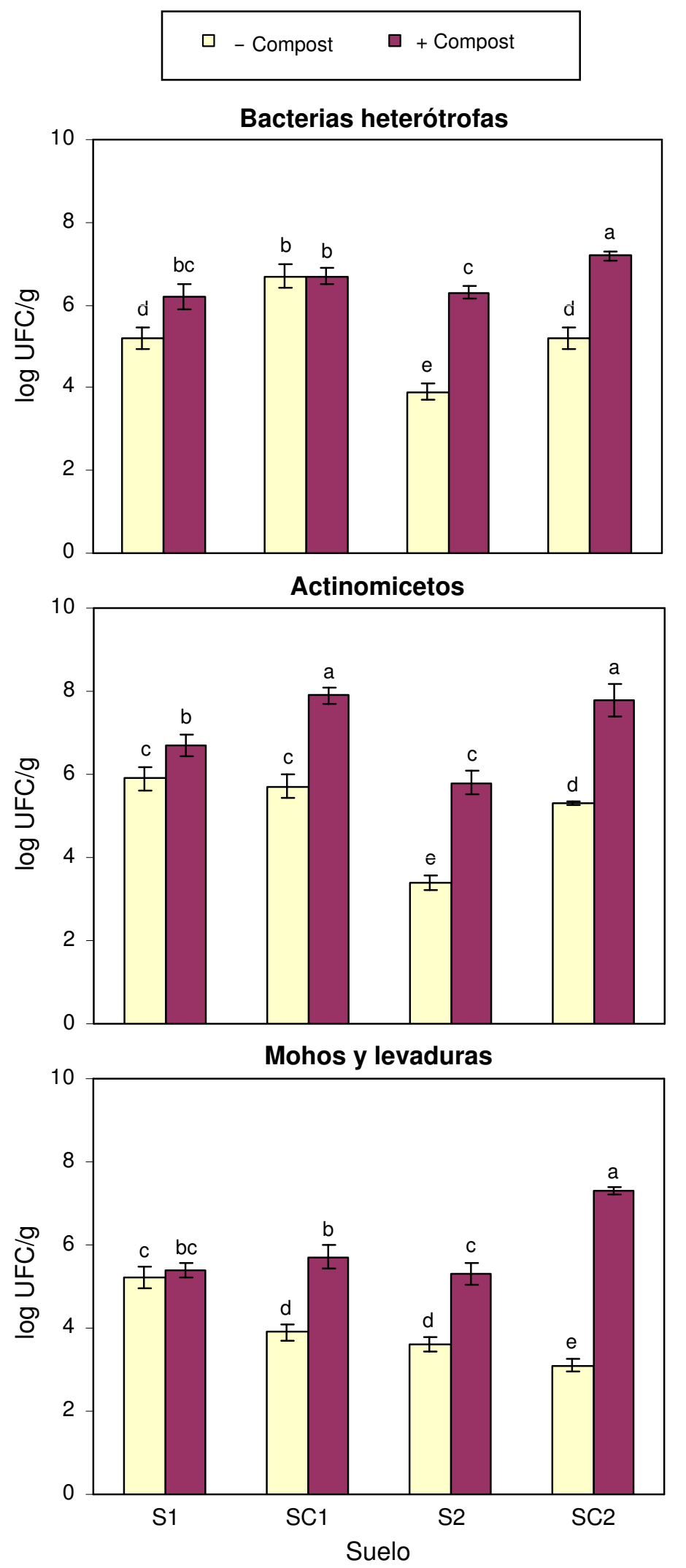

Figura 4.6.1. Población de bacterias heterótrofas, actinomicetos, y mohos y levaduras en los suelos contaminados (S1 y S2) y en sus respectivos suelos control no contaminados (SC1 y SC2) tanto enmendados con el compost A (+) como no enmendados (-), después de 16 semanas

UFC: unidades formadoras de colonias

Barras sin letra común difieren estadísticamente a $P \leq 0,05$ (test de Student-Newman-Keuls)

Las barras verticales indican el error estándar 
Tal y como se ha indicado en la sección 4.6.1.3, el número de microorganismos de las cuatro poblaciones estudiadas en los suelos ácidos S2 y SC2 fue menor que en los suelos básicos (S1 y SC1), cuando se compararon de manera independiente. La adición de compost aumentó el número de microorganismos de los cuatro grupos microbianos en los cuatro suelos estudiados, con la excepción de las bacterias heterótrofas en SC1 y de los mohos y las levaduras en S1. Estos incrementos fueron más marcados en los suelos ácidos que en los básicos, lo que estuvo probablemente relacionado con la disminución en la solubilidad (biodisponibilidad) de Al observada en los suelos ácidos tras la adición del compost. De hecho, se considera que el Al intercambiable, que está inversamente correlacionado con el pH del suelo, es el responsable -en gran medida- de la disminución de la biomasa y la actividad microbiana en los suelos ácidos (Aciego-Pietri y Brookes, 2008). Es particularmente interesante el incremento observado en la población de actinomicetos tras la aplicación del compost, ya que estos microorganismos son productores de antibióticos y pueden proteger a los cultivos de diversos patógenos vegetales, mejorando así el desarrollo vegetal y las cosechas (Hwang et al., 2001).

No se encuentra normalmente un patrón de variación concreto en los diferentes grupos de microorganismos en relación con las características de los suelos o las enmiendas -materiales orgánicos- aplicadas a éstos (Kim et al., 1997). De hecho, Pérez de Mora et al. (2006) señalaron que los perfiles de las poblaciones microbianas que se encuentran en los suelos se ven afectados por diversos factores, tales como la naturaleza y características del carbono orgánico de la enmienda, los exudados radicales en la rizosfera, la concentración de metales pesados, o el pH. Sin embargo, cuando se considera la biomasa microbiana total, sin distinción de grupos de microorganismos, generalmente se atribuye un aumento de la misma a la adición de materia orgánica, incluso utilizando diferentes tipos de suelo y enmiendas orgánicas con distinto grado de madurez (Ros et al., 2003; Pérez de Mora et al., 2005).

La Figura 4.6.2 presenta el efecto de la aplicación del compost A sobre la respiración y la actividad hidrolítica microbiana en los cuatro suelos estudiados. La actividad microbiana, medida como la hidrólisis del diacetato de fluoresceína (FDA), estuvo estrechamente relacionada con el número de microorganismos presentes en el suelo. Así, se observó mayor actividad en los suelos básicos que en los ácidos; y, la enmienda con el compost incrementó marcadamente la actividad microbiana en todos los suelos, haciéndola muy elevada en los básicos. Este efecto fue también 
encontrado por Kim et al. (1997) tras añadir diferentes tipos de materia orgánica al suelo. Los procesos hidrólisis del FDA y respiración basal son buenos indicadores de la actividad microbiana del suelo (Chen et al., 1988; Schnürer y Rosswall, 1982). La respiración (determinada como $\mathrm{O}_{2}$ consumido) fue similar en todos los suelos, salvo en SC1 en que fue notablemente superior. La adición del compost A aumentó la respiración en todos los suelos y, finalmente, los suelos básicos enmendados presentaron mayor nivel respiratorio que los ácidos que también recibieron aporte de materia orgánica.

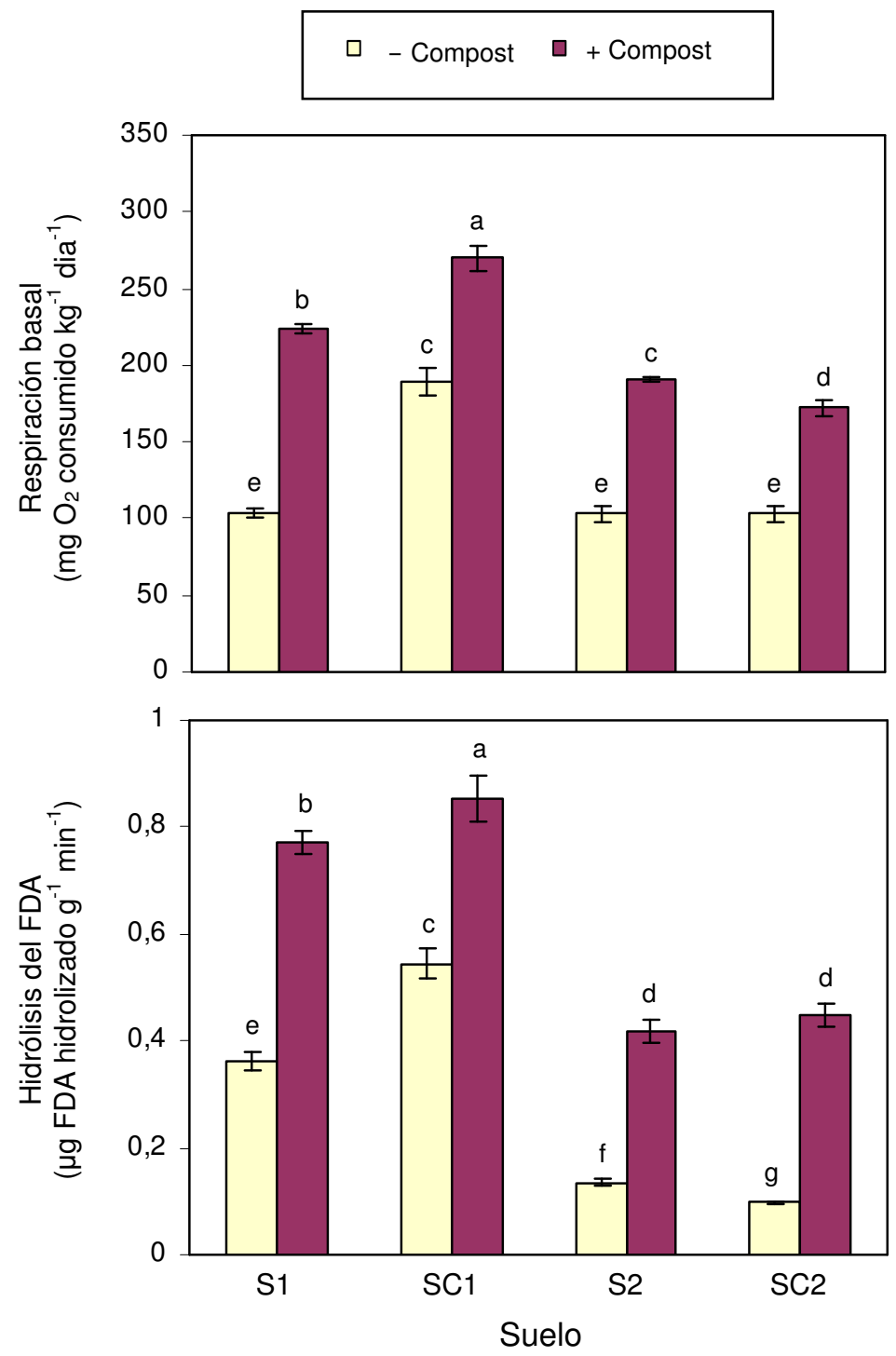

Figura 4.6.2. Respiración microbiana e hidrólisis del diacetato de fluoresceína (FDA) en los suelos contaminados (S1 y S2) y en sus respectivos suelos control no contaminados (SC1 y SC2) tanto enmendados con el compost A (+) como no enmendados (-), después de 16 semanas

Barras sin letra común difieren estadísticamente a $P \leq 0,05$ (test de Student-Newman-Keuls) Las barras verticales indican el error estándar 


\subsubsection{Efectos de la aplicación de compost de alperujo a los suelos sobre cinco especies del género Brassica}

\subsubsection{Influencia del compost en la supervivencia y el crecimiento de las plantas cultivadas en los suelos estudiados}

Tal y como se observa en la Tabla 4.6.6, ninguna planta de las cinco especies de Brassica utilizadas sobrevivió en los suelos ácidos S2 y SC2. Al aumentar el pH de éstos mediante la aplicación del compost A, las especies B. carinata, B. napus y $B$. oleracea mostraron un elevado porcentaje (>74\%) de supervivencia, pero igualmente murieron todas las plantas de B. juncea y B. rapa. De las tres especies que sobrevivieron, $B$. oleracea acumuló alrededor de cuatro veces más materia seca en el vástago que las dos restantes. En cuanto al crecimiento de las plantas de cualquiera de estas tres especies en el suelo ácido contaminado S2, en comparación con su control SC2, no se observaron diferencias estadísticamente significativas. Esto indica que el bajo $\mathrm{pH}$, y no la presencia de $\mathrm{Pb}, \mathrm{Zn}$ y As en cantidades elevadas, provocó la mortandad de las plantas de B. carinata, B. napus y B. oleracea en S2. Lo más probable es que el factor más relacionado con la toxicidad fuera el elevado contenido en Al biodisponible en las condiciones de acidez de S2, que desapareció al elevarse el pH tras la aplicación del compost A al suelo. Esto ya lo demostraron Tang et al. (2007), utilizando plantas de trigo. La causa de la muerte de todas las plantas de $B$. juncea y B. rapa no está vinculada con lo arriba indicado, ya que éstas no sobrevivieron a pesar de haber aumentado el $\mathrm{pH}$ del suelo, permaneciendo estas razones todavía desconocidas.

Asimismo, en la Tabla 4.6.6 se recogen los resultados de la supervivencia y el crecimiento de las plantas de las cinco especies de Brassica en los suelos básicos S1 y SC1. Lo primero que se observó fue que el índice de supervivencia fue mayor que en los suelos ácidos, siendo del 83\% para B. oleracea, del 92\% para B. juncea, y del $100 \%$ para las otras tres especies. Esta supervivencia fue menor en el suelo contaminado S1 que en el control SC1, salvo en el caso de B. carinata en que fue igualmente del 100\%. La aplicación del compost A afectó ligera y diferencialmente a la supervivencia de las plantas. Así, en SC1 redujo la supervivencia de $B$. napus y $B$. oleracea, mientras que en S1 aumentó el valor de dicho parámetro en B. napus, y lo disminuyó en $B$. oleracea. Por otra parte, las especies que acumularon más biomasa en el vástago cuando se cultivaron en el suelo control SC1 fueron B. rapa y $B$. 
oleracea, seguidas de B. juncea y B. carinata, y, finalmente, de B. napus, no resultando este parámetro afectado significativamente por la adición de compost al suelo. En el suelo contaminado S1 sin enmendar, el crecimiento de $B$. carinata, $B$. juncea, $B$. napus y $B$. oleracea fue igual o mayor que en el suelo control $\mathrm{SC}$, lo que reveló que los contaminantes no resultaron tóxicos para estas especies. Sin embargo, la enmienda con compost de dicho suelo S1 redujo el crecimiento de las plantas de las cinco especies. Este efecto perjudicial podría explicarse por diversos factores relacionados con las características y la composición del compost de alperujo utilizado (compost A), que, además, se aplicó a dosis elevada (equivalente a 100 t/ha). Aunque no se detectó fitotoxicidad del compost A según los bioensayos de germinación de semillas y de crecimiento de plántulas que se han presentado en la sección 4.1.3.2, una explicación para este efecto deletéreo podría ser la presencia de fenoles en este compost (ver la sección 4.1.2.2), que junto con el alto nivel de Pb biodisponible en $\mathrm{S} 1$ y el aumento considerable de la conductividad eléctrica (CE) observado en dicho suelo, resultaron en un incremento en la toxicidad. En cualquier caso, en la literatura pueden encontrarse resultados opuestos, tanto de efectos favorables como desfavorables, en cuanto a la enmienda de los suelos básicos con materiales orgánicos y su relación con la fitotoxicidad y el crecimiento de las plantas (Walker et al., 2003; Zhou et al., 2005).

\subsubsection{Efecto del compost sobre la acumulación de Al, As, $P b$ y Zn en el vástago de las plantas cultivadas en los suelos contaminados}

Cuando se cultivaron en el suelo contaminado S1, las especies que concentraron más $\mathrm{Pb}$ junto con $\mathrm{Zn}$ en sus tejidos aéreos fueron $B$. juncea seguida de $B$. carinata y $B$. napus; la especie $B$. oleracea presentó una elevada concentración de $\mathrm{Zn}$ pero no de $\mathrm{Pb}$, mientras que $B$. rapa concentró $\mathrm{Pb}$ pero no $\mathrm{Zn}$ (Tabla 4.6.7). En cuanto al contenido total de estos metales acumulado en el vástago de las plantas, que está relacionado con el potencial de crecimiento (producción de biomasa) de cada especie, $B$. carinata y $B$. juncea fueron las que más $\mathrm{Pb}$ extrajeron del suelo, seguidas de $B$. rapa, B. oleracea y B. napus, por este orden. Las especies con mayor extracción y acumulación de $\mathrm{Zn}$ fueron $B$. oleracea y $B$. juncea, seguidas de $B$. carinata, $B$. napus y B. rapa. Por tanto, y en conjunto, los mejores resultados en $\mathrm{S} 1$ se obtuvieron con $B$. juncea, que fue capaz de acumular grandes cantidades de los dos contaminantes principales. 


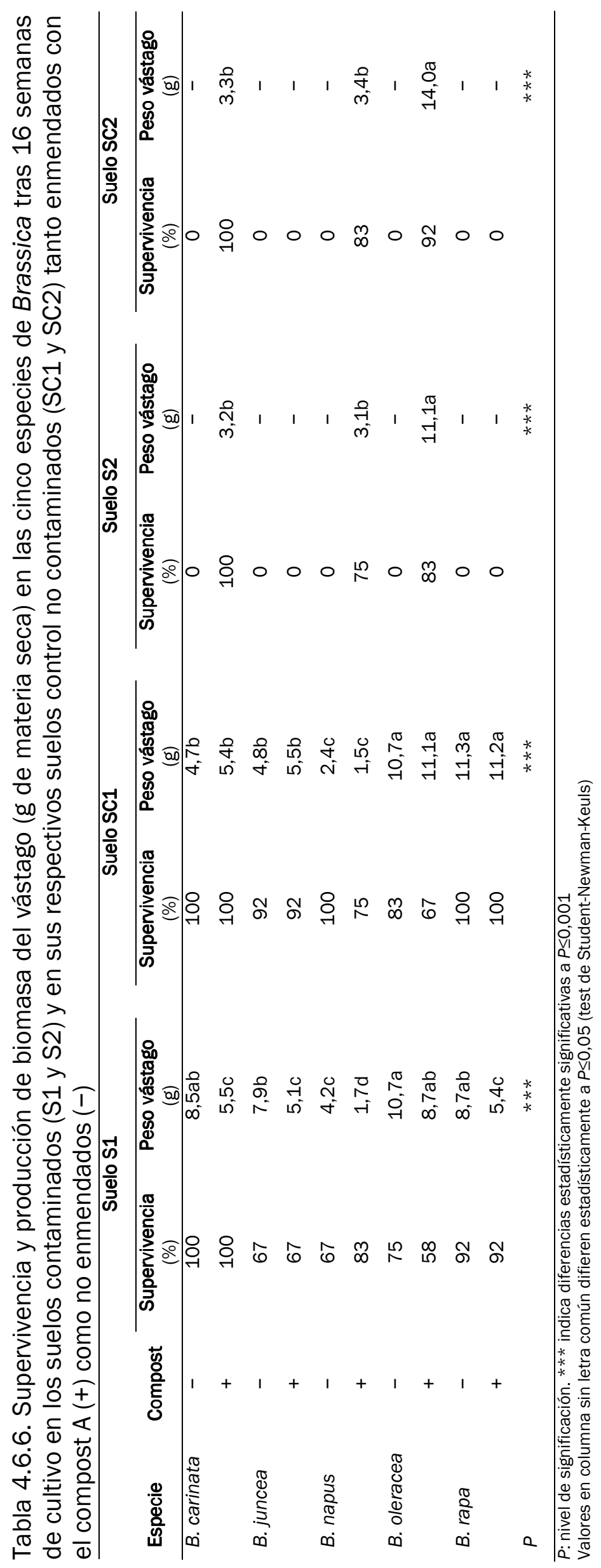




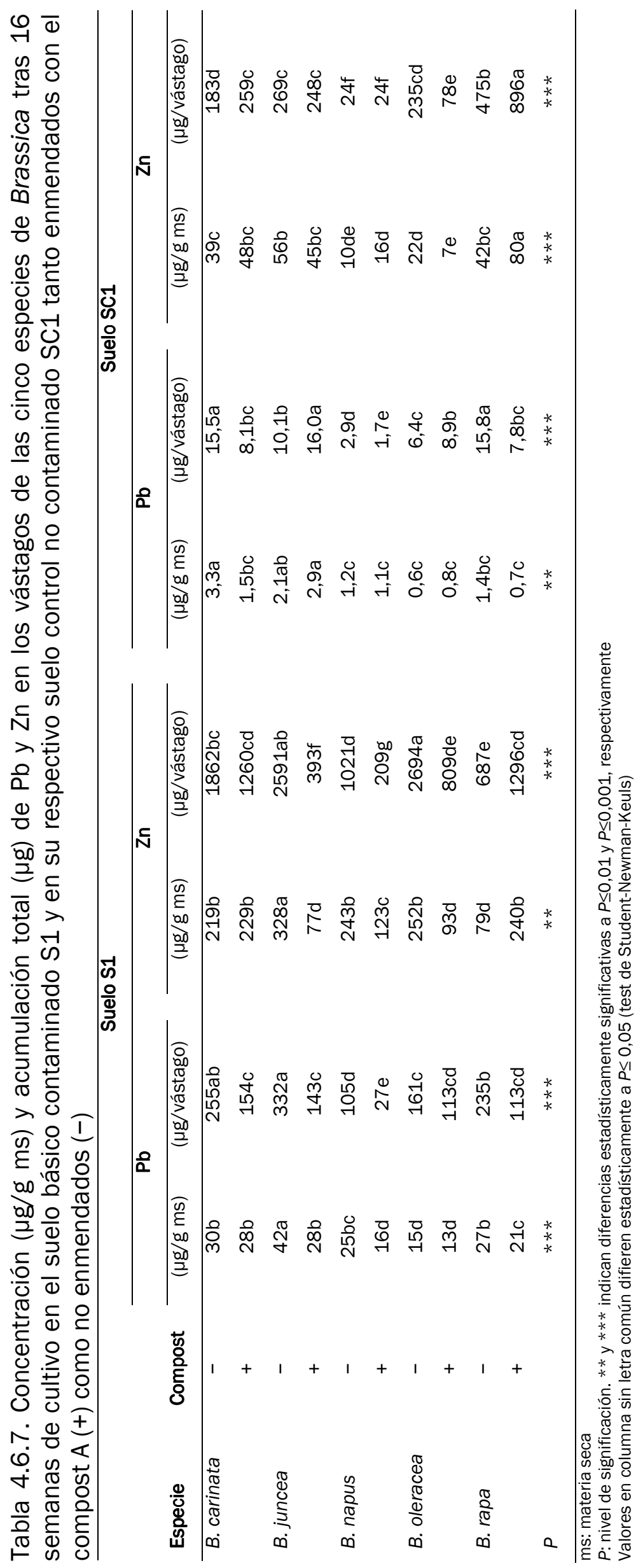


La adición del compost A a S1 no afectó (o incluso disminuyó) la concentración ni la cantidad total (acumulada) de $\mathrm{Pb}$ y $\mathrm{Zn}$ encontradas en el vástago de las plantas en todas las especies, salvo para el Zn en B. rapa. En el suelo control SC1 se obtuvieron resultados similares a los señalados para S1, aunque, lógicamente, de menor cuantía, ya que el contenido en $\mathrm{Pb}$ y Zn en SC1 fue menor que en S1.

Por otra parte, las plantas acumularon cantidades importantes de Al en sus vástagos cuando se cultivaron en los suelos ácidos S2 y SC2 enmendados con el compost (Tabla 4.6.8), encontrándose la mayor concentración de este metal en $B$. carinata, y la menor en $B$. oleracea. Sin embargo, y debido a su mayor potencial de crecimiento y producción de biomasa, B. oleracea llegó a acumular una cantidad de Al similar a B. carinata en SC2, y tres veces más que B. napus en S2. En el suelo contaminado $\mathrm{S} 2$, los vástagos de $B$. carinata y $B$. oleracea presentaron mayores concentraciones de As y $\mathrm{Zn}$, y similares de $\mathrm{Pb}$, en comparación con $B$. napus. Dado que $B$. oleracea fue la que más biomasa produjo en el suelo contaminado S2, esta especie fue la que presentó mayor acumulación total de As, Pb y Zn en su vástago.

Tabla 4.6.8. Concentración y acumulación total de Al, As, Pb y Zn en los vástagos de tres especies de Brassica tras 16 semanas de cultivo en el suelo ácido contaminado S2 y en su respectivo suelo control no contaminado SC2, ambos enmendados con el compost A

\begin{tabular}{|c|c|c|c|c|c|c|c|c|c|}
\hline \multirow[b]{2}{*}{ Suelo } & \multirow[b]{2}{*}{ Elemento } & \multicolumn{4}{|c|}{$\begin{array}{c}\text { Concentración } \\
(\mu \mathrm{g} / \mathrm{g} \mathrm{ms})\end{array}$} & \multicolumn{4}{|c|}{$\begin{array}{c}\text { Acumulación total } \\
(\mu \mathrm{g} / \text { vástago })\end{array}$} \\
\hline & & B. carinata & B. napus & B. oleracea & $P$ & B. carinata & B. napus & B. oleracea & $P$ \\
\hline \multirow[t]{4}{*}{ S2 } & $\mathrm{Al}$ & $2240 a$ & $540 b$ & $435 c$ & $* * *$ & $7168 a$ & $1674 \mathrm{c}$ & $4829 b$ & $* * *$ \\
\hline & As & $14 a$ & $10 b$ & $10 \mathrm{~b}$ & $* *$ & $44,8 b$ & $31,0 b$ & $111,0 a$ & $* * *$ \\
\hline & $\mathrm{Pb}$ & 7,0 & 5,0 & 6,0 & ns & $22,4 b$ & $15,5 b$ & $66,6 a$ & ** \\
\hline & $\mathrm{Zn}$ & $147 a$ & $108 b$ & $147 a$ & $* * *$ & $470 \mathrm{~b}$ & $335 b$ & $1632 a$ & $* * *$ \\
\hline \multirow[t]{4}{*}{$\mathrm{SC} 2$} & $\mathrm{Al}$ & $2111 a$ & $656 b$ & $404 c$ & $* * *$ & $6966 a$ & $2230 b$ & $5656 a$ & $* * *$ \\
\hline & As & $4,3 a$ & $3,4 b$ & $0,1 \mathrm{c}$ & $* * *$ & $14,2 a$ & $11,6 b$ & $1,4 \mathrm{c}$ & $* * *$ \\
\hline & $\mathrm{Pb}$ & $1,3 b$ & $2,1 a$ & $1,0 b$ & * & $4,3 c$ & $7,1 \mathrm{~b}$ & $14,0 a$ & $* * *$ \\
\hline & $\mathrm{Zn}$ & $59 a$ & $33 b$ & $3 c$ & $* * *$ & $195 a$ & $112 b$ & $42 c$ & ** \\
\hline
\end{tabular}

ms: materia seca $P \leq 0,001$, respectivamente

Valores en fila sin letra común difieren estadísticamente a $P \leq 0,05$ (test de Student-Newman-Keuls)

En general, los resultados de este experimento muestran la capacidad de las especies del género Brassica para crecer en suelos contaminados por metales pesados y arsénico. Sin embargo, las cinco especies estudiadas no fueron igual de apropiadas para suelos básicos y ácidos, ni tampoco mostraron una eficiencia similar 
para la extracción combinada (conjunta) de los cuatro contaminantes. Este hecho limitaría su uso en la restauración de suelos multicontaminados.

Brassica juncea es una de las especies no hiperacumuladoras a la que se le ha prestado mucha atención -por su potencial para la fitoextracción de metales- y, de hecho, se ha demostrado su capacidad para absorber y acumular $\mathrm{Cd}, \mathrm{Cu}, \mathrm{Ni}, \mathrm{Pb}$ y $\mathrm{Zn}$ (Marchiol et al., 2004; Quartacci et al., 2006); adicionalmente, y en concordancia con los resultados del presente experimento, se ha demostrado también que las especies de Brassica no pueden crecer en suelos cuyo pH esté por debajo de 4,5-5. No se tiene constancia de que se haya estudiado alguna otra especie, aparte de $B$. juncea, en condiciones de acidez tan elevadas como las de los suelos S2 y SC2 de este experimento. Se han realizado estudios en muy diversas condiciones (cultivos hidropónicos o en mezclas de arena y perlita) con otras especies del género Brassica (Kumar et al., 1995), habiéndose identificado B. oleracea como una especie potencialmente útil para acumular metales pesados (Kabata-Pendias, 2001). De hecho, el presente estudio es el primero en aportar información sobre el uso de plantas de $B$. carinata, $B$. napus y $B$. oleracea como fitoextractoras en suelos ácidos contaminados por $\mathrm{As}, \mathrm{Pb}$ y $\mathrm{Zn}$. Los resultados obtenidos tras enmendar los suelos contaminados con compost de alperujo, fundamentalmente con B. carinata para la absorción de $\mathrm{Al}$, y con $\mathrm{B}$. oleracea para la extracción de $\mathrm{Al}$, As, $\mathrm{Pb}$ y $\mathrm{Zn}$, deben promover la realización de más experimentos en este sentido.

Baker (1981) señaló que algunas especies del género Brassica se comportan como excluyentes de $\mathrm{Pb}$ y $\mathrm{Zn}$ hasta cierto umbral de concentración de estos metales, a partir del cual se produce un transporte no restringido de los mismos. En las condiciones experimentales del presente estudio se encontraron valores elevados (cercanos o mayores que 1) del factor de bioconcentración FBC (es decir, la relación entre la concentración del elemento en el vástago de la planta y la concentración 'total' de dicho elemento en el suelo; McGrath y Zhao, 2003) para el Zn en los suelos S1 y S2 en todas las especies utilizadas, aunque en el caso de $B$. rapa fue necesaria la aplicación del compost A para alcanzar estos valores (Tabla 4.6.9). Los valores del FBC encontrados en esta investigación con $B$. carinata, $B$. juncea y $B$. napus fueron superiores para el Zn $(0,28-1,60)$, y similares para el $\mathrm{Pb}(0,01-0,04)$, en comparación con los obtenidos por Marchiol et al. (2004), que fueron inferiores a 0,04 y 0,03, respectivamente. Aunque no hay datos disponibles en la literatura sobre Al y As para establecer comparaciones, los resultados del presente experimento mostraron valores 
bajos del FBC para el Al, que fueron similares a los del Pb, y algo mayores para el As. Cuando se estudió el factor de bioconcentración en relación al contenido de elementos traza 'biodisponibles' en el suelo (FBC'), se encontraron valores muy elevados (2-3) para el Zn (Tabla 4.6.9), indicando que las especies estudiadas fueron capaces de concentrar en sus vástagos entre 2 y 3 veces más $\mathrm{Zn}$ del que se encontraba biodisponible en el suelo. Respecto a Pb, únicamente en S2 el FBC' $(<0,9)$ fue mayor que el FBC $(0,04)$, poniéndose así de manifiesto una capacidad limitada de las especies del género Brassica para extraer $\mathrm{Pb}$ de este suelo. Con respecto a Al y As en el suelo S2, todas las especies de Brassica que sobrevivieron demostraron una capacidad apropiada para extraer y acumular en sus vástagos las formas biodisponibles de estos dos elementos traza.

Al evaluar en su conjunto la potencial utilización de las especies de Brassica estudiadas en este experimento en programas de fitorremediación de suelos contaminados por metales pesados, los resultados obtenidos permiten estimar que sobre una base de cultivo de 40000 plantas por hectárea y dos cosechas al año- la mejor extractora en S2, B. oleracea, podría extraer del orden de 130 g de Zn, 5,4 g de $\mathrm{Pb}$ y $8,8 \mathrm{~g}$ de As por hectárea y año, y la mejor en S1, B. juncea, podría extraer $207 \mathrm{~g}$ de Zn y 26,5 g de Pb por hectárea y año. En otras palabras, y para poder alcanzar los valores permitidos en suelos agrícolas por el Consejo de las Comunidades Europeas (CEC, 1986), que son de 300 mg/kg de Zn, 300 mg/kg de Pb, y 34 mg/kg de As, estas especies necesitarían del orden de 657 años para extraer el Zn, 17358 años para el $\mathrm{Pb}$, y 7234 años para el As en el suelo ácido S2, y 997 años para extraer el Zn y 18767 años para el Pb en el suelo básico S1. Teniendo presentes estas estimaciones, y a pesar de la alta eficiencia fitoextractora de B. oleracea en S2, y de B. juncea en S1, estas especies no serían capaces de descontaminar suelos fuertemente contaminados por múltiples elementos traza. 


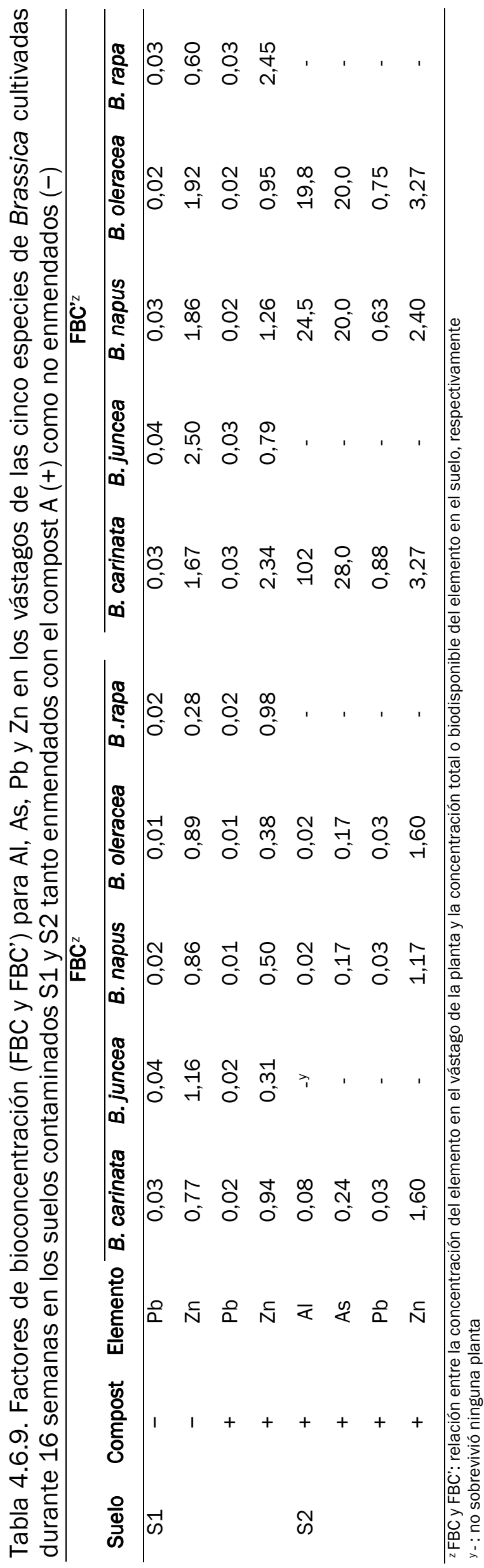




\subsection{EL USO DE COMPOST DE ALPERUJO EN LA PREPARACIÓN DE SUSTRATOS DE CULTIVO COMO NUEVA LÍNEA DE INVESTIGACIÓN. CORRECCIÓN DEL PH CON VISTAS A SU ADECUACIÓN}

Además de su uso como enmienda orgánica del suelo, el compost puede utilizarse en la formulación de sustratos para el cultivo sin suelo de planta ornamental, de flor y hortícola en contenedor, y para la preparación de semilleros, principalmente. En este campo de aplicación, el compost de calidad alcanza mayor precio que el destinado a otros usos, lo que resulta ventajoso para el productor de dicho compost. Otra ventaja derivada de este uso es la posibilidad de sustituir total o parcialmente a la turba Sphagnum - de elevado precio y cuya extracción representa, además, un fuerte impacto medioambiental- en la preparación de sustratos de cultivo.

Sin embargo, muchos composts no reúnen las características físico-químicas ( $\mathrm{pH}$ y conductividad eléctrica [CE]) adecuadas para el uso propuesto (Abad et al., 2001, 2008). En este contexto, el compost de alperujo es un claro ejemplo de ello, ya que presenta una elevada salinidad y un $\mathrm{pH}$ fuertemente alcalino.

El problema del elevado contenido en sales y nutrientes -y dado que éstos son solubles en agua- se resuelve fácilmente, lavando el compost hasta alcanzar un valor de conductividad eléctrica adecuado. Los inconvenientes de esta operación son el elevado consumo de agua de calidad que conlleva y la necesidad de recoger los lixiviados generados y procurar su reutilización, para minimizar el impacto ambiental que éstos provocarían (Fornes et al., 2010).

La corrección del pH, por su parte, puede abordarse de diferentes maneras. Por un lado, bastaría mezclar el compost alcalino con un material de reacción ácida, como es la turba Sphagnum; sin embargo, ésta no parece ser la mejor alternativa, debido a que uno de los objetivos perseguidos es la eliminación/reducción del consumo de turba. Otra posibilidad sería la adición directa de ácidos al compost, tales como ácido nítrico o ácido fosfórico, que, además de bajar el pH del medio, aportan nitrógeno y fósforo como nutrientes (Raviv, 2005); su inconveniente, especialmente en el caso del ácido nítrico, es que implica el manejo de sustancias peligrosas. Como tercera estrategia, podrían aplicarse enmiendas minerales derivadas del azufre, destacando por su alta eficiencia- el azufre elemental ( $\left.\mathrm{S}^{0}\right)$, que, a través de la acción de microorganismos oxidadores presentes en el compost, es oxidado hasta formar ácido 
sulfúrico con la consiguiente acidificación del medio (Carrión et al., 2008; García de la Fuente et al., 2007; Handreck y Black, 2002).

Dado que esta última alternativa es un proceso esencialmente biológico, su eficiencia depende en gran medida de la microbiota presente en el compost, ya que ésta variará entre unos materiales compostados y otros. Es por ello que este proceso debe estudiarse de forma específica para cada compost (según su origen), siendo además de gran interés el aislamiento e identificación de los microorganismos presentes en cada material responsables de la oxidación del $\mathrm{S}^{0}$ añadido.

Aunque el proceso de oxidación del azufre se ha investigado ampliamente en los suelos agrícolas alcalinos, dicho proceso se ha estudiado en menor medida en los materiales orgánicos. Sólo se tiene constancia de dos estudios realizados con composts de residuos de la industria oleícola (Marí et al., 2005; Roig et al., 2004) y de otro publicado por nuestro grupo de investigación con composts de distintos orígenes y características, preparados con diversos residuos orgánicos generados por el sector primario (García de la Fuente et al., 2007). Es por ello que, como parte de la exploración de las alternativas de uso del compost de alperujo en Horticultura, se incluye en esta Tesis el estudio del proceso de oxidación del $\mathrm{S}^{0}$ añadido a dicho compost, junto con la dinámica de su acidificación, así como el aislamiento, identificación y determinación de la eficiencia acidificadora de los microorganismos presentes en este material responsables del proceso indicado.

Para ello, se eligió el compost A, dado que su preparación es mucho más común que la del compost $\mathrm{A}+\mathrm{H}$, y porque, además, las características y comportamiento de aquel en el suelo parecen hacerlo más recomendable para su uso como sustrato de cultivo. Como se recordará (sección 4.1.2), dicho compost A presentó como características relevantes para el proceso de acidificación, las siguientes: $\mathrm{pH}=9,17$; $\mathrm{CE}=3,65 \mathrm{dS} / \mathrm{m} ; \mathrm{y}, \mathrm{CaCO}_{3}=10,8 \% \mathrm{~ms}$; en adición, este compost mostró un contenido en sulfatos de $0,41 \% \mathrm{~ms}$.

\subsubsection{Estudio del proceso de acidificación del compost tratado con azufre elemental micronizado}

\subsubsection{Curva de valoración del compost}

Antes de proceder al ensayo de acidificación del compost (alcalino) A fue necesario obtener la curva de valoración, a partir de la cual se calculó la dosis de 
enmienda acidificante necesaria para alcanzar el valor de $\mathrm{pH}$ final deseado. La curva de regresión (valoración) y la ecuación polinómica de segundo grado ajustada obtenidas, se muestran en la Figura 4.7.1. Asimismo, se calculó el coeficiente de determinación $\left(R^{2}\right)$, indicando, con un valor superior a 0,970, la elevada bondad del ajuste de dicha curva.

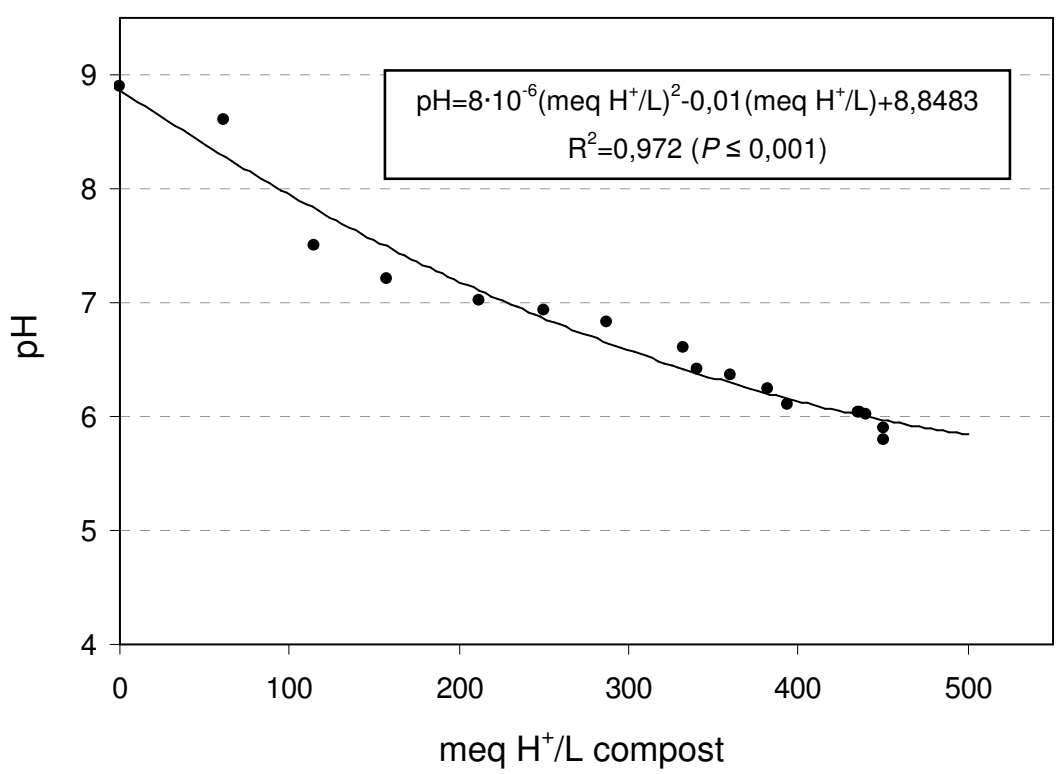

Figura 4.7.1. Curva de valoración del compost $A$, que relaciona los meq de $\mathrm{H}^{+} / \mathrm{L}$ de compost con los valores de $\mathrm{pH}$

La estabilización del pH se produjo a partir del séptimo día del ensayo, obteniéndose como valor final la media de los últimos cinco días a partir de la estabilización de éste. Se partió de un pH inicial del compost en torno a 9, disminuyendo dicho valor gradualmente, según aumentaba la concentración de ácido en la mezcla de compost y disolución valorante (sulfato ferroso), hasta alcanzar un pH final de 5,8 .

Con el fin de poder utilizar el compost A como sustrato o componente de sustratos de cultivo, el pH debería corregirse (reducirse) hasta valores comprendidos entre 5,2 y 6,3, ya que se ha señalado que este rango es el más adecuado para el cultivo de plantas sobre materiales orgánicos (Bunt, 1988; Peterson, 1981). Por ello, se seleccionó la concentración de meq de $\mathrm{H}^{+}$por litro de compost necesaria para obtener el pH óptimo de 6 en el compost A utilizado. La dosis de azufre elemental micronizado (D) que debería adicionarse al compost se calculó con la ecuación que se presentó en la sección 3.8.1.2 de Materiales y Métodos, obteniéndose como resultado 6,33 g de S\%/L de compost. En el experimento de acidificación realizado también se 
estudió el efecto que produjo la adición de 1,5 veces dicha dosis $(1,5 \times D=9,5 \mathrm{~g}$ de $\mathrm{S} \%$ L de compost) sobre el $\mathrm{pH}$, con el fin de evaluar la eficiencia obtenida en el proceso de acidificación.

\subsubsection{Experimento de acidificación: ensayo de incubación}

Cambios en las características físico-químicas y químicas del compost enmendado

El objetivo del ensayo de acidificación realizado fue determinar, en condiciones controladas de laboratorio - humedad del compost y temperatura de la cámara de incubación-, el mecanismo de acción y la eficiencia de la enmienda aplicada, con el fin de poder llegar a establecer un programa de acidificación que redujera el pH del compost A para su uso como sustrato o componente de sustratos en el cultivo y la producción de plantas en contenedor.

De cada muestra o tratamiento (compost sin enmendar [D0] y compost enmendado con las dosis $1 \times D$ y $1,5 \times D$ de $S^{0}$ ), se estudió la evolución de los parámetros físico-químicos pH y conductividad eléctrica (CE) a lo largo del ensayo, tal y como se muestra en la Figura 4.7.2.

Se observó que el pH disminuyó gradualmente a lo largo del experimento, desde el valor inicial de 9,22 hasta 6,75 en el caso de la dosis $1 \times \mathrm{x}$, y hasta 6,09 con la dosis 1,5xD. En ambos casos, se consideró como valor final de $\mathrm{pH}$ la media de los resultados de los últimos tres muestreos, en los que el pH no varió de manera significativa. Adicionalmente, se registró la variación del $\mathrm{pH}$ a lo largo de todo el ensayo en el control (D0), al que no se añadió S ${ }^{0}$.

En el caso de la CE, ésta aumentó notablemente durante el transcurso del ensayo, desde el valor inicial próximo a $4 \mathrm{dS} / \mathrm{m}$ hasta $8,5 \mathrm{dS} / \mathrm{m}$ en el caso de la dosis $1 \times D$, y hasta $9,13 \mathrm{dS} / \mathrm{m}$ con $1,5 \times \mathrm{D}$, tomando para ambos resultados el valor medio de los datos de CE de los mismos tres muestreos seleccionados para el cálculo del pH final (estabilizado).

Los resultados obtenidos con el compost A coinciden con los de otros estudios sobre adición de enmiendas azufradas $\left(\mathrm{S}^{0}\right.$ y FeSO $\left.4 \cdot 7 \mathrm{H}_{2} \mathrm{O}\right)$ a composts procedentes del sector primario, con diferentes orígenes y características (Carrión et al., 2008; García de la Fuente et al., 2007), aunque en el caso de la acidificación del compost de alperujo estudiado la estabilización del pH se alcanzó en un período de tiempo inferior (datos no presentados). 


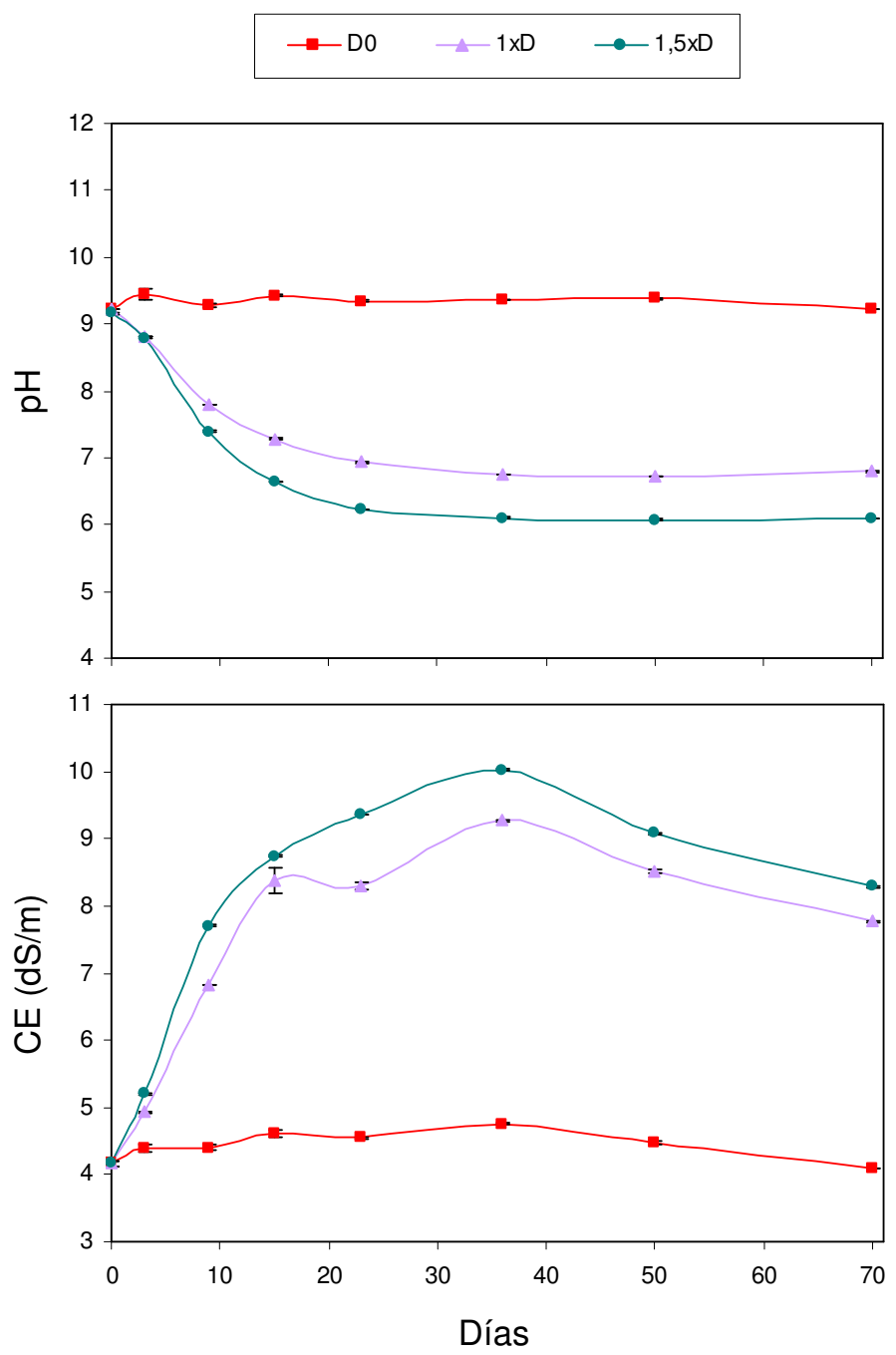

Figura 4.7.2. Variación del pH y de la conductividad eléctrica (CE) del compost A a lo largo del ensayo de acidificación con azufre elemental $\left(\mathrm{S}^{0}\right)$ micronizado

D: dosis de $\mathrm{S}^{0}$ necesaria para alcanzar el valor óptimo de $\mathrm{pH}=6$ en el compost, obtenida a partir de la curva de valoración $(6,33 \mathrm{~g} / \mathrm{L})$ D0: control sin adición de azufre; $1 \times \mathrm{D}$ y 1,5xD: adición de 1 ó 1,5 veces la dosis $\mathrm{D}$, respectivamente Las barras verticales indican el error estándar

En la Tabla 4.7.1. se recoge, para cada una de las dosis de aplicación de So estudiadas, el pH final esperado según la curva de valoración, el pH final alcanzado en el ensayo de acidificación, la disminución $(\Delta)$ de pH obtenida en función del pH inicial, y la eficiencia de acidificación (e.a., \%) calculada a partir de la ecuación mostrada en la sección 3.8.1.2 de Materiales y Métodos.

En el caso de las dosis estudiadas (1XD y 1,5xD), se obtuvieron eficiencias elevadas, superando en ambos casos el 75\%. Con ninguna de las dos dosis se consiguió alcanzar el pH final esperado; sin embargo, con la dosis 1,5xD, la eficiencia alcanzó un valor del 90\%, consiguiéndose un descenso de pH superior a 3 unidades. 
Tabla 4.7.1. Valores de la eficiencia de acidificación (e.a., \%) y de los parámetros relacionados con su cálculo para las dos dosis de azufre elemental (SO) micronizado estudiadas

\begin{tabular}{lccc}
\hline \multirow{2}{*}{ Parámetro } & \multicolumn{2}{c}{ Dosis } & \\
\cline { 2 - 4 } & 1xD & $1,5 \times D$ & - \\
\hline pH esperado & 6,00 & 5,72 & - \\
pH final & 6,75 & 6,09 & - \\
pH inicial & 9,22 & 9,22 & $* * *$ \\
$\Delta \mathrm{pH}$ & $-2,47$ & $-3,13$ & $* * *$ \\
e.a. (\%) & 77 & 90 &
\end{tabular}

D: dosis de $\mathrm{S}^{0}$ necesaria para alcanzar el valor óptimo de $\mathrm{pH}=6$ en el compost, obtenida a partir de la curva de valoración (6,33 g/L) D0: control sin adición de azufre; 1 XD y 1,5xD: adición de 1 ó 1,5 veces la dosis $\mathrm{D}$, respectivamente

$\mathrm{pH}_{\text {esperado: }} \mathrm{pH}$ final esperado según la curva de valoración; $\mathrm{pH}_{\text {final: }} \mathrm{pH}$ alcanzado una vez estabilizado el material enmendado; $\mathrm{pH}_{\text {inicial: }} \mathrm{pH}$ del día $\mathrm{O}$ de la muestra control sin enmendar: $\Delta \mathrm{pH}$ : disminución de $\mathrm{pH}$ obtenida en función del $\mathrm{pH}$ inicial $P$ : nivel de significación. *** indica diferencias estadísticamente significativas a $P \leq 0,001$

Al adicionar $\mathrm{S}^{\circ}$, el patrón de disminución del $\mathrm{pH}$ a lo largo del período de incubación se ajustó a un modelo exponencial, que respondió a la siguiente ecuación:

$$
\mathrm{pH}_{\mathrm{t}}=\mathrm{pH}_{\text {final }}+\mathrm{a} \cdot \mathrm{e}^{(-\mathrm{b} \cdot \mathrm{t})}
$$

donde $\mathrm{pH}_{\mathrm{t}}$ es el $\mathrm{pH}$ del compost enmendado en el instante $\mathrm{t} ; \mathrm{pH}_{\text {final }}$ es el $\mathrm{pH}$ alcanzado en el ensayo de acidificación una vez estabilizado el material, tomando como dicho valor la media de los resultados de los últimos tres muestreos del experimento; y, a y b son dos coeficientes de regresión.

En la Tabla 4.7.2 se muestra el valor de los coeficientes de regresión de la ecuación de ajuste (a y b), así como el coeficiente de determinación ( $\left.R^{2}\right)$, para las dosis $1 \times D$ y $1,5 \times D$.

Tabla 4.7.2. Parámetros de ajuste al modelo exponencial $\mathrm{pH}_{\mathrm{t}}=\mathrm{pH}_{\text {final }}+\mathrm{a} \cdot \mathrm{e}^{(-\mathrm{b} \cdot \mathrm{t})}$ para la variación del $\mathrm{pH}$ del compost enmendado con azufre elemental $\left(\mathrm{S}^{0}\right)$ micronizado a las dosis $1 \times D$ y $1,5 \times D$ durante el ensayo de acidificación

\begin{tabular}{lcccc}
\hline \multirow{2}{*}{ Dosis } & \multirow{2}{*}{\begin{tabular}{c}
\multicolumn{2}{c}{ Coeficiente de regresión } \\
\cline { 3 - 4 }
\end{tabular}} & $\mathrm{pH}$ & $\mathrm{b}$ & $\mathbf{R}^{2}$ \\
\hline $1 \times \mathrm{D}$ & 6,75 & 2,573 & 0,1006 & 0,992 \\
$1,5 \times \mathrm{D}$ & 6,09 & 3,275 & 0,1040 & 0,983
\end{tabular}

pH: $\mathrm{pH}$ del compost en el instante $\mathrm{t}$; $\mathrm{pH}_{\text {final: }} \mathrm{pH}$ alcanzado una vez estabilizado el material enmendado

$\mathrm{D}$ : dosis de $\mathrm{S}^{0}$ necesaria para alcanzar el valor óptimo de $\mathrm{pH}=6$ en el compost, obtenida a partir de la curva de valoración (6,33 g/L) D0: control sin adición de azufre; 1xD y 1,5xD: adición de 1 ó 1,5 veces la dosis $\mathrm{D}$, respectivamente

Los coeficientes de determinación $\left(R^{2}\right)$ mostraron un nivel de significación $P \leq 0,001$

La ecuación exponencial de ajuste presentada más arriba permite estimar el valor de $\mathrm{pH}$ del compost en un momento determinado para una dosis concreta de enmienda, considerando que este parámetro tiende al valor $\mathrm{pH}_{\text {final }}$. Un ajuste similar 
se puede encontrar en trabajos realizados por Roig et al. (2003, 2004), García de la Fuente et al. (2007) y Carrión et al. (2008).

De acuerdo con los resultados obtenidos, cuanto mayor fue la cantidad de $\mathrm{S}^{0}$ añadida al compost, tanto más elevada fue la disminución del pH de éste. Sin embargo, la adición de cantidades elevadas de $\mathrm{S}^{0}$ no sólo puede reducir la actividad de la biomasa microbiana, sino afectar también negativamente a diferentes enzimas en el compost. Adicionalmente, la presencia de concentraciones elevadas de sulfatos -como resultado de la oxidación del $\mathrm{S}^{0}$ - incrementa la CE del compost, como se ha indicado anteriormente, limitando así el uso de éste en Horticultura (Roig et al., 2003, 2004).

Por ello, a la hora de elegir una dosis de $\mathrm{S}^{0}$ con objeto de corregir el $\mathrm{pH}$ del compost, es de gran importancia conjugar dos factores: por un lado, la disminución del $\mathrm{pH}$, y por otro, el incremento de la $\mathrm{CE}$, de modo que se cumplan unos criterios de calidad mínimos, requeridos por el sistema de cultivo sin suelo (en sustrato) al que vaya a destinarse dicho compost. En este contexto, se obtuvo la recta de regresión que relacionó la disminución $(\Delta)$ del $\mathrm{pH}$ con el incremento $(\Delta)$ en la CE del compost enmendado con $\mathrm{S}^{0}$, que presentó un coeficiente de determinación $\left(\mathrm{R}^{2}\right)$ superior a 0,950, tal y como se muestra en la Figura 4.7.3.

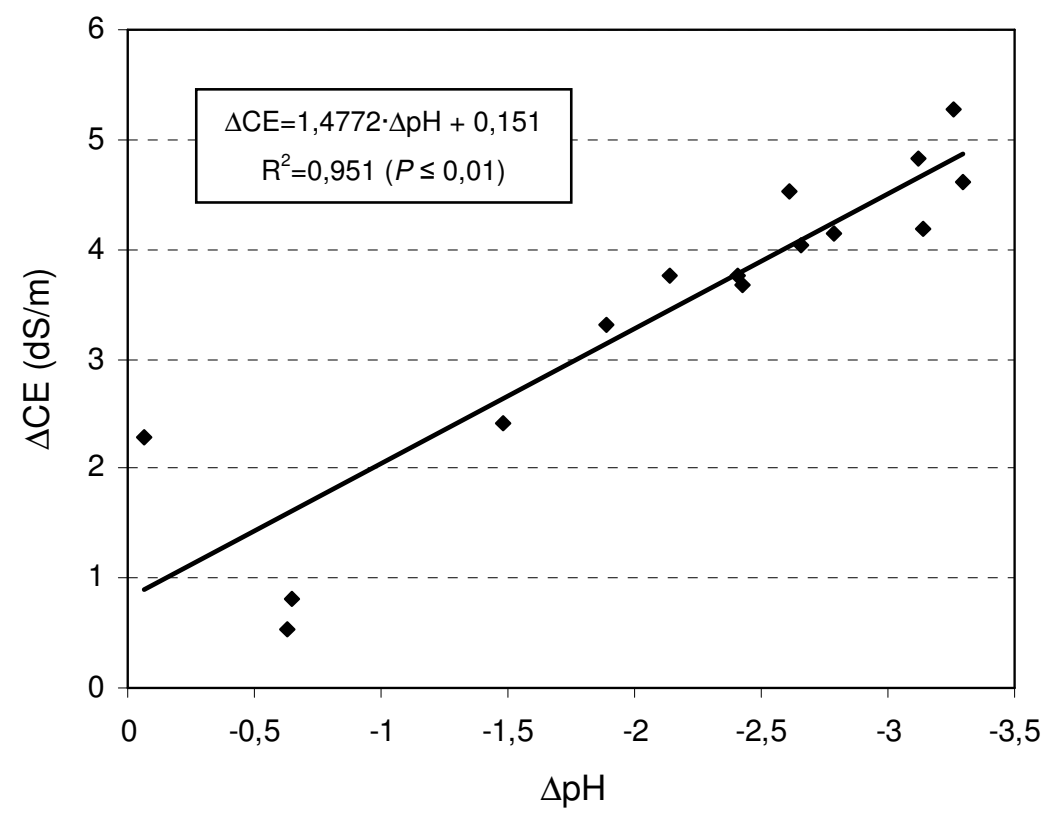

Figura 4.7.3. Relación entre el incremento de la conductividad eléctrica $(\Delta C E)$ y la disminución incremento del $\mathrm{pH}(\Delta \mathrm{pH})$ del compost $\mathrm{A}$ durante la acidificación de éste con azufre elemental $\left(\mathrm{S}^{0}\right)$ micronizado 
Se consideró que la dosis $1,5 \times D$ de $S^{0}$ fue la más eficiente, ya que tanto la disminución de $\mathrm{pH}$ alcanzada como la eficiencia de acidificación obtenida para ésta fueron mayores que para la dosis $1 \times \mathrm{D}$. De este modo, con la dosis $1,5 \mathrm{xD}$ el $\mathrm{pH}$ disminuyó 3,14 unidades, haciéndolo con la de 1XD en 2,47 unidades. Sin embargo, el incremento de CE producido con la dosis $1,5 \times D$ fue $0,6 \mathrm{dS} / \mathrm{m}$ mayor que con la dosis 1xD. La pendiente de la recta de regresión obtenida (Figura 4.7.3) mostró que cada unidad de $\mathrm{pH}$ corregido (reducido) conllevó un incremento en la CE de 1,5 dS/m, aumento que deberá tenerse en cuenta a la hora de acidificar el compost. De acuerdo con esta relación, sería posible elegir una dosis de $\mathrm{S}^{0}$ que provocara una disminución del $\mathrm{pH}$ y un incremento de la CE compatibles con los criterios de calidad requeridos para el compost, en función del uso que se le fuera a dar a éste (sustrato de cultivo puro, componente de sustratos, etc.).

La oxidación a ácido sulfúrico del azufre elemental añadido a los materiales compostados precede a la reacción de dicho ácido con los carbonatos presentes en el compost, intercambiándose después los $\mathrm{H}^{+}$del ácido con los cationes del complejo de cambio. Para estudiar este mecanismo de reacción, se determinó el contenido en sulfatos y en carbonatos (expresándose $\mathrm{como}^{\mathrm{CaSO}_{4}}$ y $\mathrm{CaCO}_{3}$, respectivamente) a lo largo del ensayo de acidificación, representándose gráficamente la evolución de estos dos parámetros, así como la del pH, para cada una de las dosis de $\mathrm{S}^{0}$ estudiadas (Figura 4.7.4).

Las curvas correspondientes al control (D0) reflejaron valores prácticamente estables de $\mathrm{CaSO}_{4}$ y $\mathrm{pH}$ durante el ensayo. Sin embargo, se observó un ligero descenso en la concentración de $\mathrm{CaCO}_{3}$, de 7,3\% a 5,7\%, debido probablemente a alguna reacción provocada por la humectación del material.

Se registró una disminución del contenido en carbonatos en los materiales enmendados, que fue tanto mayor cuanto más elevada fue la dosis de $S^{0}$ añadida. De esta manera, con la dosis $1 \times \mathrm{D}$, la concentración de carbonatos disminuyó desde el valor inicial $7,3 \%$ hasta $2 \%$, mientras que con la dosis $1,5 \times D$, este parámetro bajó desde 7,5\% hasta 1\% (Figura 4.7.4). Además, se apreció que la reducción en el contenido de carbonatos fue paralela a la bajada del $\mathrm{pH}$, produciéndose la disminución de carbonatos más marcada al mismo tiempo que el pH se redujo en mayor cuantía (entre los días 0 y 23 del ensayo). 

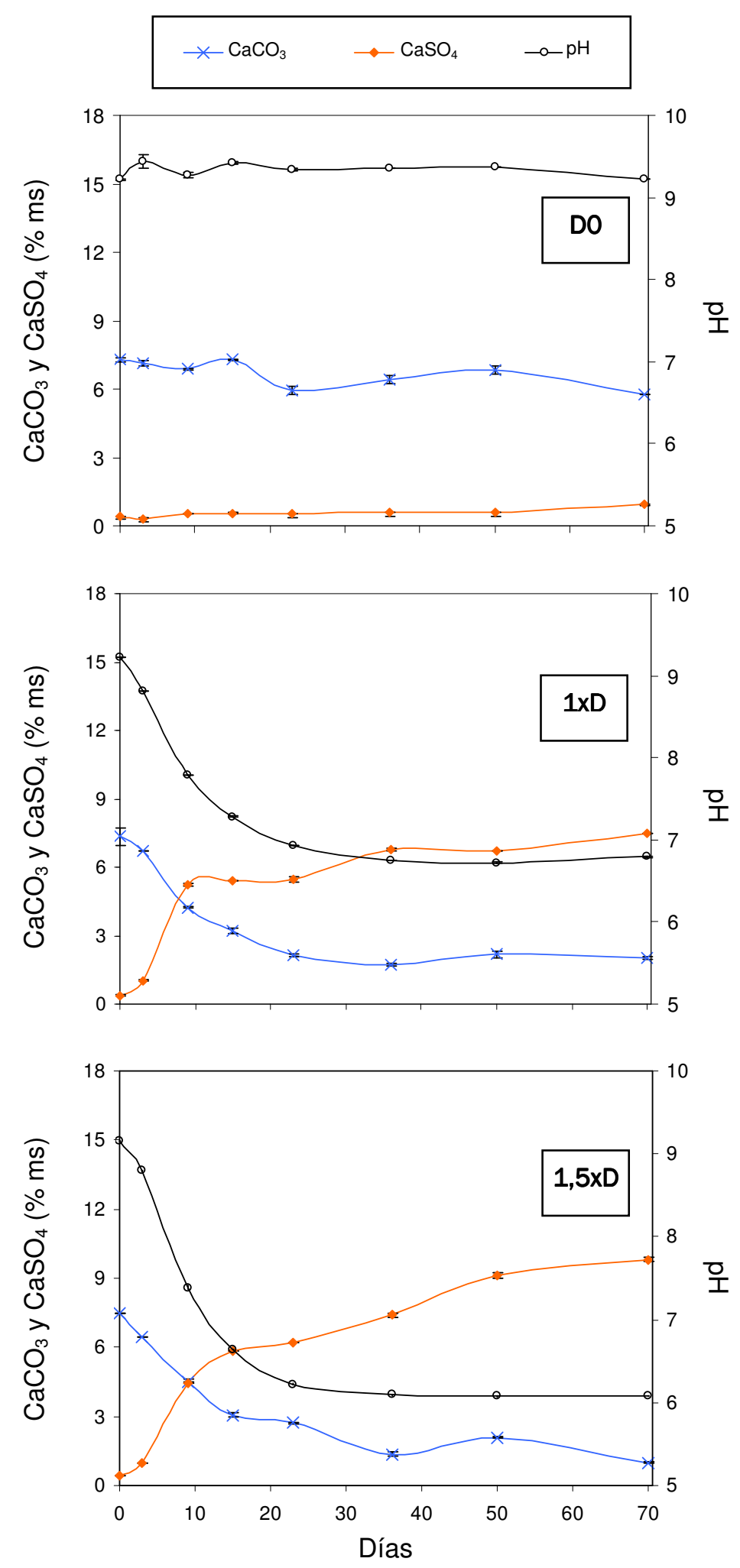

Figura 4.7.4. Variación del pH y del contenido en carbonatos y en sulfatos del compost A a lo largo del ensayo de acidificación con azufre elemental $\left(\mathrm{S}^{0}\right)$ micronizado

D: dosis de $\mathrm{S}^{0}$ necesaria para alcanzar el valor óptimo de $\mathrm{pH}=6$ en el compost, obtenida a partir de la curva de valoración (6,33 g/L) D0: control sin adición de azufre; 1XD y 1,5xD: adición de 1 ó 1,5 veces la dosis D, respectivamente Las barras verticales indican el valor estándar 
En relación con lo anterior, la producción de sulfatos fue tanto mayor cuanto más elevada fue la dosis de $S^{0}$ aplicada, aumentando también conforme disminuyó el contenido en carbonatos, tal y como era de esperar según la estequiometría de las reacciones que tienen lugar durante la acción del $\mathrm{S}^{0}$ ya indicadas más arriba.

En primer lugar, el $\mathrm{S}^{0}$ es oxidado a ácido sulfúrico:

$$
2 \mathrm{~S}^{\mathrm{O}}+3 \mathrm{O}_{2}+2 \mathrm{H}_{2} \mathrm{O} \rightarrow 2 \mathrm{H}_{2} \mathrm{SO}_{4}
$$

A continuación, el ácido sulfúrico reacciona con (disuelve) los carbonatos:

$$
\mathrm{H}_{2} \mathrm{SO}_{4}+\mathrm{CaCO}_{3} \rightarrow \mathrm{CaSO}_{4}+\mathrm{H}_{2} \mathrm{O}+\mathrm{CO}_{2}
$$

Una vez los carbonatos se han disuelto, el ácido sulfúrico puede reaccionar (intercambiarse) con los cationes del complejo de cambio del compost.

El contenido inicial de sulfatos fue bajo con ambas dosis, incrementándose hasta el $7,1 \%$ y el $9,4 \%$ al final del ensayo de acidificación con las dosis $1 \times D$ y $1,5 \times D$, respectivamente (Figura 4.7.4).

\section{Evolución de la población microbiana en el compost}

Con objeto de estudiar la evolución (en el tiempo) de la población microbiana asociada a la oxidación biológica del azufre elemental micronizado añadido, se determinó -a lo largo del ensayo de acidificación- la población de cinco grupos microbianos seleccionados: bacterias oxidadoras del azufre, bacterias heterótrofas, actinomicetos, y mohos y levaduras (estos dos últimos se enumeraron conjuntamente) (Figura 4.7.5).

La primera muestra se tomó después de tres días de incubación, para evitar el período inicial de activación de los microorganismos debido a la rehidratación, lo que puede provocar incrementos en las poblaciones de hasta 2 unidades logarítmicas (García de la Fuente et al., 2007).

En el compost control, sin enmendar (D0), la población de bacterias oxidadoras del azufre no experimentó cambios importantes, manteniéndose en valores comprendidos entre 7 y 7,5 unidades logarítmicas a lo largo de todo el ensayo. Sin embargo, las dos muestras de compost enmendadas (1XD y 1,5XD) mostraron incrementos en dicha población a la vez que disminuyó el pH. En la muestra que recibió la dosis $1 \times \mathrm{D}$, este grupo de bacterias aumentó su población hasta valores superiores a 8 unidades logarítmicas, alcanzándose una diferencia de 1 unidad logarítmica con respecto a la muestra sin enmendar (DO) al final del ensayo. En la muestra enmendada con la dosis 1,5xD, estos microorganismos alcanzaron un valor 
de 9 unidades logarítmicas el día 22 del ensayo, coincidiendo este incremento máximo con la disminución de pH más marcada.

En lo que respecta a las bacterias heterótrofas, la población de las tres muestras de compost (tratamientos) se mantuvo prácticamente constante hasta el final del ensayo, oscilando entre 7,5 y 8 unidades logarítmicas. Se observó que la población de las dos muestras enmendadas $(1 \times D$ y $1,5 \times D)$ fue ligeramente superior a la muestra control (DO) sin enmendar, no superando dicha diferencia 0,5 unidades logarítmicas en ningún caso. Por ello, se deduce que la población de bacterias heterótrofas presentes en el compost no se vio afectada por de la aplicación de $\mathrm{S}^{0}$ al mismo.

$\rightarrow-\mathrm{D} 0 \quad-1 \times 1,5 \times \mathrm{xD}$
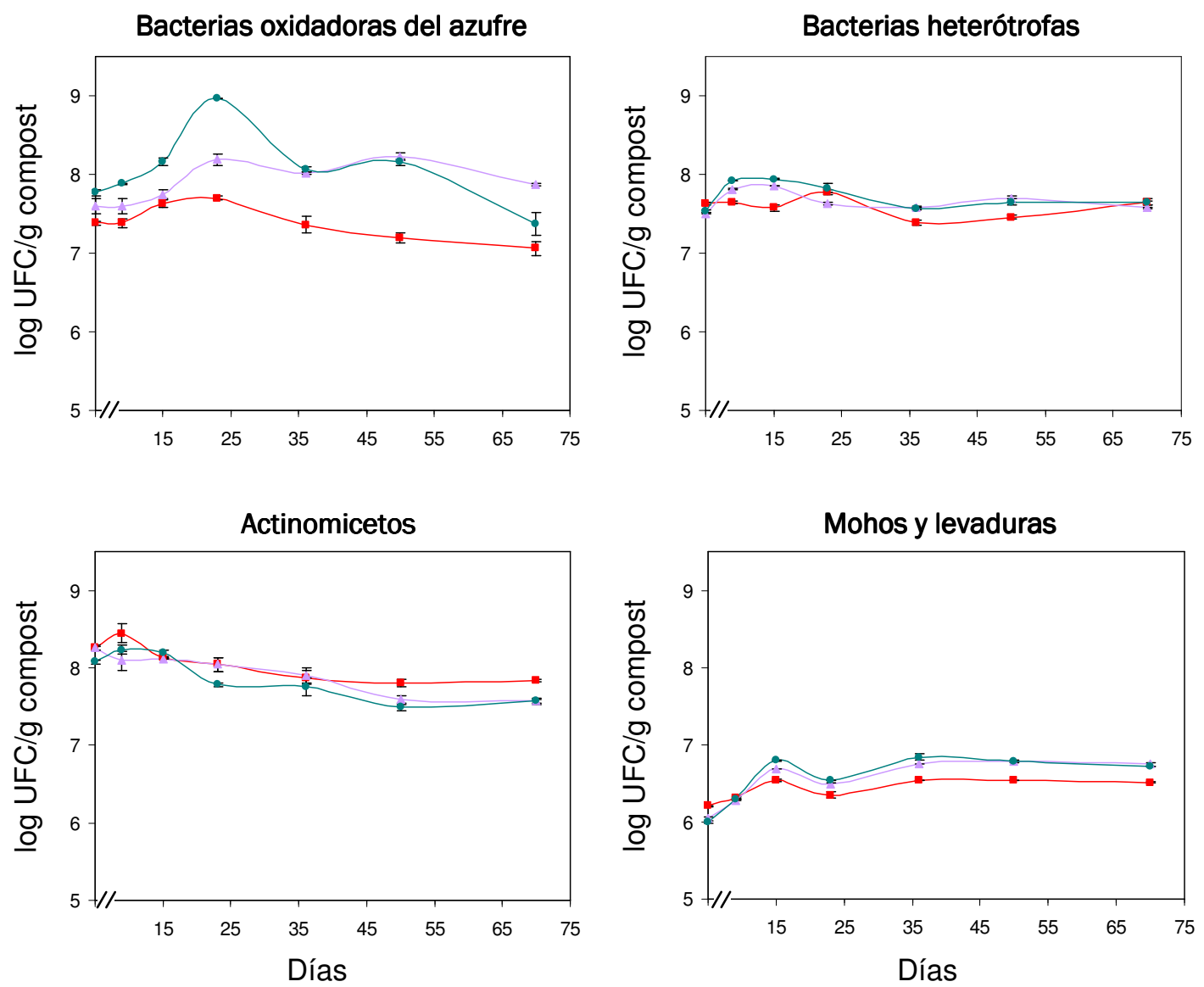

Figura 4.7.5. Variación de las poblaciones microbianas estudiadas en el compost A a lo largo del ensayo de acidificación con azufre elemental $\left(\mathrm{S}^{0}\right)$ micronizado

$\mathrm{D}$ : dosis de $\mathrm{S}$ n necesaria para alcanzar el valor óptimo de $\mathrm{pH}=6$ en el compost, obtenida a partir de la curva de valoración (6,33 g/L) DO: control sin adición de azufre; 1xD y 1,5xD: adición de 1 ó 1,5 veces la dosis D, respectivamente UFC: unidades formadoras de colonias

Las barras verticales indican el error estándar 
En cuanto al grupo de los actinomicetos, y de modo similar a las bacterias heterótrofas, su población se mantuvo prácticamente constante a lo largo de todo el ensayo, tanto en la muestra control como en las enmendadas con las dos dosis de $\mathrm{S}^{0}$ añadidas. En las tres muestras estudiadas se observó una población inicial superior a 8 unidades logarítmicas, que fue disminuyendo débil y gradualmente desde el inicio del ensayo, hasta finalizar éste con una población en torno a 7,5 unidades logarítmicas. Al final del ensayo, la población de actinomicetos en la muestra control (D0) fue ligeramente superior a las dos muestras enmendadas ( $1 \times D$ y $1,5 \times D)$, con diferencias de aproximadamente 0,3 unidades logarítmicas.

En cuanto al comportamiento de los últimos grupos microbianos estudiados, mohos y levaduras, éstos tampoco experimentaron variaciones importantes a lo largo del ensayo, aumentando su población en tan solo 0,5 unidades logarítmicas entre el inicio y el final de éste. De modo similar a las bacterias heterótrofas, la población de mohos y levaduras se mantuvo en las dos muestras de compost enmendadas (1xD y $1,5 \times D$ ) en un nivel ligeramente superior al de la muestra control (D0), en torno a 0,3 unidades logarítmicas.

Por lo tanto, se observó un incremento en el grupo de las bacterias oxidadoras del azufre en las dos muestras enmendadas con $\mathrm{S}^{0}$; en el caso del compost que recibió la dosis 1,5xD este aumento fue de 1,3 unidades logarítmicas, y de aproximadamente 1 unidad logarítmica con la dosis 1xD. Ambos incrementos se dieron el día 22 del ensayo de acidificación, coincidiendo en los dos casos con la disminución de pH más marcada. Sin embargo, las bacterias heterótrofas, los actinomicetos, y los mohos y las levaduras, además de no experimentar cambios apreciables, se mantuvieron al mismo nivel tanto en las dos muestras enmendadas como en la muestra control, pudiendo concluirse por tanto que la adición de $\mathrm{S}^{0}$ no afectó significativamente a la dinámica de estas poblaciones. Estos resultados coinciden con los obtenidos por García de la Fuente et al. (2007) -en composts preparados con diversos residuos orgánicos del sector primario- para las poblaciones de actinomicetos, mohos y levaduras; pero, para la población de bacterias heterótrofas, estos autores observaron un aumento significativo asociado a la adición de So. 


\subsubsection{Estudio de la eficiencia de acidificación de los microorganismos aislados del compost}

\subsubsection{Aislamiento y caracterización de cepas oxidadoras del azufre autóctonas del compost}

Para el aislamiento de las bacterias oxidadoras del azufre presentes en el compost $A$ enmendado con $\mathrm{S}^{0}$, y una vez realizados los recuentos del ensayo de acidificación (sección 4.7.1.2.), se seleccionaron distintas colonias crecidas en el medio 152 (American Type Culture Collection, ATCC), en virtud del viraje de éste de rojo a amarillo a $\mathrm{pH}$ ácido. Las cepas seleccionadas se aislaron en cultivo puro, obteniéndose un total de 34 colonias del compost. Al igual que en otros estudios sobre bacterias oxidadoras del azufre (Anandham et al., 2007), estas colonias se caracterizaron macroscópicamente, describiendo su color, tamaño, opacidad, etc. Posteriormente, éstas se observaron al microscopio óptico tras realizar la tinción Gram, y se realizaron también las pruebas bioquímicas de la catalasa y la oxidasa para determinar la presencia de estos enzimas. Los resultados obtenidos se muestran en la Tabla 4.7.3.

De las cepas aisladas, se seleccionaron 8 por su mayor capacidad acidificadora del medio (Alp 1, Alp 8-1, Alp 8-2, Alp 8-3, Alp 15, Alp 17, Alp 18 y Alp 30), al virar éste de rojo a amarillo en un período de tiempo más breve (48 horas) que el resto de las cepas estudiadas (Figura 4.7.6). Estas 8 cepas resultaron ser bacilos Gram negativos, respondiendo positivamente a las pruebas de la catalasa y la oxidasa (Tabla 4.7.3), lo que coincide con las características de gran parte de las bacterias consideradas tradicionalmente como oxidadoras del azufre.

La eficiencia de estas cepas oxidadoras del azufre autóctonas del compost se comparó con la de tres bacterias procedentes de la Colección del Instituto Pasteur (CIP): Halothiobacillus neapolitanus CIP 104769, Thiobacillus denitrificans CIP 104767 y Thiomonas intermedia CIP 104401, cuya caracterización se muestra en la Tabla 4.7.4. 
Tabla 4.7.3. Características macroscópicas y resultados de la tinción Gram y de las pruebas bioquímicas de la catalasa y la oxidasa realizadas en las cepas aisladas del compost A enmendado con $\mathrm{S}^{0}$

\begin{tabular}{|c|c|c|c|c|}
\hline \multirow{2}{*}{ Aislado } & \multirow{2}{*}{ Características } & \multirow{2}{*}{ Tinción Gram } & \multicolumn{2}{|c|}{ Prueba bioquímica $^{2}$} \\
\hline & & & Catalasa & Oxidasa \\
\hline Alp 1 & Rojo-amarillenta y brillante & Bacilos cortos y redondeados Gram - & + & + \\
\hline Alp 2-1 & $\begin{array}{l}\text { Amarilla, translúcida y brillante. Muy } \\
\text { pequeña }\end{array}$ & Cocos Gram + & - & - \\
\hline Alp 2-2 & $\begin{array}{l}\text { Amarilla, translúcida y brillante. Muy } \\
\text { pequeña }\end{array}$ & Bacilos cortos y redondeados Gram - & + & + \\
\hline Alp 3 & $\begin{array}{l}\text { Amarilla, translúcida y brillante. Muy } \\
\text { pequeña }\end{array}$ & Bacilos cortos y redondeados Gram - & - & - \\
\hline Alp 4-2 & Rosa claro, opaca y brillante & Bacilos finos Gram - & + & + \\
\hline Alp 6 & Blanco-amarillenta, opaca y mate & Bacilos cortos y redondeados Gram - & - & - \\
\hline Alp 7 & Amarilla, opaca y brillante & Bacilos cortos y redondeados Gram + & + & - \\
\hline Alp 8-1 & Rojo-amarillenta y brillante & Bacilos cortos y redondeados Gram - & + & + \\
\hline Alp 8-2 & Anaranjada y brillante. Muy pequeña & Bacilos pequeños Gram - & + & + \\
\hline Alp 8-3 & Rojo-amarillenta y brillante & Bacilos cortos y redondeados Gram - & + & + \\
\hline Alp 9 & Amarilla, opaca y brillante & Bacilos largos y finos Gram - & - & - \\
\hline Alp 10 & Rosa, opaca y brillante & Cocos Gram + & + & - \\
\hline Alp 13 & $\begin{array}{l}\text { Distintos tonos de amarillo, concéntricos, } \\
\text { y translúcida }\end{array}$ & Bacilos pequeños Gram - & - & - \\
\hline Alp 14 & Amarilla, brillante y translúcida & Bacilos cortos Gram - & - & - \\
\hline Alp 15 & Blanco-rosada, mate y opaca & Bacilos cortos y redondeados Gram - & + & + \\
\hline Alp 16 & Amarilla, translúcida y brillante & Bacilos cortos y redondeados Gram - & - & - \\
\hline Alp 17 & Blanco-amarillenta y translúcida & Bacilos cortos y redondeados Gram - & + & + \\
\hline Alp 18 & Amarillenta y translúcida. Muy pequeña & Bacilos pequeños y redondeados Gram - & + & + \\
\hline Alp 19 & Blanco-rosada, opaca y brillante & Bacilos Gram + & + & - \\
\hline Alp 20-1 & Amarilla, translúcida y brillante & Bacilos finos y largos Gram - & + & + \\
\hline Alp 20-2 & Amarilla, translúcida y brillante & Bacilos finos y largos Gram - & + & + \\
\hline Alp 21 & Amarilla, translúcida y brillante & Bacilos largos Gram - & - & - \\
\hline Alp 22-1 & Amarilla, opaca y brillante & Cocos Gram + & + & - \\
\hline Alp 22-2 & Amarilla, opaca y brillante & Cocos Gram + & + & - \\
\hline Alp 23-1 & $\begin{array}{l}\text { Amarilla, translúcida y brillante. Muy } \\
\text { pequeña }\end{array}$ & Bacilos finos Gram - & - & - \\
\hline Alp 23-2 & Amarilla, translúcida y brillante & Bacilos finos y largos Gram - & - & - \\
\hline Alp 24 & Amarilla, opaca y brillante & Bacilos finos Gram - & + & + \\
\hline Alp 25-1 & Blanco-rosada, opaca y brillante & Bacilos pequeños Gram + & + & + \\
\hline Alp 25-2 & Blanco-rosada, opaca y brillante & Bacilos grandes Gram + & + & - \\
\hline Alp 26 & Rosa claro, translúcida y brillante & Bacilos largos Gram + & - & - \\
\hline Alp 27 & Amarilla, opaca y brillante & Bacilos cortos y redondeados Gram - & + & - \\
\hline Alp 28 & Amarilla, mate y opaca & Cocos grandes Gram + & + & - \\
\hline Alp 29 & Amarilla, translúcida y brillante & Bacilos largos y finos Gram - & - & + \\
\hline Alp 30 & Rojo-amarillenta y brillante & Bacilos cortos y redondeados Gram - & + & + \\
\hline
\end{tabular}




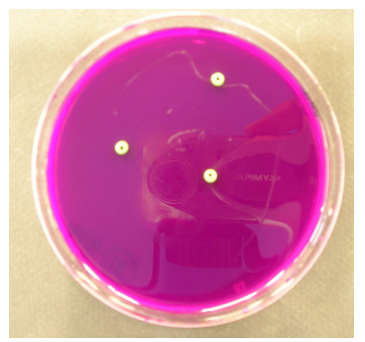

Siembra

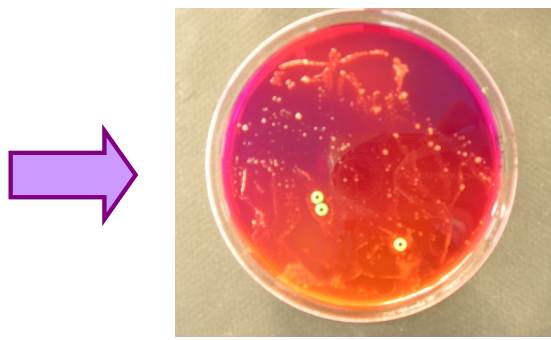

24 horas

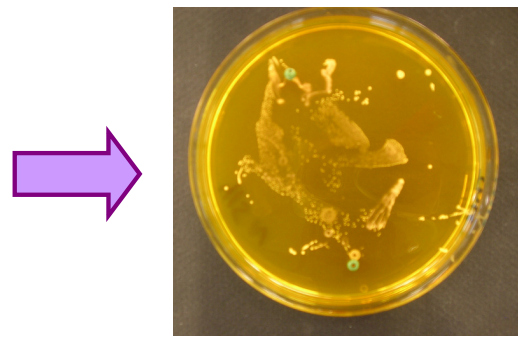

48 horas

Figura 4.7.6. Viraje del medio 152 de la colección ATCC (American Type Culture Collection) a las 24 y 48 horas tras la siembra de una cepa aislada del compost A enmendado con $\mathrm{S}^{0}$

Tabla 4.7.4. Características macroscópicas y resultados de la tinción Gram y de las pruebas bioquímicas de la catalasa y la oxidasa realizadas en las cepas de referencia de la Colección del Instituto Pasteur (CIP)

\begin{tabular}{|c|c|c|c|c|}
\hline \multirow{2}{*}{ Cepa } & \multirow{2}{*}{ Características } & \multirow{2}{*}{ Tinción Gram } & \multicolumn{2}{|c|}{ 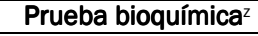 } \\
\hline & & & Catalasa & Oxidasa \\
\hline $\begin{array}{l}\text { Halothiobacillus neapolitanus } \\
\text { (CIP 104769) }\end{array}$ & Blanco-rosada, mate y opaca & $\begin{array}{l}\text { Bacilos cortos y redondeados } \\
\text { Gram - }\end{array}$ & + & + \\
\hline $\begin{array}{l}\text { Thiomonas intermedia } \\
\text { (CIP 104401) }\end{array}$ & $\begin{array}{l}\text { Blanquecina y brillante. Muy } \\
\text { pequeña }\end{array}$ & $\begin{array}{l}\text { Bacilos pequeños, finos y } \\
\text { alargados Gram - }\end{array}$ & - & + \\
\hline
\end{tabular}

\subsubsection{Identificación fenotípica y molecular de los aislados seleccionados}

Para la identificación de los aislados seleccionados se partió de un cultivo puro de cada una de las 8 cepas, realizándose la extracción del ADN según el protocolo del CTAB (Bromuro de CetilTrimetilAmonio) descrito por Wilson (1987), que se ha detallado en la sección 3.6.1.3 de Materiales y Métodos. Tras ello, se amplificó el ADN de las muestras mediante la técnica PCR, utilizando los iniciadores $27 \mathrm{f}$ y $1492 \mathrm{r}$ (Hiraishi et al., 1998; Lane, 1991). Se obtuvo un fragmento de 1500 pb (pares de bases) en la amplificación de cada cepa, tal y como puede apreciarse en la Figura 4.7.7.

Una vez obtenidas las secuencias completas de cada una de las cepas, se identificó cada una de ellas mediante la herramienta informática BLAST (Basic Local Alignment Search Tool) obtenida a través del NCBI (National Center for Biotechnology Information, 2007). Las secuencias encontradas se alinearon frente a las correspondientes a cepas de referencia, obtenidas a partir de bases de datos de bancos de genes. A partir del algoritmo del “vecino más próximo" (Saitou y Nei, 1987), y usando los paquetes informáticos PHYLIP (PHYLogenetic Inference Package; Felsenstein, 2004), se prepararon los árboles filogenéticos que se presentan en las Figuras 4.7.8. y 4.7.9. 


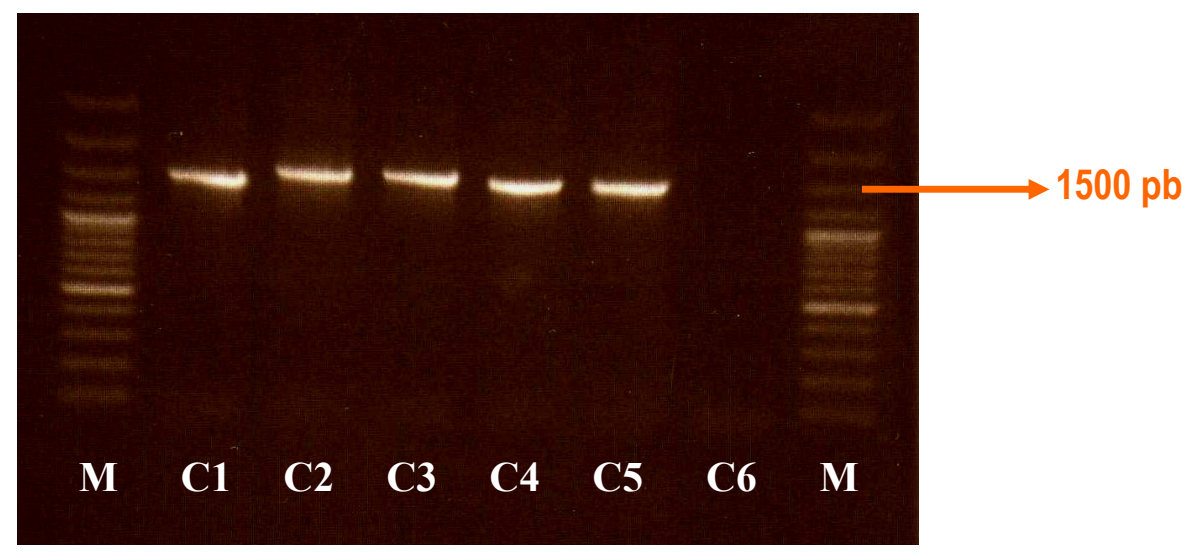

Figura 4.7.7. Productos de la amplificación del $16 S$ rADN de algunas cepas seleccionadas del compost $A$ enmendado con azufre elemental $\left(\mathrm{S}^{0}\right)$ micronizado

M: marcador de pesos moleculares; C1: cepa Alp 18; C2: cepa Alp 17; C3: cepa Alp 15; C4: cepa Alp 8-2; C5: cepa Alp 8-1; C6: blanco sin muestra de ADN; pb: pares de bases

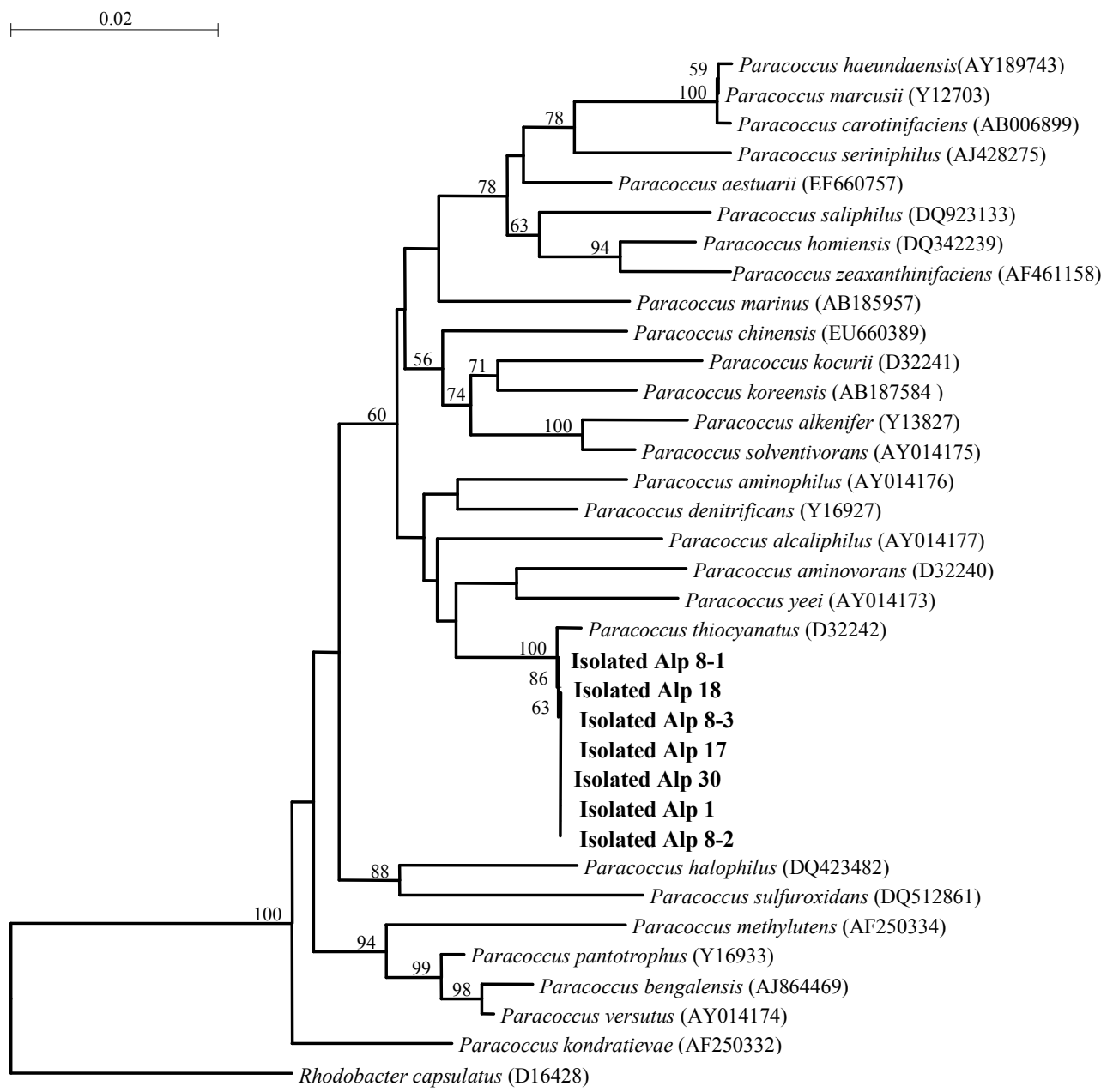

Figura 4.7.8. Árbol que muestra las relaciones filogenéticas entre los aislados Alp 1, Alp 8-1, Alp 8-2, Alp 8-3, Alp 17, Alp 18 y Alp 30 y las especies tipo del género Paracoccus más cercanas. Las cifras en los nodos indican el valor obtenido en 1000 remuestreos (bootstrapping). Sólo se muestran los valores superiores al 50\%. La escala indica 0,02 sustituciones por nucleótido Isolated: aislado 


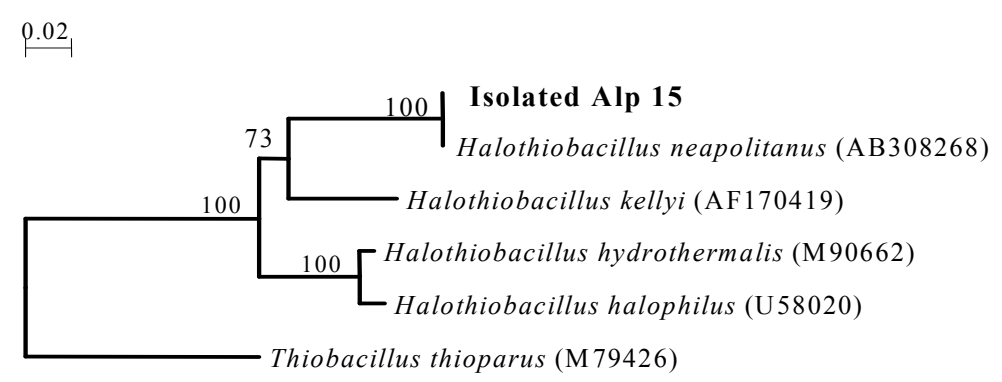

Figura 4.7.9. Árbol que muestra las relaciones filogenéticas entre el aislado Alp 15 y las especies tipo del género Halothiobacillus más cercanas. Las cifras en los nodos indican el valor obtenido en 1000 remuestreos (bootstrapping). Sólo se muestran los valores superiores al $50 \%$. La escala indica 0,02 sustituciones por nucleótido Isolated: aislado

Se determinó que los aislados Alp 1, Alp 8-1, Alp 8-2, Alp 8-3, Alp 17, Alp 18, y Alp 30, pertenecieron a la especie Paracoccus thiocyanatus con un nivel de similitud que osció entre 99,32\% y 99,77\% (Figura 4.7.8). Para la caracterización fenotípica de estos aislados se realizaron los tests propuestos por Katayama et al. (1995), descritos como apropiados para diferenciar especies de Paracoccus. Los resultados obtenidos revelaron que las 7 cepas objeto de estudio y la cepa tipo de Paracoccus thiocyanatus IAM (Institute of Applied Microbiology, Japón) 12816 eran la misma especie. Todas fueron bacterias Gram negativas, neutrófilas, mesófilas, inmóviles, y redondeadas. Crecieron como microorganismos quimiolitotróficos aerobios facultativos. Dieron, además, positivo en las pruebas de la catalasa y la oxidasa, y utilizaron D-glucosa, Dfructosa y manitol, pero no glicerol, sacarosa ni benzoato, como fuentes de carbono. Como fuentes de energía, dichas cepas utilizaron tiocianato, tiosulfato y azufre elemental, pero no tetrationato. Por otra parte, la cepa Alp 15 presentó un 99,78\% de similitud con la especie Halothiobacillus neapolitanus (Figura 4.7.9). Para esta cepa se realizó una caracterización fenotípica, según los tests propuestos por Kelly y Wood (2000), para diferenciar especies de Halothiobacillus. Los resultados demostraron que Alp 15 era la misma especie que la cepa de referencia Halothiobacillus neapolitanus DSM (Deutsche Sammlung von Mikroorganismen und Zellkulturen, Alemania) 15147. Ambas fueron bacterias Gram negativas, neutrófilas, móviles y redondeadas. Se caracterizaron como aerobias estrictas y quimioautótrofas obligadas, obteniendo su energía de compuestos reducidos del azufre como tiosulfato y azufre elemental, pero no tiocianato. Presentaron halotolerancia, pero no requirieron la presencia de $\mathrm{NaCl}$ en el medio.

La elevada proporción de aislados obtenidos del compost A correspondientes a la especie Paracoccus thiocyanatus (87,5\%), frente al menor número de los 
correspondientes a Halothiobacillus neapolitanus (12,5\%), sugiere que la primera desempeña un papel relevante en los procesos de oxidación del $S^{0}$ y en la acidificación del compost tras la adición de dicha enmienda. Hasta donde se sabe, ésta es la primera ocasión que se han aislado cepas de $P$. thiocyanatus de un compost maduro, interviniendo en la oxidación del $\mathrm{S}^{0}$ añadido de forma quimioautótrofa. Respecto a $H$. neapolitanus, sólo se había aislado anteriormente una cepa de un compost maduro preparado con residuos ganaderos y serrín (Asano et al., 2007). Ninguna otra especie oxidadora del azufre distinta de las dos indicadas ha sido aislada e identificada hasta la fecha a partir de composts.

Dado que los composts preparados con residuos lignocelulósicos (Fornes et al., 2010), incluido el alperujo, suelen mostrar salinidad elevada, y que el proceso de oxidación del $\mathrm{S}^{0}$ contribuye además a incrementar la conductividad eléctrica del compost (Carrión et al., 2008; García de la Fuente et al., 2007), el aislamiento de H. neapolitanus del compost A resulta comprensible, ya que las especies del género Halothiobacillus son típicamente halotolerantes (Kelly y Wood, 2000). En cuanto a P. thiocyanatus, y aunque no se han estudiado sus requerimientos o respuesta a medios salinos, su abundancia en el compost A, con elevada conductividad eléctrica, indica que sería también tolerante a la salinidad.

\subsubsection{Eficiencia acidificadora in situ (en el compost) de las bacterias oxidadoras del azufre seleccionadas}

Se realizó un primer experimento para evaluar la capacidad acidificadora de cada uno de los 8 aislados seleccionados por separado, sin la interferencia de la flora microbiana original presente en el compost A, por lo que éste se autoclavó. En un ensayo de 18 días de duración se estudió la variación a lo largo del tiempo del pH y la conductividad eléctrica (CE) del compost esterilizado y enmendado con la dosis 1,5xD de $S^{0}$, al ser ésta la más eficiente (ver la sección 4.7.1.2).

En la Tabla 4.7.5 se recogen los valores de la variación del pH y de la CE, así como los de la eficiencia de acidificación (e.a.), registrados en los composts enmendados con $\mathrm{S}^{0}$ que, habiendo sido esterilizados a priori, se inocularon con cada una de las 8 cepas aisladas y con las cepas de referencia procedentes del Instituto Pasteur (CIP), en comparación con el control que no se esterilizó ni se inoculó pero que sí se enmendó con So. La dosis de inóculo aplicado fue similar al valor de 


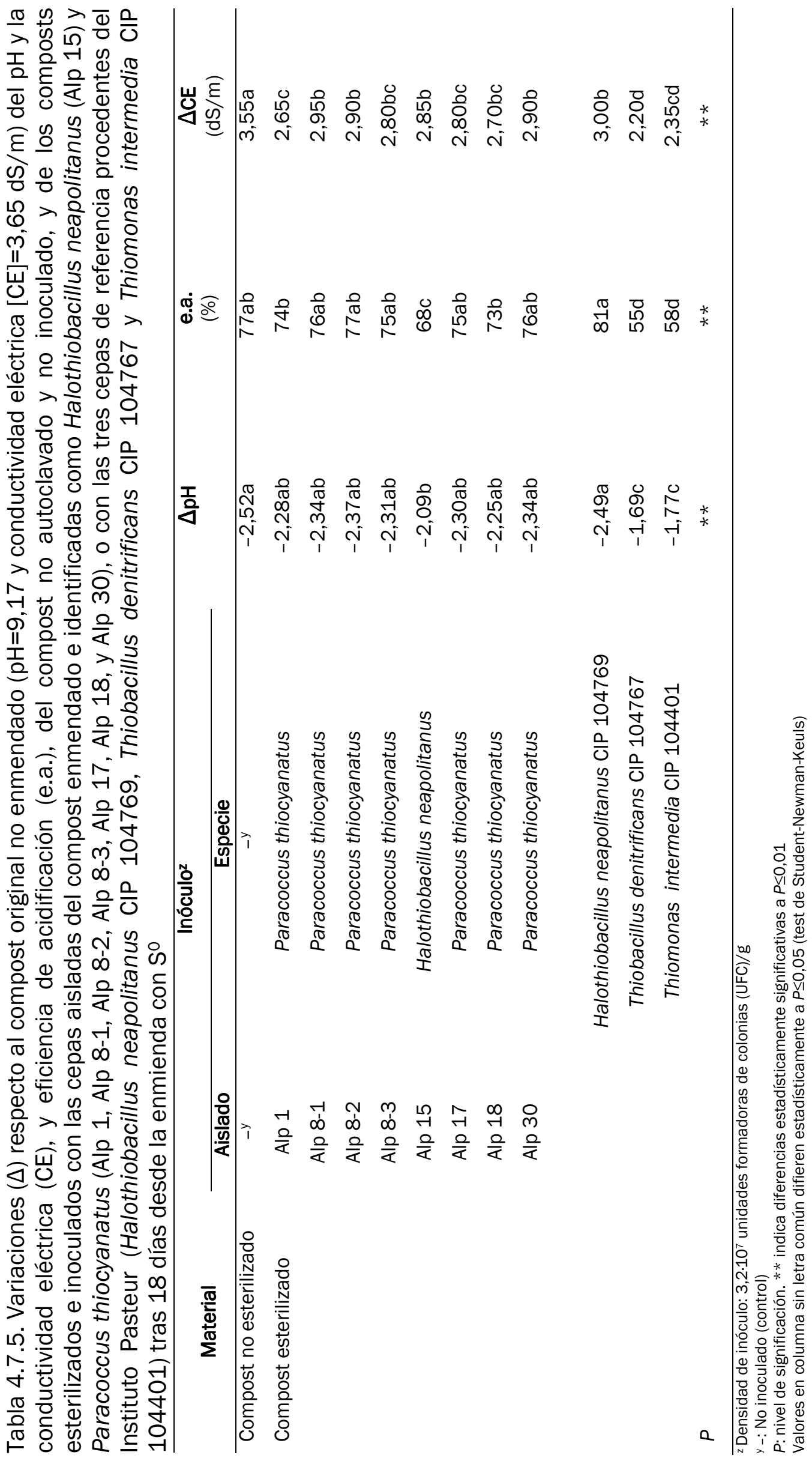


población de bacterias oxidadoras del azufre nativas, autóctonas registrado en el compost original no enmendado (3,2:107 UFC/g).

Se observó un descenso de pH de 2,52 unidades en el control indicado, alcanzándose una eficiencia de acidificación del 77\%. Todas las cepas de $P$. thiocyanatus aisladas del compost fueron tanto o más eficientes que las cepas de referencia (CIP) para acidificar dicho compost, alcanzándose disminuciones de $\mathrm{pH}$ y eficiencias de acidificación similares a las obtenidas en el control. La cepa $H$. neapolitanus Alp 15 fue menos eficiente que la cepa de referencia $H$. neapolitanus CIP 104769. Esta diferencia puede estar relacionada con la amplia variabilidad encontrada entre diferentes cepas de $H$. neapolitanus, tal y como describieron Chhatre et al. (2008). Por otra parte, las cepas de referencia (CIP) T. denitrificans y $T$. intermedia fueron las menos eficientes en el experimento realizado, alcanzando valores de eficiencia de acidificación del 55\% y el 58\%, respectivamente.

En un segundo experimento se evaluó la viabilidad de incrementar la capacidad acidificadora natural del compost -debida a su población microbiana autóctonamediante la inoculación de las cepas bacterianas procedentes de la colección del Instituto Pasteur (CIP), a la dosis que se ha indicado en el primer experimento, en un ensayo de 25 días de duración.

Los resultados obtenidos, en comparación con el compost control no inoculado, se recogen en la tabla 4.7.6. Aunque en todas las muestras inoculadas se registró un aumento en la población de bacterias oxidadoras del azufre de mayor magnitud que en la muestra control no inoculada, no se observaron diferencias significativas respecto a ésta, ni entre inóculos, en cuanto a la magnitud del descenso del pH, del incremento de la CE, o de la eficiencia de acidificación. En esta situación, Aria et al. (2010) demostraron que la adición de vermicompost a una roca fosfórica con objeto de disminuir su pH y solubilizar así el fósforo, resultó ser tan eficiente como la inoculación con una cepa de Thiobacillus thiooxidans. Todo esto revela que la población nativa, autóctona, de bacterias oxidadoras del azufre presente en el compost A tuvo máxima capacidad para oxidar este elemento, no siendo necesaria la inoculación de otros microorganismos exógenos. 
Tabla 4.7.6. Variaciones $(\Delta)$ respecto al compost original no enmendado $(\mathrm{pH}=9,17$, conductividad eléctrica $[\mathrm{CE}]=3,65 \mathrm{dS} / \mathrm{m}$, y población de bacterias oxidadoras del azufre $=3,2 \cdot 10^{7} \mathrm{UFC} / \mathrm{g}$ ) del $\mathrm{pH}$, la conductividad eléctrica (CE) y la población de bacterias oxidadoras del azufre, y eficiencia de acidificación (e.a.), del compost no inoculado (control) y del compost inoculado con las tres cepas de referencia procedentes del Instituto Pasteur (Halothiobacillus neapolitanus CIP 104769, Thiobacillus denitrificans CIP 104767 y Thiomonas intermedia CIP 104401) tras 25 días desde la enmienda con $\mathrm{S}^{0}$

\begin{tabular}{lcccc}
\hline Inóculoz & $\Delta \mathrm{pH}$ & $\begin{array}{l}\text { e.a. } \\
(\%)\end{array}$ & $\begin{array}{c}\Delta \mathrm{CE} \\
(\mathrm{dS} / \mathrm{m})\end{array}$ & $\begin{array}{c}\Delta \text { Bacterias } \\
(\log \text { UFC/g) }\end{array}$ \\
\hline- - $^{\mathrm{y}}$ & $-3,20$ & 91 & 6,13 & $9,29 \mathrm{~b}$ \\
H. neapolitanus CIP 104769 & $-3,22$ & 91 & 6,04 & $10,6 \mathrm{a}$ \\
T. denitrificans CIP 104767 & $-3,24$ & 91 & 6,03 & $10,5 \mathrm{a}$ \\
T. intermedia CIP 104401 & $-3,20$ & 91 & 5,90 & $10,3 \mathrm{a}$ \\
$P$ & $\mathrm{~ns}$ & $\mathrm{~ns}$ & $\mathrm{~ns}$ & * \\
\hline
\end{tabular}

UFC: unidades formadoras de colonias

z Densidad de inóculo: 3,2.107 UFC/g

y No inoculado (control)

$P$ : nivel de significación. ns y * indican diferencias no significativas o estadísticamente significativas a $P \leq 0,05$, respectivamente Valores en columna sin letra común difieren estadísticamente a $P \leq 0,05$ (test de Student-Newman-Keuls)

De acuerdo con los resultados presentados en esta sección 4.7, se desprende que la aplicación de azufre elemental a las dosis 1XD y 1,5xD provocó una disminución del pH del compost de 2,5 y 3,1 unidades, respectivamente, obteniéndose con la dosis máxima la mayor eficiencia de acidificación. En el compost enmendado (con $\mathrm{S}^{0}$ ) se registró un aumento en la población de bacterias oxidadoras del azufre, mientras que los grupos de bacterias heterótrofas, actinomicetos, y mohos y levaduras no experimentaron variaciones significativas en los recuentos realizados a lo largo del ensayo de acidificación desarrollado. Durante este ensayo se aislaron 8 cepas de bacterias oxidadoras del azufre, 7 de las cuales se identificaron como Paracoccus thiocyanatus y 1 como Halothiobacillus neapolitanus. Las bacterias oxidadoras del azufre aisladas del compost fueron tanto o más eficientes que las cepas de referencia utilizadas para acidificar dicho compost, observándose además que no es necesario inocular el compost original con microorganismos oxidadores exógenos, ya que la población autóctona/nativa de bacterias oxidadoras del azufre en este último compost posee gran eficacia para disminuir satisfactoriamente el pH del mismo. 
5. CONCLUSIONS 
1. The two-phase olive mill waste ('alperujo') composts studied $-\mathrm{A}$ and $\mathrm{A}+\mathrm{H}-$ differed remarkably in their physical, physico-chemical and biological properties as well as in their chemical composition due to the addition of a liquid, animal fattyproteinaceous waste from the pharmaceutical industry to mixture $\mathrm{A}+\mathrm{H}$ during the composting process.

2. Both composts exhibited valuable organic and mineral fertilizing characteristics regarding their application as soil improvers. However, maturity and stability for compost $A$ was greater than for $\mathrm{A}+\mathrm{H}$, the latter also showing attributes which were closely related to phytotoxicity.

3. The composts studied improved the physical properties and both the organic and mineral fertility of a non-cultivated calcareous soil one year after their application.

4. Compost $\mathrm{A}+\mathrm{H}$ caused mineral $\mathrm{N}$ immobilization in the short-term in two different textured soils, whereas compost A brought about N mineralization.

5. Compost A affected the first crop (radish) grown immediately after compost application much better than $\mathrm{A}+\mathrm{H}$, differences between composted materials disappearing for the following crops during the first growing year (direct effect). Compost-amended soils caused an increase in both crop growth and yield with respect to unamended controls even when mineral fertilizers were added. The residual effects, during the second growing year, of compost application on both crops and soil were much lower than the direct ones.

6. The best results regarding crop growth and productivity were achieved when the highest rate of compost (24 Mg total organic matter/ha) and mineral fertilizers (standard program, F1) were applied, within the doses studied.

7. The soluble organic matter (MOS) extracted with alkali from composts $A$ and $A+H$ enhanced the growth and yield of a lucerne crop when applied at low concentrations (particularly at $200 \mathrm{mg}$ total organic carbon/kg) to a calcareous soil. MOS application at high rates (3200-6400 mg total organic carbon/kg) increased generally organic carbon, mineral $\mathrm{N}$, and available $\mathrm{P}$ and $\mathrm{K}$ in both cultivated and non-cultivated soils. 
8. From among the 49 actinomycete strains isolated from composts $\mathrm{A}$ and $\mathrm{A}+\mathrm{H}$ and from the compost-amended calcareous soil, 12 isolates exhibited high inhibitory effects towards 6 phytopathogenic agents (5 fungi +1 bacteria) in an in vitro assay, 11 strains belonging to Streptomyces genus and 1 to Lechevalieria. A feasible reason for compost suppressiveness was probably related to the presence of antibiotic- and/or chitinase-synthesizing actinomycetes.

9. Growing media prepared with compost A showed higher inhibitory, suppressive effects than substrates containing $\mathrm{A}+\mathrm{H}$ towards Fusarium oxysporum f. sp. melonis in an in vivo assay with melon plants. Increasing compost A ratio in peatbased media promoted suppressiveness against the phytopathogen, but a detrimental effect on plant growth was found. Hence, efficient use of compost regarding suppressive effects should be taken into account together with other characteristics related to plant growth and productivity.

10. The effects of compost A on trace element bioavailability, on growth of 5 Brassica species, and on phytoextraction capability, when applied to acidic and alkaline heavy metal- and As-polluted soils, differed remarkably depending on soil $\mathrm{pH}$. Compost application had an impaired effect on plant growth in the polluted alkaline soil, whereas a positive impact on plant survival and development was found in the acidic one. The increase in soil $\mathrm{pH}$ and the decrease in $\mathrm{Al}$ and $\mathrm{Zn}$ bioavailability were the main reasons for the results obtained.

11. Brassica oleracea showed a great ability to extract and accumulate in shoots bioavailable $\mathrm{Al}, \mathrm{As}, \mathrm{Pb}$ and $\mathrm{Zn}$ from the acidic soil, whereas the best phytoextraction results in the alkaline soil were achieved with Brassica juncea, particularly for Zn removal.

12. Elemental sulphur $\left(\mathrm{S}^{0}\right)$ amendment decreased successfully the alkaline $\mathrm{pH}$ value of compost $A$, with a view to use this compost as a growing medium constituent for substrate cultivation. Eight strains of sulphur-oxidizing bacteria involved in the acidification process were isolated from the sulphur-amended compost, 7 of them being identified as Paracoccus thiocyanatus and 1 as Halothiobacillus neapolitanus. 
13. Sulphur-oxidizing strains indigenous to compost A showed per se a high acidification efficiency, and no extra effect on $\mathrm{pH}$ lowering was observed when the original, starting compost A was inoculated with exogenous reference strains.

14. Molecular techniques provided a specific and reliable identification for the actinomycete and sulphur-oxidizing bacteria strains isolated, and also supplied results which were consistent with the phenotypic characteristics observed for the isolates studied.

15. The two composts tested, and specially compost A, seem to be acceptable organic materials for amending soils for agronomic and environmental preservation purposes. 
6. BIBLIOGRAFÍA 
ABAD, M. y PUCHADES, R. (Coord.), 2002. Compostaje de Residuos Orgánicos Generados en la Hoya de Buñol (Valencia) con Fines Hortícolas. Ed. Asociación para la Promoción SocioEconómica Interior Hoya de Buñol, Valencia.

ABAD, M., FORNES, F., GARCíA, D., CEGARRA, J. and ROIG, A., 1991. Effects of humic substances from different sources on growth and nutrient content of cucumber plants. In: Allard, B., Borén, H. and Grimvall, A. (Eds.). Lecture Notes in Earth Sciences. Vol. 33. Humic Substances in the Aquatic and Terrestrial Environment. pp. 391-396. Springer-Verlag, Berlin.

ABAD, M., MARTíNEZ, P.F., MARTíNEZ, M.D. y MARTíNEZ, J., 1992. Evaluación agronómica de los sustratos de cultivo. Actas de Horticultura 23: 45-61.

ABAD, M., NOGUERA, P., NOGUERA, V., ROIG, A., CEGARRA, J. y PAREDES, C., 1997. Reciclado de residuos orgánicos y su aprovechamiento como sustratos de cultivo. Actas de Horticultura 19: 92-109.

ABAD, M., NOGUERA, P. and BURÉS, S., 2001. National inventory of organic wastes for use as growing media for ornamental potted plant production: Case study in Spain. Bioresource Technology 77: 197-200.

ABAD, M., NOGUERA, P. y CARRIÓN, C., 2004. Los sustratos en los cultivos sin suelo. En: Urrestarazu, M. (Coord. y Dir.). Tratado de Cultivo Sin Suelo. pp. 270-280. $3^{\text {a }}$ Ed. Ediciones Mundi-Prensa, Madrid.

ABAD, M., FORNES, F., MENDOZA-HERNÁNDEZ, D. y GARCÍA-DE-LA-FUENTE, R., 2008. Uso de compost como sustrato o componente de sustratos en viveros y semilleros. Tendencias futuras. Actas de Horticultura 53: 14-25.

ABAYE, D.A., LAWLOR, K., HIRSCH, P.R. and BROOKES, P.C., 2005. Changes in the microbial community of an arable soil caused by long-term metal contamination. European Journal of Soil Science 56: 93-102.

ABBOTT, L.K. and MURPHY, D.V., 2007. What is soil biological fertility? In: Abbott, L.K. and Murphy, D.V. (Eds.). Soil Biological Fertility - A Key to Sustainable Land Use in Agriculture. pp. 1-15. Springer, The Netherlands.

ABID, N. and SAYADI, S., 2006. Detrimental effect of olive mill wastewater on the composting process of agricultural wastes. Waste Management 26: 1099-1107.

ABIVEN, S., MENSASSERI, S. and CHENU, C., 2008. The effects of organic inputs over time on soil aggregate stability - A literature analysis. Soil Biology \& Biochemistry 41: 1-12.

ACHARD, F.K., 1786. Chemische Untersuchung des Torfs. Crell's Chemische Annalen 2: 391403.

ACIEGO-PIETRI, J.C. and BROOKES, P.C., 2008. Relationships between soil pH and microbial properties in a UK arable soil. Soil Biology \& Biochemistry 40: 1856-1861.

ACOSTA-MARTÍNEZ, V., KLOSE, S. and ZOBECK, T.M., 2003. Enzyme activities in semi-arid soils under conservation reserve program, native rangeland, and cropland. Journal of Plant Nutrition and Soil Science 166: 699-707.

ADANI, F., GENEVINI, P.L. and TAMBONE, F., 1995. A new index of organic stability. Compost Science \& Utilization 3: 25-37. 
ADANI, F., GENEVINI, P.L., GASPERI, F. and TAMBONE, F., 1999. Composting and humification. Compost Science \& Utilization 7: 24-33.

ADESINA, M.F., LEMBKE, A., COSTA, R., SPEKSNIJDER, A. and SMALLA, K., 2007. Screening of bacterial isolates from various European soils for in vitro antagonistic activity towards Rhizoctonia solani and Fusarium oxysporum: Site-dependent composition and diversity revealed. Soil Biology \& Biochemistry 39: 2818-2828.

AFNOR-Association Française de Normalisation, XP U44-165, 2004. Amendements organiques et supports de culture: Essai d'évaluation de la croissance de plantules. Association Française de Normalisation, La Plaine.

AGENCIA PARA EL ACEITE DE OLIVA, 2011. Información de mercados. Producción de aceite de oliva. URL: http://aao.mapa.es/ (21/3/2011).

AGGELIDES, S.M. and LONDRA, P.A., 2000. Effects of compost produced from town wastes and sewage sludge on the physical properties of a loamy and clay soil. Bioresource Technology 71: 253-259.

AGRIOS, G.N., 2005. Plant Pathology. 5th Ed. Academic Press, San Diego.

AIKEN, G.R., McKNIGHT, D.M., WERSHAW, R.L. and MacCARTHY, P., 1985. An introduction to humic substances in soil, sediment, and water. In : Aiken, G.R., McKnight, D.M., Wershaw, R.L. and MacCarthy, P. (Eds.). Humic Substances in Soil, Sediment, and Water: Geochemistry, Isolation and Characterization. pp. 1-9. Wiley-Interscience, New York.

AIT BADDI, G., ALBURQUERQUE, J.A., GONZÁLVEZ, J., CEGARRA, J. and HAFIDI, M., 2004. Chemical and spectroscopic analyses of organic matter transformations during composting of olive mill wastes. International Biodeterioration \& Biodegradation 54: 39-44.

ALBIACH, R., CANET, R., POMARES, F. and INGELMO, F., 2000. Microbial biomass content and enzymatic activities after the application of organic amendments to a horticultural soil. Bioresource Technology 75: 43-48.

ALBIACH, R., CANET, R., POMARES, F. and INGELMO, F., 2001. Organic matter components and aggregate stability after the application of different amendments to a horticultural soil. Bioresource Technology 77: 109-114.

ALBURQUERQUE, J.A., GONZÁlVEZ, J., GARCíA, D. and CEGARRA, J., 2004. Agrochemical characterisation of "alperujo", a solid by-product of the two-phase centrifugation method for olive oil extraction. Bioresource Technology 91: 195-200.

ALBURQUERQUE, J., GONZÁLVEZ, J., GARCÍA, D. and CEGARRA, J., 2006a. Effects of bulking agent on the composting of "alperujo", the solid by-product of two-phase centrifugation method for olive oil extraction. Process Biochemistry 41: 127-132.

ALBURQUERQUE, J., GONZÁLVEZ, J., GARCÍA, D. and CEGARRA, J., 2006b. Composting of a solid olive-mill by-product ("alperujo") and the potential of the resulting compost for cultivating pepper under commercial conditions. Waste Management 26: 620-626.

ALBURQUERQUE, J. GONZÁLVEZ, J., GARCÍA, D. and CEGARRA, J., 2006c. Measuring detoxification and maturity in compost made from "alperujo", the solid by-product of extracting olive oil by the two-phase centrifugation system. Chemosphere 64: 470-477. 
ALBURQUERQUE, J.A., GONZÁlVEZ, J., GARCíA, D. and CEGARRA, J., 2007. Effects of a compost made from the solid by-product ("alperujo") of the two-phase centrifugation system for olive oil extraction and cotton gin waste on growth and nutrient content of ryegrass (Lolium perenne L.). Bioresource Technology 98: 940-945.

ALBURQUERQUE, J.A., GONZÁLVEZ, J., TORTOSA, G., BADDI, G.A. and CEGARRA, J., 2009. Evaluation of "alperujo" composting based on organic matter degradation, humification and compost quality. Biodegradation 20: 257-270.

ALBURQUERQUE, J.A., DE LA FUENTE, C. and BERNAL, M.P., 2011. Improvement of soil quality after "alperujo" compost application to two contaminated soils characterised by differing heavy metal solubility. Journal of Environmental Management 92: 733-741.

ALEF, K. and KLEINER, D., 1986. Arginine ammonification, a simple method to estimate microbial activity potentials in soil. Soil Biology \& Biochemistry 18: 233-235.

ALEF, K. and KLEINER, D., 1987. Applicability of arginine ammonification as indicator of microbial activity in different soils. Biology and Fertility of Soils 5: 148-151.

ALEF, K. and NANNIPIERI, P., 1995. Methods in Applied Soil Microbiology and Biochemistry. Academic Press, San Diego, California.

ALEIXANDRE, J.L. y GARCÍA, M.J., 1999. Industrias Agroalimentarias. Editorial de la Universidad Politécnica de Valencia, Valencia.

ALFANO, G., BELLI, C., LUSTRATO, G. and RANALLI, G., 2008. Pile composting of two-phase centrifuged olive husk residues: Technical solutions and quality of cured compost. Bioresource Technology 99: 4694-4701.

ALLEN, J.R. and PREER, J.R., 1995. Use of municipal waste in vegetable crop production. Caribbean Food Crops Society Proceedings 30: 199-205.

ALT, D., 2001. Advantages and disadvantages of CAT-method for the chemical analysis of horticultural substrates as compared to several other extraction solutions. Acta Horticulturae 548: 655-661.

ALT, D., PETERS, I. und GAUS, S., 1994. Die $\mathrm{CaCl}_{2}$ /DTPA-Methode zur Untersuchung gärtnerischer Erden auf Mengen- und Spurenelemente. 7. Mitteilung: Zink. Agribiological Research 47: 75-83.

ALTIERI, R. and ESPOSITO, A., 2010. Evaluation of the fertilizing effect of olive mill waste compost in short-term crops. International Biodeterioration \& Biodegradation 64: 1-5.

ALVARENGA, P., GONÇALVES, A.P., FERNANDES, R.M., DE VARENNES, A., VALLINI, G., DUARTE, E. and CUNHA-QUEDA, A.C., 2009a. Organic residues as immobilizing agents in aided phytostabilization: (I) Effects on soil chemical characteristics. Chemosphere 74: 1292-1300.

AlVARENGA, P., PALMA, P., GONÇALVES, A.P., FERNANDES, R.M., DE VARENNES, A., VALLINI, G., DUARTE, E. and CUNHA-QUEDA, A.C., 2009b. Organic residues as immobilizing agents in aided phytostabilization: (II) Effects on soil biochemical and ecotoxicological characteristics. Chemosphere 74: 1301-1308.

ÁLVAREZ, M.A., GAGNÉ, S. and ANTOUN, H., 1995. Effect of compost on rhizosphere microflora of the tomato and on the incidence of plant growth-promoting rhizobacteria. Applied Environmental Microbiology 61: 194-199. 
AMIR, H. and ALABOUVETTE, C., 1993. Involvement of soil abiotic factors in the mechanisms of soil suppressiveness to Fusarium wilts. Soil Biology \& Biochemistry 25: 157-164.

AMLINGER, F., GÖTZ, B., DREHER, P., GESZTI, J. and WEISSTEINER, C., 2003. Nitrogen in biowaste and yard waste compost: dynamics of mobilisation and availability - A review. European Journal of Soil Biology 39: 107-116.

ANANDHAM, R., SRIDAR, R., NALAYINI, P., POONGUZHALI, S., MADHAIYAN, M. and TONGMIN S.A., 2007. Potential for plant growth promotion in groundnut (Arachis hypogea L.) CV. ALR-2 by co-inoculation of sulphur-oxidizing bacteria and Rhizobium. Microbiological Research 162: 139-153.

ANDERSON, A.S. and WELLINGTON, E.M.H., 2001. The taxonomy of Streptomyces and related genera. International Journal of Systematic and Evolutionary Microbiology 51: 797-814.

ARANCON, N.Q., LEE, S., EDWARDS, C.A. and ATIYEH, R., 2003. Effects of humic acids derived from cattle, food and paper-waste vermicomposts on growth of greenhouse plants. Pedobiologia 47: 741-744.

ARANCON, N.Q., EDWARDS, C.A., LEE, S. and BYRNE, R., 2006. Effects of humic acids from vermicomposts on plant growth. European Journal of Soil Biology 42: S65-S69.

ARAÚJO, A.S.F. and MONTEIRO, R.T.R., 2005. Plant bioassays to assess toxicity of textile sludge compost. Scientific Agriculture 62: 286-290.

ARIA, M.M., LAKZIAN, A., HAGHNIA, G.H., BERENJI, A.R., BASHARATI, H. and FOTOVAT, A., 2010. Effect of Thiobacillus, sulphur, and vermicompost on the water-soluble phosphorus of hard rock phosphate. Bioresource Technology 101: 551-554.

ARVANITOYANNIS, I.S. and KASSAVETI, A., 2008. Olive oil waste management: treatment methods and potential uses of treated waste. In: Arvanitoyannis, I.S. (Author). Waste Management for the Food Industries. pp. 453-568. Elsevier Academic Press, Burlington, Vermont.

ARVANITOYANNIS, I.S., LADAS, D. and MAVROMATIS, A., 2006. Wine waste treatment methodology. International Journal of Food Science \& Technology 41: 1117-1151.

ARVANITOYANNIS, I.S, KASSAVETI, A. and LADAS, D., 2008. Food waste treatment methodologies. In: Arvanitoyannis, I.S. (Author). Waste Management for the Food Industries. pp. 345-410. Elsevier Academic Press, Burlington, Vermont.

ASANO, R., SASAKI, T. and NAKAI, Y., 2007. Isolation and characterization of sulfur oxidizing bacteria from cattle manure compost. Animal Science Journal 78: 330-333.

ASLAM, D.N., HORWATH, W. and VANDERGHEYNST, J.S., 2008. Comparison of several maturity indicators for estimating phytotoxicity in compost-amended soil. Waste Management 28: 2070-2076.

ATIYEH, R.M., LEE, S., EDWARDS, C.A., ARANCON, N.Q. and METZGER, J.D., 2002. The influence of humic acids derived from earthworm-processed organic wastes on plant growth. Bioresource Technology 84: 7-14.

AUSTRALIAN STANDARDS, 2003. Australian Standard for Potting Mixes, AS 3743. $2^{\text {nd }}$ Ed. Standards Australia, Standards Association of Australia. Homebush, New South Wales, Australia. 
AVIANI, I., LAOR, Y., MEDINA, S., KRASSNOVSKY, A. and RAVIV, M., 2010. Co-composting of solid and liquid olive mill wastes: Management aspects and the horticultural value of the resulting composts. Bioresource Technology 101: 6699-6706.

AWAD, A., SALMAN, H. and HUNG, Y., 2008. Tratamiento de residuos de aceite de oliva. En: Wang, L.K., Hung, Y., Lo, H.H. and Yapijakis, C. (Eds.). Tratamiento de los Residuos de la Industria del Procesado de Alimentos. pp. 147-237. Editorial Acribia S.A., Zaragoza.

BÅÅTH, E., DÍAZ-RAVIÑA, M., FROSTEGÅRD, A. and CAMPBELL, C.D., 1998. Effects of metal-rich sludge on the soil microbial community. Applied Environmental Microbiology 64: 238-245.

BADIANE, N.N.Y, CHOTTE, J.L., PATE, E., MASSE, D. and ROULAND, C., 2001. Use of soil enzyme activities to monitor soil quality in natural and improved fallows in semi-arid tropical regions. Applied Soil Ecology 18: 229-238.

BADJI, B., RIBA, A., MATHIEU, F., LEBRIHI, A. and SABAOU, N., 2005. Antifungal activity of a Saharan Actinomadura strain against various pathogenic and toxinogenic fungi. Journal de Mycologie Médicale 15: 211-219.

BAETA-HALL, L., SÀÁGUA, M.C., BARTOLOMEU, M.L., ANSELMO, A.M. and ROSA, M.F., 2005. Bio-degradation of olive oil husks in composting aerated piles. Bioresource Technology 96: 6978.

BAKER, A.J.M., 1981. Accumulators and excluders - Strategies in the response of plants to heavy metals. Journal of Plant Nutrition 3: 643-654.

BAKER, A.J.M. and BROOKS, R.R., 1989. Terrestrial higher plants which hyperaccumulate metallic elements - A review of their distribution, ecology and phytochemistry. Biorecovery 1 : 81-126.

BALDOCK, J.A. and NELSON, P.N., 2000. Soil organic matter. In: Sumner, M.E. (Ed.). Handbook of Soil Science. pp. B25-B84. CRC Press, Boca Raton, Florida.

BALIS, C., NIKOLAROU, S., COPPENS, S., MARI, J. and JONES, C.E., 2001. Composting the two phase olive oil mill residues. Acta Horticulturae 549: 71-80.

BARKER, A.V., 2005. Utilización de los compost en la producción de tepes y manejo de céspedes. En: Stoffella, P.J. y Kahn, B.A. (Eds.). Utilización de Compost en los Sistemas de Cultivo Hortícola. pp. 201-239. Ediciones Mundi-Prensa, Madrid.

BARRAL, M.T., PARADELO, R., MOLDES, A.B., DOMíNGUEZ, M. and DÍAZ-FIERROS, F., 2009. Utilization of MSW compost for organic matter conservation in agricultural soils of NW Spain. Resources, Conservation and Recycling 53: 529-534.

BATISTA, J. y MARTínEZ, M.R., 1989. Análisis Multivariante. Análisis de Componentes Principales. Editorial Hispano Europea, Barcelona.

BAUER, A. and BLACK, A.L., 1994. Quantification of the effect of soil organic matter content on soil productivity. of Soil Science Society of America Journal 58: 185-193.

BAZIRAMAKENGA, R. and SIMARD, R., 2001. Effect of deinking paper sludge compost on nutrient uptake and yields of snap bean and potatoes grown in rotation. Compost Science \& Utilization 9: 115-126. 
BENTLEY, R., 1997. Microbial secondary metabolites play important roles in medicine; prospects for discovery of new drugs. Perspectives in Biology and Medicine 40: 364-394.

BERNAL, M.P. y GONDAR, D.M., 2008. Producción y gestión de los residuos orgánicos: situación actual a nivel mundial, comunitario y estatal. En: Moreno, J. and Moral, R. (Eds.). Compostaje. pp. 9-41. Ediciones Mundi-Prensa, Madrid.

BERNAL, M.P., PAREDES, C., SÁNCHEZ-MONEDERO, M.A. and CEGARRA, J., 1998. Maturity and stability parameters of compost prepared with a wide range of organic wastes. Bioresource Technology 63: 91-99.

BERNAL, M.P., ALBURQUERQUE, J.A. and MORAL, R., 2009. Composting of animal manures and chemical criteria for compost maturity assessment. A review. Bioresource Technology 100: 5444-5453.

BEVACQUA, R.F. and MELLANO, V.J., 1993. Sewage sludge compost's cumulative effects on crop growth. Compost Science \& Utilization 1: 34-37.

BIDLINGMAIER, W., 1996. Odour emissions from composting plants. In: de Bertoldi, M., Sequi, P., Lemmes, B. and Papi, T. (Eds.). The Science of Composting. Vol. I. pp. 71-79. Blackie Academic \& Professional, London.

BLACKMER, A.M. and BREMNER, J.M., 1977. Gas chromatographic analysis of soil atmosphere. Soil Science Society of America Journal 41: 908-912.

BLAYLOCK, M.J. and HUANG, J.W., 2000. Phytoextraction of metals. In: Raskin, I. and Ensley, B.D. (Eds.). Phytoremediation of Toxic Metals using Plants to Clean up the Environment. pp. 53-70. John Wiley and Sons Inc., New York.

BLOK, C., DE KREIJ, C., BAAS, R. and WEVER, G., 2008. Analytical methods used in soilless cultivation. In: Raviv, M. and Lieth, J. H. (Eds.). Soilless Culture. Theory and Practice. pp. 245288. Elsevier BV, Oxford.

BÖHME, L., LANGER, U. and BÖHME, F., 2005. Microbial biomass, enzyme activities and microbial community structure in two European long-term field experiments. Agriculture, Ecosystems \& Environment 109: 141-152.

BOLAN, N.S., SAGGAR, S. and LOGANATHAN, P., 2005. Calcium and magnesium in soils. In: Hillel, D. (Ed.). Encyclopedia of Soils in the Environment. Vol. 1. pp. 149-154. Elsevier Ltd., Oxford.

BONANOMI, G., GIORGI, V., GIOVANNI, D.L., NERI, D. and SCALA, F., 2006. Olive mill residues affect saprophytic growth and disease incidence of foliar and soilborne plant fungal pathogens. Agriculture, Ecosystems \& Environment 115: 194-200.

BONANOMI, G., ANTIGNANI, V., CAPODILUPO, M. and SCALA, F., 2010. Identifying the characteristics of organic soil amendments that suppress soilborne plant diseases. Soil Biology \& Biochemistry 42: 136-144.

BONDE, T.A. and ROSSWALL, T., 1987. Seasonal variation of potentially mineralizable nitrogen in four cropping systems. Soil Science Society of America Journal 51: 1508-1514.

BONDE, T.A., NIELSEN, T.H., MILLER, M. and SØRENSEN, J., 2001. Arginine ammonification assay as a rapid index of gross $\mathrm{N}$ mineralization in agricultural soils. Biology and Fertility of Soils 34: 179-184. 
BORJA, R., MARTíN, A., SÁNCHEZ, E., RINCÓN, B. and RAPOSO, F., 2005. Kinetic modelling of the hydrolysis, acidogenic and methanogenic stops in the anaerobic digestion of two-phase olive pomace (TPOP). Process Biochemistry 40: 1841-1847.

BORJA, R., RINCÓN, B. and RAPOSO, F., 2006. Anaerobic biodegradation of two-phase olive mill solid wastes and liquid effluents: kinetic studies and process performance. Journal of Chemical Technology and Biotechnology 81: 1450-1462.

BORRERO, C., TRILLAS, M.I., ORDOVÁS, J., TELLO, J.C. and AVILÉS, M., 2004. Predictive factor for the suppression of Fusarium wilt of tomato in plant growth media. Phytopathology 94: 1094-1101.

BORRERO, C., INFANTES, M.J., GONZÁLEZ, E., TELLO, J.C. and AVILÉS, M., 2005. Relation between suppressiveness to tomato Fusarium wilt and microbial populations in different growth media. Acta Horticulturae 697: 425-430.

BOUIZGARNE, B., HADRAMI, I.E. and OUHDOUCH, Y., 2006. Novel production of isochainin by a strain of Streptomyces sp. isolated from rhizosphere soil of the indigenous Moroccan plant Argania spinosa L. World Journal of Microbiology \& Biotechnology 22: 423-429.

BOULTER, J.I., BOLAND, G.J. and TREVORS, J.T., 2000. Compost: a study of the development process and end-product potential for suppression of turfgrass disease. World Journal of Microbiology \& Biotechnology 16: 115-134.

BREMNER, J.M., 1965. Total nitrogen. In: Methods of Soil Analysis, Part 2. Chemical and Microbiological Properties. pp. 1149-1178. American Society of Agronomy, Monograph 9. Madison, Wisconsin.

BRINK, R.H., DUBACH, P. and LYNCH, D.L., 1960. Measurement of carbohydrates in soil hydrolyzates with anthrone. Soil Science 89: 157-166.

BRIZ, J. (Ed.), 2004. Naturación Urbana: Cubiertas Ecológicas y Mejora Medioambiental. Ediciones Mundi-Prensa, Madrid.

BROADBENT, F.E., 1986. Empirical modelling of soil nitrogen mineralization. Soil Science 141: 208-213.

BROWMAN, M.G. and TABATABAI, M.A., 1978. Phosphodiesterase activity of soils. Soil Science Society of American Journal 42: 284-290.

BRYAN, H.H. and LANCE, C.J., 1991. Compost trials on vegetables and tropical crops. BioCycle 32: 36-37.

BRYAN, H.H., SCHAFFER, B. and CRANE, J.H., 1994. Solid waste compost for improved water conservation and production of vegetable crops (tomatoes/squash)-Homestead site. In: Smith, W.H. (Ed.). Summary Report for the Florida Composting Conference. pp. 6-9. Florida Department of Agriculture and Consumer Services, Tallahassee, Florida.

BRYAN, H.H., SCHAFFER, B., SANFORD, R.E. and CODALLO, M., 1995. Growth and yield of tomato in calcareous soil amended with municipal solid waste compost. Proceedings of the Florida State Horticultural Society 108: 251-253.

BUCHANAN, M. and GLIESSMAN, S.R., 1991. How compost fertilization affects soil nitrogen and crop yield. BioCycle 32: 72-77. 
BUENO, P., DÍAZ, M.J. y CABRERA, F., 2008. Factores que afectan al proceso de compostaje. En: Moreno, J. y Moral, R. (Eds.). Compostaje. pp. 93-109. Ediciones Mundi-Prensa, Madrid.

BÜNEMANN, E.K., SCHWENKE, G.D. and VAN ZWIETEN, L., 2006. Impact of agricultural inputs on soil organisms - A review. Australian Journal of Soil Research 44: 379-406.

BUNT, A.C., 1988. Media and Mixes for Container-Grown Plants: A Manual on the Preparation and Use of Growing Media for Pot Plants. Unwin Hyman Ltd., London.

BURNS, R.G., 1978. Enzyme activity in soil. Some theoretical and practical considerations. In: Burns, R.G. (Ed.). Soil Enzymes. pp. 295-339. Academic Press, New York.

BUSINELLI, D., MASSACCESI, L., SAID-PULLICINO, D. and GIGLIOTTI, G., 2009. Long-term distribution, mobility and plant availability of compost-derived heavy metals in a landfill covering soil. Science of the Total Environment 407: 1426-1435.

BUSTAMANTE, M.A., 2007. Compostaje de los Residuos Generados en la Industria Vinícola y Alcoholera. Valorización Agronómica de los Materiales Obtenidos. Tesis Doctoral, Universidad Miguel Hernández de Elche, Alicante. 555 pp.

BUSTAMANTE, M.A., PAREDES, C., MORAL, R., AGULLÓ, E., PÉREZ-MURCIA, M.D. and ABAD, M., 2008. Composts from distillery wastes as peat substitutes for transplant production. Resources, Conservation and Recycling 52: 792-799.

BUSTAMANTE, M.A., PAREDES, C., MORALES, J., MAYORAL, A.M. and MORAL, R., 2009. Study of the composting process of winery and distillery wastes using multivariate techniques. Bioresource Technology 100: 4766-4772.

BUSTAMANTE, M.A., SAID-PULLICINO, D., AGULLÓ, E., ANDREU, J., PAREDES, C. and MORAL, R., 2011. Application of winery and distillery waste composts to a Jumilla (SE Spain) vineyard: Effects on the characteristics of a calcarous sandy-loam soil. Agriculture, Ecosystems \& Environment 140: 80-87.

CABRERA, F., CLEMENTE, L., DÍAZ BARRIENTOS, E., LÓPEZ, R. and MURILLO, J.M. 1999. Heavy metal pollution of soils affected by the Guadiamar toxic flood. Science of the Total Environment 242: 117-129.

CABRERA, M.L., KISSEL, D.E. and VIGIL, M.F., 2005a. Nitrogen mineralization from organic residues: research opportunities. Journal of Environmental Quality 34: 75-79.

CABRERA, F., MARTíN-OLMEdO, P., LÓPEZ, R. and MURILLO, J.M., 2005b. Nitrogen mineralization in soils amended with composted olive mill sludge. Nutrient Cycling in Agroecosystems 71: 249-258.

CABRERA, D., LÓPEZ-PIÑEIRO, A., ALBARRÁN, A. and PEÑA, D., 2010. Direct and residual effects on diuron behaviour and persistente following two-phase olive mill waste addition to soil: Field and laboratory experiments. Geoderma 157: 133-141.

CAI, Q., MO, C., WU, Q. and ZENG, Q., 2008. Polycyclic aromatic hydrocarbons and phthalic acid esters in the soil-radish (Raphanus sativus) system with sewage sludge and compost application. Bioresource Technology 99: 1830-1836.

CAMPITELLI, P.A., VELASCO, M.I. and CEPPI, S.B., 2006. Chemical and physicochemical characteristics of humic acids extracted from compost, soil and amended soils. Talanta 69: 1234-1239. 
CANELLAS, L.P., OLIVARES, F.L., OKOROKOVA-FAÇANHA, A.L. and FAÇANHA, A.R., 2002. Humic acids isolated from earthworm compost enhance root elongation, lateral root emergence, and plasma membrane $\mathrm{H}^{+}$-ATPase activity in maize roots. Plant Physiology 130: 1951-1957.

CANET, R. y ALBIACH, M.R., 2008. Aplicaciones del compost en Agricultura Ecológica. En: Moreno, J. y Moral, R. (Eds.). Compostaje. pp. 379-395. Ediciones Mundi-Prensa, Madrid.

CANET, R., POMARES, F., CABOT, B., CHAVES, C., FERRER, E., RIBÓ, M. and ALBIACH, R., 2008. Composting olive mill pomace and other residues from rural southeastern Spain. Waste Management 28: 2585-2592.

CAPASSO, R., EVIDENTE, A., SCHIVO, L., ORRU, G., MARCIALIS, M.A. and CRISTINZO, G., 1995. Antibacterial polyphenols from olive oil mill waste waters. Journal of Applied Bacteriology 79: 393-398.

CAPUTO, A.C., SCACCHIA, F. and PELAGAGGE, P., 2003. Disposal of by-products in olive oil industry: waste to energy solutions. Applied Thermal Engineering 23: 197-214.

CARAVACA, F., TORTOSA, G., CARRASCO, L., CEGARRA, J. and ROLDÁN, A., 2006. Interaction between $A M$ fungi and a liquid organic amendment with respect to enhancement of the performance of the leguminous shrub Retama sphaerocarpa. Biology and Fertility of Soils 43: 30-38.

CARBONELl-BARRACHINA, A., JUGSUJINDA, A., DELAUNE, R.D., PATRICK, W.H., BURLÓ, F., SIRISUKHODOM, S. and ANURAKPONGSATORN, P., 1999. The influence of redox chemistry and $\mathrm{pH}$ on chemically active forms of arsenic in sewage sludge-amended soil. Environmental International 25: 613-618.

CARDOSO, M.R., PAQUALOTTO, L., ROCHA, A., MARINHO, J.G., LOPES, D. e ARAÚJO, G., 2006. Estímulo no crescimento e na hidrólise de ATP em raízes de alface tratadas com humatos de vermicomposto. I - Efeito da concentração. Revista Brasileira de Ciência do Solo 30: 649-656.

CARMONA, E. y ABAD, M., 2008. Aplicación del compost en viveros y semilleros. En: Moreno, J. y Moral, R. (Eds.). Compostaje. pp. 387-424. Ediciones Mundi-Prensa, Madrid.

CARPENA, R.O. y BERNAL, M.P., 2007. Claves de la fitorremediación: Fitotecnologías para la recuperación de suelos. Ecosistemas 16/2: 1-3.

CARPENTER-BOGGS, L., KENNEDY, A.C. and REGANOLD, J.P., 2000. Organic and biodynamic management: effects on soil biology. Soil Science Society of America Journal 64: 1651-1659.

CARRIÓN, C., GARCÍA DE LA FUENTE, R., FORNES, F., PUCHADES, R. and ABAD, M., 2008. Acidifying composts from vegetable crop wastes to prepare growing media for containerized crops. Compost Science \& Utilization 16: 20-29.

CASTALDI, P., ALBERTI, G., MERELLA, R. and MELIS, P., 2005. Study of the organic matter evolution during municipal solid waste composting aimed at identifying suitable parameters for the evaluation of compost maturity. Waste Management 25: 209-213.

CASTILLO, U.F., STROBEL, G.A., FORD, E.J., HESS, W.M., PORTER, H., JENSEN, J.B., ALBERT, H., ROBISON, R., CONDRON, M.A.M., TEPLOW, D.B., STEVENS, D. and YAVER, D., 2002. Munumbicins, wide-spectrum antibiotics produced by Streptomyces NRRL 30562, endophytic on Kennedia nigriscans. Microbiology 148: 2675-2685. 
CASTRO, O., TURRO, J., SABATÉ, J., HUERTA, O., SOLIVA, M. y ARAGAY, M., 2006. Aplicación de residuos orgánicos de distintos orígenes a un cultivo de lechugas. Influencia sobre la producción y la calidad. Residuos 92: 46-54.

CASTRO, E., MAÑAS, P. and DE LAS HERAS., J. 2009. A comparison of the application of different waste products to a lettuce crop: effects on plant and soil properties. Scientia Horticulturae 123: 148-155.

CAYUELA, M.L., 2004. Producción Industrial de Compost Ecológico a Partir de Residuos de Almazara. Tesis Doctoral, Universidad de Murcia. 295 pp.

CAYUELA, M.L., BERNAL, M.P. and ROIG, A., 2004. Composting olive mill waste and sheep manure for orchard use. Compost Science \& Utilization 12: 130-136.

CAYUELA, M.L., SÁNCHEZ-MONEDERO, M.A. and ROIG, A., 2006. Evaluation of two different aeration systems for composting two-phase olive mill wastes. Process Biochemistry 41: 616623.

CAYUELA, M.L., MILLNER, P., SLOVIN, J. and ROIG, A., 2007. Duckweed (Lemna gibba) growth inhibition bioassay for evaluating the toxicity of olive mill wastes before and during composting. Chemosphere 68: 1985-1991.

CAYUELA, M.L., MILLNER, P.D., MEYER, S.L.F. and ROIG, A., 2008a. Potential of olive mill waste and compost as biobased pesticides against weeds, fungi, and nematodes. Science of the Total Environment 399: 11-18.

CAYUELA, M.L., MONDINI, C., SÁNCHEZ-MONEDERO, M.A. and ROIG, A., 2008b. Chemical properties and hydrolytic enzyme activities for the characterisation of two-phase olive mill wastes composting. Bioresource Technology 99: 4255-4262.

CAYUELA, M.L., SÁNCHEZ-MONEDERO, M.A. and ROIG, A., 2010. Two-phase olive mill waste composting: enhancement of the composting rate and compost quality by grape stalks addition. Biodegradation 21: 465-473.

CEGARRA, J. y PAREDES, C., 2008. Residuos agroindustriales. En: Moreno, J. y Moral, R. (Eds.). Compostaje. pp. 519-551. Ediciones Mundi-Prensa, Madrid.

CEGARRA, J., REVERTE, L., LAX, A. y COSTA, F., 1974. Factores que influyen en la extracción y fraccionamiento de la materia orgánica del suelo. Anales de Edafología y Agrobiología 33: 575-590.

CEGARRA, J., ROIG, A., NAVARRO, A.F., BERNAL, M.P., ABAD, M., CLIMENT, M.D. and ARAGÓN, P., 1993. Características, compostaje y uso agrícola de residuos sólidos urbanos. En: Ponencias y Comunicaciones a las Actas de las Jornadas de Recogidas Selectivas en Origen y Reciclaje. pp. 46-55. SADECO-Empresa Municipal de Saneamientos de Córdoba S.A., Córdoba.

CEGARRA, J., PAREDES, C., ROIG, A., BERNAL, M.P. and GARCÍA, D., 1996. Use of olive mill wastewater compost for crop production. International Biodeterioration \& Biodegradation 38: 193-203.

CEGARRA, J., ALBURQUERQUE, J.A., GONZÁLVEZ, J., and TORTOSA, G., 2005a. Composting "alperujo", the main by-product of the spanish olive oil industry. In: Bernal, M.P., Moral, R., Clemente, R. and Paredes, C. (Eds.). Sustainable Organic Waste Management for Environmental Protection and Food Safety. pp. 281-283. FAO and CSIC, Murcia. 
CEGARRA, J., ALBURQUERQUE, J.A. y TORTOSA, G., 2005b. Utilización de estiércoles y residuos vegetales para compostar alperujo, el principal subproducto de la industria extractiva del aceite de oliva en España. Influencia sobre el proceso y la calidad del compost. En: Actas II Congreso sobre Residuos Biodegradables y Compost, Sevilla. 5 pp. Instituto para la Sostenibilidad de los Recursos, Madrid. Formato CD-ROM.

CEGARRA, J., ALBURQUERQUE, J.A., GONZÁLVEZ, J., TORTOSA, G. and CHAW, D., 2006. Effects of the forced ventilation on composting of a solid olive-mill by-product ("alperujo") managed by mechanical turning. Waste Management 26: 1377-1383.

CHANEY, R.L., MALIK, M., LI, Y.M., BROWN, S.L., BREWER, E.P., ANGLE, J.S. and BAKER, A.J.M., 1997. Phytoremediation of soil metals. Current Opinion in Biotechnology 8: 279-287.

CHANEY, R.L., LI, Y.M., BROWN, S.L., HOMER, F.A., MALIK, M., ANGLE, J.S., BAKER, A.J.M., REEVES, R.D. and CHIN, M., 2000. Improving metal hyperaccumulator wild plants to develop commercial phytoextraction systems: approaches and progress. In: Terry, N. and Bañuelos, G. (Eds.). Phytoremediation of Contaminated Soil and Water. pp. 129-158. Lewis Publications, Boca Raton, Florida.

CHANYASAK, V. and KUBOTA, H., 1981. Carbon/organic nitrogen ratio in water extract as measure of compost degradation. Journal of Fermentation Technology 59: 215-219.

CHANYASAK, V., KATAYAMA, A., HIRAI, M.F., MORI, S. and KUBOTA, H., 1983. Effects of compost maturity on growth of Komatsuna (Brassica rapa var. pervidis) in Neubauer's pot. Soil Science \& Plant Nutrition 29: 251-259.

CHAVES, B., DE NEVE, S., BOECKX, P., VAN CLEEMPUT, O. and HOFMAN, G., 2005. Screening organic biological wastes for their potential to manipulate the $\mathrm{N}$ release from $\mathrm{N}$-rich vegetable crop residues in soil. Agriculture, Ecosystems \& Environment 111: 81-92.

CHEN, Y. and AVIAD, T., 1990. Effects of humic substances on plant growth. In: McCarthy, P., Clapp, C.E., Malcolm, R.L. and Bloom, P.R. (Eds.). Humic Substances in Soil and Crop Sciences: Selected Readings. pp. 161-187. American Society of Agronomy and Soil Science Society of America, Madison.

CHEN, W., HOITINK, H.A.J. and MADDEN, L.V., 1988. Microbial activity and biomass in container media for predicting suppressiveness to damping-off caused by Pythium ultimum. Phytopathology 78: 1447-1450.

CHEN, Z.S., LEE, G.J. and LIU, J.C., 2000. The effects of chemical remediation treatments on the extractability and speciation of cadmium and lead in contaminated soils. Chemosphere 41: 235-242.

CHERIF, H., AYARI, F., OUZARI, H., MARZORATI, M., BRUSETTI, L., JEDIDI, N., HASSEN, A. and DAFFONCHIO, D., 2009. Effects of municipal solid waste compost, farmyard manure and chemical fertilizers on wheat growth, soil composition and soil bacterial characteristics under Tunisian arid climate. European Journal of Soil Biology 45: 138-145.

CHHATRE, S., DELEON, J., GOLDBAUM, B., LATHAM, J., PANCHALINGALA, S. and HILLIARD, N.P., 2008. Variability in Halothiobacillus neapolitanus type strain cultures. Indian Journal of Microbiology 48: 287-290.

CHICA, A.F. y GARCÍA, J.L., 2008. Aspectos técnicos en el desarrollo y control del proceso de compostaje. En: Moreno, J. y Moral, R. (Eds.). Compostaje. pp. 43-74. Ediciones Mundi-Prensa, Madrid. 
CHOI, S.R., LEE, C.H., LEE, H.S., SHIN, W.K. and LEE, Y.S., 1989. The effects of electrical conductivity of soil solution on the germination and regrowth of leaves and roots of several vegetable crops. Research Reports of the Rural Development and Administration, Soil and Fertilizer 31: 65-82.

CLARK, G.A., STANLEY, C.D. and MAYNARD, D.N., 1994. Compost utilization for improved management of vegetable crops on sandy soils-Bradenton site. In: Smith, W.H. (Ed.). Summary Report for the Florida Composting Conference. pp. 11-13. Florida Department of Agriculture and Consumer Services, Tallahassee, Florida.

CLEMENTE, R. and BERNAL, M.P., 2006. Fractionation of heavy metals and distribution of organic carbon in two contaminated soils amended with humic acids. Chemosphere 64: 12641273.

CLEMENTE, R., WALKER, D.J. y BERNAL, M.P., 2004. Uso de Enmiendas Orgánicas en la Fitorrecuperación de Suelos Contaminados por Metales Pesados. Centro de Edafología y Biología Aplicada del Segura (CEBAS) - CSIC, Murcia.

CLEMENTE, R., ESCOLAR, A. and BERNAL, M.P., 2006. Heavy metals fractionation and organic matter mineralisation in contaminated calcareous soil amended with organic materials. Bioresource Technology 97: 1894-1901.

CLIMENT, M.D., ABAD, M. y ARAGÓN, P., 1996. El Compost de Residuos Sólidos Urbanos (RSU). Sus Características y Aprovechamiento en Agricultura. Ediciones y Promociones LAV S.L., Valencia.

COMISIÓN EUROPEA, 2001. Working Document: Biological Treatment of Biowaste. $2^{\text {nd }}$ Draft. Oficina de Publicaciones Oficiales de las Comunidades Europeas, Bruselas.

CONSTANTINIDES, M. and FOWNES, J.H., 1994. Nitrogen mineralization from leaves and litter of tropical plants: relationships to nitrogen, lignin and soluble polyphenol concentrations. Soil Biology \& Biochemistry 26: 49-55.

COOK, R.J. and BAKER, K.F., 1983. The Nature and Practice of Biological Control of Plant Pathogens. 3rd Ed. APS Press, St. Paul, Minnesota.

CORDOVIL, C.M.S., CABRAL, F. and COUTINHO, J., 2007. Potential mineralization of nitrogen from organic wastes to ryegrass and wheat crops. Bioresource Technology 98: 3265-3268.

COSTA, F., GARCíA, C., HERNÁNDEZ, M.T. y POLO, A., 1991. Residuos Orgánicos Urbanos. Manejo y Utilización. Consejo Superior de Investigaciones Científicas-Centro de Edafología y Biología Aplicada del Segura y Caja Murcia, Murcia.

COTXARRERA, L., TRILLAS-GAY, M.I., STEINBERG, C. and ALABOUVETTE, C., 2002. Use of sewage sludge compost and Trichoderma asperellum isolates to suppress Fusarium wilt of tomato. Soil Biology \& Biochemistry 34: 467-476.

COURTNEY, R.G. and MULLEN, G.J., 2008. Soil quality and barley growth as influenced by the land application of two compost types. Bioresource Technology 99: 2913-2918.

COVENTRY, E., NOBLE, R. and WHIPPS, J.M., 2001. Composting of onion and other vegetable wastes, with particular reference to Allium white rot. Horticulture LINK Project Final Report CSA 4862. Horticulture Research International. Wellesbourne, Warwick. 
CRECCHIO, C., CURCI, M., MININNI, R., RICCIUTI, P. and RUGGIERO, P., 2001. Short-term effects of municipal solid waste compost amendments on soil carbon and nitrogen content, some enzyme activities and genetic diversity. Biology and Fertility of Soils 34: 311-318.

CROMMENTUIJN, T., SIJM, D., DE BRUIJN, J., VAN DEN HOOP, M., VAN LEEUWEN, K. and VAN DE PLASSCHE, E., 2000. Maximum-permissible and negligible concentrations for metals and metalloids in the Netherlands, taking into account background concentrations. Journal of Environmental Management 60:121-143.

CUNHA-QUEDA, A.C., RIBEIRO, H.M., RAMOS, A. and CABRAL, F., 2007. Study of biochemical and microbiological parameters during composting of pine and eucaliptus bark. Bioresource Technology 98: 3213-3220.

DANÉS, R. y BOIXADERA, J., 2001. Aspectos generales a considerar en la planificación y gestión de la aplicación de residuos orgánicos al suelo. En: Boixadera, J. y Teira, M.R. (Eds.). Aplicación Agrícola de Residuos Orgánicos. pp. 79-104. Edicions de la Universitat de Lleida, Lleida.

DE KREIJ, C., BENCHAALAL, K. and VAN ELDEREN, C.W., 1993a. Comparison of water, ammonium acetate, and DTPA to assess the availability of manganese in peat substrate. Communications in Soil Science and Plant Analysis 24: 927-937.

DE KREIJ, C., MARTIGNON, G. and VAN ELDEREN, C.W., 1993b. Comparison of water, DTPA, and nitric acid as extractants to assess the availability of copper in peat substrates. Communications in Soil Science and Plant Analysis 24: 227-236.

DE LA FUENTE, C., Clemente, R., MARTíneZ-ALCALÁ, I., TORTOSA, G. and BERNAL, M.P., 2011. Impact of fresh and composted solid olive husk and their water-soluble fractions on soil heavy metal fractionation; microbial biomass and plant uptake. Journal of Hazardous Materials 196: 1283-1289.

DE TOLEDO, V., LEE, H., WATT, T. and LOPEZ-REAL, J., 1996. The use of dairy manure compost for maize production and its effect on soil nutrients, maize maturity and maize nutrition. In: de Bertoldi, M., Sequi, P., Lemmes, B. and Papi, T. (Eds.). The Science of Composting. pp. 11261129. Blackie Academic \& Professional, London.

DEBOSZ, K., PETERSEN, S.O., KURE, L.K. and AMBUS, P., 2002. Evaluating effects of sewage sludge and household compost on soil physical, chemical and microbiological properties. Applied Soil Ecology 19: 237-248.

DEL POZO, M., 1983. La Alfalfa. Su Cultivo y Aprovechamiento. Ediciones Mundi-Prensa, Madrid.

DEL VAL, C., BAREA, J.M. and AZCÓN-AGUILAR, C., 1999. Assessing the tolerance to heavy metals of arbuscular mycorrhizal fungi isolated from sewage sludge contaminated soils. Applied Soil Ecology 11: 261-269.

DIACONO, M. and MONTEMURRO, F., 2011. Long-term effects of organic amendments on soil fertility. In: Lichtfouse, E., Hamelin, M., Navarrete, M. and Debaeke, P. (Eds.). Sustainable Agriculture. Vol. 2. pp. 761-786. Springer Science + Business Media B.V. Dordrecht.

DÍAZ, L.F. and SAVAGE, G.M., 2007. Factors that affect the process. In: Díaz, L.F., de Bertoldi, M., Bidlingmaier, W. and Stentiford, E. (Eds.) Compost Science and Technology. pp. 49-66. Elsevier Ltd., Oxford. 
DICK, W.A. and TABATABAI, M.A., 1993. Significance and potential uses of soil enzymes. In: Metting, F.B. (Ed.). Soil Microbial Ecology. Applications in Agricultural and Environmental Management. pp. 95-127. Marcel Dekker, New York.

DÍEZ, J.A., 1982. Consideraciones sobre la utilización de la técnica extractiva de BurrielHernando para la evaluación de fósforo asimilable en suelos. Anales de Edafología y Agrobiología 41: 1345-1353.

DIRKSEN, C., 1991. Unsaturated hydraulic conductivity. In: Smith, K.A. and Mullins, C.E. (Eds.). Soil Analysis. pp. 209-269. Marcel Dekker, Inc., New York.

DOERR, S.H., SHAKESBY, R.A. and WALSH, R.P.D., 2000. Soil water repellency: its causes, characteristics and hydro-geomorphological significance. Earth-Science Reviews 51: 33-65.

DOUBlet, J., FRANCOU, C., PÉTRAUd, J.P., DignAC, M.F., POITRENAUD, M. and HOUOT, S., 2010. Distribution of $C$ and $N$ mineralization of a sludge compost within particle-size fractions. Bioresource Technology 101: 1254-1262.

EATON, A.D., CLESCERI, L.S., RICE, E.W. and GREENBERG, A.E., 2005. Standard Methods for the Examination of Water and Wastewater. 21st Ed. American Public Health Association, Washington DC.

EHALIOTIS, C., ZERVAKIS, G.I. and KARAVITIS, P., 2005. Residues and by-products of olive-oil mills for root-zone heating and plant nutrition in organic vegetable production. Scientia Horticulturae 106: 293-308.

EIVAZI, F. and TABATABAI, M.A., 1977. Phosphatases in soils. Soil Biology \& Biochemistry 9: 167-172.

ELFSTRAND, S., HEDLUND, K. and MÅRTENSSON, A., 2007. Soil enzyme activities, microbial community composition and function after 47 years of continuous green manuring. Applied Soil Ecology 35: 610-621.

ELIAS, X., 2005. Tratamiento y Valorización Energética de Residuos. Ediciones Díaz de Santos, Barcelona.

ELLERBROCK, R.H., GERKE, H.H., BACHMANN, J. and GOEBEL, M.O., 2005. Composition of organic matter fractions for explaining wettability of three forest soils. Soil Science Society of America Journal 69: 57-66.

EL-TARABILY, K.A. and SIVASITHAMPARAM, K., 2006. Non-streptomycete actinomycetes as biocontrol agents of soil-borne fungal plant pathogens and as plant growth promoters. Soil Biology \& Biochemistry 38: 1505-1520.

EMINO, E.R. and WARMAN, P.R., 2004. Biological assay for compost quality. Compost Science \& Utilization 12: 342-348.

ERHART, E. and HARTL, W., 2010. Compost use in organic farming. In: Lichtfouse, E. (Ed.). Genetic Engineering, Biofertilisation, Soil Quality and Organic Farming. pp. 311-345. Sustainable Agriculture Reviews 4. Springer Science+Business Media B.V., Dordrecht.

ERHART, E., HARTL, W. and PUTZ, B., 2005. Biowaste compost affects yield, nitrogen supply during the vegetation period and crop quality of agricultural crops. European Journal of Agronomy 23: 305-314. 
EVANYLO, G., SHERONY, C., SPARGO, J., STARNER, D., BROSIUS, M. and HAERING, K., 2008. Soil and water environmental effects of fertilizer-, manure-, and compost-based fertility practices in an organic vegetable cropping system. Agriculture, Ecosystems \& Environment 127: 50-58.

EYHERAGUIBEL, B., SILVESTRE, J. and MORARD, P., 2008. Effects of humic substances derived from organic waste enhancement on the growth and mineral nutrition of maize. Bioresource Technology 99: 4206-4212.

FAGNANO, M., ADAMO, P., ZAMPELLA, M. and FIORENTINO, N., 2011. Environmental and agronomic impact of fertilization with composted organic fraction from municipal solid waste: a case study in the region of Naples, Italy. Agriculture, Ecosystems \& Environment 141: 100107.

FAUCETTE, L.B., RISSE, L.M., JORDAN, C.F., CABRERA, M.L., COLEMAN, D.C. and WEST, L.T., 2006. Vegetation and soil quality effects from hydroseed and compost blankets used for erosion control in construction activities. Journal of Soil and Water Conservation 61: 355-362.

FELIPÓ, M.T., 1995. Reutilización de residuos urbanos y posible contaminación. En: Soliva, M. (Coord.). pp. 15-26. Reutilización de Residuos Urbanos en Agricultura. Editorial Aedos, Barcelona.

FELSENSTEIN, J., 2004. Inferring Phylogenies. Sinauer Associates Inc. Publishers, Sunderland, Massachusetts.

FERRERAS, L., GÓMEZ, E., TORESANI, S., FIRPO, I. and ROTONDO, R., 2006. Effect of organic amendments on some physical, chemical and biological properties in a horticultural soil. Bioresource Technology 97: 635-640.

FILIPPI, C., BEDINI, S., LEVI-MINZI, R., CARDELLI, R. and SAVIOZZI, A., 2002. Co-composting of olive oil mill by-products: chemical and microbiological evaluations. Compost Science \& Utilization 10: 63-71.

FISHER, P.R. y ARGO, W.R., 2005. Manejo del pH en medios sin suelo. University of New Hampshire, USA. URL: http://ceinfo.unh.edu/Agric/AGGHFL/pHSpan.pdf (03/04/2011).

FISKE, C. H. and SUBBAROW, Y., 1925. The colorimetric determination of phosphorus. Journal of Biological Chemistry 66: 375-400.

FITZPATRICK, G.E., 2005. Utilización de los compost en los sistemas de cultivo de plantas ornamentales, viveros y semilleros. En: Stoffela, P.J. y Kahn, B.A. (Eds.). Utilización de Compost en los Sistemas de Cultivo Hortícola. pp. 135-149. Ediciones Mundi-Prensa, Madrid.

FLAVEL, T.C., MURPHY, D.V., LALOR, B.M. and FILLERY, I.R.P., 2005. Gross N mineralization rates after application of composted grape marc to soil. Soil Biology \& Biochemistry 37: 13971400.

FLOTATS, X. y SOLÉ, F., 2008. Situación actual en el tratamiento de los residuos orgánicos: aspectos científicos, económicos y legislativos. En: Moreno, J. y Moral, R. (Eds.). Compostaje. pp. 43-74. Ediciones Mundi-Prensa, Madrid.

FORNES, F., CARRIÓN, C., GARCíA DE LA FUENTE, R., PUCHADES, R. and ABAD, M., 2010. Leaching composted lignocellulosic wastes to prepare container media: feasibility and environmental concerns. Journal of Environmental Management 91: 1747-1755. 
FUENTES-YAGÜE, J.L., 1999. El Suelo y los Fertilizantes. $5^{a}$ Ed. Ministerio de Agricultura, Pesca y Alimentación y Ediciones Mundi-Prensa, Madrid.

GABRIELLE, B., DA-SILVEIRA, J., HOUOT, S. and FRANCOU, C., 2004. Simulating urban waste compost effects on carbon and nitrogen dynamics using a biochemical index. Journal of Environmental Quality 33: 2333-2342.

GARCÍA, C. y LOBO, M.C., 2008. Rehabilitación de suelos degradados y contaminados mediante la aplicación de compost. En: Moreno, J. y Moral, R. (Eds.). Compostaje. pp. 425448. Ediciones Mundi-Prensa, Madrid.

GARCÍA, C., HERNÁNDEZ, T., COSTA, F. and AYUSO, M., 1992. Evaluation of the maturity of municipal waste compost using simple chemical parameters. Communications in Soil Science and Plant Analysis 23: 1501-1512.

GARCÍA DE LA FUENTE, R., CARRIÓN, C., BOTELLA, S., FORNES, F., NOGUERA, V. and ABAD, M., 2007. Biological oxidation of elemental sulphur added to three composts from different feedstocks to reduce their pH for horticultural purposes. Bioresource Technology 98: 35613569.

GARCÍA-GIL, J.C., PLAZA, C., SOLER-RIVERA, P. and POLO, A., 2000. Long-term effects of municipal solid waste compost application on soil enzyme activities and microbial biomass. Soil Biology \& Biochemistry 23: 756-765.

GARCÍA-GÓMEZ, A. and BERNAL, M.P., 2005. The feasibility of olive husk co-composting with cotton waste. In: Bernal, M.P., Moral, R., Clemente, R. and Paredes, C. (Eds.). Sustainable Organic Waste Management for Environmental Protection and Food Safety. pp. 281-283. FAO and CSIC, Murcia.

GARCÍA-GÓMEZ, A., ROIG, A. and BERNAL, M.P., 2003. Composting of the solid fraction of olive mill wastewater with olive leaves: organic matter degradation and biological activity. Bioresource Technology 86: 59-64.

GARCÍA-GÓMEZ, A., BERNAL, M.P. and ROIG, A., 2005. Organic matter fractions involved in degradation and humification processes during composting. Compost Science \& Utilization 15: 127-135.

GARCÍA-ORENES, F., GUERRERO, C., MATAIX-SOLERA, J., NAVARRO-PEDREÑO, J., GÓMEZ, I. and MATAIX-BENEYTO, J., 2005. Factors controlling the aggregate stability and bulk density in two different degraded soils amended with biosolids. Soil \& Tillage Research 82: 65-76.

GEEBELEN, W., VANGRONSVELD, J., ADRIANO, D.C., CARLEER, R. and CLIJSTERS, H., 2002. Amendment-induced immobilization of lead in a lead-spiked soil: evidence from phytotoxicity studies. Water, Air, \& Soil Pollution 140: 261-277.

GEISSELER, D., HORWATH, W.R., JOERGENSEN, R.G. and LUDWIG, B., 2010. Pathways of nitrogen utilization by soil microorganisms - A review. Soil Biology \& Biochemistry 42: 20582067.

GETHA, K., VIKINESWARY, S., WONG, W.H., SEKI, T., WARD, A. and GOODFELLOW, M., 2005. Evaluation of Streptomyces sp. strain g10 for suppression of Fusarium wilt and rhizosfere colonization in pot-grown banana plantlets. Journal of Industrial Microbiology \& Biotechnology 32: 24-32. 
GIANFREDA, L. and BOLLAG, J.M., 1996. Influence of natural and anthropogenic factors on enzyme activity in soil. In: Stotzky, G. and Bollag, J.M. (Eds.). Soil Biochemistry. pp. 123-193. Marcel Dekker, New York.

GIGER, R., 1995. Review of the main methods of cell wall estimation: Interest and limits for ruminants. Animal Feed Science and Technology 55: 295-334.

GIL, M.V., CARBALLO, M.T. and CALVO, L.F., 2011. Modelling N mineralization from bovine manure and sewage sludge composts. Bioresource Technology 102: 863-871.

GISBERT, C., CleMENTE, R., NAVARRO-AVIÑÓ, J., BAIXAULI, C., GINER, A., SERRANO, R., WALKER, D.J. and BERNAL, M.P., 2006. Tolerance and accumulation of heavy metals by Brassicaceae species grown in contaminated soils from Mediterranean regions of Spain. Environmental and Experimental Botany 56: 19-27.

GOLCHIN, A., CLARKE, P., OADES, J.M. and SKJEMSTAD, J.O., 1995. The effects of cultivation on the composition of organic matter and structural stability of soils. Australian Journal of Soil Research 33: 975-993.

GOLUEKE, C.G., 1981. Principles of biological resource recovery. Biocycle 22: 36-40.

GÓMEZ-OREA, D., 2004. Recuperación de Espacios Degradados. Ediciones Mundi-Prensa, Madrid.

GONZÁLEZ, S., NAVARRO, M., LÓPEZ, J.I., RAD, C. y LÓPEZ, D.J., 2008. Obtención de productos de alto valor añadido a partir de compost. En: Moreno, J. y Moral, R. (Eds.). Compostaje. pp. 449-465. Ediciones Mundi-Prensa, Madrid.

GONZÁLVEZ, J., 2005. Estudio del Compostaje de Orujo de Oliva de Dos Fases y de la Materia Orgánica Soluble Extraída durante el Proceso. Tesis Doctoral, Universidad de Murcia. 263 pp.

GOYAL, S., CHANDER, K., MUNDRA, M.C. and KAPOOR, K.K., 1999. Influence of inorganic fertilizers and organic amendments on soil organic matter and soil microbial properties under tropical conditions. Biology and Fertility of Soils 29: 196-200.

GOYAL, S., DHULL, S.K. and KAPOOR, K.K., 2005. Chemical and biological changes during composting of different organic wastes and assessment of compost maturity. Bioresource Technology 96: 1584-1591.

GRANDY, A.S., PORTER, G.A. and ERICH, M.S., 2002. Organic amendment and rotation crop effects on the recovery of soil organic matter and aggregation in potato cropping systems. Soil Science Society of America Journal 66: 1311-1319.

GRAY, E. and TAWHID, A., 1995. Effect of leaf mulch on seedling emergence, plant survival, and production of bush snap beans. Journal of Sustainable Agriculture 6: 15-20.

GRIMES, S.M., TAYLOR, G.H. and COOPER, J., 1999. The availability and binding of heavy metals in compost derived from household waste. Journal of Chemical Technology and Biotechnology 74: 1125-1130.

HACHICHA, S., SALLEMI, F., MEDHIOUB, K., HACHICHA, R. and AMMAR, E., 2008. Quality assessment of composts prepared with olive mill wastewater and agricultural wastes. Waste Management 28: 2593-2603. 
HADAS, A., KAUTSKY, L. and PORTNOY, R., 1995. Mineralization of composted manure and microbial dynamics in soil as affected by long-term nitrogen management. Soil Biology \& Biochemistry 28: 733-738.

HADAS, A., AGASSI, M., ZHEVELEV, H., KAUTSKY, L., LEVY, G.J., FIZIK, E. and GOTESSMAN, M., 2004. Mulching with composted municipal solid wastes in the Central Negev, Israel. Il. Effect on available nitrogen and phosphorus and on organic matter in soil. Soil \& Tillage Research 78: 115-128.

HANDRECK, K.A. and BLACK, N.D., 2002. Growing Media for Ornamental Plants and Turf. $3^{\text {rd }}$ Ed. New South Wales University Press, Kensington.

HARADA, Y. and INOKO, A., 1980. The measurement of the cation-exchange capacity of composts for the estimation of the degree of maturity. Soil Science \& Plant Nutrition 26: 127134.

HARGREAVES, J.C., ADL, M.S. and WARMAN, P.R., 2008. A review of the use of composted municipal solid waste in agriculture. Agriculture, Ecosystems \& Environment 123: 1-14.

HATCHER, P.G., BREGER, I.A., MACIEL, G.E. and SZEVERENYI, N.M., 1985. Geochemistry of humin. In: Aiken, G.R., McKnight, D.M., Wershaw, R.L. and Maccarthy, P. (Eds.). Humic Substances in Soil, Sediment, and Water: Geochemistry, Isolation and Characterization. pp. 275-302. Wiley-Interscience, New York.

HÄTTENSCHWILER, S. and VITOUSEK, P.M., 2000. The role of polyphenols in terrestrial ecosystem nutrient cycling. Trends in Ecology \& Evolution 15 : 238-243.

HAUG, R.T., 1993. The Practical Handbook of Compost Engineering. Lewis Publishers, Boca Raton, Florida.

HERENCIA, J.F., RUIZ-PORRAS, J.C., MELERO, S., GARCÍA-GALAVIS, P.A., MORILLO, E. and MAQUEDA, C., 2007. Comparison between organic and mineral fertilization for soil fertility levels, crop macronutrient concentrations, and yield. Agronomy Journal 99: 973-983.

HERNÁNDEZ, T. and GARCÍA, C., 2003. Estimación de la respiración microbiana del suelo. En: García, C., Gil, F., Hernández, T. and Trasar, C. (Eds.). Técnicas de Análisis de Parámetros Bioquímicos en Suelos: Medidas de Actividades Enzimáticas y Biomasa Microbiana. pp. 311346. Ediciones Mundi-Prensa, Madrid.

HIRAISHI, A., NAGASHIMA, K.V.P., KATAYAMA, Y., SHIMADA, K., TAKAICHI, S., WAKAO, N. and KATAYAMA, Y., 1998. Phylogeny and photosynthetic features of Thiobacillus acidophilus and related acidophilic bacteria: its transfer to the genus Acidiphilium as Acidiphilium acidophilum comb. nov. International Journal of Systematic Bacteriology 48: 1389-1398.

HOITINK, H.A.J. and FAHY, P.C., 1986. Basis for the control of soilborne plants pathogens with composts. Annual Review of Phytopathology 24: 93-114.

HOITINK, H.A.J. and BOEHM, M.J., 1999. Biocontrol within the context of soil microbial communities: a substrate-dependent phenomenon. Annual Review of Phytopathology 37: 427446.

HOITINK, H.A.J, STONE, A.G. and HAN, D.Y., 1997. Suppression of plant diseases by composts. HortScience 32: 184-187. 
HOITINK, H.A.J., KRAUSE, M.S. y HAN, Y., 2005. Posibilidades y mecanismos que ofrecen los composts en el control de las enfermedades de las plantas. En: Stoffella, P.J. y Kahn, B.A. (Eds.). Utilización de Compost en los Sistemas de Cultivo Hortícola. pp. 263-273. Ediciones Mundi-Prensa, Madrid.

HORNICK, S.B., 1988. Use of organic amendments to increase the productivity of sand and gravel spoils: effect on yield and composition of sweet corn. American Journal of Alternative Agriculture 3: 156-162.

HUE, N.V. and LIU, J., 1995. Predicting Compost Stability. Compost Science \& Utilization 3: 815.

HWANG, B.K., LIM, S.W., KIM, B.S., LEE, J.Y., MOON, S.S., 2001. Isolation and in vivo and in vitro antifungal activity of phenylacetic acid and sodium phenylacetate from Streptomyces humidus. Applied and Environmental Microbiology 67: 3739-3745.

IGLESIAS-JIMÉNEZ, E. and PÉREZ-GARCÍA, V., 1992a. Determination of maturity indexes for city refuse composts. Agriculture, Ecosystems \& Environment 38: 331-343.

IGLESIAS-JIMÉNEZ, E. and PÉREZ-GARCÍA, V., 1992b. Composting of domestic refuse and sewage sludge. II. Evolution of carbon and some "humification" indexes. Resources, Conservation and Recycling 6: 243-257.

IGLESIAS-JIMÉNEZ, E., BARRAL, M.T. y MARHUENDA, F.C., 2008. Indicadores de la estabilidad y madurez del compost. En: Moreno, J. y Moral, R. (Eds.). Compostaje. pp. 243-283. Ediciones Mundi-Prensa, Madrid.

INGELMO, F. y RUBIO, J.L., 2008. Efecto de la aplicación del compost sobre las propiedades físicas y químicas del suelo. En: Moreno, J. y Moral, R. (Eds.). Compostaje. pp. 305-327. Ediciones Mundi-Prensa, Madrid.

INGELMO, F., MARTÍNEZ FRANCISCO, J.F. y ROGER, S., 2007. Utilización de lodos compostados como técnica sostenible para la mejora de las características hídricas de un suelo agrícola degradado. Residuos 95: 78-82.

INSAM, H. and DE BERTOLDI, M., 2007. Microbiology of the composting process. In: Díaz, L.F., de Bertoldi, M., Bidlingmaier, W. and Stentiford, E. (Eds.) Compost Science and Technology. pp. 25-48. Elsevier Ltd., Oxford.

INTERNATIONAL OLIVE COUNCIL, 2011. World olive oil figures. Production. URL: http://www.internationaloliveoil.org (21/03/2011).

IPTS, 2011. Working Document for End-of-waste Criteria on Biodegradable Waste to Biological Treatment. Institute for Prospective Technological Studies, Seville.

ISKANDAR, I.K. and ADRIANO, D.C., 1997. Remediation of Soils Contaminated with Metals. Science Reviews, Aberystwyth.

ISLAM, M.S., KHAN, S. and TANAKA, M., 2004. Waste loading in shrimp and fish processing effluents: potential source of hazards to the coastal and nearshore environments. Marine Pollution Bulletin 49: 103-110.

ISO-INTERNATIONAL ORGANIZATION FOR STANDARDIZATION, 1995. ISO Standard 11466. Soil quality. Extraction of trace elements soluble in aqua regia. International Organization for Standardization, Geneva. 
JAHIRUDDIN, M., LIVESEY, N.T. and CRESSER, M.S., 1985. Observations on the effect of soil pH upon Zn-absorption by soils. Communications in Soil Science and Plant Analysis 16: 909922.

JANOŠ, P., 2003. Separation methods in the chemistry of humic substances. Journal of Chromatography A 983: 1-18.

JANSSON, S.L. and PERSSON, J., 1982. Mineralization and immobilization of soil nitrogen. In: Stevenson, F.J. (Ed.). Nitrogen in Agricultural Soils. pp. 229-252. American Society of Agronomy, Madison, Wisconsin.

JANVIER, C., VILLENEUVE, F., ALABOUVETTE, C., EDEL-HERMANN, V., MATEILLE, T. and STEINBERG, C., 2007. Soil health through soil disease suppression: which strategy from descriptors to indicators? Soil Biology \& Biochemistry 39: 1-23.

JEGER, M.J. and VILJANEN-ROLLINSON, S.L.H., 2001. The use of the area under the diseaseprogress curve (AUDPC) to assess quantitative disease resistance in crop cultivars. Theoretical and Applied Genetics 102: 32-40.

JIMÉNEZ, P. and BONMATÍ, M., 2003. Determinación de la actividad $\beta$-glucosidasa del suelo. En: García, C., Gil, F., Hernández, T. and Trasar, C. (Eds.). Técnicas de Análisis de Parámetros Bioquímicos en Suelos: Medidas de Actividades Enzimáticas y Biomasa Microbiana. pp. 169183. Ediciones Mundi-Prensa, Madrid.

JIMÉNEZ-ESQUILÍN, A.E. and ROANE, T.M., 2005. Antifungal activities of actinomycete strains associated with high-altitude sagebrush rhizosfere. Journal of Industrial Microbiology \& Biotechnology 32: 378-381.

JOHNS, M.R., 1995. Developments in wastewater treatment in the meat processing industry: a review. Bioresource Technology 54: 293-301.

JHORAR, B., PHOGAT, V. and MALIK, E., 1991. Kinetics of composting rice straw with glue waste at different $\mathrm{C} / \mathrm{N}$ ratios in a semiarid environment. Arid Soil Research and Rehabilitation 5: 297-306.

JOKOVA, M., KOSTOV, O. and VAN CLEEMPUT, O., 1997. Cation exchange and reducing capacities as criteria for compost quality. Biology, Agriculture and Horticulture 14: 187-197.

JOLANUN, B., TRIPETCHKUL, S., CHIEMCHAISRI, C., CHAIPRASERT, P. and TOWPRAYOON, S., 2005. Effect of moisture content on fed batch composting reactor of vegetable and fruit wastes. Environmental Technology 26: 293-301.

JONES, J.B., 1991. Kjeldahl Method for Nitrogen (N) Determination. MicroMacro Publishing, Inc., Athens, Greece.

JUKES, T.H. and CANTOR, C.R., 1969. Evolution of protein molecules. In: Munro, H.N. (Ed.). Mammalian Protein Metabolism. pp. 21-132. Academic Press, New York.

JUMA, N.G., PAUL, E.A. and MARY, B., 1984. Kinetic analysis of net nitrogen mineralization in soil. Soil Science Society of America Journal 48: 753-757.

KABATA-PENDIAS, A., 2001. Trace Elements in Soils and Plants, $3^{\text {rd }}$ Ed. CRC Press, Boca Raton, Florida.

KAKEZAWA, M., MIMURA, A. and TAKAHARA, Y., 1992. Application of two-step composting process to rice straw compost. Soil Science \& Plant Nutrition 38: 43-50. 
KANDELER, E., 2007. Physiological and biochemical methods for studying soil biota and their function. In: Paul, E.A. (Ed.). Soil Microbiology, Ecology, and Biochemistry. $3^{\text {rd }}$ Ed. pp. 53-83. Elsevier Inc., Oxford.

KAO, M.M., 1993. The evaluation of sawdust swine waste compost on the soil ecosystem, pollution, and vegetable production. Water Science and Technology 27: 123-131.

KARUNGI, J., EKBOM, B. and KYAMANYWA, S., 2006. Effects of organic versus conventional fertilizers on insect pests, natural enemies and yield of Phaseolus vulgaris. Agriculture, Ecosystems \& Environment 115: 51-55.

KATAYAMA, Y., IRAISHI, A. and KURAISHI, H., 1995. Paracoccus thiocyanatus sp. nov., a new species of thiocyanate-utilizing facultative chemolithotroph, and transfer of Thiobacillus versutus to the genus Paracoccus as Paracoccus versutus comb. nov. with emendation of the genus. Microbiology 141: 1469-1477.

KAWASE, T., SAITO, A., SATO, T., KANAI, R., FUJII, T., NIKAIDOU, N., MIYASHITA, K. and WATANABE, T., 2004. Distribution and phylogenetic analysis of family 19 Chitinase in Actinobacteria. Applied and Environmental Microbiology 70: 1135-1144.

KAY, B.D. and ANGERS, D.A., 2002. Soil structure. In: Warrick, A.W. (Ed.). Soil Physics Companion. pp. 249-295. CRC Press, Boca Raton, Florida.

KEENEY, D.R. and NELSON, D.W., 1982. Nitrogen-inorganic forms. In: Page, A.L., Miller, R.H. and Keeney, D.R. (Eds.). pp. 643-698. Methods of Soil Analysis. Part 2: Chemical and Microbiological Properties. Agronomy 9, American Society of Agronomy, Madison, Wisconsin.

KELLY, D.P. and WOOD, A.P., 2000. Reclassification of some species of Thiobacillus to the newly designated genera Acidithiobacillus gen. nov., Halothiobacillus gen. nov. and Thermithiobacillus gen. nov. International Journal of Systematic Evolutionary Microbiology 50: 511-516.

KHALIL, A., DOMEIZEL, M. and PRUDENT, P., 2008. Monitoring of green waste composting process based on redox potential. Bioresource Technology 99: 6037-6045.

KIM, K.D., NEMEC, S. and MUSSON, G., 1997. Effects of compost and soil amendments on soil microflora and Phytophthora root and crow rot of bell pepper. Crop Protection 16: 165-172.

KLASINK, A. and STEFFENS, G., 1996. Grünkomposteinsatz in der Landwirtschaft - Ergebnisse aus einem Feldversuch. In: Braun, C. (Ed.). Sekundärstoffe im Stoffkreislauf der Landwirtschaft. pp. 385-388. VDLUFA - Verlag, Darmstadt.

KOHLER, J., TORTOSA, G., CEGARRA, J., CARAVACA, F. and ROLDÁN, A., 2008. Impact of DOM from composted 'alperujo' on soil structure, AM fungi, microbial activity and growth of Medicago sativa. Waste Management 28: 1423-1431.

KOIKE, S.T., GLADDERS, P. and PAULUS, A.O., 2007. Vegetable Diseases. A Colour Handbook. Manson Publishing Ltd., London.

KOMATSUZAKI, M. and OHTA, H., 2007. Soil management practices for sustainable agroecosystems. Sustainability Science 2: 103-120.

KONÉ, S., DIONNE, A., TWEDDELL, R., ANTOUN, H. and AVIS, T.J., 2010. Suppressive effect of non-aerated compost teas on foliar fungal pathogens of tomato. Biological Control 52: 167173. 
KOSTOV, O., TZVETKOV, Y., KALOIANOVA, N. and VAN CLEEMPUT, O., 1995. Cucumber cultivation on some wastes during their aerobic composting. Bioresource Technology 53: 237242.

KOTSOU, M., MARI, I., LASARIDI, K., CHATZIPAVLIDIS, I., BALIS, C. and KYRIACOU, A., 2004. The effect of olive oil mill wastewater (OMW) on soil microbial communities and suppressiveness against Rhizoctonia solani. Applied Soil Ecology 26: 113-121.

KRAUS, T.E.C., DAHLGREN, R.A. and ZASOSKI, R.J., 2003. Tannins in nutrient dynamics of forest ecosystems - A review. Plant and Soil 256: 41-66.

KROYER, G.T., 1995. Impact of food processing on the environment - An overview. Lebensmittel-Wissenschaft und Technologie 28: 547-552.

KULIKOVA, N.A., STEPANOVA, E.V. and KOROLEVA, O.V., 2005. Mitigating activity of humic substances: direct influence on biota. In: Perminova, I.V., Hatfield, K. and Hertkorn, N. (Eds.). Use of Humic Substances to Remediate Polluted Environments: From Theory to Practice. pp. 285-309. Springer, Dordrecht.

KUMAR, N.P.B.A., DUSHENKOV, V., MOTTO, H. and RASKIN, I., 1995. Phytoextraction: the use of plants to remove heavy metals from soils. Environmental Science and Technology 29: 12321238.

KUWATSUKA, S. and SHINDO, H., 1973. Behavior of phenolic substances in the decaying process of plants. Identification and quantitative determination of phenolic acids in rice straw and its decayed products by gas chromatography. Soil Science Society of America Journal 19: 219-227.

LADD, J.N. and BUTLER, J.H.A., 1972. Short-term assays of soil proteolytic enzyme activities using proteins and dipeptide derivatives as substrates. Soil Biology \& Biochemistry 4: 19-30.

LAL, R., 2006. Enhancing crop yields in the developing countries throug restoration of the soil organic carbon pool in agricultural lands. Land Degradation \& Development 17: 197-209.

LANDA, B.B., HERVÁS, A., BETTIOL, W. and JIMÉNEZ-DÍAZ, R.M., 1997. Antagonistic activity of bacteria from the chickpea rhizosphere against Fusarium oxysporum f. sp. ciceris. Phytoparasitica 25: 305-318.

LANE, D.J., 1991. 16S/23S rRNA sequencing. In: Stackebrandt, E., Goodfellow, M. (Eds.). Nucleic Acid Techniques in Bacterial Systematics. pp. 115-148. John Wiley \& Sons, New York.

LARKIN, R.P. and FRAVEL, D.R., 1998. Efficacy of various fungal and bacterial biocontrol organisms for control of Fusarium wilt of tomato. Plant Disease 82: 1022-1028.

LAUFENBERG, G., KUNZ, B. and NYSTROEM, M., 2003. Transformation of vegetable waste into value added products: (A) the upgrading concept; (B) practical implementations. Bioresource Technology 87: 167-198.

LAX, A., ROIG, A. and COSTA, F., 1986. A method for determining the cation-exchange capacity of organic materials. Plant and Soil 94: 349-355.

LECHEVALIER, M.P. and LECHEVALIER, H.A., 1980. Actinomycete taxonomy. In: Dietz, X. and Thayer, Y. (Eds). The Chemotaxonomy of Actinomycetes. pp. 227-291. Society for Industrial Microbiology, Arlington. 
LEE, J., PARK, R., KIM, Y., SHIM, J., CHAE, D., RIM, Y., SOHN, B., KIM, T. and KIM, K., 2004. Effect of food waste compost on microbial population, soil enzyme activity and lettuce growth. Bioresource Technology 93: 21-28.

LEIVA, S., YÁÑEZ, M., ZAROR, L., RODRÍGUEZ, H. y GARCÍA-QUINTANA, H., 2004. Actividad antimicrobiana de actinomycetes aislados de ambientes acuáticos del sur de Chile. Revista Médica Chile 132: 151-159.

LIN, Q. and BROOKES, P.C., 1999. Arginine ammonification as a method to estimate soil microbial biomass and microbial community structure. Soil Biology \& Biochemistry 31: 19851997.

LINARES, A., CABA, J.M., LIGERO, F., DE LA RUBIA, T. and MARTÍNEZ, J., 2003. Detoxification of semisolid olive-mill wastes and pine-chip mixtures using Phanerochaete flavido-alba. Chemosphere 51: 887-891.

LINERES, M., 1992. Transfer of inorganic pollution by composts. In: Jackson, J.V., Merillot, J.M. and L'Hermite, P. (Eds.). Composting and Compost Quality Assurance Criteria. pp. 237-245. Commission of the European Communities, Luxembourg.

LITTERICK, A.M., HARRIER, L., WALLACE, P., WATSON, C.A. and WOOD, M., 2004. The role of uncomposted materials, composts, manures, and compost extracts in reducing pest and disease incidence and severity in sustainable temperate agricultural and horticultural crop production - A review. Critical Reviews in Plant Sciences 23: 453-479.

LOFFREDO, E. and SENESI, N., 2009. In vitro and in vivo assessment of the potential of compost and its humic acid fraction to protect ornamental plants from soil-borne pathogenic fungi. Scientia Horticulturae 122: 432-439.

LOMBI, E., ZHAO, F.J., DUNHAM, S. and McGRATH, S.P., 2000. Cadmium accumulation in populations of Thlaspi caerulescens and Thlaspi goesingense. New Phytologist 149: 11-20.

LÓPEZ-PIÑEIRO, A., MURILLO, S., BARRETO, C., MUÑOZ, A., RATO, J.M., ALBARRÁN, A. and GARCÍA, A., 2007. Changes in organic matter and residual effect of amendment with twophase olive-mill waste on degraded agricultural soils. Science of the Total Environment 378: 84-89.

LÓPEZ-PIÑEIRO, A., ALBARRÁN, A., RATO NUNES, J.M. and BARRETO, C., 2008. Short and medium-term effects of two-phase olive mill waste application on olive grove production and soil properties under semiarid Mediterranean conditions. Bioresource Technology 99: 79827987.

LUCAS, J.A., 1998. Plant Pathology and Plant Pathogens. 3rd Ed. Blackwell Science, Ltd., Oxford.

LULAKIS, M.D. and PETSAS, S.I., 1995. Effect of humic substances from vine-canes mature compost on tomato seedling growth. Bioresource Technology 54: 179-182.

MacKENZIE, M.D., DELUCA, T.H. and SALA, A., 2006. Fire exclusion and nitrogen mineralization in low elevation forests of western Montana. Soil Biology \& Biochemistry 38: 952-961.

MADEJÓN, E., GALLI, E. and TOMATI, U., 1998. Composting of wastes produced by low water consuming olive mill technology. Agrochimica 42: 135-146.

MADEJÓN, E., BURGOS, P., LÓPEZ, R. and CABRERA, F., 2001a. Soil enzymatic response to addition of heavy metals with organic residues. Biology and Fertility of Soils 34: 144-150. 
MADEJÓN, E., BURGOS, P., MURILLO, J.M. and CABRERA, F., 2001b. Phytotoxicity of organic amendments on activities of selected soil enzymes. Communications in Soil Science and Plant Analysis 32: 2227-2239.

MADEJÓN, E., LÓPEZ, R., MURILLO, J.M. and CABRERA, F., 2001c. Agricultural use of three (sugar-beet) vinasse composts: effect on crops and chemical properties of a Cambisol soil in the Guadalquivir river valley (SW Spain). Agriculture, Ecosystems \& Environment 84: 55-65.

MADEJÓN, E., DÍAZ, M.J., LÓPEZ, R. and CABRERA, F., 2002. New approaches to establish optimum moisture content for compostable materials. Bioresource Technology 85: 73-78.

MADEJÓN, E., MORENO, F., MURILLO, J.M. and PELEGRÍN, F., 2007. Soil biochemical response to long-term conservation tillage under semi-arid Mediterranean conditions. Soil \& Tillage Research 94: 346-352.

MADRID, F., LÓPEZ, R., CABRERA, F. and MURILLO, J.M., 2011. Nitrogen mineralization of immature municipal solid waste compost. Journal of Plant Nutrition 34: 324-336.

MAHER, M., PRASAD, M. and RAVIV, M., 2008. Organic soilless media components. In: Raviv, M. and Lieth, J.H. (Eds.). Soilless Culture. Theory and Practice. pp. 459-504. Elsevier B.V., London.

MAHIMAIRAJA, S., BOLAN, N.S. and HEDLEY, M.J., 1994. Dissolution of phosphate rock during the composting of poultry manure: an incubation experiment. Fertilizer Research 40: 93-104.

MAHIMAIRAJA, S., BOLAN, N.S. and HEDLEY, M.J., 1995. Agronomic effectiveness of poultry manure composts. Communications in Soil Science and Plant Analysis 26: 1843-1861.

MAK, A.T.Y. and YEH, D.M., 2001. Nitrogen nutrition of Spathiphyllum 'Sensation' grown in Sphagnum peat- and coir-based media with two irrigation methods. HortScience 36: 645-649.

MANIOS, T., 2004. The composting potential of different organic solid wastes: experience from the island of Crete. Environment International 29: 1079-1089.

MANIOS, V.I. and KAPETANIOS, E., 1992. Effect of town refuse compost as soil amendment on greenhouse tomato crop. Acta Horticulturae 302: 193-201.

MANIOS, V.I., TSIKALAS, P.E. and SIMINIS, H.I., 1989. Phytotoxicity of olive tree leaf compost in relation to the organic acid concentration. Biological Wastes 27: 307-317.

MANIOS, T., MANIADAKIS, K., KALOGERAKI, M., MARI, E., STRATAKIS, E., TERZAKIS, S., BOYTZAKIS, P., NAZIRIDIS, Y. and ZAMPETAKIS, L., 2006. Efforts to explain and control the prolonged thermophilic period in two-phase olive mill sludge composting. Biodegradation 17: 285-292.

MANTOVI, P., BALDONI, G. and TODERI, G., 2005. Reuse of liquid, dewatered, and composted sewage sludge on agricultural land: effects of long-term application on soil and crop. Water Resources 39: 289-296.

MANTZAVINOS, D. and KALOGERAKIS, N., 2005. Treatment of olive mill effluents: Part I. Organic matter degradation by chemical and biological processes - An overview. Environment International 31: 289-295.

MAPA-MINISTERIO DE AGRICULTURA, PESCA Y ALIMENTACIÓN, 1994. Métodos Oficiales de Análisis. Tomo II. Secretaría General Técnica, Madrid. 
MARCHIOL, L., SACCO, P., ASSOLARI, S. and ZERBI, G., 2004. Reclamation of polluted soil: phytoremediation potential of crop-related Brassica species. Water, Air, \& Soil Pollution 158: 345-356.

MARCOTE, I., HERNÁNDEZ, T., GARCÍA, C. and POLO, A., 2001. Influence of one or two successive annual applications of organic fertilisers on the enzyme activity of a soil under barley cultivation. Bioresource Technology 79: 147-154.

MARI, I., EHALIOTIS, C., KOTSOU, M., BALIS, C. and GEORGAKAKIS, D., 2003. Respiration profiles in monitoring the composting of by-products from the olive oil agro-industry. Bioresource Technology 87: 331-336.

MARI, I., EHALIOTIS, C., KOTSOU, M., CHATZIPAVLIDIS, I. and GEORGAKAKIS, D., 2005. Use of sulfur to control $\mathrm{pH}$ in composts derived from olive processing by-products. Compost Science \& Utilization 13: 281-287.

MARÍN, J., 2008. Portagrano 2008-2009: Vademécum de Variedades Hortícolas. $11^{\mathrm{a}}$ Ed. Ediciones Mundi-Prensa, Madrid.

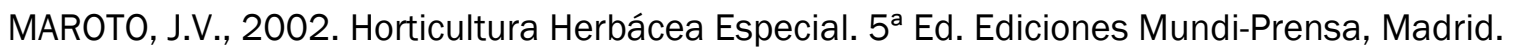

MARSCHNER, P., KANDELER, E. and MARSCHNER, B., 2003. Structure and function of the soil microbial community in a long-term fertilizer experiment. Soil Biology \& Biochemistry 35: 5567.

MARTIN, F.N., 2003. Development of alternative strategies for management of soil-borne pahogens currently controlled with methyl bromide. Annual Review of Phytopathology 41: 325350.

MARTÍNEZ, F.X., CASASAYAS, R., BURÉS, S. and CAÑAMERAS, N., 1988. Titration curves of different organic substrates. Acta Horticulturae 221: 105-116.

MASAGUER, A. y BENITO, M., 2008. Evaluación de la calidad del compost. En: Moreno, J. y Moral, R. (Eds.). Compostaje. pp. 285-304. Ediciones Mundi-Prensa, Madrid.

MATHUR, S.P., OWEN, G., DINEL, H. and SCHNITZER, M., 1993. Determination of compost biomaturity. Literature review. Biological Agriculture \& Horticulture 10: 65-85.

MATÚŠ, P., KUBOVÁ, J., BUJDOŠ, M. and MEDVED', J., 2006. Free aluminium extraction from various reference materials and acid soils with relation to plant availability. Talanta 70: 9961005.

MAYNARD, A.A., 1994. Sustained vegetable production for three years using composted animal manures. Compost Science \& Utilization 2: 88-96.

MAYNARD, A.A., 1995. Cumulative effect of annual additions of MSW compost on the yield of field-grown tomatoes. Compost Science \& Utilization 3: 47-54.

MAYNARD, A.A., 1996. Cumulative effect of annual additions of undecomposed leaves and compost on the yield of field-grown peppers. Compost Science \& Utilization 4: 81-88.

MAYNARD, A.A. and HILL, D., 2000. Cumulative effect of leaf compost on yield and size distribution in onions. Compost Science \& Utilization 8: 12-18.

MAYNARD, D.N. and HOCHMUTH, G.J., 2007. Knott's Handbook for Vegetable Growers. $5^{\text {th }}$ Ed. John \& Sons, Inc. New York. 
MAZUELA, P., SALAS, M.C. and URRESTARAZU, M. 2005. Vegetable waste compost as substrate for melon. Communications in Soil Science and Plant Analysis 36: 1557-1572.

McBRIDE, M., SAUVE, S. and HENDERSHOT, W., 1997. Solubility control of $\mathrm{Cu}, \mathrm{Zn}, \mathrm{Cd}$ and $\mathrm{Pb}$ in contaminated soils. European Journal of Soil Science 48: 337-346.

McCUTCHEON, S.C. and SCHNOOR, J.L., 2003. Phytoremediation. Transformation and Control of Contaminants. John Wiley \& Sons, Inc., Somerset, New Jersey.

McGRATH, S.P., 1998. Phytoextraction for soil remediation. In: Brooks, R.R. (Ed.). Plants that Hyperaccumulate Heavy Metals. pp. 261-287. CAB International. Wallingford.

McGRATH, S.P. and ZHAO, F.J., 2003. Phytoextraction of metals and metalloids from contaminated soils. Current Opinion in Biotechnology 14: 277-282.

MEERS, E., RUTTENS, A., HOPGOOD, M., LESAGE, E. and TACK, F.M.G., 2005. Potential of Brassica rapa, Cannabis sativa, Helianthus annuus and Zea mays for phytoextraction of heavy metals from calcareous dredged sediment derived soils. Chemosphere 61: 561-572.

MELERO, S., MADEJÓN, E., RUIZ, J.C. and HERENCIA, J.F., 2007a. Chemical and biochemical properties of a clay soil under dryland agriculture system as affected by organic fertilization. European Journal of Agronomy 26: 327-334.

MELERO, S., MADEJÓN, E., HERENCIA, J.F. and RUIZ, J.C., 2007b. Biochemical properties of two different textured soils (loam and clay) after the addition of two different composts during conversion to organic farming. Spanish Journal of Agricultural Research 5: 593-604.

MELERO, S., VANDERLINDEN, K., RUIZ, J.C. and MADEJÓN, E., 2008. Long-term effect on soil biochemical status of a Vertisol under conservation tillage system in semi-arid Mediterranean conditions. European Journal of Soil Biology 44: 437-442.

MESSIAEN, C.M., BLANCARD, D., ROUXEL, F. and LAFON, R., 1994. Enfermedades de las Hortalizas. Ediciones Mundi-Prensa, Madrid.

MICHEL, F.C., PECCHIA, J.A. and RIGOT, J., 2004. Mass and nutrient losses during the composting of dairy manure amended with sawdust or straw. Compost Science \& Utilization 12: 323-334.

MINUTO, A., SPADARO, D., GARIBALDI, A. and GULLINO, M.L., 2006. Control of soilborne pathogens of tomato using a commercial formulation of Streptomyces griseoviridis and solarization. Crop Protection 25: 468-475.

MISHRA, B.K. and MISRA, C., 1991. Kinetics of nitrification and nitrate reduction during leaching of ammonium nitrate through a limed ultisol profile. Journal of the Indian Society of Soil Science 39: 221-228.

MITTAL, G.S., 2006. Treatment of wastewater from abattoirs before land application - A review. Bioresource Technology 97: 1119-1135.

MIYATAKE, F. and IWABUCHI, K., 2006. Effect of compost temperature on oxygen uptake rate, specific growth rate and enzymatic activity of microorganisms in dairy cattle manure. Bioresource Technology 97: 961-965.

MOLINA, J.A.E., CLAPP, C.E. and LARSON, W.E., 1980. Potentially mineralizable nitrogen in soil: the simple exponential model does not apply to the first 12 weeks of incubation. Soil Science Society of America Journal 44: 442-443. 
MOLINA ALCAIDE, E., YÁÑEZ RUIZ, D.R., MOUMEN, A. and MARTÍN GARCÍA, A.I., 2003. Ruminal degradability and in vitro intestinal digestibility of sunflower meal and in vitro digestibility of olive by-products supplemented with urea or sunflower meal: Comparison between goats and sheep. Animal Feed Science and Technology 110: 3-15.

MONDINI, C., DELL'ABATE, M.T., LEITA, L. and BENEDETTI, A., 2003. An integrated chemical, thermal, and microbiological approach to compost stability evaluation. Journal of Environmental Quality 32: 2379-2386.

MONTEMURRO, F. and MAIORANA, M., 2008. Organic fertilization as resource for a sustainable agriculture. In: Elsworth, L.R. and Paley, W.O. (Eds.). Fertilizers: Properties, Applications and Effects. pp. 123-146. Nova Science Publishers, New York.

MONTEMURRO, F., CONVERTINI, G. and FERRI, D., 2004. Mill wastewater and olive pomace compost as amendments for rye-grass. Agronomie 24: 481-486.

MONTEMURRO, F., MAIORANA, M., CONVERTINI, G. and FERRI, D., 2006. Compost organic amendments in fodder crops: effects on yield, nitrogen utilization and soil characteristics. Compost Science \& Utilization 14: 114-123.

MONTEMURRO, F., DIACONO, M., VITTI, C. and DEBIASE, G., 2009. Biodegradation of olive husk mixed with other agricultural wastes. Bioresource Technology 100: 2969-2974.

MORAL, R. y MURO, J., 2008. Manejo, dosificación y gestión agronómica del compost. En: Moreno, J. y Moral, R. (Eds.). Compostaje. pp. 351-378. Ediciones Mundi-Prensa, Madrid.

MORAL, R., PAREDES, C., BUSTAMANTE, M.A., MARHUENDA-EGEA, F. and BERNAL, M.P. 2009. Utilisation of manure composts by high-value crops: safety and environmental challenges. Bioresource Technology 100: 5454-5460.

MORENO, J. y MORMENEO, S., 2008. Microbiología y bioquímica del proceso de compostaje. En: Moreno, J. y Moral, R. (Eds.). Compostaje. pp. 111-140. Ediciones Mundi-Prensa, Madrid.

MORILLO, J.A., ANTIZAR-LADISLAO, B., MONTEOLIVA-SÁNCHEZ, M., RAMOS-CORMENZANA, A. and RUSSELL, N.J., 2009. Bioremediation and biovalorisation of olive-mill wastes. Applied Microbiology and Biotechnology 82: 25-39.

MURPHY, D.V., STOCKDALE, E.A., BROOKES, P.C., and GOULDING, K.W.T., 2007. Impact of microoganisms on chemical transformations in soil. In: Abbot, L.K. and Murphy, D.V. (Eds.). Soil Biological Fertility - A Key to Sustainable Land Use in Agriculture. pp. 37-59. Springer, Dordrecht.

NANNIPIERI, P., 2006. Role of stabilised enzymes in microbial ecology and enzyme extraction from soil with potential applications in soil proteomics. In: Nannipieri, P. and Smalla, K. (Eds.) Nucleic Acids and Proteins in Soil. pp. 75-116. Springer, New York.

NANNIPIERI, P., KANDELER, E. and RUGGIERO, P., 2002. Enzyme activities and microbiological and biochemical processes in soil. In: Burns, R.G. and Dick, R. (Eds.). Enzymes in the Environment. pp. 1-33. Marcel Deckker, New York.

NAPPI, P. and BARBERIS, R., 1993. Compost as growing medium: chemical, physical and biological aspects. Acta Horticulturae 342: 249-256.

NARDI, S., PIZZEGHELLO, D., MUSCOLO, A. and VIANELLO, A., 2002. Physiological effects of humic substances on higher plants. Soil Biology \& Biochemistry 34: 1527-1536. 
NATIONAL CENTER FOR BIOTECHNOLOGY INFORMATION-NCBI, 2007. Basic Local Alignment Search Tool. Revised: October 17, 2007. URL: http://www.ncbi.nlm.nih.gov (18/10/2007).

NAVARRO, A.F., CEGARRA, J., ROIG, A. and BERNAL, M.P., 1991. An automatic microanalysis method for the determination of organic carbon in wastes. Communications in Soil Science and Plant Analysis 22: 2137-2144.

NIAOUNAKIS, M. and HALVADAKIS, C.P., 2006. Olive Processing Waste Management. Literature Review and Patent Survey. $2^{\text {nd }}$ Edition. Elsevier Ltd., Oxford.

NOBLE, R., 2011. Risks and benefits of soil amendment with composts in relation to plant pathogens. Australasian Plant Pathology 40: 157-167.

NOBLE, R. and COVENTRY, E., 2005. Suppression of soil-borne plant diseases with composts: a review. Biocontrol Science and Technology 15: 3-20.

NOGALES, R., GALLARDO-LARA, F. y GÓMEZ, M., 1984. Estudio de la asimilabilidad de calcio por plantas de ryegrass en un suelo tratado con compost urbano. Anales de Edafología y Agrobiología 43: 871-882.

OBREZA, T.A. and REEDER, R.K., 1994. Municipal solid waste compost use in tomato/watermelon successional cropping. Soil and Crop Science Society of Florida Proceedings 53: 13-19.

OECD, 2003. Glossary of Statistical Terms. URL: http://stats.oecd.org/glossary/ $(17 / 03 / 2011)$.

OJedA, G., MATtANA, S., ALCAÑIZ, J.M., MARANDO, G., BONMATÍ, M., WOCHE, S.K. and BACHMANN, J., 2010. Wetting process and soil water retention of a minesoil amended with composted and thermally dried sludges. Geoderma 156: 399-409.

OKORO, C.K., BULL, A.T., MUTREJA, A., RONG, X., HUANG, Y. and GOODFELLOW, M., 2010. Lechevalieria atacamensis sp. nov., Lechevalieria deserti sp. nov. and Lechevalieria roselyniae sp. nov., isolated from hyperarid soils. International Journal of Systematic and Evolutionary Microbiology 60: 296-300.

OLESZCZUK, P., 2008. Phytotoxicity of municipal sewage sludge composts related to physicochemical properties, PAHs and heavy metals. Ecotoxicology and Environmental Safety 69: 496505.

OLSEN, S.R. and SOMMERS, L.E., 1982. Phosphorus. In: Page, A.L., Miller, R.H. and Keeney, D.R. (Eds.). Methods of Soil Analysis. Part 2. Chemical and Microbiological Properties. pp. 403430. Ed. American Society of Agronomy, Madison, Wisconsin.

ORBIT/ECN, 2008. Compost Production and Use in the EU. Final Report of ORBIT e.V. /European Compost Network ECN, Weimar, Germany.

ORDÓÑEZ, R., GONZÁLEZ, P., GIRÁLDEZ, J.V. y GARCÍA-ORTIZ, A., 1999. Efecto de la enmienda con alperujo sobre los principales nutrientes de un suelo agrícola. In: Muñoz-Carpena, R., Ritter, A. y Tascón, C. (Eds.). Actas de las IV Jornadas sobre Investigación en la Zona no Saturada. Vol. 4. Estudios de la Zona no Saturada. pp. 123-126. Instituto Canario de Investigaciones Agrarias, Gobierno de Canarias.

ORTEGA, M.C., MORENO, M.T., ORDOVÁS, J. and AGUADO, M.T., 1996. Behaviour of different horticultural species in phytotoxicity bioassays of bark substrates. Scientia Horticulturae 66: 125-132. 
ORTíZ, O., 2001. Uso de la materia orgánica como criterio de aplicación de residuos. En: Boixadera, J y Teira, R.M. (Eds.). Aplicación Agrícola de Residuos Orgánicos. pp. 279-291. Universitat de Lleida, Lleida.

OZORES-HAMPTON, M. and BRYAN, H.H., 1993a. Municipal solid waste (MSW) soil amendments: influence on growth and yield of snap beans. Proceedings of the Florida State Horticultural Society 106: 208-210.

OZORES-HAMPTON, M. and BRYAN, H.H., 1993b. Effect of amending soil with municipal solid waste (MSW) compost on yield of bell pepper and eggplant. HortScience 28: 103.

OZORES-HAMPTON, M., SCHAFFER, B. and BRYAN, H.H., 1994. Nutrient concentrations, growth, and yield of tomato and squash in municipal solid waste-amended soil. HortScience 29: 785-788.

PANE, C., SPACCINI, R., PICCOLO, A., SCALA, F. and BONANOMI, G., 2011. Compost amendments enhance peat suppressiveness to Pythium ultimum, Rhizoctonia solani and Sclerotinia minor. Biological Control 56: 115-124.

PANKHURST, C.E., HAWKE, B.G., MCDONALD, H.J., KIRKBY, C.A., BUCKERFIELD, J.C., MICHELSEN, P., O'BRIAN, K.A., GUPTA, V.V.S.R. and DOUBE, B.M., 1995. Evaluation of soil biological properties as potential bioindicators of soil health. Australian Journal of Experimental Research 35: 1015-1028.

PARADELO, R., DEVESA, R., MOLDES, A.B. and BARRAL, M.T., 2007. Physiologically based extraction of heavy metals in compost: Preliminary results. Journal of Trace Elements in Medicine and Biology 21: 83-85.

PARADELO, R., MOLDES, A.B., PRIETO, B., SANDU, R.G. and BARRAL, M.T., 2010. Can stability and maturity be evaluated in finished composts from different sources? Compost Science \& Utilization 18: 22-31.

PAREDES, C., CEGARRA, A., ROIG, A., SÁNCHEZ-MONEDERO, M.A. and BERNAL, M.P., 1999. Characterization of olive mill wastewater (alpechín) and its sludge for agricultural purposes. Bioresource Technology 67: 111-115.

PAREDES, C., ROIG, A., BERNAL, M.P., SÁNCHEZ-MONEDERO, M.A. and CEGARRA, J., 2000. Evolution of organic matter and nitrogen during co-composting of olive mill wastewater with solid organic wastes. Biology and Fertility of Soils 32: 222-227.

PAREDES, C., BERNAL, M.P., CEGARRA, J. and ROIG, A., 2002. Bio-degradation of olive mill wastewater sludge by its co-composting with agricultural wastes. Bioresource Technology 85: 1-8.

PARKINSON, R., FULLER, M. and GROENHOF, A., 1999. An evaluation of greenwaste compost for the production of forage maize (Zea mays L.). Compost Science \& Utilization 7: 72-80.

PARR, J.F. and PAPENDICK, R.I., 1997. Soil quality: relationship and strategies for sustainable dryland farming systems. Annals of Arid Zones 36: 181-191.

PASCUAL, J.A., AYUSO, M., GARCÍA, C. and HERNÁNDEZ, M.T., 1997. Characterization of urban wastes according to fertility and phytotoxicity parameters. Waste Management \& Research 15: 103-112. 
PASCUAL, J.A., MORENO, J.L., HERNÁNDEZ, T. and GARCÍA, C., 2002. Persistence of immobilised and total urease and phosphatase activities in a soil amended with organic wastes. Bioresource Technology 82: 73-78.

PÉREZ DE MORA, A., ORTEGA-CALVO, J., CABRERA, F. and MADEJÓN, E., 2005. Changes in enzyme activities and microbial biomass after "in situ" remediation of a heavy metalcontaminated soil. Applied Soil Ecology 28: 125-137.

PÉREZ DE MORA, A., BURGOS, P., MADEJÓN, E., CABRERA, F., JAECKEL, P. and SCHLOTER, M., 2006. Microbial community structure and function in a soil contaminated by heavy metals: effects of plant growth and different amendments. Soil Biology \& Biochemistry 38: 327-341.

PÉREZ-LÓPEZ, C., 2004. Técnicas de Análisis Multivariante de Datos: Aplicaciones con SPSS. Pearson Prentice Hall, Madrid.

PÉREZ-Piqueres, A., EDEL-HeRMANN, V., ALABOUVETte, C. and STEINBERG, C., 2006. Response of soil microbiota communities to compost amendments. Soil Biology \& Biochemistry 38: 460-470.

PETERSON, J.C. 1981. Modify your pH perspective. Florist's Review 169: 34-35, 92-93.

PicCOlO, A., CELANO, G. and PIETRAMELLARA, G., 1993. Effects of fractions of coal-derived humic substances on seed germination and growth of seedlings (Lactuca sativa and Lycopersicum esculentum). Biology and Fertility of Soils 16: 11-15.

PICHTEL, J. and SALT, C.A., 1998. Vegetative growth and trace metal accumulation on metalliferous wastes. Journal of Environmental Quality 27: 618-624.

PILON-SMITS, E.A.H., 2005. Phytoremediation. Annual Reviews in Plant Physiology 56: 15-39.

PINAMONTI, F., STRINGARI, G., GASPERI, F. and ZORZI, G., 1997. The use of compost: its effects on heavy metal levels in soil and plants. Resources, Conservation and Recycling 21: 129-143.

PINTON, R., CESCO, S. and VARANINI, Z., 2009. Role of humic substances in the rhizosphere. In: Senesi, N., Xing, B. and Ming-Huang, P. (Eds.). Biophysico-chemical Processes Involving Natural Nonliving Organic Matter in Environment. John Wiley \& Sons, Inc., West Sussex.

PIOTROWSKA, A., IAMARINO, G., RAO, M.A. and GIANFREDA, L., 2006. Short-term effects of olive mill waste water (OMW) on chemical and biochemical properties of a semiarid Mediterranean soil. Soil Biology \& Biochemistry 38: 600-610.

PIOTROWSKA, A., RAO, M.A., SCOTTI, R. and GIANFREDA, L., 2011. Changes in soil chemical and biochemical properties following amendment with crude and dephenolized olive mill waste water (OMW). Geoderma 161: 8-17.

PLAZA, C., NOGALES, R., SENESI, N. BENITEZ, E. and POLO, A., 2008. Organic matter humification by vermicomposting of cattle manure alone and mixed with two-phase olive pomace. Bioresource Technology 99: 5085-5089.

PORTA, J., LÓPEZ-ACEVEDO, M. y ROQUERO, C., 2003. Edafología para la Agricultura y el Medio Ambiente. $3^{\mathrm{a}}$ Ed. Ediciones Mundi-Prensa, Madrid.

PORTA, J., LÓPEZ-ACEVEDO, M. y POCH, R., 2010. Introducción a la Edafología: Uso y Protección del Suelo. Ediciones Mundi-Prensa, Madrid. 
POSTMA, J., MONTANARI, M. and VAN DEN BOOGERT, P.H.J.F., 2003. Microbial enrichment to enhance the disease suppressive activity of compost. European Journal of Soil Biology 39: 157-163.

PRASAD, M.N.V. and FREITAS, H., 2003. Metal hyperaccumulation in plants - biodiversity prospecting for phytoremediation technology. Electronic Journal of Biotechnology 6: 285-321.

PUCHADES, R., MAQUIEIRA, A., RUBIO, J.L. y PRIMO-YÚFERA, E., 1985. Evolución del nitrógeno nítrico y amoniacal en un suelo de cítricos fertilizado con urea recubierta de azufre. Relación con el nitrógeno foliar. Agrochimica XXIX: 30-39.

QUAGGIOTTI, S., RUPERTI, B., PIZZEGHELlO, D., FRANCIOSO, O., TUGNOLI, V. and NARDI, S., 2004. Effect of low molecular size humic substances on nitrate uptake and expression of genes involved in nitrate transport in maize (Zea mays L.). Journal of Experimental Botany 55: 803-813.

QUARTACCI, M.F., ARGILLA, A., BAKER, A.J.M. and NAVARI-IZZO, F., 2006. Phytoextraction of metals from a multiply contaminated soil by Indian mustard. Chemosphere 63: 918-925.

RAMOS, C., 2005. El análisis del nitrógeno mineral del suelo como guía para la fertilización nitrogenada de los cultivos hortícolas. Actas de Horticultura 44: 95-102.

RAMOS, C. y ÚBEDA, S., 2009. El abonado nitrogenado de los cultivos hortícolas en los Programas de Actuación para la reducción de la contaminación por nitrato de las diferentes Comunidades Autónomas. Actas de Horticultura 56: 87-92.

RAMOS-CORMENZANA, A., JUÁREZ-JIMÉNEZ, B. and GARCÍA-PAREJA, M.P., 1996. Antimicrobial activity of olive mill waste-waters (alpechín) and biotransformed olive oil mill wastewater. International Biodeterioration \& Biodegradation 38: 283-290.

RAVIV, M., 1998. Horticultural uses of composted material. Acta Horticulturae 469: 225- 234.

RAVIV, M., 2005. Production of high-quality composts for horticultural purposes: a mini-review. HortTechnology 15: 52-57.

RAVIV, M., WALLACH, R., SILBER A. and BAR-TAL, A., 2002. Substrates and their analysis. In: Savvas, D. and Passam, H. (Eds.). Hydroponic Production of Vegetables and Ornamentals. pp. 25-101. Embryo Publications, Athens, Greece.

RAVIV, M., OKA, Y., KATAN, J., HADAR, Y., YOGEV, A., MEDINA, S., KRASNOVSKY, A. and ZIADNA, H., 2005. High-nitrogen compost as a medium for organic container-grown crops. Bioresource Technology 96: 419-427.

REIDER, C., HERDMAN, W., DRINKWATER, L. and JANKE, R., 2000. Yields and nutrient budgets under composts, raw dairy manure and mineral fertilizer. Compost Science \& Utilization 8: 328-339.

RENELLA, G., LANDI, L., ASCHER, J., CECCHERINI, M.T., PIETRAMELLARA, G. and NANNIPIERI, P., 2006. Phosphomonoesterase production and persistence and composition of bacterial communities during plant material decomposition in soils with different $\mathrm{pH}$ values. Soil Biology \& Biochemistry 38: 795-802.

RENELLA, G., SZUKICS, U., LANDI, L. and NANNIPIERI, P., 2007. Quantitative assessment of hydrolase production and persistente in soil. Biology and Fertility of Soils 44: 321-329. 
RHOADES, J.D., 1982a. Cation exchange capacity. In: A.L. Page, R.H. Miller and D.R. Keeney (Eds.). Methods of Soil Analysis. Part 2. Agronomy Monograph No. 9. pp. 149-157. American Society of Agronomy and Soil Science Society of America, Madison, Wisconsin.

RHOADES, J.D. 1982b. Soluble salts. In: A.L. Page, R.H. Miller and D.R. Keeney (Eds.). Methods of Soil Analysis. Part 2: Chemical and Microbiological Properties. Agronomy Monograph No. 9. pp. 167-179. American Society of Agronomy and Soil Science Society of America, Madison, Wisconsin.

RICHARDS, L.A. (Ed.), 1954. Diagnosis and Improvement of Saline and Alkali Soils. USDA Handbook No. 60, Washington DC.

RICHARDS, D., LANE, M. and BEARDSELL, D.V., 1986. The influence of particle-size distribution in pinebark:sand:brown coal potting mixes on water supply, aireation and plant growth. Scientia Horticulturae 29: 1-14.

RICHTER, J., NUSKE, A., BOEHMER, U. and WEHRMANN, J., 1980. Simulation of nitrogen mineralization and transport in Loess-Parabrownearthes: plot experiments. Plant and Soil 54: 329-337.

ROBERTS, D.P., LOHRKE, S.M., MEYER, S.L.F., BUYER, J.S., BOWERS, J.H., BAKER, C.J., LI, W., SOUZA, J.T., LEWIS, J.A. and CHUNG, S., 2005. Biocontrol agents applied individually and in combination for suppression of soilborne diseases of cucumber. Crop Protection 24: 141-155.

ROCA-PÉREZ, L., MARTíNEZ, C., MARCILLA, P. and BOLUDA, R., 2009. Composting rice straw with sewage sludge and compost effects on the soil-plant system. Chemosphere 757: 781787.

RODDA, M.R.C, CANELLAS, L.P, FAÇANHA, A.R., ZANDONADI, D.B., GUERRA, J.G.M., DE ALMEIDA, D.L. y DE SANTOS, G.A., 2006. Estímulo no crescimento e na hidrólise de ATP em raízes de alface tratadas com humatos de vermicomposto. I - Efeito da concentração. Revista Brasileira de Ciência do Solo 30: 649-656.

RODIS, P.S., KARATHANOS, V.T. and MANTZAVINOU, A., 2002. Partitioning of olive oil antioxidants between oil and water phases. Journal of Agricultural and Food Chemistry 50: 596-601.

RODRÍGUEZ, I.R. and MILLER, G.L., 2000. Using a chlorophyll meter to determine the chlorophyll concentration, nitrogen concentration, and visual quality of St. Augustinegrass. HortScience 35: 751-754.

ROE, N.E., 2005. Efectos de los compost sobre el desarrollo y el rendimiento en horticultura comercial. En: Stoffella, P.J. y Kahn, B.A. (Eds.). Utilización de Compost en los Sistemas de Cultivo Hortícola. pp. 123-134. Ediciones Mundi-Prensa, Madrid.

ROE, N.E. and CORNFORTH, G.C., 1997. Yield effects and economic comparison of using fresh or composted dairy manure amendments on double cropped vegetables. HortScience 32: 462.

ROE, N.E. and STOFFELLA, P.J., 1994a. Influence of "uncured" compost on growth and yield of bell pepper. In: Proceedings of the National Pepper Conference. 6 pp. New Mexico State University, Las Cruces, New Mexico.

ROE, N.E. and STOFFELLA, P.J., 1994b. Influence of immature compost on growth and yields of tomato. Caribbean Food Crops Society Proceedings 30: 194-198. 
ROE, N.E., KOSTEWICZ, S.R. and BRYAN, H.H., 1990. Effects of municipal soild waste compost and fertilizer rates on broccoli. HortScience 25: 1066.

ROE, N.E., BRYAN, H.H., STOFFELLA, P.J. and WINSBERG, T.W., 1992. Use of compost as mulch on bell peppers. Proceedings of the Florida State Horticultural Society 105: 336-338.

ROE, N.E., STOFFELLA, P.J. and BRYAN, H.H., 1993. Utilization of MSW compost and other organic mulches on commercial vegetable crops. Compost Science \& Utilization 1: 73-84.

ROE, N.E., STOFFELLA, P.J. and BRYAN, H.H., 1994. Growth and yields of bell pepper and winter squash grown with organic and living mulches. Journal of American Society for Horticultural Science 119: 1193-1199.

ROE, N.E., STOFFELLA, P.J. and GRAETZ, D., 1997. Composts from various municipal solid waste feedstocks affect vegetable crops. II. Growth, yield, and fruit quality. Journal of the American Society for Horticultural Science 123: 433-437.

ROGER, D., REEVES, R.D. and BAKER, A.J.M., 2000. Metal-accumulating plants. In: Raskin, I., Ensley, B.D. (Eds.). Phytoremediation of Toxic Metals using Plants to Clean up the Environment. pp. 193-220. John Wiley and Sons Inc., New York.

ROIG, A., LAX, A., CEGARRA, J., COSTA, F. and HERNÁNDEZ, M.T., 1988. Cation-exchange capacity as a parameter for measuring the humification degree of manures. Soil Science 146: 311-316.

ROIG, A., CAYUELA, M.L., BERNAL, M.P. and SÁNCHEZ-MONEDERO, M.A., 2003. Elemental sulfur as $\mathrm{pH}$ regulator in a compost prepared with olive oil industry wastes. In: Pullammanappallil, P., McComb, A., Díaz, L.F. and Biglingmaier, W. (Eds.). Proceedings of the International Conference of ORBIT Association on Biological Processing of Organics: Advances for a Sustainable Society. pp. 67-74. Perth.

ROIG, A., CAYUELA, M.L. and SÁNCHEZ-MONEDERO, M.A. 2004. The use of elemental sulphur as organic alternative to control $\mathrm{pH}$ during composting of olive mill wastes. Chemosphere 57: 1099-1105.

ROIG, A., CAYUELA, M.L. and SÁNCHEZ-MONEDERO, M.A., 2006. An overview on olive mill wastes and their valorisation methods. Waste Management 26: 960-969.

ROLETTO, E., BARBERIS, R., CONSIGNLID, M. and JODICE, R., 1985. Chemical parameters for evaluation of compost maturity. BioCycle 26: 46-48.

ROMAGUERA, F., BOLUDA, R., FORNES, F. and ABAD, M., 2008. Comparison of three sequential extraction procedures for trace element partitioning in three contaminated Mediterranean soils. Environmental Geochemistry and Health 30: 171-175.

ROS, M., HERNÁNDEZ, M.T. and GARCÍA, C., 2003. Soil microbial activity after restoration of a semiarid soil by organic amendments. Soil Biology \& Biochemistry 35: 463-469.

ROS, M., KLAMMER, S., KNAPP, B., AICHBERGER, K. and INSAM, H., 2006a. Long-term effects of compost amendment of soil on functional and structural diversity and microbial activity. Soil Use and Management 22: 209-218.

ROS, M., PASCUAL, J.A., GARCÍA, C., HERNÁNDEZ, M.T. and INSAM, H., 2006b. Hydrolase activities, microbial biomass and bacterial community in a soil after long-term amendment with different composts. Soil Biology \& Biochemistry 38: 3443-3452. 
ROY, S., ARUNACHALAM, K., DUTTA, B.K. and ARUNACHALAM, A., 2010. Effect of organic amendments of soil on growth and productivity of three common crops viz. Zea mays, Phaseolus vulgaris and Abelmoschus esculentus. Applied Soil Ecology 45: 78-84.

RUBIO, V. y FERERES, A., 2005. Control biológico de plagas y enfermedades de los cultivos. En: Marín, I., Sanz, J.L. and Amils, R. (Eds.). pp. 215-229. Biotecnología y Medio Ambiente. Ephemera, Madrid.

RUGGIERI, L., ARTOLA, A., GEA, T. and SÁNCHEZ, A., 2008. Biodegradation of animal fats in a co-composting process with wastewater sludge. International Biodeterioration \& Biodegradation 62: 297-303.

RYNK, R. y RICHARD, T., 2005. Sistemas de producción comercial de compost. En: Stoffella P.J. y Kahn, B.A. (Eds.) Utilización de Compost en los Sistemas de Cultivo Hortícola. pp. 51-93. Ediciones Mundi-Prensa, Madrid.

SAADI, I., LAOR, Y., RAVIV, M. and MEDINA, S., 2007. Land spreading of olive mill wastewater: Effects on soil microbial activity and potential phytotoxicity. Chemosphere 66: 75-83.

SAID-PULLICINO, D., ERRIQUENS, F.G. and GIGLIOTTI, G., 2007. Changes in the chemical characteristics of water-extractable organic matter during composting and their influence on compost stability and maturity. Bioresource Technology 98: 1822-1831.

SAITOU, N. and NEI, M., 1987. The neighbour-joining method: a new method for reconstructing phylogenetic trees. Molecular Biology and Evolution 4: 406-425.

SÁNCHEZ-MONEDERO, M.A., ROIG, A., MARTíNEZ-PARDO, C., CEGARRA, J. and PAREDES, C., 1996. A microanalysis method for determining total organic carbon in extracts of humic substances. Relationships between total organic carbon and oxidable carbon. Bioresource Technology 57: 291-295.

SÁNCHEZ-MONEDERO, M.A., ROIG, A., CEGARRA, J. and BERNAL, M.P., 1999. Relationships between water-soluble carbohydrate and phenol fractions and the humification indices of different organic wastes during composting. Bioresource Technology 70: 193-201.

SÁNCHEZ-MONEDERO, M.A., ROIG, A., PAREDES, C. and BERNAL, M.P., 2001. Nitrogen transformation during organic waste composting by the Rutgers system and its effects on $\mathrm{pH}$, EC and maturity of the composting mixtures. Bioresource Technology 78: 301-308.

SÁNCHEZ-MONEDERO, M.A., MONDINI, C., DE NOBILI, M., LEITA, L. and ROIG, A., 2004. Land application of biosolids. Soil response to different stabilization degree of the treated organic matter. Waste Management 24: 325-332.

SÁNCHEZ-MONEDERO, M.A., MONDINI, C., CAYUELA, M.L., ROIG, A., CONTIN, M. and DE NOBILI, M., 2008. Fluorescein diacetate hydrolysis, respiration and microbial biomass in freshly amended soils. Biology and Fertility of Soils 44: 885-890.

SANJUÁN, N., CÁRCEL, J.A., CLEMENTE, G., y MULET, A., 2001. Aprovechamiento de Subproductos en las Industrias Agroalimentarias. Editorial de la Universidad Politécnica de Valencia, Valencia. 159 pp.

SANTIBÁÑEZ, C., VERDUGO, C. and GINOCCHIO, R., 2008. Phytostabilization of copper mine tailings with biosolids: implications for metal uptake and productivity of Lolium perenne. Science of the Total Environment 395: 1-10. 
SAÑA, J. i SOLIVA, M., 1987. El Compostatge. Procés, Sistemes i Aplicacions. Diputació de Barcelona, Àrea de Medi Ambient, Barcelona.

SASTRE-CONDE, I., CABEZAS, J.G., GUERRERO, A., VICENTE, M.A. and LOBO, M.C., 2006. Evaluation of the soil biological activity in a remediation soil assay using organic amendments and vegetal cover. Science of the Total Environment 378: 205-208.

SAUSSURE, T., 1804. Recherches Chimiques sur la Végétation. Paris.

SCHEUERELL, S.J., SULLIVAN, D.M. and MAHAFFEE, W.F., 2005. Suppression of seedling damping-off caused by Pythium ultimum, P. irregulare, and Rhizoctonia solani in container media amended with a diverse range of Pacific Northwest compost sources. Phytopathology 95: 306-315.

SCHINNER, F., ÖHLINGER, R., KANDELER, E. and MARGESIN, R. (Eds.), 1996. Methods in Soil Biology. Springer, Berlin.

SCHLOTER, M., DILLY, O. and MUNCH, J.C., 2003. Indicators for evaluationg soil quality. Agriculture, Ecosystems \& Environment 98: 255-262.

SCHNÜRER, J. and ROSSWALL, T., 1982. Fluorescein diacetate hydrolysis as a measure of total microbial activity in soil and litter. Applied and Environmental Microbiology 43: 12561261.

SCHÖNFELD, J., GELSOMINO, A., OVERBEEK, L.S., GORISSEN, A., SMALLA, K. and VAN ELSAS, J.D., 2003. Effects of compost addition and simulated solarisation on the fate of Ralstonia solanacearum biovar 2 and indigenous bacteria in soil. FEMS Microbiology Ecology 43: 63-74.

SCHUMANN, G.L. and D'ARCY, C.J., 2006. Essential Plant Pathology. The American Phytopathological Society, St. Paul, Minnesota.

SELIM, E.M., MOSA, A.A. and EL-GHAMRY, A.M., 2009. Evaluation of humic substances fertigation through surface and subsurface drip irrigation systems on potato grown under Egyptian sandy soil conditions. Agricultural Water Management 96: 1218-1222.

SENESI, N., 1989. Composted materials as organic fertilizers. Science of the Total Environment 81/82: 521-542.

SENESI, N., MIANO, T.M. and BRUNETTI, G., 1996. Humic-like substances in organic amendments and effects on native soil humic substances. In: Piccolo, A. (Ed.). Humic Substances in Terrestrial Ecosystems. pp. 531-593. Elsevier B.V., Amsterdam.

SENESI, N., PLAZA, C., BRUNETTI, G. and POLO, A., 2007. A comparative survey of recent results on humic-like fractions in organic amendments and effects on native soil humic substances. Soil Biology \& Biochemistry 39: 1244-1262.

SEOÁNEZ, M., 2002. Manual de Tratamiento, Reciclado, Aprovechamiento y Gestión de las Aguas Residuales de las Industrias Agroalimentarias. Ediciones Mundi-Prensa, Madrid.

SHANER, G. and FINNEY, R.E., 1977. The effect of nitrogen fertilization on the expression of slow-mildewing resistance in Knox wheat. Phytopathology 67: 1051-1056.

SHIRAZI, M.A. and BOERSMA, L., 1984. A unifying quantitative analysis of soil texture. Soil Science Society of America Journal 48: 142-147. 
SHIRLING, E.B. and GOTTLIEB, D., 1966. Methods for characterization of Streptomyces species. International Journal of Systematic Bacteriology 16: 313-340.

SIDDIQUI, Y., MEON, S., ISMAIL, M.R. and ALI, A., 2008. Trichoderma-fortified compost extracts for the control of choanephora wet rot in okra production. Crop Protection 27: 385-390.

SIERRA, J., MARTÍ, E., GARAU, A. and CRUAÑAS, R., 2007. Effects of the agronomic use of olive oil mill wastewater: Field experiment. Science of the Total Environment 378: 90-94.

SIGEL, H. and SIGEL, A. (Eds.), 1988. Metal lons in Biological Systems. Vol. 24: Aluminium and its Role in Biology. Marcel Dekker, New York.

SIKORA, L.J. and SZMIDT, R.A.K., 2005. Los compost como fuentes de nitrógeno, aportación a la mineralización y ventajas para la nutrición nitrogenada de las plantas. In: Stoffella, P.J. y Kahn, B.A. (Eds.). Utilización de Compost en los Sistemas de Cultivo Hortícola. pp. 287-305. Ediciones Mundi-Prensa, Madrid.

SISTANI, K.R., ADELI, A., McGOWEN, S.L., TEWOIDE, H. and BRINK, G.E., 2008. Laboratory and field evaluation of broiler litter nitrogen mineralization. Bioresource Technology 99: 26032611.

SMITH, S.R., 2009. A critical review of the bioavailability and impacts of heavy metals in municipal solid waste composts compared to sewage sludge. Environment International 35: 142-156.

SMITH, D.C. and HUGHES, J.C., 2004. Changes in maturity indicators during the degradation of organic wastes subjected to simple composting procedures. Biology and Fertility of Soils 39: 280-286.

SMITH, S.R., HALL, J.E. and HADLEY, P., 1992. Composting sewage sludge wastes in relation to their suitability for use as fertilizer materials for vegetable crop production. Acta Horticulturae 302: 203-215.

SMITH, J.L., PAPENDICK, R.I., BEZDICEK, D.F. and LYNCH, J.M., 1993. Soil organic matter dynamics and crop residue management. In: Metting, F.B. (Ed.). Soil Microbial Ecology. Applications in Agricultural and Environmental Management. pp. 65-94. Marcel Dekker, New York.

SOLIVA, M., 2001. Compostatge i Gestió de Residus Orgànics. Diputació de Barcelona, Barcelona.

SOLIVA, M. y MOLINA, N. 1996. ¿Qué significado tiene el término compost? Riegos y Drenajes 87: 29-33.

SOLIVA, M. y PAULET, S., 2001. Compostaje de residuos orgánicos y aplicación agrícola. En: Boixadera, J. y Teira, M.R. (Eds.). Aplicación Agrícola de Residuos Orgánicos. pp. 63-78. Edicions de la Universitat de Lleida, Lleida.

SOLIVA, M., LÓPEZ, M. y HUERTA, O., 2008. Antecedentes y fundamentos del proceso de compostaje. En: Moreno, J. y Moral, R. (Eds.). Compostaje. pp. 75-92. Ediciones Mundi-Prensa, Madrid.

SOMMERS, S.G., KJELLERUP, V. and KRISTJANSEN, O., 1992. Determination of total ammonium nitrogen in pig and cattle slurry: sample preparation and analysis. Acta Agriculturae Scandinavica 42: 146-151. 
STANECK, J.L. and ROBERTS, G.D., 1974. Simplified approach to identification of aerobic actinomycetes by thin-layer chromatography. Applied Microbiology 28: 226-231.

STANFORD, G. and SMITH, S.J., 1972. Nitrogen mineralization potentials of soils. Soil Science Society of America Proceedings 36: 465-472.

STATISTICAL GRAPHICS CORP., 2005. Statgraphics Plus for Windows 5.1. Statistical Graphics Corporation. Rockville, Maryland.

STENTIFORD, E.I., 1996. Composting control: Principles and practice. In: de Bertoldi, M., Sequi, P., Lemmes, B. and Papi, T. (Eds.). The Science of Composting. pp. 49-59. Blackie Academic and Professional, Glasgow.

STEVENSON, F.J., 1994. Humus Chemistry: Genesis, Composition, Reactions. $2^{\text {nd }}$ Ed. John Wiley \& Sons, New York.

STOFFELLA, P.J. and GRAETZ, D.A., 1997. Sugarcane filtercake compost influence on tomato emergence, seedling growth, and yields. In: de Bertoldi, M., Sequi, P., Lemmes, B. and Papi, T. (Eds.). The Science of Composting. Part 2. pp. 1351-1356. Blackie Academic and Professional, London.

SUÁREZ-ESTRELLA, F., VARGAS-GARCÍA, M.C., LÓPEZ, M.J. and MORENO, J., 2004. Survival of Fusarium oxysporum f. sp. melonis on plant waste. Crop Protection 23: 127-133.

SUÁREZ-ESTRELLA, F., VARGAS-GARCÍA, M.C., LÓPEZ, M.J., CAPEL, C. and MORENO, J., 2007. Antagonistic activity of bacteria and fungi from horticultural compost against Fusarium oxysporum f. sp. melonis. Crop Protection 26: 46-53.

SULLIVAN, D.M and MILLER, R.O., 2005. Propiedades cualitativas, medición y variabilidad de los compost. En: Stoffella, P.J. y Kahn, B.A. (Eds.). Utilización de Compost en los Sistemas de Cultivo Hortícola. pp. 95-119. Ediciones Mundi-Prensa, Madrid.

TABATABAl, M.A., 1982. Soil enzymes. In: Page, A.L., Miller, R.H. and Keeney, D.R. (Eds.). Methods of Soil Analysis. Part 2, Chemical and Microbiological Properties. pp. 907-943. Soil Science Society of America, Madison, Wisconsin.

TABATABAI, M.A., 1994. Soil enzymes. In: Weaver, R.W., Angel, J.S. and Bottomley, P.S. (Eds.). Methods of Soil Analysis. Part 2, Microbiological and Biochemical Properties. pp. 775-833. Soil Science Society of America, Madison, Wisconsin.

TABATABAI, M.A. and BREMNER, J.M., 1969. Use of p-nitrophenyl phosphate for assay of soil phosphatase activity. Soil Biology \& Biochemistry 1: 301-307.

TAN, K.H. and BINGER, A., 1986. Effect of humic acid on aluminium toxicity in corn plants. Soil Science 141: 20-25.

TANG, Y., ZHANG, H., SCHRODER, J.L., PAYTON, M.E. and SHOU, D., 2007. Animal manure reduces aluminium toxicity in an acid soil. Soil Science Society of America Journal 71: 16991707.

TEJADA, M., GARCíA, C., GONZÁLEZ, J.L. and HERNÁNDEZ, M.T., 2006. Use of organic amendment as a strategy for saline soil remediation: influence on the physical, chemical and biological properties of soil. Soil Biology \& Biochemistry 38: 1413-1421.

TEJADA, M., HERNÁNDEZ, M.T. and GARCÍA, C., 2009. Soil restoration using composted plant residues: Effects on soil properties. Soil \& Tillage Research 102: 109-117. 
TERMORSHUIZEN, A.J., VAN RIJN, E., VAN DER GAAG, D.J., ALABOUVETTE, C., CHEN, Y., LAGERLÖF, J., MALANDRAKIS, A.A., PAPLOMATAS, E.J., RÄMERT, B., RYCKEBOER, J., STEINBERG, C. and ZMORA-NAHUM, S., 2006. Suppressiveness of 18 composts against 7 pathosystems: Variability in pathogen response. Soil Biology \& Biochemistry 38: 2461-2477.

TESTER, C.F., PARR, J.F. and PAOLINI, P., 1980. Effect of sieving on the compost properties. In: Proceedings of the National Conference on Municipal and Industrial Sludge Composting. Organized by the Hazardous Materials Control Research Institute. pp. 126-135. Information Transfer, Inc., Silver Spring, Maryland.

THEILLEUX, J., 2000. Capítulo 6: Los actinomicetos. En: Leveau, J.Y. y Bouix, M. (Eds.). Microbiología Industrial. Los Microorganismos de Interés Industrial. pp. 417-478. Ed. Acribia. Zaragoza.

THOMPSON, R.B. and NOGALES, R., 1999. Nitrogen and carbon mineralization in soil of vermicomposted and unprocessed dry olive cake ("orujo seco") produced from two-stage centrifugation for olive oil extraction. Journal of Environmental Science and Health B 34: 917928.

TIQUIA, S.M., 2000. Evaluating phytotoxicity of pig manure from the pig-on-litter system. In: Warman, P.R. and Taylor, B.R. (Eds.). Proceedings of the International Composting Symposium, pp. 625-647. CBA Press Inc., Truro, New Scotland, Canada.

TIQUIA, S.M., 2005. Microbiological parameters as indicators of compost maturity. Journal of Applied Microbiology 99: 816-828.

TIQUIA, S.M. and TAM, N.F.Y., 1998. Elimination of phytotoxicity during co-composting of spent pig-manure sawdust litter and pig sludge. Bioresource Technology 65: 43-49.

TITTARELLI, F., PETRUZZELLI, G., PEZZAROSSA, G., CIVILINI, M., BENEDETTI, A. and SEQUI, P., 2007. Quality and agronomic use of compost. In: Diaz, L.F., de Bertoldi, M., Bidlingmaier, W. and Stentiford, E. (Eds.). Compost Science and Technology. pp. 119-158. Elsevier Ltd., Oxford.

TOGNETTI, C., MAZZARINO, M.J. and LAOS, F., 2008. Compost of municipal organic waste: Effects of different management practices on degradability and nutrient release capacity. Soil Biology \& Biochemistry 40: 2290-2296.

TOMATI, U., GALLI, E., PASETTI, L. and VOLTERRA, E., 1995. Bioremediation of olive-mill wastewaters by composting. Waste Management \& Research 13: 509-518.

TRASAR-CEPEDA, C., GIL, F. and LEIRÓS, M.C., 2003. Determinación de la actividad fosfatasa del suelo. En: García, C., Gil, F., Hernández, T. and Trasar, C. (Eds.). Técnicas de Análisis de Parámetros Bioquímicos en Suelos: Medidas de Actividades Enzimáticas y Biomasa Microbiana. pp. 51-76. Ediciones Mundi-Prensa, Madrid.

TREVISAN, S., FRANCIOSO, O., QUAGGIOTTI, S. and NARDI, S., 2010. Humic substances biological activity at the plant-soil interface. Plant Signaling \& Behavior 5: 635-643.

TRILLAS, I., 2002. Apuntes del Taller "Supresividad en Sustratos" en el marco de las VI Jornadas de Sustratos de la SECH, Barcelona. $12 \mathrm{pp}$.

TRILLAS, I., CASANOVA, E., COTXARRERA, L., ORDOVÁS, J., BORRERO, C. and AVILÉS, M., 2006. Composts from agricultural waste and the Trichoderma asperellum strain T-34 suppress Rhizoctonia solani in cucumber seedlings. Biological Control 39: 32-38. 
TRIPATHI, C.K.M., PRAVEEN, V., SINGH, V. and BIHARI, V., 2004. Production of antibacterial and antifungal metabolites by Streptomyces violaceusniger and media optimization studies for the maximum metabolite production. Medicinal Chemistry Research 13: 790-799.

TURNER, B.L., HOPKINS, D.W., HAYGARTH, P.M. and OSTLE, N., 2002. $\beta$-glucosidase activity in pasture soils. Applied Soil Ecology 20: 157-162.

UKITA, M., IMAI, T. y HUNG, Y., 2008. Tratamiento de residuos de alimentos. En: Wang, L.K., Hung, Y., Lo, H.H. y Yapijakis, C. (Eds.). Tratamiento de los Residuos de la Industria del Procesado de Alimentos. pp. 355-389. Editorial Acribia S.A., Zaragoza.

UN-UNITED NATIONS, 1997. Glossary of Environment Statistics. Studies in Methods, Series F, No. 67. Department for Economic and Social Information and Policy Analysis, New York.

UNE NORMA ESPAÑOLA, 1996. NORMA UNE 77301-1. Calidad del suelo. Determinación de los efectos contaminantes sobre la flora del suelo. Parte I: Método para la medida de la inhibición del crecimiento radicular. Asociación Española de Normalización y Certificación (AENOR), Madrid.

UNE-EN NORMA ESPAÑOLA. Mejoradores del Suelo y Sustratos de Cultivo. Asociación Española de Normalización y Certificación (AENOR), Madrid.

UNE-EN 12579, 2000. Toma de muestras.

UNE-EN 13037, 2001. Determinación del pH.

UNE-EN 13038, 2001. Determinación de la conductividad eléctrica.

UNE-EN 13039, 2001. Determinación del contenido en materia orgánica y de las cenizas.

UNE-EN 13040, 2008. Preparación de muestras para ensayos químicos y físicos, determinación del contenido de materia seca, contenido de la humedad y de la densidad aparente compactada en laboratorio.

UNE-EN 13041:2001/A1, 2007. Densidad aparente seca, volumen de aire, volumen de agua, valor de contracción y porosidad total.

UNE-EN 13650, 2002. Extracción de elementos solubles en agua regia.

UNE-EN 13651, 2002. Extracción de nutrientes solubles en cloruro cálcico/DTPA (CAT).

UNE-EN 13652, 2002. Extracción de nutrientes y elementos solubles en agua.

UNE-EN 13806, 2003. Productos alimenticios. Determinación de elementos traza. Determinación de mercurio por espectrometría de absorción atómica con vapor frío (CVAAS) tras digestión bajo presión.

UNE-EN 15428, 2008. Determinación de la granulometría de las partículas.

VALDRIGHI, M.M., PERA, A., AGNOLUCCI, M., FRASSINETTI, S., LUNARDI, D. and VALLINI, G., 1996. Effects of compost-derived humic acids on vegetable biomass production and microbial growth within a plant (Cichorium inthybus)-soil system: a comparative studyAgriculture, Ecosystems \& Environment 58: 133-144.

VAN SOEST, P.J., ROBERTSON, J.B. and LEWIS, B.A., 1991. Methods for dietary fiber, neutral detergent fiber, and nonstarch polysaccharides in relation to animal nutrition. Journal of Dairy Science 74: 3583-3597.

VAN-CAMP, L., BUJARRABAL, B., GENTILE, A.R., JONES, R.J.A., MONTANARELLA, L., OLAZÁBAL, C. AND SELVARADJOU, S. (Eds.), 2004. Reports of the Technical Working Groups established under the Thematic Strategy for Soil Protection - Volume III - Organic Matter. Office for Official Publications of the European Communities, Luxembourg.

VANCE, E.D., BROOKES, P.C. and JENKINSON, D.S., 1987. An extraction method for measuring soil microbial biomass-C. Soil Biology \& Biochemistry 19: 703-707. 
VARANINI, Z. and PINTON, R., 2006. Plant-soil relationship: role of humic substances in iron nutrition. In: Barton, L.L. and Abadía, J. (Eds.). Iron Nutrition in Plants and Rhizospheric Microorganisms. pp. 153-168. Springer, Dordrecht.

VARGAS, M.C. y SUÁREZ-ESTRELLA, F., 2008. Efecto de la aplicación del compost sobre las propiedades biológicas del suelo. En: Moreno, J. y Moral, R. (Eds.). Compostaje. pp. 329-350. Ediciones Mundi-Prensa, Madrid.

VEEKEN, A., NIEROP, K., DE WILDE, V. and HAMELERS, B., 2000. Characterisation of $\mathrm{NaOH}$ extracted humic acids during composting of a biowaste. Bioresource Technology 72: 33-41.

VERLINDEN, G., COUSSENS, T., DE VLIEGHER, A., BAERT, G. and HAESAERT, G., 2010. Effect of humic substances on nutrient uptake by herbage and on production and nutritive value of herbage from sown grass pastures. Grass and Forage Science 65: 133-144.

VIGIL, M.F. and KISSEL, D.E., 1995. Rate of nitrogen mineralized from incorporated crop residues as influenced by temperature. Soil Science Society of America Journal 59: 16361644.

VILLALBÍ, I. y VIDAL, M., 1988. Análisis de Suelos y Foliares: Interpretación y Fertilización. Fundación Caja de Pensiones, Barcelona.

VINIEGRA, V., 2001. Gestión y tratamiento de residuos sólidos orgánicos de la industria de transformados vegetales. En: Actas I Encuentro Internacional Gestión de Residuos Orgánicos en el Ámbito Rural Mediterráneo, Pamplona. 6 pp.

VOGTMANN, H. and FRICKE, K., 1989. Nutrient value and utilization of biogenic compost in plant production. Agriculture, Ecosystems \& Environment 27: 471-475.

VOGTMANN, H., MATTHIES, K., KEHRES, B. and MEIER-PLOEGER, A., 1993. Enhanced food quality: effects of composts on the quality of plant foods. Compost Science \& Utilization 1: 82100.

VOLTERRANI, M., PARDINI, G., GAetANI, M., GROSSI, N. and MIELE, S., 1996. Effects of application of municipal solid waste compost on horticultural species yield. In: de Bertoldi, M., Sequi, P., Lemmes, B. and Papi, T. (Eds.). The Science of Composting. pp. 1385-1388. Blackie Academic \& Professional, London.

WAKSMAN, S.A. and HENRICI, A.T., 1943. The nomenclature and classification of the Actinomycetes. Journal of Bacteriology 46: 337-341.

WALKER, D.J. and BERNAL, M.P., 2008. The effects of olive mill waste compost and poultry manure on the availability and plant uptake of nutrients in a highly saline soil. Bioresource Technology 99: 396-403.

WALKER, D.J., CLEMENTE, R., ROIG, A. and BERNAL, M.P., 2003. The effects of soil amendments on heavy metal bioavailability in two contaminated Mediterranean soils. Environmental Pollution 122: 303-312.

WALKLEY, A. and BLACK, I.A., 1934. An examination of Degtjareff method for determining soil organic matter and a proposed modification of the chromic acid titration method. Soil Science 37: 29-37.

WANDER, M.M., WALTER, G.L., NISSEN, T.M., BOLLERO, G.A., ANDREWS, S.S. and CAVANAUGH-GRANT, D.A., 2002. Soil quality: science and process. Agronomy Journal 94: 2332. 
WANG, W., ZHANG, Z., TANG, Q., MAO, J., WEI, D., HUANG, Y., LIU, Z., SHI, Y. and GOODFELLOW, M., 2007. Lechevalieria xinjiangensis sp. nov., a novel actinomycete isolated from radiationpolluted soil in China. International Journal of Systematic and Evolutionary Microbiology 57: 2819-2822.

WARMAN, P.R. and HAVARD, K.A., 1997. Yield, vitamin and mineral content of organically and conventionally grown carrots and cabbage. Agriculture, Ecosystems \& Environment 61: 155162.

WILLIAMS, S.T., GOODFELLOW, M., ALDERSON, G., WELLINGTON, E.M.H., SNEATH, H.P.A. and SACKIN, M., 1983. Numerical classification of Streptomyces and related genera. Journal of General Microbiology 129: 1743-1813.

WILLIAMS, S.T., SHARPE, M.E. and HOLT, J.G. (Eds.), 1989. Bergey's Manual of Systematic Bacteriology. Lippincott Williams and Wilkins, Baltimore, Maryland.

WILSON, K. 1987. Preparation of genomic DNA from bacteria. In: Ausubel, F. M., Brent, R., Kingston, R. E., Moore, D. D., Smith, J. A., Seidman, J. G., Smith, J. A. and Struhl, K. (Eds.). Current Protocols in Molecular Biology. John Wiley \& Sons, New York.

WOLF, B. and SNYDER, G.H., 2003. Sustainable soils: The Place of Organic Matter in Sustaining Soils and Their Productivity. The Haworth Press, New York.

WONG, M.H., 1985. Phytotoxicity of refuse compost during the process of maturation. Environmental Pollution 37: 159-174.

WU, J., JOERGENSEN, R.G., POMMERING, B., CHAUSSOD, R. and BROOKES, P.C., 1990. Measurement of microbial biomass $C$ by fumigation-extraction. An automated procedure. Soil Biology \& Biochemistry 22: 1167-1169.

WU, L., MA, L.Q. and MARTíNEZ, G.A., 2000. Comparison of methods for evaluating stability and maturity of biosolids compost. Journal of Environmental Quality 29: 424-429.

YAKOVCHENKO, V.P. and SIKORA, L.J., 1998. Modified dichromate method for determining low concentrations of extractable organic carbon in soil. Communications in Soil Science and Plant Analysis 29: 421-433.

YOGEV, A., RAVIV, R., HADAR, Y., COHEN, R. and KATAN, J., 2006. Plant waste-based composts suppressive to diseases caused by pathogenic Fusarium oxysporum. European Journal of Plant Pathology 116: 267-278.

YOGEV, A., RAVIV, M., KRITZMAN, G., HADAR, Y., COHEN, R., KIRSHNER, B. and KATAN, J., 2009. Suppression of bacterial canker of tomato by composts. Crop Protection 28: 97-103.

YOGEV, A., RAVIV, M., HADAR, Y., COHEN, R., WOLF, S., GIL, L. and KATAN, J., 2010. Induced resistance as a putative component of compost suppressiveness. Biological Control 54: 46-51.

ZEYTIN, S. and BARAN, A., 2003. Influences of composted hazelnut husk on some physical properties of soils. Bioresource Technology 88: 241-244.

ZHANG, R. 1997. Determination of soil sorptivity and hydraulic conductivity from the disk infiltrometer. Soil Science Society of America Journal 61: 1024-1030.

ZHOU, D.M., HAO, X.Z., WANG, Y.J., DONG, Y.H. and CANG, L., 2005. Copper and Zn uptake by radish and pakchoi as affected by application of livestock and poultry manures. Chemosphere 59: 167-175. 
ZHU, N.W., 2006. Composting of high moisture content swine manure with corncob in a pilotscale aerated static bin system. Bioresource Technology 97: 1870-1875.

ZMORA-NAHUM, S., MARKOVITCH, O., TARCHITZKY, J. and CHEN, Y., 2005. Dissolved organic carbon (DOC) as a parameter of compost maturity. Soil Biology \& Biochemistry 37: 21092116.

ZUCCONI, F. and DE BERTOLDI, M., 1987. Compost specifications for the production and characterization of compost from municipal solid waste. In: de Bertoldi, M., Ferranti, M.P., L'Hermite, P. and Zucconi, F. (Eds.). Compost: Production, Quality and Use. pp. 30-50. Elsevier Applied Science, London.

ZUCCONI, F., MONACO, A., FORTE, M. and DE BERTOLDI, M., 1981a. Biological evaluation of compost maturity. BioCycle 22: 27-29.

ZUCCONI, F., PERA, A., FORTE, M. and DE BERTOLDI, M., 1981b. Evaluating toxicity of immature compost. BioCycle 22: 54-57. 


\section{ANEJO I MÉTODOS ANALÍTICOS}




\section{I.1. CARACTERIZACIÓN FÍSICA, FÍSICO-QUÍMICA, QUÍMICA Y BIOLÓGICA DE LOS COMPOSTS DE ALPERUJO}

\section{I.1.1. Toma de muestras}

La toma de muestra de los composts de alperujo recibidos en el laboratorio se lleva a cabo según la Norma UNE-EN 12579.

\section{I.1.2. Propiedades físicas}

\section{I.1.2.1. Granulometría. Índice de grosor y diámetro medio geométrico}

El análisis granulométrico se realiza siguiendo la metodología especificada en la Norma UNE-EN 15428 (2008), utilizando una tamizadora electromagnética digital CISA modelo 002, con tamices de $20 \mathrm{~cm}$ de diámetro y los siguientes tamaños de luz de malla: $31,5,16,8,4,2,1,0,5,0,25$ y $0,125 \mathrm{~mm}$.

Se toman aproximadamente 200 g de muestra, que se extienden sobre una hoja de papel de filtro para permitir su secado al aire. Una vez seca, la muestra se pesa con una precisión de 0,1 $\mathrm{g}\left(\mathrm{M}_{\mathrm{t}}\right)$, y se tamiza durante 10 minutos a la amplitud 8 (sobre 10) de la tamizadora. A partir del peso retenido en cada uno de los tamices $\left(M_{i}\right)$ se calcula el porcentaje (en peso) de cada fracción granulométrica $\left(P_{i}\right)$, según la ecuación:

$$
P_{i}(\%)=\frac{M_{i}}{M_{t}} \cdot 100
$$

Los resultados se expresan con una aproximación del 1\%.

El índice de grosor (IG) se obtiene sumando los porcentajes $\left(\mathrm{P}_{\mathrm{i}}\right.$, en peso) de las partículas con diámetro mayor de $1 \mathrm{~mm}$ (adaptación del método propuesto por Richards et al., 1986), según:

$$
\mathrm{IG}(\%)=\sum \mathrm{P}_{\mathrm{i}} ; \quad \mathrm{i}>1 \mathrm{~mm}
$$

Finalmente, con los datos obtenidos se representan histogramas de frecuencias y se calcula el diámetro medio geométrico de las partículas $\left(d_{g}\right)$ a partir de los porcentajes (en peso) de cada fracción granulométrica, utilizando la siguiente ecuación (Shirazi y Boersma, 1984):

$$
d_{g}(m m)=\exp (a) ; \text { siendo } a=\sum m_{i} \cdot \ln d_{i}
$$


donde $m_{i}$ es la fracción de peso retenida en el tamiz i, en \%, y di el diámetro medio de dos tamices consecutivos, en mm.

\section{I.1.2.2. Densidad aparente}

La densidad aparente $\left(D_{A}\right)$ corresponde a la relación entre la masa o el peso de las partículas y el volumen aparente que éstas ocupan -es decir, considerando el volumen poroso existente entre las mismas-, expresada en $\mathrm{kg} / \mathrm{m}^{3}$.

La determinación de la $D_{A}$ se basa en la metodología recogida en la Norma UNEEN 13041:2001/A1 (2007).

El cálculo de la DA se realiza a partir del peso seco del material contenido en un cilindro de volumen conocido, tras haber sido saturado con agua y sometido a una succión de $10 \mathrm{~cm}$ de columna de agua (c.a.) (equivalente a $1 \mathrm{kPa}$ ).

Para ello, se utilizan anillas de acero inoxidable - de 3 y $4 \mathrm{~cm}$ de altura y $82 \mathrm{~mm}$ de diámetro- y tela de nylon. Un extremo de la anilla de $4 \mathrm{~cm}$, de volumen conocido $\left(\mathrm{V}, \mathrm{cm}^{3}\right)$, se cubre por debajo con tela de nylon y se determina el peso del conjunto $(A)$ con una precisión de 0,1 g. Al otro extremo se acopla la anilla de $3 \mathrm{~cm}$ y, en el cilindro formado, se introduce la muestra de material a caracterizar (previamente humedecida), sin apelmazar ni apretar, hasta $1 \mathrm{~mm}$ del borde superior (Figura 2.1). A continuación, el cilindro se coloca en un recipiente, al que se le añade agua hasta 0,5 $\mathrm{mm}$ del borde superior, y se deja saturar por capilaridad durante 48 horas.

Transcurrido este tiempo, y con el fin de someter la muestra a una tensión de 10 $\mathrm{cm}$ de columna de agua, el cilindro se coloca en un baño de arena durante 48 horas.

El baño de arena consiste en un recipiente cilíndrico de 25 litros, al que se le ha realizado una perforación (drenaje) a unos $15 \mathrm{~cm}$ de la base. Se llena con arena de mar lavada de grano fino $(0,25-0,30 \mathrm{~mm})$ hasta $10 \mathrm{~cm}$ por encima del drenaje y se añade agua en cantidad suficiente para que ésta rebose por el mismo. La capilaridad garantiza que la capa de arena situada por encima de la línea de drenaje se mantenga permanentemente húmeda. 

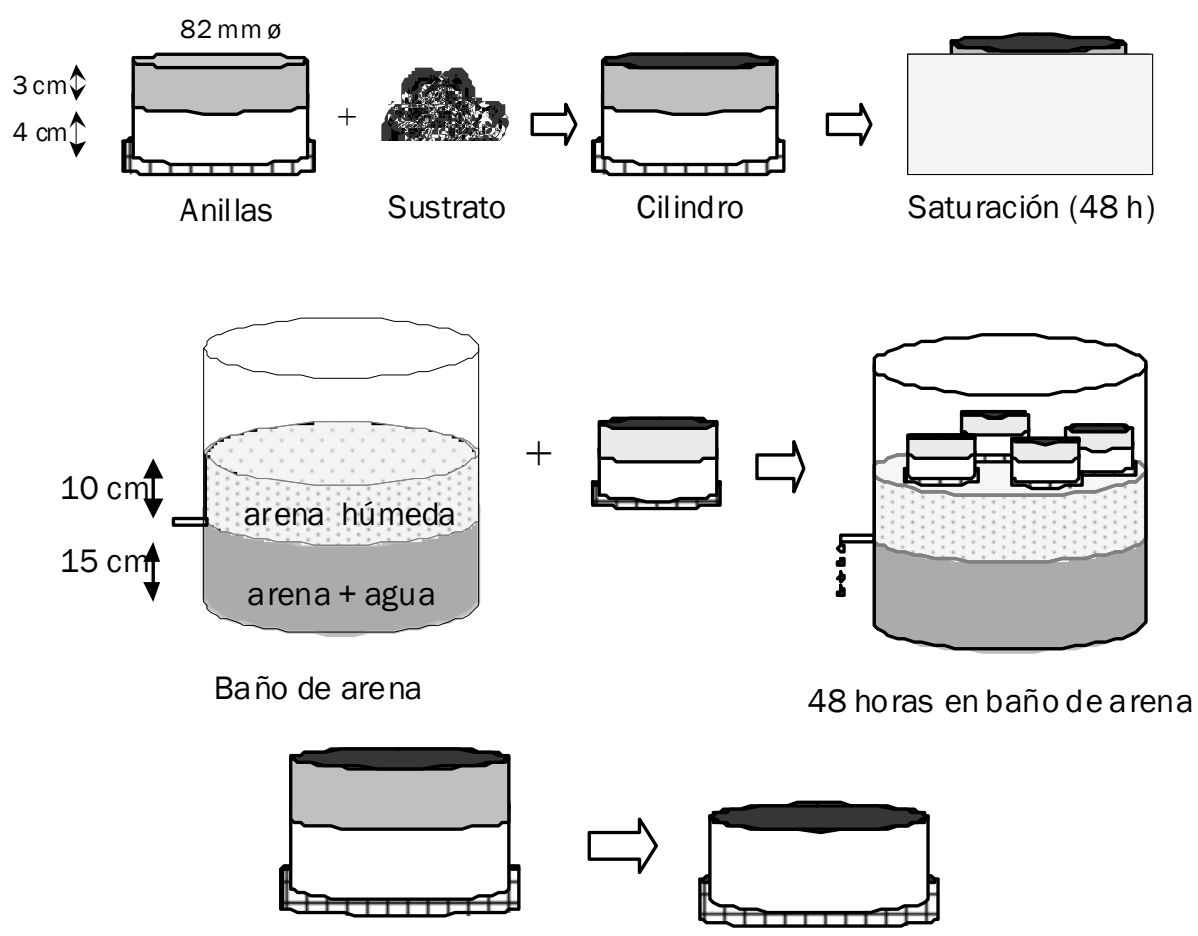

Separación de la anilla superior

Esquema del procedimiento utilizado en la determinación de la densidad aparente

Posteriormente, se saca el cilindro del baño de arena y se separan las anillas que lo forman, eliminando a continuación con una espátula el material sobrante de la anilla inferior $(4 \mathrm{~cm})$ para pesar el conjunto anilla+sustrato húmedo (B). Finalmente, se introduce el conjunto en estufa a $105^{\circ} \mathrm{C}$ hasta peso constante (C).

Con los valores de los pesos A, B y C, se calcula la humedad (X) -en porcentaje en peso- según la expresión:

$$
X(\%)=\frac{B-C}{B-A} \cdot 100
$$

Con los valores medios de la humedad, se estima la densidad aparente $\left(D_{A}\right)$ mediante la ecuación:

$$
D_{A}\left(k g / m^{3}\right)=\frac{B-A}{V} \cdot \frac{100-X}{100} \cdot 1000
$$

\section{I.1.2.3. Densidad de partícula}

La densidad de partícula $\left(D_{P}\right)$ es la relación entre la masa o el peso de las partículas y el volumen real que éstas ocupan -es decir, excluyendo el volumen poroso entre las mismas-, expresada en $\mathrm{kg} / \mathrm{m}^{3}$. 
La $D_{P}$ de los materiales inorgánicos o minerales se determina directamente por picnometría, mientras que en los materiales orgánicos la $D_{p}$ se estima indirectamente a partir de los contenidos en materia orgánica (MO) y en materia mineral (MM), determinados por calcinación (a $450^{\circ} \mathrm{C}$ ), según la siguiente ecuación:

$$
\mathrm{D}_{\mathrm{P}}\left(\mathrm{kg} / \mathrm{m}^{3}\right)=\frac{100}{\frac{\% \mathrm{MO}}{1550}+\frac{\% \mathrm{MM}}{2650}}
$$

donde $1550 \mathrm{~kg} / \mathrm{m}^{3}$ y $2650 \mathrm{~kg} / \mathrm{m}^{3}$ son la densidad media de la materia orgánica y la materia mineral, respectivamente.

Una descripción detallada del método se recoge en la Norma UNE-EN 13041:2001/A1 (2007).

\section{l.1.2.4. Porosidad total}

La porosidad total $\left(P_{T}\right)$ se calcula según la Norma UNE-EN 13041:2001/A1 (2007), a partir de los datos de densidad de partícula $\left(D_{P}\right)$ y densidad aparente $\left(D_{A}\right)$, aplicando la ecuación:

$$
P_{T}(\% v / v)=1-\frac{D_{A}}{D_{P}} \cdot 100
$$

\section{I.1.2.5. Volumen de agua}

El cálculo del volumen de agua retenida tras aplicar la presión hidrostática de 1 $\mathrm{kPa}$ al material humedecido en condiciones normalizadas, se realiza utilizando la ecuación recogida en la Norma UNE-EN 13041:2001/A1 (2007):

$$
\mathrm{V}_{\text {agua }}(\% \mathrm{v} / \mathrm{v})=\frac{\mathrm{B}-\mathrm{C}}{\mathrm{V}} \cdot 100
$$

donde $\mathrm{V}$ corresponde al volumen de la anilla de $4 \mathrm{~cm}$ utilizada para la determinación de la densidad aparente, y B y C son los pesos (de anilla + material) húmedo y seco, respectivamente, obtenidos para su cálculo (sección I.1.2.2).

\section{I.1.2.6. Volumen de aire}

El volumen de aire se calcula según la ecuación recogida en la Norma UNE-EN 13041:2001/A1 (2007): 


$$
\mathrm{V}_{\text {aire }}(\% \mathrm{~V} / \mathrm{v})=\mathrm{P}_{\mathrm{T}}-\mathrm{V}_{\text {agua }}
$$

donde $\mathrm{P}_{\mathrm{T}}$ es la porosidad total y $\mathrm{V}_{\text {agua }}$ el volumen de agua, ambos parámetros expresados en porcentaje de volumen (\% v/v).

\section{I.1.2.7. Mojabilidad}

La mojabilidad de los composts se determina siguiendo la Norma australiana AS 3743 (1993). Para ello, se seca un volumen de muestra de aproximadamente $300 \mathrm{~mL}$ a $40^{\circ} \mathrm{C}$ y posteriormente se coloca el material en un recipiente de $35 \mathrm{~mm}$ de altura. $\mathrm{A}$ continuación, se hace una pequeña depresión en el centro, de $50 \mathrm{~mm}$ de diámetro y 5 $\mathrm{mm}$ de profundidad. Por último, se añaden $10 \mathrm{~mL}$ de agua destilada en la depresión, midiéndose el tiempo (en minutos) que tarda el agua en infiltrarse en el material.

\section{I.1.2.8. Contracción de volumen}

La contracción de volumen $\left(\mathrm{C}_{\mathrm{t}}\right)$ se calcula, siguiendo la metodología recogida en la Norma UNE-EN 13041:2001/A1 (2007), como la pérdida de volumen aparente experimentada por el material húmedo contenido en la anilla de acero de $4 \mathrm{~cm}$ anteriormente descrita, tras secado a $105^{\circ} \mathrm{C}$ (ver la sección I.1.2.2), utilizando la siguiente ecuación:

$$
C_{t}(\% v / v)=\frac{V-V_{s s}}{v} \cdot 100
$$

donde $\mathrm{V}$ es el volumen de la anilla utilizada para la determinación de la densidad aparente y $V_{s s}$ el volumen de material contenido en la anilla tras secado a $105^{\circ} \mathrm{C}$.

El parámetro $V_{s s}$ se calcula a partir de la ecuación del volumen de un cilindro $\left(h \pi r^{2}\right)$, donde $r$ y $h$ se obtienen como valor medio de las medidas del diámetro (dos) y de la altura (cuatro), respectivamente, realizadas en el material seco contenido en la anilla.

\section{I.1.3. Características físico-químicas}

\section{l.1.3.1. Obtención del extracto acuoso 1/5 (v/v)}

Un gran número de propiedades físico-químicas y químicas de los composts se determinan sobre el extracto acuoso $1 / 5(\mathrm{v} / \mathrm{v})$ del material. Para su realización, en 
primer lugar se determina la densidad aparente compactada en laboratorio del material, utilizando un cilindro de ensayo rígido de $1 \mathrm{~L}$ que se llena con éste, sobre el que se aplica un pistón para mantener una presión de 9,17g/cm², expresando los resultados en g/L, según se especifica en el anexo A de la Norma UNE-EN 13040 (2008). Posteriormente, se coloca en un recipiente el peso equivalente a $60 \mathrm{~mL}$ de compost -calculado a partir del valor de la densidad aparente compactada- y $300 \mathrm{~mL}$ de agua. Tras una hora de agitación, la suspensión obtenida se filtra utilizando un sistema de vacío.

\section{I.1.3.2. $p H$}

La determinación del pH se lleva a cabo sobre la suspensión acuosa 1/5 (v/v) del material, inmediatamente después de la agitación y con anterioridad al filtrado de la misma, de acuerdo con la Norma UNE-EN 13037 (2001).

Para ello se utiliza un pH-metro marca CRISON modelo 2000 provisto de un electrodo CRISON modelo 5000-20.

\section{I.1.3.3. Conductividad eléctrica}

La conductividad eléctrica (CE) se determina en el extracto obtenido mediante filtración a vacío de la suspensión acuosa 1/5 (v/v), según describe la Norma UNE-EN 13038 (2001). Las medidas se realizan utilizando un conductímetro marca CRISON modelo 522, equipado con una célula de conductividad marca CRISON modelo 52-89. Tras efectuar la corrección de temperatura correspondiente, los resultados se expresan en $\mathrm{mS} / \mathrm{m}$ a $25^{\circ} \mathrm{C}$.

\section{I.1.3.4. Capacidad de intercambio catiónico}

La capacidad de intercambio catiónico (CIC) se determina según el método descrito por Harada e Inoko (1980), siguiendo además las modificaciones propuestas por Kakezawa et al. (1992) y Jokova et al. (1997). El procedimiento se fundamenta en el lavado del material con ácido clorhídrico y la posterior saturación del complejo de cambio con bario. Los protones así liberados se valoran con hidróxido de sodio, a partir de los cuales se calcula la capacidad de intercambio catiónico. 
Reactivos

Ácido clorhídrico $(\mathrm{HCl})$ 0,05 N

Hidróxido de sodio $(\mathrm{NaOH}) 0,1 \mathrm{~N}$

Acetato de bario $\left(\mathrm{Ba}\left(\mathrm{CH}_{3} \mathrm{COO}\right)_{2}\right) 1 \mathrm{~N}(\mathrm{pH} 7)$

Ácido oxálico $\left(\mathrm{C}_{2} \mathrm{H}_{2} \mathrm{O}_{4}\right)$

Rojo de metilo al 0,1\%

Procedimiento

En un matraz de $250 \mathrm{~mL}$ se pesa $1 \mathrm{~g}$ de muestra seca triturada y tamizada por malla de luz de 1,5 mm, preparándose además un matraz control, sin muestra, que se somete a idéntico procedimiento.

Se añaden $100 \mathrm{~mL}$ de $\mathrm{HCl}$ 0,05 $\mathrm{N}$ y se deja en reposo durante 18 horas. Se preparan embudos de percolación y se disponen sobre matraces de $250 \mathrm{~mL}$. Se agita la muestra con $\mathrm{HCl}$ y se vierte sobre los embudos de percolación. Una vez percolada toda la muestra, se lava sucesivamente el matraz original con agua destilada (4 veces, con $50 \mathrm{~mL}$ cada una) para recoger toda la muestra sólida sobre el embudo y retirar los restos de $\mathrm{HCl}$. A continuación, se sellan todos los orificios del embudo que contiene la muestra y se añaden a éste $100 \mathrm{~mL}$ de acetato de bario, dejándolo en reposo durante 24 horas. Transcurrido dicho periodo de tiempo, se filtra el acetato contenido en el embudo, recogiendo el filtrado, y se toma una alícuota de $25 \mathrm{~mL}$ para valorarlo después con $\mathrm{NaOH}$ 0,1 N (estandarizada con ácido oxálico), utilizando fenolftaleína como indicador.

La CIC se calcula mediante la ecuación:

$$
\operatorname{CIC}(\text { meq } / 100 \mathrm{~g} \mathrm{~ms})=\left(\mathrm{V}_{\mathrm{m}}-\mathrm{V}_{\mathrm{b}}\right) \cdot \mathrm{N}_{\mathrm{t}} \cdot \mathrm{f} \cdot \frac{100}{25} \cdot 100
$$

donde $\mathrm{V}_{\mathrm{m}}$ es el volumen (en mililitros) de $\mathrm{NaOH}$ utilizados en la valoración de la muestra, $\mathrm{V}_{\mathrm{b}}$ es el volumen (en mililitros) de $\mathrm{NaOH}$ utilizados en la valoración del control, $\mathrm{N}_{t}$ es la normalidad teórica del $\mathrm{NaOH}$, y f es el factor de corrección de la normalidad de la disolución de $\mathrm{NaOH}$ utilizada.

\section{I.1.4. Composición química. Fracción orgánica y mineral}

\section{I.1.4.1. Materia orgánica total (MOT) y cenizas}

La determinación del contenido en materia orgánica total (MOT) y cenizas se lleva a cabo siguiendo la metodología indicada en la Norma UNE-EN 13039 (2001). 
Para ello, se pesan $5 \mathrm{~g}$ de material seco a $105^{\circ} \mathrm{C}$ en un crisol de porcelana de 8 $\mathrm{cm}$ de diámetro. Tras calcinar a $450 \pm 25^{\circ} \mathrm{C}$ en un horno mufla durante 6 horas, se introduce el crisol en un desecador hasta alcanzar la temperatura ambiente y se pesa. La cantidad de cenizas presentes en la muestra (MM) se expresa como porcentaje de residuo seco referido a la masa seca inicial. La materia orgánica total (MO) se calcula como porcentaje de pérdida de masa referida a la masa seca inicial, utilizando la expresión:

$$
\mathrm{MO}(\%)=100-\mathrm{MM}(\%)
$$

\section{I.1.4.2. Carbono orgánico total (COT), nitrógeno total $\left(N_{T}\right)$ y relación $C O T / N_{T}$}

El carbono orgánico total (COT) y el nitrógeno total $\left(\mathrm{N}_{\mathrm{T}}\right)$ se determinan según el método de Navarro et al. (1991) de análisis elemental de carbono mediante la medida del anhídrido carbónico producido al quemar la muestra a $1020^{\circ} \mathrm{C}$ en un analizador elemental.

Reactivos

Atropina

$\mathrm{HCl} 1 / 10(\mathrm{v} / \mathrm{v})$

Procedimiento

La muestra tamizada por $0,5 \mathrm{~mm}$ se muele en un mortero de ágata hasta conseguir su completa homogeneización. Para el carbono orgánico total (COT) se pesan entre 1 y 2 mg, con precisión de 0,001 mg, en una cápsula de estaño, eliminando a continuación los carbonatos mediante la adición de unas gotas de una disolución de $\mathrm{HCl} 1 / 10(\mathrm{~V} / \mathrm{v})$, para posteriormente secarlo en estufa a $40^{\circ} \mathrm{C}$. Para el nitrógeno total $\left(\mathrm{N}_{\mathrm{T}}\right)$ se pesan entre 4 y $5 \mathrm{mg}$ de la muestra, con precisión de 0,001 mg. Ambas muestras, una vez secas, se introducen en un analizador elemental (CARLO ERBA, modelo ANA 1500), utilizando para el calibrado atropina.

La relación COT/ $\mathrm{N}_{\mathrm{T}}$ se calcula como ratio de los contenidos en COT y $\mathrm{N}_{\mathrm{T}}$.

\section{l.1.4.3. Carbono orgánico oxidable}

El carbono orgánico oxidable se determina mediante el método Walkley-Black (Walkley and Black, 1934), según se describe en el análisis de suelos (sección I.2.4.1), pero utilizando una cantidad de muestra de $50 \mathrm{mg}$ (Roca-Pérez et al., 2009). 


\section{l.1.4.4. Carbono orgánico extraíble en medio alcalino ( $\left.C_{E X T}\right)$. Fraccionamiento del carbono de ácido húmicos $\left(C_{A H}\right)$ y ácidos fúlvicos $\left(C_{A F}\right)$}

El carbono extraído con una disolución de hidróxido sódico y el carbono de la fracción fúlvica se determinan según las técnicas utilizadas por Sánchez-Monedero et al. (1996) y Cegarra et al. (1974), respectivamente, utilizando un analizador elemental para muestras líquidas mediante combustión a alta temperatura con oxidación catalítica.

Reactivos

$\mathrm{NaOH} \mathrm{0,1} \mathrm{M}$

$\mathrm{H}_{2} \mathrm{SO}_{4}$ concentrado (95\%)

Procedimiento

Para la determinación del carbono orgánico extraíble se realiza una extracción con $\mathrm{NaOH}$ 0,1 M en la proporción 1/20 (p/v) mediante agitación mecánica durante 4 horas y posterior centrifugación a 4000 rpm durante 20 minutos. El extracto así obtenido se filtra por malla de fibra sintética. De dicho filtrado se introduce una alícuota, con una dilución adecuada, en el analizador de carbono TOC-V CSH de la marca Shimadzu. El carbono total de la muestra se mide frente a una recta patrón preparada con hidrógeno ftalato de potasio anhidro en el intervalo 0-2000 mg/L, y el carbono inorgánico frente a una recta patrón preparada con $\mathrm{Na}_{2} \mathrm{CO}_{3} / \mathrm{NaHCO}_{3}$ (intervalo de 0 a $1000 \mathrm{mg} / \mathrm{L}$ ). El contenido de carbono orgánico se obtiene por diferencia entre el carbono total y el carbono inorgánico, y se expresa en porcentaje.

Para la determinación del carbono de ácidos húmicos y fúlvicos, una vez obtenido el extracto con hidróxido de sodio, se adiciona $\mathrm{H}_{2} \mathrm{SO}_{4}$ concentrado hasta $\mathrm{pH}$ 2, dejándolo reposar durante 24 horas para conseguir una completa precipitación de los ácidos húmicos. Éstos se separan del sobrenadante (fracción fúlvica) por decantación y posterior centrifugación a 4000 rpm durante 20 minutos. El líquido resultante se pasa por una malla de fibra sintética y, a continuación, se determina el carbono de los ácidos fúlvicos con la misma metodología que con el carbono orgánico extraíble. El carbono de los ácidos húmicos se calcula por diferencia del carbono extraíble y el carbono de los ácidos fúlvicos, expresando los resultados en porcentaje. 


\section{l.1.4.5. Carbono orgánico hidrosoluble $\left(C_{W}\right)$ y nitrógeno hidrosoluble $\left(N_{W}\right)$}

El carbono orgánico y el nitrógeno extraído con agua destilada ( $C_{w}$ y $N_{w}$, respectivamente) se determinan según la metodología propuesta por SánchezMonedero et al. (1996) en un analizador elemental para muestras líquidas. Se extrae la muestra con agua destilada en una proporción 1/20 (p/v) durante 2 horas. A continuación, se centrifuga a $4000 \mathrm{rpm}$ durante 20 minutos. El sobrenadante se filtra por malla de fibra sintética y se introduce una alícuota del filtrado en el analizador elemental. La determinación se realiza tal y como se ha indicado en I.1.4.4., utilizando en el caso del nitrógeno $\mathrm{KNO}_{3}$ para la recta patrón.

\section{I.1.4.6. Elementos solubles en agua regia}

Los elementos “totales” (P, K, S, Ca, Mg, Na, Fe, Mn, Zn, Cu, B y Mo) se extraen mediante digestión con agua regia y posteriormente se determinan mediante espectrofotometría de emisión atómica con plasma acoplado inductivamente (ICPAES), tal y como recoge la Norma UNE-EN 13650 (2002).

Reactivos

Ácido clorhídrico $12 \mathrm{M}$

Ácido nítrico 0,5 M

Las curvas de calibrado se preparan por dilución de los patrones obtenidos a partir de una disolución madre de 1000 mg/L ó 10000 mg/L

Procedimiento

Se pesa aproximadamente $1 \mathrm{~g}$ de muestra seca molida con precisión de 0,001 g en un matraz de reacción y se humedece con $1 \mathrm{~mL}$ de agua. A continuación, se añaden lentamente, mientras se agita la muestra, $21 \mathrm{~mL}$ de ácido clorhídrico $12 \mathrm{M}$, seguido de $8 \mathrm{~mL}$ de ácido nítrico. Se deja reposar la muestra durante 16 horas a temperatura ambiente, permitiendo así la lenta oxidación de la materia orgánica de la muestra. Una vez transcurrido dicho período de tiempo, se añaden varias bolas de vidrio y se coloca el matraz en un aparato calefactor, ensamblándose en la parte superior del recipiente un condensador de reflujo, tipo "straight-through". Se eleva lentamente la temperatura de la mezcla de reacción hasta que se alcanzan las condiciones de reflujo y éstas se mantienen durante 2 horas con la zona de condensación por debajo de $1 / 3$ de la altura del condensador. Una vez finalizada la digestión, se deja enfriar la mezcla y se transfiere a un matraz aforado de $100 \mathrm{~mL}$, 
enrasando con agua destilada y dejando sedimentar los compuestos en suspensión. Finalmente, se filtra el sobrenadante sobre papel de filtro cuantitativo sin cenizas para proceder a la determinación del contenido en los elementos indicados. Para ello, se utiliza un espectrofotómetro de emisión atómica con plasma acoplado inductivamente con nebulizador "cross-flow" y Ar 5,6 a una presión de 2,9 bar (ICP-AES Spectroflame, marca Spectro Analytical Instruments Inc.). En el caso de la determinación de P y S, y con el fin de evitar la interferencia de las bandas de emisión del $\mathrm{O}_{2}$, el equipo se purgó con $\mathrm{N}_{2} 4,8$ a baja presión durante 2 horas. Las condiciones analíticas utilizadas se recogen en la siguiente tabla:

Condiciones analíticas utilizadas para la determinación de elementos minerales

\begin{tabular}{lccc}
\hline Elemento & $\begin{array}{c}\text { Longitud de onda } \\
(\mathrm{nm})\end{array}$ & $\begin{array}{c}\text { Rango dinámico } \\
(\mathrm{mg} / \mathrm{L})\end{array}$ & $\begin{array}{c}\text { Límite de detección } \\
(\mathrm{mg} / \mathrm{L})\end{array}$ \\
\hline $\mathrm{P}$ & 214,914 & $0-10 ; 0-100$ & 0,$0009 ; 0,0006$ \\
$\mathrm{~K}$ & 766,491 & $0-100 ; 0-500$ & 0,$007 ; 0,013$ \\
$\mathrm{~S}$ & 182,040 & $0-100 ; 0-250$ & 0,$032 ; 0,019$ \\
$\mathrm{Ca}$ & 318,128 & $0-50 ; 0-200$ & 0,$015 ; 0,018$ \\
$\mathrm{Mg}$ & 279,553 & $0-50 ; 0-100$ & 0,$010 ; 0,012$ \\
$\mathrm{Na}$ & 589,592 & $0-20 ; 0-200 ; 0-500$ & 0,$002 ; 0,018 ; 0,038$ \\
$\mathrm{Fe}$ & $0-5 ; 0-10$ & 0,$0012 ; 0,0040$ \\
$\mathrm{Zn}$ & 238,204 & $0-0,5 ; 0-1$ & 0,$0001 ; 0,0001$ \\
$\mathrm{Cu}$ & 206,190 & $0-0,5 ; 0-1$ & 0,$0001 ; 0,0001$ \\
$\mathrm{Mn}$ & 327,396 & $0-5 ; 0-10$ & 0,$0006 ; 0,0003$ \\
$\mathrm{Mo}$ & 257,610 & $0-5 ; 0-10$ & 0,$0007 ; 0,0003$ \\
$\mathrm{~B}$ & 202,03 & $0-3 ; 0-5$ & 0,$001 ; 0,006$ \\
\hline
\end{tabular}

\section{I.1.4.7. Nitrógeno mineral (amoniacal y nítrico)}

a) Nitrógeno amoniacal

Para determinar el nitrógeno amoniacal $\left(\mathrm{N}-\mathrm{NH}_{4}{ }^{+}\right)$se realiza una extracción 1/20 $(\mathrm{p} / \mathrm{v})$ con $\mathrm{KCl}(2 \mathrm{M})$ de la muestra fresca, mediante agitación mecánica durante 2 horas. Posteriormente se centrifuga a 4000 rpm durante 15 minutos y se filtra con papel de filtro cuantitativo (Sommers et al., 1992). 
b) Nitrógeno nítrico

Se realiza una extracción del nitrógeno nítrico $\left(\mathrm{N}^{-\mathrm{NO}_{3}}{ }^{-}\right)$1/20 (p/v) de la muestra fresca con agua destilada, mediante agitación mecánica durante 2 horas. Posteriormente se centrifuga a $4000 \mathrm{rpm}$ durante 15 minutos y se filtra con papel de filtro cuantitativo (Bernal et al., 1998).

La determinación de nitrógeno nítrico y amoniacal se lleva a cabo mediante análisis de inyección en flujo FIA (ver sección I.2.4.4).

\section{I.1.4.8. Elementos minerales solubles en agua}

Para determinar P, K, S, Ca, Mg, Na, Fe, Zn, Cu, Mn, Mo y B solubles en agua se filtra el extracto 1/5 (v/v) -obtenido según se describe en la sección I.1.3.1- sobre papel de filtro cuantitativo sin cenizas y se procede a la determinación de los elementos mediante espectrofotometría de emisión atómica con plasma acoplado inductivamente (ICP-AES) (ver sección I.1.4.6) según se especifica en la Norma UNEEN 13652 (2002).

La determinación de $\mathrm{N}-\mathrm{NH}_{4}{ }^{+}$y $\mathrm{N}_{-} \mathrm{NO}_{3}$ - se realiza por arrastre de vapor mediante destilación de los extractos acuosos 1/5 (v/v) (Norma UNE-EN 13652, 2002) y los extractos en $\mathrm{CaCl}_{2}$-DTPA $1 / 5$ (v/v) (Norma UNE-EN 13651, 2002), respectivamente, utilizando MgO y aleación Devarda en un analizador de nitrógeno semiautomático (Puchades et al., 1985)

Reactivos

Aleación Devarda

Óxido de magnesio anhidro

Disolución concentrada de indicador: Disolver $1 \mathrm{~g}$ de verde de bromocresol y 0,66 g de rojo de metilo y aforar a un litro con etanol $96^{\circ}$

Ácido bórico-indicador: Disolver, mediante agitación y calentamiento, 20 g de $\mathrm{H}_{3} \mathrm{BO}_{3}$ en $800 \mathrm{~mL}$ de agua destilada y adicionar $20 \mathrm{~mL}$ de disolución concentrada de indicador. Ajustar la mezcla a $\mathrm{pH} 5$ y aforar a $1 \mathrm{~L}$ con agua destilada

$\mathrm{H}_{2} \mathrm{SO}_{4} 0,01 \mathrm{~N}$ y $0,05 \mathrm{~N}$, preparadas a partir de $\mathrm{H}_{2} \mathrm{SO}_{4}$ concentrado (95\%) 


\section{Procedimiento}

Se toman $25 \mathrm{~mL}$ de extracto y se introducen en un tubo de la unidad de destilación 2200 Kjeltec Auto Distillation marca FOSS Tecator. A continuación, se adicionan 0,2 g de $\mathrm{MgO}$ anhidro y se destila en corriente de vapor durante 2 minutos y 40 segundos, recogiendo aproximadamente $150 \mathrm{~mL}$ de destilado sobre $20 \mathrm{~mL}$ de ácido bórico-indicador para obtener el $\mathrm{N}_{-} \mathrm{NH}_{4}{ }^{+}$. Seguidamente, se añaden al tubo anterior 0,2 g de aleación Devarda y se procede del modo descrito anteriormente para obtener el $\mathrm{N}^{-\mathrm{NO}_{3}}$. Por valoración del $\mathrm{NH}_{3}$ obtenido en las dos destilaciones sucesivas se determinan las concentraciones de N-nítrico y N-amoniacal, utilizando para ello $\mathrm{H}_{2} \mathrm{SO}_{4} 0,01 \mathrm{~N}$ ó 0,05 N, según la cantidad obtenida. El punto final de la valoración se detecta visualmente por viraje de la disolución de color verde a rojizo.

Los resultados se expresan en mg de $\mathrm{N}$ por kg de materia seca.

\section{I.1.4.9. Elementos minerales solubles en $\mathrm{CaCl}_{2}-\mathrm{DTPA}$ (CAT)}

La determinación de $\mathrm{N}^{-\mathrm{NH}_{4}}{ }^{+}$y $\mathrm{N}^{-\mathrm{NO}_{3}}, \mathrm{P}, \mathrm{K}, \mathrm{S}, \mathrm{Mg}, \mathrm{Na}, \mathrm{Fe}, \mathrm{Zn}, \mathrm{Cu}, \mathrm{Mn}, \mathrm{Mo}$ y $\mathrm{B}$ solubles en $\mathrm{CaCl}_{2}$-DTPA (extracto $1 / 5, \mathrm{v} / \mathrm{v}$ ) se realiza tal y como se recoge en la Norma UNE-EN 13651 (2002), siguiendo el procedimiento señalado en la sección I.1.4.8, pero utilizando dicho extractante (en lugar de agua destilada) para disolver los elementos minerales y en la preparación de los patrones.

\section{I.1.4.10. Carbonatos}

La determinación se realiza utilizando el calcímetro de Bernard (MAPA, 1994), según se describe en la sección I.2.4.9, pero utilizando alrededor de 1 g de muestra de compost (García de la Fuente et al., 2007).

\section{I.1.4.11. Sulfatos}

Para la determinación del contenido en sulfatos se utiliza el método gravimétrico con incineración del residuo según Eaton et al. (2005).

Reactivos

Ácido clorhídrico $\mathrm{HCl} 18,25 \mathrm{~N}$

Solución de cloruro de bario: Disolver $100 \mathrm{~g} \mathrm{BaCl}_{2} \cdot 2 \mathrm{H}_{2} \mathrm{O}$ en $1 \mathrm{~L}$ de agua destilada Solución extractante de $\mathrm{CaCl}_{2}$ 0,15\%: Disolver 1,986 g de $\mathrm{CaCl}_{2} \cdot 2 \mathrm{H}_{2} \mathrm{O}$ en $1 \mathrm{~L}$ de agua destilada 
Reactivo de nitrato de plata y ácido nítrico: Disolver 8,5 g $\mathrm{AgNO}_{3}$ y 0,5 $\mathrm{mL}$ de ácido nítrico $36 \%$ en $500 \mathrm{~mL}$ de agua destilada.

Procedimiento

Se pesan $2 \mathrm{~g}$ de compost y se añaden $40 \mathrm{~mL}$ de la solución extractante en un matraz erlenmeyer, agitando la suspension durante 1 hora. A continuación, se centrifuga a $5000 \mathrm{rpm}$ durante 5 minutos a $21^{\circ} \mathrm{C}$, recuperando el sobrenadante en otro matraz. Se repite dicho procedimiento (adición de solución extractante, agitación y centrifugación) sobre la misma muestra (extracción secuencial) hasta que no se detecta una cantidad apreciable de sulfatos en ésta (García de la Fuente et al., 2007). Se añaden 1 ó 2 gotas de $\mathrm{HCl}$ 18,25 N hasta pH próximo a 2. Después se calienta hasta ebullición, y en ese instante se añade poco a poco el cloruro de bario tibio hasta la aparición del precipitado, mientras se agita suavemente el erlenmeyer. El precipitado obtenido se mantiene a $80-90^{\circ} \mathrm{C}$ al menos durante 2 horas. Transcurrido este tiempo se filtra la muestra a través de papel sin cenizas y se añade otro papel de filtro troceado para asegurar que el precipitado queda retenido en el filtro. Se lava el precipitado con pequeñas alícuotas de agua destilada tibia hasta obtener lixiviados exentos de cloruros, es decir hasta que no aparezca precipitado blanco al añadir una gota de reactivo $\mathrm{AgNO}_{3}-\mathrm{HNO}_{3}$ en el lixiviado. Se calcina el papel de filtro con el precipitado a $800^{\circ} \mathrm{C}$ durante 1 hora. Se enfría en desecador y se pesa en balanza analítica.

El contenido de sulfatos en el extracto de la muestra se determina mediante la siguiente ecuación:

$$
\mathrm{SO}_{4}{ }^{2-}(\mathrm{mg} / \mathrm{L})=\frac{\mathrm{mg} \mathrm{BaSO}}{4} \frac{\mathrm{M}_{\mathrm{SO}_{4}^{2-}}}{\mathrm{mLmuestra}_{\mathrm{BaSO}_{4}}} \cdot 1000
$$

donde $\mathrm{M}_{\mathrm{SO}_{4}^{2-}}$ es la masa molar del $\mathrm{SO}_{4}{ }^{2-}(96,06 \mathrm{~g})$ y $\mathrm{M}_{\mathrm{BaSO}_{4}}$ la masa molar del $\mathrm{BaSO}_{4}$ $(233,39 \mathrm{~g})$.

Los resultados se presentan como contenido en $\mathrm{CaSO}_{4}$, expresado en porcentaje sobre materia seca.

\section{I.1.4.12. Lignina, celulosa y hemicelulosa}

Para el análisis de estos biopolímeros se sigue la determinación secuencial de fibras detergentes, utilizando la metodología propuesta por Van Soest et al. (1991) con un tratamiento previo de la muestra con amilasa termoestable (Giger, 1995). 


\section{Reactivos}

Solución NDF: Disolver 18,61 g de EDTA, 6,81 g de tetraborato sódico, $30 \mathrm{~g}$ de lauril sulfato de sodio y 4,56 g de fosfato disódico anhidro en agua destilada, añadir $10 \mathrm{~mL}$ de trietilenglicol, y aforar a $1 \mathrm{~L}$. Comprobar que el pH está en el rango 6,9-7,1

Solución ADF: Pesar 20 g de bromuro de cetiltrimetilamonio y llevar a $1 \mathrm{~L}$ con $\mathrm{H}_{2} \mathrm{SO}_{4} 1 \mathrm{~N}$

$\mathrm{H}_{2} \mathrm{SO}_{4}$ al $72 \%$ : Disolver $700 \mathrm{~mL}$ de $\mathrm{H}_{2} \mathrm{SO}_{4} 96 \%$ en $300 \mathrm{~mL}$ de agua destilada Antiespumante: alfa-amilasa termoestable 3306 (Sigma-Aldrich Química, S.A.).

Procedimiento

Los porcentajes de lignina, celulosa y hemicelulosa se calculan a partir de la determinación de los contenidos de fibra neutro detergente (NDF, que incluye hemicelulosa, celulosa y lignina), fibra ácido detergente (ADF, hemicelulosa y lignina), y lignina ácido detergente (ADL, lignina). Se utiliza un equipo analizador de fibra ANKOM200/220, equipado con bolsas de filtración, sistema de filtración, sellador de calor, y bolsas antihumedad.

a) Determinación de NDF

Se pesan 0,5 g de muestra seca y molida (D) -con una precisión de 0,1 mg- en una bolsa de filtración previamente pesada (B). Se sella la bolsa a 0,5 cm del extremo abierto utilizando un sellador de calor. Se repite esta operación con una bolsa vacía que se utilizará como blanco, y se pesa (A). Después se colocan las bolsas en el suspensor y se introducen en el depósito de digestión del analizador. Se cierra el desagüe del depósito de digestión y se añaden 1900-2000 mL de disolución NDF a temperatura ambiente, $20 \mathrm{~g}$ de sulfito sódico y $1 \mathrm{~mL}$ de la enzima alfa-amilasa termoestable. Se programa el equipo de modo que transcurridos 75 minutos cese la agitación y calefacción. Se abre la válvula de desagüe con el fin de evacuar la disolución caliente, tras lo cual ésta se cierra y se abre la tapa. Se añaden 1900-2000 $\mathrm{mL}$ de agua caliente $\left(90-100^{\circ} \mathrm{C}\right)$ para el lavado, se enciende, se cierra la tapa, y se agitan las bolsas en el agua de lavado durante 5 minutos (repetir esta operación 2 veces). A continuación se retiran las bolsas de filtrado del suspensor, se elimina el exceso de agua y se introducen en un vaso de $250 \mathrm{~mL}$, cubriéndolas con acetona. Transcurridos tres minutos, se toman las bolsas y se secan - primero al aire y después en estufa a $103 \pm 2^{\circ} \mathrm{C}$ - durante 4 horas. Finalmente, se enfrían en desecador y se pesan $\left(\mathrm{P}_{\mathrm{NDF}}\right)$. 
b) Determinación de ADF

Se sitúan las bolsas procedentes de la etapa anterior en el suspensor, se introduce éste en el depósito de reacción y se añaden 1900-2000 mL de la disolución ADF. Se procede tal y como se ha descrito para la fibra neutro detergente (NDF). Finalmente, se pesan las bolsas $\left(\mathrm{P}_{\mathrm{ADF}}\right)$.

c) Determinación de $A D L$

Las bolsas procedentes de la determinación de ADF se colocan en un vaso de precipitados de $3 \mathrm{~L}$ y se recubren con ácido sulfúrico al 72\% ( 250 mL). Tras mantenerlas en este medio durante 3 horas, agitando a intervalos de 30 minutos, se elimina el ácido sulfúrico y se lavan con agua caliente $\left(90-100^{\circ} \mathrm{C}\right)$ hasta $\mathrm{pH}$ neutro. Luego se realiza un lavado con $250 \mathrm{~mL}$ de acetona (3 minutos) para eliminar el agua, y se secan las bolsas - primero al aire y posteriormente en estufa de desecación a $103^{\circ} \mathrm{C}$ - durante 4 horas. Finalmente, se pesan las bolsas $\left(P_{A D L}\right)$ y se incineran a $550^{\circ} \mathrm{C}$ durante 5 horas en crisoles de porcelana previamente tarados, pesando los crisoles tras la calcinación.

Cálculos

El porcentaje de fibra obtenido en cada determinación se calcula utilizando las ecuaciones siguientes:

$$
\begin{aligned}
& \operatorname{NDF}(\%)=\frac{P_{N D F}-\left(C_{M}-B \cdot \frac{C_{b}}{A}\right)}{\frac{D \cdot M S}{100}} \cdot 100 \\
& A D F(\%)=\frac{P_{A D F}-\left(C_{M}-B \cdot \frac{C_{b}}{A}\right)}{\frac{D \cdot M S}{100}} \cdot 100 \\
& A D L(\%)=\frac{P_{A D L}-\left(C_{M}-B \cdot \frac{C_{b}}{A}\right)}{\frac{D \cdot M S}{100}} \cdot 100
\end{aligned}
$$

donde $C_{M}$ es el contenido en cenizas de la muestra, $C_{b}$ el contenido en cenizas del blanco, B el peso de la bolsa de filtración vacía que se usa para la muestra, A el peso de la bolsa de filtración vacía que se usa como blanco, D el peso de la muestra, y MS el porcentaje de materia seca de la muestra.

El contenido en los diferentes componentes fibrosos se obtiene a partir de los porcentajes de NDF, ADF y ADL, tal como se indica a continuación: 
Hemicelulosa $(\%)=$ NDF $(\%)-$ ADF $(\%)$

Celulosa $(\%)=\operatorname{ADF}(\%)-\operatorname{ADL}(\%)$

Lignina $(\%)=A D L(\%)$

\section{I.1.4.13. Grasas}

Reactivos

Éter etílico

Procedimiento

Para la determinación de las grasas en los composts se realiza una extracción mediante sistema Soxhlet (Alburquerque et al., 2004) de 2,5 g de muestra, con precisión de $0,0001 \mathrm{~g}$, con $250 \mathrm{~mL}$ de éter etílico a $35^{\circ} \mathrm{C}$ durante 2 horas. Tras recuperar gran parte del éter (200 mL aproximadamente), se filtra la disolución por fibra de celulosa sobre un vaso de precipitados, y se deja evaporar el éter. A continuación se seca en estufa a $80^{\circ} \mathrm{C}$ durante 4 horas. El contenido en grasa se calcula por diferencia de peso respecto a la muestra seca inicial en mg por kg.

\section{I.1.4.14. Polifenoles solubles}

Los polifenoles solubles se determinan colorimétricamente mediante una modificación del método de Folin-Ciocalteu (Kuwatsuka y Shindo, 1973), según se indica en la Orden PRE/630/2011, de 23 de marzo, utilizando ácido p-cumárico para la recta de calibrado.

Reactivos

$\mathrm{Na}_{2} \mathrm{CO}_{3}$ al $20 \%$

Reactivo Folin-Ciocalteu

Ácido p-cumárico

Procedimiento

Se realiza una extracción de la muestra con agua desionizada en la proporción 1/20 (p/v) mediante agitación mecánica durante 2 horas, centrifugando la suspensión a continuación a 4000 rpm durante 5 minutos. La recta patrón se prepara a partir de una disolución de $60 \mathrm{mg} / \mathrm{L}$ de ácido p-cumárico. En matraces aforados de $50 \mathrm{~mL}$ se añaden $0,1,2,3,4$ y $5 \mathrm{~mL}$ de la disolución anterior; posteriormente se adicionan 2,5 $\mathrm{mL}$ de reactivo Folin-Ciocalteu, se agita, y, tras 3 minutos, se añaden 5 $\mathrm{mL}$ de la disolución de $\mathrm{Na}_{2} \mathrm{CO}_{3}$ al $20 \%$ y se lleva a enrase con agua destilada. En 
matraces aforados de $50 \mathrm{~mL}$ se añaden $0,5 \mathrm{~mL}$ del extracto acuoso problema y se sigue el mismo procedimiento utilizado en los patrones. Estas disoluciones y las de la recta patrón se dejan en reposo 1 hora y se mide la absorbancia en un espectrofotómetro Jenway UV/visible 6300 (Bibby Scientific) a $\lambda=625 \mathrm{~nm}$, calculándose la concentración de polifenoles respecto a la recta patrón.

\section{I.1.4.15. Carbohidratos solubles}

Los carbohidratos solubles se determinan por el método de la antrona descrito por Brink et al. (1960).

\section{Reactivos}

Disolución de antrona al 0,2\% en $\mathrm{H}_{2} \mathrm{SO}_{4}$ concentrado (96\%)

Glucosa

Procedimiento

Se realiza una extracción de la muestra con agua destilada en la proporción 1/20 (p/v) mediante agitación mecánica durante 2 horas, centrifugando la suspensión a continuación a 4000 rpm durante 5 minutos.

Para la determinación de los carbohidratos solubles en el extracto se prepara una recta patrón a partir de una disolución de $25 \mathrm{mg} / \mathrm{L}$ de glucosa. Se toman $5 \mathrm{~mL}$ de extracto acuoso problema o de la recta patrón y se añaden $10 \mathrm{~mL}$ de disolución de antrona 0,2\%, se agita unos 15 segundos, y se deja en reposo durante 15 minutos para que desarrolle color. Después de este tiempo, se mide la absorbancia de las disoluciones coloreadas en un espectrofotómetro Jenway UV/visible 6300 (Bibby Scientific) a $\lambda=625 \mathrm{~nm}$ y se determina la concentración de carbohidratos respecto a la recta patrón.

\section{I.1.4.16. Metales pesados}

La determinación de los metales pesados se realiza mediante digestión con agua regia de la muestra, tal y como se describe en I.1.4.6, y posterior análisis, utilizando espectrofotometría de emisión atómica con plasma acoplado inductivamente (ICPAES; Spectroflame, Spectro Analytical Instruments, Inc.) para los elementos $\mathrm{Cd}, \mathrm{Cu}, \mathrm{Ni}$, $\mathrm{Pb}, \mathrm{Zn}$ y $\mathrm{Cr}$, mientras que el Hg se determina mediante espectroscopía de absorción atómica empleando la técnica de vapor frío (CV-ASS; Analyst 100 PerkinElmer, Inc.) de acuerdo con la Norma UNE-EN 13806 (2003). 
El cromo hexavalente $(\mathrm{Cr} \mathrm{VI})$ se determina por reacción con difenilcarbacida tras digestión alcalina de la muestra, según lo especificado en el Real Decreto 824/2005, de 8 julio, sobre Productos Fertilizantes.

\section{I.1.5. Propiedades biológicas. Actividad y biomasa microbiana. Bioensayos de germinación}

\section{I.1.5.1. Enumeración de poblaciones microbianas}

Se realizan recuentos de los siguientes grupos microbianos: bacterias autótrofas, bacterias heterótrofas, actinomicetos, y mohos y levaduras.

Para el recuento de estos grupos microbianos se pesan, en condiciones de asepsia, $10 \mathrm{~g}$ de muestra previamente homogeneizada, que se depositan en un erlenmeyer con $90 \mathrm{~mL}$ de agua de peptona tamponada -obtenida disolviendo $20 \mathrm{~g}$ de peptona en un litro de agua destilada- (dilución $10^{-1}$ ). El erlenmeyer se agita a $28^{\circ} \mathrm{C}$ durante 15 minutos. A continuación, se preparan diluciones decimales seriadas desde $10^{-1}$ hasta $10^{-8}$ para realizar el recuento en placa en medio selectivo.

Recuento de bacterias autótrofas (y oxidadoras del azufre)

Se utiliza el medio de cultivo 126 de la Colección del Instituto Pasteur (Thl). Este medio se prepara diluyendo $5 \mathrm{~g}$ de extracto de levadura, $5 \mathrm{~g}$ de $\mathrm{Na}_{2} \mathrm{~S}_{2} \mathrm{O}_{3}, 1,5 \mathrm{~g}$ de $\mathrm{K}_{2} \mathrm{HPO}_{4}, 4,5 \mathrm{~g} \mathrm{Na}_{2} \mathrm{HPO}_{4}, 0,1 \mathrm{~g}$ de $\mathrm{MgSO}_{4} \cdot 7 \mathrm{H}_{2} \mathrm{O}$ y 0,3 g de $\mathrm{NH}_{4} \mathrm{Cl}$ en $1 \mathrm{~L}$ de agua destilada. Se ajusta el pH a 7 y se añaden 15 g de agar. Una vez autoclavado durante 15 minutos a $121^{\circ} \mathrm{C}$, el medio se enfría en baño de agua a $50^{\circ} \mathrm{C}$ y se reparte en placas petri que se guardan en nevera a $3^{\circ} \mathrm{C}$ hasta su utilización. Los días de muestreo se sacan las placas de la nevera 1 hora antes de realizar la siembra en superficie. Para dicha siembra, se toman $0,1 \mathrm{~mL}$ por placa de cada uno de los tubos de las diluciones, sembrándolos mediante pipeta de punta paja en dos placas petri estériles de $90 \mathrm{~mm}$ de diámetro. Se extienden uniformemente los $0,1 \mathrm{~mL}$ de dilución mediante la ayuda de un asa Drigalsky estéril y las placas se dejan secar a temperatura ambiente antes de ser incubadas a $28^{\circ} \mathrm{C}$ en posición invertida. A las 48 horas se realizan los recuentos de colonias de bacterias autótrofas, calculando la media aritmética de las 2 placas y expresando el resultado como el logaritmo de las unidades formadoras de colonias por g de compost (log UFC/g). 
Recuento de bacterias heterótrofas

El medio utilizado para este recuento es Plate Count Agar (PC), que se prepara diluyendo $22,5 \mathrm{~g}$ de PC (Merck) en $1 \mathrm{~L}$ de agua destilada y esterilizando a $121^{\circ} \mathrm{C}$ durante 15 minutos. Transcurrido este tiempo, el medio se lleva a baño de agua a $50^{\circ} \mathrm{C}$ hasta su utilización. Se realiza una siembra en profundidad, tomando $1 \mathrm{~mL}$ por placa petri de cada uno de los tubos correspondientes a las diluciones y depositándolo mediante pipeta de punta paja en dos placas petri estériles de $90 \mathrm{~mm}$ de diámetro. A continuación, se vierte el PC líquido en las placas y éstas se agitan con movimientos circulares suaves. Las placas se dejan enfriar a temperatura ambiente hasta la solidificación del medio, se invierten, y se incuban a $28^{\circ} \mathrm{C}$. Transcurridas 48 horas, se realiza el recuento de las colonias presentes, expresando los resultados en log UFC/g.

\section{Recuento de actinomicetos}

El medio utilizado para este recuento es Actinomycete Isolation Agar (AIA), que se prepara diluyendo $22 \mathrm{~g}$ de AIA comercial (Difco) más $5 \mathrm{~g}$ de glicerol en $1 \mathrm{~L}$ de agua destilada. Tras ser autoclavado durante 15 minutos a $121^{\circ} \mathrm{C}$, el medio se enfría en baño de agua a $50^{\circ} \mathrm{C}$ y se vierte en placas petri, que se guardan en nevera a $3^{\circ} \mathrm{C}$ hasta su utilización. Los días de muestreo se sacan las placas de la nevera 1 hora antes de realizar la siembra en superficie. Para ello, se toman $0,1 \mathrm{~mL}$ por placa de cada uno de los tubos correspondientes a las diluciones, depositándolos mediante pipeta de punta paja en placas petri estériles de $90 \mathrm{~mm}$ de diámetro por duplicado y, a continuación, se extiende el extracto diluido mediante un asa Drigalsky estéril. Las placas se dejan secar a temperatura ambiente antes de ser incubadas a $28^{\circ} \mathrm{C}$ en posición invertida, y, tras 10 días de incubación, se realizan los recuentos de actinomicetos, presentando los resultados en log UFC/g.

\section{Recuento de mohos y levaduras}

El medio utilizado para este recuento es Agar Sabouraud (Sab), que se prepara diluyendo 65 g de Sabouraud comercial (Merck) y 0,5 g de cloranfenicol (Panreac) en $1 \mathrm{~L}$ de agua, y autoclavando 15 minutos a $121^{\circ} \mathrm{C}$. Transcurrido este tiempo, el medio se lleva a baño de agua a $50^{\circ} \mathrm{C}$ hasta su utilización. Como en el caso del medio PC, se realiza una siembra en profundidad, tomando $1 \mathrm{~mL}$ por placa de cada uno de los tubos correspondientes a las diluciones y depositándolo mediante pipeta de punta paja en dos placas petri estériles de $90 \mathrm{~mm}$ de diámetro. El resto del procedimiento 
es idéntico al explicado en el caso del recuento de bacterias heterótrofas, con la excepción de que el recuento se realiza transcurridas 72 horas de incubación a $28^{\circ} \mathrm{C}$.

\section{I.1.5.2. Actividad microbiana}

Para determinar la actividad microbiana se utiliza el método de la hidrólisis del diacetato de fluoresceína (FDA; Schnürer y Rosswall, 1982) y la medida de la respiración basal. Para ello, los composts se humedecieron hasta alcanzar el $60 \%$ de su capacidad de contenedor (equivalente al volumen de agua, sección 1.12.5) y se preincubaron a $28^{\circ} \mathrm{C}$ durante 24 horas.

Hidrólisis del diacetato de fluoresceína (FDA)

Reactivos

$\mathrm{NaH}_{2} \mathrm{PO}_{4} 60$ mM estéril pH 7,6

Diacetato de fluoresceína (FDA): Preparar una disolución stock de FDA en acetona de concentración 2000 ppm y, a partir de ésta, diluir hasta una concentración final de 10 ppm. Para la curva de calibrado, preparar una disolución de FDA de concentración equivalente a 100 ppm en $\mathrm{NaH}_{2} \mathrm{PO}_{4} 60$ mM estéril pH 7,6 y hervir durante 30 minutos

Procedimiento

Se pesan aproximadamente $5 \mathrm{~g}$ de muestra preincubada en un erlenmeyer, se añaden $20 \mathrm{~mL}$ de $\mathrm{NaH}_{2} \mathrm{PO}_{4} 60 \mathrm{mM}$ y $400 \mu \mathrm{L}$ de la disolución de FDA de concentración de 10 ppm, y se agita la suspensión a $25^{\circ} \mathrm{C}$ durante 20 minutos. Una vez transcurrido este tiempo, se añaden $10 \mathrm{~mL}$ de acetona y, a continuación, se centrifuga a $6000 \mathrm{rpm}$ durante 5 minutos y se filtra el sobrenadante. La curva de calibración se prepara a partir del FDA prehidrolizado (100 ppm) en tampón fosfato con cantidades conocidas de FDA y 5 g de material en cada uno de los patrones. Se mide la absorbancia con un espectrofotómetro Jenway UV/visible 6300 (Bibby Scientific) a $\lambda=490 \mathrm{~nm}$.

\section{Respiración basal}

Para determinar la respiración basal del compost preincubado se mide el oxígeno consumido tras 48 horas con un detector Dräger MiniWarn equipado con un sensor XS 202 - 6810375 (Dräger Safety AG and Co.), expresando la respiración como $\mathrm{mg}$ de $\mathrm{O}_{2}$ consumido por kg de compost seco por día. 


\section{I.1.5.3. Bioensayos de germinación y crecimiento}

Bioensayo 1: germinación de semillas de berro y lechuga

Los bioensayos de germinación se basan en la colocación de semillas de una o varias especies vegetales en contacto con el extracto acuoso del material a testar, controlando la tasa de germinación de dichas semillas y la elongación de las radículas emergidas en comparación con un control (Zucconi et al., 1981a, 1981b).

Los bioensayos de germinación se realizan utilizando semillas de dos especies, berro (Lepidium sativum, cv. 'Alenois') y lechuga (Lactuca sativa, cv. 'Bionda Degli Ortolani'), y el extracto acuoso $1 / 5$ (v/v) del material en estudio. Se preparan dos niveles de dilución de este extracto (puro, 100\% y diluido al 25\% con agua destilada). El blanco (control) es agua destilada.

Como soporte para la germinación se utilizan placas petri, en las que -sobre un papel de filtro humedecido con unas gotas del extracto preparado a partir del material a testar- se depositan 10 semillas de la especie a estudiar. Tras cubrir las semillas con otro papel de filtro humedecido con el extracto (para cada placa se utilizan alrededor de 1,5 mL), la germinación se lleva a cabo en oscuridad, utilizando una cámara termostatada.

Transcurridos 3 días $\left(a 23^{\circ} \mathrm{C}\right.$ ) para berro y 5 días $\left(a 17^{\circ} \mathrm{C}\right.$ ) para lechuga, se controla el porcentaje de germinación de las semillas (\% G) en cada placa y se mide la longitud de la radícula de las semillas que han germinado ( $\mathrm{Lm}, \mathrm{mm})$. El índice de germinación (IG) se calcula a partir de estos valores, utilizando la expresión:

$$
I G(\% \text { del control })=\frac{\% G_{\text {extracto }}}{\% G_{\text {control }}} \cdot \frac{L m_{\text {extracto }}}{L m_{\text {control }}} \cdot 100
$$

Todos los bioensayos se realizan por quintuplicado.

Bioensayo 2: germinación y crecimiento de berro

El bioensayo 2 se lleva a cabo siguiendo la metodología recogida en la Norma AFNOR XP U44-165 (2004), utilizando semillas de berro (Lepidium sativum, cv. 'Alenois').

Para la realización de este bioensayo, el material a estudiar se tamiza utilizando una malla de $10 \mathrm{~mm}$ de luz y posteriormente se mezcla con un sustrato comercial (turba Sphagnum rubia fina enmendada - $\mathrm{pH}$ alrededor de 6,5- y ligeramente fertilizada; Biolan Substrate C1L, Biolan Oy) en una proporción de compost y turba 
2/3 ( $\mathrm{v} / \mathrm{v})$, con el fin de disminuir - por efecto de dilución- la salinidad y el pH de dicho material.

Como contenedores se usan macetas cilíndricas de plástico de 0,5 L de capacidad, con perforaciones en el fondo para permitir el riego por subirrigación.

Las macetas se disponen sobre una bandeja estanca en la que se vierte lentamente agua destilada hasta alcanzar una altura de $2 \mathrm{~cm}$, la cual se mantiene durante 4 horas. Transcurrido este tiempo se completa el riego con un aporte superficial de $100 \mathrm{~mL}$ de agua destilada por litro de sustrato de cultivo (con ayuda de un pulverizador), eliminando el excedente de agua. El riego se repite tantas veces como sea necesario a lo largo del ensayo con objeto de mantener la lámina de agua de $2 \mathrm{~cm}$ y evitar la desecación superficial de las macetas.

Las semillas de berro se colocan de forma regular sobre la superficie del sustrato, a razón de 25 semillas por maceta, quedando éstas recubiertas por una fina capa de dicho sustrato.

Las macetas (más las bandejas) se sitúan en una cámara de germinación a $23^{\circ} \mathrm{C}$, con fotoperíodo de 16 horas e intensidad luminosa mínima de 4000 lux.

Se dispone un diseño experimental completamente aleatorizado, con cuatro repeticiones por tratamiento. La unidad experimental es una maceta con 25 semillas.

Los parámetros a controlar y determinar son:

- Número total de plántulas emergidas a las 72 horas desde la siembra, expresado en porcentaje

- Número total de plántulas "normales" (es decir, con las características morfológicas habituales de la especie) y "anormales" emergidas 7 días después de la siembra, expresado en porcentaje

- Peso fresco de la parte aérea de las plántulas emergidas 7 días después de la siembra, expresado en mg por plántula

- Biomasa aérea acumulada (tras secado a $65^{\circ} \mathrm{C}$ ) en las plántulas producidas, expresada en miligramos de peso seco por plántula.

\section{I.2. CARACTERIZACIÓN DE LOS SUELOS}

\section{I.2.1. Preparación de la muestra}

Para acondicionar el suelo para la posterior realización de los distintos análisis, se disgregan mecánicamente los agregados y se deja secar al aire. Posteriormente, el 
suelo se tamiza por malla de $2 \mathrm{~mm}$ de luz y se conserva para realizar los análisis químicos y las determinaciones físicas que son independientes de la forma y disposición de los agregados y poros del suelo. Para las determinaciones físicas restantes, se utilizan muestras de suelo inalteradas.

\section{I.2.2. Propiedades físicas}

\section{I.2.2.1. Textura}

La determinación de la textura se realiza mediante densímetro Bouyoucos (MAPA, 1994). Este método se basa en la ley de Stokes, según la cual la velocidad V de caída libre de una partícula no coloidal esférica, de diámetro $D$ y densidad $\rho_{s}, a$ través de un líquido en reposo, de viscosidad $\eta$, densidad $\rho_{\mathrm{L}}, \mathrm{y}$ movimiento relativo laminar respecto al de caída de la partícula, tiene un valor constante dado por:

$$
V=\frac{g \cdot\left(\rho_{S}-\rho_{L}\right)}{18 \cdot \eta} \cdot D^{2}
$$

donde $\mathrm{g}=980,7 \mathrm{~cm} / \mathrm{s}^{2}$.

\section{Reactivos}

Dispersante: Se disuelven 50 g de Calgón en $1 \mathrm{~L}$ de agua o 35,7 g de $\mathrm{NaPO}_{3}$ y $7,94 \mathrm{~g}$ de $\mathrm{Na}_{2} \mathrm{CO}_{3}$ en $1 \mathrm{~L}$ de agua

\section{Procedimiento}

Para la determinación de la textura por el método del Densímetro Bouyoucos se coloca una muestra de 40 g de suelo en una cápsula de porcelana, se añaden 100 $\mathrm{mL}$ de solución de Calgón, y se deja reposar durante unos 10 minutos. Se transfiere la suspensión al vaso de una batidora, ayudándose con un frasco lavador con agua corriente, y se bate la suspensión durante 5 minutos, transfiriéndola seguidamente a una probeta de $1 \mathrm{~L}$, y enrasando con agua del grifo hasta la señal de enrase de 1000 $\mathrm{mL}$. Se prepara a su vez una probeta en blanco añadiendo $100 \mathrm{~mL}$ de la solución de Calgón a una probeta, llevándola hasta $1 \mathrm{~L}$ con agua destilada, y mezclando la solución con el émbolo agitador.

Una vez estabilizada la temperatura de las probetas, se toma nota de la misma. Se anota la lectura del densímetro introducido en la probeta en blanco, $L_{L}$, que coincide con el borde superior del menisco que rodea el vástago de dicho densímetro.

Se introduce el émbolo en la suspensión del suelo y se mueve de arriba abajo para mezclar bien. Una vez realizada la agitación, se anota el tiempo to $=0$. Después 
de 30 segundos, a partir del tiempo to, se introduce el densímetro en la suspensión y se anota la lectura $L_{1 / 2}$, que corresponde al tiempo $t=1 / 2$ minuto; sin sacar el densímetro de la suspensión se hace otra lectura $\left(L_{1}\right)$ correspondiente al tiempo $t=1$ minuto. Se saca el densímetro con cuidado, evitando provocar turbulencias, y se vuelven a hacer lecturas (i) transcurridos 3, 10, 30 y 90 minutos, y un tiempo superior a 8 horas, contando siempre desde el instante to en que se homogeneizó la suspensión.

El diámetro $D_{i}$ de las partículas en suspensión se determina según la ley de Stokes, en función de la profundidad a la que se mide la densidad y los tiempos de medida.

El tamaño de las partículas $\left(D_{\mathrm{i}}\right)$ debe corregirse por medio del factor correspondiente a $30^{\circ} \mathrm{C}(f)$; de esta forma, el valor del diámetro corregido $\mathrm{D}^{\prime}{ }_{\mathrm{i}}$ se obtiene por la expresión:

$$
\mathrm{D}^{\prime}{ }_{\mathrm{i}}=\mathrm{D}_{\mathrm{i}} \cdot f
$$

La concentración de la suspensión se expresa como $C_{i}=L_{i}-L_{L}$, en g/L.

El porcentaje $\left(P_{i}\right)$ de suelo seco conteniendo partículas de tamaño inferior a $D_{i}$, se expresa como:

$$
\mathrm{P}_{\mathrm{i}}=100 \cdot \mathrm{C}_{\mathrm{i}} / \mathrm{C}_{0}
$$

donde $\mathrm{C}_{0}$ es la concentración de la suspensión a t $=0$.

Una vez realizados estos cálculos, se representan gráficamente -en un sistema de coordenadas con escala semilogarítmica- los valores de $D_{i}^{\prime}$ en función de $\mathrm{P}_{\mathrm{i}}$. De la curva resultante se obtienen los porcentajes de las fracciones de arena, limo y arcilla según el sistema U.S.D.A. Dichos valores se representan en el diagrama triangular del mismo sistema para determinar la textura.

\subsubsection{Humedad volumétrica a capacidad de campo}

La determinación de la humedad del suelo a capacidad de campo se realiza con un equipo de placas de presión, según Richards (1954).

Las muestras de suelo saturadas de agua se colocan en una cámara de presión sobre una membrana porosa, en contacto por su cara inferior con agua libre a presión atmosférica. Mediante la aplicación de una sobrepresión en la cámara, el agua que permanece retenida en el suelo estará en equilibrio con el agua libre que se mantiene a presión atmosférica, estando a un potencial matricial igual al valor negativo de la sobrepresión aplicada. 
Se toman $25 \mathrm{~g}$ de suelo tamizado por la malla de $2 \mathrm{~mm}$ y se colocan los anillos retenedores de la muestra sobre la membrana porosa, vaciando cada muestra en un anillo de una vez, para evitar segregación de partículas por tamaño, y se nivelan. Se dejan las muestras en reposo durante al menos 16 horas con exceso de agua en la membrana. Después se coloca en la cámara la membrana con las muestras y se une la salida de agua de la membrana a la salida de agua de la cámara y se cierra. Se conecta una bureta al tubo de salida de la cámara y se aplica la presión de $33 \mathrm{kPa}$ $(0,33 \mathrm{~atm})$ hasta que la bureta indique que ha cesado el flujo de agua (generalmente, a las 48 horas de haberse iniciado la extracción). Entonces se cierra el tubo de salida de agua de la membrana, se elimina la sobrepresión, y se retiran las muestras de la cámara, colocándolas inmediatamente en recipientes para determinar su humedad tras secarlas a $105^{\circ} \mathrm{C}$.

El contenido de agua tras aplicar la tensión de 0,33 atm (equivalente a capacidad de campo) se expresa en porcentaje sobre volumen (humedad volumétrica).

\subsubsection{Capacidad de retención de agua disponible para las plantas}

El valor de la capacidad de retención de agua disponible (CRAD) para las plantas se define como el intervalo de humedad disponible que puede ser absorbida a un ritmo adecuado para permitir el crecimiento normal de las plantas (Porta et al., 2003).

Para determinar dicho parámetro, en primer lugar, se determina la humedad volumétrica a capacidad de campo (sección l.2.2.2) y, para determinar el punto de marchitamiento, se procede con idéntica metodología, pero aplicando una tensión de 1500 kPa en el equipo de placas de presión.

Se calcula como la diferencia entre los valores de humedad volumétrica obtenidos para la capacidad de campo y el punto de marchitamiento.

\subsubsection{Densidad aparente y porosidad}

La densidad aparente se calcula como la relación entre la masa y el volumen ocupado por las partículas del suelo, incluyendo su espacio poroso, expresándose en $\mathrm{kg}$ de suelo seco por $\mathrm{m}^{3}$ :

$$
\rho^{b}=\frac{M_{s}}{V_{T}}
$$


donde $M_{s}$ es la masa de partículas del suelo seco en estufa a $105^{\circ} \mathrm{C}$ que ocupan el contenedor (maceta) y $V_{\mathrm{T}}$ el volumen del contenedor (maceta) que éstas ocupan.

La porosidad del suelo se define como la proporción del volumen total del suelo ocupado por poros. Considerando que la densidad de partícula $\left(\rho_{s}\right)$ hace referencia a la relación entre la masa total de las partículas sólidas y su volumen total, excluyendo el volumen que ocupan los poros entre dichas partículas, de los conceptos de densidad de partícula y densidad aparente se deduce la relación entre ambos parámetros para determinar la porosidad $\left(\varepsilon_{T}\right)$, que se calcula como:

$$
\varepsilon_{\mathrm{T}}=1-\frac{\rho^{\mathrm{b}}}{\rho_{\mathrm{s}}}
$$

donde $\rho^{b}$ es la densidad aparente y $\rho_{s}$ la densidad de partícula.

La densidad de partícula $\left(\rho_{\mathrm{s}}\right)$ se calcula de forma empírica mediante la ecuación de De Leenheer, que recogen Porta el al. (2003):

$$
\rho_{s}=2650-\frac{1450 \cdot \mathrm{m} . \mathrm{o}}{100}
$$

donde m.o. es el contenido en materia orgánica del suelo, determinado según se indica en I.2.4.1.

\subsubsection{Conductividad hidráulica}

a) Conductividad hidráulica saturada en laboratorio

Para la determinación de la conductividad hidráulica en condiciones de saturación $\left(\mathrm{K}_{\mathrm{HS}}\right)$ se utiliza un depósito de agua a nivel constante y una grada que sirve de soporte para las muestras (MAPA, 1994).

Se colocan cilindros con las muestras de suelo inalteradas sobre un material poroso sumergido en un recipiente con agua y se llevan a saturación por inmersión durante 20 horas, dejando que las muestras se saturen lentamente por capilaridad, para minimizar los cambios estructurales que podrían provocar la rápida expulsión de aire. Una vez saturado el suelo, se ensambla un collarín suplementario a un extremo del cilindro, sujetado por una banda de goma. En el otro extremo se ajusta un papel de filtro con una malla plástica de $2 \mathrm{~mm}$ de luz, que mantiene el cilindro en contacto con el agua por dicho extremo. A continuación, se vierte agua poco a poco sobre el cilindro hasta que ésta alcanza un nivel en el collarín suplementario de 2/3 ó 3/4 partes de su altura. Se transfieren rápidamente las muestras a la grada de percolación y se conectan por medio de un sifón al depósito de agua a nivel 
constante, impidiendo que el agua rebase el borde superior del collarín. Una vez se ha estabilizado el nivel de agua sobre el suelo, se recoge el agua que percola en probetas de $100 \mathrm{~mL}$ y se anota -en momentos sucesivos $\left(\mathrm{t}_{\mathrm{i}}\right)$ - el volumen acumulado de agua $\left(V_{i}\right)$ hasta que el cociente entre $\Delta V_{i}$ y $\Delta t_{i}$ se haya estabilizado, midiendo entonces el volumen de agua ( $\mathrm{V}$, en $\mathrm{mL}$ ) que percola en un tiempo conocido (t, en horas), y la pérdida de carga $\left(\mathrm{h}\right.$, en $\mathrm{m}$ o cm). La conductividad hidráulica saturada ( $\left.\mathrm{K}_{\mathrm{HS}}\right)$ se calcula como:

$$
\mathrm{K}_{\mathrm{HS}}=\frac{\mathrm{V} \cdot \mathrm{I}}{\mathrm{A} \cdot \mathrm{t} \cdot \mathrm{h}}
$$

donde $\mathrm{A}$ es el área (en $\mathrm{cm}^{2}$ ) y I la altura de la columna de suelo (en las mismas unidades que $h$ ), expresándose $K_{H S}$ en cm/h.

b) Conductividad hidráulica en campo a $0,5 \mathrm{~cm}$ de succión

La conductividad hidráulica a la tensión de 0,5 cm de columna de agua (c.a.) se determina mediante un infiltrómetro de minidisco (Decagon Devices). Este infiltrómetro consta de dos cámaras, la superior (cámara de burbujeo) y la inferior (reserva de agua), que deben llenarse con agua. La cámara de burbujeo controla la succión, y la de reserva contiene el volumen de agua que se infiltra en el suelo a la velocidad determinada por dicha succión. Ambas cámaras se llenan de agua y el infiltrómetro se coloca sobre el suelo, succionando la matriz de éste el agua de la cámara de reserva para que se infiltre en dicho suelo. A medida que el nivel de agua desciende, debe registrarse el volumen infiltrado a intervalos específicos de tiempo. Para calcular la conductividad hidráulica, se ajustan los resultados obtenidos experimentalmente para la infiltración y el tiempo correspondiente según Zhang (1997).

Las indicaciones del fabricante incluyen el soporte informático para realizar los cálculos. El método requiere representar gráficamente la infiltración acumulada frente a la raíz cuadrada del tiempo transcurrido y ajustar la curva resultante a una ecuación polinómica de segundo grado. La conductividad hidráulica $\left(K_{H}{ }^{\prime}\right)$, expresada en cm/h, se calcula según la ecuación:

$$
\mathrm{K}_{H^{\prime}}=\frac{\mathrm{C}_{1}}{\mathrm{~A}}
$$

donde $\mathrm{C}_{1}$ es la pendiente de la ecuación de segundo grado indicada más arriba y $\mathrm{A}$ un valor relacionado con los parámetros de la ecuación de Van Genuchten para un suelo, una succión y un radio del disco concretos. 
En el caso del suelo calizo utilizado en el experimento, se consideró el valor de A $(=6,0)$ correspondiente a la textura franco arcillosa y la succión de 0,5 cm.

\section{I.2.3. Características físico-químicas}

\section{I.2.3.1. $\mathrm{pH}$}

Se procede siguiendo los Métodos Oficiales de Análisis del Ministerio de Agricultura, Pesca y Alimentación (MAPA, 1994), preparando una suspensión acuosa $1 / 2,5(\mathrm{p} / \mathrm{v})$, con $10 \mathrm{~g}$ de suelo y $25 \mathrm{~mL}$ de agua, que se agita durante 10 minutos, y después se deja en reposo y otros 30 minutos. A continuación se agita la suspensión, inmediatamente antes de entrar en contacto con el electrodo, pero no durante la medida. Para la determinación del pH, se utiliza un pH-metro CRISON modelo 2000 y un electrodo CRISON modelo 5000-20.

\subsubsection{Conductividad eléctrica}

La conductividad eléctrica (CE) se determina en el extracto acuoso $1 / 5(\mathrm{p} / \mathrm{v})$ (MAPA, 1994). Se toman $10 \mathrm{~g}$ de suelo y se añaden $50 \mathrm{~mL}$ de agua destilada. Se agita la mezcla durante 30 minutos y, a continuación, se filtra la suspensión. La conductividad eléctrica se mide con un conductímetro CRISON modelo 522, equipado con una célula de conductividad CRISON modelo 52-89. Tras efectuar la corrección de temperatura correspondiente, los resultados se expresan en $\mathrm{dS} / \mathrm{m}$ a $25^{\circ} \mathrm{C}$.

\subsubsection{Capacidad de intercambio catiónico}

La capacidad de intercambio catiónico $(\mathrm{CIC})$ es la cantidad total de cationes metálicos cambiables, que están adsorbidos en las partículas coloidales orgánicas e inorgánicas del suelo.

El método de determinación de la CIC se basa en el desplazamiento de los cationes metálicos adsorbidos en el suelo por cationes $\mathrm{Na}^{+}$y la posterior determinación del $\mathrm{Na}^{+}$adsorbido mediante un segundo desplazamiento (Rhoades, 1982a). 
Desplazamiento de los cationes retenidos en el suelo

Se pesan de 4 a 6 g (dependiendo de la textura; a mayor grosor, mayor cantidad) de suelo, se lava posteriormente con $33 \mathrm{~mL}$ de solución tampón $\left(\mathrm{NaCl}\right.$ 0,1 $\mathrm{N}$ y Na${ }_{2} \mathrm{CO}_{3}$ 0,4 $\mathrm{N}$ en etanol al 60\%, pH 8,2), agitando durante 5 minutos, y seguidamente se centrifuga. Esto se repite de nuevo con otras tres alícuotas de $33 \mathrm{~mL}$ de tampón. El sobrenadante se desecha en todos los casos.

Desplazamiento del sodio intercambiable

El segundo paso consiste en el tratamiento de la muestra con otras tres alícuotas de $33 \mathrm{~mL}$ de nitrato magnésico $0,5 \mathrm{~N}$, agitando y centrifugando, pero en esta ocasión reteniendo el líquido sobrenadante en un matraz aforado de $100 \mathrm{~mL}$. Tras haber recogido el último decantado, se enrasa el matraz.

En esa solución se determinan por separado la concentración, en meq/L, de $\mathrm{Na}^{+}$, (Na total) y de $\mathrm{Cl}^{-}(\mathrm{Cl}$ total).

\section{Determinación de cloruros}

Los iones cloruro, $\mathrm{Cl}^{-}$, se determinan por amperometría (Rhoades, 1982b).

Mediante la adición de iones plata, $\mathrm{Ag}^{+}$, a la solución del suelo, a una velocidad constante, los iones $\mathrm{Cl}^{-}$precipitan como $\mathrm{AgCl}$. Cuando todos los cloruros han precipitado, se produce un incremento en la concentración de Ag. Esa situación se determina amperométricamente y el aporte de plata se detiene, al igual que el temporizador que había empezado a contar desde el momento en que comenzó la adición de plata. El contenido de $\mathrm{Cl}^{-}$en la solución se determina por relación directa con el tiempo transcurrido, medido por el temporizador, y la velocidad de aporte de iones plata.

\section{Determinación de sodio}

El sodio se determina por fotometría de llama.

Cálculo de la CIC

La capacidad de intercambio catiónico se expresa en $\mathrm{cmol}$ de $\mathrm{Na}^{+}$y $\mathrm{Cl}^{-}$ adsorbidos por kg de suelo seco, según la expresión:

$$
\mathrm{CIC}=\left[\left(\mathrm{Na}_{\mathrm{t}}\right)-\left(\mathrm{Cl}_{\mathrm{t}}\right)(\mathrm{Na} / \mathrm{Cl})_{\mathrm{sol}}\right] 10 / \mathrm{p}_{\mathrm{ss}}
$$

donde $\mathrm{Nat}_{t}$ es la concentración de $\mathrm{Na}$ total de la solución diluida, $\mathrm{Cl}_{\mathrm{t}}$ de la de la solución sin diluir, $(\mathrm{Na} / \mathrm{Cl})_{\text {sol }}$ la relación $\mathrm{Na} / \mathrm{Cl}$ de la solución tampón y $\mathrm{p}_{\mathrm{ss}}$ el peso del suelo seco. 


\section{I.2.4. Características químicas. Fracción orgánica y mineral}

\section{I.2.4.1. Carbono orgánico}

Reactivos

$\mathrm{K}_{2} \mathrm{Cr}_{2} \mathrm{O}_{7} 1 \mathrm{~N}$ : Disolver 49,04 g de dicromato potásico, seco a $105^{\circ} \mathrm{C}$, en agua y diluir a $1 \mathrm{~L}$

$\mathrm{FeSO}_{4} \cdot 7 \mathrm{H}_{2} \mathrm{SO}_{4}$ 0,5 N: Disolver $140 \mathrm{~g}$ de sulfato ferroso heptahidratado en água destilada. Añadir $15 \mathrm{~mL}$ de ácido sulfúrico concentrado, enfriar y diluir hasta $1 \mathrm{~L}$. Normalizar esta disolución valorándola con $10 \mathrm{~mL}$ de la disolución de dicromato potásico $1 \mathrm{~N}$.

$\mathrm{H}_{2} \mathrm{SO}_{4}$ concentrado (al 96\%)

Procedimiento

El carbono orgánico se determina por el método de Walkley-Black (Walkley y Black, 1934). Para ello, se pesa $1 \mathrm{~g}$ de suelo en un matraz erlenmeyer de $250 \mathrm{~mL}$ y se añaden $10 \mathrm{~mL}$ de dicromato potásico $1 \mathrm{~N}$, moviendo el matraz para dispersar el suelo en la solución; a continuación, y en una campana de extracción de humos, se añaden $20 \mathrm{~mL}$ de ácido sulfúrico concentrado, se agita durante un minuto, y se deja enfriar. Se añaden $100 \mathrm{~mL}$ de agua destilada, $10 \mathrm{~mL}$ de ácido fosfórico y 4 ó 5 gotas del indicador complejo ferroso de ortofenantrolina, y el exceso de dicromato se valora con sulfato ferroso $0,5 \mathrm{~N}$.

Por este procedimiento se oxida el $77 \%$ del carbono que se recuperaría por combustión, por lo que el C orgánico del suelo se calcula según la siguiente ecuación:

$$
\mathrm{C}_{\text {org }}(\mathrm{g} / \mathrm{kg})=\frac{\mathrm{meqK}_{2} \mathrm{Cr}_{2} \mathrm{O}_{7}-\text { meq FeSO }_{4}}{\mathrm{~g}_{\mathrm{ms}}} \cdot 0,003 \cdot 1000 \cdot 1,3
$$

donde $g_{m s}$ son los gramos de suelo seco.

El contenido en materia orgánica se calcula multiplicando el valor obtenido para el $C_{\text {org }}$ por el factor $1,72$.

\subsubsection{Carbono orgánico hidrosoluble}

El carbono orgánico hidrosoluble se determinó según Yakovchenko y Sikora (1998). 


\section{Reactivos}

$\mathrm{K}_{2} \mathrm{Cr}_{2} \mathrm{O}_{7}$ 0,2 N: Disolver 9,808 g de $\mathrm{K}_{2} \mathrm{Cr}_{2} \mathrm{O}_{7}$ en $250 \mathrm{~mL}$ de agua destilada y enrasar a $1 \mathrm{~L}$ con $\mathrm{H}_{2} \mathrm{SO}_{4}$ concentrado $(26,7 \mathrm{~N})$

Disolución madre de 1000 ppm de C: Disolver 0,25 g de glucosa en 100 mL de agua destilada

Procedimiento

Se pesan $10 \mathrm{~g}$ de suelo en una botella de $60 \mathrm{~mL}$, se añaden $25 \mathrm{~mL}$ de agua destilada y se agita durante 30 minutos. Después se centrifuga y se filtra sobre papel de filtro cuantitativo. Para la reacción colorimétrica se utilizan tubos de ensayo, en los que se adicionan $2 \mathrm{~mL}$ del extracto de la muestra y $3 \mathrm{~mL}$ de $\mathrm{K}_{2} \mathrm{Cr}_{2} \mathrm{O}_{7} 0,2 \mathrm{~N}$. Se agita la mezcla en vortex y se tapa con papel de aluminio. A continuación se coloca en estufa a $140^{\circ} \mathrm{C}$ durante 20 minutos. Para la determinación del carbono orgánico hidrosoluble en el extracto, se realiza una curva de calibrado de 0 a 400 ppm de $\mathrm{C}$ a partir de la disolución madre de glucosa de 1000 ppm, midiendo la absorbancia con un espectrofotómetro Jenway UV/visible 6300 (Bibby Scientific) a $\lambda=590 \mathrm{~nm}$ tanto en los patrones como en la muestra.

\subsubsection{Nitrógeno total}

El nitrógeno total se determina según el método Kjeldhal (Bremner, 1965), utilizando las muestras secas y trituradas. Para ello, se pesan 0,5 g de muestra en un tubo de digestión Tecator con precisión de 0,0001; a continuación se añaden 3,8 g de catalizador, $10 \mathrm{~mL}$ de mezcla ácida $\left(\mathrm{H}_{3} \mathrm{PO}_{4}\right.$ y $\left.\mathrm{H}_{2} \mathrm{SO}_{4}\right)$ y $10 \mathrm{~mL}$ de $\mathrm{H}_{2} \mathrm{O}_{2}$ al 33\%.

Después de dejar en reposo durante media hora a temperatura ambiente, los tubos se introducen en un digestor a $420^{\circ} \mathrm{C}$ durante media hora aproximadamente. Finalizada la etapa de digestión, se dejan enfriar y se añaden $50 \mathrm{~mL}$ de agua destilada, para proceder a la destilación por medio del Tecator. Se basifican los digestados con $\mathrm{NaOH} 40 \%$ y se destilan en corriente de vapor durante 2 minutos y 40 segundos, recogiendo $150 \mathrm{~mL}$ de destilado sobre $20 \mathrm{~mL}$ de ácido bórico-indicador. Se determina la concentración de $\mathrm{N}$ mediante valoración del destilado con $\mathrm{HCl}$ 0,005 N. El punto final de la valoración se detecta visualmente por viraje de la disolución de color verde a rojizo. Todas las digestiones se realizan por duplicado, incluido el blanco.

Para obtener el nitrógeno total, se suma el contenido en nitrógeno determinado por el método Kjeldahl al contenido en nitrógeno nítrico determinado según I.2.4.4. 


\subsubsection{Nitrógeno mineral}

Para determinar el nitrógeno mineral en extracto de $\mathrm{KCl}$ se colocan $10 \mathrm{~g}$ de suelo en un matraz erlenmeyer de $250 \mathrm{~mL}$ y se realiza una extracción con $100 \mathrm{~mL}$ de $\mathrm{KCl}$ $2 \mathrm{M}$, agitando dicha suspensión durante 1 hora. Transcurrido dicho período, se deja que la suspensión sedimente, se centrifuga, y el sobrenadante se trasvasa a un frasco de plástico.

La determinación de nitrógeno amoniacal $\left(\mathrm{N}_{-} \mathrm{NH}_{4}{ }^{+}\right)$y nítrico $\left(\mathrm{N}_{-} \mathrm{NO}_{3}{ }^{-}\right)$se realiza de acuerdo con Keeney y Nelson (1982), según se indica a continuación.

a) Nitrógeno amoniacal

Reactivos

KCl 2 N: Disolver 149,1 g en $1 \mathrm{~L}$ de agua destilada

$\mathrm{NaOH}$ 0,5 M: Disolver 20 g en $1 \mathrm{~L}$ de agua destilada

Disolución indicadora: Disolver $1 \mathrm{~g}$ de mezcla de indicador de amonio en $5 \mathrm{~mL}$ de $\mathrm{NaOH}$ 0,1 M y diluir a $200 \mathrm{~mL}$ con agua destilada (disolución stock). Pipetear 10 $\mathrm{mL}$ de la disolución stock y diluir a $500 \mathrm{~mL}$ con $\mathrm{KCl} 2 \mathrm{M}$. Ajustar el $\mathrm{pH}$ a un valor de 5,5 y medir la absorbancia, que deberá estar comprendida entre 450 y 600 mAU (miliequivalentes de Unidades de Absorbancia) a $\lambda=590 \mathrm{~nm}$.

Procedimiento

A partir del extracto obtenido de la muestra se determina el nitrógeno mineral, en forma de ion amonio, mediante análisis por sistema automatizado de inyección en flujo en el equipo FIAstar 5000 Analyzer FOSS TECATOR y el software SoFIA versión 1.10. Dicha metodología se basa en la inyección del extracto obtenido en una corriente de hidróxido sódico. En la corriente alcalina resultante se produce amoniaco en forma gaseosa, que se difunde a través de una membrana permeable hasta una corriente indicadora, generando una reacción colorimétrica que permite su determinación por espectrofotometría con el sistema FIA a $\lambda=590 \mathrm{~nm}$.

b) Nitrógeno nítrico

Reactivos

KCl 2 N: Disolver 149,1 g en $1 \mathrm{~L}$ de agua destilada

$\mathrm{NH}_{4} \mathrm{Cl}$ 0,1 M: Disolver 5,35 g en $1 \mathrm{~L}$ de agua destilada

Sulfanilamida (4-aminobencenosulfonamida): Disolver $5 \mathrm{~g}$ en $250 \mathrm{~mL}$ de agua destilada. Añadir $25 \mathrm{~mL}$ de $\mathrm{HCl}$ concentrado, mezclar y enrasar a $500 \mathrm{~mL}$ con agua destilada. 
NED (N-1-naftil-etilendiaminadihidrocloruro): Disolver 0,5 g de NED en $500 \mathrm{~mL}$ de agua destilada

Procedimiento

La determinación de nitratos se basa en la reducción del ion nitrato a nitrito en una columna reductora que contiene cadmio. El ion nitrito reacciona con sulfanilamida en medio ácido y la mezcla de este compuesto con N-1-naftiletilendiaminadihidrocloruro genera una coloración púrpura. Para llevar a cabo estas reacciones químicas se utiliza el sistema automatizado de análisis por inyección de flujo (FIA) con el equipo FIAstar 5000 Analyzer FOSS TECATOR. Una alícuota de la muestra se inyecta en una corriente portadora, que se mezcla con los reactivos, produciéndose la reacción colorimétrica. La absorbancia medida a $\lambda=540 \mathrm{~nm}$ está linealmente relacionada con la concentración de nitratos.

La suma del nitrógeno amoniacal y el nitrógeno nítrico es el nitrógeno mineral $\left(\mathrm{N}_{\min }\right)$.

\subsubsection{Fósforo asimilable}

Método Olsen

El fósforo asimilable se determina por el método colorimétrico de Olsen (Olsen y Sommers, 1982).

Reactivos

Carbón activo

$\mathrm{NaHCO}_{3}$ 0,5 M: Disolver 42,0 g de $\mathrm{NaHCO}_{3}$ en unos $950 \mathrm{~mL}$ de agua destilada. Ajustar el pH a 8,5 con $\mathrm{NaOH} 1 \mathrm{M}$ y enrasar a $1 \mathrm{~L}$

$\mathrm{H}_{2} \mathrm{SO}_{4}$ 2,4 M: Diluir $70 \mathrm{~mL}$ de $\mathrm{H}_{2} \mathrm{SO}_{4}$ concentrado (18 M) hasta $500 \mathrm{~mL}$ con agua destilada

$\left(\mathrm{NH}_{4}\right)_{6} \mathrm{Mo}_{7} \mathrm{O}_{24} 4 \mathrm{H}_{2} \mathrm{O}$ : Disolver $20 \mathrm{~g}$ de molibdato amónico en $500 \mathrm{~mL}$ de agua desionizada

$\mathrm{K}(\mathrm{SbO}) \cdot \mathrm{C}_{4} \mathrm{H}_{4} \mathrm{O}_{6} \cdot 1 / 2 \mathrm{H}_{2} \mathrm{O}$ : Disolver $0,2728 \mathrm{~g}$ de tartrato de antimonio y potasio en $100 \mathrm{~mL}$ de agua destilada

$\mathrm{C}_{6} \mathrm{H}_{8} \mathrm{O}_{6}$ 0,1 M: Disolver 1,76 de ácido ascórbico en $100 \mathrm{~mL}$ de agua destilada Reactivo mixto: Mezclar cuidadosamente $50 \mathrm{~mL}$ de ácido sulfúrico 2,5 M, $15 \mathrm{~mL}$ de disolución de molibdato amónico, $30 \mathrm{~mL}$ de disolución de ácido ascórbico, y 5 $\mathrm{mL}$ de disolución de tartrato p-nitrofenol: Disolver 0,25 g en $100 \mathrm{~mL}$ de $\mathrm{H}_{2} \mathrm{O}$ 
Disolución concentrada de fosfato de 100 ppm de P: Disolver 0,4394 g de $\mathrm{KH}_{2} \mathrm{PO}_{4}$ en agua, añadir $25 \mathrm{~mL}$ de ácido sulfúrico $2,5 \mathrm{M}$, y diluir hasta $1 \mathrm{~L}$

\section{Procedimiento}

Para la determinación del P asimilable según el método Olsen, se lleva a cabo la extracción del P de la muestra, pesando 2,5 g de suelo en un erlenmeyer de $250 \mathrm{~mL}$, añadiendo una cucharada de carbón activo, $50 \mathrm{~mL}$ de disolución de $\mathrm{NaHCO}_{3}$ 0,5 $\mathrm{M}$ a $\mathrm{pH} 8,5$, y agitando durante 30 minutos en un agitador orbital. A continuación se filtra la suspensión a través de un papel de filtro de análisis cuantitativo.

Una vez extraído el P se transfiere una alícuota de $5 \mathrm{~mL}$ a un matraz aforado de $25 \mathrm{~mL}$ y se añaden $400 \mu \mathrm{L}$ de ácido sulfúrico 2,5 M para bajar el $\mathrm{pH}$-agitando lentamente para eliminar el $\mathrm{CO}_{2}$ que se forma al acidificar el bicarbonato-, agua destilada hasta la mitad del matraz para diluirlo, y $4 \mathrm{~mL}$ del reactivo mixto. Se agita y enrasa con agua destilada.

A continuación se prepara una curva patrón a partir de una disolución madre de concentración de P igual 100 ppm y, después de 10 minutos, se lee la absorbancia a $\lambda=880 \mathrm{~nm}$.

\section{Método Burriel-Hernando}

En las muestras en que no puede realizarse la extracción de fósforo por el método Olsen, debido a la elevada cantidad de carbón activo que debería adicionarse para obtener un extracto claro, se utiliza el método de extracción de Burriel-Hernando, modificado por Díez (1982) (secciones 4.2 y 4.4 de Resultados y Discusión).

\section{Reactivos}

Disolución extractora: Disolver $0,1 \mathrm{~g}$ de $\mathrm{CaCO}_{3}$ y $0,088 \mathrm{~g}$ de $\mathrm{MgCO}_{3}$ en $700 \mathrm{~mL}$ de agua destilada, añadir $0,5 \mathrm{~mL}$ de $\mathrm{H}_{2} \mathrm{SO}_{4}$ al $20 \%$ y $2,5 \mathrm{~mL}$ de ácido acético (98\%), y enrasar a 1 L. El pH de la disolución debe oscilar entre 3,2 y 3,4.

\section{Procedimiento}

La extracción de $\mathrm{P}$ asimilable se realiza empleando 4 g de muestra y $100 \mathrm{~mL}$ de solución extractora. Se agita 5 minutos, después se filtra y, para la determinación de $\mathrm{P}$, se procede como se ha indicado con el método Olsen. 


\section{I.2.4.6. Potasio, calcio, magnesio y sodio asimilables}

Para la determinación de K, Ca, Mg y Na en el suelo se sigue el procedimiento de extracción indicado en los Métodos Oficiales de Análisis del Ministerio de Agricultura, Pesca y Alimentación (MAPA, 1994)

\section{Reactivos}

$\mathrm{NH}_{4} \mathrm{CH}_{3} \mathrm{COO} 1 \mathrm{~N}$ : Añadir $58 \mathrm{~mL}$ de ácido acético glacial $\left(\mathrm{HCH}_{3} \mathrm{COO}\right)$ a aproximadamente $600 \mathrm{~mL}$ de agua destilada, y luego, en campana de extracción de humos, añadir $70 \mathrm{~mL}$ de hidróxido amónico $\left(\mathrm{NH}_{4} \mathrm{OH}\right)$ concentrado mediante un embudo de vidrio con vástago alargado, para que el $\mathrm{NH}_{4} \mathrm{OH}$ se ponga en contacto con el fondo de la disolución ácida. Dejar enfriar y ajustar el pH a 7 con ácido acético o hidróxido amónico.

Procedimiento

Para la extracción de K, Ca, Mg y Na se pesan 7,5 g de suelo en un tubo de centrífuga de $50 \mathrm{~mL}$, se añaden $33 \mathrm{~mL}$ de acetato amónico $1 \mathrm{~N}$ ajustado a $\mathrm{pH} 7$, y se agita durante 10 minutos.

Seguidamente se centrifuga el tubo hasta que el líquido sobrenadante queda claro y se decanta en un matraz aforado de $100 \mathrm{~mL}$. Este proceso se repite dos veces más hasta obtener $100 \mathrm{~mL}$ de disolución.

A continuación, se determina el contenido por medio del ICP-AES, según se indica en I.1.4.6.

\section{I.2.4.7. Elementos traza totales}

Se utilizan las muestras de suelo (contaminado) secadas al aire y tamizadas a través de $2 \mathrm{~mm}$. Se pesa $1 \mathrm{~g}$ de material al que se adicionan $10 \mathrm{~mL}$ de $\mathrm{HNO}_{3}$, diluido en agua en proporción 2/5, para realizar una predigestión. Transcurridas 20 horas, se lleva a cabo la digestión de la muestra, primero a temperatura de $120^{\circ} \mathrm{C}$ durante 1 hora para, posteriormente, incrementarse ésta de forma progresiva hasta alcanzar los $200^{\circ} \mathrm{C}$, obteniéndose finalmente un precipitado de color blanco. Seguidamente se adicionan $10 \mathrm{~mL}$ de una mezcla de $\mathrm{HClO}_{4} / \mathrm{HNO}_{3} / \mathrm{H}_{2} \mathrm{O}$ destilada, en relación 3/5/2, hasta obtener un precipitado de color blanco y un sobrenadante amarillo claro. El sobrenadante se filtra a través de papel para análisis cuantitativo y se afora a un volumen final de $50 \mathrm{~mL}$ con agua destilada (Norma ISO 11466, 1995). 
El análisis de $\mathrm{Al}, \mathrm{Cd}, \mathrm{Cr}, \mathrm{Cu}, \mathrm{Ni}, \mathrm{Pb}$ y $\mathrm{Zn}$ se realiza con ICP-AES (ver sección I.1.4.6), y el de As utilizando espectrofotometría de absorción atómica combinada con un generador de hidruros.

\section{I.2.4.8. Elementos traza biodisponibles}

Se parte de $5 \mathrm{~g}$ de suelo (contaminado) preparado de la manera descrita en 1.2.4.7. Para la extracción de As, $\mathrm{Pb}$ y $\mathrm{Zn}$ se adicionan $50 \mathrm{~mL}$ de EDTA 0,05M (Romaguera et al., 2008), agitando durante 4 horas, y filtrando posteriormente a través de papel de filtro para análisis cuantitativo. El extracto así filtrado se afora con agua destilada hasta un volumen final de $50 \mathrm{~mL}$. En el caso del Al, la extracción se realiza en las mismas condiciones, pero utilizando $\mathrm{KCl} 1 \mathrm{M}$ como extractante (Matúš et al., 2006). Las determinaciones de los elementos traza se realizan como se indica en I.2.4.7.

\subsubsection{Carbonatos}

La determinación del contenido en carbonatos (caliza total) del suelo se realiza midiendo -en condiciones idénticas de presión y temperatura- la cantidad de $\mathrm{CO}_{2}$ desprendido al acidificar con $\mathrm{HCl}$ un peso de muestra y una cantidad conocida de $\mathrm{CaCO}_{3}$, mediante el calcímetro de Bernard (MAPA, 1994).

Reactivos

Ácido clorhídrico (37\% p/p) diluido al $50 \%$

Disolución saturada de $\mathrm{CO}_{2}$ : Disolver $100 \mathrm{~g}$ de $\mathrm{NaCl}$ y $1 \mathrm{~g}$ de $\mathrm{NaHCO}_{3}$ en $350 \mathrm{~mL}$ de agua, acidificar con $\mathrm{H}_{2} \mathrm{SO}_{4}$ diluido hasta viraje del indicador naranja de metilo, agitando para eliminar el exceso de $\mathrm{CO}_{2}$

Carbonato cálcico finamente pulverizado

Procedimiento

Se pesan aproximadamente 0,7 g de muestra con una precisión de 0,1 mg y se introducen en el erlenmeyer del calcímetro Bernard. Se introduce un tubo de ensayo que contiene $\mathrm{HCl}$ y, con la llave abierta para mantener la presión atmosférica en el interior del erlenmeyer, se cierra el recipiente con un tapón de goma (Figura). Después se coloca el depósito para enrasar a cero el nivel de la disolución saturada de $\mathrm{CO}_{2}$ en la bureta y se cierra la llave, inclinando el erlenmeyer de modo que el $\mathrm{HCl}$ se vierta sobre la muestra y agitando para facilitar la reacción del ácido. A medida que 
desciende el nivel de líquido en la bureta, se modifica la posición del depósito hasta igualar ambos niveles. Cuando el nivel de la disolución saturada en la bureta es estacionario, se para la agitación y se anota la lectura del nivel alcanzado por la disolución saturada de $\mathrm{CO}_{2}$ en la bureta. Dicho procedimiento se repite con una cantidad conocida ( $200 \mathrm{mg}$ ) de carbonato cálcico pulverizado como blanco.

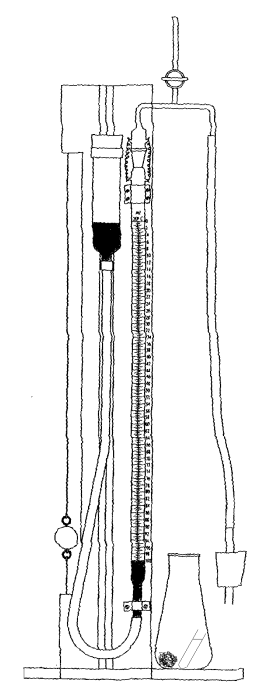

\section{Calcímetro Bernard}

La determinación del contenido en carbonato cálcico de la muestra se realiza aplicando la siguiente ecuación:

$$
\mathrm{CaCO}_{3}(\mathrm{~g} / \mathrm{kg})=\frac{\mathrm{V}_{\mathrm{mCO}_{2}}}{\mathrm{~V}_{\mathrm{bCO}}} \cdot \frac{\mathrm{P}_{\mathrm{b}}}{\mathrm{P}_{\mathrm{m}}} \cdot 1000
$$

donde $\mathrm{V}_{\mathrm{mCO}_{2}} \mathrm{y}_{\mathrm{bCO}_{2}}$ son el volumen de $\mathrm{CO}_{2}$ desprendido por la muestra y el blanco $\left(\mathrm{CaCO}_{3}\right)$, respectivamente, y $\mathrm{P}_{\mathrm{b}}$ y $\mathrm{P}_{\mathrm{m}}$ el peso de $\mathrm{CaCO}_{3}$ y de muestra, respectivamente.

\section{I.2.5. Propiedades biológicas y bioquímicas}

\section{I.2.5.1. Recuentos de poblaciones microbianas}

Se utilizan las mismas metodologías que se indican en I.1.5.1 


\subsubsection{Biomasa microbiana}

Reactivos

$\mathrm{CHCl}_{3}$ libre de etanol

$\mathrm{K}_{2} \mathrm{SO}_{4}$ 0,5 M: Se pesan $87,1 \mathrm{~g}$ de $\mathrm{K}_{2} \mathrm{SO}_{4}$ y se enrasa a $1 \mathrm{~L}$

Procedimiento

La biomasa microbiana se determina según el método de fumigación-extracción (Vance et al., 1987; Wu et al., 1990).

Para ello, se añaden $12 \mathrm{~g}$ de suelo a un vaso de precipitados y se fumigan con $\mathrm{CHCl}_{3}$ libre de etanol en un desecador. Para ello, se coloca un vaso con cloroformo y bolas de vidrio, se cierra el desecador y se aplica vacío hasta que el cloroformo hierve vigorosamente durante 2 minutos, tras lo cual se cierra la llave de paso del desecador y se mantienen las muestras y el vaso con cloroformo a $25^{\circ} \mathrm{C}$ en oscuridad durante 24 horas. Tras la incubación, se evacúa el cloroformo aplicando vacío hasta la desaparición del olor a cloroformo. Entonces, a los 12 g de muestra se añaden $60 \mathrm{~mL}$ de $\mathrm{K}_{2} \mathrm{SO}_{4}$ 0,5 M, y se agita la suspensión durante 30 minutos. A continuación, se filtra ésta sobre papel para análisis cuantitativo y se mantienen los extractos en nevera para la posterior determinación de carbono y nitrógeno de la biomasa microbiana.

Paralelamente, se prepara una extracción de 12 g de suelo no fumigado con 60 $\mathrm{mL}$ de $\mathrm{K}_{2} \mathrm{SO}_{4}$ como muestra control, con la que se sigue el mismo protocolo de extracción (agitación y filtrado).

La medida del $\mathrm{C}$ y el $\mathrm{N}$ de la biomasa microbiana se realiza utilizando un analizador automático Multi N/C 2100 (Analytik Jena), restando posteriormente la lectura de los controles sin fumigar a las muestras fumigadas, y corrigiendo los valores obtenidos para $\mathrm{C}$ y $\mathrm{N}$ de la biomasa microbiana con el factor de proporcionalidad del $\mathrm{C}$ y $N$ microbiano extraído bajo condiciones estándar, $K_{C}=0,35$ y $K_{N}=0,54$, respectivamente.

\subsubsection{Actividad microbiana}

Hidrólisis del diacetato de fluoresceína

Se determina según se ha indicado en la sección I.1.5.2. 
Respiración basal

a) Medida del consumo de $\mathrm{O}_{2}$

Para determinar la respiración basal se mide el oxígeno consumido tras 48 horas con un detector Dräger MiniWarn equipado con un sensor XS 202 - 6810375 marca Dräger Safety AG and Co, expresándose la respiración como mg de $\mathrm{O}_{2}$ consumido por kg de compost seco por día (sección I.1.5.2).

b) Medida del $\mathrm{CO}_{2}$ producido

Se añaden 100 g de suelo a recipientes de $1 \mathrm{~L}$ provistos de una válvula de tres vías, incubando los frascos a $25^{\circ} \mathrm{C}$ durante 56 días en oscuridad. La respiración del suelo se mide semanalmente mediante toma de muestras gaseosas y medida del $\mathrm{CO}_{2}$ por cromatografía de gases (Blackmer y Bremner, 1977) con el equipo HP 6890 Series GC System Plus+ (Hewlett Packard), considerando la medida del $\mathrm{CO}_{2}$ en blancos (recipientes de $1 \mathrm{~L}$ vacíos) y los coeficientes de solubilidad del $\mathrm{CO}_{2}$ en función del $\mathrm{pH}$ del suelo, y expresando la respiración en $\mathrm{mg}$ de $\mathrm{C}-\mathrm{CO}_{2}$ producidos por $\mathrm{kg}$ de suelo.

\section{I.2.5.4. Amonificación de la arginina}

La amonificación de la arginina se determina siguiendo las indicaciones de Lin y Brookes (1999).

En un tubo de centrifugación de $12 \mathrm{~mL}$ se pesa $1 \mathrm{~g}$ de suelo y se añaden $0,2 \mathrm{~mL}$ de disolución de L-arginina $10 \mathrm{mM}$ y 1,8 mL de agua Milli-Q. Paralelamente, se incluye una serie de controles a los que solamente se añade suelo y agua en las proporciones antes señaladas. Todas las muestras se agitan en vortex y se incuban durante 2 horas a $25^{\circ} \mathrm{C}$. Una vez finalizado dicho período, se añaden $0,2 \mathrm{~mL}$ de la disolución de $\mathrm{L}$ arginina $10 \mathrm{mM}$ también a los controles, y rápidamente se bloquea la reacción con 8 $\mathrm{mL}$ de $\mathrm{KCl} 1 \mathrm{M}$. Se agitan los tubos y se centrifugan a 5000 rpm durante 10 minutos a $4^{\circ} \mathrm{C}$.

Finalmente, se determina el nitrógeno amoniacal $\left(\mathrm{N}^{-} \mathrm{NH}_{4}{ }^{+}\right)$por inyección en flujo con el equipo FIAstar 5000 Analyzer FOSS TECATOR según se ha indicado en I.2.4.4. La amonificación de la arginina se calcula restando el contenido en $\mathrm{N}^{-\mathrm{NH}_{4}+}$ de los controles a las muestras que se añadió inicialmente arginina, expresándose el resultado en $\mu \mathrm{g} \mathrm{N}-\mathrm{NH}_{4}{ }^{+} \mathrm{g}^{-1} \mathrm{~h}^{-1}$. 


\subsubsection{Actividades enzimáticas}

a) Actividades fosfomonoesterasas ácida y alcalina

Para la determinación de las actividades fosfomonoesterasas ácida y alcalina se utiliza la metodología descrita por Tabatabai y Bremner (1969).

Reactivos

Tampón Universal Modificado (MUB): Disolución stock preparada disolviendo 12,1 g de tris-hidroximetil-aminometano, 11,6 g de ácido maleico, $14 \mathrm{~g}$ de ácido cítrico y 6,28 g de ácido bórico en agua destilada. Añadir $488 \mathrm{~mL}$ de $\mathrm{NaOH} 1 \mathrm{M}$ y enrasar a $1 \mathrm{~L}$ con agua destilada. Almacenar a $4^{\circ} \mathrm{C}$

Tampón Universal Modificado (MUB) ajustado a pH 6,5: Verter 200 mL de la disolución stock de MUB en un vaso de precipitados de $500 \mathrm{~mL}$ y llevar luego a $\mathrm{pH}$ 6,5 con $\mathrm{HCl}$ 0,1 M, agitando continuamente en un agitador magnético. Trasvasar la disolución a un matraz de 1 L y enrasar con agua destilada. Almacenar a $4^{\circ} \mathrm{C}$

Tampón Universal Modificado (MUB) ajustado a pH 11: Disponer $200 \mathrm{~mL}$ de la disolución stock de MUB en un vaso de precipitados de $500 \mathrm{~mL}$ y llevar luego a $\mathrm{pH} 11$ con $\mathrm{NaOH} \mathrm{0,1} \mathrm{M}$, agitando continuamente en un agitador magnético. Trasvasar la disolución a un matraz de 1 L y enrasar con agua destilada. Almacenar a $4^{\circ} \mathrm{C}$

p-nitrofenil disodio ortofosfato 0,115 M (sustrato): Disolver 2,134 g en $50 \mathrm{~mL}$ de agua. Mantener a $4^{\circ} \mathrm{C}$ y utilizar el mismo día de la preparación

p-nitrofenol $1000 \mu \mathrm{g} \mathrm{mL}-1$ : Disolver $1 \mathrm{~g}$ de p-nitrofenol en $800 \mathrm{~mL}$ de agua destilada y enrasar a $1000 \mathrm{~mL}$. Conservar a $4{ }^{\circ} \mathrm{C}$. A partir de esta disolución se preparan, por dilución con agua destilada, patrones que contengan hasta $250 \mu g$ $\mathrm{mL}^{-1}$ de $p$-nitrofenol, y se conservan a $4^{\circ} \mathrm{C}$

$\mathrm{CaCl}_{2} 0,5 \mathrm{M}$

$\mathrm{NaOH} 1 \mathrm{M}$

Procedimiento

Para la determinación de las actividades fosfatasa ácida y alcalina, se pesan entre 0,455 y 0,555 g de suelo en tubos de centrífuga de $12 \mathrm{~mL}$ y se añaden $2 \mathrm{~mL}$ de solución tampón y 0,5 mL de sustrato. A su vez, se incluyen muestras control en las que adiciona la solución tampón pero no el sustrato. Se agita durante 1 hora a $37^{\circ} \mathrm{C}$ en un baño de agua y, una vez finalizada la incubación, se añade el sustrato también 
a los controles y se finaliza la reacción añadiendo $0,5 \mathrm{~mL}$ de $\mathrm{CaCl}_{2}$ 0,5 M, $2 \mathrm{~mL}$ de $\mathrm{NaOH} 1 \mathrm{M}$ y $5 \mathrm{~mL}$ de agua destilada. Posteriormente, se centrifuga a $5000 \mathrm{rpm}$ a $4^{\circ} \mathrm{C}$ y se mide la absorbancia en el sobrenadante, en espectrofotómetro a $\lambda=400 \mathrm{~nm}$. Se obtiene una curva de calibrado utilizando patrones de p-nitrofenol y se restan los resultados de las muestras control, determinando la actividad fosfomonoesterasa (ácida o alcalina) como la concentración de p-nitrofenol liberado, según la ecuación:

$$
p \text {-nitrofenol }\left(\mu g g^{-1} h^{-1}\right)=\frac{C \cdot V}{P \cdot T}
$$

donde $\mathrm{C}$ es la cantidad de $p$-nitrofenol en la muestra, en $\mu \mathrm{g}$; $\mathrm{P}$ el peso de material seco utilizado, en g; V el factor de dilución, en caso de diluir la muestra; y, T el factor relativo al tiempo de incubación (1 hora).

\section{b) Actividad fosfodiesterasa}

La actividad fosfodiesterasa se determina siguiendo el protocolo indicado por Browman y Tabatabai (1978).

\section{Reactivos}

Tampón Tris $50 \mathrm{mM}$, ajustado a pH 8: Disolver 6,1 g de tris-hidroximetilaminometano en $800 \mathrm{~mL}$ de agua destilada y ajustar a pH 8 con $\mathrm{H}_{2} \mathrm{SO}_{4}$ 0,1 M, enrasando a continuación a $1 \mathrm{~L}$

Bis-p-nitrofenil fosfato 0,005 M (sustrato): Disolver 0,1811 g de bis-p-nitrofenil fosfato en agua, enrasando a $100 \mathrm{~mL}$. Mantener a $4^{\circ} \mathrm{C}$ y utilizar el mismo día de la preparación

p-nitrofenol $1000 \mu g \mathrm{~mL}^{-1}$

$\mathrm{CaCl}_{2}$ 0,5 M

$\mathrm{NaOH} 1 \mathrm{M}$

\section{Procedimiento}

Se sigue la misma metodología que en las fosfatasas ácida y alcalina, pero utilizando tris-hidroximetil-aminometano como tampón y bis-p-nitrofenil fosfato como sustrato. Asimismo, se calcula la actividad fosfodiesterasa como la concentración de p-nitrofenol liberado en $\mu g g^{-1} \mathrm{~h}^{-1}$. 


\section{c) Actividad $\beta$-g/ucosidasa}

Para la actividad $\beta$-glucosidasa, la determinación se realiza de acuerdo con el método de Tabatabai (1982).

\section{Reactivos}

Tampón Universal Modificado (MUB) ajustado a pH 6: Verter $200 \mathrm{~mL}$ de la disolución stock de MUB (ver el apartado a) en un vaso de precipitados de 500 $\mathrm{mL}$ y llevar luego a pH 6 con $\mathrm{HCl}$ 0,1 M, agitando continuamente en un agitador magnético. Trasvasar la disolución a un matraz de 1 L y enrasar con agua destilada. Almacenar a $4^{\circ} \mathrm{C}$

p-nitrofenil-ß-D-glucopiranósido 0,115 M: Disolver 1,732 g en $50 \mathrm{~mL}$ de agua. Mantener a $4^{\circ} \mathrm{C}$ y utilizar el mismo día de la preparación

p-nitrofenol $1000 \mu g \mathrm{~mL}^{-1}$

$\mathrm{CaCl}_{2} 0,5 \mathrm{M}$

$\mathrm{NaOH} 1 \mathrm{M}$

Procedimiento

Se procede de manera similar a la indicada en las actividades fosfomonoesterasa y fosfodiesterasa (apartados a y b), pero utilizando el tampón MUB

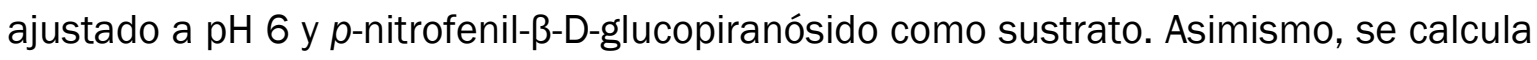
la actividad $\beta$-glucosidasa como la concentración de $p$-nitrofenol liberado en $\mu g \mathrm{~g}^{-1} \mathrm{~h}^{-1}$.

\section{d) Proteasa}

La actividad proteasa se determina según Ladd y Butler (1972), tal y como se indica a continuación.

\section{Reactivos}

Tampón fosfato 0,1 M, ajustado a pH 7: Disolver 13,8 g de $\mathrm{NaH}_{2} \mathrm{PO}_{4} \cdot \mathrm{H}_{2} \mathrm{O}$ en 14 $\mathrm{mL}$ de $\mathrm{NaOH} 5 \mathrm{M}$. Añadir $800 \mathrm{~mL}$ de agua destilada. Ajustar el pH y enrasar a 1 L. Almacenar a $4^{\circ} \mathrm{C}$

N-benzoil-L-arginina amida (BAA) (sustrato) 0,03 M: Disolver 0,2986 g del sustrato en $50 \mathrm{~mL}$ de agua destilada. Mantener a $4^{\circ} \mathrm{C}$ y utilizar el mismo día de la preparación

$\mathrm{KCl} 1 \mathrm{M}$ 


\section{Procedimiento}

Para la determinación de la actividad proteasa, se pesa entre 0,455 y 0,555 g de suelo en tubos de centrífuga de $12 \mathrm{~mL}$ y se añaden $2 \mathrm{~mL}$ de solución tampón fosfato y $0,5 \mathrm{~mL}$ de sustrato. A su vez, se incluyen muestras control en las que adiciona la solución tampón pero no el sustrato. Se agita durante 1 hora a $37^{\circ} \mathrm{C}$ en un baño de agua y, una vez finalizada la incubación, se añade el sustrato también a los controles y se finaliza la reacción añadiendo $8 \mathrm{~mL}$ de $\mathrm{KCl} 1 \mathrm{M}$. A continuación, se centrifuga a $5000 \mathrm{rpm}$ a $4^{\circ} \mathrm{C}$.

Finalmente, se determina el nitrógeno amoniacal $\left(\mathrm{N}-\mathrm{NH}_{4}{ }^{+}\right)$por inyección en flujo con el equipo FIAstar 5000 Analyzer FOSS TECATOR, según se indica en 1.2.4.4. La actividad proteasa se calcula restando el contenido en $\mathrm{N}^{-N_{4}}{ }^{+}$de los controles a las muestras en las que se añadió inicialmente sustrato, expresando el resultado en $\mu \mathrm{g} N$ $\mathrm{NH}_{4}+\mathrm{g}^{-1} \mathrm{~h}^{-1}$.

\section{I.2.5.6. Bioensayo de fitotoxicidad con semillas de cebada}

El bioensayo de fitotoxicidad en que se evalúa el crecimiento de las raíces de plántulas de cebada (Hordeum vulgare, cv. "Nevada") se realiza siguiendo la metodología descrita en la Norma UNE-77301-1 (1996).

Para dicho bioensayo se requiere el suelo a estudiar, un suelo conocido de buena calidad (no fitotóxico) y un sustrato de arena, de referencia. En primer lugar, se secan los materiales y, a continuación, se pasan a través del tamiz de $4 \mathrm{~mm}$ de luz y se colocan (500 g) en macetas (de 0,5 L de capacidad) sin que éstos se compacten, preparando tres repeticiones de cada uno de ellos. Durante el ensayo, los materiales se mantienen a una humedad equivalente al $70 \%$ de la capacidad de retención de agua, pesando las macetas y añadiendo el agua destilada necesaria para mantener dicha humedad.

Las semillas de cebada se pregerminan en placas petri, de 36 a 48 horas, a $20^{\circ} \mathrm{C}$ y en oscuridad, sobre papel de filtro humedecido con agua destilada, controlando que la radícula haya emergido tras dicho período pero que su longitud sea inferior a $2 \mathrm{~mm}$. Se siembran 6 semillas, con la radícula orientada hacia la parte inferior, a unos $10 \mathrm{~mm}$ por debajo de la superficie del material a ensayar. Las macetas así sembradas se colocan en una cámara de crecimiento $\left(20^{\circ} \mathrm{C}, 14\right.$ horas de luz y 25000 lux) durante 5 días. 
Después de dicho intervalo, se elimina el suelo de las macetas con precaución y se lava cada planta, midiéndose la raíz de mayor longitud con precisión de 0,5 mm. La fitotoxicidad potencial se evalúa comparando la longitud media de la raíz del tratamiento y de los materiales control (suelo de buena calidad y arena).

\section{I.3. ANÁLISIS ELEMENTAL DEL MATERIAL VEGETAL}

\section{I.3.1. Nitrógeno total}

Para el análisis de nitrógeno total en el material vegetal se utiliza el método Kjeldahl, según lo indicado por Jones (1991).

Reactivos

Disolución concentrada de indicador, ácido bórico-indicador y disoluciones de $\mathrm{HCl} 0,01 \mathrm{~N}$ y $0,05 \mathrm{~N}$

$\mathrm{H}_{2} \mathrm{SO}_{4}$ concentrado (97\%)

$\mathrm{H}_{2} \mathrm{O}_{2}$ al $33 \%$

$\mathrm{NaOH}$ al $40 \%$

Mezcla de catalizadores: Mezclar $\mathrm{K}_{2} \mathrm{SO}_{4}, \mathrm{CuSO}_{4}$ y Se en la proporción 10/1/0,1, y triturar hasta polvo fino

Procedimiento

Se pesan 0,5 g de muestra de material vegetal (triturada y tamizada por tamiz de luz de 0,5 mm) con una precisión de 0,1 mg y se introducen en un tubo de digestión. Se añaden $1,5 \mathrm{~g}$ de la mezcla de catalizadores, $10 \mathrm{~mL}$ de $\mathrm{H}_{2} \mathrm{SO}_{4} 97 \%$ y $5 \mathrm{~mL}$ de $\mathrm{H}_{2} \mathrm{O}_{2}$ 33\%. Se introducen los tubos en el bloque de digestión FOSS Tecator 2020 Digestor (Foss España S.A.) a $420^{\circ} \mathrm{C}$ durante media hora. Se sacan los tubos de digestión, se dejan enfriar, y se añade agua destilada hasta $50 \mathrm{~mL}$.

Se basifican los digestados con $\mathrm{NaOH} 40 \%$ y se destilan con el equipo 2200 Kjeltec Auto Distillation de FOSS Tecator (Foss España S.A.) en corriente de vapor durante 2 minutos y 40 segundos, recogiendo $150 \mathrm{~mL}$ de destilado sobre $20 \mathrm{~mL}$ de ácido bórico-indicador. La concentración de $\mathrm{N}$ foliar se determina mediante valoración del destilado con $\mathrm{HCl} \mathrm{0,01} \mathrm{Nó} \mathrm{0,05} \mathrm{N,} \mathrm{según} \mathrm{la} \mathrm{cantidad} \mathrm{esperable.} \mathrm{El} \mathrm{punto} \mathrm{final} \mathrm{de}$ la valoración se detecta visualmente por viraje de la disolución de color verde a rojizo. 


\section{I.3.2. Potasio, calcio, magnesio y sodio}

Reactivos

$\mathrm{HNO}_{3}$ al $35 \%$

Mezcla sulfúrico-perclórica: Mezclar, con cuidado y en campana extractora, 83 $\mathrm{mL}$ de $\mathrm{H}_{2} \mathrm{SO}_{4}$ concentrado y $117 \mathrm{~mL}$ de $\mathrm{HClO}_{4}$

Disoluciones patrón de K, Ca, Mg y Na de 1000 mg/L

Procedimiento

Se pesan 100 mg de muestra de material vegetal (triturada y tamizada por tamiz de luz de 0,5 mm) con una precisión de 0,1 $\mathrm{mg}$ y se introducen en un tubo de digestión de boca esmerilada. Se enciende el digestor FOSS Tecator Digestor (Foss España S.A.), ajustando la temperatura a $150^{\circ} \mathrm{C}$. A continuación, se añaden $2 \mathrm{~mL}$ de $\mathrm{HNO}_{3} 35 \%$, se ponen los condensadores en los tubos, y se introducen en el digestor. Cuando desaparecen los humos rojizos y la muestra queda de color amarillo claro (aproximadamente 30 minutos), se sacan los tubos del digestor, y se dejan enfriar. A cada tubo se le añaden $2 \mathrm{~mL}$ de la mezcla sulfúrico-perclórica y se calientan a $210^{\circ} \mathrm{C}$ durante 2 horas. Después se sacan los tubos de digestión y se dejan enfriar. Los digestados se filtran sobre matraces de $50 \mathrm{~mL}$ utilizando papel para análisis cuantitativo. Se lavan los tubos de digestión con agua destilada, se filtran y se enrasan los matraces también con agua destilada. Finalmente, se vierte su contenido en botellas de plástico estériles y se guardan en nevera hasta el análisis.

La determinación de K, Ca, Mg y Na se realiza utilizando espectrofotometría de emisión atómica con plasma acoplado inductivamente (ICP-AES Spectroflame, Spectro Analytical Instruments Inc.) según se describe en la sección I.1.4.6.

\section{I.3.3. Fósforo}

La muestra de material vegetal se digiere según se ha indicado en I.3.2., y el fósforo se determina mediante el método de Fiske y Subbarow (1925), que se detalla a continuación.

Reactivos

$\mathrm{H}_{2} \mathrm{SO}_{4} 10 \mathrm{~N}$

Molidabto amónico (2,5\%): Disolver $25 \mathrm{~g}$ de $\mathrm{Mo}_{7} \mathrm{O}_{24}\left(\mathrm{NH}_{4}\right)_{6} \cdot 4 \mathrm{H}_{2} \mathrm{O}$ en $200 \mathrm{~mL}$ de agua. Verter en un aforado de $1 \mathrm{~L}$ que contenga $500 \mathrm{~mL}$ de $\mathrm{H}_{2} \mathrm{SO}_{4} 10 \mathrm{~N}$ y enrasar a $1 \mathrm{~L}$ con agua destilada 
Ácido amino-naftol-sulfónico: Mezclar en seco 650 g de bisulfito sódico, 30 g de sulfito sódico anhidro y 7,5 g de ácido 1-amino-2-naftol-sulfúrico. Homogeneizar en un mortero y mezclar

Agente reductor: Disolver 5,2 g del ácido amino-naftol-sulfónico anterior en 100 $\mathrm{mL}$ de agua. Dejar reposar la disolución 30 minutos antes de su uso (máximo 4 días tras la preparación)

Disolución de 1000 ppm y 10 ppm de fósforo: Disolver 4,39 g de $\mathrm{KH}_{2} \mathrm{PO}_{4}$, añadir $10 \mathrm{~mL}$ de $\mathrm{H}_{2} \mathrm{SO}_{4} 10 \mathrm{~N}$ y diluir hasta $1 \mathrm{~L}$ con agua destilada (1000 ppm). Añadir $10 \mathrm{~mL}$ de $\mathrm{H}_{2} \mathrm{SO}_{4} 10 \mathrm{~N}$ a $10 \mathrm{~mL}$ de la disolución de 1000 ppm de fósforo y diluir hasta $1 \mathrm{~L}$ con agua destilada (10 ppm)

\section{Procedimiento}

Se toma una cantidad de digestado que contenga 0,02-0,03 ppm de fósforo y se vierte en un aforado de $10 \mathrm{~mL}$. Se añade $1 \mathrm{~mL}$ de molibdato amónico al 2,5\%, y se mezcla, y en seguida $1 \mathrm{~mL}$ del agente reductor, para después homogeneizar y enrasar con agua destilada. Tras un intervalo de 20-30 minutos se mide la absorbancia con un espectrofotómetro Jenway UV/visible 6300 (Bibby Scientific) a $\lambda=680 \mathrm{~nm}$. Para obtener la curva de calibrado, se toman $0,1,2,3,4$ y $5 \mathrm{~mL}$ de la disolución de 10 ppm de fósforo en un aforado de $10 \mathrm{~mL}$, y se procede de idéntica manera que con las muestras.

\section{I.3.4. Elementos traza}

El material vegetal utilizado para la determinación de los elementos traza, finamente triturado con mortero y tamizado por malla de luz de $0,5 \mathrm{~mm}$, se seca en estufa a $70^{\circ} \mathrm{C}$ durante 72 horas.

Se toman $100 \mathrm{mg}$ de muestra seca y se digieren en un digestor FOSS Tecator (Foss España S.A.), tal y como se ha indicado en I.3.2. Después de diluir y aforar convenientemente, los digestados se filtran a través de papel de filtro para análisis cuantitativo. Los filtrados se conservaron a $4^{\circ} \mathrm{C}$ hasta su análisis.

La determinación de $\mathrm{Pb}, \mathrm{Zn}$ y Al se realiza mediante ICP-AES (ver sección I.1.4.6), y la de As utilizando espectrofotometría de absorción atómica combinada con un generador de hidruros. 


\section{ANEJO II \\ MATRIZ DE CORRELACIÓN}

(entre las características y propiedades físicas, físico-

químicas, químicas y biológicas de los composts $\mathrm{A}$ y $\mathrm{A}+\mathrm{H}$ ) 


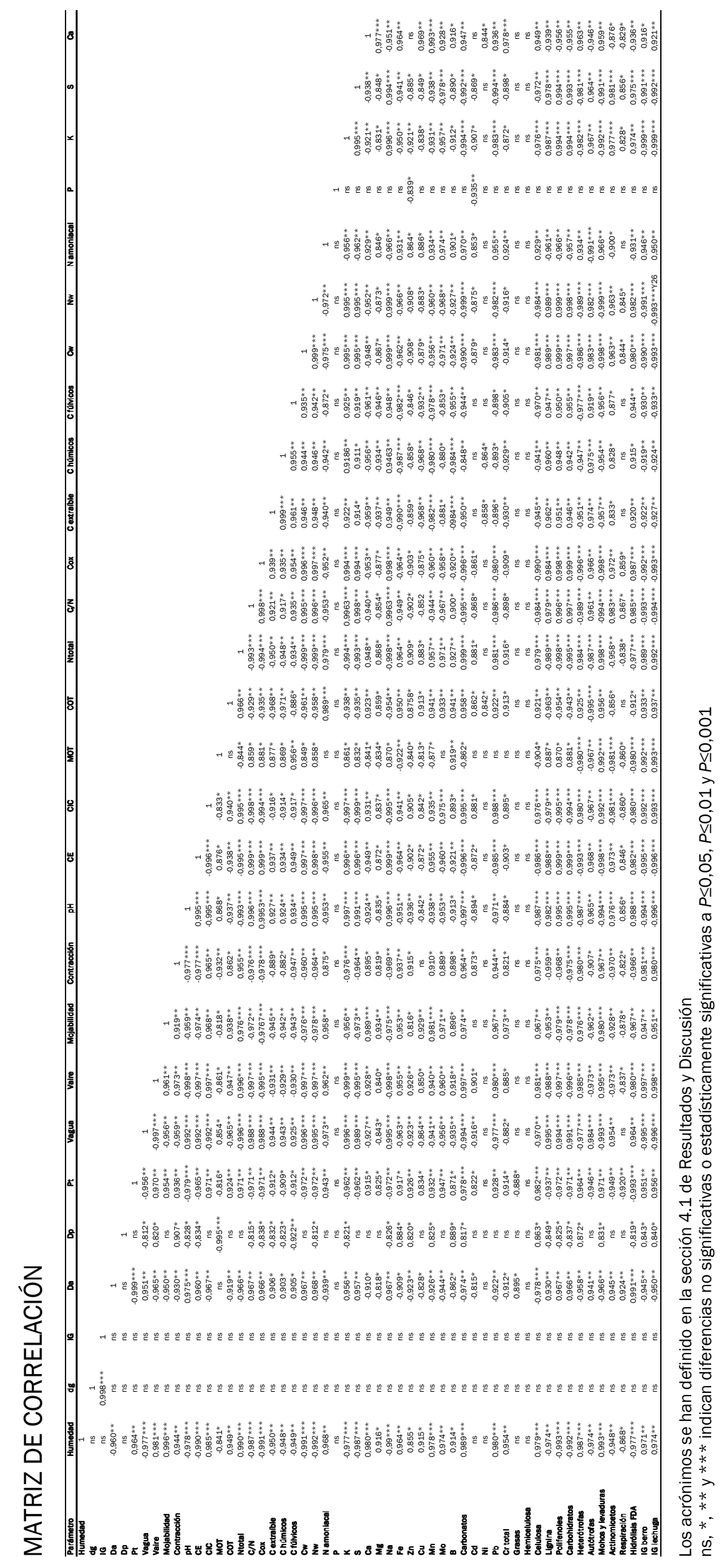




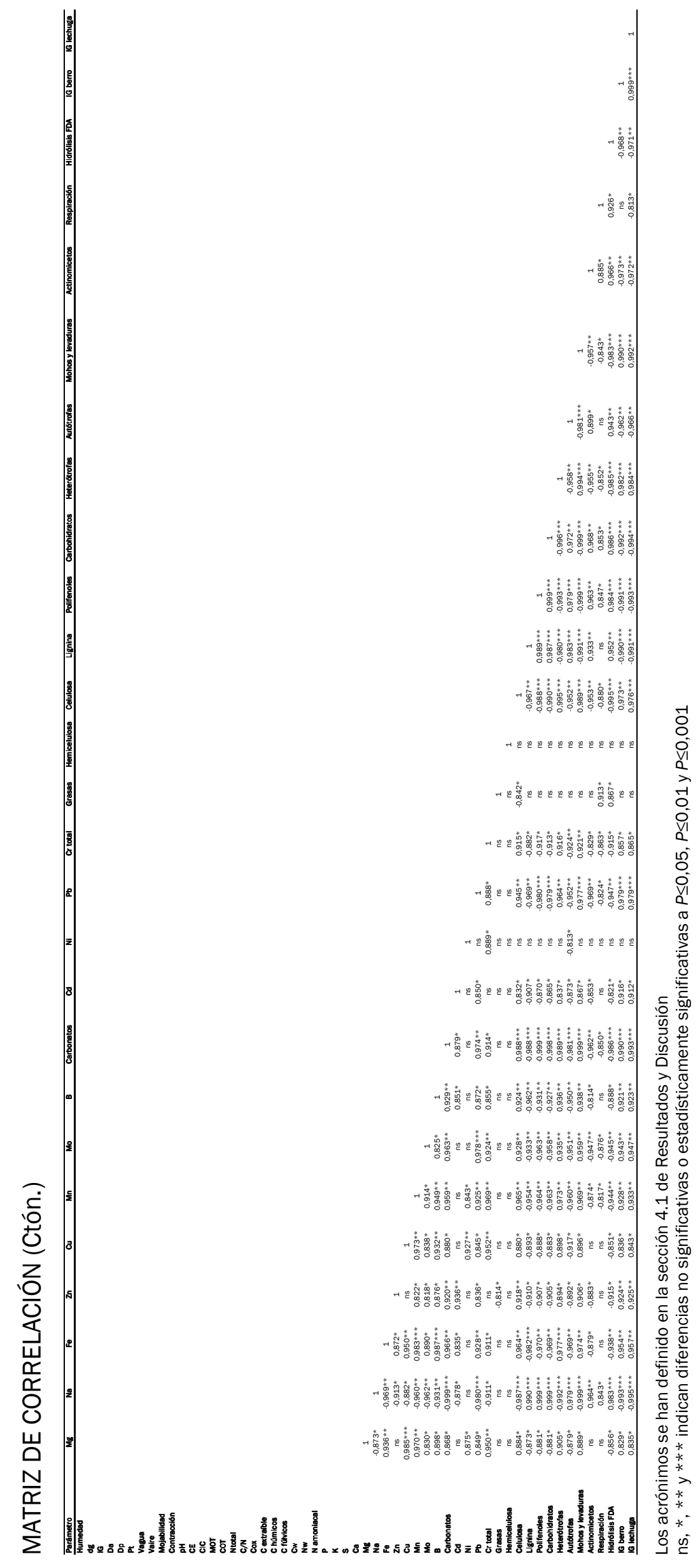


LOCALIZACIÓN

Pág. 292, Tabla 4.4.18,

Columna 10, Na, 2. Dosis de MOS

Pág. 318, Figura 4.5.6, Plantas infectadas (\%), ab Sustrato A2-E

Pág. 351, Línea 18

Pág. 351, Figura 4.7.3

Pág. 352, Línea 7

\section{DICE}

$365,399,410,457,454,505 \mathrm{a}$

0,950, tal

$\Delta \mathrm{CE}=1,4772 \cdot \Delta \mathrm{pH}+0,151$

$\mathrm{R}^{2}=0,951(P \leq 0,01)$

cada unidad...1,5 dS/m

\section{DEBE DECIR}

365d, 399c, 410c, 457b, 454b, 505a

0,900, tal

$\Delta \mathrm{CE}=-1,2283 \cdot \Delta \mathrm{pH}+0,809$

$\mathrm{R}^{2}=0,905(P \leq 0,01)$

una unidad...2 $\mathrm{dS} / \mathrm{m}$ 